


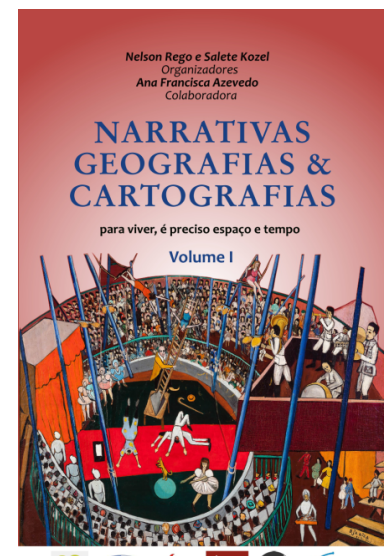

200.
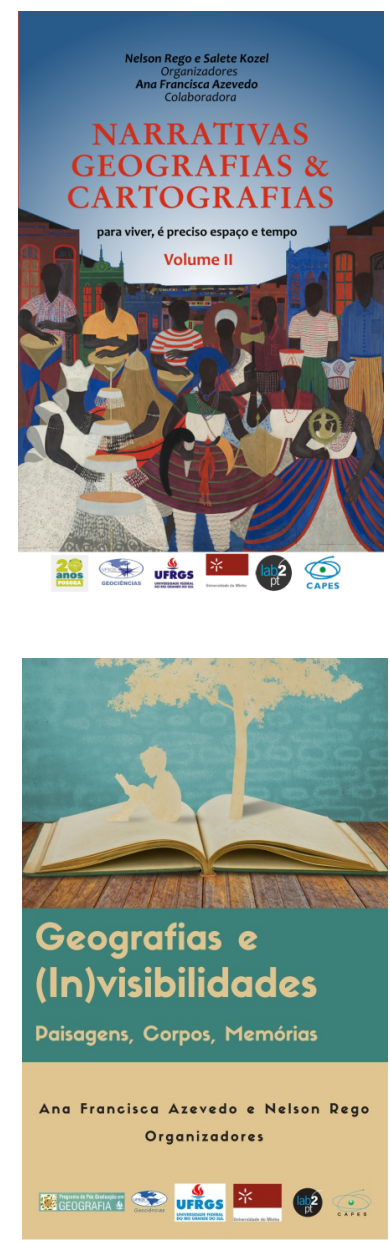

REGO, Nelson; KOZEL, Salete (orgs.). Narrativas, Geografias e Cartografias: para viver é preciso espaço e tempo.Volume 1. Porto Alegre: Editora Compasso LugarCultura e Editora IGEO. 2020.

REGO, Nelson; KOZEL, Salete (orgs.). Narrativas, Geografias e Cartografias: para viver é preciso espaço e tempo.Volume 2. Porto Alegre: Editora Compasso LugarCultura e Editora IGEO. 2020.

AZEVEDO, Ana Francisca; REGO, Nelson (orgs.) Geografia e (In)Visibilidades: paisagens, corpos, memórias. Porto Alegre: Editora Compasso Lugar-Cultura e Editora IGEO. 2017. 


\section{Geografias e \\ (In)visibilidades \\ Paisagens, Corpos, Memórias}

Ana Francisca Azevedo e Nelson Rego Organizadores

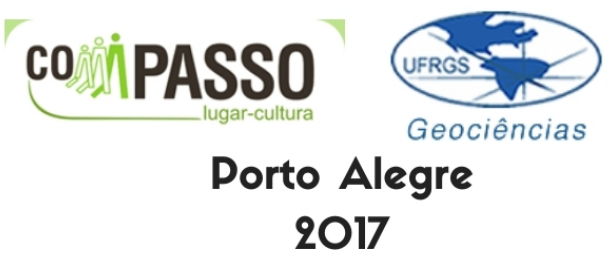


ISBN E-book: 978-85-94121-00-4

D.O.I: $10.29327 / 518552$

$1^{\mathrm{a}}$ Edição - 2017

É proibida a reprodução total ou parcial desta obra, sem autorização expressa dos autores ou da editora. A violação importará nas providências judiciais previstas no artigo 102, da Lei $n^{\circ} 9.610 / 1998$, sem prejuízo da responsabilidade criminal. Os textos deste livro são de responsabilidade de seus autores.

\section{Editora Compasso Lugar- Cultura}

Responsável André Suertegaray Rossato

Porto Alegre - RS - Brasil

Telefones (51) 984269928

compassolugarcultura@gmail.com

www.compassolugarcultura.com

\section{Editora IGEO - UFRGS}

\section{Editores}

Cristiano Quaresma de Paula

Dirce Maria Antunes Suertegaray

\section{Capa}

Cristiano Quaresma de Paula

Design by www.canva.com

Imagem de Capa: Designed by Jannoono28 / Freepik
Conselho Editorial

Álvaro Heidrich

Carlos Henrique Aigner

Cláudia Luíza Zeferino Pires

Dakir Larara Machado da Silva

Dilermando Cattaneo da Silveira

Dirce Maria Antunes Suertegaray

Helena Copetti Callai

Jaeme Luiz Callai

João Osvaldo Rodrigues Nunes

Laurindo Antonio Guasselli

Maíra Suertegaray Rossato

Nelson Rego

Roberto Verdum

Rosa Maria Vieira Medeiros

Sinthia Batista

Dados Internacionais de Catalogação na Publicação (CIP)

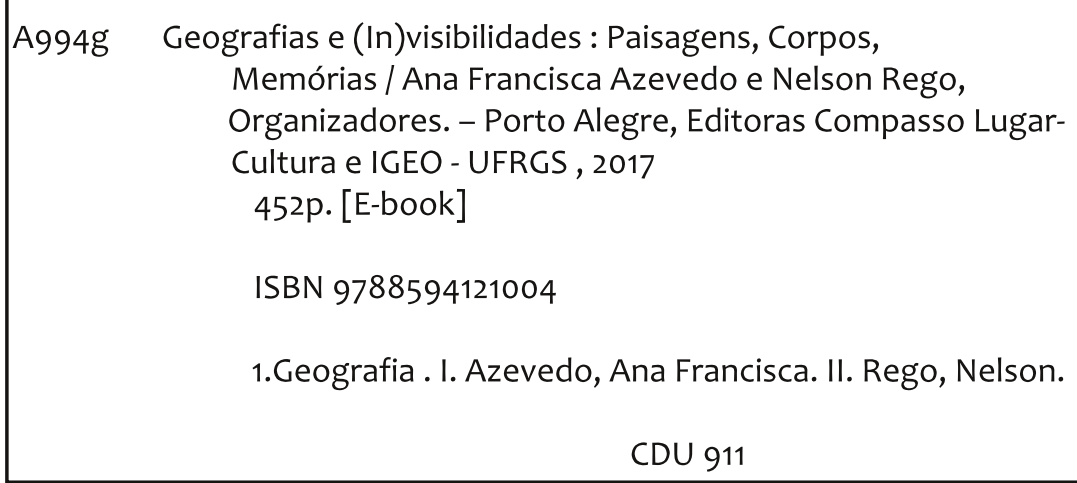

Bibliotecária Responsável: Maria da Graça Artioli - CRB10/793 


\section{Prefácio}

Dirce Maria Antunes Suertegaray 
o receber esta solicitação, escrever um prefácio para esta obra,
confesso que fiquei apreensiva. O motivo da apreensão, para quem me conhece, se deve ao fato de que, mesmo sendo geógrafa, falo de um outro lugar. De um lugar que trata do visível e busca essa interpretação pela mediação dialética que perfaz a vida, ou seja, busca compreender no invisível dos processos a essência do visível, a vida, objetivamente no contexto de relações sociais que a conformam e, com estas, suas paisagens e seus espaços. De outra parte, não trabalho conceitualmente com corpo e memória, embora opere com o conceito de paisagem. Como se referem os organizadores, corpo, memória e paisagem são, neste livro, apresentados como palavras em triangulação. Portanto, expressam diferentes possibilidades de leitura dessa triangulação, conforme se manifestam nos textos aqui apresentados. Então, esse indicativo foi o que me permitiu escrever essas breves palavras.

Entendo, pois, que Geografias e (in)visibilidades tem como pressuposto tencionar a Geografia e suas clássicas leituras do mundo, pois, o mundo em si, na sua objetividade, é de uma clareza ímpar para quem não estiver encoberto por discursos ideologizantes, centrados na imbricada relação entre patriarcado, colonialismo e capitalismo. Desvendada essa relação, a visibilidade está posta.

Então, Geografias e (in)visibilidades busca demonstrar essa dialética entre visível e invisível, ou seja, revelar espaços geograficamente opacos e trazê-los à "luz" do conhecimento geográfico. Abrindo com isso a possibilidade de construir uma geografia que revele a multiplicidade, a diversidade e a desigualdade da vida humana e, ao mesmo tempo, a multiplicidade, a diversidade e a desigualdade das paisagens habitadas. Podem ser essas paisagens reconstituídas pela memória daqueles que as habitam, invisíveis à Geografia sob outras análises, mas certamente visíveis a quem as habita.

Possibilidades analíticas novas, neste início de século XXI, especialmente nesses anos em que pelo menos duas forças estão em jogo. De um lado, o desejo de liberdade, autonomia e respeito ao outro valoriza o olhar diverso. De outro, o desejo homogeneizador, 
dominador, explorador e controlador de corpos e de paisagens - que a memória histórica mostra como sempre recorrente nesta roda mundo - promove a submissão.

A obra é a expressão dessa construção em Geografia, que resulta do encontro dos distantes, porém próximos dois países, Portugal e Brasil. Nas nossas origens estão os portugueses, mas não só. Nossas origens trazem a marca da colonização, mas também da resistência, muito dos corpos e paisagens que aqui se revelam é a expressão no presente de uma memória histórica que não poderá ser apagada, pois estaríamos negando para estes, para os quais o desejo é dar visibilidade, o reconhecimento de sua identidade, indígena, africana, por exemplo, e sua forte presença na formação histórica brasileira, de forma visível e contraditoriamente invisível, ou sendo desejada invisível.

Enfim, Geografias e (in)visibilidades expressa uma trama de leituras, onde as referências ao corpo e a opressão se expressam em questões de gênero, em questões étnicas, em questões raciais ou sobre necessidades fundamentais. Resgatam memórias e espaços (paisagens) e, no conjunto, o livro encaminha para uma reflexão que diria epistemológica, na medida em que tenciona a geografia, historicamente visível, através de uma geografia das invisibisibilidades.

Dirce Suertegaray

Outono, Hemisfério Sul, 2017 



\section{Sumário}

\section{Prefácio}

Dirce Maria Antunes Suertegaray.............................................. 5 Apresentação

Ana Francisca de Azevedo \& Nelson Rego....................................11

Sobre o Esforço de Tradução

Ana Francisca de Azevedo......................................................15

Ausência dos Corpos. Presença dos Corpos

Nelson Rego .........................................................................21

\section{PARTE I: Leituras de Leituras Feitas de Presenças e}

Ausências Geográficas

Paisagem-província, Corpos Pré-modernos e Fracturas

da Memória

Ana Francisca de Azevedo.

Etnopaisagem, Corpo e Memória: Uma Viagem pelo

Cinema Português

Tiago Campos Vieira Carvalho da Silva

Paisagem, Corpo e Memória nas Narrativas Científicas

da Geografia Colonial Portuguesa

Marta Rodrigues

A Estética da Paisagem Cênica, Pitoresca e Sublime Lucimar de Fátimas dos Santos Vieira \& Roberto Verdum

\section{PARTE II: Para Construir Espaços - Geografias}

Memórias

Corporeidades e Paisagem: a cosmologia da terra no Quilombo dos Alpes/RS

Cláudia Luísa Zeferino Pires; Daiane da Silva Ellias; Karina Rejane da Silva Ellias; Lara Machado Bitencourt; Marilia Guimarães

Rathmann; Mateus dos Santos Viegas; Matheus Eilers Penha, Rosângela da Silva Ellias \& Winnie Ludmila Mathias Dobal ............161 Ribeirinhos, Organizações Comunitárias e Alimentação: Flona de Tefé/AM, Brasil

Cleder Fontana, Cristiano Quaresma de Paula \& Dirce Maria Antunes Suertegaray 
Paisagens Vividas e Imaginários Urbanos em Disputa: memórias e paisagens nas narrativas de jovens do Bairro Guajuviras (Canoas/RS)

Nola Patrícia Gamalho \& Álvaro Luiz Heidrich.

Políticas Públicas e Construção de Um Imaginário

Favorável à Instalação da Silvicultura sobre os Areais do Sudoeste Gaúcho

José Carlos Corrêa Ribeiro \& Roberto Verdum

PARTE III: A paisagem no corpo. 0 corpo na paisagem..273 Tellusmorfismo: A Reconceptualização Corporal da Paisagem Através da Memória como Narrativa de Movimento

Ricardo Nogueira Martins 275

Desconstrução Imagética da Mulher Negra na Bahia Camila Xavier Nunes, Juliana Cunha Costa Radek \& Nelson Rego...311 O Corpo e a Geografia do Cotidiano

Benhur Pinós da Costa, Edipo Djavan dos Reis Goergen, Flávia R.

Durgante \& Taiane Flôres do Nacimento

Geografia, Imaginário e Performances de Gêneros e Sexualidades

Benhur Pinós da Costa 383

O papel das Mãos: a Leitura e a Costura entre Memória, Paisagem e Corpo Janderson Gonçalves

Autores 445

Agradecimentos 450 


\section{Apresentação}

Ana Francisca de Azevedo e Nelson Rego 


\section{G} eografias e (in)visibilidades: paisagens, corpos, memórias reúne treze textos onde a triangulação entre paisagem, corpo e memória se faz visível. Durante a concepção do livro, essas três palavras inicialmente não expressavam conceitos, mas noções flexíveis que enfeixavam de modo aberto os trabalhos de pesquisas das autoras e dos autores convidados. Não se tratava, pois, de um determinado conceito de paisagem, de um conceito de corpo e de um conceito de memória. Pode-se dizer: foram três palavras que guiaram a formulação do convite às escritas.

A triangulação entre as três palavras foi proposta como provocação inicial para as escritas de pesquisadoras e pesquisadores, considerando que de variados modos essa triangulação vinha se fazendo presente em seus respectivos trabalhos e conceituações. Portanto, há, sim, presença forte de conceitos: as variadas construções com as quais as autoras e autores deram significados conceituais às três palavras em seus respectivos textos. Acreditamos que os treze textos oferecem um painel ao mesmo tempo de convergências e singularidades, propiciando uma gama instigante de possibilidades de diálogos, pesquisas e intercâmbios.

O convite ligava-se a uma perspectiva de curadoria: um olhar que identificou a presença, ainda que antes não nominada, daquela triangulação nas pesquisas de hábito realizadas pelas pesquisadoras e pesquisadores. Foi como se convidássemos artistas a criarem obras para uma exposição coletiva e, então, justificássemos o critério para a definição do conjunto: a percepção de um diálogo latente entre obras anteriores dos convidados, diálogo feito por semelhanças e dessemelhanças que relacionam paisagem, corpo e memória e dão passagem à outra noção-chave - as (in)visibilidades das geografias que ficariam registradas em Geografias $e$ (in)visibilidades: paisagens, corpos, memórias. Pois nos parece que isso perpassa os textos aqui reunidos, dar visibilidade ao que é constitutivo da existência e se faz presente na geograficidade de contextos de vida que, por diversos meios, são empurrados para a invisibilidade. 
Convites aceitos, textos recebidos, a curadoria os classificou em três diferentes partes - Leituras de leituras feitas de presenças $e$ ausências geográficas; Para construir espaços: geografar memórias; $A$ paisagem no corpo. O corpo na paisagem - cientes de que cada texto posto sob o título de uma parte pode ser transferido para ao menos um dos outros dois grupos. Assim, a curadoria começou com uma provocação e entrega o livro à leitura com outra, pois conforme escrevemos umas poucas linhas antes "acreditamos que os treze textos oferecem um painel ao mesmo tempo de convergências e singularidades, propiciando uma gama instigante de possibilidades de diálogos, pesquisas e intercâmbios”.

Geografias e (in) visibilidades: paisagens, corpos, memórias é resultado do convênio firmado entre os Programas de PósGraduação em Geografia da Universidade do Minho, Portugal, e da Universidade Federal do Rio Grande do Sul, Brasil, para a realização de intercâmbios e pesquisas conjuntas. A assinatura dos termos do convênio aconteceu em 2016, mas a parceria vem de antes, iniciada aos poucos, sem uma data exata a ser fixada, como é próprio da história do que é orgânico, desde que a doutoranda Camila Xavier Nunes, vinculada à universidade brasileira, realizou um período de intercâmbio na universidade portuguesa, estabelecendo uma orientação para a sua pesquisa em cada lado do Atlântico, o que levou aos diálogos entre a orientadora do Hemisfério Norte e o orientador do Hemisfério Sul, o que, por sua vez, conduziu ao convênio abrangendo pesquisadoras e pesquisadores com trajetórias associadas à Universidade do Minho ou à Universidade Federal do Rio Grande do Sul. Motivo pelo qual concluímos esta apresentação com nosso agradecimento a Camila, por ter iniciado a aproximação entre geógrafas e geógrafos criadores de algumas visibilidades para as triangulações entre paisagem, corpo e memória.

Ana Francisca de Azevedo e Nelson Rego Braga, Portugal, e Porto Alegre, Brasil, fevereiro de 2017 



\section{Sobre o Esforço de Tradução}

Comentários de Ana Francisca de Azevedo 
$\mathrm{O}$ livro que aqui se apresenta surge, antes de mais, como resultado de quase uma década de trocas entre os dois lados do oceano atlântico. Entre uma miríade de trocas que a história conta, e todas as outras, muitas mais, que ficaram por contar. A troca entre dois académicos, um homem brasileiro e uma mulher portuguesa, envoltos em compromissos profissionais, a troca entre seres humanos que foi envolvendo outros e outros. Uma troca entre viajantes culturais, entre geógrafos e geógrafas, que tentam encontrar-se, numa época alegadamente bem distante das explorações coloniais e das missões de reconhecimento com fins imperialistas. Introduzir este livro, teria de partir, pois, de considerações que nos pareceram fundamentais tais como sublinhar a distinção tradicional que diferencia o cientista viajante da figura do descobridor, explorador ou aventureiro, porque todos pertencemos a uma vasta família de criaturas errantes. O nosso propósito prende-se exclusivamente com o enriquecer do conhecimento, no sentido íntimo do termo, e não rescrever a terra fazendo uso de categorias fechadas. Se, por um lado, somos herdeiros daquele modelo do cientista viajante, mapeando o mundo e os fenómenos de acordo com os contextos institucionais dominantes, tentamos afastar-nos dos estereótipos do especialista profissional treinado nos cânones oficiais para a organização de uma colecção de textos, de acordo com as estritas normas de recoleccção, preparação e preservação de espécies dos mais variados tipos. Por vezes este exercício de curadoria de textos dilui a propriedade única de cada exemplar, submetendo a voz autoral de cada espécie a uma voz monolítica em uso no momento de produção. Sobretudo retira-lhe a vida, aprisionando-o numa suma fórmula interpretativa. Este foi o maior desafio do presente trabalho de edição. A profunda generosidade dos e das agentes e autores envolvidos nas pesquisas que o tornaram possível, ao disponibilizarem as suas 'recolecções' e experiências, ofereceu-nos alento para a sua concretização nos termos em que se encontra este livro, ao qual preferimos designar como manual de trabalho. E explicaremos porquê. 
Tínhamos como dado de partida que não iríamos definir um programa base para a organização do livro. Apenas pedimos aos autores um texto em que fosse visível a triangulação entre paisagem, corpo e memória, por considerarmos três conceitos operativos centrais em geografia. A resposta foi imediata e, confrontados com os textos, logo nos confrontamos com aquilo que eram as nossas principais suspeitas; a centralidade da tarefa de tradução no labor geográfico de qualquer época e a insuficiência dos dispositivos formais e normalizadores de produção científica para lidar com os mecanismos de diferença e alteridade. O suporte daquilo que usamos designar por língua portuguesa a par dos dispositivos académicos predefinidos para a organização, compilação e negociação das espécies de textos consignados, por forma a alcançar a coerência e estrutura do conhecimento especializado, revelaram, desde muito cedo, a sua fragilidade. No início do século XXI vimo-nos confrontados com as diferentes delimitações da translatio imperii, um conceito profundamente relacionado com a textura simbólica das práticas espaciais, com a história da sua fundação e com os legados do conceito medieval de translatio, o processo de apropriação, aquisição e finalmente colonização que perpassam os processos paradigmáticos de globalização amiúde turvados pela imediatez do transito de informação facilitado pelos meios técnicos que tacitamente se encontram ao dispor de muitos. A disseminação do conhecimento para vastas e heterogéneas audiências pressupõe um conhecimento do humano e do não humano que o acto de tradução científica muitas vezes tende a terraplenar. Concretizando, inclusos nos textos que aqui se apresentam, encontram-se um incontável número de encontros que excedem em muito meras aproximações de género, raça ou classe, a que hoje deitamos mão para tentar deslindar as complexas veredas dos sujeitos de trabalho, bem como as rupturas e continuidades que marcam de forma indelével os corpos geográficos. A abordagem a uma tarefa científica transnacional implica inevitavelmente o envolvimento com a história de construção de sistemas simbólicos em que assenta cada cultura, perspectivada, de acordo com Raymond Williams, como 
estrutura de sentimentos partilhados. A expressão desta estrutura entronca nas relações entre ser humano e ambiente físico e requer o envolvimento com sistemas linguísticos e texturas discursivas que por vezes se escondem sob ideologias de estilo. O envolvimento com outras línguas, ainda que sob a fachada da mesma língua, permite perceber as operações dos vários géneros de escrita científica. Mais ainda no caso em que cada língua se ergue como subterfúgio para explanação de todas as outras que foram suprimidas ou são acomodadas no acto de interpretação e tradução científica dando origem a discursos majestáticos sobre o objecto de estudo. Os múltiplos contextos sócio-históricos e biográficos que as produzem encobrem processos mais vastos de passagem do encontro colonial ao pós-colonial, de especismo, das desventuras modernas que armadilham outras tantas metanarrativas, como as de etnia, sexo, ou religião, tecnologias para a reorganização da experiência num momento em que renovados sistemas de poder se legitimam com recurso ao discurso científico e à urgência de uma língua comum sobre a qual se celebra a verdade do estado-nação, a reorganização da nova geopolitik e a redistribuição do espaço vital pelas grandes potências, para o novo milénio. $\mathrm{O}$ realinhamento dos processos de tradução da experiência, neste contexto, não pode ficar prisioneiro de uma língua franca, ou línguas francas, do 'período democrático', passíveis de retomar a autoridade sobre os sujeitos científicos. Não há uma simples tradução ou reprodução de um texto original, de um contexto situado. A translatio imperii, anuindo à legitimidade de uma civilização superior, e respectivo poder político, para a transferencia ou tradução das culturas e do conhecimento, movimentou-se desde a antiguidade até aos dias de hoje de modo intricado e através das mais diversas práticas disciplinares, hipersimplificando os mecanismos de transferência, de troca e do encontro. Qualquer processo de conhecimento implica dinâmicas de tradução dos mundos de experiência, um tempo e um espaço da demora que incorpora a riqueza e o trauma da viagem, e do próprio encontro, uma dinâmica de negociação das relações em que os sujeitos se possam situar em planos de equivalência. Neste 
sentido, o desafio que deixamos aos leitores é o de se confrontarem com um conjunto de textos com validade em si mesmos, mas que, para além da sua riqueza interna, podem funcionar como espécies através das quais experimentamos o esforço de transferência e tradução de experiências múltiplas, como manual de trabalho para o conhecimento, proporcionando uma base a partir da qual podemos experimentar diferentes configurações, organizar e reorganizar, por em contacto ou desfragmentar, reflectir sobre o processo curatorial como método de tradução, sobre os aspectos paradigmáticos envolvidos nesta tarefa, como por exemplo heterogeneidade, heterolinguagem, transculturalismo ou desterritorialização e reterritorialização. Analisando o modo como as disciplinas científicas tentam lidar com este e outros problemas, propomos uma reflexão alargada sobre o processo de globalização como um processo de tradução, ao qual a geografia contemporânea não é alheia. 



\section{Ausência dos Corpos. Presença dos Corpos}

Comentários de Nelson Rego 
Wa madrugada de 29 de novembro, o avião da empresa aérea 1 LaMia levava o time brasileiro da Chapecoense, dirigentes do clube, jornalistas e convidados para a cidade de Medellín, na Colômbia, para a disputa do título de campeão da Copa SulAmericana de Futebol de 2016 contra o time colombiano do Atlético Nacional. O avião caiu a poucos quilômetros da cidade, setenta e um foram os mortos.

A espantosa causa do desastre logo se tornou conhecida: falta de combustível. Os quatro motores falharam um após o outro devido ao esgotamento do combustível. As gravações do diálogo entre os controladores de tráfego e o piloto, que era também sócioproprietário da empresa aérea e do avião fretado, indicam que, quando decolou na última escala, na Bolívia, para o trecho final da viagem até Medellín, ele estava ciente de que o combustível encontrava-se no limite do necessário para o término da viagem, sem reservas. Por consequência de sua decisão de risco, nenhum fator poderia prolongar o tempo da viagem, nenhum daqueles fatores considerados corriqueiros: condições meteorológicas adversas, alguma espera no ar ou pequeno desvio de rota para adequar-se ao tráfego aéreo e à permissão para o pouso. $O$ avião também transportava um pouco de excesso de peso em bagagens, $\mathrm{o}$ que acentuava o risco da viagem com o combustível no limite do necessário. O piloto e proprietário do avião bancou a aposta contra as probabilidades, ele arriscou contra as leis da Física. As gravações dos últimos minutos evidenciam o quanto ele se esforçou para pousar o avião em pane, mas o risco inerente à sua aposta era alto demais, preponderou sobre a suposta perícia e a abusiva autoconfiança do piloto.

Foram severas as dificuldades econômicas e políticas no Brasil em 2016. Foram tamanhas as consequências da crise em diferentes frentes e níveis que se torna possível dizer que houve uma falência do cotidiano.

Assim que ocorreu a tragédia aérea, eclodiu na imprensa e nas redes sociais a disseminação de comentários declarando o 
desastre como o símbolo do ano difícil de suportar. Houve quem pedisse a 2016: acabe logo, por favor.

Considero que dizer que foi símbolo do ano nefasto o acontecimento causado pelo piloto e proprietário de avião que decidiu decolar ciente de que o combustível estava no limite é pouco. Se for símbolo, ele remete ao quê? E seja o que for, é referente apenas a 2016?

Penso que melhor é olhar para decisão de altíssimo risco como se ela fosse um hiperlink: clicar em cima do acidente e do insano que arrisca - e liquida com - a própria vida e as vidas de setenta outros, na presumível intenção de poupar e lucrar umas merrecas a mais com a economia de combustível, e esse clique dará passagem para a metafísica. Sim, dá passagem para a metafísica, e peço ao leitor que me perdoe por essa afirmação que tem aparência de trocadilho acidental e infeliz sobre o fim que veio de súbito. Espero que ela seja entendida como algo mais do que isso.

Metafísica não é somente para falar de Deus, do Nada, da atemporalidade do Tempo, do Espaço como vazio substrato da multiplicidade dos lugares e de outros infinitos sobre os quais é preciso muito dizer para tangenciar dizer os porquês do impossível de eles serem capturados pelo finito da linguagem. Não é somente deixar em suspensão a hipótese de que todos esses intangíveis não sejam mais (ou não sejam menos) do que sonhos.

Metafísica também serve para fazer truques de desaparecimentos. Por exemplo, a técnica, aliás, a Técnica. As técnicas são produtos históricos, são modos de lidar com o ambiente (com as mãos, com martelos e serrotes, computadores, ideias), maneiras de não apenas nos adaptarmos ao ambiente, mas de adaptarmos o ambiente a nós. As técnicas são modos de lidar. E acúmulos de modos de lidar. E rupturas e reinvenções do modo de acumular modos de lidar com: o mundo. $\mathrm{O}$ mundo feito de pessoas fazendo técnicas. As pessoas fazendo técnicas conforme o mundo onde nasceram. As técnicas fazendo pessoas... Oculte-se o processo, 
exalte-se o produto, aliene-se a noção de que é das relações cotidianas que emergem as técnicas, o que vai para o trono? A Técnica. A Grande Deusa, essa agora que é apresentada como a razão de si mesma, sem nascimento, eterna, sem história, acima do mundo que a pariu. Semelhante ao totem cultuado como se ele mesmo fosse o deus, adorado por gerações que esfarelaram a memória de que foram seus ancestrais que o esculpiram. Quem vem ao mundo já encontra a Deusa Técnica instaurada: é preciso servirlhe servindo à aceleração de tudo, correr, correr e correr para produzir, produzir e cumprir os prazos de multiplicadas metas. Um controle se instala: internalizar a aceleração como jeito de ser. Correr, correr e tornar-se mais carente de aparelhinhos de bolso que nos acompanharão por toda parte e que nos deixarão mais rápidos para digitar mais e mais enquanto atravessamos a rua de costas para o trânsito e somos atropelados pelo motorista que não nos viu porque também digitava em seu aparelhinho, pois precisava postar com urgência um desaforo nas redes sociais contra o sujeito que...

Isso é metafísico, não? Tornamo-nos sem corpos. Sim, sem corpos. Agora somos deuses, ascendemos para além do físico. $\mathrm{Ou}$ tem corpo este que vimos ainda agora atravessando a rua e digitando em seu aparelhinho e de costas para o trânsito, alheio aos motoristas alheios aos pedestres? É claro que ele não tem corpo. Tornou-se inatingível. Ele e nós e o piloto-proprietário do avião não morremos mais.

O dinheiro, por exemplo. Ele nasceu e cresceu como uma técnica para facilitar as trocas entre produtos diferentes. Quantas enxadas valem sete sacos de trigo? Valem quanto o tecido e o trabalho de alinhavar o tecido na forma de saco em comparação ao trigo nele ensacado? Complicado estar-se sempre a discutir a quantidade necessária de uma coisa para equivaler ao valor de outra coisa. O dinheiro é uma das invenções universais que demonstram para nós mesmos, atuais representantes da espécie que o criou, o quanto somos capazes de criar instrumentos abstratos para os quais podemos olhar e declararmos orgulhosos: vejam (num diálogo imaginário com os primos primatas) como somos, nós, humanos, 
cotidianamente geniais. Mas quem se lembra, cotidianamente, do dinheiro como uma técnica de troca para o acesso aos bens necessários? O proprietário-piloto do avião? Suponho que ele pensava no dinheiro, no Deus Dinheiro, de outro modo, como algo que se fez razão e finalidade por si mesmo, sem nascimento, eterno, sem história. Metafísico, não?

Faz lembrar aquela história do pirata (ou talvez fosse um capitão fiel à Sua Majestade, esqueci os detalhes, são parecidos demais um com o outro, confundo os tipos) que, sabendo nadar feito peixe, foi ao fundo e morreu afogado por não desabraçar o baú pesado das moedas. Ah, sim, a história é do tempo das grandes pilhagens, dos impérios competindo pela posse de mares e continentes, das aldeias tornando-se um só mundo pelo avanço das técnicas a serviço do acúmulo de moedas. Antes, a competição era entre nações em busca de se afirmarem imperiais na corrida pela acumulação. A primazia agora é dos megacapitais empresariais em busca da autorreprodução e da expansão pela via do domínio sobre o mercado. Talvez isso tenha reflexos na metafísica do novo cotidiano, isto é, no modo de internalizar a diretriz da aceleração em busca de...

Talvez não sejam tão diferentes entre si o obsecado proprietário-piloto que decola sem combustível e o pedestre que vimos ainda agora atravessar a rua de costas para o trânsito e obsecado por seu aparelhinho acelerador de fluxos, alheio aos motoristas alheios aos pedestres. Acho que estamos todos, proprietário-piloto, pedestres e motoristas, transpassados pela mesma negação do óbvio perpetrada pelo cotidiano dominado pela metafísica.

Talvez não sejamos muito diferentes do gestor hospitalar obsecado em ampliar a taxa de lucro de $19,64 \%$ para $20,16 \%$, tão obsecado que faz questão de ignorar que os técnicos em enfermagem já foram empurrados até o limite da exaustão pelo somatório do tamanho da jornada de trabalho com o esgotamento existencial causado tanto pelas condições ambientais dos recintos 
quanto pela penúria da remuneração. $\mathrm{O}$ exemplar gestor apenas reconsiderará sua última decisão (cortar a despesa do café sempre disponível para os plantonistas) quando o quase adormecido técnico em enfermagem injetar a droga errada na veia do paciente impaciente e fã de um bom tumulto.

Serão mesmo assim tão diferentes entre si as lógicas que comandam as ações do proprietário-piloto, do gestor hospitalar, do diretor disso e daquilo, do fornecedor de leite com soda cáustica, do pivete ali da esquina, do Governador do Estado, do Presidente da República e dos donos do agronegócio? Ou será que a diferença não vai além do tamanho das cifras pelas quais se atenta contra as vidas e do fato de que as consequências da conduta do proprietário-piloto tornaram-se estrondosamente visíveis de uma só vez?

Desconfio de que essa enxurrada de filmes de legiões de mortos-vivos vagando pelas ruas e estradas de um colapso global é versão caricata da observação do cotidiano metafísico.

Metafísica não é somente para falar de Deus, do Nada e de outros infinitos e tangenciar o Impossível. Ela serve para fazer truques de ocultação: esquecimentos. Por exemplo, esquecimento de que temos necessidades por algumas levezas elementares, como o descanso e a vontade de nos desligarmos da obrigação de estarmos sempre estimulados pelos ditames da Técnica que acelera horas, minutos e segundos a serviço do Grande Deus Consumo e da Grande Deusa Acumulação. Metafísica é também a hipnose coletiva que faz desaparecer a percepção de que estamos sempre e sempre ciscando estímulos, feitos frangos estressados em regime de engorda acelerada para o abate em modernos aviários.

De negação do óbvio em negação do óbvio, passam por normais múltiplas e diárias situações que se tornam veículos para a produção cotidiana do esquecimento sobre o básico da vida: a vida.

Quantos séculos de história global insana são necessários para que um homem ache que está tudo normal ao decolar ciente de que o combustível está no limite do limite, em troca da chance de poupar algumas moedas? E para produzir a cena do pedestre que 
atravessa a rua fetichizado pelo aparelhinho que o torna alheio aos motoristas que aceleram alheios ao pedestre?

De quanto materialismo vulgar precisa a metafísica para multiplicar mortos-vivos crentes de serem deuses acima da mais básica noção de limites? De quanta metafísica precisa o materialismo vulgar para não se enxergar no espelho dos acontecimentos estúpidos?

Por que recordo o acidente e apresento esses comentários sobre cotidianos esquecimentos do óbvio, que, de tão estrondosos, tem jeito de metafísica surreal encarnada num materialismo vulgar? Para, por meio do contraste, convidar o leitor aos textos reunidos neste livro, pois o que aqui se manifesta é o retorno da atenção ao esquecido óbvio da vida: somos corpos que necessitam dos frutos da Terra e, para isso, trabalham, e merecem descansos e os acolhimentos de boas casas feitas de céus, mares, pedras e barro, e de cidades e campos plenos de encontros, e de memórias de vidas construtoras de casas. Talvez por aqui também pulse a metafísica, mas aquela outra, que namora os intangíveis que talvez não sejam mais (ou não sejam menos) do que sonhos. 



\section{PARTE I}

\section{Leituras de Leituras Feitas de Presenças e Ausências Geográficas}





\section{Paisagem-província, Corpos Pré-modernos e Fracturas da Memória}

Ana Francisca de Azevedo 


\section{Corpos de Trabalho, um Continuum na Cadeia de Subjugação Humana}

$\mathrm{D}$ estronado dos mapas presentes nos manuais escolares ou dos sistemas de informação geográfica, o conceito de província surge, à primeira vista, como ferramenta obsoleta, um intruso incomodativo que circula indevidamente (?) na memória colectiva dos portugueses associado à ideia de paisagem. Accionada pela propaganda comercial, turística e pelas indústrias culturais, a ideia de província vai sendo alvo de refluxos espasmódicos que, ora celebram o idílio rural ora dramatizam o abandono e a corrupção da natureza. A esquizofrenia latente que subjaz o uso desta ferramenta conceptual pode perfeitamente ser explicada pela sua falta de actualidade; um conceito que 'fez sentido' no tempo e no espaço em que foi produzido. Mas será assim tão simples? O que sustem o onde, o como e o quando da província?

O conjunto de transformações económicas e sociais que desde as primeiras décadas de Oitocentos resultaram num novo quadro político e administrativo para Portugal integraram a divisão do território nacional em províncias, comarcas e concelhos, denotando profundas tensões decorrentes da interpenetração de novas e velhas forças de poder. A província tornou-se parte integrante do edifício legislativo e administrativo, respondendo à assunção de uma nova classe política implicada com a redefinição de Portugal na Europa e no mundo e com a modernização dos sectores de actividade económica, processo que vinha já a ser preparado desde o século anterior. Se, o censo de 1527 permitiu a consolidação de uma estratégia de reconhecimento do território nacional completada pela representação cartográfica do reino de Portugal de Álvares Seco em 1561 e por trabalhos subsequentes, já “(n)os meados do século XVIII, dá-se o advento de uma nova representação do espaço, marcada pelos desígnios utilitaristas de reordenação territorial ligada a projectos de reforma da administração e da economia" (SILVA; ESPANHA, 1993, p. 44). Objecto de sucessivas estratégias políticas e ideológicas orientadas para o seu domínio efectivo pelos grupos de 
poder, o espaço era integrado numa cartografia do conhecimento através de representações que enfatizavam a continuidade entre diferentes tipos de descrições que desde os séculos XVII e XVIII, desenhavam os contornos do corpo do território nacional. Como salientam Ana Cristina Nogueira da Silva e António Manuel Hespanha (SILVA; ESPANHA, 1993, p. 44) “(a) estratégia de conhecimento prepara, a partir de certa altura, a da reforma territorial. Deve notar-se que o objectivo de reforma territorial só aparece quando se dissolve a ideia de que as marcações políticas do espaço estão indissoluvelmente ligadas a uma constituição objectiva do mundo físico-natural, [...] e sugere, em contrapartida, que o espaço, tal como a sociedade, podem ser objecto de reformas racionais."

A história da província encontra-se embrenhada na história da Razão, numa teia de re-ordenamentos espácio-temporais que responderam à transição 'do poder soberano ao poder disciplinar (FOCAULT, 1976), particularmente desde finais do século XVIII a finais do século XIX. Não obstante, tal transição estaria longe de ser pacífica, num contexto em que a geografia como ciência moderna preparava a sua institucionalização enquanto ciência dos homens de Estado e do poder político, dentro da qual a fisionomia do território assumia funções de uma “'lei geográfica' da política e da guerra, (operando) a substituição da força 'legislativa' do direito internacional (lei 'política') pela força 'legislativa' das condições geográficas (lei 'natural')" (PIMENTA, 2004, p. X-XI). A materialidade do território funcionava pois como pretexto para legitimação de políticas identitárias e a representação como esfera de acção. A despeito das diferentes propostas de reestruturação territorial que marcaram uma ambiência cultural em profunda mutação, o estudo detalhado de cada província como base para a proposta de uma nova divisão administrativa na Primeira República foi entendido como indispensável para a reforma do país no conjunto das 'nações civilizadas', mostrando bem a força operativa do conceito para a afirmação da identidade nacional que iria encontrar veículo de legitimação no ambicioso projecto disciplinar 
da ciência antropológica, dedicado à história natural do homem. Especificamente, através do decreto $\mathrm{n}^{\circ} 23$ de 16.05.1832, da autoria de Mouzinho da Silveira, e ao nível do direito administrativo, a província era apresentada como a mais vasta das circunscrições administrativas com base numa autarquia local com âmbito e competências de um magistrado administrativo, na qual se previa exercer funções um prefeito auxiliado por uma junta geral electiva. Tentava transpor-se para Portugal, e de forma sistemática, a organização administrativa francesa, que na sua versão anterior de regime absolutista representava uma circunscrição vocacionada para fins militares, mas que em 1808 com Junot, viria a alargar-se a circunscrição administrativa para efeitos gerais. Contudo, por razões diversas, a autarquia provincial não funcionou como esperado ${ }^{1}$, não sendo de descurar a dificuldade de importação de modelos externos a uma realidade nacional dentro da qual a renegociação de poderes em torno da administração e jurisdição dos territórios não era clonável.

A ideia de província foi-se metamorfoseando de acordo com as sucessivas transições políticas, acomodando-se aos mecanismos da Razão e do poder disciplinar, do poder soberano e do poder da pastoral cristã que ecoava dos tempos medievais. Tentava desenvencilhar-se o conceito de província da sua herança medieval, da tutela do clero e dos senhores da terra, atendendo à profunda interpenetração entre a noção de província como divisão administrativa, divisão territorial de certos Estados, e a noção de província eclesiástica, o conjunto de propriedades pertencentes a uma Ordem monástica dentro do mesmo país, governado pelo provincial, superior religioso de uma província (COSTA). Nesta acepção, a província correspondia ao espaço directamente controlado pelo provincial, entidade detentora de superioridade hierárquica, o erudito medieval que transitara para o Antigo Regime com o domínio da linguagem, da erudição, locução, maneiras e costumes (e das sociabilidades comunitárias). A terra encontrava-se

1 - O Manual de Direito Administrativo da autoria de Marcello Caetano com data de 1973 é uma fonte bibliográfica valiosa para a compreensão parcial deste processo. 
regulada por um sistema filosófico, o providencialismo, que tudo atribuía à providência divina, pelo que o provimento, o ato de abastecer, era mediado pela lógica religiosa de 'dar providências', do prover, regular, despachar, nomear ou dispor dos proventos da cultura da terra gerados pelos seus habitantes. A província permitia abastecer as Ordens e os provinciais, e 'remediar' os que nela trabalhavam, numa ordem dominante de propriedade e controlo do corpo e do território em que esta era colocada num quando e num onde ambíguos, definida em várias fontes como todo o território excepto a capital. A passagem da verdade divina para a verdade científica gerou a deslocação da conotação 'positiva' de provincialismo para a conotação negativa de provincianismo, nas maneiras, costumes, locução ou sotaque; do provincial para o provinciano. Tentava resgatar-se a ideia de uma região equívoca e obscura, ininteligível para os domínios da Razão, para uma nova ordem discursiva dentro da qual o sentido da origem pura, da pastoral e da margem prevaleciam. Do provincial como o representante da Providência, da sabedoria suprema de Deus em favor dos homens, o designado para assegurar o controlo e a provisão das comunidades sob tutela, para o provinciano, o habitante da província, percebido como género humano natural de uma terra, comunidade ou região, para o qual a própria etimologia do termo remete; a ideia de proveniência como lugar donde uma coisa ou pessoa provem, como uma origem, procedência ou fonte.

Mas era ainda um legado anterior, o legado imperial do próprio termo, que se via renegociado num outro regime político e ideológico, respondendo à tendência histórica de colonização e preparando o quadro da racionalidade imperialista de domínio e ocupação de territórios e recursos do século XIX. A província, designação atribuída pelo império romano aos territórios que se iam tornando sua propriedade após guerra vitoriosa, eram territórios 'externos' providos de organização própria mas submetidos ao imperium de um magistrado escolhido pelo Estado e a sua organização competia ao Senado. Constando de um diploma especial, a lex provincialis, geralmente redigida por um general, 
continha 'tudo' que interessava, tal como os limites do território e o conjunto da informação necessárias para o comando superior das forças locais, a jurisdição civil, criminal, fiscalização de cobranças ou impostos. A ideia de província encontra-se em todas as épocas associada aos mecanismos de governação do território e dos seus recursos físicos e humanos. A genealogia do conceito moderno de província parece encontrar raízes na ideia de território conquistado, claramente definido pela província romana (provincere), os espaços conquistados que passavam a integrar o império (etimologicamente, o domínio dos vencedores), um país ou território fora do Estado Romano, sob domínio romano e administrado por um governador enviado por Roma.

Enquanto divisão administrativa de um país ou Estado, como principal divisão de um reino ou império, como área sob jurisdição de arcebispos ou 'metropolitanos', o conceito de província consolidou-se como designação compreensiva para todas as partes do território fora da capital, mas sob domínio. A construção cultural da província foi incorporando as diferentes formas de poder que a cada momento modelavam as tecnologias de organização da experiência e a formação de subjetividades. A província moderna é entendida como as outras partes de um território, ainda assim como sua parte integrante. $\mathrm{Da}$ exaltação da escola de poetas provençais e da sua influência na literatura como parte integrante das batalhas de lugar dos franceses, da defesa das instituições, interesses e culturas comunitárias, da luta pela autonomia da província acima dos interesses da unidade nacional no século XIX, a Provença como domínio simbólico do império Romano no espaço Europeu, à evocação da barbárie das maneiras provinciais pelos ingleses ( $\mathrm{da}$ moda, à estreiteza de pensamento), que, desde o século XVII, detinham termos como to provinciate para o acto de reduzir à condição de província, ou countrified person, para os que habitavam a província ou dela provinham, ou ainda o uso que faziam do termo quando se referiam aos nativos irlandeses ou aos habitantes brancos da América do Norte². 
Para Portugal, as políticas de lugar esgrimidas em torno do conceito de província, durante o século XIX encontram-se bem testemunhadas por obras que, como a de Leite de Vasconcelos, tentavam lidar com a força metonímica das palavras dobradas pela cultura oficial investida da missão de corrigir os barbarismos que caracterizavam os sujeitos e a educação provinciana. À ideia de 'fala própria da aldeia' como algo a corrigir em prol da unidade nacional, contrapunha-se a escolha particular de certos vocábulos, alterações na fonética das palavras e na construção das frases como manifestações de cultura nascidas da vida e da experiência de todos os dias, como locuções que emprestavam à narrativa realismo, movimento e vivacidade, usados por escritores. Escritores que se quis entender como prestando testemunho de provincianismos, que se celebraram como valorosos contributos da mostra da cultura popular, como repositórios do vernáculo local; o minhoto para Camilo, o Beirão para Aquilino, os alentejanismos para Fialho. Neste contexto, a província surgia como área específica de intercepção com 'outras' identidades, diacrónica e sincronicamente.

Aparentemente desconectada das instâncias de domínio e administração colonial, a província convocava valores e representações que não podem dissociar-se do forte legado da antropobiologia nos produtores do pensamento colonial português do período, reenviando também para uma noção antropológica de cultura assaz primordialista, como característica típica da psicologia dos povos rústicos no âmbito do evolucionismo cultural que insuflava a ideologia do estado-nação. A designação de província não remetia explicitamente para as questões de raça ou etnicidade que regiam os discursos sobre os territórios ultramarinos, o código administrativo ou as leis do trabalho de então. Mas, a ideologia metropolitana do período, fundada sobre uma visão estritamente eurocêntrica do trabalho dentro da qual só se encontrava inserido na

2- The Oxford Universal Dictionary on Historical Principles. Oxford University Press (1933). 
economia de mercado o detentor de propriedade passível de ser comercializada, fomentava a invisibilidade do trabalho não remunerado fundada na ideia do dever moral do trabalho.

Se, para os territórios ultramarinos, a designação de indígena funcionou juridicamente como recurso operativo para legitimar uma forma de opressão diferente da de escravatura, como meio de justificar o recrutamento forçado de trabalhadores (CAHEN, 2009, p. 155), já ao nível doméstico, e para justificar as prática capitalistas de exploração de recursos humanos, a designação de provinciano terá funcionado como recurso operativo para legitimar uma forma de exploração que colocava o grosso da população portuguesa num patamar largamente inferior frente a um género humano 'novo e único'; o moderno. Descurar o alcance das leis pombalinas que vieram a determinar gradualmente o fim do modelo esclavagista de relações de produção na metrópole lusitana e das quais resultaram consequências económicas e sociais variáveis de região para região, seria ingénuo. É que, as consequências do branqueamento da metrópole que se faziam sentir por toda a Europa também fizeram sentir-se em Portugal mas de outro modo, com repercussões directas no recrutamento de mão-de-obra 'branca', da dita província. Os trabalhos mais pesados eram assegurados com base no recrutamento progressivo de sujeitos provenientes 'das periferias'.

Apesar das variações na interpretação das sucessivas disposições legais que integraram o pensamento constitucional Oitocentista, a província metropolitana e a colónia ultramarina faziam parte de um continuum na cadeia de subjugação humana. Relativamente à segunda, a situação de menoridade civil determinada por lei para o liberto e com vista à sua protecção e educação civilizacional, era incompatível com o exercício dos direitos políticos (SILVA, 1993, p. 236). Como explica Cristina Nogueira da Silva (ibidem, p. 236) "a fastar algumas pessoas do exercício dos direitos políticos não era um problema complexo para o pensamento constitucional de oitocentos. Era comum distinguir-se 
entre os cidadãos que podiam e os que não podiam exercer direitos políticos, existindo para isso critérios universalmente aplicáveis; o censo, o grau de alfabetização, a idade e outros, considerados como sinais de presença da 'autonomia da vontade' dos sujeitos.” A aplicação destes critérios colocava em situação de menoridade política parte significativa da população metropolitana, desde logo porque analfabeta. A questão dos direitos naturais é também complexa deste outro lado do continuum, desde logo porque o entendimento da menoridade como momento na constituição do indivíduo, deixava ampla margem para a manutenção das posições na cadeia hierárquica de apropriação do direito aos e dos indivíduos. Como limite extremo de apropriação do sujeito em território metropolitano uma figura específica da mulher da província permaneceu até meados da segunda metade do século XX sem estatuto jurídico definido mas como figura socialmente aceite: a criada doméstica.

Aquilo que pretendo ressalvar é que a evolução ideológica e política na transição do século XIX para o século XX, assentou em grande medida numa reorganização social que, tanto da parte dos poderes conservadores como da burguesia liberal, integrou a exploração de segmentos do social que ignoravam quase por completo a cultura dos que os exploravam, a moderna cultura urbana. Mais, defendo que esta evolução ideológica e política assentou na edificação de uma sofisticada máquina de biopoder que permitiu sustentar o crescimento da cidade, e que os discursos do progresso, da higienização e da mecanização, da estética da máquina e do movimento, e da filosofia das formas puras, tão bem mascararam. E se a minha interpretação é passível de suscitar críticas no sentido de uma excessiva atenção ao marginal e ao periférico, esta é feita precisamente com esse intuito; compreender o desfasamento entre a circulação de ideias e modelos científicos, filosóficos e estéticos e as práticas de uma época, como modo de sublinhar o facto de que, tal como na actualidade, o estatuto de periférico e marginal engloba muito mais do que uma minoria. $\mathrm{E}$ ainda que assim não fosse, a dinâmica das relações de grande prestígio que 
alimentaram o ethos heróico moderno e a dinâmica das práticas de sujeição adoptadas em cada momento tem de ser alvo de escrutínio, por não se encontrarem divorciadas.

\section{Encontro Colonial, Expressões de Redomesticação na Metrópole Portuguesa}

Sobretudo na capital, a reorganização tecnológica da experiência operou-se em grande medida com base na força de trabalho 'dos provincianos' numa escalada de branqueamento que colocava o cidadão como centro de premissas doutrinárias, dentro das quais Rosseau e o Iluminismo serviam como fonte de inspiração para o realinhamento dos mecanismos de sujeição de 'outras' classes sociais e corpos vários. No entanto, e como sublinha Ricardo Roque, a afirmação de um nacionalismo imperial assentava num modelo de contrato social entre soberanos europeus e povos indígenas que emerge como reverso do contrato social de Rosseau; “o poder dos governantes, no contrato imperial, não deriva do povo nativo; a este cabe um papel de sujeição e obediência total [...], (pois) o imperialismo, neste sentido, estipula o direito à 'autopreservação'”. (ROQUE, 2011, p. 39). Porém, a ideia de povo nativo aplicada exclusivamente às províncias de além mar deixa dúvidas. É um espaço de tensão que está por esclarecer e que encontra ressonância na designação Oitocentista de ciências sociais do homem natural, da região natural. A própria ideia de "biogeografia universal contém todas as características de um metaparadigma que percorre transversalmente todas as ciências do homem natural, do homem espécie” (PIMENTA, 2004, p. XIII). A humanidade como resultante biológica do meio difere em raça de acordo com as diferenciações do próprio meio. $\mathrm{Na}$ sua formulação colonial esta acepção era perfeitamente clara, turvando-se a compreensão da sua aplicação no que respeita às províncias intrauterinas do território metropolitano português. 
O poder da analogia evolucionista no pensamento Oitocentista, servindo paralelamente como política de naturalização do espaço e dos corpos ao serviço do Estado, ajuda a compreensão da sua aplicação. A questão do movimento e das migrações, é central em todo este processo, como central é a problemática da miscigenação aplicada, uma vez mais e apenas, aos territórios ultramarinos e silenciada para a metrópole por trair o princípio de fixação e estabilidade da ideia de identidade colectiva. A correspondência entre a afirmação sociológica das disciplinas científicas, a luta pela personalidade científica, e o modelo político dominante no trajecto da burguesia Oitocentista para a tomada de poder exprime não somente uma visão do mundo, mas também uma crise ao nível da viragem paradigmática cuja resposta resulta numa separação entre raças naturais e raças históricas, salienta José Pimenta (2004). O detectar de tal peculiaridade como marca da geografia Oitocentista portuguesa é determinante para a compreensão da integração dos modelos dominantes de organização do espaço no contexto da cultura portuguesa ${ }^{3}$. Mais do que um atraso na integração dos modelos mais avançados da civilização moderna, esta é uma das configurações possíveis da modernidade, uma outra resposta à transformação na organização da experiência que a história forçava num momento em que o ser humano se confrontava com um novo mistério; Deus como a consciência do indivíduo e a natureza como possibilidade última de materialização das relações de transcendência.

O movimento de formação da consciência histórica e geográfica fez parte de um movimento mais vasto de formação da consciência antropológica e da consciência sociológica do sujeito do

3 - Para uma compreensão aprofundada da problemática consultar a publicação, Obras de Silva Telles. A Ciência Geográfica. APG: Lisboa. Esta problemática é tratada especificamente na análise introdutória à obra por J. R. Pimenta. Como o autor salienta, "apesar de apresentar as imagens e o sentido da natureza sob uma retórica explicitamente positivista, materialista e recheada de analogias e metáforas orgânicas [...] Silva Telles preserva manifestações mecanicistas na sua linguagem [...] enriquecida por hesitações neo-lamarkianas" (2004, p. XVIII). 
humanismo, manifesto na ciência, na arte e na estética contemporâneas, o que possibilitou a redefinição 'dos lugares de cada um' e, paralelamente, a possibilidade de os suplantar. Tal movimento das ideias e das políticas metropolitanas e coloniais, ao colocar-se prisioneiro das novas hierarquias de classe como fundamento de outras formas de exploração legitimadas pelo modelo de evolucionismo cultural e biológico e pela ética da diversidade, recorreu à óptica primordialista como forma de descriminação da aldeia relativamente à cidade, da província relativamente à capital. Uma outra viragem no conceito de província decorria pois de uma viragem na própria cosmovisão, tornada definitiva agora para o sujeito racional. Neste processo, uma versão cosmológica e sexualizada colocava a mulher como bolsa de fertilidade e trabalho doméstico, domesticada e passível de ser violada, preparada para o trabalho da terra, fonte primeira de subsistência do agregado familiar num quadro comunitário de sedentarização e de uma ideologia da aldeia natal e do solo nação, masculinizado, pelo sangue da raça.

Acompanhando a renegociação das relações com as outras potências imperiais, a renegociação das relações com o Brasil e a tentativa de definição de novas políticas para os territórios aquém e além-mar, tentava resgatar-se o país de uma crise económica que se acreditava ser possível suplantar através de uma nova dinâmica financeira, da actividade industrial e mercantil e da activação do mercado de capitais pela banca e pelas novas mobilidades. Não obstante, para um país cuja economia interna dependia sobremaneira do sector primário, a província tocava os carrilhões da certeza de sucesso de uma série de reformas que afectariam a ruralidade e o sistema de propriedade e que contribuiriam decisivamente para a afirmação do Portugal moderno. Neste enquadramento, a província funcionou como parte integrante das políticas de produção da região liberal, com os seus corpos geográficos.

O modo como a província operou a produção da região liberal prende-se com a definição dos mecanismos económicos para 
as diferentes partes do país, sobre os quais assentou a incorporação dos modelos de civilização e progresso que irradiavam das mais poderosas potências imperiais. À escala doméstica, este processo teve também como efeito a reordenação da hierarquia de corpos e territórios, de dinâmicas espaciais geradoras de linhas de divisão facilitadoras das novas formas de desigualdade social e geográfica no contexto de uma visão implícita e explícita do trabalho como actividade mercantil. A província foi naturalizada como parte integrante do projecto da modernidade e, para os 'educados', era parte integrante de uma geografia da nação moderna e colonial dentro da qual cada corpo era retratado no seu lugar, um lugar em que o sentido de pertença pressupunha a fusão orgânica entre identidade e território, cumprindo uma linha hierárquica que se deslocava do primitivismo à civilização. Tratava-se pois de reorganizar em quadros estáticos e harmoniosos, - a paisagem, novas políticas de centro/periferia passíveis de responder aos re-arranjos geopolíticos das nações e ao apelo das sociedades industriais e do capitalismo. E se a revisão das constituições da república enfatizava a necessidade de assegurar a igualdade de todos os cidadãos sem distinção de origem, raça ou religião, certo é que, no caso português, a solução do trabalho forçado nas colónias legitimada pelo indigenato encontrava ressonância na metrópole no recrutamento de mão-de-obra, da criadagem e dos analfabetos para todo o serviço, por forma a responder a uma ideia de modernização do país bem como aos acordos comerciais com as outras potências que desde há muito exploravam os recursos físicos e humanos no continente como nas ilhas.

Enfatizando a pureza congénita dos lugares, uma identidade primordial e inalienável da terra e das gentes circunscritas em áreas protegidas dos efeitos secundários do progresso e da civilização, a ideia de província permitia a paulatina deslocação da noção de provincial para provinciano, esse género pré-moderno responsável pelo atraso da nação mas paralelamente fundamental para a sua coesão, o qual se distinguia do 'vadio urbano' através da exaltação da puritana convenção pastoral. Os fundamentos ontológicos, 
epistemológicos e éticos mobilizados neste processo artificial de construção de categorias espaciais e identitárias, permitiu o acentuar das descontinuidades territoriais e de classe legitimadas pela jurisprudência, pelo manuseamento hábil das teorias científicas e pela celebração dos conceitos que, como o de cultura, condenavam o grosso da população à ignorância, à pobreza e à subjugação. $\mathrm{O}$ sentido unívoco de modernidade mascarava os mecanismos artificiais de definição da alteridade e fracturava as continuidades intrínsecas que caracterizam germinalmente uma cultura. A reificação de uma civilização radicalmente nova e libertadora pelos centros de império mais poderosos contaminava as demais potências com territórios metropolitanos colonizados, justificando o recrutamento e exploração dos sujeitos sem propriedade de terra e das 'raças naturais', dentro de uma nova ordem de reorganização do trabalho e de uma doutrina que apregoava a igualdade para o sujeito do humanismo.

O conceito moderno de província, assente sobre o ideário do humanismo e da maioridade política e sobre o dualismo tradição/modernidade, possibilitava a acomodação de corpos subalternos, de um género humano pré-moderno, num quadro jurídico que legitimava formas de descriminação e controlo entre os grupos populacionais que habitavam um mesmo território sob designação de colectivo nacional. Internamente, permitia apaziguar as batalhas que se esgrimiam entre velhos e novos poderes, respondendo ilusoriamente à perpetuação dos primeiros, cabalmente à afirmação dos segundos, e decisivamente à reconfiguração da ordem social e económica no quadro de uma cultura hegemónica emergente. A província moderna surgia como uma série de espaços periféricos e circunscritos que urgia redomesticar, o domínio da natureza configurado em retratos de paisagem de que a civilização moderna não prescindia pelo seu valor económico e pela garantia do 'enraizamento', tornados terra e gente uma vez mais em mercadoria. Mas a redomesticação desses espaços urgia também pelo seu significado simbólico; para os monárquicos, que não prescindiam do direito de propriedade dos espaços metropolitanos de inscrição das 
suas linhas de sangue que remetiam para a fundação da nacionalidade e que se alargavam à amplitude do território; para a burguesia liberal, que, por mecanismos de reprodução social, reclamava esse mesmo espaço simbólico como espaço de inscrição e, para o clero, cuja engenhosa máquina de controlo com epicentro em Roma reorganizava o controlo da população em todo o território desde a paróquia à arquidiocese.

Como uma muito séria ficção, a província moderna configurava-se como espaço constituído por relações sociais, económicas e jurídicas que enfatizavam as descontinuidades territoriais através de constelações de forças éticas, morais e ideológicas em colisão, forças implicadas, por uma lado com as políticas urbanas de mercantilização e, por outro, com a manutenção de uma ordem dominante (herdada do Antigo Regime), que renegociava o comando da terra e seus recursos com a violência do capitalismo e com a subtileza de uma estética naturalista do evolucionismo cultural marcadamente androcêntrica. Neste processo, que colocava a província como um espaço-tempo subalterno, designações como o norte, o interior ou o sul de Portugal funcionaram como estratégias de posicionamento dos mais pobres ou atrasados na corrida ao progresso, daqueles cujo determinismo geográfico legitimava um discurso dominante como central ao desenvolvimento histórico de um projecto político muito mais vasto e definido na cidade e por quem está 'de fora'. Complementando a política de colonização branca e o domínio da metrópole pelas elites, tais estratégias funcionavam como meio de controlo dos corpos e territórios ditos periféricos pelos 'senhores da terra' e pelo exército, às escalas local e regional, tendo em conta as 'trocas' a que deu lugar a revisão do sistema de propriedade. Neste quadro, duas regiões culturais foram sendo construídas material e discursivamente para o território metropolitano português e consolidadas durante o século XIX, preparando a entrada no século $\mathrm{XX}$ : a cidade e a província. $\mathrm{O}$ engordar da primeira à custa da segunda representa um dos problemas mais graves com os quais nos debatemos ainda hoje. 
À semelhança do que aconteceu noutros países em que a dicotomia cidade/campo integrou o projecto do nacionalismo, bem como o branqueamento das metrópoles, a província portuguesa traçou o seu próprio trajecto. Esse ser um tempo lento num espaço distante, intramuros, merece um escrutínio atento à sua motivação ou ressonância extramuros, se queremos perceber quem somos na armadilhada histórica de poetas e navegadores com geografia de uma manhã de nevoeiro subtropical, racionalmente marcada num mapa universal 'pelos modernos', devotados a atribuir fisionomia a um território cujos nativos se debatiam, de forma diversa, com o culto do exílio e da saudade, ou com o esforço da sobrevivência. Isto, num contexto em que um novo modelo de cultura prefigurava a substituição abrupta dos modelos convencionais de organização tecnológica da experiência, iniciando um processo abusivo de desqualificação das micro-economias e culturas de auto-subsistência, forçando uma perigosa correspondência entre teoria e prática de ser no espaço e no tempo, do ser com o Outro. Trata-se pois de repensar a moderna construção de província percebida como geografia de um Eu subalterno (das identidades subjugadas dentro dos espaços metropolitanos) que, não sendo explicitamente uma geografia do Outro, também o é, por assentar na definição de linhas categóricas que dividem a espécie humana em dois géneros: o moderno e o pré-moderno. Uma geografia imaginária tornada muito real pela Lei e por práticas concretas de recodificação cultural, assente nas dicotomias rural/urbano, natural/cultural, moderno/tradicional ou rico/pobre. Estrutura forjada 'na metrópole' ou por 'metropolitanos' como processo de construção identitária do $\mathrm{Eu}$, o sujeito urbano do humanismo, frente a um Outro, o objecto humano a civilizar, preferencialmente rural ou 'etnicamente dúbio', destituído de solo mercantilizável, da propriedade da terra e do seu próprio corpo, sem estatuto jurídico definido (como era o caso das crianças e adolescentes transacionados para efeitos de serventia a que as feiras de criados e os processos migratórios prestavam invisibilidade). Tais sujeitos inaptos relativamente ao domínio das formas simbólicas e das modernas 
tecnologias de organização da experiência e da economia liberal foram tornados objecto de aculturação no fervor das modernas deliberações institucionais.

A questão tão seriamente desenvolvida por uma série de autores, desde Fanon a Said e a Bhabha, entre muitos outros, que persegue a compreensão do encontro e do psicodrama colonial como forma de clarificação de um conjunto de alicerces sobre o qual assentou a época contemporânea, de explicitação das tantas arestas da problemática colonial e suas repercussões para o presente, implica pois a recolocação desse mesmo encontro tendo em conta todo o processo de categorização de corpos, territórios e culturas como um processo que engloba um leque vastíssimo de geografias de exclusão dentro das próprias metrópoles, envolvendo o sujeito 'branco', a unidade espacial 'província' e a ideia de paisagem como construção essencial através da qual se legitimou o moderno retrato-mundo. E esta é a nota para que pretendo chamar a atenção num momento em que um sério exercício se desenvolve dentro e fora da academia com o intuito de detonar os legados imperiais e colonialistas que marcam as políticas e práticas quotidianas. Por identificar um veio deformador que persiste nas formulações correntes aprisionadas numa sistemática oscilação entre norte e sul, branco e preto, colonizador e colonizado, mas também porque tais formulações incorrem numa miopia persistente relativamente à miríade de 'entres' sobre a qual assenta a própria modernidade, mesmo quando se desloca o discurso para a necessidade de ter em conta a riqueza emancipatória dos territórios de fronteira ou do hibridismo.

Num momento em que a estratégia de consolidação do imaginário colectivo nacional se debatia com o desmantelamento de anteriores categorias de conhecimento e com a crescente incorporação da diferença nas narrativas do progresso económico e na fixação da ideia de cultura com as suas categorias antropológicas e estéticas de inclusão e exclusão, a ciência, a arte e a tecnologia, percebidas também elas na sua moderna acepção, iam respondendo a este desígnio por se encontrarem implicadas com um projecto que irradiava dos centros de poder. 
A resposta da ciência e da arte separadas pela ambiguidade de um sistema de pensamento cartesiano que fracturava corpo e mente e colocava o domínio da experiência ancorado em um e só um destes dois atributos, se funcionou como modo de legitimação da passagem de um modelo teológico de conhecimento para um modelo teleológico de conhecimento, não poderia, a despeito da força ideológica que o sustinha, deixar de dar espaço a toda uma multiplicidade de formas culturais que se mantiveram com estatuto marginal ou excêntrico, resistindo à premissa da universalidade. E se, nos finais do século XIX, a modernidade se sondava numa profundíssima transformação nas tecnologias de organização da experiência, como tão brilhantemente explica Walter Benjamin, esta era parte essencial daquele mesmo encontro, um encontro marcado por uma agressiva colonização cultural que contaminou 'os nativos' das diferentes metrópoles com uma doença a que a nova medicina não sabia dar resposta. Este não era, portanto, um problema de medicina tropical mas um problema de 'medicina temperada', um problema que afectava os grupos dominantes e que a psiquiatria com o seu cortejo de fórmulas ajudava a resolver condenando sobretudo as mulheres a novos espaços de reclusão, pois que, para os outros subalternos, uma potentíssima arquitectura de espaços de exclusão preparados para prevenir a doença e o 'desvio', e para alojar os infectados do corpo ou da mente, era suficiente. A maladie du siecle, afectou Portugal tardiamente, podíamos dizer, como já é tradição. Eu diria apenas que nos afectou diferentemente, porque diferente foi o encontro colonial, da modernidade, na metrópole portuguesa, sem revolução agrária (?) e sem revolução industrial (?), à luz da nova sociedade mercantil e da nova ordem monetária.

A resposta dos homens 'dos climas temperados' à doença (encontro) da modernidade foi variada e circunstancial, a das mulheres silenciada, a 'dos outros' metropolitanos, dramática, ainda que o mais progressivo motor da transformação. A província explicava este fenómeno de inadequação dos corpos tornados objectos, de mudança. A materialidade do espaço funcionava como pretexto da inadequação pela definição da província como paisagem 
tipo do sujeito pré-moderno. A panóplia de técnicas e tecnologias de reprodução mecânica que ao tempo se desenvolvia robustecia esta representação cultural que, através do efeito da imagem, da mimese e do realismo, levava a um público progressivamente mais vasto a ilusão da província. Em Portugal, nos finais do século XIX, quase tudo era província e a transformação nas tecnologias de organização da experiência produzia-se em grande medida artificialmente, abruptamente, para fazer valer o império, terraplanando anteriores encontros com especificidades próprias, mas, sobretudo, terraplanando os efeitos da ameaça do colapso da transcendência, esse salto para um devir que a modernidade reclamava.

\section{Imperialismo Urbano, Movimento de Acomodação do Género Humano Pré-moderno}

Caixa de violetas cristalizadas que os amantes ofereciam às amadas como relíquia de mundos perdidos, a província moderna é elemento constituinte do cosmopolitismo Novecentista que reivindicava para sua própria constituição a 'verdade' regeneradora do campo, pela evocação de uma origem que os diversos movimentos estéticos iam expressando. À primeira vista, a construção harmoniosa de cultura e natureza, a paisagem-província, funcionou como ferramenta crucial num processo de aculturação que apaziguou as batalhas sociais em torno da negociação das políticas de centralização que recolocaram a urbanidade como o clímax da civilização. Uma tentativa de compreensão demorada do romantismo português, ou dos romantismos em Portugal, nas suas diversas manifestações, ajuda a compreender que talvez não tenha sido assim tão simples ${ }^{4}$. A construção da província passou pela afirmação cultural das urbanidades modernas, pela autorização da

4 - Para uma melhor compreensão deste argumento, entre outras, consultar a obra de Alvaro Manuel Machado, Les Romantismes an Portugal. Modeles Etrangers et Orientations Nationales, FCG-CCP: Paris, 1986. 
voz do sujeito do humanismo na produção dos discursos e representações sobre a província, o qual, através da experiência desta ficção, do contacto com 'os provincianos' de diversos tipos, funcionou como tradutor de uma alegada essência do lugar e do carácter do seu povo (culturas e lugares cristalizados no tempo). E se muitos dos intrincados romances consumidos pelas camadas letradas exploravam a raiz cultural de uma nação popular, estes enunciavamse frequentemente como narrativas de viagem que propunham a descoberta de um país e de uma nação moral a que a ciência dava voz. E não será a ciência moderna a maior utopia romântica?

A importância do 'ter estado lá' era condição determinante para o forjar de uma cultura da viagem e do visual, para uma cultura que através da estética da contemplação 'da natureza' integrava o nexo do movimento e do visual, e uma nova relação com o absoluto dentro da qual a linearização da memória detinha papel crucial. Aliás, era condição determinante da própria 'era da reprodução mecânica', por indexar a ideia de natureza original e o grito da possibilidade da sua mera não existência. Através de narrativas e imagens, os artistas e os cientistas, os viajantes, os escritores, os cronistas, produziram textos de natureza diversa que provavam que tinham estado lá, não somente como observadores mas como intérpretes. Textos que a cultura oficial decantava para audiências ávidas pelo consumo de curiosidades 'do povo', e que lhes permitiam construir-se a si próprios, pela diferença, como modernos. Tais relatos sobre a província lembravam-lhes que eles já não eram daquele 'ali', funcionando como mecanismos de descorporização da natureza. Em grande medida, a construção cultural da província moderna passou pela produção de espetáculos da diferença (para os dois lados), pela exibição de monumentos de rusticidade, ou de marcas materiais e imateriais que sublinhavam o carácter único de cada região, em que a ideia de paisagem configurava a sua própria formação social. A celebração da fotogenia da paisagem associava-se à evocação de mundos residuais, testemunhos materiais de pristinas que, no quadro de um romantismo dito tardio, traduzia ritos de lamentação de experiências de ser perdidas no tempo. Para alguns a 
província era o Portugal passado, um Portugal idealizado com base num campo não industrializado mas genuíno, donde poderia obterse um território para consumo, observação e contemplação. Para outros, a província não era.

À semelhança daquilo que aconteceu noutros países, a construção da província portuguesa teve em conta o valor potencial dos 'espaços naturais' enquanto vistas privilegiadas do moderno observador e como reservas de produção da diferença que tinham de ser experimentadas, ainda que por mediação. Mas a especificidade da província portuguesa moderna não deixa dúvidas, nem permite generalizações, nomeadamente se tivermos em conta a ferocidade da divisão entre a cidade moderna e os confins da província ${ }^{5}$. E aqui é importante anuir à entrada da ideia moderna de província num país detentor de uma ruralidade riquíssima, com uma revolução agrária pioneira, não ao nível da mecanização mas ao nível da introdução de espécies exóticas e adaptação das técnicas de cultivo, pelo contacto com outras culturas, mas que não respondia aos preceitos económicos liberais, sobretudo tendo em conta os acordos estabelecidos com outras potências imperiais que detinham o monopólio dos circuitos de produção, distribuição e venda dos produtos portugueses para exportação. Aquilo que era importante cerzir, a despeito das múltiplas ideias de província que se escondem sob o manto de estopa do idílio rural não conflituoso, era a voluptuosidade incomodativa de uma economia de auto-subsistência que desafiava os princípios de prosperidade do Estado-nação à luz das nações civilizadas, e que internamente incomodava a burguesia porque ia permitindo a perpetuação de antigos laços de poder. Alimentando-se da ideia de natureza e comunitarismo, dos costumes e tradições de um povo-nação retratado em vinheta pitoresca, a província moderna tratou de fragilizar laços ancestrais, fortalecendose com outros centros de poder. Mas aquilo que ela escondia,

5 - O 'fundo da província', expressão usada por José Augusto França e que tão bem traduz o sentido da província portuguesa moderna. 
essencialmente, era a imensa massa de população sem propriedade da terra e sem maioridade política num território dito seu, o que ajuda a compreender o sucesso da designação de 'modernidade tardia portuguesa'.

O poderoso aparato institucional que desde o século XVII se organizou na Europa por forma a exercer poder sobre os indivíduos como parte de um território, aquilo que Michel Foucault refere como a máquina de biopoder, o poder exercido sobre a vida das populações, ou o poder de acesso à vida, mais do que à terra, consolidou-se em grande medida através do modelo binário cidade/província. Exercida sobre o corpo individual e colectivo da população, substituindo o poder soberano para tirar a vida, esta forma de poder é o novo poder para fazer, suster ou remover vida, como nova norma política numa sociedade disciplinar, dentro da qual a biométrica surgiu como tecnologia revolucionária e imprescindível para o progresso dos impérios e das nações. Esta prática assente nas características biológicas e físicas dos indivíduos, tornou-se um procedimento político do Estado nação que resolvia o poder sobre os corpos e territórios. O controlo desta máquina de fazer, suster ou remover a vida individual e colectiva assume contornos específicos no caso português pela sua própria posição de potência imperial com expressão significativa no manuseamento, comércio e selecção de seres humanos. A transformação desta máquina de biopoder no século XIX em norma política, acompanhando a tendência que irradiava das demais potências europeias, terá sido particularmente complexa e merece escrutínio. Dentro desta, podem identificar-se um conjunto de práticas e conhecimentos institucionais (saúde pública, alojamento, mecanismos de controlo de abastecimento de alimentos aos que não tem provimento, da doença e anormalidade física e sexual, entre outros), que, irradiando da cidade como parte integrante da racionalidade política do liberalismo, funcionavam como instrumentos de medição e controlo de grupos de seres humanos designados como população. Esta máquina de controlo dos corpos é espacial e constituída por engenhos de escalas diversas. A 
organização de um aparato de controlo dos sujeitos subalternos é parte integrante da construção cultural da paisagem moderna como engrenagem pivot, à escala nacional e em contexto metropolitano, daquela máquina.

A tentativa de compreensão deste processo passa ainda pela análise dos fenómenos de difusão cultural que ao tempo iam afectando o conjunto do território português, diferentemente. Passa, antes de mais, pela compreensão dos mecanismos de negociação que os diferentes segmentos do social esgrimiam para fazer valer os seus códigos culturais e estatuto identitário. Rui Ramos salienta que no princípio do século XX “(a) 'cultura' deixou [...] de ser um termo descritivo para passar a ser uma utopia. Paradoxalmente era como se a 'modernidade' só pudesse ser vivida como a nostalgia do passado, como a luta pela integração de todos os seres num conjunto coerente. [...] (Era) a emergência da entidade chamada 'Portugal' na vida dos portugueses - na rotina quotidiana, na política, na criação artística. 'Portugal' passou a designar uma cultura colectiva, isto é, um conjunto coordenado de referências comuns.” (1994, p. 567). Neste sentido, perceber 'a vida social das coisas' (APPADUARAI, 1988) é perceber as relações que se estabelecem entre o ser humano e o mundo objectual, a sua expressão e negociação em cada momento. A questão de como os valores culturais circulam e são produzidos. Percebida como um dos fenómenos mais contundentes da modernidade, a difusão da cultura urbana sondou-se num complexo processo de colonização das 'outras culturas', parte integrante do encontro colonial.

O fenómeno de colonização urbana integrou a construção de hierarquias territoriais (e identitárias) que funcionaram como veículos de afirmação de um novo modelo de conhecimento, de um novo sistema simbólico e de interacção social. Se o impacto das leis liberais imanadas 'da capital' da República se fez sentir 'na província' no que respeita às estruturas familiares, formas de propriedade da terra, composição da unidade agrícola, padrões de formação de agregados domésticos, práticas de casamento, herança e estratificação 
social, entre outras, ele fez-se sentir de igual modo na modernização do comércio e da indústria, das infra-estruturas, na arquitectura, na reorganização dos espaços públicos e nas novas sociabilidades que chegavam com o desenvolvimento dos transportes e comunicações, por ordem oficial, mas também através daqueles que traziam códigos culturais urbanos, ou simplesmente exóticos, no regresso 'à província'. Sim, porque não pode negligenciar-se o papel dos estrangeirados, industriais e viajantes na construção de categorias identitárias e de alteridade num contexto marcado pelo poder das relações imperiais. Ora, também neste sentido, o envolvimento entre província e modernidade reverte numa miríade de cruzamentos culturais responsável pela produção de resultados idiossincráticos muito mais do que na homogeneidade espácio-temporal.

Desde muito cedo as suas intromissões estéticas feriam a integridade cultural 'da província'. Veja-se o caso dos 'brasileiros' no noroeste português, que, sendo 'naturais', e ao contrário dos 'ingleses', no Douro, eram tidos como séria ameaça à originalidade da paisagem 'da província'. O que interessa perceber são os mecanismos que regem a imposição das fronteiras e a individualização artificial dos territórios que vieram mascarar a porosidade e as continuidades espácio-temporais que nutrem as múltiplas geografias da diferença e exclusão, do acesso dos sujeitos ao território através da sua própria cultura. Como perceber pois as batalhas esgrimidas em torno da vida social das coisas? Como textos e discursos, infra-estruturas públicas e privadas, abriram caminho para novas formas culturais 'na província', num contexto político e ideológico em a que a materialização da cultura urbana, nas suas mais diversas manifestações, se celebrava como o advento do progresso e da civilização?

Um pouco por todo o lado o crescimento das 'cidades de província', nomeadamente pela emergência da burguesia ligada à indústria, ao comércio e à emigração, funcionou como testemunho da afirmação da modernidade disseminada por 'todo o país'. De acordo com Maria Alexandre Lousada (2009), a definição de cidades 
de província associada às capitais de distrito, decorre da reforma administrativa de 1835 que instituiu os distritos e, através dela, estas cidades portuguesas foram dotadas de um conjunto de funções político-administrativas que confirmaram a sua posição como centros de nível regional. Fenómeno que se encontra indissociavelmente ligado às dinâmicas centro-periferia que, ao tempo, moldaram a redefinição das políticas de lugar e identitárias para a afirmação da coesão nacional no quadro do sistema liberal português. Neste quadro, as cidades de província são uma das expressões materiais mais contundentes da formalização daquela cultura de biopoder - o Portugal dos pequeninos, à falta de uma mitologia de gnomos e duendes, que as missas em latim e os 'apertos de confissão' tornavam bem explícita.

A exposição do emaranhado de assunções que legitimam o espelho colonial da diversidade é particularmente sensível quando se analisa esta problemática, desvelando as contradições do moderno imperialismo urbano. Nas cidades de província construíram-se as primeiras salas de teatro, careciam as culturas vernaculares de dramaturgia (?), levou-se a música para o campo, manifestação cultural inexistente entre as populações rurais (?), assim como a dança, que não integrava as práticas rituais das culturas ditas tradicionais (?). Edificaram-se infra-estruturas destinadas à prática do desporto e do lazer, despromovendo-se as práticas locais de ocupação dos poucos ou diferentes tempos e espaços de ócio. Construíram-se estabelecimentos de ensino para levar a linguagem e o conhecimento àqueles que não o detinham (?), rompendo-se a força da oralidade e da transmissão do saber intergeracional e intrageracional, fragilizando-se a força secular das culturas do campo e do mar, do monte e do rio, em prol da civilização, das novas tecnologias, do conhecimento científico e da mercantilização. À semelhança daquilo que acontecia 'na grande cidade', construíam-se nas cidades de província os palácios da alta cultura (a escalas diversas), colocavam-se os sujeitos em posição de recepção passiva, lançavam-se os pilares para a cultura tornada espectáculo de produção e consumo. Criavam-se as condições para a afirmação em todo o país de uma 
classe média que por mecanismos de reprodução social iria responder aos apelos de uma nova esfera pública e de novas sociabilidades, nomeadamente em torno da actividade comercial, dos serviços e de novos espaços públicos. Uma 'novidade' em patamares, importada das práticas das elites, responsável paralelamente pela corrupção e recriação dos seus códigos, práticas privadas e públicas que emergiam como novos espaços de encontro.

As políticas culturais urbanas segmentaram as práticas quotidianas de indivíduos e grupos que detinham as suas próprias formas simbólicas, rompendo-se progressivamente as estruturas de sentimentos sobre as quais se alicerçava o acto de comunicação e partilha que funda o sentido de identidade comunitária, despromovendo-se funcionalmente as expressões materiais $\mathrm{e}$ imateriais das culturas não urbanas. Através da actividade industrial introduziam-se outras temporalidades, a aceleração e a mecanização, tornadas sinónimo de vanguarda. Reproduziam-se processos de exploração e realinhavam-se os mecanismos de abuso de poder do campo para a fábrica. A despeito da moral cristã difundida por todo o país e da precariedade das linhas de montagem que tentava organizar-se para fazer frente à competitividade internacional, o progresso trazido pela indústria não andou desde logo de mãos dadas com declarações de direitos humanos. A memória de situações de violência física e de abuso sexual crónico perpetrado em espaços fabris encontra-se viva, ainda hoje, 'na província', discernida em inúmeros relatos e silêncios que pontuam incontáveis histórias de vida, como nos corpos de trabalho. É que as profundas transformações ao nível da reorganização dos espaços de trabalho e $\mathrm{da}$ domesticidade não prescindiram de novos modelos de domesticação (de corpos e sujeitos). E se outras formas simbólicas, como o cinema e a fotografia, se manifestavam abrindo caminho para novas práticas de representação e para a compressão espáciotemporal, paralelamente estas afirmavam-se como expressões tangíveis da ruptura entre urbanidade e ruralidade que a cidade de província prometia suturar. 
As soluções encontradas para a tentativa de resolução da ruptura do modelo binário cidade/campo, expressas em conceitos operativos tais como bairro urbano ou cidade de província, serviram para iludir a violência cultural de um modelo de civilização assente sobre a hegemonia urbana. A 'cidade de província' funcionou como conceito operativo nesta máquina de colonização cultural ditada pelos grupos de poder, um aparatoso engenho espacial que da rede de escolas à rede de transportes silenciava um pernicioso encontro: o do sujeito moderno com o sujeito pré-moderno. O psicodrama colonial do sujeito da província (na cidade ou fora dela), é o drama dos corpos 'sem cultura', da (des) autorização do indivíduo, é o drama da impossibilidade da diferença num colectivo nacional. É também o drama do declínio das 'culturas da terra', da gente nómada e sem propriedade, da normalização dos corpos diferenciais. Este drama da recolocação do sujeito, sujeito agora a uma abrupta dissolução de relações estabelecidas com o ambiente físico através da imposição de outros códigos culturais, é o drama da objectificação, (estratégia para uma redistribuição da terra e dos recursos absolutamente desigual). Mas, é também a vertigem do materialismo enxertada a ferros pelos centros que difundiam oficialmente um novo quadro relacional dentro do qual as práticas quotidianas que davam significado à paisagem e a outros modos de ser passavam a funcionar por mediação de novas tecnologias para a organização da experiência. O conturbado processo de acomodação das novas tecnologias e práticas culturais posto em jogo nas cidades de província, tendo por pano de fundo o incremento do imperialismo urbano, sondava-se num profundo espasmo, sentimento misto de sedução e de alienação a que a estética do sublime dava voz, enquanto a estética do pitoresco permitia lidar com o desconforto que advinha do manifesto estatuto de menoridade do Outro subalterno.

A legitimação do quadro relacional de objectificação dos corpos que percorre o sistema de pensamento ocidental, funcionou como estratégia de renegociação de poder exercido sobre os condenados ao estatuto de ser em processo (de sujeição). A despeito 
do pernicioso aparato organizado sobre uma rede de espaços com vida e história particulares condenados agora oficialmente ao estatuto de 'cidades de província', em Portugal resistiu-se avidamente ao movimento hegemónico de colonização cultural da modernidade, à imposição categórica de fronteiras artificias, ao imperialismo urbano. Não tardiamente mas quase radicalmente, diria. Mas este é apenas um dos lados mais explícitos do processo de colonização cultural pelo moderno império da urbanidade, na preparação da transição para o novo século. As implicações biopolíticas da consolidação desta engrenagem espacial, da rede de cidades de província em Portugal, foram inúmeras, sendo retrabalhadas e consolidadas no século XX durante o longo período da Ditadura em que as colónias de além mar passaram a designar-se províncias do ultramar. Através dela difundiu-se uma racionalidade governativa para todo o território que permitiu a implementação do moderno modelo de poder, verdade e conhecimento, cuja enxertia vergava a vontade dos sujeitos considerados ou não como válidos para o efeito colonial, atendendo à validade casuística do encontro.

O drama da modernidade é pois um drama biopolítico, o drama do encontro, da sujeição intra e extramuros, do precário registo da vida. Não será assim tão novo. Do sujeito pré-moderno objectificado pelo império da urbanidade. Do sujeito moderno tornado objecto da sua própria condição de obsessiva superação, de incapacidade de paragem, de incompreensão da substância do movimento para além da velocidade e da circulação, da resposta fácil pelo consumo, turismo e propriedade. E se o liberalismo se associava à liberdade individual como base da vida humana, na prática, as suas instituições políticas e sistemas económicos frequentemente colidiram com outras (?) forças, promovendo uma distribuição sócio-espacial bastante desigual dos direitos e obrigações. Em Portugal, as políticas de branqueamento que integram a máquina de biopoder organizada através da ideia de paisagem-província, mostra bem este fenómeno, não sendo mais do que estratégias para legitimar a racialização de identidades sustentadas por sistemas de privilégio que entroncam num sistema geopolítico muito mais vasto. Como 
parte integrante de uma imaginação geográfica com raízes extensíssimas, tais políticas identitárias e de segregação ergueram alguns dos mais potentes códigos culturais transportando consigo sinuosos percursos de normalização e a naturalização de corpos geográficos.

Como nos vemos e como nos representamos na escalada normativa do branqueamento e na cartografia biométrica que insuflou a ideologia do império e do Estado-nação e a fantasia de domínio cultural que permeia a história da expansão Europeia é uma questão complexa que está ainda por resolver. Como nos vêem e como nos representamos para exportação e consumo, manuseando o constructo da cidade/província é um nó que está por desatar. Seguramente através de ambíguos retratos e descrições, falares arbitrários que se perpetuam no tempo até nos baterem à porta para nos confrontarem com a nossa própria distorção, instruídos da força da vida que se insinua nos hábitos e repetições da materialidade sem devir. Há muitas maneiras de receber o estrangeiro dentro da nossa própria casa. Pela consciência da matéria enquanto fluxo de vida, é uma delas. Mais do que tentar aceder à essência universal das coisas e da vida, às divisões categóricas dos corpos e lugares, seria importante atender à sua incontável heterogeneidade, aos momentos de encontro generativo, à rede de relações que terá levado cada indivíduo para fora de si mesmo, "aos impulsos morfogénicos de replicação e diferenciação, multiplicidade e singularidade através dos quais o fluxo dos devires mundanos toma, resiste e muda de forma" (WHATMORE, 2009, p. 47). Ao actuarmos no terreno da consciência, ao percebermos como a memória e a experiência modelam a nossa identidade somos impelidos a pensar sobre as coisas através dessa matéria, coisas como o conceito de paisagem e de província. 


\section{Referências}

APPADUARAI, A. The Social Life of Things: Commodities in Cultural

Perspective. Cambridge University Press: Cambridge, 1988.

AZEVEDO, A. F. "Desgeografização do corpo. Uma política de lugar”. In: AZEVEDO,

A.F.; PIMENTA, J.R.; SARMENTO, J. (Eds.). Geografias do Corpo. Porto: Figueirinhas, 2009, p. 31-80.

AZEVEDO, A. F. A ideia de paisagem. Figueirinhas: Porto, 2008.

. A experiência de paisagem. Figueirinhas: Porto, 2012.

BHABHA, H. The location of culture. Routledge: London, 2004.

BONIFÁCIO, M. F. O século XIX português. Lisboa: Instituto de Ciências Sociais, 2002.

BRANCO, R. M. C. O Mapa de Portugal. Estado, Território e Poder no Portugal de Oitocentos. Livros Horizonte: Lisboa, 2003.

CAHEN, M. Les couleurs du racisme colonisateur. Africana Studia, n.13, CEAUP, 2009, p.149-162.

COSTA, J.A.; MELO, A.S. Dicionário de Português. 2. ed. Porto Editora.

FANON, F. Black Skin, White Masks. New York: Grove Press, 1967.

FOUCAULT, M. Discipline and Punish: The Birth of the Prison. Allen Lane: London, 1976.

GOUVEIA, A. C. "Estratégias de interiorização da disciplina". In: MATTOSO, J. (dir.) e HESPANHA, A.M. (Coord.). História de Portugal. Lisboa, Editorial Estampa, 1993, p. 415-449. v. IV.

HALL, P. Cities in Civilization. Culture, Innovation and Urban Order. Phoenix Giant: London, 1999.

LOUSADA, M. A. "Vida Privada, sociabilidades culturais e emergência do espaço público". In: MONTEIRO, N.G. (Coord.). História da Vida Privada em Portugal. A Idade Moderna. Lisboa: Circulo de Leitores. Temas e Debates, 2011, p. 424-446.

MACHADO, A. M. Les Romantismes au Portugal. Modeles Etrangers et Orientations Nationales. FCG-CCP: Paris, 1986.

MATTOSO, J. (Dir.); VAQUINHAS, I. (Coord.) História da Vida Privada em Portugal. A Época Contemporânea. Circulo de 
Leitores: Lisboa, 2011.

PICKLES, J. A History of Spaces. Routledge: London, 2006.

PIMENTA, J.R. Introdução. Traços de uma biografia científica. In: Obras de Silva Telles. A Ciência Geográfica. APG: Lisboa, 2004.

PIMENTA, J.R. Portuguese Colonial Geographical Tradition. Africana Studia, n.14, CEAUP, 2010, p.313-324.

RAMOS, R. "A Religião dos Tempos Modernos: Ideia de Cultura”. In: MATTOSO, J. (Dir.); e RAMOS, R. (Coord.). História de Portugal. Lisboa: Estampa, 1994, p. 565-596. v. VI.

ROBINSON, J. Cities in a World of Cities: the comparative gesture. International Journal of Urban and Regional Research, n. 35, p. 1-23, 2011.

ROQUE, R. Etnografias coloniais, tecnologias miméticas: a administração colonial e os usos e costumes em Timor-Leste no final do século XIX. Edições Colobri/IEL: Instituto de Estudos de Literatura Tradicional, 2011.

SAID, E. Culture and Imperialism. New York: Vintage Books, 1993.

SERRÃO, J.; MARQUES, O. (Dir.). Portugal e a Instauração do Liberalismo. Presença: Lisboa, 2002.

SILVA, A. C. N.; HESPANHA, A. M. "O quadro espacial". In: MATTOSO, J. (dir.) e HESPANHA, A.M. (Coord.). História de Portugal. Lisboa: Editorial Estampa, 1993, p. 39-48. v. IV.

SILVA, A.C.N. Escravidão e direitos fundamentais no séc. XIX. Africana Studia, n.14, CEAUP, p. 231-254, 2010.

TORGAL, L. R.; VARGUES, I. N. "Produção e reprodução cultural". In: MATTOSO, J. (Dir.); TORGAL, L. R. (Coord.). História de Portugal. Lisboa: Editorial Estampa, 1993, p. 685-712. 



\section{Etnopaisagem, Corpo e Memória: Uma Viagem pelo Cinema Português}

Tiago Campos Vieira Carvalho da Silva 


\section{Paisagem e Pátria Ancestral: 0 Artifício como Ponto de Partida}

A consolidação de uma ideia de paisagem é precedida por um Limutável processo de aculturação que encontra a sua génese numa primeira captação do ambiente físico através do olhar, e que, posteriormente, o vai converter num artifício cultural a partir do momento que passa a reconhecê-lo como 'paisagem', diz-nos Malcolm Andrews, em Landscape and Western Art (1999). Na sua contemporânea acepção, a paisagem subsiste como o resultado de uma transformação histórica, cultural, social e estética que atravessou e continuará a atravessar a relação entre ser humano e ambiente físico, transformação que, segundo Mattoso, Daveau e Belo (2010), começou a partir da terra na sua constituição geomorfológica, com a posse do relevo e a sua relação com a água, com a tempestade e com a ordem dos ventos. A terra sem raízes etimológicas ou escrava de sentidos figurados vai assumir-se o ponto de partida para o próprio processo de observação, aculturação e estudo da paisagem.

As relações entre o desenvolvimento das raças humanas e o seu habitat preocuparam sempre os antropólogos, diz-nos Silva Telles (2004). A relação com o ambiente físico estabelece-se a partir de um colectivo que, segundo Anthony Smith, vai fazer com que o território espelhe a comunidade étnica e seja historizado pelos eventos e processos comunais e pelas relíquias e monumentos que marcam a paisagem, tornando-se numa pátria ancestral. Nesta moderna acepção, a terra começa a pertencer a um povo do mesmo modo que o povo pertence a uma particular terra, relação que se vai inspirar numa "ideologia que privilegia o direito ao controlo e administração dos territórios do estado” (SMITH, 2000, p. 55). É através deste pressuposto que se consolida a ideia moderna de etnopaisagem, isto é, um espaço que, ao exaltar as normas e doutrinas tradicionais, objectiva preservar a integridade das relações entre indivíduos, grupos e lugares, consagrando uma ideia de cultura distinta com direitos políticos em virtude da sua peculiaridade 
étnica. Irit Rogoff alega que, através deste tipo de processos, “a unidade entre lugares e sujeitos foi fundida até ao ponto em que surgem corpos marcados ideologicamente que vão projectar a especificidade das relações entre um povo e um lugar” (2000, p. 145). É a partir desta relação, em que actuam as ideias de etnia, território e identidade colectiva, que vai nascer o conceito de etnopaisagem, construção cultural que estriba em perspectivas imperialistas e nacionalistas, albergando comunidades 'que se definem' física e ideologicamente consoante as características geográficas 'naturais' de um território. Pimenta, na introdução de Obras de Silva Telles: a Ciência Geográfica (2004) ${ }^{1}$ diz que aquilo a que Silva Telles dá atenção, no contexto da movimentação e fixação das raças, é à estabilidade, marca única de identidade geográfica que as variantes da espécie humana apresentam; ao dizer que uma raça é um lugar, o autor vai privilegiar a estabilidade das relações finalistas entre as raças e as unidades geográficas (2004, p. 15).

Ao analisarmos as diferenças que existem entre a etimologia germânica e latina de paisagem, verificam-se interpretações algo diferentes na transmutação de ambas as palavras: "a Landschaft como resultado da relação entre o lugar e os habitantes, convertida através do ato de criar a terra (o landschaffen) que, na geografia norteamericana, enfatizava o mesmo sentido de modelar a terra (landshape) na consagração do conceito Landscape, e a Paysage como derivante de pays e paysan, que se refere ao habitante, mais concretamente, ao camponês (paysan) de uma determinada região (pays). Ainda assim, a génese da ideia de etnopaisagem, em ambas as etimologias, vai assentar no pressuposto referido por Mattoso, Daveau e Belo (2010)", que, antes de falarem da relação do ser humano com a terra, falam da maneira como a fizeram 'dar os seus frutos', como se apropriaram dela, como se movimentaram sobre ela, como se agruparam em função do que ela lhes podia dar ou a maneira que os podia ajudar a defenderem-se.

1. - Francisco Xavier da Silva Telles foi o primeiro doutorado em Geografia em Portugal. A sua obra bem como, a de Leite de Vasconcelos e, mais tardiamente, a de Mendes Corrêa, são indispensáveis para a compreensão dos fundamentos do conceito moderno de etnopaisagem. 
A relação entre ser humano e ambiente físico vai estar assim na génese da produção cultural, e, a este propósito, Mendes Corrêa (1943) vai referir-se à 'cultura' como tudo o que homem adiciona à natureza, e consequentemente todas as modificações que ele introduz nesta para a colocar ao seu serviço, já que as manifestações culturais abrangem diversos domínios da vida humana. A actividade de um mundo em diáspora revela-se assim determinante na consolidação de uma visão nacionalista, já que o continente europeu, tendo marcado o seu percurso na Idade Moderna sobretudo através da expansão territorial e da colonização, vai desenhar uma cartografia que separava claramente o seu território 'soberano' dos restantes espaços 'além-fronteiras, divididos pelo mar ou por outra 'porção da natureza' que estava associado ao 'selvagem'. À medida que estes lugares iam sendo conquistados e gradualmente dominados pelos impérios europeus, a cultura ocidental foi consolidando representações destas novas paisagens, e que eram interceptadas por questões políticas e ideológicas, por questões étnicas e de classe, de género e de sexualidade. A paisagem como pátria ancestral, com grupo étnicos associados, como espaço ideologicamente saturado, reflexo das perspectivas imperialistas e nacionalistas do território, e que encontra a sua moderna acepção no estado-nação, modelo em que se vieram a inspirar grande parte dos governos europeus a partir do século XVIII. Neste enquadramento, Silva Telles (2004) diz que as raças humanas, sendo produtos da natureza, precisam equilibrar-se com o meio que as cerca, já que é através da maneira que essas correlações se estabelecem, do grau de harmonia ou do antagonismo entre o meio e as colectividades étnicas, que estas ou se fixam no tempo, estacionam, ou degeneram.

A ideia de estado-nação, ancorando-se na união entre a unidade política (o Estado) e unidade étnica e cultural (a nação) veio a ser apropriado, no século XX em Portugal, pelo regime do Estado Novo, como um modelo que se distanciava dos princípios do liberalismo republicano. António Medeiros, em Dois lados de um rio - nacionalismo e etnografias na Galiza e em Portugal (2006), a este propósito, vem dizer que a instauração do Estado Novo em 1933 foi 
precedida por movimentos que ambicionavam veicular oficialmente uma ideologia com evidentes raízes totalitárias, defendendo o ensino de uma nova cultura nacional que impulsionou a urgência de formas mais visíveis de representação das culturas provinciais com as suas peculiaridades étnicas. Estas representações consolidavam imagens de etnopaisagens que encontravam forte expressão na diversidade territorial de Portugal, definido por Silva Telles como uma unidade geomorfológica que se distinguia do resto da Península Ibérica, exceptuando pela Galiza, considerada pelo geógrafo como um prolongamento geográfico do norte de Portugal e mantendo com este mais semelhanças do que com as restantes províncias espanholas (RIBEIRO, 1977).

Leite de Vasconcelos, ao dizer que Portugal começou a aparecer na história a partir do norte, inicialmente como embrião regional, e depois como Estado constituído que começou a expandirse sucessivamente para sul, vai sugerir um processo gradual de domínio territorial definido por uma diversidade geográfica, ao mesmo tempo que exalta o contraste entre as terras do norte do Tejo e as do sul. As primeiras com predomínio de montanhas e as segundas com predomínio de planícies, comparação à qual se encontra subjacente o estudo das redes fluviais, com a maior abundância de rios no norte e a escassez dos mesmos do sul (VASCONCELOS, 1980). Percebe-se uma visão romantizada de corpo e território que o Estado Novo adoptou nomeadamente da geografia e antropologia dos séculos XIX e XX, e que o cinema repercute através de representações culturais de etnopaisagem. José Pimenta, na introdução de Obras de Silva Telles: a ciência geográfica, diz que:

Uma noção muito restrita das relações entre colectividades étnicas e o meio geográfico contribuiu poderosamente, pelo seu critério analítico, para a aceitação das hipóteses particularistas, tendentes a explicar a distribuição e a fixação, no tempo, das raças humanas, em determinadas zonas geográficas, pela influência de certos factores formados isoladamente (TELLES, 2004, p. 4). 
Não nos podemos esquecer que o trabalho de muitos geógrafos portugueses foi condicionado pela ideologia do Estado Novo, como refere Duarte Belo, em Portugal, Luz e Sombra - O país depois de Orlando Ribeiro (2012), a propósito do trabalho desta figura canónica da geografia portuguesa. Mesmo estando conotado como o 'geógrafo do Regime', vincado a uma perspectiva nacionalista que não o permitia separar a observação científica dos costumes, da distinção de classes e grupos humanos, Duarte Belo vai referir-se às suas fotografias dos territórios portugueses como encontrando-se providas de um código ético que emanava das paisagens, do espírito dos lugares e das pessoas que as habitavam. Também mais recentemente Duarte Belo fotografou esses lugares captados pela câmara de Orlando Ribeiro, explorando as transformações que ocorreram no espaço ao longo do tempo.

As transformações que ocorreram no território português, em espaços rural ou urbano, passaram a fazer parte da própria identidade nacional, pois, como diz Richard Jenkins, "a identidade nacional e o nacionalismo envolvem, quase sempre, a identificação em grupo e a categorização social, seja a inclusão ou a exclusão" (2008, p. 86). Sem rejeitar a ideia de que o nacionalismo possui fortes raízes históricas - em que se encontra subjacente o sentimento da pátria ancestral - Jenkins vai exaltar as relações entre vários conceitos, desde o nacionalismo, a etnicidade, a identidade nacional..., sem recorrer à ideia de que todos dependem uns dos outros, e que, por isso, acabam por permanecer imunes às novas transformações e configurações da experiência. Nesta senda, podemos ressalvar a perspectiva de Stone e Rizova, em Nationalism and Ehnosymbolism: History, Culture and Ethnicity in the Formation of Nations (2007) que afirmam que um dos eixos da controvérsia em torno do conceito de 'nacionalismo' se encontra relacionado com uma questão bastante paradoxal, tão superficial como complexa: o que é que constitui uma nação? É uma questão sem uma resposta única e precisa, todavia, também como Jenkins, a obra exalta a constituição da nação como uma complexa rede de significados heterogéneos, que emerge através do tempo mas não varia apenas 
além dele, já que se encontra totalmente susceptível à mudança. Também a este propósito, Braga da Cruz diz:

Porque os homens das democracias parecem sempre emocionados, incertos, ansiosos, prestes a mudar de vontade e de lugar, imagina-se que eles vão abolir de repente as suas leis, adoptar novas crenças e novos costumes. Não se imagina que, se a igualdade leva os homens às mudanças, ela sugere-lhes interesses e gostos que têm necessidade da estabilidade para se satisfazer; impele-os, e ao mesmo tempo, detém-nos, espicaçaos e liga-os a terra; inflama os seus desejos e limita as suas forças (CRUZ, 2013, p. 281).

A etnopaisagem como artifício que condensa memórias de corpo e território codificadas em sistemas de significados que articulam noções de raça e etnia - que ritualiza a incorporação de espaços e tempos - e, paralelamente, reactualiza estas noções, acompanhando as novas configurações da experiência e a urgência de contemporaneidade. Neste contexto, Arjun Appadurai (1996) vai mesmo referir-se à paisagem como sufixo, de forma a clarificar como os processos de globalização, ao unirem diferentes grupos de pessoas, acabam por estabelecer divisões entre outros grupos (1996, p. 33), empregando a palavra "scape" como sufixo de mediascapes, ethnoscapes, ideoscapes, financescapes, e technoscapes. Contudo, antes de se falar em representações culturais de paisagem no cinema, é crucial incidir no funcionamento do aparato cinematográfico enquanto reprodutor do arranjo hierárquico dos componentes físicos e simbólicos do território.

O processo de aculturação à ideia moderna de paisagem é acompanhado por uma exaltação da superioridade estética da imagem associada à superioridade 'étnica' do sujeito do humanismo, através de um primeiro olhar do ser humano sobre o meio ambiente, que vai definir, dentro do seu próprio ângulo de visão, os limites convencionados que permitem eleger determinada porção da natureza como uma paisagem. Mas quando é que determinada porção da natureza é uma paisagem? Georg Simmel explica esta problemática argumentando que "um pedaço de natureza é, em rigor, uma contradição em si, pois a natureza não tem fracções”, acrescentando também que "raramente nos damos conta de que 
ainda não há paisagem quando muitas e diversas coisas se encontram lado a lado numa parcela de solo e são directamente contempladas" (2009, p. 5). E que dizer dos fundamentos ontológicos da ideia de natureza?

Não obstante, para a ideia moderna de paisagem, é justamente essencial a demarcação, conclui Simmel. Ao demarcar uma porção de natureza como 'necessária' para que esta seja entendida como paisagem, envereda-se num "processo de construção cultural de uma imagem ou imagens do mundo, que se inicia a partir do ato de marcar, retirar ou subtrair uma porção do território entendido como esteticamente superior" (Deleuze; Guattari, 2004, p. 19). O trabalho sobre o "corpo pleno da terra" de que falam Gilles Deleuze e Felix Guattari em $O$ Anti-Édipo: Capitalismo e Esquizofrenia (2004), vai ocorrer a partir da dinâmica de um mundo globalizado, processo através do qual o percurso oscilante de comunidades ou grupos vai resultar na sua fixação em determinados territórios. Mas a fixação humana, sendo efémera e sobretudo política, vai ser seguida de outras fixações que vão alterar a própria constituição do território, podendo deixar - ou não - marcas que vêm transformar e recodificar a ideia de paisagem. O cinema vai acompanhar essas reactualizações e recodificações do território, ao mesmo tempo que se empenha na construção de um imaginário geográfico que procura adaptar-se à ditadura da modernidade como factor implicante na maneira como os espaços, ou, neste contexto, as etnopaisagens, se vão metamorfoseando nas suas representações. Ao falarem do "corpo pleno da terra”, Deleuze e Guattari vão evitar ao máximo as categorizações, ainda que se sirvam das mesmas para explorarem o movimento dos corpos humanos nesse mesmo corpo 'pleno', movimento fluído e que vai condensar memórias que, mesmo acabando por ser desconstruídas com o passar do tempo, não são esquecidas. Ao catalogarmos estes movimentos como parte dos processos de 'desenvolvimento', é relevante evocarmos Joel Wainwright, que, ao analisar a dicotomia Natureza/ Desenvolvimento em Decolonizing Development: Colonial Power and the Maya (2008), vai dizer que o primeiro conceito surgiu talvez antes 
do segundo - e evoca Raymond Williams, que disse que a palavra Natureza é a mais complexa da língua inglesa ${ }^{2}$ - mas que ambos os conceitos acabam por se relacionar segundo a perspectiva de Aristóteles, que se refere à natureza como um princípio ou causa interna de mudança.

\section{Etnopaisagem no Cinema Português: A Afirmação do Paradigma Heróico e Imperialista}

No contexto da arte contemporânea e das culturas emergentes, o cinema vem problematizar as representações culturais da etnopaisagem na sua relação com o corpo e memória. O cinema como mecanismo condensador do corpo e da memória encontra nas representações de etnopaisagem formas distintas de expressar o mundo como um memorial das relações humanas com o território, que, no Estado Novo, se revela muito a partir das projecções imperialistas e nacionalistas de paisagens ideologicamente e pictoricamente saturadas por códigos e convenções estabelecidos de acordo com o ideário fascista. Após a revolução de Abril em 1974, vai desvelar-se o processo de desconstrução dos espaços iniciado anteriormente, atribuindo-lhes concomitantemente novos simbolismos que pretendem contestar uma rigidez conceptual. $\mathrm{O}$ cinema, porém, jamais perde a intrínseca capacidade de gerar relações entre a memória e os corpos, passando a representá-los a partir de ópticas diferentes que acompanham as novas configurações da experiência humana. E, encontrando-se grande parte dos estudos geográficos portugueses do período muito implicados com perspectivas regionalistas e provinciais do território, são precisamente essas representações que afluem vigorosamente no imaginário colectivo, em paralelo com a idealização nostálgica de Portugal como um dos grandes impérios do 'passado', através das evocações saudosistas e orgulhosas da Lisboa quinhentista e das

2 - A propósito da obra Keywords: A Vocabulary of Culture and Society (1976). 
províncias de aquém e além-mar.

A crença na pátria ancestral de que nos fala Anthony Smith encontra forte expressão em grande parte das obras do cinema estado-novista, seja através das representações em tom educacional, a exaltação do ruralismo das várias províncias, ou pontos específicos do território nacional, ou dos filmes históricos - difundidos pelo Secretariado de Propaganda Nacional, liderado por António Ferro, como um dos géneros cinematográficos supremos - que evocam histórias de 'heróis da pátria', sobretudo de um tempo 'distante', como Camões ou Bocage, ou ainda adaptações de obras literárias ou peças de teatro, como Frei Luís de Sousa, ou de mitos saudosistas da História nacional, como Inês de Castro. Só que, aqui, a memória prende-se nomeadamente com o simbolismo patriota, não com as representações dos indivíduos, tampouco dos corpos como elementos multidimensionais da natureza humana. Agustina Bessa Luís evoca, em Contemplação Carinhosa da Angústia (2000), a perspectiva generalista que é tida de Luís Vaz de Camões:

[...] não como o poeta d'Os Lusíadas, não o artista dos sonetos; não o misterioso soldado mutilado, não também o náufrago e o exilado. Não o amigo de aventureiros, de fidalgos avarentos ou generosos, de mulheres, belas, menos belas, maldosas, ternas, confidentes, traidoras, leais, indiferentes, mortas. E um símbolo [...] quando se fala de Camões, diz-se Portugal (BESSA-LUIS, 2000, p. 99).

$\mathrm{Na}$ obra do cineasta Leitão de Barros, Camões é exactamente esse símbolo cultural, um 'pretexto' para expressar, através das representações da paisagem urbana da Lisboa quinhentista, o poder e a imponência imperial que almejam vincular à capital como uma estirpe vernacular, atributos dos quais a mesma padece no século XX; as sequências alternadas dos espaços mais sumptuosos da cidade - como a praça do Rossio a estender-se perante o bairro de Alfama e o castelo de São Jorge, e as reuniões na corte real no Paço da Ribeira celebram a memória de uma Lisboa soberana, uma das capitais supremas europeias.

Perante a descrição anteriormente feita, seria de esperar que a evocação dessa época 'áurea' de Portugal fosse tingida por um 
sentimento de lamento perante a sua inexistência no presente. Contudo, é necessário ressalvar que o regime ditatorial que governava Portugal empenhava-se ao mesmo tempo numa idealização utópica do território que jamais permitia que a população fosse confrontada com quaisquer sentimentos negativos da memória colectiva. Quando esse sentimento saudosista aflui, o seu propósito é meramente pedagógico, de maneira a educar a população sobre os 'bons' e os 'maus' caminhos que permeiam as relações humanas. Font e Rufí (2006), ao falarem de uma paisagem simbólica nacionalista, salientam a existência de uma iconografia nacionalista da paisagem, quer dizer, um conjunto de signos e emblemas nacionalistas impressos na paisagem, fenómeno que se reflecte na paisagem visível de qualquer nação, e mais especialmente na arquitectura emblemática e em monumentos. Neste sentido, a memória, nestas obras fílmicas, assume-se como resgatadora de um paradigma heróico e nacionalista que, além de fomentar a crença numa pátria ancestral, pretende ao mesmo tempo perpetuar uma utopia, não só para fazer a população portuguesa acreditar que ainda seria o 'nobre povo lusitano' agrupado em categorias étnicas e corpos moldados pelo território, enaltecendo o mito do orgulbosamente sós, linha política de isolamento que se conservou até 1974.

Flagrantemente diferente desta galeria de filmes, as obras Lisboa, Crónica Anedótica (1930) de Leitão de Barros e Douro Faina Fluvial (1931) repercutem a tradição cinematográfica das 'sinfonias urbanas europeias', como Berlim: A Sinfonia de uma Capital (1927) de Walter Ruttmann e O Homem da Câmara de Filmar (1929) de Dziga Vertov, cujo propósito se prende com a emancipação da metrópole dinâmica, cosmopolita e modernista. Todavia, ainda que Douro Faina Fluvial consiga um entendimento com o pressuposto destas obras, através da exaltação da "moderna poesia do ferro e do aço", como diz Michelle Sales em Em Busca de um Novo Cinema Português (2011), que se equilibra harmoniosamente com a actividade mercantil e tradicional nas margens do Douro, por outro lado, Lisboa, Crónica Anedótica projecta a imagem de uma cidade 
precariamente modernizada, contaminada por um espectro decadente, que se materializa nas sequências das ruas estreitas, pátios velhos, e das práticas rurais desempenhadas pela população. As representações de Lisboa e do Porto nestes filmes, projectando o espírito das cidades no então presente, acabariam por servir de referência temporal mais tarde. A capital periférica de Lisboa, Crónica Anedótica como imaginário preferencial do cinema novo, na década de sessenta e no panorama pós-revolução, cujo epíteto é possivelmente Lisboa, o Direito à Cidade (1974) de Eduardo Geada, filme lançado imediatamente após a revolução de Abril, e também no imaginário colectivo da nova geração da década de noventa, e o Porto que, em Manoel de Oliveira, é exaltado como o universo chave da sua obra. Em Porto da Minha Infância (2001), presencia-se a celebração da cidade como o universo pessoal do cineasta, a sua cidade natal, que ele explora através de fragmentos dos seus filmes, sejam as brincadeiras das crianças na Ribeira ou na linha de comboio em Aniki Bobó (1942) ou as sequências que tomam a forma de pinturas em aguarela em O Pintor e a Cidade (1959). O Porto como espaço condensador das memórias íntimas da vida do cineasta, o Porto como universo da burguesia em decadência, grupo social que Oliveira explora incisivamente através de narrativas burlescas e esotéricas.

Só que Lisboa, Crónica Anedótica e Douro, Faina Fluvial não representam dimensões imperialistas da cidade. Se essa tarefa era delegada sobretudo por alguns filmes históricos, também os filmes que elevavam o imaginário colonial das províncias ultramarinas, como Feitiço do Império (1946) de António Lopes Ribeiro ou Chaimite (1953) de Jorge Brum do Canto reflectem, como diz Patrícia Vieira (2011) os esforços do Estado Novo na difusão de uma concepção de nacionalidade segundo a qual o dinamismo imperial da metrópole se encontrava fortemente enraizada no universo dos territórios ultramarinos. O cinema vem reclamar assim um entendimento dos significados das etnopaisagens tendo em conta a sua dimensão espácio-temporal. Richard Jenkins, em Rethinking Ethnicity: Arguments and Explorations (2008), ao dizer que os 
conceitos de nacionalismos e etnicidade, não obstante encontraremse ligados de alguma forma, acabam por ser diferentes, vai assumir que é a partir dessa crença que se suportam os nacionalismos. Porém, a sua concretização é efémera, sejam os vestígios do império romano ou árabe que ainda persistem como parte da identidade pictórica da paisagem portuguesa, ou, de maneira diferente, a relutância da população portuguesa em aceitar o domínio filipino entre os séculos XVI e XVII, já que vinha comprometer directamente essa crença na pátria ancestral.

Mesmo quando a Europa do pós-segunda guerra, atormentada pelo projecto de hegemonia racial da Alemanha nazi, se voltou revoltosamente para o Portugal colonial, a crença na pátria ancestral procurou arranjar maneira de subsistir. Portugal empenhou-se determinantemente na legitimação do colonialismo português a fim de salvaguardar as províncias ultramarinas, como nos mostra a perspectiva de Mendes Corrêa, que adopta integralmente a teoria do luso-tropicalismo de Gilberto Freyre, que enfatiza a capacidade inata dos portugueses se adaptarem aos trópicos, dada a sua própria origem étnica, que se fundou, primeiramente, a partir do longo contacto com os mouros e judeus na Península Ibérica, e, mais tarde, através da miscigenação cultural e étnica. Corrêa fala-nos assim da maneira como Lisboa se encontra marcada, desde o século XVI, por uma onda de fluxos migratórios de portugueses que, ao estabelecerem-se nas colónias, levados pela "grande empresa da África e do Oriente [...] vai-se o território, sobretudo Lisboa, enchendo não só de estrangeiros, atraídos pela aventura, pelas navegações, pelo comércio, como de indígenas de colónias, trazidos à força” (CORRÊA, 1943, p.178).

Nesta galeria de filmes, a pátria ancestral assume-se como um conceito imutável, um universo que faz parte do presente e que resiste gloriosamente à efemeridade e que seria reactualizada em Tabu (2012) de Miguel Gomes. Neste filme, os personagens acreditam ainda na pátria ancestral de que nos fala Anthony Smith (2000) crença que motivou os projectos nacionalistas ancorados na 
segregação étnica. Mas Tabu, ao contrário dos filmes coloniais do velho cinema, ao invés de celebrar essa crença, vai acompanhar o seu devir. Tabu já não é Chaimite (1953) de Jorge Brum do Canto, que representa África como clímax da selvajaria das províncias portuguesas a despeito do mapa "Portugal não é um país pequeno", organizado por Henrique Galvão - o mesmo autor que foi acusado de ser antipatriota pela abordagem feita ao domínio colonial em África $^{3}$ - e exposto em 1934. A África de Tabu, aparece na forma de reminiscências perdidas, assaz oníricas, que, fazendo uso de diversos registos narrativos, vão recompor um espaço-tempo que pretende, acima de tudo, jogar com a memória, mas de um outro modo.

Aqui, a África já não é o Império como fetiche aos olhos do cineasta, como refere Patrícia Vieira (como em Chaimite) mas antes, é-o aos olhos das personagens, nomeadamente Aurora e a sua criada, corpos sonâmbulos e errantes que já não se comportam como os corpos do cinema colonial estado-novista, figuras meticulosamente desenhadas segundo estigmas raciais e de género, e cuja história se desenvolvia em torno de um clássico pressuposto maniqueísta. Em Tabu, os corpos são totalmente independentes dessa encenação prévia que os congratulava com as virtudes de desmedida autoconfiança e soberania social que outrora definiam o homem colonizador. Mesmo durante os flashbacks da África colonial, há sempre um olhar de lamento; passam a evocar saudosamente uma etnopaisagem agora transformada num espaço que se desdobra a partir da narrativa episódica e da narração de Ventura, preservada somente através da memória subjectiva.

Em Tabu, a retrospectiva da vida de Aurora em África vai espelhar precisamente a crença da protagonista numa ideia de pátria ancestral que o cinema português consolidou muito a partir da possessão das províncias ultramarinas, e que obrigava a olhar a História numa perspectiva fixa, imune às alterações que vinham colocar em causa os compromissos ideológicos. Neste filme, a pátria

3 - A propósito da sua obra Em Terra de Pretos (1929). 
ancestral não é evocada como um compromisso ideológico, mas antes, como um lugar de memória que se insere na perspectiva de Pierre Nora, coordenador da obra Les Lieux de Memoire (editada a partir de 1984), que afirmou que a memória e a história, estando longe de ser sinónimas, encontram-se agora fundamentalmente opostas. A memória é a vida, e perdura ao longo da evolução, enquanto a história é reconstrução, problemática e incompleta, e sempre efémera. Em Tabu, a narrativa é assim construída a partir das reminiscências mais fortes de Aurora, que se encontram fortemente marcadas pelo sentimento patriota e saudosista de que nos fala Smith, e que se materializa em grande medida através dos projectos de etnicidade, e, consequentemente, de territorialização, mesmo quando se encontram em questão territórios situados além das 'fronteiras nacionais'.

Ao falarmos de fronteiras, é necessário também evocar, não só a fluidez, mas também a negociação e a disputa, diz-nos Luís Cunha, acrescentando ainda que "justamente na medida em que são fronteiras, ao mesmo tempo em que se separam, unem e articulam, por elas passando discursos de legitimação da ordem social tanto quanto do conflito" (CUNHA, 2000, p. 72). Se, no passado, a noção de um mundo em diáspora era usada como uma ferramenta do imperialismo e do nacionalismo na representação destes territórios além das 'fronteiras nacionais', hoje em dia continua a existir, mas numa dimensão diferente, tocando temas que, durante o Estado Novo, eram considerados tabu, como em muitos casos a emigração. A 'Paris de portugueses' em Ganhar a Vida (2001) de João Canijo, ou A Gaiola Dourada (2014) de Ruben Alves, as férias dos emigrantes durante o verão nas aldeias portuguesas em Aquele Querido Mês de Agosto (2008) de Miguel Gomes. Mas Aquele Querido Mês de Agosto vem fundir dois imaginários idiossincráticos da portugalidade, seja pela questão da emigração ou pela ruralidade como símbolo indissociável do universo territorial nacional, que perpassou a história do cinema português desde a Primeira República até finais do regime estado-novista muito através de espaços e corpos ideologicamente saturados. 
Não é à toa que Agustina Bessa-Luís vai chamar ao campo "memória das artes", chegando mesmo a defender que quem não teve uma relação profunda com o campo fica de certo modo desacompanhado da memória, e terá assim que produzir tudo com o auxílio da mesma. Acrescenta ainda a autora que, "ao crescerem os centros urbanos, ao criar-se a uniformidade dos costumes, podemos estar certos de que isso vai contribuir para que os genes da criação literária e artística se atrofiem. A natureza está ligada ao rito criador; a imaginação não a pode igualar" (2000, p. 177). Leonor Areal, em Ficções do Real no Cinema Português: Um País Imaginado (2011), ao catalogar o universo rural português do cinema estado-novista através de províncias, regiões ou espaços específicos, como a Nazaré e as praias mais a norte, o Ribatejo, as aldeias e os arquipélagos, e, em contraposição, os territórios menos apreciados, como Trás-osMontes ou o Alentejo, vai deixar subjacente um interesse educacional que pretendia deformar a vivência dos corpos consoante os princípios e valores difundidos pela ideologia ditatorial e a trilogia Deus, Pátria e Família. Não vai haver espaço para a exposição das legislações de determinadas regiões que desprezam as leis civis, como nos diz António Fontes em Etnografia Transmontana - O comunitarismo de Barroso (1992) a propósito da região do Barroso, em Trás-os-Montes, cuja prática comum era o casamento entre primos. Os vários tabus, restrições e leis que emergiram de uma mitologia local nem sempre vão aparecer nas representações culturais de determinadas etnopaisagens portuguesas, (seja na fotografia, no cinema, no turismo, na publicidade...), encontrando-se deste modo subjacente um trabalho de disciplina dos corpos, como se verifica no exemplo dado por Fontes, que colidia escandalosamente com os princípios da Igreja Católica que regiam a própria estruturação social portuguesa.

Por outro lado, essa disciplina do corpo vai também funcionar como mecanismo ideológico em filmes como Gado Bravo (1934), A Canção da Terra (1938) de Jorge Brum do Canto ou Um Homem no Ribatejo (1946) de Henrique Campos, que sobrelevam a ideologia do sangue e solo. Estes filmes evocam mitologias locais 
que, neste caso, se equilibram harmoniosamente com os princípios do salazarismo, projectando espaços e corpos com forte conotação ideológica. A memória desses lugares como territórios não tocados pela modernização aflui no cinema estado-novista como forma de preservar um imaginário 'ancestral', que perdurou ao longo da História remotamente tocado pelas novas configurações da modernidade. Em Nationalism and Ehnosymbolism: History, Culture and Ethnicity in the Formation of Nations (2007), refere-se a forma como Anthony Smith seguiu Max Weber na sua formulação de uma ideia de nação como uma comunidade autodefinida, cujos membros cultivam mitos comuns, memórias, símbolos e valores, possuem e disseminam uma distinta cultura pública, residem e identificam com a sua 'terra natal' e criam e disseminam leis e costumes comuns. Só que, no cinema português, o nacionalismo é essencialmente o próprio universo idealizado do regime estado-novista, substituindo uma representação "livre" do nacionalismo destas comunidades como vimos pela questão do casamento entre primos da região do Barroso - sejam as comunidades do Portugal continental, insular ou colonial; tal como o cinema colonial, também a grande parte destes filmes ambientados nos territórios rurais vai ser permeado pela ideia de comunidades étnicas que, ao "espelharem o respectivo território e vice-versa”, vão colmatar a ideia de corpos ideologicamente encenados consoante os modelos sociais do Regime. O corpo do homem associado aos valores de honra, vergonha e coragem, e o corpo da mulher como símbolo da fidelidade e da aceitação da fatalidade, diz-nos Leonor Areal.

\section{Filme-Memorial e Desconstrução da Etnopaisagem: A Libertação dos Corpos e da Câmara}

Com o surgimento do neo-realismo e do cinema novo passa a ser conferida a devida consistência uma nova especificidade aos territórios representados. Desprendendo-se das raízes nacionalistas consagradas pelo romantismo nas categorias de etnopaisagem, inúmeras obras fílmicas passam a exaltar a dimensão humana da 
experiência que se encontrava mais aproximada da realidade: o sofrimento das famílias de pescadores da costa litoral, os costumes vernaculares das aldeias, a pobreza e a miséria de várias comunidades. Em A Imagem-Tempo (2006), Gilles Deleuze, ao explorar o movimento dos corpos em Les Mâ̂tres Fous (1955), vai exemplificar um processo que se pode equiparar às espacialidades emergentes que fracturam representações situadas de etnopaisagem, assim como o próprio movimento dos corpos no espaço:

[...] quando as personagens do rito, possuídas, bêbadas, escumando, em transe, são primeiro mostradas na sua realidade quotidiana em que sâo criados de café, serventes, trolhas, tal como voltarão a ser depois da cerimónia [...]. Já não é Birth of a Nation, mas constituição ou reconstituição ]de um povo em que o cineasta e as suas personagens devêm outros em conjunto e um pelo outro, colectividade que ganha passo a passo, de lugar em lugar, de pessoa em pessoa, de intercessor em intercessor (DELEUZE, 2006, pp. 196-198).

$\mathrm{Na}$ cinematografia portuguesa a que se alude, é ainda evidente o vínculo à tradição realista, porém, existe ao mesmo tempo um distanciamento desta relativamente à relação com a realidade que se procura registar desprovida de 'artificialismos', como o uso de atores não profissionais e o escasso recurso à encenação. A perspectiva de Alves Redol, inserindo-se na tradição neo-realista que defendia a 'batalha pelo conteúdo' vai complementar-se através de uma vinculação política alinhada com os movimentos culturais de esquerda, em que se debate a posição social dos grupos economicamente desfavorecidos. Esta posição vai assentar no princípio de que a arte deve ter uma função que favoreça o ser humano, e todos os assuntos devem servir em seu proveito. Alexandre Pinheiro Torres vai salientar assim a existência da riqueza como "algo que deve ser gozado por toda a humanidade, a ciência como guia do homem, e a arte como proveito essencial e não apenas como prazer estéril” (TORRES, 1979, p. 15). Sendo a ênfase no ser humano o grande tema do neo-realismo, torna-se perceptível que a sua grande questão passa exactamente pelo restabelecimento da união entre a arte e a vida, união essa que deve distanciar-se inteiramente do excesso formal do modernismo. E, alicerçando-se na 
tradição literária neo-realista, Manuel Guimarães vem reivindicar o papel do cinema nacional que havia sido forjado pela ligação ao modernismo de António Ferro (SALES, 2011, p. 82). Em Nazaré (1952) de Manuel Guimarães, o paradigma heróico e nacionalista associado ao mar que vinha desde a tradição quinhentista é invertido para mostrar uma história protagonizada por corpos condenados ao sofrimento e à miséria, desconstruindo o ideal de pobreza honrada que perpassava as narrativas dos filmes ambientados nos territórios rurais do velho cinema, da mesma maneira que $O$ Trigo e o Joio (1965), do mesmo realizador, onde a felicidade da família se vê constantemente embargada pelas intempéries da vida, o trabalho árduo que jamais é recompensado, e que vem desmentir a crença na Divina Providência como uma força que, no final, soluciona todos os problemas. No final de O Trigo e o Joio, os personagens mantém a esperança e continuam a sua luta com optimismo, sequência talvez exigida pela censura, ou para mostrar uma faceta da Divina Providência não tão misericordiosa, e, também em Saltimbancos (1951) do mesmo realizador, os artistas de circo, corpos assombrados pela pobreza, jamais rejeitam o seu ofício; o final esperançoso é, ao mesmo tempo, tingido por uma atmosfera lúgubre que não nos dá certezas se os personagens virão a alcançar a prosperidade que tanto almejam.

Rosalind Galt fala da retórica espacializante da "paisagem política”, em que as paisagens são revestidas por um saturado simbolismo nacional que o animismo do território europeu implicou durante a Segunda Guerra Mundial, "retórica que fez assim com que a paisagem figurasse frequentemente na cultura visual da Europa do pós-guerra, especialmente no cinema, e muitas vezes com diferentes perspectivas políticas" $(2006, \text { p. } 27)^{4}$. É neste contexto que presenciamos uma convivência entre o cinema 'conformista' e o cinema 'insurrecto', já que a memória saudosista e nacionalista deixa de ser evocada como elemento crucial na representação dos espaços. Consequentemente, também o movimento dos corpos no espaço muda, seja a população primitiva, rancorosa e ignorante de O Crime de Aldeia Velha (1964) de Manuel Guimarães ou as personagens 
pouco confiáveis e de valores perversos que habitam a paisagem de aglomerados de prédios velhos, circundados por resíduos rurais, de Os Verdes Anos (1963) de Paulo Rocha, filme que se inicia com a chegada de um jovem provinciano à cidade de Lisboa. Só que, neste filme, não existe a oposição ideológica entre o campo e a cidade, como em Maria Papoila (1937) de Leitão de Barros, em que o espírito mundano da cidade é exaltado pela figura cândida, inocente, de Maria Papoila, uma aldeã de visita à capital. Como refere Michelle Sales, vem encabeçar uma revolução estética que já não enclausura os corpos dentro de determinado território, mas revoluciona o seu próprio quotidiano a partir da abertura de fronteiras outrora delimitadas pelo velho cinema. Deixa de existir a cidade, a aldeia e o campo nas suas tradicionais acepções e corpos disciplinados do 'cada um no seu lugar'. Os espaços fílmicos passam a caracterizar-se por uma hibridez que vem desconstruir a própria organização geográfica estado-novista. $\mathrm{O}$ cinema novo vai apresentar corpos que não se identificam, ou rejeitam mesmo a inserção na sociedade portuguesa, indivíduos marginais sem raízes territoriais, como Pedro Só (1972) de Alfredo Tropa, cujo protagonista Pedro é isento de qualquer julgamento moral ou justificação psicológica para o seu comportamento errante, e, em Belarmino (1964), de Fernando Lopes, a câmara vai empreender uma revolução estética que, afastando-se de um registo essencialmente ficcional, vai assumir um ponto de vista subjectivo do personagem como um factor essencialmente determinado pela objectividade que o cerca; objectividade que aflui a partir dos treinos no ginásio e das sequências compostas por uma diversificada escala de planos que captam o personagem a passear nas ruas da cidade como mais um corpo no meio de vários corpos sem qualquer semelhança entre eles.

Vislumbrando as obras deste período, parece incorrecto afirmar que havia um objectivo colectivo que se prendia com a ruptura e negação dos pressupostos associados a categorias irrefutáveis de etnopaisagem. Com Vilarinho das Furnas (1971), António Campos consegue contornar a problemática inerente à

4 - Tradução livre do autor. 
ideia moderna de etnopaisagem (associada a uma ideologia política nacionalista e imperialista), desmentindo a realidade colmatada pelas etnopaisagens ideologicamente saturadas do Estado Novo, mas imprime à sua obra uma visão que vem lamentar a perda de um território, da sua identidade. António Campos cria um filmememorial, pois, ao invés de romantizar a comunidade de Vilarinho das Furnas, vai registá-la, assim como aos seus costumes e tradições, a fim de a preservar e ao seu território. Vilarinho das Furnas retrata ao vivo "a rudeza da serra agreste que moldou os caracteres de um povo que encontrara no velho sistema comunitário o melhor meio de sobrevivência” (ANTUNES, 1985, p. 71). Realizado um ano antes da inauguração da barragem de Vilarinho das Furnas, em 1972, o filme procura registar a realidade de uma aldeia de que não subsistirá muito mais tempo, sendo alvo de remoção. A obra vem cristalizar essa realidade que desapareceria um ano mais tarde, mas que se encontra materializada através da lente de António Campos, que faz uma descrição minuciosa dos costumes, hábitos e tradições que ligam a população à 'sua terra'. Vilarinho das Furnas é a aldeia serrana desterritorializada, cuja memória subsiste, em parte, graças à obra de António Campos, que desafia a perpetuidade da nova recodificação territorial encabeçada pela construção da barragem resultante dos modernos planos de ordenamento e alterações jurídicas de propriedade. A efemeridade é um sentimento fortemente presente na obra de António Campos, e é precisamente essa plena consciência que o leva a conservar a paisagem de Vilarinho das Furnas no seu filme, da mesma maneira que o fez com a pesca do atum em A Almadraba Atuneira, em 1963, inovador representante do 'novo documentário', sendo mesmo considerado por Bénard da Costa como um dos "melhores exemplos do documentarismo etnográfico português, com notória influência dos filmes de Jean Rouch” (COSTA, 1991, p.138).

Podemos estabelecer uma intercepção entre estes filmes de António Campos e um exemplar bastante mais tardio, No Quarto da Vanda (2000) de Pedro Costa, em que a etnopaisagem já não é um espaço pictórico, sobretudo relacionado com o meio rural pitoresco e com as tradições e costumes ancestrais que o definem, mas, pelo 
contrário, vai projectar uma desconfiguração da ideia de etnopaisagem cuja composição audiovisual assume o resultado das transformações espaciais da actualidade. Pedro Costa, recorrendo à antropologia visual, vai eliminar quaisquer possibilidades de uma leitura estereotipada ou provida de pré-conceitos que possam distorcer o imaginário do bairro das Fontainhas. No Quarto da Vanda, e também Juventude em Marcha (2006) do mesmo realizador, não são filmes que se debruçam essencialmente na dependência das drogas, na pobreza, miséria ou na imigração cabo-verdiana (este último tema ganhando destaque central em Juventude em Marcha), mas antes, estas questões e abordagens vão fluir em perfeito uníssono na construção de uma paisagem idiossincrática de corpos que habitam as periferias urbanas. A etnopaisagem nestes filmes, se existe, reúne os elementos essenciais que concedem ao espectador liberdade para que ele possa fazer a própria leitura do universo diegético: o bairro social como realidade não estigmatizada, que não quer denunciar a pobreza ou a miséria, tampouco fazer julgamentos morais, mas antes, expô-la de maneira crua.

Em certo sentido, podemos vislumbrar No Quarto da Vanda, tal como em Vilarinho das Furnas, a construção do filmememorial, neste caso o Bairro das Fontainhas em Lisboa, que se sabia estar prestes a ser extinto. Haveria a intenção de 'conservar' uma etnopaisagem concebida em moldes totalmente distintos relativamente à sua moderna acepção? As sequências em que os bulldozers vão destruindo gradualmente as casas captam essa iminente desintegração do bairro enquanto um território específico e multiétnico, definido não só pela arquitectura deteriorada, mas também pelos aglomerados de corpos que o vão perder: os toxicodependentes, os imigrantes, as famílias pobres. Em No Quarto da Vanda, um olhar de lamento vem evocar as memórias desses corpos que nós vemos em sofrimento e agonia - não exclusivamente devido à exclusão social - mas pelo sentimento de vazio melancólico que os vai corroendo conforme vão tendo a certeza que o seu bairro está condenado ao desaparecimento. Essa plena consciência da efemeridade aflui, por exemplo, na sequência em que o canário é 
retirado da gaiola na casa de um dos personagens, cessando o seu movimento enquanto um corpo simbólico daquele espaço específico; a ausência do seu canto é a anunciação da iminente destruição do espaço, das memórias, presságio do exílio dos corpos subalternos.

A problemática levantada pela obra de Pedro Costa obriga a que seja executada uma revisão do papel do cineasta autor, que, tendo-se emancipado mais livremente com a revolução de 1974, veio conferir diferentes especificidades ao território. As visões tradicionalistas ou insurrectas, as diferentes crenças ideológicas, culturais ou religiosas, todas estas perspectivas continuaram a persistir, só que desprovidas de qualquer fidelidade a ideias saturadas ou categorias estanque de paisagem como se verificava no Estado Novo. Luís Cardoso, em Ruralidade e pós-ruralidade no cinema português: sedução, sedição e dissídio (2013), vai falar do imaginário rural no cinema contemporâneo evocando uma ideia de pósruralidade, já que os imaginários fílmicos que tomam o meio rural a partir do século XXI vão debater-se com um processo de desconstrução da ideia de ruralidade à qual estávamos habituados.

Os filmes vão incidir ou redescobrir estes territórios sem se confinarem a um único registo (já não há o registo apenas documental ou registo apenas ficcional, mas uma junção entre ambos, na mesma tradição de Belarmino, por exemplo), e mostram uma realidade bem mais desprovida de artificialismos ao mesmo tempo que se empenham em renovar o próprio processo de redescoberta da identidade nacional. Luís Cardoso vai explicar esta tendência fazendo uma retrospectiva da própria história do cinema português, que, marcado por sucessivos episódios de ruptura desde o Estado Novo, acabaria por instituir vários momentos de dissídio explícito com a ruralidade, e até mesmo de sedição, não só marcada pelas mudanças sociais e de valores, mas também pela própria redefinição de paradigmas estéticos. Com isto, o cinema português acabaria por mergulhar numa dimensão de pós-ruralidade, como nos diz Luís Cardoso, desconstruindo os territórios ao mesmo tempo que os procurava libertar dos estereótipos de lugar, classe e etnia que 
outrora condicionavam o movimento dos corpos no espaço, assim como dos princípios e ideais associados à respectiva terra. Neste contexto, é pertinente evocarmos Silva Telles (2004) que afirmou que os movimentos das raças humanas que se realizam sempre dentro de certos limites de tempo e espaço não são ainda hoje rigorosamente interpretados pela antropologia.

Autores como Ricardo Costa (1991), e de uma geração mais recente, Jorge Pelicano e Gonçalo Tocha, vêm trabalhar esta dimensão da pós-ruralidade nos seus filmes ao convocarem o diálogo do espectador com um real negociável. O seu olhar pode ser nostálgico, de lamento, ou até mesmo crítico, contudo, agora já não distorce o mundo real segundo uma óptica ideológica monolítica indissociável da construção sociocultural do Estado Novo, como no velho cinema. Os cineastas filmam o espaço sem lhe atribuir, ou à população, os simbolismos sociais e ideológicos que permeiam, por exemplo, filmes como A Canção da Terra (1938) de Jorge Brum do Canto, Um Homem do Ribatejo (1946) de Henrique Campos ou Heróis do Mar (1949) de Fernando Garcia, libertando os territórios de uma perspectiva saudosista com conotação ideológica. Esse saudosismo vai ser essencialmente individual, como em Viagem ao Princípio do Mundo (1999) de Manoel de Oliveira, através da incursão às raízes simbolizadas a partir de uma aldeia, ou a terra natal do seu outro filme, Porto da Minha Infância (2001), que celebra a cidade como lugar de inspiração artística, retrospectiva não só da sua vida, mas também do seu trabalho. Inserindo fragmentos das suas obras numa narrativa que funciona como simulacro das suas memórias, Oliveira explora um universo que pulsa vibrantemente na sua filmografia, como se verifica por exemplos precoces na sua carreira, como O Pintor e a Cidade (1959): a neblina que se abate aquosamente sobre a ponte D. Luís e sobre o aglomerado colorido de moradias, prédios, igrejas e palácios, cruzados por resíduos rurais que preenchem as duas margens do Douro, o movimento célere da câmara que assume a posição do comboio que ruma na direcção da estação de São Bento. 
A complexidade da condição de pós-ruralidade que Luís Cardoso associa aos espaços fílmicos vai evocar a perspectiva de Jean-Paul Sarte, que disse certa altura construir as suas memórias a partir do presente. Em Aquele Querido Mês de Agosto (2008), Miguel Gomes revisita a aldeia portuguesa a partir de alguns personagens que, durante o velho cinema, eram olvidados das representações do ethos do imaginário ruralista do velho cinema. No presente, continuam a existir os bailaricos, as canções, as quermesses, mas também a comunidade de emigrantes em férias durante o verão, mais especificamente, o saudoso mês de Agosto, 'mês dos emigrantes', que marca o seu regresso à terra natal, repositório de memórias que não procuraram insurgir-se contra a urgência da contemporaneidade. Tal como em Ganhar a Vida (2001), de João Canijo, a emigração é exposta como uma outra dimensão da paisagem portuguesa que, durante o velho cinema, havia sido condenada e suprimida das representações fílmicas. $O$ olhar de Miguel Gomes reactualiza, no pleno sentido da palavra, a aldeia portuguesa, pois vai congratular o imaginário colectivo com uma história que exalta imediatamente uma das dimensões mais idiossincráticas da identidade nacional: as férias dos emigrantes nas aldeias portuguesas. Aquele Querido Mês de Agosto vai, com efeito, ignorar as ideias fixas de códigos territoriais, culturais e sociais, e colocar-se nos antípodas da etnopaisagem ideologicamente saturada.

Se a ideia moderna de etnopaisagem atravessou a história consolidando ideias cristalizadas de corpos e territórios que acabaram por se popularizar e enraizar no próprio inconsciente colectivo, a contemporaneidade vem, por sua vez, oferecer novas visões e representações do espaço sem recorrer a códigos culturais com o intuito de fixar ideias hegemónicas de paisagem. O olhar incisivo lançado sobre o indivíduo vai ser uma marca idiossincrática do cinema de autor, sejam os corpos vulneráveis de David, em Montanha (2015) de João Salaviza, ou de Vanda, em No Quarto da Vanda, o corpo de João de Deus como alter-ego de César Monteiro ou os corpos fetiche em O Fantasma (2000) de João Pedro Rodrigues, o que vem imediatamente contrastar com as 
representações colectivas das comunidades da etnopaisagem pitoresca, não só do velho cinema, mas que também surge em obras mais actuais. Em Benilde ou a Virgem Mãe (1975), Manoel de Oliveira, ainda que aborde o casamento - tema omnipresente em grande parte da sua filmografia - como uma regra social ou uma formalidade em correspondência com as fantasias dos indivíduos, parece ao mesmo tempo criar um universo que, sendo claustrofóbico, obscuro, isolado, vai permanecer totalmente alheio ao ambiente exterior. Nesta obra, os corpos só se movimentam dentro do casarão onde decorre a acção, que condensa, não só as memórias do conservadorismo que imperava durante o Estado Novo, mas também a opressão familiar que não se extinguiu com a revolução. A sua obra, começando com uma sequência do backstage até incidir finalmente num cenário onde se inicia a acção do filme, vai servir-se dos artifícios do teatro na sua criação do ambiente exterior, que "é uma devassa - tal como todo o ambiente exterior em pleno processo revolucionário em curso” (AREAL, 2011, p. 179), através dos uivos de um louco ou da sinistra ventania que chega até a abanar a casa. $\mathrm{O}$ tabu do incesto subterraneamente abordado e descobrindo a figura do pai como uma das mais controversas no imaginário nacional. A perpetuação do patriarcado na estrutura familiar é também criticada ao longo dos anos que se seguem à revolução no cinema.

\section{Movimentação das Terras e o Filtro da Identidade: Revolução da Experiência Estética e o Universo Fantasmagórico dos Tabus}

Gilles Deleuze diz que o cinema "não apresenta apenas imagens, envolve-as num mundo, tendo desde muito cedo procurado circuitos cada vez maiores que unissem uma imagem actual a imagens-lembrança, imagens-sonho, imagens mundo" (2006, p. 95). Se o autor refere, por exemplo, o navio como elemento essencial num circuito que cristaliza e repercute estas várias imagens, 
referindo Lady from Shangai (1947) de Orson Welles, e podemos também acrescentar Dodsworth (1936) ou Ship of Fools (1965) - é necessário apontar o pai como um elemento crucial neste circuito de imagens dispersas e fragmentadas que perpassam todo o cinema português. O pai tirano que se revela em dois pontos separados por um intervalo de trinta anos, em Brandos Costumes (1974) de Alberto Seixas Santos, e em Noite Escura (2004) de João Canijo. Este último filme vem projectar uma visão do pai que pode perfeitamente colocar-se como antípoda do pai do velho cinema, ainda que não seja essa a intenção primordial do cineasta. O filme de Canijo é essencialmente uma feroz crítica à hipocrisia dos costumes, que segue de perto a decadência dos corpos, decadência que, através de uma paisagem 'suja' - tão característica do universo fílmico do cineasta - vai funcionar como uma mordaz sátira ao mito saudosista da casa portuguesa: a liquidificação do corpo, da família, da moral religiosa da fertilidade entroncada na castidade impoluta, do pai como autoridade suprema.

Muito do cinema de autor contemporâneo vai, deste modo, inserir-se na perspectiva de Zygmunt Bauman, em Liquid Modernity (2000), que diz que a sociedade sempre estabeleceu uma relação ambígua com a autonomia do indivíduo, pois tanto pode revelar-se uma inimiga como um elemento crucial na sua existência. Contrastando com o velho cinema, que prezava a vida em comunidade face às adversidades da natureza (sem se associar ao colectivismo marxista), o cinema contemporâneo vem desconstruir ideias de etnopaisagem como representação colectiva dos corpos homogéneos e coerentes enraizados num território. As transformações na organização da experiência vão surgir no cinema como forma de acompanhar a afirmação da diferença, como modo de dar a conhecer as práticas radicalmente dispares de coabitação humana, e, mais visivelmente, a maneira como vai ser captado o envolvimento dos corpos na execução de funções colectivas. Estes territórios do cinema produzido por um vasto leque de realizadores portugueses não obedecem a princípios 'específicos' e 'meticulosos' de planeamento urbano. Pode ser a paisagem industrial, em que os 
resíduos rurais e urbanos se alternam em complexas composições textuais em Tempos Difíceis (1988) de João Botelho, o bairro da Musgueira no volume III de As Mil e uma Noites: O Encantado (2015) de Miguel Gomes, ou em Montanha (2015) de João Salaviza, sobretudo na sequência em que o protagonista incendeia a mota que roubou num descampado perpassado pela linha de comboio, avistando-se ao fundo um horizonte preenchido por blocos de prédios. Em Montanha, essas representações do espaço vão servir-se também do corpo do protagonista, muitas vezes filmado em tronco nu, a dormir defronte de uma ventoinha, deitado na varanda ou no terraço de uma casa em construção, a deambular pelos corredores exteriores do prédio, sequências que parecem transpor para o espectador as sensações produzidas pela relação que estabelece com o ambiente físico, independentemente de os planos serem fechados ou abertos. O calor por vezes irrespirável em várias cenas, a calma enigmática do crepúsculo a abater-se sobre os blocos de prédios, a morosa melancolia - e podemos até mesmo sugerir o cheiro a éter que irradia dos corredores velhos e lúgubres do hospital em que o seu avô se encontra internado.

As novas configurações espaciais vão ser transformadas e reflectidas pelo cinema, já que "a movimentação de terras, algumas de dimensão excessiva, nomeadamente para a edificação de grandes estruturas [...] contribui pouco a pouco para o desaparecimento de uma lógia primordial de entendimento da superfície da terra" (MATTOSO; DAVEAU; BELO, 2010, p. 511). Esta "movimentação de terras" vai obrigar a uma eventual movimentação dos corpos, sem que a memória perca o seu derradeiro papel na reactualização dos universos subjectivos. Segundo Umberto Eco, "the idea that the lack of memory leads to the 'triumph of the eternal present' and of its (false) promise of happiness, with all that goes with the delicate balances of culture and art, more and more ephemeral, hedonistic and 'without history"' A memória das etnopaisagens ideologicamente saturadas do Estado Novo pode aparecer no cinema feito depois da revolução, como Os Demónios de Alcácer-Kibir (1975) de José Fonseca e Costa, que segue o percurso de um grupo de teatro ambulante por um 
universo de fantasmagórica opressão. Confrontando-se com as figuras e grupos sociais emblemáticas do território alentejano, desde o grupo de aristocratas representado em tom caricatural, o filme vai também desmitificar o ideal de pobreza honrada a partir da personagem da velha beata, que vai distanciar-se do arquétipo da mulher de família de valores conservadores que habitava as etnopaisagens rurais portuguesas, ao dizer: "Vejo que há cada vez menos gente disposta a sofrer e a calar. E ainda bem”. E o seu filho acrescenta: "A vida é cada vez mais dura para os que ficam. E maior é a repressão". O filme de Fonseca e Costa, apesar da visão satiricamente mordaz, e de se inserir no período pós-revolucionário, vê-se assombrado pelo espectro do Estado Novo, como se verifica sobretudo na sequência final, em que as forças polícias repressoras liquidam os personagens.

A transformação das etnopaisagens que acompanha as novas configurações da experiência vai culminar no 'despaisamento', como referiu Dórdio Guimarães a propósito do filme Trás-os-Montes (1976) de António Reis e Margarida Cordeiro. Actualmente, as representações culturais da etnopaisagem, desterrando a perspectiva imperialista dos espaços, vão estar também muito relacionadas com a diversidade cultural provocada pelos fluxos migratórios de que nos fala Lucinda Fonseca; a autora afirma que esta diversidade cultural manifesta-se de formas distintas na paisagem urbana:

[...] através da emergência de bairros degradados onde se concentram os imigrantes e minorias étnicas pobres e do aumento da segregação residencial de base étnica; da introdução de elementos arquitetónicos característicos das regiões de origem dos imigrantes (locais de culto religioso, organização interna das habitações, pátios, janelas, varandas, jardins e diversos elementos decorativos); da presença de múltiplos estabelecimentos de comércio étnico; da variedade das formas de vestuário; dos cheiros e sabores das comidas

5 - Umberto Eco: for na aesthetic of memory. (s.d). Blummprize. A ideia que a falta ou o vazio da memória leva ao "triunfo do presente eterno" e das suas (falsas) promessas de felicidade implica que se desvaneçam os delicados balanços da cultura e da arte, que se vão tornando mais e mais efémeros, hedonísticos e sem história" (tradução livre do autor). 
tradicionais de diferentes regiões do mundo; da sonoridade das línguas que se ouvem nas ruas e noutros espaços públicos e da variedade da música, e de outras formas de expressão artística e cultural transportadas de países e regiões dispersas por todo o Planeta. Deste modo, graças à imigração, no virar do século, Lisboa é também, cada vez mais, uma sociedade pluricultural, embora com uma forte dominante dos imigrantes de Língua Portuguesa e de confissão religiosa católica (MALHEIROS, 2000 apud FONSECA et al., 2009, p. 73).

Ao desvendarmos nas representações culturais de espaço do cinema contemporâneo uma heterogeneidade que se opõe à meticulosa cartografia desenhada pelo velho cinema do Estado Novo, encontramo-nos em sintonia com a perspectiva de Eduardo Lourenço, em Portugal como destino seguido de Mitologia da saudade (2009), que se refere a Portugal como um país com dificuldades em reconhecer a sua própria identidade, já que, após a Revolução de 25 de Abril, foram alterados 500 anos de auto-imagem como poder colonial, obrigando o país a confrontar-se como nunca antes com a sua identidade. $O$ autor nota ainda que a crise profunda de identidade que se seguiu à instalação da democracia após o final da ditadura do Estado Novo "deixou o país sem uma ideia clara sobre como relacionar-se com as suas experiências e códigos culturais. Além do mais, o estatuto de membro da Comunidade Europeia e as suas implicações capitalistas ampliaram ainda mais esta crise de identidade" (LOURENÇO, 2009, p. 68). Esta afirmação vem corroborar a imagem de um país com uma conflituosa relação com a sua memória, uma memória que se definiu duradouramente pelas suas raízes imperialistas, coloniais, nacionalistas e patriarcais, um processo que tem passado frequentemente por complexos mecanismos de uma 'forçada' amnésia colectiva. Inúmeras obras fílmicas feitas hoje por homens e mulheres portuguesas, ou que trabalham o universo problemático da portugalidade, lidam com esta questão, e fazem-no com recurso 'à ideia de paisagem como tecnologia para a organização da experiência” (AZEVEDO, 2012). Neste contexto, a moderna ideia de etnopaisagem vai desintegrar-se dentro do imaginário fílmico, acabando por renascer, contudo, a partir de novas ópticas, operando um trabalho catártico de crítica, 
confronto e revisão, que, de formas diversas, vai descodificar a paisagem, a memória e os corpos.

\section{Referências}

ANDREWS, M. Landscape and Western Art. Oxford: Oxford University Press, 1999.

ANTUNES, M. A. Vilarinho das Furnas, uma aldeia afundada. Lisboa: Regra do Jogo, 1985.

AREAL, L. Ficções do Real no Cinema Português. Um País Imaginado. Lisboa: Edições 70, 2011. v.1 e 2.

AZEVEDO, A. F. A experiência de paisagem. Porto e Lisboa: Figueirinhas, 2012.

AZEVEDO, A. F. Políticas de Pós-memória e paisagem cinematográfica como categoria epistémica. Um lugar rugoso da experiência. In: AZEVEDO, A.F., RAMÍREZ, R. C.; OLIVEIRA, W.M. (Eds.). Intervalo II: entre geografias e cinemas. UMDGEO: Universidade do Minho, 2015.

BAUMAN, Z. Liquid Modernity. Cambridge: Polity Press, 2000.

BELO, D. Portugal, Luz e Sombra - o paÍs depois de Orlando Ribeiro. Lisboa: Círculo de Leitores/Temas e Debates, 2012.

BESSA-LUÍS, A. Contemplação Carinhosa da Angústia. Local: Guimarães Editores, 2000.

CARDOSO, L. 'Ruralidade e pós ruralidade no cinema português: sedução, sedição e dissídio'. In: MARTINS, A. et al. (Org.) O Futuro do Mundo Rural em Questão: Atas do I Congresso de Estudos Rurais do Norte Alentejano. Instituto Politécnico de Portalegre C3i - Coordenação Interdisciplinar para a Investigação e Inovação, 2013, p. 230-244.

CORRÊA, M. Raças do Império. Porto: Portucalense Editora, 1943.

COSTA, J. B. Histórias do Cinema Português: Sínteses da Cultura Portuguesa. Lisboa: Europália 91, Ed. Imprensa Nacional - Casa da Moeda, 1991.

CRUZ, M. B. Teorias sociológicas: os fundadores e os clássicos. Lisboa: Fundação Calouste Gulbenkian, 2013.

CUNHA, L.Terras lusitanas e gentes dos brasis: a nação e o seu retrato 
literário. Fortaleza: Universidade Federal do Ceará. Revista Ciências Sociais, v. 40, n. 2, p. 72-86. 2009.

DELEUZE, G. A imagem-tempo. Cinema 2. Lisboa: Assírio e Alvim, 2006.

DELEUZE, G.; GUATTARI, F. O Anti-Édipo: Capitalismo e Esquizofrenia. Lisboa: Assírio e Alvim, 2004.

FONSECA, M. L. et al. (Eds.) Imigração, Diversidade e Política Cultural em Lisboa. Lisboa: Centro de Estudos Geográficos, 2009.

FONT, J. N. \& RUFÍ, J. Geopolítica, Identidade e Globalização. São Paulo: Annablume, 2006.

FONTES, A. L. Etnografia Transmontana. O comunitarismo de Barroso. Porto: Editorial Domingos Barreira, 1992. v. 2.

GALT, R. The New European Cinema: Redrawing the map. Columbia University Press: New York, 2006.

JENKINS, R. Rethinking Ethnicity: Arguments and Explorations. London: Sage, 2008.

LEOUSSI, A. S.; GROSBY, S. (Eds.). Nationalism and Ehnosymbolism: History, Culture and Ethnicity in the Formation of Nations. Edinburgh: Edinburgh University Press, 2007.

LOURENÇO, E. Portugal como destino seguido de mitologia da saudade. Lisboa: Gradiva, 2009.

MATTOSO, J.; DAVEAU, S. \& BELO, D. Portugal: O Sabor da Terra Um retrato histórico e geográfico por regiões. Lisboa: Temas e Debates, Círculo de Leitores, 2010.

NORA, P. 'Between Memory and History: Les Lieux de Memoire'. In: Representations, n. 26, 1984. (Special Issue: Memory and CounterMemory Spring, 1989).

RIBEIRO, O. Silva Telles, introdutor do ensino da geografia em Portugal. In: Finisterra, n. 11, s.n., s.l., p. 10-36, 1977.

ROGOFF, I. Terra Infirma. London e New York: Routledge, 2000.

SALES, M. Em Busca de um Novo Cinema Português. Covilhã: Livros LabCom, 2011.

SIMMEL, G. A Filosofia da Paisagem. Covilhã: Universidade da Beira Interior, 2009. (Textos Clássicos de Filosofia).

SMITH, A. 'Images of the Nation - Cinema, art and the national identity'. In: HJORT; MACKENZIE (Orgs.). Cinema and Nation. London: 
Routledge, 2000.

TELLES, F. X. S. Obras de Silva Telles - Ciência Geográfica. Lisboa: Associação Portuguesa de Geógrafos, 2004WAINWRIGHT, J. Decolonizing Development: Colonial Power and the Maya. London: Blackwell Publishing, 2008.

TORRES, A. P. Os Romances de Alves Redol. Lisboa: Moraes Editores, 1979.

UMBERTO ECO: for an aesthetic of memory. (s.d). Blummprize, 1979. Completar, site etc.

VASCONCELOS, J. L. Etnografia portuguesa. Lisboa: Imprensa Nacional - Casa Moeda, 1980. v.2.

WAINWRIGHT, J. Decolonizing Development: Colonial Power and the Maya. Blackwell Publishing, 2008. 

Paisagem, Corpo e Memória nas Narrativas Científicas da Geografia Colonial Portuguesa

Marta Rodrigues 


\section{$\mathrm{O}$} presente estudo aborda o texto científico como um tipo particular de narrativa, uma narrativa que assenta no princípio de autoridade da ciência sobre as demais formas de produção de conhecimento. Inscrito no âmbito de um projecto mais vasto que analisa a produção do conhecimento científico por geógrafas portuguesas, o estudo de que aqui dou conta debruça-se sobre uma parcela do trabalho da primeira mulher doutorada em Geografia na Península Ibérica, com o intuito de perceber as especificidades de uma narrativa geográfica inclusa num contexto de produção científica dominado por homens, num momento em que as políticas coloniais se encontravam em profunda metamorfose e em que a ideia de missões geográficas tinha substituído a ideia de viagens de descoberta e exploração.

A relação entre exploração e produção de conhecimento, especificamente conhecimento incorporado nos discursos científicos europeus, conta com uma longa tradição e encontra-se associada à expansão dos Estados Nação. Com a institucionalização da Geografia no século XIX, instalou-se um sentimento de ruptura que em certo sentido é uma ficção, a ideia de que as viagens de descoberta deixaram de ser de exploração uma vez que os seus objectivos passaram a ser científicos mais do que heróicos impulsos de viajantes, ou respondendo a propósitos pessoais ou nacionalistas (RYAN; NAYLOR, 2009). As narrativas de viagem de 'mundos desconhecidos' proporcionaram, desde sempre, um manancial de informação geográfica, sendo fulcrais para averiguar como o conhecimento do espaço do Outro é constituído, pondo a descoberto as relações entre paisagem, corpo e memória. Mas a viagem de exploração sempre foi um processo de contacto físico e material, mental e psicológico, emocional e disruptivo, pelo que a análise de narrativas científicas e de viagem, permite compreender tanto sobre o Outro como sobre o sujeito de exploração, autor ou autora da narrativa, bem como o contexto de produção em que se encontra inserido. Os trabalhos de Louise Pratt em torno de narrativas ocidentais de viagem e exploração são, a este propósito, reveladores, na medida em que a autora as considera como processos 
de transculturação que juntam europeus e não-europeus ao longo de zonas de contacto, processos de encontro que transformam ambas as partes e através dos quais os sujeitos envolvidos se esforçam por acomodar as percepções culturais do Outro.

As narrativas científicas organizadas em formatos linguísticos codificados e envolvendo exercícios de intertextualidade (a escrita, a fotografia, o mapa), são documentos riquíssimos para a tentativa de compreensão dos diferentes tipos de encontro despoletados pela viagem, deslocação e contacto entre corpos. Elas configuram-se mesmo como um exercício facilitador dos processos de estranhamento que marcam o contacto com 'o desconhecido', uma forma de lidar com o medo, o desejo, a insegurança, uma tentativa de domesticar o Outro mas também dos sentimentos que tomam conta do próprio sujeito de investigação. Uma forma de disciplinar o corpo, de lidar com emoções fracturantes e contraditórias. $\mathrm{O}$ desenvolvimento de uma retórica do estranhamento que permite controlar os efeitos de desintegração do sujeito perante a diferença radical, através da mobilização de conceitos, imagens, artefactos e aparelhos que permitem colocar à distância o que é novo, transformado em objecto de investigação.

Esgrimindo um aparato de controlo e poder sobre si próprio e sobre o Outro, o viajante, agora investigador-cientista, ordena e categoriza antes de mais como forma de organização interna, de acomodação da experiência nas suas representações culturais, incorporando em cada ponto e em cada linha o efeito fracturante da experiência do que chama clima, geomorfologia, raça, lugar, território, fronteira. Donde a paisagem como objecto de estudo da Geografia, pela potência do conceito, da "ideia de paisagem como tecnologia para a organização da experiência” (AZEVEDO, 2012). Constituindo-se desde o início das descobertas enquanto poderoso sistema simbólico sobre o qual assentou a construção da moderna imagem do mundo, a ideia de paisagem funcionou como conceito operativo que permitiu ao europeu lidar com o distúrbio emocional provocado pelo efeito de estranhamento e dos circuitos de transculturação. Através dele organizou a 
experiência estética, científica e ética de comando de territórios e recursos, a tecnologia do observador. A estratégia de distância e abstracção. O exercício de posicionalidade.

A produção de representações discursivas através de textos e imagens, foi "arma" fulcral através da qual o Ocidente veio a cimentar a colonização de outras regiões culturais. Por meio de narrativas científicas e de viagem, imagens e metáforas linguísticas, criou-se e manteve-se um imaginário geográfico que serviu propósitos nacionalistas, imperiais e eurocêntricos. $\mathrm{O}$ modo como estas narrativas legitimaram o poder instituído, é agora alvo de escrutínio em diversas áreas, associando-se a um crescente interesse na relação entre a disciplina geográfica e o seu uso pelos centros de poder, procurando descodificar-se como a geografia académica tem trabalhado as suas estratégias discursivas, de representação e de posicionalidade. Neste sentido, a análise de texto é estratégia fundamental por se entender que cada narrativa é um espaço de inscrição de corpos e sujeitos, uma arena de representação através da qual se esgrimem diferentes formas de poder e identidade, tendo os trabalhos sobre a produção e representação do espaço colonial e sobre como estes foram construídos ao redor de conceitos diferenciais como classe, género e raça demonstrado o seu impacto nos diferentes encontros coloniais. Ao postular os textos como uma produção de significados, Homi Bhabha assume que estes são construídos numa relação de diferenças no que concerne a outros discursos construídos historicamente. Isto resulta na produção de uma imagem híbrida, contendo traços de vários discursos, fazendo com que a representação do colonizado seja vista como uma prática discursiva. Para o autor as posições discursivas em situações coloniais são fornecidas pelo processo de construção da identidade, onde o desejo colonial é sempre articulado em relação ao Outro. O próprio processo de identificação não só se limita a afirmar uma identidade pré-existente mas também produz uma imagem de identidade acompanhada pela tentativa de transformar o sujeito, de modo a que assuma essa imagem. Ao destacar o papel da alteridade e da relação como constituintes da identidade, Bhabha não separa a construção 
da identidade do colonizador da construção de identidade do colono, dando ênfase à análise que tem em conta a identidade híbrida do colono e do colonizador.

Neste sentido, e sendo a hibridização um modo de questionar as narrativas da historiografia clássica da nação, a análise crítica de Bhabha aos textos coloniais, tem como objectivo principal entender o modo como o sujeito colonial era representado ou podia ser representado, focando-se em especial no confronto entre as linguagens usadas para essa mesma representação e a questão da construção da identidade do sujeito. Ao valorizar o hibridismo como o elemento constituinte da linguagem, Bhabha recusa a tendência de substituir as imagens 'distorcidas' do colonizado por formas mais autênticas das previamente retratadas na literatura colonial, procedendo à desconstrução da análise de imagens como modo crítico de abordar o "autêntico" através do conceito de discurso como prática significativa. A escolha de textos coloniais prende-se, portanto, com a convicção de que estes funcionaram e funcionam como verdadeiros instrumentos de colonização cultural que pedem a desconstrução e, mesmo no caso de textos científicos, ou se calhar mais ainda no caso dos textos científicos, estes funcionam como verdadeiros testemunhos de operação das redes de poder, verdade e conhecimento postas em jogo para a moderna legitimação e superioridade da cultura ocidental. Donde a opção pela análise do discurso colonial em textos geográficos, pelo modo como através deles se operou a 'naturalização' de uma metanarrativa geográfica passível de colocar o sujeito do humanismo como entidade dotada para o controlo, administração e subjugação dos outros.

\section{Paisagem e Memória: Sentimentos de Lugar}

Dando ênfase à análise de contextos institucionais, intelectuais e sociais onde as práticas exploratórias tiveram lugar, a Geografia considera o papel dos viajantes, legitimadores de 
autoridade científica e símbolo de visões do mundo. Em certa medida, as descrições científicas coloniais podem ser compreendidas como um tipo específico de narrativas de viagem, através das quais se processa em maior ou menor grau a corporização de espaços, tempos e identidades. Como narrativas oficiais institucionalizadas, as narrativas científicas operam com as lentes autorais do sujeito soberano da Razão. Mas quem é esse sujeito e como se inscreveram as narrativas de mulheres nas redes masculinistas de poder, verdade e conhecimento sobre as quais se ergueu um imaginário geográfico total?

No caso específico da geografia portuguesa, a entrada da mulher na produção de conhecimento científico moderno deu-se com Maria Raquel Viegas Soeiro de Brito que entre muitas outras obras deixou o tratado canónico "Goa e as Praças do Norte” (1966), fruto da sua integração na Missão Geográfica da Índia (1955). Sob a égide do geógrafo Orlando Ribeiro, coordenador das Missões de Geografia da Junta de Investigações Coloniais, cabia a esta mulher a tarefa do elaborar científico da paisagem do Império Português do Oriente, estruturando um discurso sobre um território que, tendo como base um projecto do prestígio nacional, validasse a política colonial portuguesa à luz do ideário do Estado Novo. Não podemos esquecer que à época era necessário criar um corpus de conhecimento acreditado pela autoridade da ciência moderna, para cada uma das províncias portuguesas, do Minho a Timor.

Definindo o império português do Oriente como um "facto sem paralelo tanto na expansão portuguesa como na dos outros povos da Europa" (BRITO, 1966, p. 7), devido à abertura a novas culturas e povos sem receios, e à colonização do território indiano como algo sem precedentes e original, Raquel Soeiro de Brito vai expondo desde o início da obra a sua própria agenda ideológica através de uma narrativa espacial de base histórica sobre a construção do império português no Oriente (BRITO, 1966, p. 7). Como explica J. R. Pimenta (2010), os maiores problemas gerados pelo rearranjo geopolítico do pós-guerra forçaram Portugal a um envolvimento mais efectivo com uma política de ocupação dos 
territórios (parte deles apenas nominalmente) sob jurisdição portuguesa. Isto justificou as 'missões coloniais' e o apoio pelo governo de todo um programa colonial de investigação geográfica estribado numa 'cartografia da expansão' e replicado pela academia. Um programa iniciado nas ilhas atlânticas e que vai ao reconhecimento territorial do Império português quinhentista, englobando o conjunto dos designados territórios inter-tropicais apresentados como a fundação do império. Neste contexto político e de produção de conhecimento, a autora faz uma descrição ampla e pormenorizada dos modos de vida da Índia Portuguesa estruturando a sua obra na história e na descrição dos aspectos físicos e humanos.

Iniciando a obra com os termos gerais da Missão Geográfica da Índia enquanto ponto de partida para o estudo geográfico, cabia à geógrafa "o estudo dos processos e organização da pesca e arranjo do espaço agrícola, além do levantamento de pormenor de três aldeias de Goa” (BRITO, 1966, p. 5) com base na observação directa. A este propósito a autora lembra que desde o início do estudo (1955) à impressão da obra (1966), poderão existir pequenas diferenças no espaço indiano, mas, e de acordo com a autora, "as estruturas evolucionam lentamente no espaço indiano e é de crer que as transformações nos últimos anos não tenham alterado substancialmente o que foi matéria deste estudo" (BRITO, 1966, p. 6). Trata-se de evocar, desde o início do estudo, a percepção de um 'tempo lento', a ideia de um espaço parado no tempo, uma ideia aliás vinculada nos tratados orientalistas do início do séc. $\mathrm{XX}$, onde o Ocidente se descreve "como progressivo, no sentido do fazer da história e da transformação do mundo, enquanto que o Oriente foi definido (pelos europeus) como estático e intemporal" (CRANG, 1998 , p. 66). Dois princípios organizadores orientam esta narrativa científica; o sentido de um tempo lento associado ao Oriente e a ideia de império mítico português com base espacial no Oriente.

Raquel Soeiro de Brito abre o capítulo "Goa" com a descrição do quadro natural, promovendo a exaltação da natureza regional e contextualizando a obra na escola vidaliana francesa, grande influência da escola de geografia portuguesa. A narrativa 
apresenta uma clara divisão entre o meio natural e humano, dando primazia ao quadro físico da região, como modo de 'fixar' o quadro da paisagem retratada. Ao longo da descrição de Goa, Raquel Soeiro de Brito vai avançando os traços individualizados da paisagem cultural, dando ênfase à inscrição das culturas locais na paisagem, passando a ideia de uma legitimação do cultural por 'natureza', e descrevendo a 'natureza natural' de modo a legitimar um estado de atraso civilizacional subjacente no texto escrito e visual.

O estudo das regiões é essencial para a autora, movimentando-se num quadro epistemológico mais lato dentro do qual a geografia regional permitia consolidar a moderna imagem do mundo de pendor eurocêntrico, tentando afastar-se das anteriores abordagens da antropogeografia. Baseada em generalizações socialmente construídas, a questão de identidade de lugar na narrativa de viagem é transmitida pela estetização da paisagem. Assumida por Vidal de la Blache, a intimidade entre cultura, paisagem e região (GREGORY et al., 2009, p. 634) consolidou um muito específico conhecimento do mundo, organizado de forma a perceber a 'personalidade de lugar'. Desde a sua posição de cientista europeia debruçada sobre as características de um território, a autora vai exprimindo ideias e sentimentos como forma de tornar inteligível a percepção de um espaço que era urgente descodificar para consumo interno e externo. Deste modo, a paisagem apresenta uma geografia histórica distintiva que vai permitir que Raquel Soeiro de Brito desenvolva uma narrativa geográfica descritiva onde exprime, através da fisionomia dos lugares e do trabalho da memória, os sentimentos que o lugar lhe impõe: as complexas relações entre o ser humano e o ambiente físico.

Observando o espaço goês, a autora denota como "feições mais marcantes da paisagem" (BRITO, 1966, p. 13), as plataformas litorais onde encontra "superfícies rígidas", com "magros arbustos” e zonas "quase completamente estéreis" (Figura1), a par da acção humana que "cortando e desbastando a mata original para aí colocar culturas alimentares ou lançar o gado a pastar, contribui para a descrição do delgado solo" (BRITO, 1966, p. 14). A linguagem usada pela geógrafa produz um discurso que não deixa dúvidas; rigidez, 
magreza e esterilidade. Apoiando-se em metáforas, a narrativa potencia ao leitor uma imagem de pobreza e subdesenvolvimento da Índia, criando uma teia de problemas e adensando o carácter salvador da missão portuguesa nas colónias. Cria-se assim uma relação de poder e dominação cultural onde aquele que constitui o Oriente não tem permissão para falar (o direito à autorepresentação), sendo objecto de construção europeia. E. Said (1978), mostrou claramente este fenómeno, sendo o orientalismo visto como um estilo ocidental de dominação, reestruturação e sustentação de autoridade ocidental sobre o Oriente perspectivado como macro-região cultural.

\section{Figura 1 - Rebordo do Planalto dos Gates}

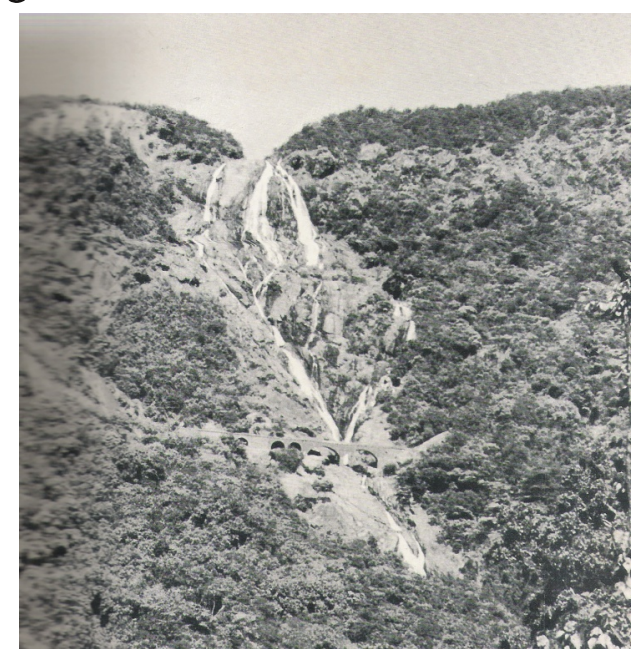

Fonte: Goa e as Praças do Norte (1966)

Esta ideia de domesticação encontra-se fortemente ligada às premissas ocidentais de civilização e progresso, presente nas práticas políticas coloniais, que permitiram justificar o carácter civilizador do império português. Raquel Soeiro de Brito tenta justificar a actualidade deste carácter civilizador ao avançar com a descrição de espaços vazios e pobres, perpassando imagens sobre a superfície terrestre, onde os solos pouco ocupados constituem territórios exíguos, onde a ideia de uma relação harmoniosa com a natureza é fulcral na geografia imaginária ocidental. A narrativa conduz a um sentido de memória de um passado áureo marcado pela ocupação portuguesa e votado ao declínio, de falta de progresso, constituindo 
um artifício para a articulação dos modos de representação colonial. O discurso enviesado pela visão eurocêntrica e pelo gesto compartivo, descrevendo a rigidez de superfícies, a magreza dos arbustos ou a esterilidade das "zonas", vai desenvolvendo o trabalho de construção de significados sobre os lugares retratados, onde não é difícil fazer evoluir o conhecimento. De acordo com Bhabha: “(u)m traço importante do discurso colonial para a construção ideológica da alteridade é a sua dependência do conceito de "fixidez". A fixidez, enquanto signo da diferença cultural/histórica/ racial no discurso do colonialismo, constitui um modo paradoxal de representação: conota rigidez e uma ordem imutável, bem como desordem, degeneração e repetição compulsiva" (BHABHA, 2005, p. 143). As visões e ideias da rigidez da paisagem vão organizando a construção da imagem do lugar sob a fachada de uma linguagem neutra e científica, progredindo a narrativa em julgamentos supostamente legitimados pelo 'natural', onde à medida que se vai procedendo à antropomorfização das formas físicas vai-se também tornando mais complexo o sentimento de lugar. À senilidade dos relevos contrapõese a maturidade dos vales (Figura 2) e ainda a juventude das formas, num processo crescente de historicização das formas físicas (Figura 3) que aprisiona o meio numa leitura tão situada quanto as teorias geológicas o impunham.

Figura 2 - Plataformas do litoral

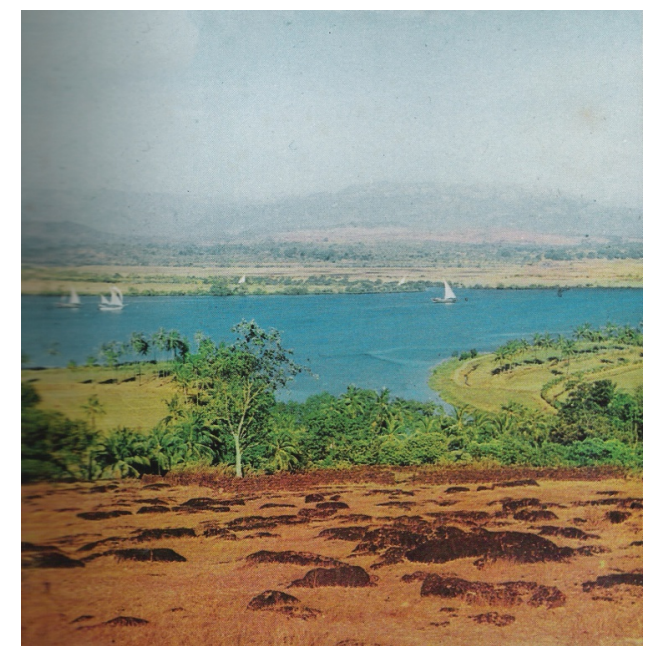

Fonte: Goa e as Praças do Norte (1966) 
Figura 3 - Vista aérea da Fortaleza de Damão

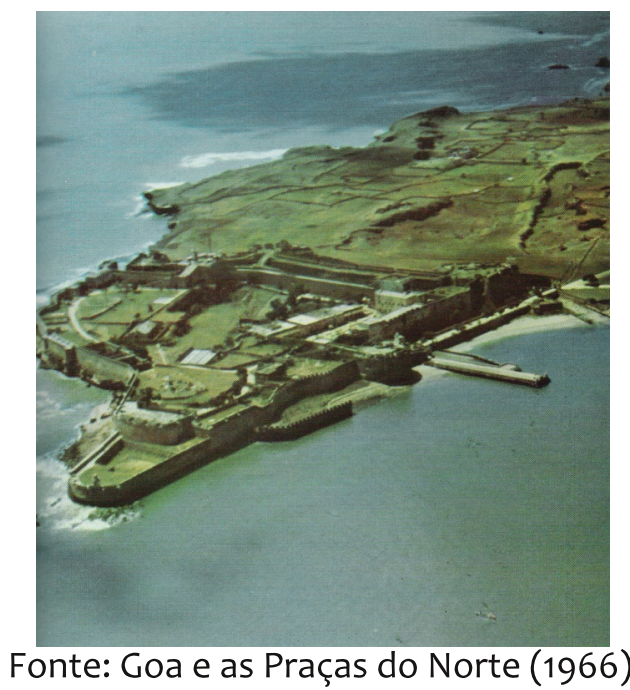

A preocupação com as ressonâncias subjectivas e artísticas do conceito de paisagem despoletaram todo um conjunto de estudos em torno das suas representações como forma de compreender questões geográficas, o que envolveu um percurso crítico de examinação histórica do próprio conceito (AZEVEDO, 2007, 2009) e a relação com outras noções como corpo e memória. Criam-se assim alternativas à construção ocidental do Oriente enquanto "processo de representação construído [...] que resulta em 'algo feito', uma ficção no verdadeiro sentido da palavra” (GREGORY, 1998 , p. 8). Contra a posição totalizadora do argumento de Said, defendendo que este presumia facilmente uma intenção inequívoca por parte do Ocidente, a de governar sobre o Oriente através de produções discursivas, Bhabha demonstra que o discurso colonial, forma mais subdesenvolvida de discurso, funcionava não só como uma construção instrumental de conhecimento, mas também segundo protocolos ambivalentes da fantasia e do desejo, visto ser articulado em torno de formas estereotipadas de alteridade.

Mas as questões de diferença não são apenas perceptíveis no discurso textual e imagético da autora. O corpo e as emoções respondem também ao clima, que enquanto condicionante da ocupação do solo, condiciona também a vida das populações e cria 
diferentes formas de sentir e uma narrativa de contrastes descritos de uma forma maravilhosamente pormenorizada: "De um céu coberto por grossas nuvens cor de cinza que se desfazem durante horas seguidas em catadupas de água, passa-se a uma transparência atmosférica quase sem limites, em que os mais pequenos pormenores são avistados com toda a nitidez a muitos quilómetros de distância, e durante meses seguidos não cai nem uma gota” (BRITO, 1999, p. 18). O que a autora recria é um espaço de contraste, onde a natureza contrastante e encantadora, provoca um sentimento ambíguo que surpreende, ameaça e cativa. É o jogo entre a ambivalência e o estereótipo que se desenvolve através do texto e a sua repetibilidade efectiva a própria estratégia de posicionalidade. O 'Eu' torna-se “de algum modo, uma entidade centrada, que emerge da interacção relacional e reflexiva com outras pessoas e eventos" (CONRADSON, 2005, p. 106), um efeito de práticas e discursos externos a que o corpo não é alheio. Trata-se, pois, de construir um sujeito colonial através da descrição da paisagem, onde a articulação das formas da diferença se efectiva pela expressão do sentimento de lugar. Nesta mistura de ciência descritiva e sentimentos de lugar, Raquel Soeiro de Brito apresenta Goa como deprimente, onde o tempo de monção cria "uma atmosfera quente e muito carregada de humidade, profundamente desagradável, e para pessoas sensíveis, mesmo doentia." (CONRADSON, 2005, p. 21). Os trópicos deixam de ser exóticos e encantadores, acarretando consigo uma imagem negativa e desagradável atribuindo-se-lhe a ideia de inferioridade e doença.

O clima tropical, onde a contestação do selvagem, do excessivo e do bruto contrasta com o clima temperado, modela a produção do conhecimento e marca a originalidade do clima da região, comentando a autora na sua visão essencialista que: "se todas as regiões da terra têm o seu clima próprio, em poucos mais ele será tão exclusivamente dominante como nestas" (CONRADSON, 2005, p. 20). A insistência na tentativa de recriar uma representação de espaço através de relações de oposição permeia este discurso de reconhecimento. Todas estas descrições invocam sensações 
perturbadoras; "é um tempo depressivo e sob o qual o menor esforço é assinalado por leve camada de suor, que fica colada ao corpo e provoca quase sempre sensação de mal-estar” (p. 23). Esta sensação apenas parece passar em Outubro quando "reinam os tempos mais frescos, secos e radiosos de sol” (p. 123), parecendo alegrar e dar ânimo aos dias da cientista. Efectua-se a construção de um espaço teórico para afirmação de uma identidade originária assente em discriminações e contradições sobre um 'objecto' que se pretendia colocar "no seu lugar". Como se a duplicidade essencial do asiático, e da Ásia enquanto região cultural, pudessem ser efectivamente comprovadas pelo discurso científico.

A modificação da paisagem pela acção humana é outro tema retratada pela autora quando pretende dar a conhecer a organização dos diferentes espaços existentes em Goa, Damão e Diu. O estudo geográfico passa pelo exame combinado de factos humanos e físicos visando a produção de especificidades locais. As representações de espaço, "onde a presença do homem adquire maior continuidade e a sua marca na transformação da paisagem é mais profunda" (CONRADSON, 2005, p. 56), demonstram como o meio em grande medida se define em função da obra humana que o transforma, enfatizando o papel modelador da sociedade na natureza através dos "modos de vida padronizados funcionalmente" (LIVINGSTONE, 1992). A estratégia textual organiza-se de forma a que a paisagem natural se transforme em paisagem cultural. A paisagem natural é vista "como um material bruto a partir do qual as forças produtivas de uma variedade de sistemas sociais engendraram os seus espaços particulares" (LEFEBVRE, 2002, p. 138). Havendo a necessidade de descodificar os diferentes processos que criam a multiplicidade de espaços, a autora observa: "se a topografia é obra da natureza, ao homem cabe a responsabilidade [...] da esterilização dos planaltos" (BRITO, 1966, p. 56). A descrição da paisagem como afirmação da cultura masculinista opera-se por forma a que o sujeito dominante esteja estrategicamente situado dentro da narrativa, de tal modo que o processo de subjectivação é elaborado tendo por base o cenário inconsciente do orientalismo. 
Ao longo da narrativa, a autora socorre-se de fontes para afirmar o destino frágil do território, como é o caso do documento ${ }^{1}$ escrito no século XVIII pelo Governador D. Frederico Guilherme de Sousa (1780): "Encontrei a cidade de Goa em deplorável estado de conservação ${ }^{2}$, com ruas inteiras sem casas, alguns quarteirões transformados em plantações de coqueiros, e os outros, de que a maior parte está arruinada, dificilmente poderão ser restaurados devido à pobreza dos seus proprietários. À parte algumas sumptuosas igrejas e conventos, os outros grandes edifícios como palácios e hospitais estão quase todos mais ou menos em mau estado" (SOUSA, 1780, p. 105). Este discurso é essencial na narrativa da autora, tendo em conta que esta ideia de decadência pela distanciação da governação portuguesa passa a ideia da fragilidade dos povos não modernos aos olhos ocidentais. Deste modo, fundamenta-se a doutrina portuguesa de civilização, colocando a cultura indiana como dependente da ajuda do centro metropolitano para evoluir; "Pensamos que há raças decadentes e atrasadas perante as quais assumimos o compromisso de as levarmos à civilização" (SALAZAR, 1957).

$\mathrm{Na}$ sua viagem de investigação, e com acusada nostalgia, a autora constata Goa como triste e crua (Figura 4): “Onde se levantava a opulenta cidade, nada mais se vê que denso palmar. Um pouco mais de um século chegou para apagar o traço de seus esplêndidos palácios e inúmeras casas. A ausência de vida e o silêncio impressionante sucederam-se ao movimento de outrora." (ibidem, p. 106).

1 - Relatório a D.Maria I sobre o estado de Goa.

2 - Estado de Goa depois da invasão pelos maratas em 1739. 
Figura 4 - Ruínas de Edifícios Goeses

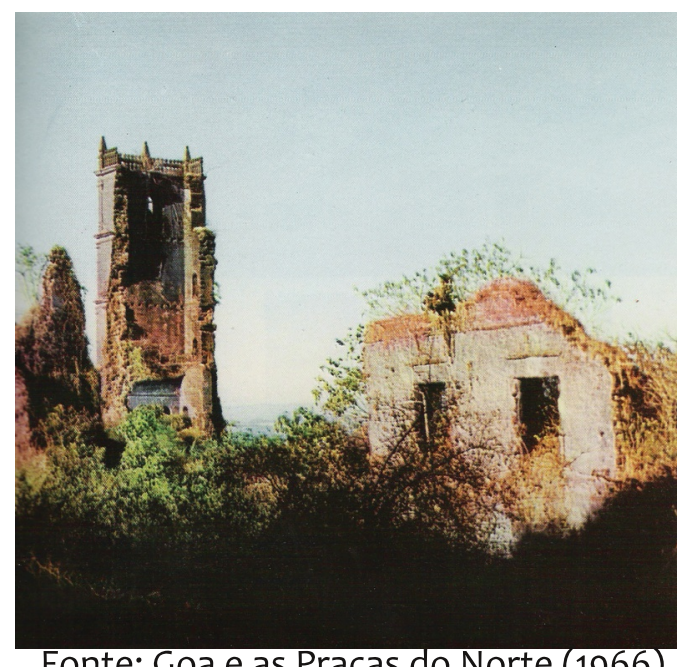

A ideia de tristeza e morte de um lugar é parte integrante de uma narrativa estratégica de memória inserida num contexto ideológico imperial. Narrativa de memória em que os juízos estéticos ditam as qualidades relacionais dos lugares, transformando a paisagem num símbolo de declínio que contagia o leitor e perpetua a noção de decadência que apenas pode ser suplantada com a influência portuguesa do colonizador. Aliás, a narrativa releva que com a chegada dos portugueses, o impulso ocidental e racional concedeu a Goa "uma carta de privilégios quase igual à de Lisboa" (ibidem, p. 96), tornando a cidade apetecível de viver, e valorizando um "traçado [...] que lembrava, à primeira vista, o das mais opulentas cidades ibéricas e italianas de então; igrejas monumentais, palácios, casas de acentuado ar aristocrático testemunhavam as riquezas acumuladas" (ibidem, p. 97). A autora faz uma clara apologia imperial, ilustrando a inscrição portuguesa e europeia na paisagem. O uso de termos como ocidental, racional, palácios, riquezas denota a presença de um discurso colonial e nacionalista que pretende demonstrar a urgência da permanência portuguesa em Goa e celebra a memória da grandeza do Império. 
$\mathrm{Na}$ tentativa de afirmar a identidade e a cultura portuguesa como um factor constante em todas as províncias portuguesas de além-mar, a distância e proximidade cultural enformam o discurso $\mathrm{da}$ autora. A positiva influência portuguesa, o seu carácter civilizador e cultural, inscrita na modelação da paisagem indiana, é um dos argumentos centrais da obra, uma paisagem onde figuram “imponentes igrejas, numerosas cruzes e cruzeiros e a abundância de casas caiadas” (ibidem, p. 36-37) de inspiração arquitectónica portuguesa (Figura 5).

Figura 5 - Casas Goesas

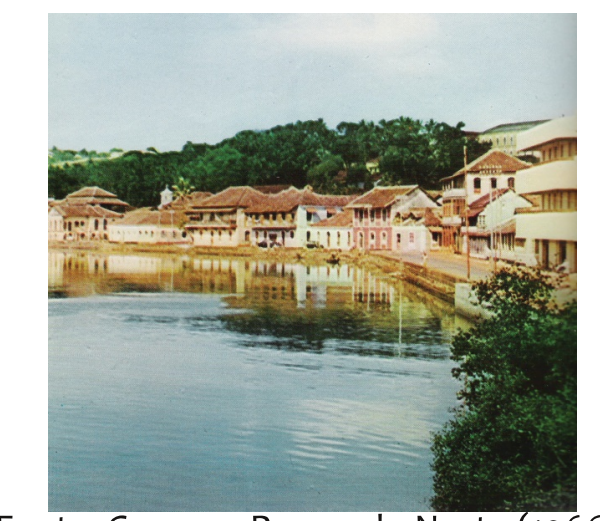

Fonte: Goa e as Praças do Norte (1966)

A abundância de casas que "não mais saem dos olhos de quem as viu [...]” (ibidem, p. 126) transporta a autora para outro universo visual que a maravilha, que a encanta e que, ao mesmo tempo, reforça o carácter de expansão e unidade cultural do império. A mística imperial do Regime e a tese do Luso-tropicalismo defendida por Gilberto Freire ecoam na narrativa. Mas o trabalho da memória vai fazendo sentir-se de forma cada vez mais forte nas descrições, revelando os processos de transculturação e acomodação da experiência e trazendo à superfície do texto a mulher autora. As "paredes decoradas com inúmeras fotografias e grandes espelhos, são rodeadas por cadeiras baixas, mesinhas, arcas, às vezes canapés de palhinha, recordando tantas salinhas de entrada do Alentejo e da Andaluzia [...]", e o "barulho desta sala, ruídos de trabalhos domésticos e conversas misturadas com o riso das mulheres e crianças” (ibidem, p.142-143). Tudo isto são elementos de 
caracterização que esta viajante em tantos aspectos muito à frente do seu tempo valoriza, devido às semelhanças que encontra com o seu lugar de origem.

Os paralelismos (Figura 6) com elementos culturais portugueses encontrados nas "paredes [...] profusamente ornamentadas com grandes espelhos, fotografias, imagens religiosas e papeis de cores garridas com formas caprichosas, como tantas vezes se vê nas salinhas de entrada do Alentejo e dos Açores" (ibidem, p. 159), são exaltados enquanto parte de uma biografia. Esta é uma outra maneira de dar visibilidade ao papel da memória por parte de um sujeito que se quer descorporizado mas que vai diluindo o efeito do estranhamento através de uma forma de substituição e fixação ambígua operada pelo conhecimento oficial do colonialismo. E não será por acaso que a casa e o ambiente doméstico são tão fortes para esta mulher 'deslocalizada'. As comparações descritivas evocam as próprias memórias corporizadas de movimentação através dos lugares, criando um sentimento de identidade comum entre a metrópole e a colónia, entre o Eu e o Outro. Um sentimento que, não obstante, ajuda a consolidar uma geografia do império português que promove a portugalidade, o sentido de união e uma cooperação íntima entre todos os territórios portugueses, entre as colónias, agora províncias; as "províncias do ultramar são parte integrante do Estado português solidárias entre si e solidárias com a metrópole” (REVISÃO CONSTITUCIONAL, 1951, artigo 135).

Figura 6 - Casa Moura em Damão

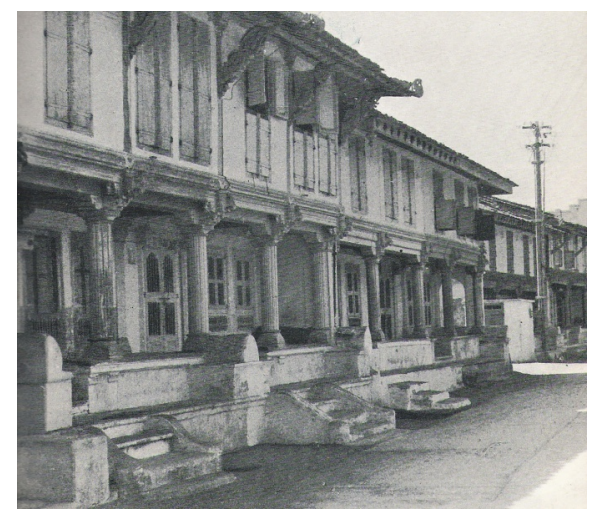

Fonte: Goa e as Praças do Norte (1966) 
Ramirez et al. (2008) chamam a atenção para a complexidade dos relatos de viagem da mulher, branca e ocidental, pela cumplicidade e resistência ao projecto colonial, analisando-os através do conceito de ambivalência. Aliás, também neste caso, as semelhanças são rapidamente atenuadas por uma geografia de contrastes implícita na descrição da paisagem, onde o estranho volta a ser motivo de atenção configurando uma "topografia de alteridade" (LITVAK, 1990). Ao usar termos como "gritante”, “aberração" e "estranhas" para descrever a arquitectura de Deuca, a autora insere de forma ambígua as ideias de exótico e beleza oriental na experiência da paisagem oriental.

A representação do território em Raquel Soeira de Brito, foca-se muito no uso de termos contrastantes onde a beleza, o exotismo, o medo e o estranho são presença assídua (Figura 7). Aqui a zona de ambivalência fala mais alto. De um momento para o outro, este espaço de estranhamento estava implícito na ideia de mentalidade aberrante, imprecisão e atraso que caracterizava o Oriente. Como descreve a autora a aldeia "morria sob o piso do silêncio; e ao cair da noite, as silhuetas dessas casas estranhas e das palmeiras quietas em estampas e a própria deambulação do guarda único ser humano da aldeia - tinham um ar trágico e irreal" (ibidem, p. 127). De quem falava Raquel Soeira de Brito ao longo de um ano neste território longínquo?

Figura 7 - Casa em Diu

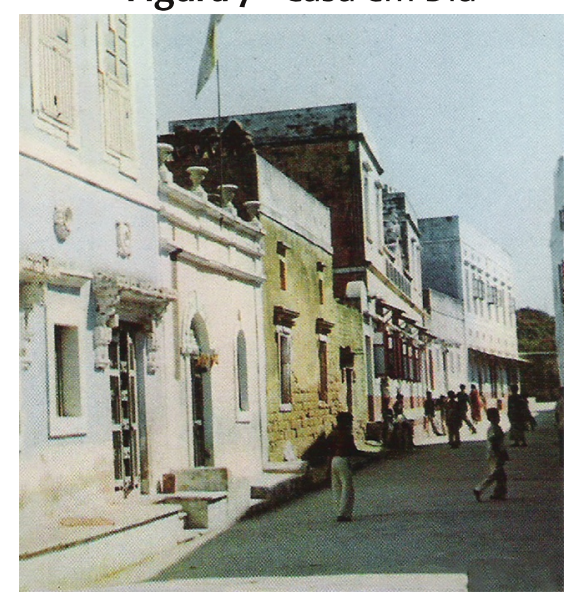

Fonte: Goa e as Praças do Norte (1966) 
Ao narrar um mundo fantasmagórico, o discurso da autora encontra-se intimamente ligado à noção de vazio e de paragem, insinuando a necessidade de 'penetração' ocidental como solução para os problemas existentes. Com o recurso a estereótipos e à simplificação explanatória representa-se uma paisagem imobilizada, fixa, e este jogo de significação de relações psíquicas e emocionais é também uma relação de poder e hierarquia que se vai efectuando. Donde a necessidade de representar um sujeito de origem pura, um sujeito que para ser representado tem que ser construído. A decadência enfatizada pela autora, representa "o resto degradado de uma antiga grandeza" (SAID, 2004, p. 273) que, de acordo com Raquel Soeiro de Brito, só foi passível de ser superada através da influência de intelectuais portugueses na segunda metade do séc. XIX, demonstrando repetidamente a eficácia da colonização portuguesa ao longo da obra.

Raquel procura ainda encontrar semelhanças com as terras portuguesas nos processos agrícolas; "no primeiro caso empregam-se seis a dez bois, ou búfalos, presos a uma estaca central em torno da qual giram, como se usa nos Açores (Ilha do Corvo) e nalgumas aldeias de Trás-os-Montes" (ibidem, p. 68). A ideia perpassada anteriormente sobre uma identidade comum é reforçada também nas actividades agrícolas onde o desenvolvimento das técnicas é muito semelhante às portuguesas, com técnicas de irrigação onde "a água era tirada dos poços por meio de noras de madeira movidas por animais, semelhantes às algarvias" (ibidem, p. 131). Desencadeia-se uma memória cultural que resiste no tempo através de objectos físicos e ancorada em imagens, realidades materiais que provam que os hábitos portugueses estão impregnados na terra e na gente.

Usando a memória dos espaços portugueses que habitou, por onde viajou e que estudou, a autora afirma, através de representações simbólicas variadas de uso do solo, decorativas e arquitectónicas, uma herança cultural onde a paisagem como elemento unificador de uma mesma identidade, retrata um lugar comum, crucial para manter o ideário da nação una portuguesa. As memórias e emoções encriptadas no texto são espacial e 
politicamente articuladas, indo contra a reivindicação de que "o conhecimento é, e deve ser, uma construção abstracta, descorporizada, puramente racional e objectiva" (JONES, 2005, p. 8). A narrativa e descrições efectuadas pela geógrafa são um meio de, através de experiências socio-espaciais passadas, criar um elo entre a metrópole e a colónia, uma representação de unidade na diversidade em que o jogo da ambivalência persiste.

\section{Visões de Género: A Cientista vs a Mulher}

A necessidade de analisar o modo como poder e conhecimento são produzidos e reproduzidos através da diferença, espaço e patriarcado é um dos focos da geografia feminista póscolonial. A importância das práticas científicas do conhecimento situado é um dos elementos centrais sobre o qual a geografia se tem debatido para a afirmação do sujeito corporizado da diferença. $\mathrm{O}$ próprio acto de investigação integra a formação e luta política para dar voz aos sujeitos vistos tradicionalmente como subalternos e marginalizados; “(d)ecorrendo de complexas políticas da diferença que tomam lugar num presente pós-colonial, o trabalho de recolocação de subjectividades a que também a Geografia deitou mão, enuncia a urgência de autorização das diferentes vozes no que respeita à codificação das inúmeras dimensões espaciais e a produção de 'outras' espacialidades.” (AZEVEDO, 2007, p. 58). A geografia tem dado atenção ao modo patriarcal de produção e reprodução das relações sociais, onde a estigmatização social da mulher estabelece uma variedade de estratégias sociais com a finalidade de controlar o poder feminino.

De acordo com Nash (1994) a geografia feminista póscolonial tem abordado a natureza das identidades nacionais e conexões transnacionais, incluindo a re-avaliação do passado imperial e colonialista. A geografia tem também desempenhado um papel fundamental ao examinar a literatura de viagem e a produção do conhecimento científico produzido por 'mulheres brancas', 
analisando a questão da alteridade de uma forma menos hegemónica e mais heterogénea do que se tivermos em conta apenas a perspectiva masculina de contacto com o "Outro" (CERAROLS, 2009, p. 16) e interrogando como as geografias de género foram reformuladas em vários contextos.

O convite das geografias feministas para se reconsiderar as diferentes vozes e formas de perceber os impérios coloniais, através de textos escritos por mulheres é um campo de investigação recente na geografia que, através da narrativa de viagem, pode elucidar-nos sobre as intersecções existentes entre geografia e colonialismo, criando um corpus geográfico sobre a alteridade mais rico, detalhado e crítico (GARCIA RÁMON et al. 2008; GREGORY, 1994, 1995 apud GARCÍA RAMON \& CERAROLS, 2012, p. 225). Isto porque, os relatos femininos oferecem novas pespectivas de estudo relativamente aos relatos masculinos, em parte devido à diferente socialização que a mulher viajante aplica no processo.

Raquel Soeiro de Brito enquanto viajante, é o que Pratt (1992) denomina de "exploradora social" relatando o quotidiano e o Oriente de modo mais privado, tendo em conta o facto de ser mulher e considerada inofensiva "facilitava-lhes o diálogo e muitas vezes lhes abria portas aos aspectos mais privados das pessoas cujas vidas partilhavam enquanto viajavam" (SLUNG, 2001, p. 232), conhecendo mais profundamente as populações nativas $\mathrm{e}$ aumentando o valor etnográfico dos seus relatos.

A viagem e narrativa é construída com base numa interacção com o Outro e numa construção desde a diferença (CERAROLS, 2009, p. 11) que na obra "Goa e as Praças do Norte" é exprimida através da observação e análise da mulher hindu, figurando como corpo representado e descrito pelos olhos da geógrafa portuguesa. Porém, se as descrições da mulher tem papel preponderante nesta narrativa científica elas distanciam-se em parte das clássicas descrições de viagem de pendor orientalista. Enfatizando o seu papel pela vivência com a sociedade hindu, o feminino hindu é tratado com bastante pormenor, retratado no seu próprio contexto cultural, apresentado como radicalmente diferente 
do ocidental. Usando a narrativa histórica da construção da sociedade indiana como ligação para o examinar dos elementos humanos e a observação empírica, Raquel Soeiro de Brito depara-se com o novo, o estranho da sociedade hindu em relação à sociedade ocidental: o sistema de castas e a impossibilidade de o interpenetrar.

A impossibilidade de interpenetração constrói, para a autora, uma ambiência que ignora o indivíduo em prol da sociedade, criando uma clara relação de hierarquia com base num conjunto de relações sociais que modelam crenças e interferem nas acções colectivas. As práticas que se desenvolvem neste espaço integram o poder, a ideologia e o conhecimento, formando um espaço de subjugação da mulher estreitamente associado às relações hierárquicas e à ordem imposta nessa mesma sociedade. Num espaço masculinista, onde o corpo feminino se cinge às regras impostas pela sociedade e pela família, projectam-se identidades de lugar e articulam-se práticas culturais onde o corpo feminino, frágil e silencioso parece "mais sombras do que seres humanos" (BRITO, 1966, p. 41). A ênfase na mulher e as descrições detalhadas do mundo feminino, tanto na esfera privada como na esfera pública, denota uma tentativa de ilustrar o carácter semi-animalesco e brutal da organização social hindu.

Mais do que uma preocupação com a compreensão de género, aquilo que sobressai é a preocupação em fornecer uma base para a construção de um povo no território que é marcadamente inferior, mesmo e sobretudo ao nível da organização social e das relações humanas, através do que Dolores García Ramón (2007) denomina de 'imperialismo simbólico' onde a política do país colonizador é elogiado no território colonizado ou se mantêm atitudes de superioridade em relação aos nativos. Neste contexto, em que as descrições fluem, o papel civilizador do Ocidente enquanto macro-região cultural de referência dominante onde se localiza uma raça superior, é absolutamente imprescindível, no caso concreto, o papel de Portugal como centro do império. Remetendo-nos para "o espaço que não é visível no enquadramento mas que se pode inferir por aquilo que se torna visível pelo enquadramento" (LAURETIS, 
1988, p. 26), Raquel aborda a esfera doméstica, onde as mulheres fazem "toda a lida caseira, deslocando-se sem cessar, como sombras silenciosas e vigilantes" (p. 46). A diferença de género que determina a hierarquia de poder desvela-se pela descrição dos rituais culturais impostos pela sociedade que consideram a mulher invisível e suja. A geógrafa é impressionada pela situação da mulher que passa grande parte da sua vida em trabalhos constantes e em reclusão, sendo como fantasmas na sociedade indiana, que devem seguir apenas a vontade do homem. Raquel centra a sua observação na mulher trabalhadora. De acordo com a autora, o papel da mulher é secundário e "na vida do dia-a-dia o homem é que põe e dispõe” (BRITO, 1966, p. 46), girando toda a vida da mulher indiana em volta do regime patriarcal e masculinista que estabelece a atribuição de papéis na sociedade.

Veja-se como exemplo o caso das mulheres indianas viúvas que aquando da morte do marido deveriam atirar-se com ele para a pira funerária. Apesar deste ritual ter sido quebrado com a chegada dos portugueses à Índia, a autora continua a ver a condição da mulher com pesar e indignação: "mesmo assim a condição da mulher é muito degradante: não poderá casar e deverá, em sinal de luto, rapar a cabeça completamente, quebrar as manilhas e usar só saris velhos e sem cor" (BRITO, 1966, p. 50). Em todos os espaços que a autora descreve, a presença da mulher é constante, dando a entender que os aspectos que circundam a vida feminina lhe chamam a atenção, principalmente os aspectos laborais. A paisagem goesa, enquanto espaço de diferenciação, inscreve-se como superfície de representação do Outro feminino. A narrativa científica desvela uma mútua afectação dos corpos. E a dimensão emocional faz sentir-se fortemente com o avanço da narrativa que em certos pontos assume quase a forma de manifesto. $\mathrm{Na}$ vida agrícola "a adubação é feita quase só por mulheres" (ibidem, p. 67), e "pelo meio-dia, as mulheres levam aos campos o almoço [...] se há participação de trabalho feminino, as mulheres ficam ajudando até ao cair da noite e ao chegarem a casa ainda têm que fazer o jantar [...]; caso contrário, depois do almoço regressam para o trabalho doméstico que nunca falta" (ibidem, p. 68). E prossegue referindo que quando no arrozal 
"se faz a monda [...], são sempre as mulheres que procedem a este trabalho" (p. 68), sendo também as mulheres que "dispõem o estrume, fazem as mondas, ceifam e apanham em pequenos feixes as plantas cortadas" (Figura 8) (ibidem, p. 68). Ao demorar-se em descrições deste tipo, Raquel Soeiro de Brito constrói uma imagem da mulher 'indígena' que em quanto seria assim tão diferente da mulher portuguesa trabalhadora?

A autora vai elaborando o seu ponto de vista sobre a subjugação da mulher também no que respeita à faina (Figura 9). O papel da mulher e das filhas é fundamental na pesca, demonstrando que na pesca de alto mar a mulher desempenha um papel central onde "além da venda de peixe pelas aldeias e no mercado da cidade, ajudam os homens a fazer e a consertar redes" (ibidem, p. 164-165), mas apesar de tudo, um papel partilhado com os homens nas tarefas relacionadas com pesca de alto mar. $\mathrm{Na}$ pesca de água doce, pelo contrário, a apanha e venda na praia de moluscos é realizado apenas por mulheres e crianças "curvadas, ágeis e silenciosas" (ibidem, p. 87), como que invisíveis aos olhos do observador.

Apesar de todo o trabalho que fazem e do quão duro possa

Figura 8 - Mulher Indiana na monda

Figura 9 - Mulher Indiana na faina
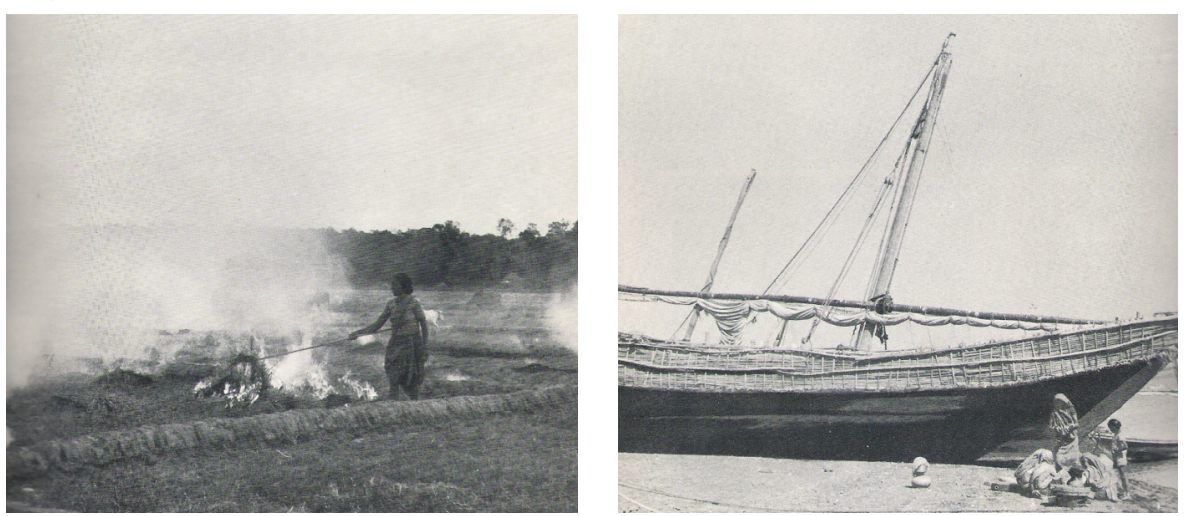

Fonte: Goa e as Praças do Norte (1966)

ser, a mulher é sempre inferior ao homem, recebendo um salário muito baixo, mas continuando resignada à sua condição, explica. E o que dizer então das potenciais similaridades com o centro do 
império? Porque não se aborda este aspecto? Ou estaria a autora a falar do Outro falando de um Nós, sobre o qual não podia manifestar-se no quadro político e ideológico de uma ditadura que celebrava o ruralismo, o poder patriarcal e a pobreza honrada, criando uma geografia de proximidade entre as mulheres da metrópole e da colónia na Índia portuguesa?

Esta representação estereotipada do Oriente é reforçada nas descrições de Gogolá, onde exprime de um modo mais intenso o seu sentido de estranheza, o seu olhar sobre o outro feminino. A mulher indiana não tem voz para contestar o que lhe é imposto como correcto e certo pela sociedade e limita-se a obedecer, havendo uma negação da mulher como sujeito. Não tem a liberdade que a autora encontra em si mesma, nem o poder de pensar e agir por si própria. Existe um conjunto de diferenciações que mostram pesar, dor, indignação pela mulher indiana que é vigilante e vigiada, é um fantasma, o outro feminino e subjugado, presa num enredo de representações do Eu e do Outro onde as posições sociais do sujeito são construídas por meio de discursos de corpo e memória, desejo e sexualidade. Mas a autora não concebe a imagem da mulher indiana como sua igual, mas como um sujeito desafortunado que necessita da ajuda ocidental para ser validado enquanto sujeito, naquilo que García Ramon e Cerarols (2012) vêm como uma “(auto)representação das mulheres europeias muito superior à das indígenas” (p. 235), numa análise ambivalente da relação entre ocidental e nativa, um claro quadro de hierarquias de poder entre mulheres.

Não é apenas o papel da mulher e a sua relação com aspectos laborais que prende a atenção da geógrafa. E voltamos ao jogo da ambivalência. Também a mulher enquanto corpo e presença inspiradora evoca a sua atenção. As mulheres "com agilidade, elegância e garradice” (ibidem:170), aquando da sua ida ao poço, fixam os olhos de Raquel Soeiro de Brito. É notável o modo como a cientista efectua no texto o jogo da fantasia e desejo ocidental sendo ela própria mulher. Se de algum modo há uma mimetização do discurso masculinista orientado para a descrição do elemento 
feminino, por outro lado a geógrafa desloca-se dele no modo de enaltecer o corpo da mulher. É uma noção diferente das mulheres no poço a que a autora está acostumada, como a própria relata: “o caminho faz-se em silêncio, umas atrás das outras, raramente a par [...]” (Figura 10) (p. 170). Seria desejo da autora mostrar que esta visão não era comum principalmente para quem vivia em Portugal onde o trabalho de ir buscar água ou lavar a roupa no tanque continha muito ruido, muitas conversas e muitas cantigas? E continua; "entre elas aos olhos inacostumados do Ocidental, parece estabelecer-se uma surda competição: cada uma pretende ser mais airosa, mais etérea, do que a que a antecede" (p. 170).

Figura 10 - Ida ao poço

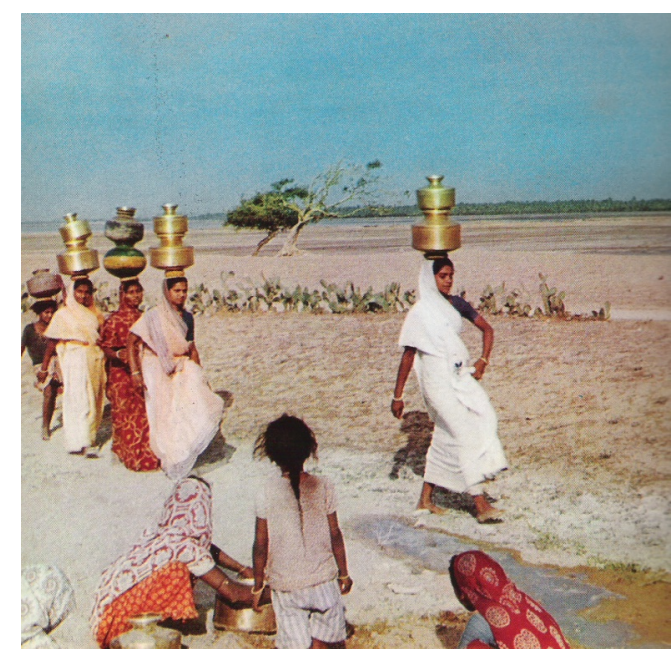

Fonte: Goa e as Praças do Norte (1966)

O sonho e fantasia que animam as geografias imaginárias e cedem ao lugar uma poética particular, denotam-se nas descrições do feminino: “aqueles corpos pequenos e franzinos, graciosamente envoltos em longos saris de cor lisa e suave ou, em contraste com estes, totalmente cheios de desenhos policoloridos, lembram, sem querer, afinado corpo de baile num palco gigantesco" (BRITO, 1966, p. 170) (Figura 11). O carácter feminino do Oriente como lugar supremo de satisfação visual do Ocidente. 


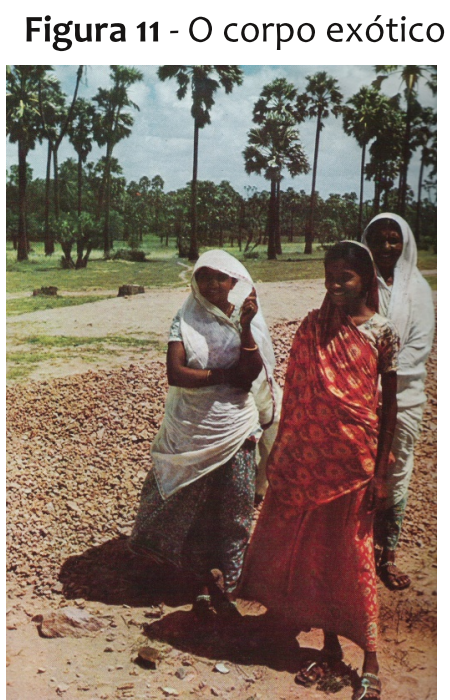

Fonte: Goa e as Praças do Norte (1966)

O corpo enquanto paisagem sexualizada, denota uma relação com o espaço e permite uma diferenciação dentro do género feminino. Em todos os aspectos de caracterização da mulher, o gesto comparativo como marca da ciência colonial faz-se sentir. As comparações entre a mulher indiana e a mulher que a autora reconhece do mundo ocidental são inquestionáveis, dando-nos a representação do corpo uma perspectiva da sociedade em que vivem, funcionando como processo de 'naturalização' da diferença. As percepções e emoções da autora sobre o outro feminino Oriental conduzem, deste modo, ao "reforço de normas e outros estereótipos dominantes, incluindo os de género" (MEHTA; BONDI, 1999; NAMASTE, 1996; BROWNE, 2004 apud DAVIDSON, BONDI, SMITH, 2005, p. 8). Said reconhece características dicotómicas entre o Ocidente e o Oriente, referindo-se ao Oriente como feminino, dócil e exótico aos olhos do Ocidente dominador. Ser feminino era ser inferior, mas também ser portador de uma profunda fragilidade e delicadeza, parte integrante da paisagem.

O trabalho dos corpos na paisagem faz-se sentir ao longo da narrativa em grande medida com recurso à observação e ao método comparativo, marcas inequívocas do pensamento científico colonial que percorrem o programa de pesquisa dentro do qual a autora se 
encontrava inserida. O trabalho de Jennifer Robinson (2011), é elucidativo a este propósito. Agarrando a questão perturbadora de como lidar com a diferença através da abordagem comparativa para o estudo do espaço, permite efetuar a revisão da violência cultural dos textos e práticas coloniais em diferentes contextos espácio-temporais. A necessidade de desvelar as distorções induzidas pelo pensamento académico ocidental e a força das perspectivas desenvolvimentalistas marcadas por um claro ênfase na dicotomia moderno/primitivo é fundamental. Limitando a análise do fenómeno espacial no seu conjunto, tal estrutura de pensamento inclui as complexidades da herança intelectual colonial que contribuiu para a modelação da nossa compreensão dos processos de produção do conhecimento. A narrativa geográfica é em grande medida fruto do gesto comparativo, a expressão da resposta da viajante estrangeira aos corpos e lugares que lhe são estranhos. De acordo com Said, através da viagem constrói-se um arquivo que se estrutura internamente com base nos escritos que resultam destas experiências. Destes textos resultam uma série de reduções "a viagem, a história, a fábula, o estereótipo, o confronto polémico. Estas são as lentes através das quais o Oriente é experienciado" (SAID, 2004). Neste processo, a cientista reage à mudança do ambiente físico e cultural através do seu próprio corpo e com recurso ao método científico em que foi formada. Ainda que tentando subtraí-lo da narrativa científica o corpo está presente nela, ele constrói a cada passo o seu próprio sentido de lugar. $\mathrm{O}$ corpo funciona como meio de comunicação das experiências vivenciadas e meio de (res)significação do espaço e da memória associado à produção do conhecimento geográfico. O corpo, enquanto entidade emocional, conduz a uma construção e interpretação do mundo, influenciada por práticas espaciais que moldam o modo como o conhecimento geográfico é produzido. 


\section{Conclusão}

Espaço, paisagem, corpo e memória tiveram, e têm, um papel formativo na construção das narrativas geográficas que não pode ser desconsiderado para uma análise das geografias imperiais passadas num presente pós-colonial. Uma sistematização cuidadosa das preocupações feministas e pós-coloniais em torno da imaginação comparativa permite a compreensão da relação entre o uso dos métodos comparativos pela geografia e a construção de uma perspectiva metropolitana dominante. Deste modo, a disponibilidade para perceber o espaço através de conhecimentos críticos viajantes, prefigura-se como uma viragem que permite uma compreensão mais aprofundada da experiência de lugar com base em quadros relacionais alternativos.

Ao destacar categorias de género, raça e classe, os relatos das mulheres viajantes quebram os padrões da escrita masculina e contribuem criticamente para uma reescrita da história, sendo neste sentido necessário recuperar as narrativas das mulheres e aprofundar os estudos sobre o papel da mulher como produtoras de conhecimento geográfico.

\section{Referências}

AZEVEDO, A.F. A ideia de paisagem. Porto: Figueirinhas, 2008.

- Geografias Pós-Coloniais: contestação e renegociação dos mundos culturais num presente pós-colonial? In: PIMENTA, J. R.; AZEVEDO; SARMENTO, A. F. (Eds.) Geografias Pós-Coloniais. Porto: Edições Figueirinhas, 2009.

. A Experiência de paisagem. Porto e Lisboa: CEG/FCT/ Figueirinhas, 2012.

AZEVEDO, A. F.; PIMENTA, J. R.; SARMENTO, J. (Eds.) Geografias do Corpo. Porto: Figueirinhas, 2009.

BHABHA, H. The Location of Culture. London: Routledge, 1994.

. 'A Questão outra'. In: SANCHES, M. "Deslocalizar a Europa Antropologia, Arte, Literatura e História na Pós-colonialidade”. Edições Cotovia, 2005. 
BRITO, R. S. Goa e as Praças do Norte. Lisboa: Junta de Investigações do Ultramar, 1966.

CERAROLS, R. Viajeras españolas em Marruecos: literatura de viajes, género y geografias imaginarias. Almería: Instituto de Estudios Almerienses, 2009.

CONRADSON, D. 'Freedom, Space and perspective: Moving Encounters with Other Ecologies'. In: DAVIDSON, J.; BONDI, L.; M. SMITH (Eds.). Emotional Geographies. Ashgate Publishing, Ltd, 2005, p. 103-116.

DAVIDSON, J.; BONDI, L. \& SMITH, M. Emotional Geographies. Ashgate Publishing, Ltd, 2005.

DIÁRIO DO GOVERNO. Lei nº 2.048. I Série, nº117, 1951.

GARCÍA RAMÓN, M. D. \& CERAROLS, R. 'Geografías Imaginarias del Marruecos Colonial Español: Las miradas de las viajeras” In: LINDÓN, A.; BERDOULAY, V. (Eds.). Geografías de lo imaginario. Anthropos Editorial: México, 2012, p. 223-237.

GARCÍA RAMÓN, M. D. Exploració, geografia i estudis postcolonials: una mirada de gènere sobre les narratives de viatges (Gertrude Bell, 1868-1926): discurs de recepció de Maria Dolors Garcia Ramon com a membre numerària de la Secció de Filosofia i Ciències Socials, llegit el dia 21 de maig de 2007. Barcelona: Institut d'Estudis Catalans, 2007.

GARCÍA RAMÓN, M. D.; NOGUÉ, J., \& ZUSMAN, P. Una mirada catalana a l'Àfrica: viatgers i viatgeres dels segles XIX i XX (18591936). Lleida: Pagès Editors, 2008.

GREGORY, D. Geographical Imaginations. Oxford: Blackwell Publishers, 1998.

JOHNSTON, R.J. et al. Dictionary of Human Geography. Oxford: Blackwell Publishers, 2009.

JONES, O. 'An Ecology of Emotion, Memory, Self and Landscape'. In: DAVIDSON, J.; BONDI, L.; SMITH, M. (Eds.). Emotional Geographies. Ashgate Publishing, Ltd, 2009, p. 205-218.

LAURETIS, T. de. Techonologies of Gender: Essays on Theory. Film and Fiction. London: Macmillan, 1988.

LEFEBVRE, H. 'The Production of Space'. In: DEAR, M.; FLUSTY, S. (Eds.). The spaces of postmodernity. Oxford: Blackwell, 2002, p. 131-141.

LITVAK, L. España 1900: modernismo, anarquismo y fin de siglo. 
Anthropos Editorial, 1990. v. 8.

LIVINGSTONE, D. N. The geographical tradition. Oxford (UK) e Cambridge (USA): Blackwell, 1992.

$\mathrm{NASH}, \mathrm{C}$. 'Remapping the body/land: New cartographies of identity, gender, and landscape in Ireland'. In: BLUNT, A.; ROSE, G. (Eds.). Writing women and space: Colonial and postcolonial geographies, 1994, p. 227-250.

NAYLOR, S.; RYAN, J. New Spaces of Exploration: Geographies of Discovery in the Twentieth Century. London: IB Tauris, 2009.

PIMENTA, J.R. 'Portuguese Colonial Geographical Tradition (19261974)'. Africana Studia, n.14, p. 313-322, 2010.

PRATT, M. L. Imperial Eyes. Travel Writing and Transculturation. London \& New York: Routledge, 1992.

ROBINSON, J. Comparisons: Cosmopolitan or colonial? In: Singapore Journal of Tropical Geography, v. 32, n. 2, p. 125-40, 2011.

SAID, E. Orientalismo. 2. ed. Lisboa: Edições Cotovia, 2004.

SALAZAR. Discurso Radiofónico.1º de novembro de 1957.

SLUNG, M. Viviendo con caníbales y otras historias de mujeres. Barcelona: RBA, 2001.

SOJA, E. 'Thirdspace: Expanding the Scope of the Geographical Imagination'. In: D. MASSEY, D.; ALLEN, J.; SARRE, P. (Eds.). Human Geography Today. Cambridge: Polity Press, 1999, p. 260278. 



\section{A Estética da Paisagem Cênica, Pitoresca e Sublime}

Lucimar de Fátima dos Santos Vieira

Roberto Verdum 
E ste artigo ocupa-se especificamente de algumas concepções filosóficas e geográficas sobre a percepção e a identidade estética da paisagem, bem como de algumas referências para tratar das paisagens institucionalizadas pela memória humana como belezas cênicas, pitorescas e sublimes.

A percepção estética pode ser definida como uma atitude (procedimento) que gera sentimentos (representação subjetiva) e sensações (representação objetiva dos sentidos) diante do objeto ou da representação dele, ou seja, a habilidade para julgar as qualidades dos objetos positiva ou negativamente (belos ou feios). É influenciada pelo conhecimento adquirido com as experiências (vivências) que são registradas na mente humana (memória) a partir das impressões (percepções) e da construção das nossas ideias (imagens mentais). Essas experiências podem ser representações do passado e a disposição de perceber o futuro e de praticar o exercício da atenção a ser dirigida à presença sensitiva dos objetos observados.

Neste sentido, a beleza é um tipo de percepção estética determinada por um conjunto de propriedades estéticas de um objeto capaz de produzir certo tipo de experiência agradável (afetiva positiva) para o observador, propriedades essas formais e estruturais (harmonia, proporção, ordem, claridade, textura, cor e integridade) e que dependem dos sentidos humanos.

Nota-se que até hoje se admiram as paisagens de acordo com os padrões do século XVIII, buscando essencialmente as sensações que elas nos fornecem pela sua beleza, pela sublimidade, pelo pitoresco e, de preferência, por serem na área rural, ou seja, é uma busca pelas paisagens que são dignas de serem representadas em uma imagem. Ainda se exibem essas paisagens em folhetos, fotos de calendário, cartões postais nas lojas de souvenir e nas empresas de turismo, e atualmente em folhetos publicitários para venda de casas e apartamentos em condomínios fechados. 


\section{Estética da Natureza, do Ambiente ou da Paisagem}

Os conceitos de natureza, ambiente e paisagem são usados na área da estética de forma aparentemente indistinta, muitas vezes como se fossem sinônimos, apesar de serem conceitos diferentes. Autores como Ronald Hepburn, Malcolm Budd e Martin Seel proferem sobre estética da natureza. Allen Carlson e Arnold Berleant discorrem sobre a estética do ambiente. Rosario Assunto e Paolo D'Angelo defendem o uso de estética da paisagem.

Para o filósofo escocês Ronald Hepburn (1966), natureza é todo objeto que não é artefato humano, incluindo as criaturas vivas. Martin Seel (1996) justifica a utilização do termo natural como sendo aquilo que é autossuficiente e autorregenerativo, projetando-se para o caráter sistêmico e de seu próprio funcionamento, isto é, para a sua inteira independência da sociedade, mesmo que por ela modificado. Assim, ele inclui no seu objeto de estudo a maior parte das realidades que nos circundam. Malcolm Budd (2002) explica que o mais importante é a consciência do apreciador, ou seja, para ser natural basta que o apreciador tenha consciência de estar diante de uma realidade inteiramente natural/virgem ou intervencionada pela sociedade humana. Como exemplo, ele cita a visita a um jardim zoológico, em que reconhecemos um ambiente construído pela sociedade, mas estamos interessados em apreciar esteticamente os animais como naturais.

Allen Carlson (1995) e Arnold Berleant (2004) preferem a palavra ambiente que, além de ter um sentido de envolvência e pertença, remete ao mundo da ecologia. $O$ ambiente terá uma importância notável no modelo de percepção que Carlson defende, pois, para ele, "o ambiente não pode ser encaixilhado ou emoldurado”. Para Berleant, o ambiente é um todo integral, uma união interdependente de lugares e pessoas, juntamente com os seus processos recíprocos.

Para o filósofo italiano Rosario Assunto (2011), a paisagem é um espaço autolimitado no infinito e, ao mesmo tempo, a chave de 
compreensão da finitude, ou seja, é tida como a finitude aberta. $\mathrm{O}$ caráter de infinidade da paisagem é definido pela sua abertura ao céu, e o caráter limitado, mas não finito, pelo seu enraizamento no solo.

Assunto (2011) explica que:

É exatamente pelo fato da paisagem ser natureza que nós somos também natureza, não nos limitamos a viver na paisagem, mas vivemos a paisagem, porque vivemos a natureza e, ademais, vivemos da natureza: daquela natureza que na paisagem se configura em imagem, imagem da qual nós somos, à qual pertencemos, e não simplesmente imagem que observamos estando fora dela. Mas quando se diz que vivemos a paisagem porque vivemos da natureza, devemos estar atentos a não crer que viver da natureza seja aqui uma simples metáfora (ASSUNTO, 2011, p. 366).

Paolo D’Angelo (2001), também filósofo italiano, entende a paisagem como uma identidade estética dos lugares (traduz a especificidade de cada lugar). Tanto Rosario Assunto quanto Paolo D’Angelo defendem a utilização do termo paisagem porque ela é uma realidade intrinsecamente estética e real, defendendo que a sua apreensão é feita com os cinco sentidos, e não só com a visão.

A substituição da palavra paisagem por ambiente, ou a confusão de ambas, pode também ser resultado, segundo D’Angelo (2001), de uma tendência atual de desconsiderar o caráter estético da paisagem em favor de uma visão biofísica e dita científica da mesma.

\section{Estética da Paisagem: Referência para Tratar a Beleza Cênica, o Pitoresco e o Sublime}

As obras sobre estética no século XVIII e XIX tratavam preferencialmente do belo, do sublime e do pitoresco natural. Até a primeira metade do século XX, a estética chegou a ser definida por alguns autores apenas como a "filosofia da arte" ou a "filosofia da crítica”, como análise da linguagem e dos conceitos usados na descrição e avaliação dos objetos artísticos. Para descobrir por que e 
quando ocorreu a mudança de "olhares" é preciso analisar as mudanças ocorridas, principalmente, no gosto estético.

A ideia do belo foi aplicada nas paisagens da Europa, principalmente na criação dos jardins; a ideia do sublime era explicada nas manifestações da natureza; e a ideia do pitoresco, na natureza enquadrada pelas pinturas. A influência do pitoresco permanece até os dias de hoje. A ideia de conhecer o mundo natural ainda é vendida em folhetos, fotos de calendários e cartões postais nas lojas de souvenir e nas empresas de turismo.

A representação da natureza - como "paisagem modelada" - como suprema expressão da arte, além de incidir na pintura e na literatura, também ocorreu com a "arte da jardinagem” no século XVIII na Inglaterra. E, posteriormente, no século XIX, com a criação dos parques, sob a influência dos jardins. Os parques criados na Europa foram definidos pelo príncipe alemão Hermann Ludwig Heinrich von Pückler-Muskau (1785-1871) como "um terreno que (anexo a uma propriedade habitável) é destinado à exposição de uma pintura da natureza", e que deve ter, por isso, o "caráter da natureza livre e da paisagem”, conforme cita Ritter (1974, p. 119).

As “excursões pitorescas” eram relacionas às expedições europeias realizadas pelos artistas viajantes ${ }^{1}$ (intelectuais, artistas, escritores e filósofos) para fora da Europa, os quais se aventuraram em busca de paisagens pitorescas nos séculos XVIII e XIX. Um desses artistas e escritores foi William Gilpin (1724-1804), o qual afirmava que, numa área inexplorada, a mente é mantida num estado de agradável suspense com cenas de belezas variadas e abrindo e revelando-se à sua visão (VALLADÃO DE MATTOS, 2007).

Valladão de Mattos (2007) explica que os artistas viajantes dedicavam-se à análise do território e dos povos nos novos continentes por meio de poemas, relatos e pinturas pelo "olhar

1 - Artistas viajantes: conceito estabelecido na historiografia da arte sobre o século XIX. Nome dado aos artistas que viajavam com o objetivo de buscar o pitoresco, que se aventuraram por lugares distantes, localizados para além das fronteiras da própria Europa (VALLADÃ̃O DE MATTOS, 2007). 
britânico", pelo “olhar alemão” e pelo "olhar francês”. As paisagens pitorescas possuíam tonalidades quentes e luminosas, com cenários variados, destacando a irregularidade e a diversidade do mundo natural.

O naturalista e geógrafo alemão Friedrich Wilhelm Heinrich Alexander Von Humboldt (1769-1859), pai da Geografia moderna, durante suas expedições à América Latina, publicou na Alemanha e na França Quadros da Natureza e uma obra de 30 volumes intitulada A Viagem às Regiões Equinociais do Novo Continente, lançada na França, com relatos científicos da expedição. No livro Quadros da Natureza, publicado em 1808, sugere-se ao leitor o cultivo simultaneamente estético e científico das cenas naturais, a união entre a literatura e a ciência ou entre sentimento e ideia. Na avaliação de Humboldt, o leitor era "levado a ver quase com seus próprios olhos”.

Pedras (2000) explica que:

[...] A construção da paisagem em Humboldt supõe-se o duplo percurso da observação científica incidindo sobre o estatuto da paisagem humboldtiana e convertendo-a na mesma prévia duplicidade. Termina por formar o caráter e revelar o destino de dois tipos recorrentes de paisagem em Quadros: a paisagem, transcrição exata da imagem visualizada no contato direto junto à natureza, e a paisagem que, embora programada pelo cálculo exato e pontual, vai ser manipulada e reconstruída a fim de atingir uma paisagem ideal. [...] Paisagem ideal é exatamente aquela que figura um conteudo predado e consome a aparência na medida mesma em que esta sirva de conduto para a dedução de leis frente à diversidade de elementos naturais. [...] Esse nosso esforço visa a confrontar o entendimento da paisagem como resultado puro e simples de uma construção mental com a ideia de que a paisagem vinha sendo construída também via descrições do encontro com o real, via descrição daquilo que se apresentava à vista. Desse modo, o estatuto da descrição em Humboldt é válido não só como forma de conhecimento - limitada pela especulação -, mas também como técnica de representar o mais fielmente possível a realidade captada pelo olhar e pela imaginação (PEDRAS, 2000, pp. 99-101).

Assim, em Humboldt, a natureza se "transformou" em paisagem, particular e delimitada, fazendo parte de um todo, mas 
que, na análise, torna-se uma totalidade independente. Não havia, na visão de Humboldt, uma exclusão das perspectivas estéticas e cognitivas da paisagem: elas eram complementares e permitiam um conhecimento ordenado e artístico, simultaneamente. Humboldt tinha uma visão holística da paisagem, associando os elementos da natureza e da ação humana, sistematizando, assim, a ciência geográfica.

$\mathrm{Na}$ paisagem europeia no século XIX, “cada lugar e cada objeto tinha sua lenda, real ou romântica”, afirma Saito (2004, p. 324), influenciada pela teoria da estética associacionista ${ }^{2}$; enquanto, nos Estados Unidos, a paisagem era descrita como "árida”, "vazia”, "insípida” e destituída de gosto. Consequentemente, pintores e escritores começaram a defender o valor estético da paisagem americana tratando-a como "o grande palco dos acontecimentos humanos".

Apenas alguns filósofos norte-americanos tratavam da experiência estética da natureza, motivados pelas novas descobertas da biologia (principalmente pelas Teorias da Evolução de Charles Darwin e Alfred Wallace) e pela filosofia do Romantismo. Valorizava-se a natureza a partir de uma noção de pertencimento e também pelo prazer da contemplação estética. A natureza selvagem passa a ser admirada pelas suas características pitorescas, de beleza e de sublimidade. As florestas, os grandes desertos, as montanhas, a vastidão das pradarias, os rios e o mar passaram a representar uma natureza transcendental, que estava além do artefato humano, conforme explica Franco (2011). Tais concepções foram representadas e defendidas por Henry David Thoreau, John Muir, George Perkins Marsh e pelo movimento preservacionista.

As viagens, com o intuito de conhecer e usufruir a natureza e a cultura das localidades distantes, a partir do século XIX, foram importantes para a valorização da natureza mais selvagem, a

2 - Associacionista: doutrina do conhecimento pela associação de ideias (AZEREDO, 2011). 
wilderness ${ }^{3}$. Franco (2011) explica que:

Essa valorização da wilderness esteve, ao mesmo tempo, na origem das áreas protegidas, do turismo de apreciação da natureza e dos esportes de aventura - tais como o montanhismo e a descida de corredeiras (cursos d'água acidentados). Indivíduos como Henry David Thoreau e John Muir começaram a mostrar a wilderness como um "outro" complementar à civilização. Esta já havia avançado demais espaços urbanos tumultuados, poluídos e apressados e um homem civilizado estressado e carente de espontaneidade e liberdade - e a wilderness com a sua grandiosidade selvagem vinha perdendo espaço - as terras eram transformadas em pastagens, plantações e cidades, e os animais selvagens estavam desaparecendo. A wilderness era espaço de contemplação estética, superação de limites, lazer e busca de conhecimento (FRANCO, 2011, p. 3).

O poeta, naturalista, historiador e filósofo norte-americano Henry David Thoreau (1817-1862) foi um dos primeiros defensores da conservação dos recursos naturais, da preservação e da apreciação estética e espiritual da vida selvagem (wilderness) como terras públicas. Em meados do século XIX, com o avanço dos colonos, de grandes mineradoras e madeireiras para o oeste dos Estados Unidos, houve uma grande destruição florestal. Diegues (2001, p. 26) cita que Thoreau "criticava a destruição das florestas para fins comerciais e foi um dos defensores dos vales e das montanhas com grande beleza”.

O diplomata e filólogo americano George Perkins Marsh (1801-1882), outro defensor das belezas cênicas e apontado como o primeiro ambientalista americano, explica que o conhecimento da Geografia, das experiências do comércio, as viagens e as explorações permitia a comparação de paisagens, inicialmente sendo apreciadas apenas na literatura. Marsh, em suas obras Man and Nature: or Physical Geography as Modified by Human Action, de 1864, e Man and Nature, de 1865, abordou a natureza como fonte de contemplação e

3 - O termo wilderness é definido como um local em que a presença humana é pouco perceptível, espaços "desertos" e/ou deserdados pela civilização, e onde predomina a natureza em toda a sua "selvageria", ou onde os habitantes humanos vivem em uma proximidade e intimidade com o "mundo selvagem" (FRANCO, 2011, p. 2). 
a matéria original para as futuras “imitações”, além de descrever os efeitos negativos não intencionais das atividades econômicas humanas (CARLSON, 2010; DIEGUES, 2001).

O tipo de apreciação da natureza praticado por John Muir (1838-1914), naturalista e escritor, associou-se ao ponto de vista contemporâneo chamado "estética positiva" (CARLSON, 2010). Na medida em que tal apreciação evita a presença da humanidade sobre o ambiente "natural", é um pouco o inverso da apreciação estética influenciada pela ideia de pitoresca, que encontra interesse e prazer em evidência de presença humana.

A posição filosófica negava a possibilidade da experiência estética da natureza, pois essa envolve julgamentos estéticos do objeto de apreciação, e a natureza não era considerada um produto de uma intelectualidade. Por outro lado, para alguns filósofos a natureza era apreciada esteticamente, por ser obra de um criador ou como um cenário pitoresco. Carlson (2010) cita como exemplo o modelo de apreciação da natureza pelas pinturas de paisagens, "como se fosse uma série de cenas bidimensionais e com foco tanto em qualidades estéticas formais ou qualidades artísticas que dependem do tipo de imagens românticas associadas com a ideia de pitoresco".

\section{Séculos XX e XXI: Novas Leituras sobre a Estética}

Também é possível constatar que alguns autores utilizam determinados termos como natureza, campo e cidade para citar a paisagem, e não citam a cultura - por exemplo, Georg Simmel, Joachim Ritter e Malcolm Budd. Outros autores incluem nos seus discursos a natureza e a cultura, entre eles Rosario Assunto, Yuriko Saito, Nicolas Grimaldi, Martin Seel, Eugenio Turri, Augustin Berque, Michel Corajoud, Paolo D’Angelo e Luisa Bonesio.

$\mathrm{O}$ primeiro texto filosófico dedicado inteiramente à paisagem como categoria do pensamento humano foi Filosofia da Paisagem, escrito em 1913 pelo sociólogo alemão Georg Simmel. Para Georg Simmel (1858-1918) a paisagem nasce de uma 
justaposição de fenômenos naturais espalhados no território, a qual é apreendida num peculiar tipo de unidade, chamada de Stimmung ${ }^{4}$. Para o autor, uma paisagem não é natureza, mas, pela naturalidade do seu conteúdo e pela vitalidade que a anima, sempre é natural. A paisagem recompõe momentaneamente o caráter unitário e homogêneo de um todo, da natureza.

Simmel (1913) refere que a situação atual da nossa estética dificilmente permitirá muito mais do que estabelecer as mesmas regras que a pintura de paisagem institui com a escolha do objeto e do ponto de vista, a iluminação e a ilusão do espaço, a composição e a harmonia de cores.

Em 1974, o filósofo alemão Joachim Ritter (1903-1974) diz que existem duas naturezas, a natureza científica, com uma série de leis universais que a regem, e uma natureza atraente, próxima e qualitativa que se dá sensivelmente na experiência estética. Essa última corresponde à paisagem.

Segundo Ritter (1974, p. 105), a paisagem é natureza que se torna esteticamente presente no olhar de um contemplador sensível e sentimental, originalmente por meio da arte estética, numa "livre" contemplação para encontrar-se na natureza. Esse contemplador da paisagem, designado de "viajante" (wanderer), é sujeito da paisagem. Cita ainda: "o que outrora foi utilizado, ou foi considerado inútil enquanto terra erma, e o que ao longo de séculos foi ignorado e desprezado, ou o território hostil e desconhecido, torna-se grandeza, sublime e belo: torna-se esteticamente na paisagem".

Ritter (1974) ainda menciona:

$\mathrm{Na}$ paisagem observada durante uma viagem e na paisagem turística sobrevive ainda o eco da sua função estética original. A linguagem com que a paisagem turística é louvada ganha a sua força publicitaria na potência eufórica do partir ao encontro de uma paisagem "romântica" e "pitoresca", da sua

4 - Conforme Serrão (2011), stimmung "seria a conformação singular das partes que dota cada paisagem de um "caráter" individual; a conjunção dos traços anímicos do sujeito numa peculiar "disposição" ou "índole" e, também, a fusão de ambas, a vertente objetiva e subjetiva, numa tonalidade única". 
contemplação livre e fluidora e de sentir feliz e como em casa. [...] Assim, os conceitos originalmente estéticos e os locais da paisagem como a montanha e o campo tornam-se num elemento no qual a paisagem se pode representar enquanto paisagem de repouso (RITTER, 1974, p. 115).

Semelhante ao que acontece com a história da arte, com a distinção entre paisagens clássicas e ideais, heroicas e românticas, a história da paisagem é a história do processo em que determinadas zonas da terra são sucessivamente descobertas e tornadas esteticamente visíveis, explica Ritter (1974). As paisagens institucionalizadas deixam de ser contempladas como natureza e passam a ser contempladas apenas pela sua esteticidade, como sinônimos de beleza, tornando-se elementos vitais para a sociedade.

Tanto para Simmel quanto para Ritter a invenção da paisagem pela perspectiva da pintura renascentista não é aceita. Ambos acreditavam que, nas épocas precedentes, o que prevalecia era o "sentimento pela natureza". Para Simmel, a paisagem pode até se objetivar na pintura, mas, para ele, é uma experiência do indivíduo moderno, que se faz e refaz em cada ato contemplativo e tem nela o seu lugar de invenção. Já para Ritter, a paisagem é a consciência histórica de um mundo passado, para sempre perdido.

Dentro de estética filosófica em si, o interesse pela estética da natureza surgiu com a publicação, em 2011, do artigo do filósofo escocês Ronald Hepburn (1927-2008), considerado o pai da estética da natureza pela Sociedade Britânica de Estética, intitulado Contemporary Aesthetics and the Neglect of Natural Beauty ${ }^{5}$. O filósofo afirma que é necessário pensar a natureza fora dos modelos artísticos, pois os fenômenos e as situações sem enquadramento que acontecem em espaços abertos precisam ser apreciados e analisados como natureza, e não somente contemplados.

Hepburn (2011, p. 231) cita algumas experiências da estética da natureza que não podem ser proporcionadas pelos objetos da arte,

5 - A Estética Contemporânea e o Desprezo pela Beleza Natural. 
tais como o grau de envolvimento mútuo do espectador com o objeto; o efeito reflexivo pelo qual o espectador conhece a si mesmo de uma maneira incomum e vivida, ou seja, esteticamente vivida; a existência de movimento na cena, principalmente se for por parte do espectador; e o desafiar o espectador em integrar a sua experiência num mundo sem molduras e sem limites. O efeito estético é mais intensamente compreendido e mais penetrante na experiência da natureza, pois "estamos na natureza e somos parte da natureza; não estamos diante dela como estamos diante de uma pintura colocada na parede". O autor afirma ainda que somos tanto atores como espectadores, somos ingredientes da natureza.

A qualidade estética da natureza é sempre provisória, corrigível por referência a um contexto diferente, apercebido com mais particularidades, criando uma espécie de entusiasmo no fato de as formas da natureza oferecerem um domínio para o exercício da imaginação - apercebido no sentido de criar ou tornar vivida a percepção ou a imaginação, ou seja, compreender, tornar-se consciente. Como exemplo disso, Hepburn (2011, p. 250) menciona: "Há muito que sabia que a Terra não era plana, mas nunca me tinha apercebido da sua curvatura até ter visto aquele navio desaparecer no horizonte".

O filósofo italiano Rosario Assunto (1915-1994), no seu artigo A Paisagem e a Estética, de 1973 e traduzido em 2011, cita que a paisagem possui uma dimensão espacial e temporal, um espaço limitado e aberto, constituindo-se como presença, e não como representação do infinito no finito, que se constitui como um objeto de experiência e tema de um juízo estético. A experiência estética da paisagem toma consciência, a unidade simbiótica com a natureza, que, para o autor, é paisagem, objeto de uma contemplação total, ou seja, pelos nossos sentidos (visão, audição, olfato, tato e paladar).

Assunto (1973) cita os versos de Schiller (escritos em 1786) para explicar melhor sobre os sentidos:

A paisagem com seus aromas, mas também com suas cores, as suas luzes: Com o seu céu; as suas águas, as suas rochas, a sua vegetação, as suas aves e insetos e animais de todo o tipo; o ar 
que chega aos nossos pulmões entra-nos literalmente, no sangue, e expande-se pelos membros, fazendo-nos sentir unos com a natureza: e exalta o nosso ser natureza, a natureza que está em nós, e reaviva-a; e dela faz objeto de deleite, para a alma, suscitando em nós a alegria da nossa identificação com a natureza, de fazer da sua a nossa alegria (ASSUNTO, 1973, p. 368).

Assim, a existência da paisagem não depende somente da naturalidade dos seus elementos, nem se confina a espaços naturais intocados, pois está sempre impregnada pela história e encontra-se, atualmente, invadida por elementos tecnoindustriais.

O filósofo francês Nicolas Grimaldi (2011, p. 134) publicou, no artigo A Estética da Bela Natureza: Problemas de uma Estética da Paisagem, o que é preciso para definir uma estética da paisagem. Segundo Grimaldi (2011), a paisagem, quando esteticamente considerada, tende a ser pensada como o que genericamente designase por "beleza da natureza”. As qualidades essenciais sob as quais essa beleza da natureza nos pode aparecer de um ponto de vista estético são duas: não representar a natureza nem como objeto do nosso saber nem como objeto da nossa vontade; e reconhecer por meio da natureza o sentido de uma linguagem que nos é endereçada (reiteração da nossa própria linguagem). Segundo ele, ainda, devemos contemplar a natureza de forma desinteressada para sentir sua beleza, paisagens que podemos contemplar, mas não habitar, como já pensava Immanuel Kant.

Há “modas” da paisagem, assim como há “modas” da pintura. A degradação da natureza ou da paisagem (para o autor, os termos são sinônimos) ocorre porque a cada geração há uma influência educadora ao contemplá-la. Só será preservada se mantivermos com ela a mesma relação que temos com as obras de arte, afirma o filósofo. Para localizar, inventariar e conservar as paisagens cuja beleza tiver sido reconhecida, é preciso não intervir na paisagem e deixar que o tempo a reconstrua, transformando em passado o que fora presente próximo.

O geógrafo francês Augustin Berque (1993) explica que a paisagem surgiu como um estudo para compreender a lógica 
relacional do ecúmeno (écoumène), relação da humanidade com a extensão terrestre. A noção de paisagem não pode ser aplicada a todas as épocas nem a todas as culturas. Há muitos desacordos quanto a sua origem, pois, para Berque, os autores não falam da mesma coisa.

O autor utiliza critérios empíricos para distinguir as sociedades que possuem uma cultura paisageira, tais como: uma literatura oral e escrita louvando a beleza dos lugares; uma toponímia indicando a apreciação visual do local; jardins de recreio; uma arquitetura disposta para a fruição de uma bela vista; pinturas representando a natureza; uma ou mais palavras para dizer “paisagem"; e uma reflexão explícita sobre a "paisagem”.

Berque (2008, p. 189) explica que a paisagem era perceptível apenas para a elite (classe de lazer) e não para os camponeses, ou seja, a paisagem era vista como contemplativa para a classe de lazer, enquanto que, para os camponeses, o local era o meio de subsistência e de vida. O campo e a natureza eram desprovidos de urbanidade, era tanto rural quanto selvagem. A paisagem nasceu "do ócio daqueles que não trabalhavam a terra, ou seja, que não transformavam a natureza pelas suas mãos”.

Berque (2008), em seu artigo O Pensamento Paisageiro: Uma Aproximação Mesológica ${ }^{6}$, expõe que:

Antes da modernidade, inversamente, as sociedades humanas compuseram no mundo inteiro paisagens admiráveis - as mesmas que hoje amamos e procuramos, mas que matamos por todo o lado, salvo alguns ícones conservados. Elas tinham, incontestavelmente, um pensamento paisageiro (pensée paysagère) e, no entanto, até ignoravam a noção de paisagem (BERQUE, 2008, p. 200).

A modernidade, desencadeada pela revolução científica do século XVII, teve como referência o conhecimento do mundo físico (ou objetivo) e irredutível à ilusão do mundo fenomenológico. $\mathrm{O}$ mundo era abstraído do sujeito, constituído por objetos quantificáveis e manipuláveis, dispostos num espaço absoluto,

6 - La Pensée Paysagère: Une Approche Mésologique. 
homogêneo e infinito, onde os lugares eram neutros. Depois do desenvolvimento das ciências da natureza (com o centramento do objeto), surge o desenvolvimento das ciências humanas (pelo ponto de vista do sujeito) e, por conseguinte a paisagem. Paisagem como dimensão sensível e simbólica da natureza, que depende sempre de uma subjetividade coletiva e que não existe independentemente de uma cultura (BERQUE, 1993).

O geógrafo italiano Eugênio Turri (1998) usa a metáfora "a paisagem como teatro" para libertar a paisagem da expressão de cenário ou pano de fundo das ações humanas e confere-lhe um sentido mais global, atribuindo o papel da sociedade humana como atora (transformadora do seu espaço de vida), imprimindo a sua marca, e como espectadora (ao observar, ao perceber e reconhecer as suas ações), mudando ao longo do tempo o palco. O resultado da função de ator e espectador fará que sejam produzidas as paisagens mais belas, esteticamente mais celebradas, pois exprimem a harmonia entre a obra humana $\mathrm{e}$ as formas naturais.

Turri, no seu livro A paisagem como Teatro: do Território Vivido ao Território Representado, cita que na Itália, seu país, ocorreu a perda de valor da paisagem porque se perdeu a relação com os mitos fundadores da sociedade italiana, gerando a incapacidade de reconhecer e decodificar os signos nela presentes, os quais remetem à relação entre natureza e cultura e entre o passado e o presente. Em outros países europeus, o culto pelos valores paisagísticos próprios da cultura nacional mantém-se respeitado até o presente - por exemplo, o reconhecimento do terroir como identidade patrimonial e produtiva (amor pelo terroir) na França.

A concepção de paisagem para Turri é que ela é a representação e o iconema ${ }^{7}$ do território ao revelar os significados

7 - Iconema é a unidade elementar de percepção, como signo no interior de um conjunto orgânico de signos, como parte que exprime o todo, ou que o exprime como uma função hierárquica primária, seja enquanto elemento que, melhor que outros, encarnam o genius loci de um território, seja como referência visual de forte carga semântica da relação cultural que uma sociedade estabelece com o próprio território. (TURRI, 1998, p. 178) 
subjetivos dos valores histórico-culturais da identidade territorial. Segundo esse autor, é como uma interface entre natureza e cultura; entre observação, representação e ação; reflexo da ação humana sobre o território.

Turri (1998) concede à paisagem a função de referência fundamental para a construção de um território. Cita ainda que:

A construção territorial realiza-se no momento em que um espaço de natureza anônimo, que vive sem o homem, se transforma em espaço cultural, isto é, quando se carrega de referências, de símbolos, de denominaçôes [...] e depois de objetos humanos, propondo-se como palco ou teatro no qual os indivíduos e as sociedades recitam as próprias histórias (TURRI, 1998, p. 174).

Todas as paisagens são o reflexo de uma organização do espaço, de uma maneira própria de os objetos sociais se ordenarem e revelarem no território, das histórias que tais ordens determinam. Isto sobre a base de espacialidades ou regionalidades mais ou menos amplas, sendo que a distribuição dos elementos componentes dá o tom à paisagem (TURRI, 1998, p. 178).

Turri (1998, p. 180) explica que uma pesquisa urgente que se faz necessária em cada território, principalmente na Itália, é

[...] a individualização dos lugares de forte carga simbólica e espetacular, isto é, os topoi ou, ou dito de outra forma, os iconemas e os respectivos lugares que a cultura (cultos religiosos, arte, literatura, cinema, fotografia, ensaística, histórica, geográfica, naturalista etc.) reconheceu como referências importantes da identidade cultural (a nível local ou regional ou nacional conforme os casos) (TURRI, 1998, p. 178).

Renunciando à subjetividade, ao sentimentalismo e à contemplação pura e desinteressada, o filósofo americano Allen Carlson defende a importância do conhecimento como o fator determinante para a apreciação estética, e argumenta que devam existir duas estéticas: a da natureza e a da arte.

Carlson (1995, p. 270) não aceita a apreciação estética pelo desinteresse quando o objeto de apreciação fica isolado das suas inter-relações, ficando aberto o caminho para a identificação. Segundo ele, é como se, por exemplo, toda apreciação partisse do 
olhar desinteressado e contemplativo, como se convergisse para o "olhar parado e vazio da vaca".

A natureza deve ser apreciada. A apreciação é um conhecimento neutro, objetivo e impessoal que oferece os conhecimentos precisos e os conceitos adequados para reconhecer, julgar e discriminar as qualidades e as propriedades inerentes, afirma Carlson no seu artigo Apreciar a Arte e Apreciar a Natureza, de 1995. A apreciação da natureza deve ser por intermédio de um modelo teórico, o qual é designado por "object-orientated" (ordem-orientada). Neste modelo os objetos devem ser selecionados com referência a uma história geral não artística e não estética orientada pela ordem da diversidade dos seus elementos e a variedade dos seus padrões, tal como eles são e tendo as propriedades que têm pelas forças de produção ${ }^{8}$, pelas narrativas e pelas inter-relações que existem entre eles.

Carlson (1995) acredita que a estética deve fornecer pontos de apoio adequados para apreciar a paisagem com base nas ciências da natureza, enquanto Yuriko Saito (2004) acredita que o importante é apreciar a paisagem com a incorporação das narrativas populares sobre os lugares nativos.

O filósofo inglês Malcolm Budd, presidente da revista British Society of Aesthetics, referência no âmbito da estética da natureza, faz sua argumentação baseada no filósofo Kant e é defensor da estética positivista. Budd (2002), em seu artigo A Apreciação Estética da Natureza, revela que a apreciação estética da natureza não deve ser entendida como se fosse arte, e menciona:

[...] embora incorreto pensar na natureza como aquela parte do mundo que não foi alterada nem afetada significativamente pela ação humana, grande parte da natureza não tem permanecido na sua condição natural, mas tem sido sujeita à interferência humana. [...] se algum segmento de ambiente natural foi afetado pela humanidade pode continuar a ser apreciado esteticamente como natureza, mas a apreciação de quem está ciente do seu caráter não-prístino será

8 - Forças de produção para Carlson são as geológicas, biológicas ou meteorológicas. 
provavelmente uma apreciação como natureza afetada pela humanidade (BUDD, 2002, p. 303).

De que modo alguma coisa natural pode fundar uma resposta estética? Que tipos de características, de aspectos ou propriedades as coisas naturais podem possuir virtudes as quais podem ser apreciadas esteticamente como naturais? Para Budd (2002, p. 315), são as características que valorizam certas coisas, em virtude de elas serem coisas naturais de determinados tipos, pois a natureza deve ser apreciada enquanto natureza, tal como ela é. Para o autor, a natureza "deve ser reconhecida como tendo sido formada, e por ser continuamente o lugar, de processos físicos, químicos, geológicos, ecológicos, meteorológicos e evolucionistas, todos acontecendo de forma indiferente ao observador”.

O conceito inovador de "comprometimento", desenvolvido pelo filósofo norte-americano Arnold Berleant, levou a novas perspectivas para o estudo da estética. Segundo Berleant, em seu artigo A estética da Arte e a Natureza (2004), "o homem como ser total habita a natureza que o envolve, transforma-a e é transformado por ela. Não se pode defender, em rigor, que ele vê a natureza, uma vez que, vivendo nela, ela se torna parte integrante daquilo que ele é". Seria incorreto defender que a paisagem é uma secção limitada do mundo que se observa ao longe ou que se confina àqueles restos ainda naturais de uma civilização altamente industrializada, sendo antes constantemente percepcionada e modelada como resultado e componente da nossa cultura.

Concorda-se plenamente com Berleant (2004) quando ele afirma que não se pode separar a natureza e a cultura, pois:

[...] a natureza, no sentido da terra separada da intervenção humana, desapareceu na sua grande parte. Vivemos num mundo profundamente afetado pela açẫo humana, não só na destruição quase completa da primitiva natureza selvagem do planeta e na distribuição da flora e da fauna longe dos seus habitats originais, mas também, na alteração das formas e das

9 - Comprometimento no sentido de uma atitude de imersão sensorial no mundo, estética e simultaneamente ética porque acompanha a responsabilidade. 
características da superfície terrestre, do seu clima e da própria atmosfera. [...] Não só a natureza é visivelmente afetada pela ação humana, como a nossa própria concepção de natureza emergiu historicamente e diverge amplamente de umas tradições culturais para outras. O que queremos dizer com natureza, as nossas crenças sobre a vida selvagem, $\mathrm{O}$ reconhecimento de uma paisagem, o nosso próprio sentido de ambiente, todos eles fizeram aparições historicas e foram entendidos de maneiras diferentes em diferentes tempos e locais. Não é surpreendente que uma estética que aspira a universalizar como as ciências tenha dificuldade em encaixar a natureza (BERLEANT, 2004, p. 289).

Para Berleant (2004, p. 294), a “marca estética” não é a contemplação desinteressada, nem os requisitos de objetivação nem a ordem, mas um envolvimento total, uma imersão sensorial no "mundo natural", acompanhada de uma consciência perceptiva de elevada acuidade e ampliada pela sensação de compreensão que o conhecimento assimilado proporciona. Explica ainda que, como apreciadores participativos num cenário ambiental, a "apreciação da beleza natural reside no fascínio de detalhes intrincados, tons subtis, variedade sem fim e o encanto imaginativo a que num artefato humano chamaríamos de invenção maravilhosa".

Portanto, para Berleant (2004) é preciso adotar uma estética participativa e de comprometimento, seja em relação à arte seja em relação à natureza, com todas as suas manifestações culturais, sem que o local e o observador tenham fronteiras delineadas. A percepção não é apenas o ato visual, mas, antes, um comprometimento somático no campo estético, pois a sociedade não pode mais manipular o ambiente em função do seu conforto sem que resulte de uma transgressão de si mesmo, nem pode agir como se o seu futuro não estivesse dependente das ações praticadas no dia a dia. É preciso comprometimento no sentido de uma atitude de imersão sensorial no mundo, estética e simultaneamente ética, porque acompanha a responsabilidade.

A filósofa japonesa Yuriko Saito (2004) também menciona que vários autores utilizaram a apreciação pictórica para apreciar os objetos naturais, herança da noção do pitoresco, do século XVIII, 
como formas gerais, ações e combinações com arranjos de forma e cor, ou seja, ver uma paisagem como se fosse um quadro de uma paisagem. No século XX, a natureza deveria ser apreciada apenas em termos de cor, forma, textura e perspectiva tridimensional.

Saito (2004, p. 321) também refere que a perspectiva pitoresca/formalista ainda hoje é trabalhada por diversos profissionais (como geógrafos, arquitetos, engenheiros) e pela maioria dos turistas quando definem a paisagem no seu sentido estético como "uma abstração compreensiva em que todas as formas específicas são dissolvidas na linguagem básica da arte: em cor, textura, massa, linha, posição, simetria, equilíbrio e tensão”. Saito concorda com esta perspectiva, mas a questiona, pois para ela a apreciação pictórica negligencia os meios não visuais como, por exemplo, o cheiro, o som, o ar e as partes microscópicas. É preciso reconhecer que a natureza possui a sua história e a sua função, com propriedades sensíveis específicas, ou seja, da sua origem, composição, função e funcionamento, e que independe do significado histórico, cultural ou literário que lhe é atribuído pela sociedade.

Saito (2004) não considera um problema a atração pela beleza cênica. Ela considera isso importante, mas entende que também é preciso ir mais longe, ou seja, precisamos "cultivar nossa sensibilidade para podermos discernir e apreciar os diversos modos de discursos da natureza" (2004, p. 317). Saito concorda com Allen Carlson quando ele afirma que, para ocorrer a apreciação estética da natureza, é necessário o conhecimento científico e também o senso comum de naturalistas e ecologistas, com fatos científicos relevantes.

Entretanto, Saito reconhece que algumas informações científicas (as informações constituídas por qualidades primárias) afastam a experiência estética, a partir do momento em que a informação deixa de ser sensitiva. Por outro lado, as informações científicas de qualidade secundária, como as observações feitas pelos cientistas da história natural, ampliam a experiência estética. Saito (2004, p. 331) cita, como exemplo, a origem geológica de uma montanha ou o fenômeno de camuflagem de um inseto, em que 
“estão incorporados ou manifestam-se nas características observáveis do objeto e nós apreciamos o modo como cada objeto nos conta a sua origem, estrutura ou função".

Além do conhecimento científico, Saito também considera importantes as narrativas biorregionais (contos folclóricos, mitos e contos indígenas), que tentam explicar ou dar sentido às características observáveis de objetos naturais específicos de uma verdade local (de uma região específica). Ela não concorda com as narrativas de apreciação associacionista, as quais assumem que a natureza é muda, sem qualquer história para contar até que algum acontecimento humano a consagre, pois, seu principal interesse são os feitos humanos. A autora não rejeita globalmente a apreciação pictórica ou associacionista, pois acredita que a apreciação deve ser orientada pela educação e pelo conhecimento científico.

A natureza só será esteticamente evidente quando, na linguagem corrente, puder identificar na forma, na cor, no seu crescimento e nos seus movimentos, os seus objetos conhecidos e desconhecidos, explica o filósofo alemão Martin Seel no seu artigo, publicado em 1991 e em 1996, Uma Estética da Natureza.

Seel (1996) cita que a estética da natureza é uma teoria da natureza "livre", valorizada e procurada devido a sua liberdade, porque a bela natureza apenas pode existir numa natureza mais o menos livre, mas não por sua "intangibilidade", nem por sua “estabilidade", nem por sua "sanidade" ecológica. Os critérios ecológicos são totalmente incapazes de substituir a explicação dos pontos de vista estéticos, porque são valorativos.

Seel (1996) explica ainda que:

[...] o espaço da paisagem é o espacco-tempo modelado pela natureza. [… A paisagem é a realidade de vida do homem modelada pela natureza estética. [...] A paisagem estética é uma totalidade que não pode ser apreendida, figurada ou seriada como um todo. [...] E o espaço da moderna liberdade na natureza. [...] A unidade da contemplação paisagística não é a unidade sem todo, mas é a unidade na ilusão do todo perdido: [...] A bela paisagem é uma realidade que não é apenas intensificamente contemplativa, mas igualmente uma apresentação intuitiva e suspensâo intuitiva da nossa visão das coisas, do nosso projeto de vida (Seel, 1996, pp. 407-408). 
Portanto, para Seel (1996), a paisagem é a natureza estética percepcionada. $O$ conceito de paisagem utilizado também pode ser aplicado para a paisagem urbana, desde que se envolva o sujeito e a cidade no mesmo espaço-tempo contemplativo.

\section{A Paisagem como Identidade Estética dos Lugares}

Segundo o filósofo italiano Paolo D’Angelo (2001), o tratamento da paisagem como fenômeno estético é marcado por duas doutrinas: a doutrina biológico-científica (modelo da objetividade e da causalidade) e a culturalista (paradigma da pintura).

A primeira doutrina, a biológico-científica ou etológica, é explicada por D'Angelo no seu livro Estetica della natura - bellezza naturale, paesaggio, arte ambientale, de 2001, em que descreve uma pesquisa feita pelo geógrafo britânico Jay Appelton - The Experience of Landscape - e publicada em 1975 e republicada em 1996.

Uma paisagem apreciável esteticamente está, pelo menos em parte, associada à história biológica da espécie humana e às condições de vida nas quais os nossos antepassados encontravam-se há muito tempo.

D’Angelo (2001) explica as duas teorias criadas por Jay Appelton, que são a habitat theory e a prospect/refuge theory:

A satisfação estética, experienciada na contemplação da paisagem, é oriunda dos atributos visíveis da paisagem, como forma, cor, organização espacial, entre outros, que atuam como sinais-estímulos indicativos das condições para sobrevivência. E o babitat theory. [...] Uma vez que os nossos antepassados mais remotos viveram como caçadores na savana puderam desenvolver uma particular sensibilidade e reatividade a dois fatores e à sua correlação: poderem dispor de uma vista adequada que lhes permitisse avistar presas de caça e poderem simultaneamente ter à disposição vias de fuga em direção a refúgios que os abrigassem de animais potencialmente perigosos. E a chamada prospect/refuge theory. Assim a resume Appelton: A habitat theory postula que o prazer estético na paisagem deriva do fato de o observador experienciar um ambiente favorável à satisfação das suas necessidades biológicas. [...] A prospect/refuge theory postula 
que, como a sua habilidade de ver sem ser visto é uma passagem intermediária na satisfação de muitíssimas necessidades, a capacidade de um ambiente assegurar a ocorrência dessa condição torna-se numa fonte imediata de prazer estético. O valor estratégico de uma paisagem quer seja natural, quer seja artificial, estạ relacionado çom a disposição de objetos que possam garantir, no seu conjunto, estas duas oportunidades, e quando este valor estratégico deixa de ser essencial à sobrevivência, continua a ser apreciado esteticamente (D'ANGELO, 2001, p. 422).

As características estéticas da paisagem devem ser semelhantes às características que asseguram a vista ou o refúgio ou a sobrevivência, além da possibilidade de serem expressas simbolicamente, ou seja, por elementos culturais. Essas características são encontradas em todas as épocas e em todas as culturas, afirma D’Angelo (2001).

Outra teoria discutida por D'Angelo é a Savannab Theory ou Teoria da Savana, de Gordon H. Orians e Judith H. Heerwagen, escrita em 1986. Essa teoria considera que a espécie humana possui prazer na percepção das paisagens naturais, sendo que a paisagem ideal é aquela semelhante às savanas africanas, lugar em que ocorreu a sua hominização. Kirchof (2008) também cita essa teoria:

O fato de que tal fenômeno tenha ocorrido nesse ambiente específico propiciou uma seleção filogenética quanto ao nosso biótopo de preferência. [...] aquele espaço era gratificante para os coletores, por ser rico em frutos silvestres e raízes. Para os caçadores, por, sua vez, havia concentração de animais ruminantes. Além disso, as savanas também eram abundantes em água e em árvores. Estas últimas serviam como fonte de energia e como abrigo, na medida em que forneciam esconderijo para possíveis ameaças (KIRCHOF, 2008, p. 103).

O filósofo D’Angelo (2001) também discorre sobre como explicar o gosto pelo sublime, pois esse gosto opõe-se às teorias etológicas.

A segunda doutrina, a pictórica, pode "até funcionar para explicar as preferências paisagísticas de muitas épocas passadas” e talvez por isso "é tantas vezes erroneamente associada ao panorama, à vista ou a uma representação que oferece (imediatamente) a 
realidade a um sujeito contemplador instalado em um ponto fixo". Para o filósofo, essa teoria pode até estar correta, mas é parcialmente falsa, porque também pode ser pensada no processo inverso, em que a "visão da paisagem real é condição do aparecimento da paisagem pintada”, não sendo como a nossa percepção da paisagem real, que nada mais é do que "um reflexo e uma consequência da paisagem como gênero artístico” (D’ANGELO, 2001, p. 429-430).

A partir do século XX, a apreciação da paisagem não precisa mais ser explicada pela representação artística de um ponto de vista e das condições panorâmicas. Ela pode ser explicada como a identidade estética dos lugares, sem negar que na natureza podem ocorrer diversos tipos de experiências que podem contribuir para a nossa experiência estética. Por um lado, experiência subjetiva (depende da experiência que constitui um sujeito) e, por outro, experiência objetiva (que a caracteriza e contribui para fixar a sua identidade e a sua esteticidade), afirma D’Angelo (2001).

A identidade estética de um lugar é fruto da interação da natureza, da cultura e da história evolutiva na paisagem. Essas identidades dos lugares não devem ser desfiguradas, devem ser protegidas perante a forma legal (por legislação), ou modificadas, desde que as alterações não interfiram na esteticidade; mas não devem ser transformadas em museus, pois a paisagem, para ser verdadeira, deve ser viva, evoluindo com a história (D'ANGELO, 2001).

Um dos principais tópicos relevantes do pensamento de D’Angelo (2001) consiste em:

Reivindicar uma saudável distinção entre paisagem e ambiente é antes de mais um fato de clareza lógica, mas não significa de todo afirmar que os conceitos biológicos, geograficos ou ecológicos não entram na percepção da identidade estética de um lugar. Apreciamos verdadeiramente aquelas paisagens que conhecemos: a relação é similar à que se instaura, por exemplo, entre os conhecimentos iconológiços e a apreciação de uma pintura. [...] devemos tomar a estetica como modelo para a desconstrução da oposição entre natureza e arte, mostrando quanta arte há naquilo a que chamamos natureza e quanta natureza há naquilo a que chamamos de arte. [...] Devemos perguntar qual o contributo que as artes podem dar 
à nossa compreensão da natureza hoje, tendo em conta os fenômenos recentes e evitando decalcar sobre o boje, velhos paradigmas de dois séculos atrás (D’ANGELO, 2001, pp. 438439).

A concepção da identidade do lugar como fundamental para apreciação da estética da paisagem e para pensar em termos da criação de projetos à proteção também é defendida pela filósofa italiana Luisa Bonesio (2002).

Reabilitar um lugar significa projetar na paisagem no passado e no futuro, unindo-a a sua dimensão retrospectiva e prospectiva, para que reapareça na sua expressividade total e deixe de ser algo fruído apenas visualmente, sendo destinada a servir de objeto de contemplação durante os momentos da experiência estética (BONESIO, 2002).

Bonesio (2002) justifica seu ponto de vista utilizando a geofilosofia, disciplina filosófica a qual possui uma proposta transdisciplinar, pois a produção da paisagem (manutenção e incremento do seu valor) não pode acontecer na ausência de consciência e responsabilidade ambiental e na falta de reconhecimento da paisagem como um espaço simbólico das comunidades, principalmente para os urbanistas, arquitetos e legisladores.

Bonesio (2002, p. 465) diz também que, para compreender o belo da paisagem moderna, é preciso olhar a paisagem "não como uma coleção ideal de parcelas extraídas de lugares e tempos diversos, nem tão pouco como uma compilação da beleza natural, mas como uma manifestação visível das modalidades do habitar do homem sobre a Terra". A beleza deve ser entendida no seu alcance ontológico (essência e qualidade da paisagem). 


\section{Uma Breve Conclusão}

A paisagem é uma marca impressa no espaço geográfico pela sociedade humana, criada, identificada e nomeada, inicialmente, de duas maneiras. Primeiro, por artistas e naturalistas que, durante as suas viagens, realizadas a partir do século $\mathrm{XV}$, puderam visualizar diferentes paisagens e, posteriormente, desenhá-las e transformá-las em quadros, poemas e narrativas. Segundo, pela apropriação do espaço físico para as atividades agrícolas e pastoris, espaço esse designado como paisagem para quem vive na área urbana, pois o produtor rural não considera o local onde vive como uma paisagem e, sim, como a "sua terra".

No pensamento filosófico, a paisagem é a experiência do indivíduo moderno (SIMMEL, 1913), evocativa de um mundo passado; de uma unidade para sempre perdida (RITTER, 1974); chamada de campo por alguns, ainda permanece intacta pela naturalidade dos seus elementos e procurada como terapia, higiene de vida e revivescência de religiosidade; categoria mista e complexa entre natureza e cultura (ASSUNTO, 1973); esfera de significações, como uma criação cultural (TURRI, 1998; BERQUE, 1993); o lugar onde a terra e o céu se tocam (CORAJOUD, 1982); só é bela pelos nossos olhos (GRIMALDI, 2011); deve ser apreciada fora do enquadramento da estética da arte (Hepburn e Budd); apreciada como um fator cognitivo baseado nas ciências naturais (CARLSON, 2010) ou por um fator cognitivo incorporado pelas narrativas biorregionais sobre os lugares nativos (Saito); analisada como uma estética participativa e de comprometimento, com todas as suas manifestações culturais (BERLEANT, 2004); e, ainda, é a identidade estética dos lugares (D’ANGELO, 2001) e objeto de contemplação durante os momentos da experiência estética (BONESIO, 2002).

A beleza cênica da paisagem é a identidade estética quando o espaço se transforma em lugar, devendo ser lida nas suas concepções ontológica (essência e qualidade), estética (modo de apreciação e valoração) e ética (possibilidades e limites do agir e de 
conservar no seu conjunto paisagístico). Assim, reconhecer a beleza cênica significa identificar e respeitar as suas propriedades estéticas formais e estruturais marcadas pela harmonia e pela sua historicidade.

A beleza cênica da paisagem é o espaço cênico de observação da paisagem. Caracteriza-se por ser o local central do olhar do observador ao fazer a leitura de uma paisagem, ou seja, é o cenário com propriedades estéticas formais e estruturais marcadas pela harmonia, proporção, luminosidade e pelo equilíbrio. A paisagem cênica caracteriza-se por gerar sentimentos ou sensações agradáveis, como prazer, deleite, satisfação, tranquilidade, paz de espírito.

A paisagem sublime caracteriza-se por gerar sentimentos ou sensações de medo, de inquietação ante a noção de um perigo real ou imaginário, de deformidade, de uma ameaça, de susto, de irregularidades, da variação repentina, do perigo, é a discordância entre a razão e a imaginação.

A paisagem pitoresca caracteriza-se pela singularidade, pela raridade, excentricidade, complexidade, variada e irregular, vibrante, com energia e graciosamente original.

A qualidade cênica é determinada pelo conjunto de elementos que caracterizam visualmente uma paisagem. Ao observar e fazer uma leitura da paisagem, o observador faz um exercício de selecionar, organizar e formar imagens mentais para caracterizá-las fisiograficamente e morfologicamente em relação ao seu entorno e à sequência de seus componentes, principalmente aqueles que conduzem a lembranças de experiências passadas.

Assim, a beleza cênica é um conceito estético subjetivo e objetivo. É um dos atributos da paisagem e um dos fatores que determinam a sua valorização. Agregando todos os conceitos, a beleza cênica é o resultado final, visual, audível, harmônico, de singularidade marcante, um juízo de valor pessoal e coletivo da paisagem, independentemente do seu valor histórico, cultural ou biológico, e incorporada ao longo de um tempo. É formada por um 
conjunto de elementos (água, rochas, formas do relevo e vegetação) que se destacam na paisagem, proporcionando uma harmonia visual que nos faz lembrar como um local representativo de um todo representa uma marca na memória. Evoca um sentimento de paz, de admiração, de prazer, de inspiração, de lembranças do passado, uma sensação de que fazemos parte da paisagem.

Portanto, pode-se ressaltar que houve um caminho teórico em busca do belo natural em relação ao belo artístico e um comprometimento com a natureza no sentido de envolvimento, de pertencimento. Como se a paisagem fosse uma simbiose entre natureza e sociedade humana, devendo, no momento atual, ser protegida também esteticamente, e não só pelas suas características físicas e culturais.

\section{Referências}

ASSUNTO, R. A paisagem e a estética. 1973. Tradução Adriana Veríssimo Serrão. In: SERRÃO, A. V. Filosofia da paisagem: uma antologia. Centro de Filosofia da Universidade de Lisboa, 2011.

AZEREDO, J. C. Santos de. Dicionário Aulete. 2011. Desenvolvido por Lexikon Editora Digital Ltda. Disponível em http://aulete.uol.com.br/

BERLEANT, A. A estética da arte e a natureza. 2004. Tradução de Adriana Veríssimo Serrão. In: SERRÃO, A. V. Filosofia da paisagem: uma antologia. Centro de Filosofia da Universidade de Lisboa, 2011.

BERQUE, A. La pensée paysagère: une approche mésologique. In: SALERNO, Rosseta; CASONATO, C. (Dir.). Paesaggi culturali. Roma: Gangemi Editore, 2008.

BERQUE, A. A ecúmena: medida terrestre do Homem, medida humana da Terra Tradução de Adriana Veríssimo Serrão. 1993. In: SERRÃO, A. V. Filosofia da paisagem: uma antologia. Centro de Filosofia da Universidade de Lisboa, 2011.

BONESIO, La. Oltre il paesaggio. I luoghi tra estetica e geofilosofia. Casalecchio: Arianna, 2002.

BUDD, M. The aesthetic appreciation of nature: essays on the aesthetics of 
nature. Oxford: Clarendon Press, 2002.

CARLSON, . Appreciating art and appreciating nature. In: KEMAL, S.; GASKELL, I. (Eds.). Landscape, Natural Beauty and the Arts. Cambridge University Press, 1995.

Contemporary Environmental Aesthetics and the Requirements of Environmentalism. Environmental Values, 2010.

CORAJOUD, M.. Tradução Adriana Veríssimo Serrão. 1982. In: SERRÃO, A. V. Filosofia da paisagem: uma antologia. Centro de Filosofia da Universidade de Lisboa, 2011.

D'ANGELO, P. Estetica della natura. Bellezza naturele, paesaggio, arte ambientale. Roma-Bari: GLF, Editori Laterza, 2001.

DIEGUES, A. C. O mito moderno da natureza intocada. 3. ed. São Paulo: Hucitec: Núcleo de Apoio à Pesquisa sobre Populações Humanas e Áreas Úmidas Brasileiras, USP, 2001.

FRANCO, J. L. A. A contribuição do Turismo na Preservação e na Socioeconomia das Nações: uma perspectiva histórica. Palestra proferida no II CONGRESSO DE NATUREZA, TURISMO E SUSTENTABILIDADE (CONATUS). Cuiabá, MT. 2011. Disponível em $<$ conatus.org.br/DownloadAnexo.php?Anexo = arquivos $/ . . . p d f>$ Acesso em: 02 jan.2014.

GRIMALDI, N. A estética da bela natureza. Problemas de uma estética da paisagem. Tradução de Adriana Veríssimo Serrão. In: SERRÃO, A. V. Filosofia da paisagem: uma antologia. Centro de Filosofia da Universidade de Lisboa, 2011.

HEPBURN, R. W. Contemporary aesthetics and the neglect of natural beauty'. In: CARLSON A.; BERLEANT A. (Eds.), The Aesthetics of Natural Environments (Broadview Press). First published in WILLIAMS B.; MONTEFIORE A. (Eds.), British Analytical Philosophy. London: Routledge and Kegan Paul, 1966, p. 43-62.

. A estética contemporânea e o desprezo pela beleza natural. In: SERRÃO, A. V. Filosofia da paisagem: uma antologia. Centro de Filosofia da Universidade de Lisboa, 2011.

HUMBOLDT, A. Quadros da natureza. Rio de Janeiro: M. Jackson, 1952.

KIRCHOF, E. Estética e Biossemiótica. Canoas: Ulbra, 2008.

PEDRAS, L. R. V. A paisagem em Alexander von Humboldt: o modo descritivo dos quadros da natureza. Revista USP, São Paulo, n. 46, 
p. 97-114, jun./ago. 2000.

RITTER, J. Paisagem. Sobre a função do estético na sociedade moderna. 1974. Tradução Adriana Veríssimo Serrão. In: SERRÃO, A. V. Filosofia da paisagem: uma antologia. Centro de Filosofia da Universidade de Lisboa, 2011.

SAITO, Y. Apreciar a natureza nos seus próprios termos. 2004. Tradução Adriana Veríssimo Serrão. In: SERRÃO, A. V. Filosofia da paisagem: uma antologia. Centro de Filosofia da Universidade de Lisboa, 2011.

SEEL, M. Eine Ästhetic der Natur. Frankfrut am Main: Suhrkamp, 1996.

<http://books.google.com.br/books?id=JJIQAQAAIAAJ\&dq= Martin +Seel\&q= natur $>$. Acesso em: 26 de maio de 2011.

SERRÃO, A. V. Filosofia e Paisagem: aproximações a uma categoria estética. Philosophica, 2004.

SERRÃO, A. V. Filosofia da paisagem: uma antologia. Centro de Filosofia da Universidade de Lisboa, 2011.

SIMMEL, G. "Philosophie der Landschaft. In: Die Güldenkammer. Norddeutsche Monatshefte", Bremem.1913 Tradução Adriana Veríssimo Serrão. In: SERRÃO, A. V. Filosofia da paisagem: uma antologia. Centro de Filosofia da Universidade de Lisboa, 2011.

TURRI, Eo. A paisagem como teatro: do território vivido ao território representado. 1998. Tradução de Adriana Veríssimo Serrão. In: SERRÃO, A. V. Filosofia da paisagem: uma antologia. Centro de Filosofia da Universidade de Lisboa, 2011.

VALLADÃO de MATTOS, C. Artistas viajantes nas fronteiras da história da arte. III Encontro de História da Arte - IFCH: Unicamp, 2007. Disponível em: < http://www.unicamp.br/chaa/eha/atas/2007/MATTOS,\%20Cla udia\%20Valladao\%20de.pdf) > . Acesso em 23 de maio de 2012. 


\section{Para Construir Espaços:} Geografar Memórias 



\section{Corporeidades e Paisagem: a cosmologia da terra no Quilombo dos Alpes/RS}

Cláudia Luísa Zeferino Pires

Daiane da Silva Ellias

Karina Rejane da Silva Ellias

Lara Machado Bitencourt

Marilia Guimarães Rathmann

Mateus dos Santos Viegas

Matheus Eilers Penha

Rosângela da Silva Ellias

Winnie Ludmila Mathias Dobal 
Cláudia Pires; Daiane Ellias; Karina da Silva Ellias; Lara Bitencourt; Marilia Rathmann; Mateus Viegas; Matheus Penha; Rosângela da Silva Ellias \& Winnie Dobal

\section{Os corpos apresentam-se}

$V$ ou fazê cento e quatro [...] agora. Porque quando eu vim pra cá, aqui não tinba igreja, não tinha casa, não tinha nada, era tudo mato, prá mim entra pra cá prá dentro desse mato eu tinha que abrindo assim, senão moiava a gente tudo, né! Ficava toda moiada do mato, não podia. E tinha só aquelas estradinha assim, curtinha como isso aqui, prá gente entrá nas casinha. Lá pra minha casinha onde eu morava, eu morava lá em cima. A igreja dos padre não tinha. (PMPA, Arquivo Histórico de Porto Alegre Moysés Vellinho. Relato obtido em 20/01/1993).

Esse trecho corresponde a uma parte da entrevista concedida por Edwirges Francisca Garcia da Silva para a coletânea Memória dos Bairros de Porto Alegre. Sendo ela uma das moradoras mais antigas do morro dos Alpes e seu entorno, sua fala é guiada pela sua trajetória de vida, pela sua relação com o espaço e por como, a partir dela, foi-se constituindo um processo de ocupação e pertencimento territorial. $\mathrm{Na}$ busca pela autonomia, pela sobrevivência, pela permanência para garantir sua existência, Edwirges e seus descendentes resistiram no espaço e dele constroem a base para suas vidas. É nessa relação significada entre espaço e corporeidade que o Quilombo dos Alpes torna-se uma referência de identidade, de reconhecimento político-social e cultural, estabelecendo um modo de existência que luta contra uma cidade que se constituiu pelo racismo socioespacial. Existência pressupõe visibilidade e, para que esta realização concretize-se, negros e negras de nossa cidade não podem estar marginalizados espacial, social e culturalmente. A Figura 1 localiza espacialmente o Quilombo dos Alpes no município de Porto Alegre, capital do estado do Rio Grande do Sul. 
Figura 1 - Localização do Quilombo dos Alpes no município de Porto Alegre.

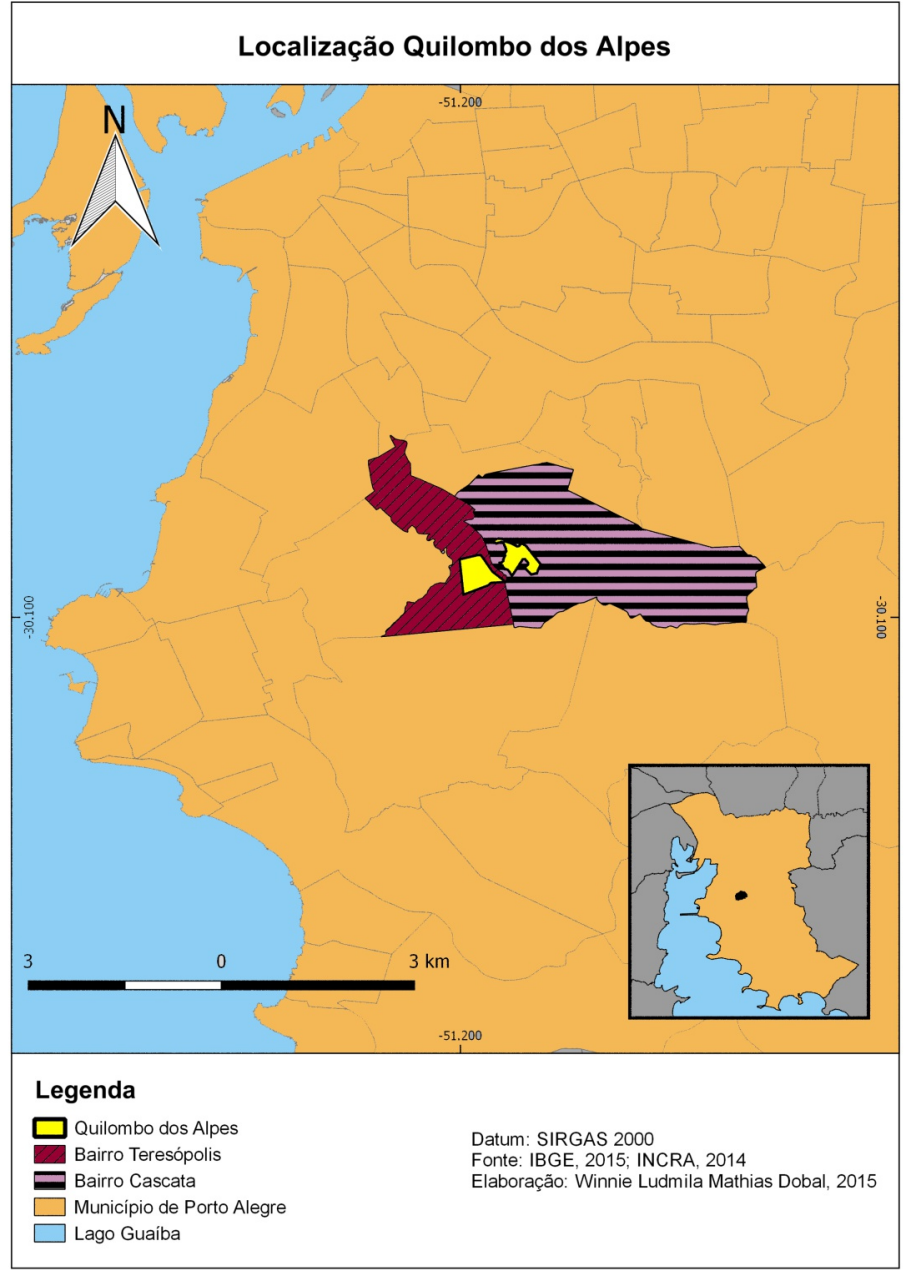

Fonte: Dobal (2015).

O Quilombo dos Alpes constitui um espaço integrado às relações entre sociedade e natureza, materializadas e subjetivadas por ações que reconstituem os saberes e a diversidade de apropriações espaciais. A tradição oral e suas manifestações culturais estão presentes no cotidiano dos sujeitos, na organização comunitária e 
Cláudia Pires; Daiane Ellias; Karina da Silva Ellias; Lara Bitencourt; Marilia Rathmann; Mateus Viegas; Matheus Penha; Rosângela da Silva Ellias \& Winnie Dobal

nas relações espaciais. Atualmente, possui uma área de aproximadamente 58 hectares (MDA, 2016), sendo o maior quilombo urbano de Porto Alegre. O quilombo está localizado entre dois bairros: Cascata e Teresópolis.

Do tempo de Dona Edwirges até o presente, é na figura da mulher que está centralizada a luta pela terra e pelo pertencimento ao lugar, sendo esse protagonismo transmitido de geração a geração, como observamos no relato a seguir:

[...] Não é que a gente queira ter coisas específicas demais, às vezes já ouvi o pessoal dizer 'ah, tu tá muito alienada, querendo tudo de individual'. Não é isso, mas é que a partir do momento que a comunidade se reconhece como quilombola, e o governo dá esse autorreconhecimento a ela, as pessoas que estão lá nos órgãos, eles também teriam que ter um entendimento maior do que que eles tão lidando, ne. Não é uma coisa como outra qualquer, tem algumas especificidades, que é aquela coisa que eu falei pra vocês, são coisas que não vão ser visíveis, tu não vai ver, tu não vai enxergar, tu vai sentir. Tu vai ter que ter a sensibilidade de olhar e rever teus conceitos e dizer 'bah, mas por quê?' Eu te pergunto por que, mas tem um porquê disso, tem resposta, mas não e uma coisa que vem pronta. (Arquivo do NEGA, entrevista concedida por Karina Rejane da Silva Ellias à equipe do NEGA em 28/07/2015.)

$\mathrm{O}$ relato de Karina, neta de Edwirges, indica a necessidade de olhar para a invisibilidade que as diversidades culturais afrobrasileiras e quilombolas possuem ao longo do processo de formação do Estado Nacional. Essa invisibilidade vai dificultando a construção de uma identidade quilombola, uma vez que nossa sociedade, pautada num sistema racista, vai promovendo sua exclusão corpo-acorpo. Entretanto, sua presença vai afirmando-se no espaço por meio de relações sociais e culturais estabelecidas por lutas e conquistas pela terra. Para garantir sua sobrevivência, torna-se resiliente, regressa às suas raízes para tornar-se forte e enfrentar a supremacia de uma cultura opressora e hegemônica.

Dentre as ações corpo a corpo, podemos indicar as trilhas presentes no tempo-espaço no Quilombo dos Alpes. Impregnadas do viver e das estratégias de se opor às opressões sofridas, a 
corporeidade dos quilombolas marca o espaço pelo caminhar. A comunidade compreende uma necessidade importante de permanência em seu espaço - mapear as trilhas que constituíram suas vivências.

Para construir este projeto, Clarice Moraes Freitas (Instituto de Pesquisa e Assessoramento em Direitos Humanos, Gênero, Raça e Etnia - AKANNI) propõe uma interlocução entre o Quilombo dos Alpes e o NEGA. Este contato realiza-se pela construção de mapas-narrativas do bairro Restinga/Porto Alegre (PIRES, C. et al., 2015). Os mapas-narrativas trataram da construção de um conto geográfico, que valorizou as histórias de vida, e sua relação com as transformações do espaço. É neste momento que conhecemos Rosângela da Silva Ellias, conhecida como Janja, Presidente da Associação Quilombo dos Alpes Dna. Edwirges. Ao conhecer o trabalho desenvolvido por nosso laboratório, ela nos propôs a realização de um projeto similar no Quilombo dos Alpes. Inicialmente, este trabalho se constituiu dentro da disciplina de Organização e Gestão Territorial (segundo semestre de 2013) do Departamento de Geografia/UFRGS e, na sua continuidade, estabeleceu-se uma parceria de trabalhos entre o Quilombo dos Alpes e o Núcleo de Estudos em Geografia e Ambiente (NEGA).

Essa forma de aproximação tem conexão com nossa perspectiva metodológica, que é uma resposta com relação a uma prática de extensão e pesquisa vinculadas, em que sujeito e objeto confundem-se. Na realidade, nós pesquisadores somos objetos, na medida em que os próprios sujeitos quilombolas valem-se de nós para expressar suas lembranças, suas narrativas e seus marcadores. Ao mesmo tempo, também somos corpos e sujeitos integrados nesse processo, porque as narrativas juntam-se às nossas lembranças e às perspectivas em que acreditamos, que são principalmente: dar visibilidade aos acontecimentos vividos pela matriarca e por todos seus descendentes devido à invisibilidade da negritude na cultura e no espaço, ficando isso bastante evidente em todo nosso processo de trabalho coletivo. 
Cláudia Pires; Daiane Ellias; Karina da Silva Ellias; Lara Bitencourt; Marilia Rathmann; Mateus Viegas; Matheus Penha; Rosângela da Silva Ellias \& Winnie Dobal

\section{A paisagem nos desvela}

O valor estético da paisagem tornou-se paradigma e referência nos trabalhos de Geografia, de Artes e de planejamentos urbanos. Assim, elementos visíveis que pertencem à natureza integram as atividades socioculturais, dando-lhes forma, estrutura e funcionalidade que, muitas vezes, são analisadas de maneira compartimentada. Quando se qualifica qualquer espaço segundo seus padrões estéticos, estamos recortando a Terra, e esses recortes passam a ser tratados em contradição, pois natureza e sociedade não são fragmentos de um todo, mas, sim, o próprio todo que possui certas singularidades.

Pensando em discutir sobre essas dimensões, dialogamos com Dardel (2011), para o qual Geografia não é, de início, um conhecimento, uma realidade geográfica concebida como 'objeto' e que compreende o espaço geográfico como um espaço em branco a ser preenchido e/ou colorido. A ciência geográfica deve pressupor que o mundo seja conhecido geograficamente, que o homem [e a mulher] (grifo nosso) se reconheçam ligados à Terra como seres que se realizam em sua condição terrestre.

Os recortes, aprisionados pelo olhar, modelam a Terra, integrando um grupo de fenômenos, e assim denominam a paisagem e reivindicam sua própria autonomia. Para Dardel (2011) toda a geografia está na análise da paisagem. É a geografia compreendida como o que está em torno do homem, como ambiente terrestre, como muito mais do que uma justaposição de detalhes pitorescos. É uma convergência, um momento vivido, uma "impressão" que une todos os elementos.

Os estudos sobre quilombos, especialmente urbanos, surgem como um grande desafio para a Geografia, pois o fluxo sociocultural da cidade torna-se uma rede complexa para os diferentes saberes que se apropriam deste espaço. Para Silva (2001), há dois tipos de espaços urbanos a serem reconhecidos: o oficial, 
projetado pelas instituições e feito antes que o cidadão o conceba, e $o$ diferencial, que consiste em marcas espaciais usadas e inventadas na medida em que o cidadão nomeia ou inscreve o espaço.

No Quilombo dos Alpes (Figura 2), podemos observar o diferencial inscrito no espaço e na paisagem por meio de marcas concretas e simbólicas, tornando possível reconhecer seus limites e conteúdos. Essas marcas estão presentes em cada morador e moradora quilombola e (re)produzem os significados dos sujeitos e as ações que compõem o espaço. Dessa forma, cada paisagem será concebida conforme sua interpretação. Surge então a necessidade de compreender e reconhecer-se na paisagem pelo processo de interpretação do quilombo no espaço urbano, revendo as bases epistemológicas que sustentam nossas visões de mundo. Aliás, na esfera do conhecimento, no campo epistemológico, é imprescindível nossa crítica pela necessidade de rompimento com o discurso colonial. Para Fanon (2008), o povo colonizado, o qual nasce de um complexo de inferioridade, enterra sua originalidade cultural local a partir de uma linguagem civilizadora, isto é, a cultura metropolitana. Ele será tanto mais branco quanto mais rejeitar sua negrura.

Figura 2 -Vista da Sede da Associação do Quilombo dos Alpes, Octógno Djanira. Ao fundo, observa-se o centro da Cidade de Porto Alegre e o Lago Guaíba.

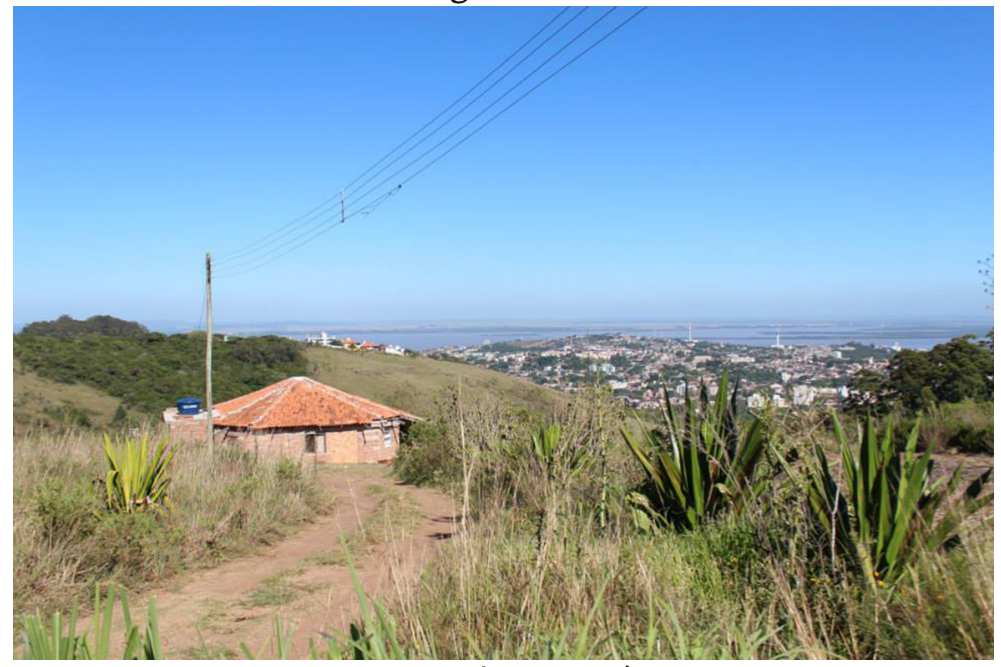

Fonte: Arquivos do NEGA /UFRGS - 2013

Geografias e (In)visibilidades: Paisagens, Corpos, Memórias 167 
Cláudia Pires; Daiane Ellias; Karina da Silva Ellias; Lara Bitencourt; Marilia Rathmann; Mateus Viegas; Matheus Penha; Rosângela da Silva Ellias \& Winnie Dobal

Numa discussão sobre paisagem e sobre como ela se manifesta, nossa preocupação está articulada à compreensão, não somente de um sistema de significados e valores subjetivos, mas também da maneira como as relações sociais de um grupo são estruturadas e constituídas, assim como suas formas são produzidas, experienciadas, entendidas e interpretadas. Conforme Dardel (2011):

A paisagem não é um círculo fechado, mas um desdobramento. Ela não é verdadeiramente geográfica a não ser pelo fundo, real ou imaginário, que o espaço abre além do olhar. [...] A paisagem é um escape para toda a Terra, uma janela sobre as possibilidades ilimitadas: um horizonte. Não uma linha fixa, mas um movimento, um impulso. (DARDEL, 2011, p. 30)

Percebe-se uma totalidade complexa no Quilombo dos Alpes, que reúne diferentes paisagens, nas quais natureza e sociedade sobrepõem-se. Num primeiro momento, as paisagens apresentam-se pela forma, possuindo espaços com predominâncias - elementos ora naturais, ora sociais, ora culturais, caracterizados por uma dimensão estética que se materializa pela apropriação territorial. Num segundo momento, à medida que nos aprofundamos nas marcas territoriais do quilombo por diferentes percepções, identificamos a multidimensionalidade do "vivido" territorial pelos membros de uma coletividade quilombola, ao mesmo tempo em que o processo territorial se constrói por intermédio de um sistema de relações produtivas, mas acima de tudo existenciais, trazendo à tona uma corporeidade marcada pelo vivido. Paisagem, como tempo e espaço, é também memória, herança. A Figura 3 revela as técnicas construtivas utilizadas por Janja na construção de sua casa. São técnicas autoconstrutivas e estão associadas à ancestralidade e aos saberes vernaculares presentes na cosmologia da Terra. 
Figura 3: Técnicas construtivas utilizadas por Janja na construção de sua casa.

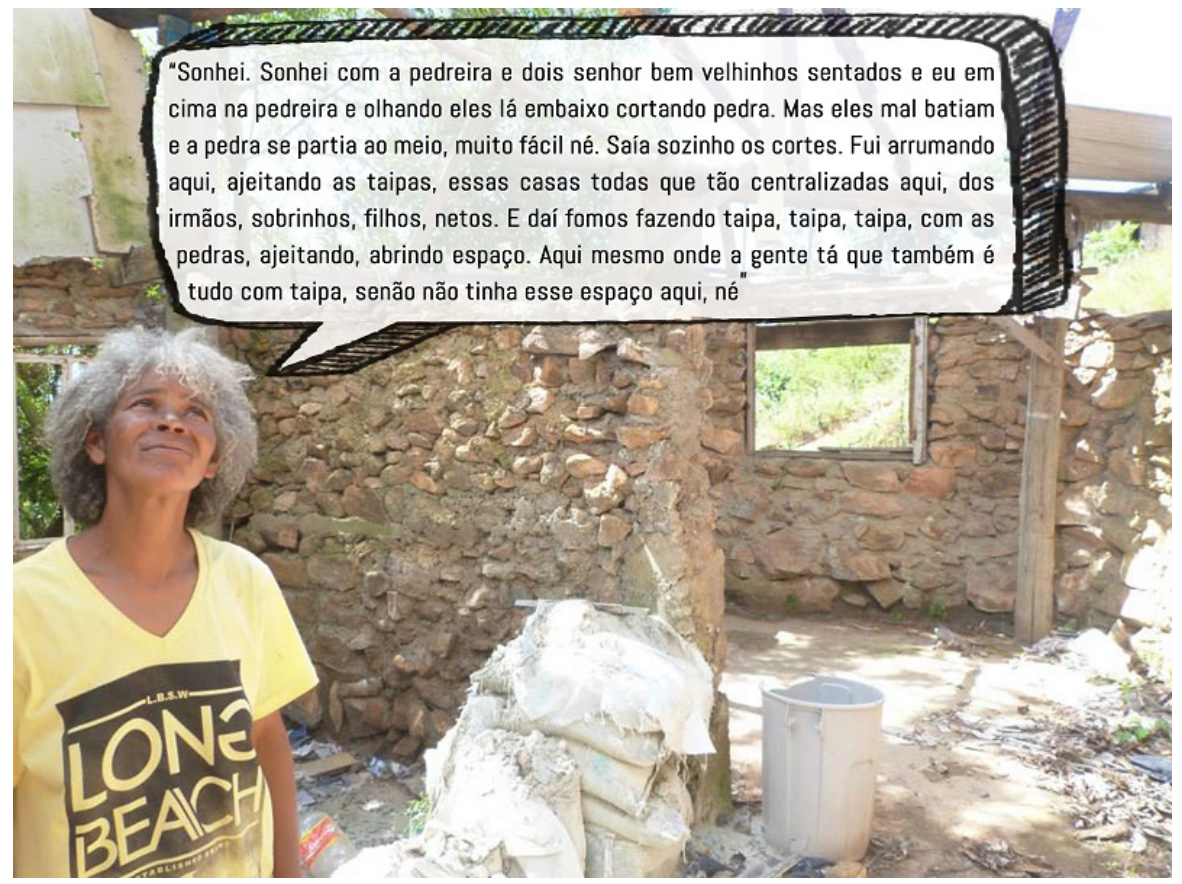

Fonte: Arquivos do NEGA /UFRGS - 2013

A relação e o sentimento de pertencimento territorial indicam representações coletivas do espaço, dando sentido ao lugar e explicando os vínculos territoriais. Essa relação processa-se em tensões identitárias entre subjetividades individuais e coletivas e/ou contextuais e universais, principalmente entre ser e não ser quilombola. Nessas condições, é preocupante ter uma visão idealista sobre uma paisagem de quilombo, pois ela não representa unicamente um conjunto de percepções limitadas às análises de espaço "vivido" e "percebido". Muitos estudos ainda negligenciam a existência "objetiva" da paisagem e as relações de corporeidade - e quando nos referimos à "existência objetiva" estamos tratando daquilo que está abarcado pelo campo da visão.

Nesse sentido, procura-se refletir sobre essa apropriação da paisagem, bem como contribuir para o seu entendimento a partir de sua importante materialização de ações, atitudes e valores culturais constantes que ficam registrados no tempo como herança. Essas 
Cláudia Pires; Daiane Ellias; Karina da Silva Ellias; Lara Bitencourt; Marilia Rathmann; Mateus Viegas; Matheus Penha; Rosângela da Silva Ellias \& Winnie Dobal

heranças foram transmitidas aos descendentes de Dona Edwirges, e suas ações, trajetória de vida, memórias ganham corporeidade pela paisagem que é configurada, constantemente, por novas formas e significados na comunidade.

Acreditamos que a análise da produção do espaço significa, também, uma análise da (des)construção do espaço produzido, valendo dizer, então, que a paisagem consiste numa geografia do movimento, traduzida e interpretada segundo suas formas, funções, estruturas e subjetividades que, ao se combinarem, (re)produzem o espaço. Podemos dizer que este espaço carrega um sentido de território porque tem seus limites, suas conquistas, lutas e resistências. A paisagem é a vida que o anima, preenchida por um cotidiano que supõe um passado como herança e um futuro como projeto. Nosso presente é uma estreita nesga entre o passado e o futuro. Santos (1996) complementa esta ideia de uma existência do passado, que nos pertence e da qual não podemos nos libertar porque já se deu, e de um futuro que nos possibilita esperanças. Somos fruto de uma relação que oscila entre a necessidade e a liberdade, entre o que somos e o que queremos ser, entre a dificuldade de afirmação diante das situações e a crença de que podemos ser outro. Isso nos remete às relações de corporeidade, individualidade, socialidade e espacialidade. Quando estamos no Quilombo dos Alpes, sentimos que esse cotidiano é permeado dessas relações, garantindo sua existência e permanência na Terra.

\section{Corporeidade e paisagem: a construção de uma cartografia}

As ações metodológicas utilizadas ao longo do processo de cartografia e autorrepresentação visaram compreender uma análise espacial do Quilombo dos Alpes, possibilitando a interpretação de sua paisagem. A interpretação remete à compreensão de uma cosmologia da Terra associada à identificação de marcas territoriais, verificando como diferentes saberes e práticas colaboram para a 
configuração do espaço. A cosmologia refere-se aos princípios que situam percepções e ações dos quilombolas em conexão com os saberes sagrados. O sagrado é identificado por diferentes códigos e símbolos no quilombo, os quais são projetados pelos moradores e podem ser identificados na constituição da paisagem, compreendendo as configurações materiais e as conotações simbólicas atribuídas ao espaço. A cosmologia presente possibilitou o percurso de compreensão do território quilombola enquanto conhecimento e comunicação, tornando possível o consenso acerca do sentido do mundo vivido.

As paisagens tornam-se passíveis de serem reconhecidas, pois se legitimam pelo reconhecimento de um ou vários sentidos ligados às práticas sociais do quilombo. A percepção das expressões subjetivas (atributos, valores, atitudes) da paisagem remete a um conjunto de intencionalidades, de práticas constituídas e situadas em um contexto espacial em um processo muito imbricado com o contexto social e histórico e, acima de tudo, político da sociedade brasileira - sobretudo, porque as lutas de reconhecimento territorial nos levam às matrizes formadoras de nossa sociedade: negritude e quilombismo. Quilombo é a expressão da liberdade! No Brasil temos o movimento denominado de quilombismo, proposto por Abdias do Nascimento, principalmente na década de 1980, como legado de uma mobilização política da população afrodescendente nas Américas e com base na sua própria experiência histórica e cultural.

Ao perceber que várias marcas constituídas na paisagem apresentam características híbridas desse processo de reconhecimento, de apreensão simbólica, compreende-se que suas variantes vão delineando identidades. Para nós, a identidade que estamos retratando é a de um coletivo construído a partir dos sentidos de uma comunidade afro-brasileira dentro de um centro urbano cuja consciência perpassa pelo sentimento de criação, de resistência, de doação e coesão territorial. 
Cláudia Pires; Daiane Ellias; Karina da Silva Ellias; Lara Bitencourt; Marilia Rathmann; Mateus Viegas; Matheus Penha; Rosângela da Silva Ellias \& Winnie Dobal

Captada por entrevistas, a expressão subjetiva é mais uma indicação da importante relação entre corpo e paisagem. O “subjetivo/invisível” não é o oposto ao que é material, mas é, além disso, uma forma de compreendê-lo como um saber acerca de uma determinada coisa. Os objetos e a linguagem, de maneira geral, são os níveis intermediários entre o espectador e o invisível. O subjetivo - invisível - estaria projetado no que é visível, representado no próprio interior desse por categorias específicas dos objetos, como os sistemas naturais, as diversidades culturais e sociais, assim como tudo aquilo que surge numa relação de significados. Para Dardel (2011):

Sua 'objetividade' se estabelece em sua subjetividade, que não é pura fantasia. Que a denominemos sonho ou devoção, um elemento impulsiona a realidade concreta do ambiente para além dele mesmo, para além do real, e, então, o saber o resigna sem culpa a um nâo saber, a um mistério. A realidade geográfica exige uma adesão total do sujeito, através de sua vida afetiva, de seu corpo, de seus hábitos, que ele chega a esquecê-los, como pode esquecer sua própria vida orgânica. Ela está, contudo, oculta e pronta a se revelar. (DARDEL, 2011, p. 34)

São esses sentidos ocultos presentes nos valores dessa cosmologia da Terra e do sagrado que se revelam nas vivências do e no Quilombo dos Alpes. E é a partir da relação dialética entre sujeito-objeto dada entre pesquisadores e quilombolas que se compõe um olhar nosso retroalimentado no trabalho coletivo, proporcionando compreensões e ferramentas preciosas para a grafia e representação da paisagem.

\section{Memória e palavra: cartografia do pertencimento}

As primeiras experiências do grupo no Quilombo dos Alpes foram para mapear as trilhas e os percursos no território, retomando o sagrado - da ancestralidade à atualidade ${ }^{1}$. A 1 - Este trabalho foi realizado primeiramente com a participação da turma da disciplina de Organização e Gestão Territorial 2013/2. Essa experiência e construção estão disponíveis em

https://www.youtube.com/watch?v=10i0lB4pA2o. 
comunidade tinha como demanda um mapa que mostrava as trilhas, pois elas tinham sido inventariadas e representadas por eles ao caminharem pelo espaço. As trilhas foram atualizadas e narradas pelos quilombolas e representam trajetos realizados cotidianamente desde a chegada de Dona Edwirges e seus descendentes. Visto que o ser quilombola supera as fronteiras políticas, suas trilhas também cruzam a delimitação, evocando sua história desde a matriarca fundadora do quilombo. Conforme relato de Dona Edwirges:

Plantei laranjeira, plantei bergamota, depois que tava tudo grande foi que eles vieram, corrê com cerca nova agora aqui... Âh, viero corrê a cerca, me botaro prá cá... Aí eu disse prá eles que eu tinha quase cem anos... Fecharam eles mesmos, fizeram a cerca e deixaram o arroio do lado de dentro prá mim. Os outros arroios eles tiraram tudo. E. Pro vê quantos anos eu moro aqui. Quantos anos já marquei ái? (PMPA, Arquivo Histórico de Porto Alegre Moysés Vellinho. Relato obtido em 20/01/1993).

Os relatos de Dona Edwirges reúnem em sua oralidade toda a ancestralidade do espaço em que vivem os quilombolas. Esse pertencimento está presente na memória de seus descendentes, que evocam a palavra para dar continuidade as suas tradições. Fanon (2008) conta que diversos grupos culturais da África se reúnem para "parlamentar" como forma de resolver problemas, ou seja, buscar pela palavra o entendimento e a negociação de tensões. Essa prática é muito associada ao que se conhece academicamente por "oralidade". Foi pela palavra, juntamente com nossos interlocutores e com a comunidade que o mapa passou a ser narrado.

A palavra representa, no mapa narrado, a marca! Caminhando com a Janja pelo seu lugar e ouvindo suas memórias representamos no mapa seus marcadores territoriais, que por sua vez são a grafia dos percursos cotidianos da comunidade. Os marcadores, não necessariamente materiais, são marcas espaciais e asseguradas pela identidade. Os usos das trilhas vão desde os mais corriqueiros, como ir ao campo de futebol ou à associação de moradores, até os estritamente religiosos, como entregar oferendas aos Orixás, por exemplo, as ofertas a Xangô são entregues na Pedreira. 
Cláudia Pires; Daiane Ellias; Karina da Silva Ellias; Lara Bitencourt; Marilia Rathmann; Mateus Viegas; Matheus Penha; Rosângela da Silva Ellias \& Winnie Dobal

As trilhas estão gravadas no espaço e no conhecimento dos membros da comunidade quilombola, que as corporificam circulando em seu território. Sendo assim, estas trilhas e percursos configuram-se como patrimônio cultural e histórico imaterial da comunidade quilombola dos Alpes. A Figura 4 apresenta o mapeamento realizado:

Figura 4: Pelas trilhas do Quilombo do Alpes: percursos, memórias e identidades.

\section{PELAS TRILHAS DO QUILOMBO DOS ALPES: PERCURSOS, MEMÓRIAS E IDENTIDADES}

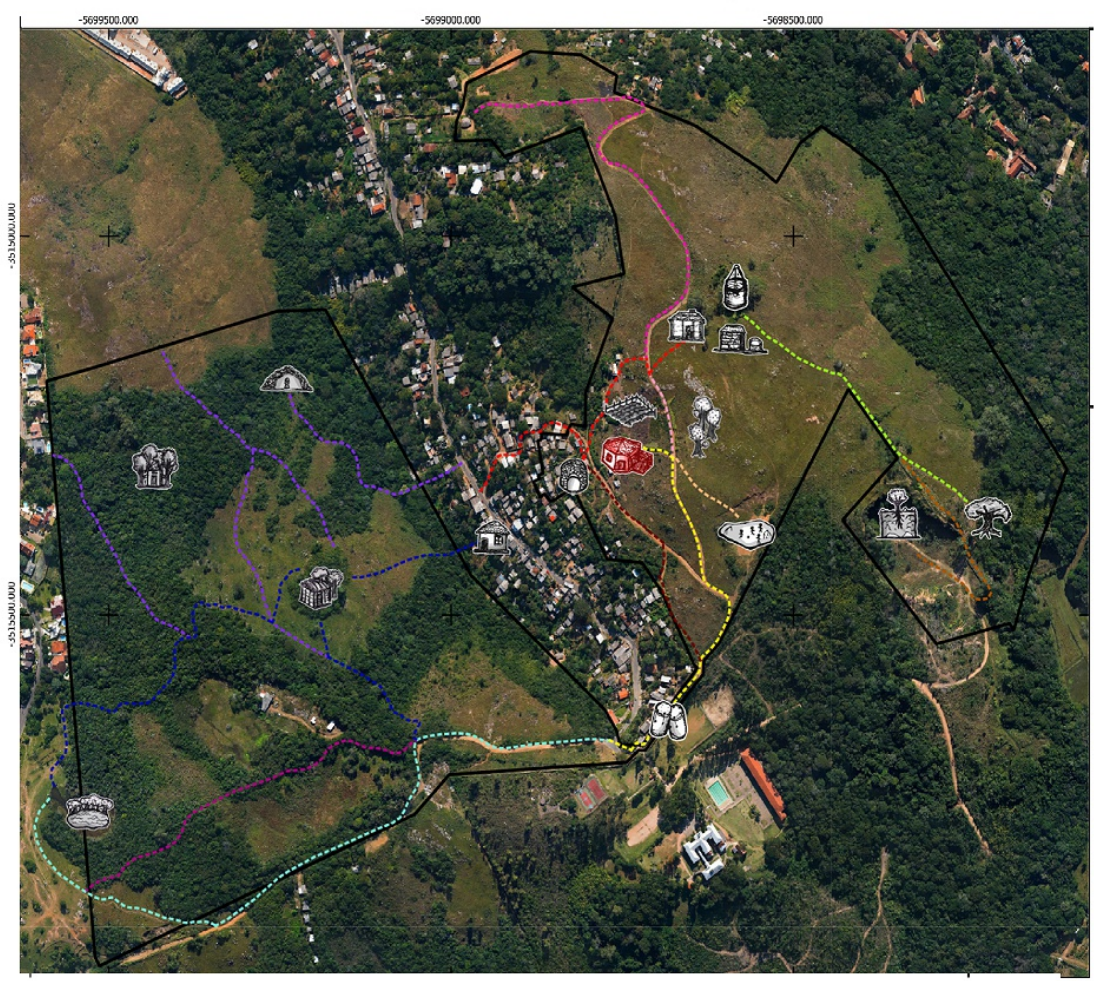

TRILHAS E PERCURSOS

Limite territorial do Quilombo

Percurso da Religiosidade

---- A Trilha da Casa dos Pretos Velhos Percurso da oralidade e ludicidade

-.-- $\mathbf{B}$ Trilha da Figueira

-... $\mathbf{C}$ Trilha da Lagoa

-.-- D Trilha da Pedreira

Projeçäo/DATUM: UTM-22S/WGS-84 (DRA/2015

Elaboracão: Núcleo de Estudos Geoarafia e Ambiente - NEGA/UFRGS
Percurso da ancestralidade e memória Percurso da musicalidade, circularidade,

-.-. Trilha das Ervas

-... Trilha do Capão da Vó

.... - A Trilha do Mato

-.-. I Trilhas do Matinho do Tio Wilson

--- | Trilhas do Capão do Vela corporeidade e cooperativismo

J Trilha da Associação

K Trilha da Horta e Pomar

L Trilha do Campinho

Fonte: Arquivos do NEGA /UFRGS - 2013 
Os marcadores, como a primeira e a última casa de Dona Edwirges e a trilha do Capão da Vó, mostram a trajetória que a matriarca do quilombo fez ao chegar ao Morro dos Alpes no início do século XX, quando "aquilo tudo era só mato". Outros caminhos, como a pedreira e o campinho, são locais preferidos para as brincadeiras das várias gerações de crianças quilombolas ao longo de mais de um século. Essa múltipla temporalidade é uma característica muito presente nos marcadores territoriais do quilombo. A seguir descrevemos os marcadores e os percursos que compõem a legenda do mapa:

Figura 5: Legenda do mapa Pelas trilhas do Quilombo dos Alpes: percursos, memórias e identidades.

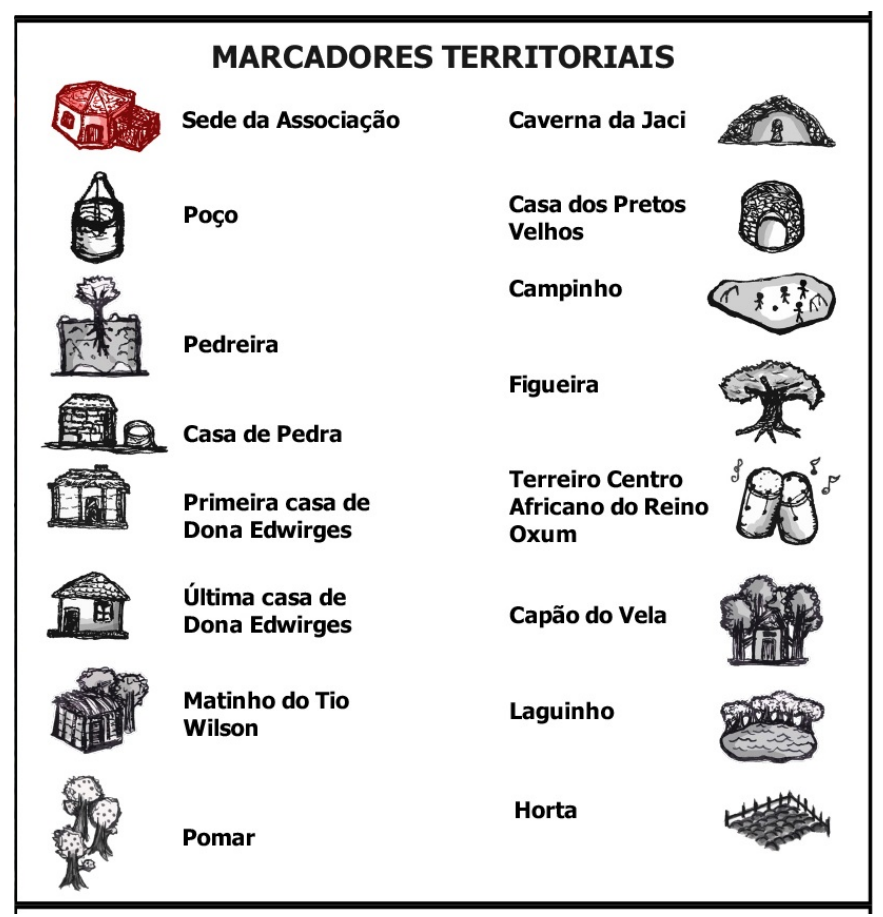

Fonte: Arquivos do NEGA/UFRGS - 2013 
Cláudia Pires; Daiane Ellias; Karina da Silva Ellias; Lara Bitencourt; Marilia Rathmann; Mateus Viegas; Matheus Penha; Rosângela da Silva Ellias \& Winnie Dobal

\section{Legenda:}

1. Sede da Associação: o octógono Djanira é a sede da Associação Quilombola Dona Edwirges (Vó), e sua construção marca a luta pelo autorreconhecimento. É um espaço comunitário que agrega os moradores e visitantes onde são realizados os rituais, as reuniões, as festividades e as atividades culturais.

2. Poço: construído por D. Edwirges para abastecer a família durante o tempo que morava na primeira casa.

3. Pedreira: pedreira inativa que várias gerações de quilombolas utilizam para lazer. Possui grande significado religioso, visto que é nesse local que são entregues as oferendas para os Orixás.

4. Casa de Pedra e Poço: ruínas de uma casa de pedra que foi habitada por um médico e seu filho. Com a chegada deles, D. Edwirges mudou-se para outro lugar do morro. A Vó plantou sizal e babosa para uso medicinal.

5. Primeira casa de Dona Edwirges: local onde a matriarca do quilombo construiu a sua primeira morada, uma pequena casa feita de vassoura no topo do morro, no início do século XX.

6. Última casa de Dona Edwirges: local onde a matriarca passou seus últimos anos de vida morando junto com sua filha Jane e netos.

7. Matinbo do Tio Vilson: tio Vilson, filho da D. Edwirges e chamado por ela de Meio-quilo, vivia no mato, numa casa feita de vassoura, barro e taquara. Plantou diversos tipos de ervas e árvores, como café, taquara e arnica.

8. Pomar: local de árvores frutíferas nativas. Antigo espaço de plantio de amendoim, batata-doce, abóbora.

9. Caverna da Tia Jaci: tia Jaci era irmã de D. Edwirges. Construiu sua moradia dentro do barranco que passou a ser chamado de Caverna. Localizada junto ao Capão do Vela. Tia Jaci era uma negra que vivia como índia no meio do mato e cultivava frutos e ervas.

10. Casa dos Pretos Velhos: lugar de culto aos Orixás e aos 
Caboclos. A gruta dos Pretos Velhos foi construída sobre uma grande rocha próxima ao núcleo familiar da maior parte dos moradores da comunidade quilombola. brincadeiras.

11. Campinho: espaço utilizado para atividades de lazer e

12. Figueira: ponto de visitação e lazer para várias gerações de vários lugares do bairro. Era muito comum ocorrerem piqueniques neste local, que também é de culto de vários tipos de obrigações religiosas.

13. Terreiro Centro Africano do Reino de Oxum: é a principal casa de religião da comunidade. Regida pelo Babalorixá Pai Milton de Oxum, cultua a nação Jejé com Ijexá, conhecida por operar com o cruzamento entre duas nações, e caracterizando-se por ser um batuque de Linha Cruzada.

14. Capão do Vela: companheiro da tia Jaci, vivia numa casa no capão. Sobrevivia das frutas do mato, pescava, trabalhava com carroça.

15. Laguinbo: chamada de Baliza, é um ponto de lazer utilizado pela comunidade quilombola. Local cultuado e, ao seu arredor, matas, pedras e águas para as obrigações religiosas doces.

16. Horta: local de plantio de ervas medicinais e aromáticas para uso na culinária e nas festas religiosas.

\section{Percursos e trilhas}

Os percursos que identificam as trilhas são baseados na trajetória de vida dos moradores do Quilombo dos Alpes ao longo dos séculos XX e XXI. Representam os valores afro-civilizatórios da geografia histórica do nosso país. Estão situados no mapa os marcadores sagrados que foram relacionados às orientações educativas do projeto $A$ cor da Cultura, de Azoilda da Trindade.

Percurso da religiosidade: o percurso da religiosidade engloba as trilhas da pedreira, figueira, laguinho, casa dos pretos 
Cláudia Pires; Daiane Ellias; Karina da Silva Ellias; Lara Bitencourt; Marilia Rathmann; Mateus Viegas; Matheus Penha; Rosângela da Silva Ellias \& Winnie Dobal

velhos e o terreiro Centro Africano do Reino de Oxum. Esses caminhos fazem parte dos lugares sagrados para a comunidade e é onde são homenageadas as entidades Xangô, Xapanã, Oxum e os Pretos Velhos (Figura 6).

Figura 6: Casa dos Pretos Velhos.

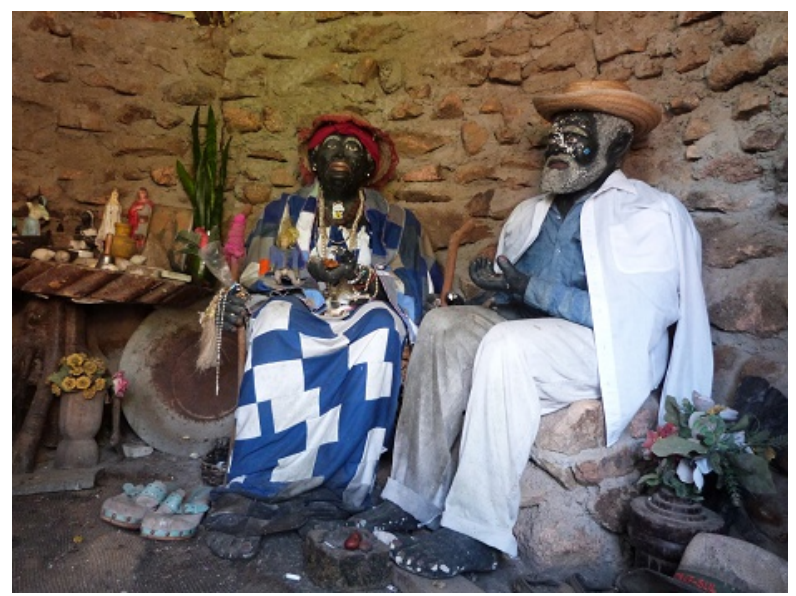

Fonte: Arquivos do NEGA /UFRGS - 2013

Percurso da ancestralidade e memória: encontramos nesse percurso o início da história do Quilombo dos Alpes. É onde está a primeira morada de D. Edwirges, também chamada de Capão da Vó (Figura 7). A trilha das ervas remete aos saberes e fazeres religiosos, medicinais e culinários transmitidos de geração para geração.

Figura 7: Vista parcial do Quilombo dos Alpes. Ao fundo, observamos o Capão da Vó.

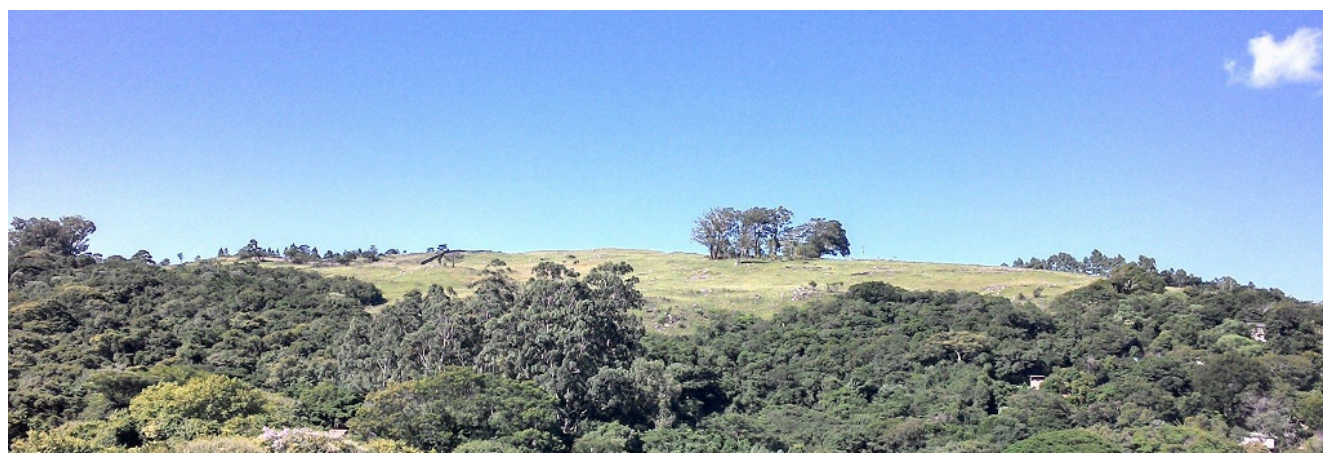

Fonte: Arquivos do NEGA /UFRGS - 2013 
Percurso da oralidade e ludicidade: estas trilhas (Capão do Vela, Matinho do Tio Vilson e Trilha do Mato) (Figura 8) estão associadas aos saberes e fazeres compartilhados e transmitidos oralmente que envolvem os conhecimentos acerca das ervas e da lida com a natureza. O lúdico também está associado aos caminhos dos jogos e às brincadeiras das crianças do quilombo nestas trilhas.

Figura 8: Capões no Quilombo dos Alpes.

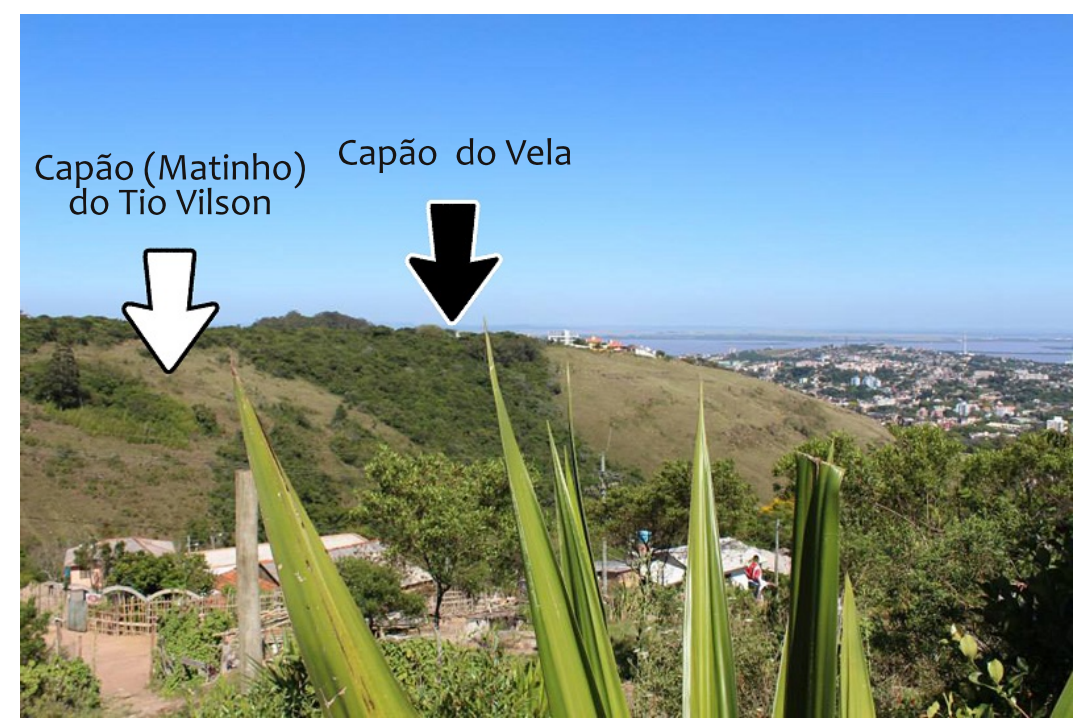

Fonte: Arquivos do NEGA /UFRGS - 2014

Percurso da musicalidade, circularidade, corporeidade e cooperativismo: este percurso começa na sede da associação, local em que são realizadas diversas atividades artísticas, religiosas e culturais. Engloba, também, a trilha da horta e do pomar, criadas e mantidas pelos quilombolas. A trilha do campinho refere-se ao lugar de jogos e brincadeiras de diferentes gerações. Representa memórias, rodas de conversa e festividades, o corpo individual/coletivo, construído em cooperação e seus ritmos. A Figura 9 expressa um desses momentos de atividades culturais. 
Cláudia Pires; Daiane Ellias; Karina da Silva Ellias; Lara Bitencourt; Marilia Rathmann; Mateus Viegas; Matheus Penha; Rosângela da Silva Ellias \& Winnie Dobal

Figura 9: Atividades culturais presentes na Associação do Quilombo dos Alpes.

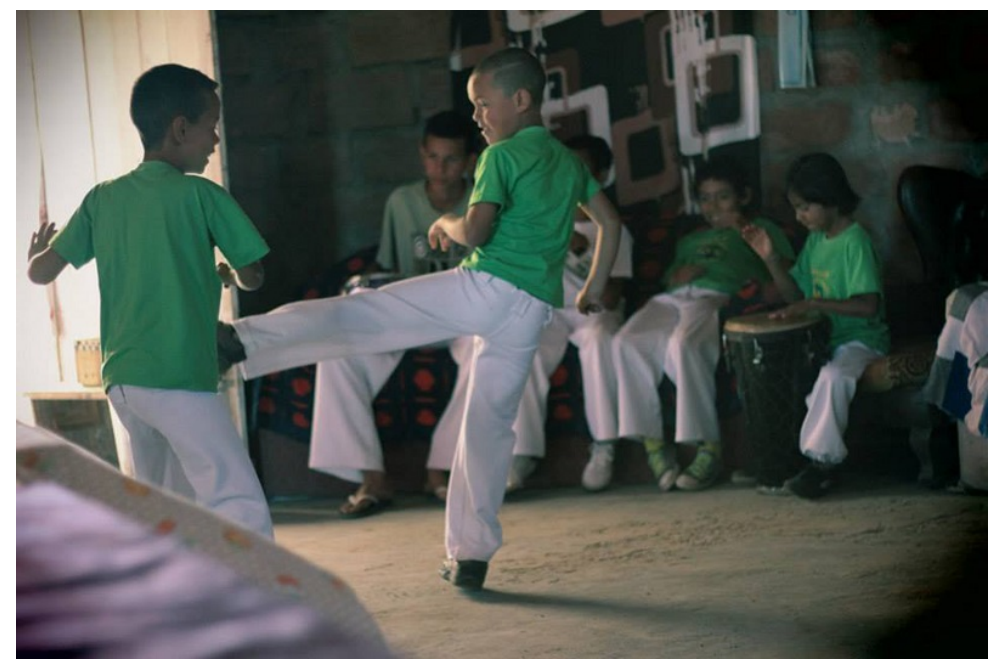

Fonte: Arquivos do NEGA /UFRGS - 2014

Dentro do grupo de trabalho, foi possível identificar nos marcadores e percursos correlações com os valores afro-civilizatórios propostos no caderno A Cor da Cultura, de Azoilda Trindade. Esse entrelaçamento deu ao mapa uma orientação para a educação antirracista, como proposto nas Leis 10.639/03 e 11.645/08, as quais constituem a obrigatoriedade da temática da história e da cultura afro-brasileira e indígena na educação.

A metodologia usada na elaboração do mapa foi a da pesquisa participante, estratégia da pesquisa social que mantém uma ampla relação entre os pesquisadores e as pessoas que se encontram na situação investigada. O grupo realizou diversos trabalhos de campo na comunidade a fim de encontrar marcadores territoriais, presentes na fala dos moradores do quilombo, que ligam o território à sua condição simbólica. Essas ações, juntamente com o estudo de documentos guardados pela Associação Quilombo dos Alpes Dona Edwirges, serviram como base para o trabalho de destacar esses marcadores, que foram selecionados pela própria comunidade por possuírem uma profunda significância histórica e de resistência. Depois de sistematizadas as informações e descrições obtidas pela 
pesquisa e selecionados os marcadores e trilhas que seriam apresentados no mapa em reunião com os quilombolas, o grupo utilizou um software de SIG (Sistema de Informações Geográficas) para criar um banco de dados com as informações e imagens de satélite do território. O programa escolhido foi o Quantum GIS, por ser um software livre, por ser de fácil uso e por possuir suporte para diversas funções de geoprocessamento diferentes. A localização dos marcadores territoriais e das trilhas foi sobreposta a uma imagem de satélite do Google com o território do quilombo já demarcado pelo INCRA/RS (2015) e com as ilustrações feitas pelo grupo, para melhor caracterizar cada marca.

Os quilombolas desenvolvem formas de ocupação diferenciada ao valorizarem em suas práticas os ensinamentos oriundos do conhecimento e pertencimento à natureza, os quais são transmitidos de geração para geração e representam uma forma de resistência ao sistema político e econômico que banaliza os lugares e os sujeitos. As estruturas sociais pelas quais estão amparadas comunidades como a do Quilombo dos Alpes fazem parte de um sistema de organização opressivo e paralisante, reflexo de uma violenta desigualdade econômica oriunda de um passado e de um presente de exploração da mão de obra dos sujeitos às margens do sistema de produção colonialista, baseado em pilares como o consumismo e a obsolescência programada.

Uma comunidade que tem como cultura valorizar e preservar o passado, lutando no presente para melhorar o futuro, a partir do autorreconhecimento e da autorrepresentação, expressa uma ameaça ao conservador sistema de manutenção do pobre e do negro às margens do fazer político, bem como representa uma esperança a todos os povos e comunidades quilombolas.

Dentro da perspectiva do mapeamento participativo, destacamos mais uma vez o protagonismo das mulheres quilombolas neste processo. As mulheres estão concomitantemente nos espaços de decisão, na manutenção da comunidade, à frente das conquistas históricas em seu território, mas ainda assim não estão isentas das violências dirigidas às mulheres dentro do contexto social 
Cláudia Pires; Daiane Ellias; Karina da Silva Ellias; Lara Bitencourt; Marilia Rathmann; Mateus Viegas; Matheus Penha; Rosângela da Silva Ellias \& Winnie Dobal

predominantemente machista e patriarcal em que vivemos. Desta forma, ao cartografarem seu território e se autorrepresentarem, vemos surgir um duplo tensionamento nos limites de compatibilidade impostos.

\section{Por que paisagem, corpo e memória}

A paisagem para nós, como todos falam, no olhar imobiliário, é muito rica. Aqui, o espaço é muito cobiçado, e pra nós, nossa maior riqueza é esses verdes, os capão, isso e nosso. Para nós é uma riqueza que não tem valor, em dinheiro, é em memória, é em convivo. Sinceramente, se concretasse tudo aqui, tirasse os capões... a gente ia procurar outro mato pra morar. Gostamos de estar juntos, meus manos não iam se adaptar. Quando a gente foi viajar e conhecer outras comunidades, tem algumas que até me senti em casa. No meio do mato, no meio do morro, no meio das pedras. Bem idêntica. E aqui a gente toma todo um cuidado, além de ter áreas pico de morro e áreas de preservação que não pode mexer. A gente mesmo preserva e não queremos que mexam.

Depois que a gente se autorreconheceu, a gente conseguiu resgatar isso, saber da onde ela (a Vó) tinha vindo, de repente até veio de outro lugar, mas quando veio pra cá, veio desse lugar, Charqueadas. Charqueadas, foi um lugar onde os negros viviam, como se diz: um centro de concentração ali, né. Aonde se concentravam todos pra depois serem distribuídos para outras regiôes, né. E com reconhecimento da gente em se autorreconhecer como quilombola, isso pra nós foi muito bom. Foi saber de onde ela veio. Quando ela chegou cá, né, ela chegou aqui no século XIX, XX. Quando ela chegou aqui nos Alpes não tinha morador, não tinha nada, só mato e campo. Se instalou lá perto da sede, a primeira estadia da sede ali, fez o caminho, com fillhos, ela mesma fez o quarto dela. E depois mais adiante vai chegando mais moradores, aqui mesmo vai sair a rua, aqui era só uma trilha, a gente via só carroça, só cavalo. Pessoal descia a pé, só lá embaixo, na faixa, na rua da Oscar Pereira era onde passava o bonde. Tinha as trilhas do bonde, a vó falava muito. E então a chegada dela cá, desbravou, foi a primeira, ela mesmo sempre fala da chegada dela. E tem outros relatos, também, de outros moradores antigos, que faleceram, que deixaram os relatos deles lá, contando que quando chegaram cá, a Vó já tava aqui: "só morava uma velhinha”. E aqui sobreviveu, resistiu, existiu na área aqui por 117 anos. Foi falecer só de velhice mesmo. 
E para as pesşoas que tão olhando, que olhem com carinho, que é uma coisa bem pura, verdadeira. As coisas que estão aí, que é dito pela Vó mesmo, que a gente vai olhar são coisas bem pura quando eu digo isso, é sem malícia, sem maldade, e acho que é isso que identifica a nós, a, família aqui e alguns dos parentes que têm consciência assim. É esse jeito de ser, a gente é bem simples, bem humilde. Com todo o trabalho e sofrimento que já passamos. Mas a gente não deixa de ser essas pessoas que somos. Até tentamos, mas não conseguimos. As vezes, a Karina e a minha filha aqui a Daiane dizem, "mãe, tem que mudar, a gente vai ter que mudar", mas não adianta, a gente não consegue. Então acho que é isso também que identifica nós, é o que a Vó deixou pra nós, deixou pra mãe, a mãe passou pra nos, nós passamos para os nossos filhos e nossos filhos para os nossos netos. Por mais que as perdas que tivemos fossem bem duras por conta do reconhecimento, a gente achou que ia se endurecer, se fechar. Inclusive até nos fechamos, mas não adiantou, tivemos que voltar ao normal de novo. Se a gente tem, a gente divide. Eu acho que é isso que faz, que torna não só a nossa comunidade aqui mas também as outras comunidades. Então a gente está aí, botando na cabeça deles, ensinando os nossos costumes, tentando passar pra eles, "não, isso é coisa das antigas". Então é isso e a mensagem é essa para deixar para o pessoal! (Janja, filha de Dona Jane, neta de D. Edwirges, quilombola).

Representar é pertencimento. Pertencimento é uso e ocupação, que é espaço. É também território, conflito, disputa de terra e de fronteiras (domínio). É lugar, onde permanecemos e vivemos com colaboração, solidariedade, trocas e convivência. Saber situar-se, localizar-se é estratégico para viver, para morrer, para se movimentar e também resistir. É corpo. E tudo isso é quilombo, tudo isso é presente e é memória, está registrado no corpo, está grafado no espaço, está marcado na paisagem do Morro dos Alpes. Estas são algumas reflexões a partir desse grupo de trabalho (Figura 10). 
Cláudia Pires; Daiane Ellias; Karina da Silva Ellias; Lara Bitencourt; Marilia Rathmann; Mateus Viegas; Matheus Penha; Rosângela da Silva Ellias \& Winnie Dobal

Figura 10: $O$ grupo de trabalho.

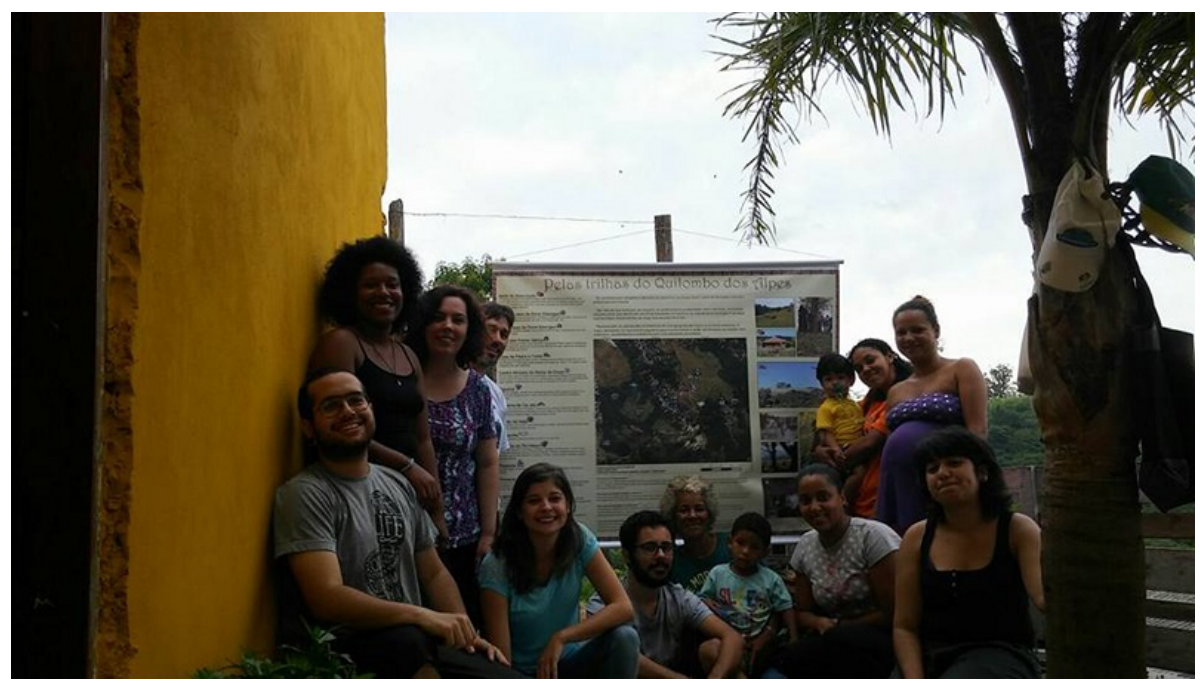

Fonte: Arquivos do NEGA /UFRGS - 2015

\section{Referências}

BRASIL. Ministério do Desenvolvimento Agrário. Instituto Nacional de Colonização e Reforma Agrária (INCRA). Portaria n. 173, de 19 de abril de 2016.

BRASIL. Lei $\mathrm{n}^{\circ} 10.639$, de 9 de janeiro de 2003, estabelece as diretrizes e bases da educação nacional, para incluir no currículo oficial da rede de ensino a obrigatoriedade da temática "História e Cultura AfroBrasileira", e dá outras providências.

BRASIL. Lei 11.645 de 10 de março de 2008, estabelece as diretrizes e bases da educação nacional, para incluir no currículo oficial da rede de ensino, a obrigatoriedade da temática "História e Cultura AfroBrasileira e Indígena" nos estabelecimentos de ensino fundamental e de ensino médio, públicos e privados.

DARDEL, E. O Homem e a Terra: A natureza da realidade geográfica. Tradução Werther Holzer. São Paulo: Perspectiva, 2011.

DOBAL, W. L. M. Narrativas espaciais do Quilombo dos Alpes/Porto Alegre/RS: Instrumento de encrespamento do ensino de Geografia, na busca de uma educação territorial antirracista. (Monografia) UFRGS, Porto Alegre, 2015. 
FANON, F. Pele negra, máscaras brancas. Tradução de Renato da Silveira. Salvador: EDUFBA, 2008.

GEHLEN, I. (Coord.). Relatório Sócio, Histórico e Antropológico da Comunidade Quilombola dos Alpes - Porto Alegre/RS. Porto Alegre: UFRGS/ Instituto de Filosofia e Ciências Humanas/ Laboratório de Observação Social, 2007.

PIRES, C. et al. A relação entre pesquisa, ensino e "extensão": possibilidades que se articulam com o espaço e a multidimensionalidade do que é fazer pedagógico na Geografia. In: SUERTEGARAY, D. M. A.; PIRES, C. L. Z.; OLIVEIRA, M. G. (Org.). Geografia e Ambiente. Porto Alegre: Imprensa Livre e Compasso Lugar - Cultura, 2015, v. 1, p. 118-138.

SANTOS, M. Por uma geografia cidadã: por uma epistemologia da existência. Boletim Gaúcho de Geografia, n. 21, agosto de 1996.

SILVA, A. C. Imaginários urbanos. São Paulo: Perspectiva, 2001. 



\section{Ribeirinhos, Organizações Comunitárias e Alimentação: Flona de Tefé/AM, Brasil}

\section{Cleder Fontana}

Cristiano Quaresma de Paula

Dirce Maria Antunes Suertegaray 


\section{Introdução}

A proposta deste capítulo é falar de corpo, paisagem e memória. 1 Abordaremos o corpo a partir de uma das necessidades fundamentais de homens e mulheres - a alimentação. Abordamos o corpo biológico e o corpo social envolvidos numa paisagem com características peculiares (Amazônia) resgatada por meio da memória ou oralidade dos ribeirinhos. Ao final abordamos corpo como corpo social, revelado na organização comunitária.

Por um lado, o texto toma como referência as condições alimentares da população ribeirinha da Floresta Nacional de Tefé, estado do Amazonas, Brasil. E, por outro, as organizações comunitárias e os direitos adquiridos, por meio de lutas sociais, no âmbito das comunidades tradicionais. Este corpo social, que pode ser compreendido enquanto comunidade, se expressa na relação diferenciada estabelecida com a natureza, que produz paisagens congruentes com o modo de viver ribeirinho.

Partimos da análise da base alimentar dos ribeirinhos, suas necessidades alimentares, suas formas de supri-las, os caminhos percorridos, os conflitos e as formas organizativas para sua superação. Propomos analisar as preocupações e estratégias adotadas pela população na obtenção das necessidades alimentares. Assim, pela observação da alimentação, buscamos compreender: o uso de produtos locais possibilitados pela floresta amazônica, bem como a disponibilidade de recursos econômicos para compra de mantimentos; as relações cotidianas de compartilhamento e trocas que atenuam as dificuldades de fazer frente ao mínimo desejado e/ou necessário; e as relações entre a alimentação, as estratégias para suprir as necessidades e as condições naturais locais.

Neste sentido, buscamos estabelecer uma compreensão sobre o sujeito (coletivo) ribeirinho, destacando o processo de união dos povos da floresta para garantir sua permanência em contexto de criação de unidade de conservação e a manutenção dos seus modos de viver. Um dos argumentos que fundamentam esta luta é a 
expressão da paisagem comunitária, a qual parece se reproduzir de uma forma mais "harmoniosa" com a natureza, seus ciclos e capacidade de resiliência. Assim, a paisagem da comunidade expõe marcas, que são próprias desta matriz ou modo de viver ribeirinho.

Os povos da Amazônia - "Povos das Águas" - integram em suas vidas a floresta e os rios. Estabelecem trocas entre comunidades vizinhas e com centros urbanos próximos. Sustentam a condição de um modo de viver designado como comunidades tradicionais, mas que, na relação social, econômica, tecnológica, política e ambiental vivida pelo país, não podem ser consideradas paradas no tempo. Muitas práticas associadas aos saberes e fazeres dos povos da Amazônia estão sendo integradas em novas políticas territoriais. Contudo, quando as políticas não reconhecem os saberes tradicionais, não são aceitas pelas comunidades.

Paisagem neste texto é entendida como materialidade (formas ou marcas presentes no espaço habitado) e, ao mesmo tempo, processo enquanto expressão de uma dinâmica no tempo, ou o que também se denomina matriz na perspectiva de Berque (1998), e que constitui um modo de viver.

Os sujeitos desta pesquisa são populações que vivem no estado do Amazonas e que são reconhecidos, na região Norte do Brasil, como ribeirinhos. Eles vivem à beira de rios, lagos, igarapés e à beira do mar (DIEGUES, 2007). A dependência do mundo natural, de seus ciclos e de seus produtos é fundamental para a produção e reprodução do seu modo de vida. Ao se autodeterminarem assim, os ribeirinhos são contemplados em políticas públicas para povos tradicionais (DE PAULA et al., 2016)

No estado do Amazonas, são moradores, mais especificamente, da FLONA de Tefé (Floresta Nacional de Tefé) e entorno. A denominação FLONA resulta da sistematização de Unidades de Conservação (UCs) presentes na Lei n. 9.985, de 18 de julho de 2000. Trata-se do Sistema Nacional de Unidades de Conservação (SNUC), elaborado pelo Estado brasileiro para fins de gestão das unidades de conservação em território nacional. 
No SNUC, uma Floresta Nacional é definida como: "uma área com cobertura florestal de espécies predominantemente nativas e tem como objetivo básico o uso múltiplo sustentável dos recursos florestais e a pesquisa científica, com ênfase em métodos para exploração sustentável de florestas nativas” (artigo 17).

Pires et al. comentam sobre as FLONAS:

As FLONAS são criadas visando estabelecer um manejo múltiplo e sustentável dos recursos florestais praticados atravẹ́s de técnicas de prọdução, para utilização, especialmente, de produtos vegetais, como os do extrativismo. Além disto, em uma FLONA, são permitidos: a pesquisa científica, ações de educação ambiental e atividades de lazer. O manejo deve, também, ajudar a recuperar áreas degradadas - como regiões desmatadas ou rios poluídos - e a preservar a diversidade biológica - dos animais e das plantas -, além de garantir o controle ambiental das áreas vizinhas da unidade. (PIRES et al., 2016)

As transformações desta paisagem, sejam decorrentes de sua dinâmica própria sejam decorrentes de intervenções externas, em particular o processo de construção do Plano de Manejo pelos gestores da FLONA, ICMBio - Tefé, promoveram a possibilidade de os ribeirinhos, que desde os anos 1960/1970 do século XX tinham se organizado em comunidades, estimularem-se para novas formas de organização social, objetivando a melhoria de suas condições alimentares e, por extensão, do seu modo de viver.

Expressamos aqui parte de um processo de pesquisa mais amplo e fazemos isso por meio de duas expedições de campo organizadas pelo Núcleo de Estudos Geografia e Ambiente (NEGA), no projeto Mapeamento Participativo em Comunidades da FLONA de Tefé (2012-2013). Essas expedições foram realizadas em comunidades ribeirinhas com vistas à construção do Plano de Manejo pelos gestores da FLONA de Tefé, necessário em unidades de conservação no Brasil e devendo ser elaborado em conjunto com as comunidades locais.

Portanto, este texto expressa uma análise produzida a partir da interconexão entre três dimensões: corpo, paisagem e organização 
social. Quando falamos de corpo, estamos nos referindo ao corpo biológico, à sua necessidade alimentar e à organização para suprir tal necessidade. Ao tratar da paisagem, buscamos estabelecer uma conexão entre a constituição histórica do grupo representado nesta narrativa e sua originária relação com a paisagem e sua dinâmica. É essa paisagem que lhes permite uma alimentação singular, herdada e que persiste apesar das transformações.

\section{Diálogo de saberes e grupos focais}

Os trabalhos de campo deram-se em duas expedições em que se estabeleceram diálogos com os comunitários para entender seus mundos da vida, ou seja, os aspectos normativos, objetivos e subjetivos intrínsecos às suas falas (HABERMAS, 2012). Além disso, foram realizadas entrevistas a fim de compreender os hábitos e as estratégias para suprir as necessidades alimentares.

Na primeira expedição, no mês de abril de 2012, durante 10 dias, tivemos a oportunidade de observar e questionar os ribeirinhos sobre a alimentação praticada e de dialogar sobre as formas de organizações comunitárias. Quanto à alimentação, decorreu um levantamento de hábitos alimentares, da forma como logram as necessidades e de possíveis ocorrências de demandas não suprimidas.

$\mathrm{Na}$ segunda expedição, no mês de agosto de 2012, durante 10 dias, além de ser feito o mesmo procedimento realizado anteriormente, conduziram-se entrevistas semiestruturadas em grupos focais. As entrevistas e diálogos realizados privilegiaram a memória, sejam as mais longínquas, as mais recentes, as individuais e as coletivas, pois, conforme Chauí (1999, p.31), ao escrever sobre o livro Memória e sociedade: Lembranças de velhos, de Ecléa Bosi: “o modo de lembrar é individual tanto quanto social: o grupo transmite, retém e reforça as lembranças, mas o recordador, ao trabalhá-las, vai paulatinamente individualizando a memória comunitária”. 
$\mathrm{Na}$ compreensão dos hábitos alimentares, como recorte optamos por entrevistar mulheres, as responsáveis pela elaboração e preparo das refeições em seus respectivos domicílios. Com esse procedimento foram realizadas sete entrevistas em grupos focais, totalizando 31 participantes. Com o mesmo roteiro, abriu-se uma exceção ao serem entrevistados dois homens. Desta maneira, como forma de fazer, na tentativa de analisar e compreender um contexto social, a exposição associa-se à pesquisa qualitativa.

As entrevistas em grupo, pela sua dinâmica de falas que podem ser abreviadas ou complementadas por quaisquer das participantes, permitem que, no conjunto, as falas revelem com mais clareza a memória coletiva. Uma vez que todas as participantes são parte do que está sendo "buscado" nas memórias, elas se sentem à vontade para complementar ou detalhar algo. Além disso, a memória dos mais velhos, que no caso estudado remete a vivências de outros locais, consolida o presente com o passado, revelando um modo de se alimentar (e de viver) que conecta o individual e o coletivo com uma condição natural, resultando em uma paisagem, a ribeirinha.

Para compreender a realização do corpo social, ou seja, as organizações comunitárias e conquistas políticas das comunidades tradicionais, a pesquisa empírica está inserida no âmbito dos diálogos de saberes. Podemos entender os diálogos de saberes enquanto espaço de sinergias e complementaridades entre os saberes existentes a respeito do mundo atual e a realidade presente. Ainda há a produção de novas formas de compreensão do mundo que surgem do intercâmbio dialógico de saberes e da disputa de sentidos da sustentabilidade, da reapropriação social da natureza e da cultura (LEFF, 2006, p. 387-390).

A partir do agir comunicativo se estabelece um processo de redefinição continuada, o qual promove a subordinação de certos conteúdos a determinados mundos, de acordo com o que é tido, respectivamente, como válido: como integrante do mundo objetivo, interpretado consensualmente; como componente normativo do mundo social, reconhecido intersubjetivamente; como componente 
privado do mundo subjetivo, ao qual se tem acesso privilegiado. Assim, a cada definição comum da situação, os sujeitos determinam os limites entre a natureza exterior, a sociedade e a natureza interior, em um processo de renovação das diferenças entre eles, na qualidade de intérpretes que se posicionam perante o "mundo exterior e seus respectivos mundos interiores" (HABERMAS, 2012, p. 223). Assim, os resultados que apresentamos como resultantes dos diálogos de saberes entre geógrafos e comunidades ribeirinhas se dão a partir da intersecção desses mundos da vida.

Mais especificamente, o que aqui é apresentado resulta, por um lado, do que se denominou, de acordo com Leff (2006), diálogo de saberes e, por outro, do resgate da história e constituição de seu modo de viver a partir da história oral. $\mathrm{O}$ diálogo de saberes ao qual nos referimos diz respeito à conexão, por meio de trabalho em campo, do conhecimento dos ribeirinhos ou comunitários, dos pesquisadores da Universidade Federal do Rio Grande do Sul/Brasil e dos gestores da FLONA de Tefé. Deste trabalho resultou um conhecimento partilhado entre todos, cujo produto consistiu na sistematização do modo de viver e no mapeamento do Uso da Terra da FLONA de Tefé, material que deu suporte a gestão participativa.

\section{A FLONA de Tefé e seus moradores}

As comunidades da FLONA de Tefé são constituídas de pessoas que se autodenominam ribeirinhos, e sua origem étnica é constituída de indígenas, afrodescendentes e migrantes nordestinos provenientes, principalmente, do Ceará, os quais se deslocaram para o Amazonas no período da exploração da borracha (1890 e 1910). Na década de 1940, eram conhecidos como "soldados da borracha", ou seja, os seringueiros, aqueles que desbravaram a mata equatorial para extrair látex no período do auge da exploração deste produto extrativista no Brasil. $\mathrm{Na}$ região da FLONA de Tefé, eles constituíram família, vivendo em comunidades cuja origem data dos anos 1960/1970, em decorrência da forte ação da Igreja Católica por 
meio das CEBs (Comunidades Eclesiais de Base). Antes dos anos 1960, os seringueiros viviam (após o declínio da exploração da borracha), isoladamente, no interior da floresta.

Atualmente, estes ribeirinhos vivem em comunidades ou localidades ao longo dos rios que drenam a área da FLONA de Tefé (Figura 1). Os principais rios são o Tefé, o Bauana, o Curumitá de Baixo e o Andirá.

Figura 1: Localização da FLONA de Tefé.
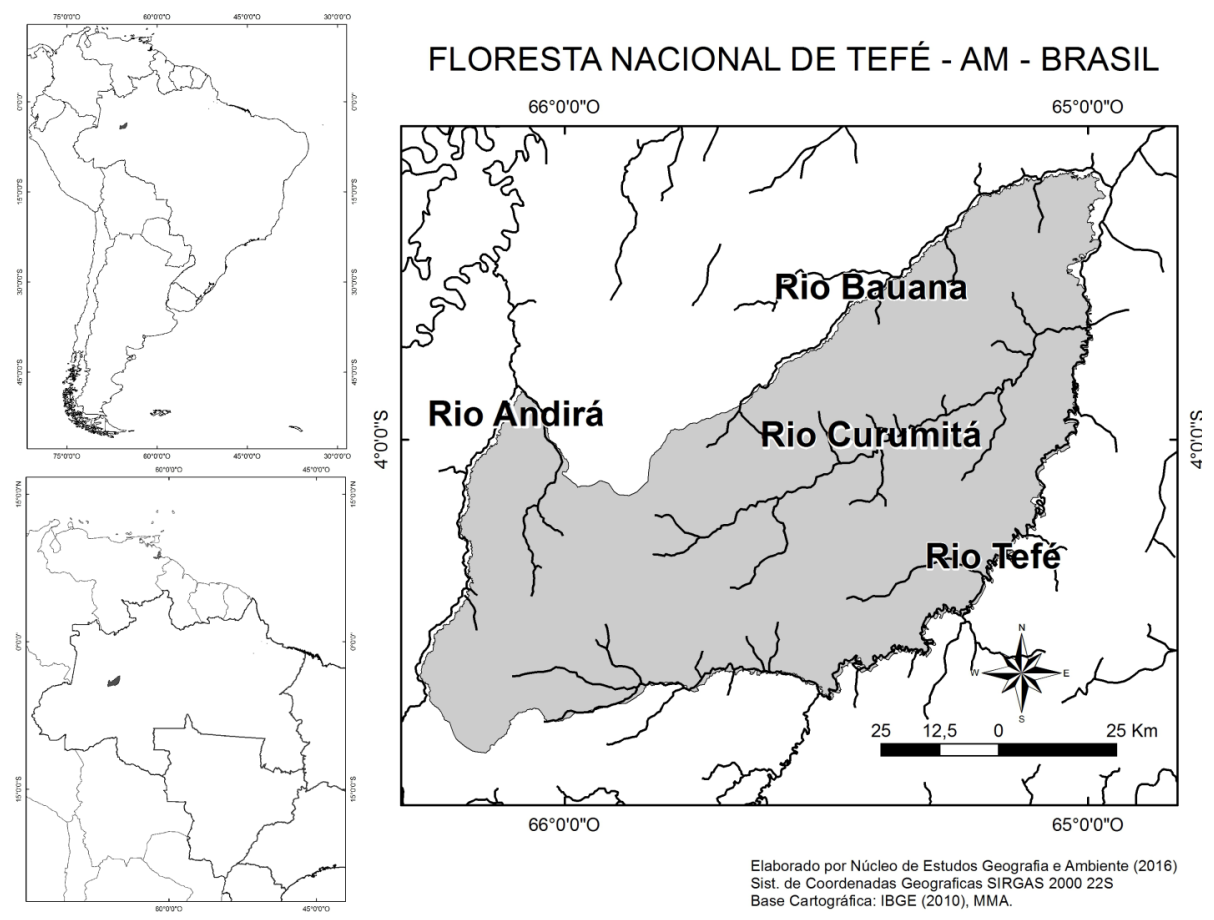

Fonte: Arquivos do NEGA /UFRGS - 2016

O rio Tefé é o maior rio da FLONA, com $226 \mathrm{~km}$ de percurso no interior da FLONA, constituindo seu limite leste. É um dos rios mais navegados, sendo utilizado tanto por pequenas embarcações quanto por barcos de médio e grande porte. Suas nascentes localizam-se fora da unidade de conservação, e sua foz localiza-se no lago Tefé. 
O rio Bauana, limite norte da FLONA, é ocupado por aproximadamente 23 comunidades e localidades, estando elas mais concentradas próximo ao lago Tefé. A várzea do rio Bauana, um rio de águas pretas, é muito utilizada para a extração de materiais para artesanato, como os cipós e as talas. Também se extrai daí alimentos para consumo, como o açaí. Esta atividade desenvolve-se até o repartimento do rio, ou seja, onde o rio Bauana Branco encontra o rio Bauana (OLIVEIRA et al., 2016).

O rio Curumitá de Baixo limita os municípios de Tefé e Alvarães, drena a área central da FLONA e deságua no lago Tefé. É o rio mais densamente povoado da FLONA, possuindo aproximadamente 24 comunidades e localidades. Além de ser usado para pesca, sua várzea é aproveitada para atividades de extrativismo até o repartimento do Curumitá de Baixo com seu afluente igarapé Cachorra.

Localizado no extremo oeste da FLONA, o rio Andirá pode ser considerado o de mais difícil acesso dentre os cursos d'água da unidade de conservação. Em suas proximidades, existem apenas duas localidades no interior da FLONA, sendo elas: São Francisco do Marabaia e São José do Andirá.

\section{A paisagem e o modo de viver}

A paisagem de vivências desses povos, a Amazônia, apresenta-se constituída pela forte interação entre a floresta e a abundância de água sob condições de clima Equatorial (quente e úmido).

Os ribeirinhos vivem em área de floresta (Amazonas), e seus cotidianos são regulados pelo ciclo das chuvas (Figura 2), das quais dependem as cheias e vazantes nos rios. A seca é o período do ano em que as chuvas são escassas ou eventuais, promovendo a vazante processo em que baixam as águas dos rios e lagos. Os rios são as vias de deslocamento - por meio de barcos, voadeiras, canoasrabetas e montarias. No período das cheias, os deslocamentos para 
outras localidades, comunidades ou cidades são mais fáceis. Durante a seca, o deslocamento é mais difícil, entretanto é um período mais fácil para a pesca (OLIVEIRA et al., 2016).

Figura 2: (a) cheia e (b) seca. Meses de março e agosto respectivamente.
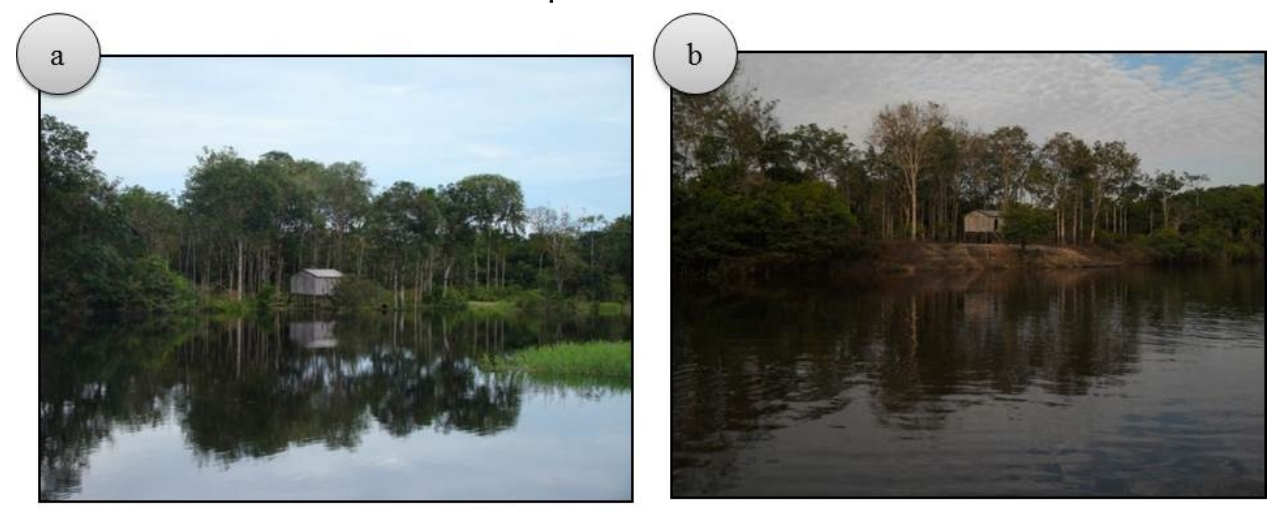

Foto: Dirce Suertegaray; Cleder Fontana - 2012.

O período da cheia começa no mês de outubro e vai aproximadamente até o mês de abril. Nestes meses há um aumento na quantidade de água, que pode ser visto no reaparecimento de muitas ressacas e igarapés que se encontravam secos na estação anterior. Isso permite que as comunidades mais afastadas tenham acesso fluvial a lugares que antes ficavam isoladas, como as comunidades vizinhas e a cidade de Tefé, onde é possível vender e comprar nas feiras.

A partir da metade de maio até o fim de setembro, a temperatura média tende a ser um pouco mais baixa que nos outros meses (OLIVEIRA et al., 2016). No período da cheia, há maior dificuldade para a pesca, devido à dispersão dos cardumes ao longo dos rios caudalosos e lagos.

O período de seca inicia, aproximadamente, no mês de maio e se estende até o mês de setembro, quando reduzem as chuvas e o nível dos rios começa a baixar rapidamente. Esse é o melhor período para pesca, pois os peixes ficam confinados em igarapés e lagos cada vez menores (OLIVEIRA et al., 2016). Em síntese: 
A água é um dos elementos principais na existência dos povos indigenas e comunidades tradicionais. Os períodos de cheias e secas regulam a vida dos ribeirinhos, uma vez que esse ciclo sazonal influencia as atividades de extrativismo vegetal, agriculta e pesca. Logo, cabe entender o ribeirinho como pessoa que realiza muitas atividades. Observa-se que quando começa a cheia torna-se difícil fazer roça, e mesmo a pesca e a caça de subsistência ficam mais restritas e, nesse sentido, a vida social é dificultada (DIEGUES, 2007). Na FLONA de Tefé, as comunidades se localizam em sua maioria em Terra Firme, assim, só em períodos de cheias extremas tem 'seus roçados inundados. (DE PAULA et al., 2016)

A atividade dos ribeirinhos está centrada na subsistência da mandioca e seus derivados, como tapioca, goma, tucupi, farinha branca e amarela, pé de moleque, beiju, bolo e soro, que juntamente com o peixe é o principal alimento. Esta atividade materializa-se na existência comum, nas comunidades, da casa de farinha (Figura 3) (SUERTEGARAY, et al., 2016).

Figura 3: Casa de Farinha.

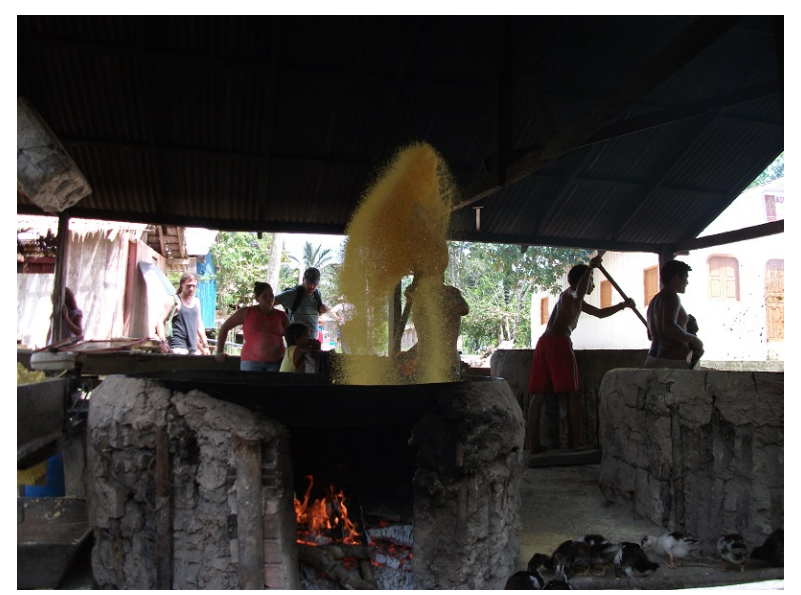

Foto: Dirce Suertegaray - 2012.

O roçado é a denominação da atividade de plantio. Caracteriza-se como agricultura de subsistência. No roçado é produzido, além da mandioca branca (macaxeira), destinada para alimentação, e da mandioca amarela, para produção de farinha e principal fonte de renda local, açaí, banana, cupuaçu, manga, abacate e tucumã, cana-de-açúcar, abacaxi, pupunha, cará, melancia, milho, 
jerimum (abóbora), feijão, pepino, maxixe, melão, batata, castanha (SUERTEGARAY et al., 2016).

A pesca (Figura 4) ocorre o ano todo, sendo que o período mais piscoso, ou seja, com mais fartura de peixes, é o período da seca, em decorrência da concentração dos peixes nos lagos e rios que se tornam menos caudalosos, isto é, com menos volume de água. Os peixes mais comuns são: aracu, jaraqui, matrinxan, sardinha, caparari, surubim, pirapitinga, tambaqui, pirarucu e bodó.

Figura 4: Pesca artesanal no lago Tefé.

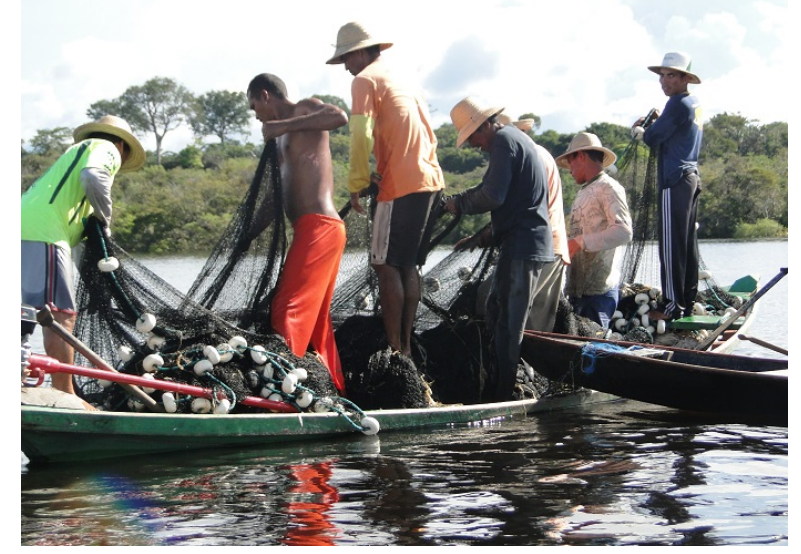

Foto: Dirce Suertegaray - 2012.

A produção alimentar, o extrativismo e a pesca são reveladores do modo de viver e das condições alimentares dos ribeirinhos. Diante disso, o cotidiano dessas pessoas expressa-se numa dinâmica que envolve essas três atividades como centrais acrescidas da fabricação da farinha e mais, no caso das mulheres, do cuidado dos filhos e da casa (SUERTEGARAY et al., 2016).

$O$ ribeirinho tem um conhecimento e um vínculo efetivo com a natureza, registrados pela lógica da produção em associação com os recursos obtidos da floresta e das águas, seja em relação ao alimento, seja em relação aos objetos produzidos para o desenvolvimento das atividades. Esses objetos são construídos a partir dos recursos locais, a exemplo do paneiro, do tipiti, da prensa, da emboladeira, da peneira, da masseira e do tarubá (remo), 
todos objetos símbolos da produção de mandioca, bem como os caniços da pesca, ou mesmo as canoas e outros utensílios (SUERTEGARAY et al., 2016).

Esta realidade, por sua vez, vem lentamente se transformando, ocorrendo a substituição dos objetos técnicos utilizados. Por exemplo, o uso da voadeira, um barco de alumínio, com motor de popa, mais rápido que a canoa, com motor rabeta.

Essa transformação manifesta-se, igualmente, na mudança dos hábitos alimentares, favorecidos pelas políticas sociais que permitem ao ribeirinho acesso a outros bens, como alimentos industrializados, vestuários e equipamentos eletrônicos (máquinas fotográficas, celulares e, mais restritamente, computadores) (SUERTEGARAY et al., 2016).

Esta transformação não é ampla. Por isso, persiste entre os ribeirinhos uma maneira de viver centrada nas relações comunitárias, no trabalho coletivo - por exemplo, quando da produção da farinha, em especial da torra, o caso mais emblemático - ou ainda no hábito de vizinhar, ou seja, compartilhar a alimentação em períodos de escassez com os vizinhos com maiores dificuldades, ou em momentos de abundância, por questões de armazenamento.

\section{A alimentação nas comunidades ribeirinhas}

O suprimento das necessidades básicas, sobretudo da alimentação, tanto individual como coletivamente, em todas as sociedades, é motivo de preocupação. A forma como cada sociedade, em seu tempo e condições naturais, encontra meios para suprir as necessidades alimentares implica formas de apropriação da natureza e/ou aquisição de produtos; no caso da população da FLONA de Tefé, inclusive, constituindo uma paisagem específica. Neste processo, instituem-se relações sociais e relações da sociedade com a natureza, pois a alimentação, uma necessidade natural, é resolvida de modo social, em estrito contato com as condições naturais locais. 
Nesse sentido, sobre a alimentação na região amazônica, Castro (1946, p. 55) afirmou: "A região da Amazônia representa, sob o ponto de vista ecológico, um tipo unitário de área alimentar muito bem caracterizado, tendo como alimento básico a farinha de mandioca". No mapa das áreas alimentares do Brasil (CASTRO, 1946, Figura 1), junto com a farinha de mandioca o autor acrescentou como alimento básico da região o peixe, o feijão e a rapadura. Nas entrevistas realizadas na FLONA de Tefé, o peixe e a farinha de mandioca sempre foram apontados como os alimentos principais.

La Blache, em Princípios de Geografia Humana, escreve um capítulo sobre a alimentação. Uma passagem do que o autor afirmou pode ser tomada como luz para compreender a alimentação da população ribeirinha da FLONA de Tefé. No entendimento de La Blache (1954, p.195), "entre as relações que ligam o homem a um certo meio, uma das mais tenazes é a que aparece quando se estudam os modos de alimentação". A alimentação da população estudada é estreitamente associada ao contato com as condições naturais locais.

Há uma considerável bibliografia sobre a ligação da alimentação com as condições locais na região amazônica. Além do próprio Castro (1946), há também Lima (1975), com Amazônia, a terra e o homem, publicado originalmente em 1933 e que pode ser apontado como uma das referências mais longínquas, porém com temas ainda relevantes. Do que Lima abordou, destaca-se: a crítica ao determinismo climático e, entre outros tantos pontos a respeito do contexto social amazônico, a questão da alimentação (e sua insuficiência) na relação com a ocupação da região; as atividades desenvolvidas e os recursos locais; a forma de produzir e a propriedade; a alimentação como resposta para o que até então era um problema de clima; a crise da economia da borracha, que abre espaço para o cuidado com a agricultura e, assim, melhora as condições alimentares, afastando as doenças (LIMA, 1975, p.108).

A alimentação da população ribeirinha é ajustada conforme o contato com o meio, algo bastante previsível para um local com acesso que pode chegar a algumas dezenas de horas de barco, ainda 
que, como afirma uma das entrevistadas, atualmente se tem muitas facilidades. Essa condição dificulta tanto a compra de mantimentos como a venda de produtos de origem local, a qual poderia representar um acréscimo de renda e, consequentemente, aumentar a compra de mantimentos.

A origem dos moradores da FLONA de Tefé e suas histórias de vida ajudam a compreender a forma de viver na floresta. Apesar da origem de boa parte dos atuais moradores da FLONA de Tefé remontar ao nordeste brasileiro, na sua grande maioria são nascidos na própria região, são "filhos do amazonas". Em relação à alimentação, essa história de imigração é buscada na memória mais como reminiscência do que como prática atual, pois a alimentação está profundamente associada aos recursos disponíveis no local.

As entrevistas apontam a centralidade da mandioca e do peixe na composição da alimentação, os quais são consumidos durante o ano todo (Figura 5). Além deles, apesar de sazonal, o açaí tem grande consumo e destaca-se pela capacidade de "matar" a fome e de dar energia; além de ser saboroso. A castanha também é consumida. O café (eventualmente, com leite), a banana, a pupunha, a macaxeira, o jerimum e o cará também estão entre os principais produtos consumidos cotidianamente. $\mathrm{O}$ arroz, o feijão, o frango e as carnes vermelhas são lembrados de forma secundária.

Figura 5: Prato servido e bacia com farinha de mandioca que, junto com o peixe, é a base da alimentação ribeirinha.

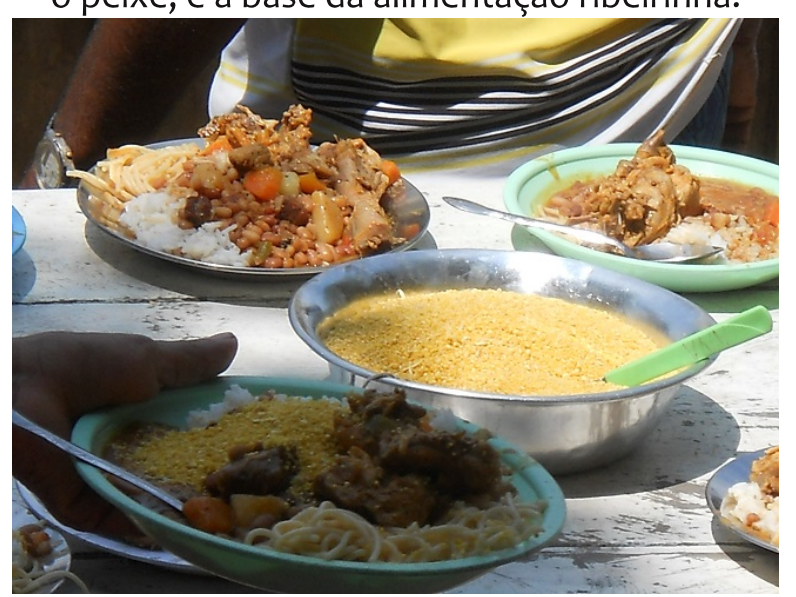

Foto:Cleder Fontana - 2012. 
A alimentação da população estudada é fortemente influenciada pela sazonalidade dos produtos locais. Épocas de maior ou menor dificuldade em prover os mantimentos devem-se às condições naturais, ou seja, épocas de menor ou maior disponibilidade de alimentos, as quais são influenciadas pela dinâmica das águas. As épocas de enchente ou de vazante influenciam a disponibilidade de alimentos, inclusive do peixe, que com o aumento da água tem uma captura dificultada. Os vegetais, sejam de origem extrativa ou de plantação, possuem épocas de maior ou de menor disponibilidade. Assim, o contato com a natureza e a organização da satisfação da alimentação formam uma totalidade em que o natural e o social combinam-se de uma forma genuína e generosa, possível de ser compreendida pela composição da paisagem ribeirinha.

As casas às margens dos corpos de água, os barcos (canoas e voadoras) e os aparatos de pesca, as plantações em forma de roçado, as plantas frutíferas permanentes mais próximas das casas e, especialmente, as casas de farinha formam uma composição única, em que a forma de produzir a vida está diretamente associada ao tempo/dinâmica da natureza. Aprofundando essa relação, os gestos, as palavras e, sobretudo, a intimidade com a água ao nadar sintetizam a proximidade dos corpos humanos com um corpo natural mais amplo, o da terra, da água, dos animais e das plantas.

Essa sintonia com a natureza é reforçada pelas técnicas de produzir os alimentos necessários para o sustento. Tanto no extrativismo como na agricultura, na pesca e no próprio preparo dos alimentos, o uso de equipamentos e de técnicas um tanto rudimentares, porém pertinentes à realidade local, faz lembrar o que Martínez Alier (2009) define como ecologismo dos pobres (Figura 6). Essa rudimentariedade não se restringe a equipamentos e técnicas utilizados nas tarefas nos próprios domicílios, mas se estende aos aparatos de uso comunitário como, por exemplo, os usados nas casas de farinha, em que, para além do consumo local, a farinha é produzida para comercialização (a venda da farinha de mandioca, aparentemente, é a principal fonte de renda da população). 
Figura 6: Comunitário preparando açaí. Uso de técnica um tanto rudimentar na preparação de um dos alimentos mais consumidos pelos comunitários.

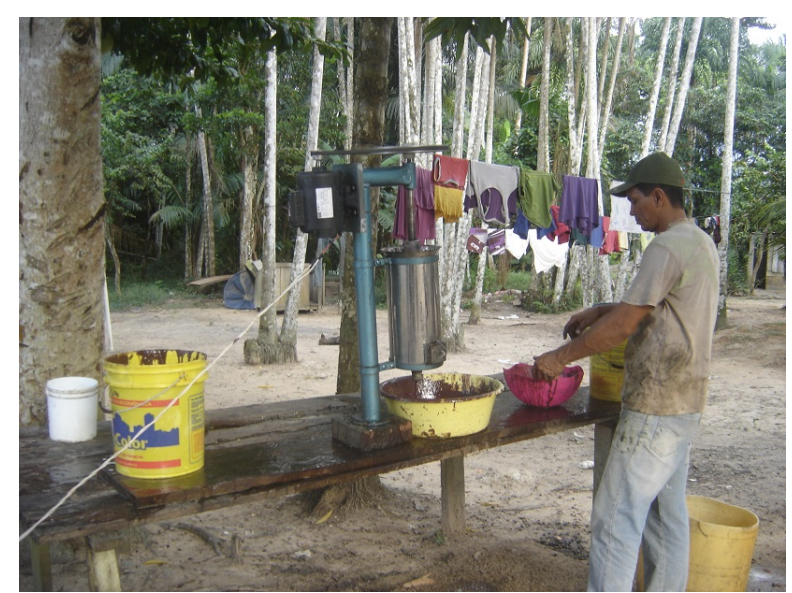

Foto: Cláudia Luiza Zeferino Pires - 2012.

A produção do que é necessário à vida seguidamente se dá de forma coletiva. As próprias refeições, em muitos casos, são coletivas, quando não muito envolvendo toda a população da comunidade, como relatam as ribeirinhas (Figuras 7 e 8). Esse tipo de prática, para além do suprimento das necessidades individuais, revela o coletivo (as comunidades) como um corpo ampliado.

Figura 7 - Cozinha Comunitária.

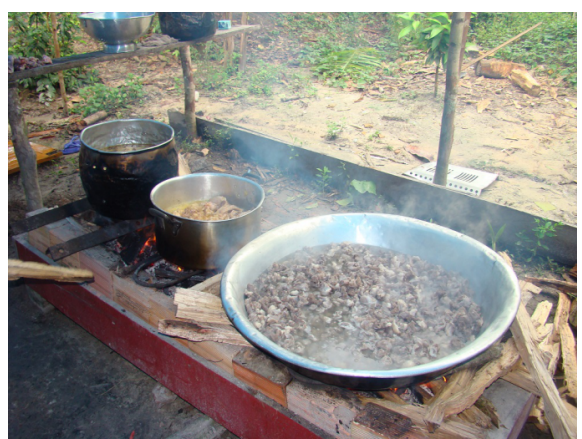

Foto: Renato Barbieri - 2012
Figura 8 - Mesa comunitária.

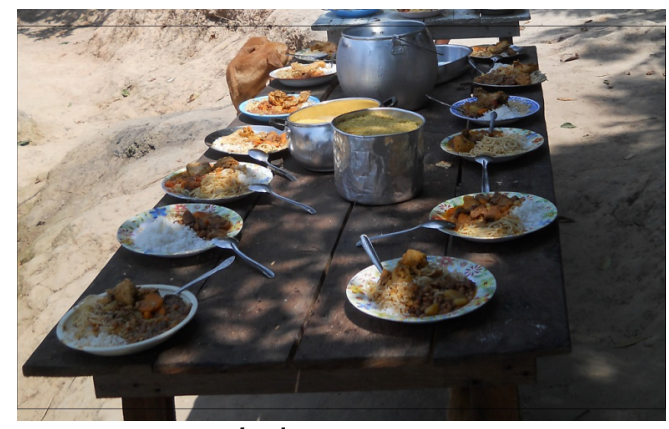

Foto: Cleder Fontana - 2012 
Em período recente, os programas sociais de distribuição de renda, relatam as moradoras, representam um considerável acréscimo nas rendas familiares. Em suas percepções, essa renda é positiva, bem como insuficiente para satisfazer as necessidades de compra de alimentos. Essa renda, normalmente, é gasta em uma compra mensal, um "rancho" de produtos um tanto exóticos para os padrões alimentares locais, como o frango, e também na compra de produtos de usos gerais não produzidos no local, como sal, açúcar, sabão e material escolar.

A compra de alimentos, apesar de crescente, não aparenta resultar em um grande impacto na lista de produtos consumidos, na satisfação das necessidades, bem como nas práticas alimentares. $\mathrm{Da}$ mesma forma, o recebimento de alimentos (como havia ocorrido pouco tempo antes das entrevistas, com a entrega de cestas básicas pela Defesa Civil em função de uma enchente), de entidades como igrejas e a própria merenda escolar, não altera as práticas e os produtos consumidos.

Soma-se a essas questões a ausência de infraestrutura como, por exemplo, energia elétrica para a produção e o armazenamento de alimentos. Isso aflige cotidianamente quem administra as necessidades alimentares, gerando preocupação com a possibilidade de faltar alimentos. As entrevistadas afirmam, inclusive, ocorrer diminuição da quantidade de alimentos consumida, eventualmente chegando ao extremo da não realização de alguma refeição.

Essas situações, entretanto, segundo o que relatam as moradoras, tornam-se cada vez menos frequentes. Em suas memórias, recordando os momentos de preparação de refeições, o suprimento das necessidades alimentares, atualmente, é melhor do que em outros tempos. Mais significativo que isso, como pode-se perceber nas entrevistas, as situações de escassez normalmente são amenizadas pelas relações coletivas, como ocorre com a prática de vizinhar, que consiste em realizar refeições nas casas de outros moradores da comunidade. A prática de vizinhar, apesar de ser um hábito que independe da disponibilidade de alimentos (segundo os relatos, ela ocorre mesmo quando não há falta de alimentos nos 
domicílios), pela sua dinâmica coletiva, tem um papel regulador da alimentação, especialmente na satisfação das necessidades. As entrevistadas relatam que, quando de escassez de mantimentos em seus domicílios, recorrem ao vizinhar, e que, em outras ocasiões, recebem moradores em suas casas nas horas das refeições.

A dinâmica coletiva associa a produção da vida com o trabalho e a alimentação. Isso pode ser percebido na prática do ajuri, quando os moradores da comunidade trabalham no roçado de um dos comunitários. Nesse dia a alimentação é oferecida pelo proprietário do roçado.

Assim, a alimentação tem um papel agregador da coletividade, unindo o corpo social com as condições naturais locais. Em termos de satisfação das necessidades alimentares associadas a uma paisagem específica, a da vida comunitária ribeirinha, a alimentação, uma necessidade natural e individual, é satisfeita pela organização social, em que se sobressaem as trocas coletivas e as trocas com o meio mais imediato, a floresta amazônica.

\section{A vida na floresta e as organizações comunitárias}

Primeiramente queremos destacar este sujeito (coletivo) denominado “ribeirinho". Tal designação não foi fácil de ser estabelecida, uma vez que, mesmo no âmbito das normas, ou seja, das políticas ambientais e das comunidades tradicionais, existe uma pluralidade de possibilidades de entendimentos desses sujeitos. Muitas publicações sobre povos amazônicos, como Diegues (2007), referem-se aos caboclos. Ainda pelo trabalho tradicional que desenvolvem poderiam ser designados camponeses ou pescadores artesanais. Não podemos também excluir possibilidades de entendimento desses sujeitos como descendentes de indígenas ou remanescentes de quilombolas. Os trabalhos de campo expressam essas possibilidades. Então, ficou a seguinte interrogação: como designar esses sujeitos de forma que seja possível distingui-los na sociedade capitalista e, ao mesmo tempo, respeitar a diversidade presente nas comunidades? 
Esse questionamento foi transmitido aos sujeitos da pesquisa, em trabalho de campo, os quais, diante do diálogo com os pesquisadores e das possibilidades apresentadas, autodenominaram-se ribeirinhos. $\mathrm{O}$ autorreconhecimento do ribeirinho emergiu a partir do diálogo e com base na experiência subjetiva, que uma vez compartilhada expôs elementos que unem tais sujeitos. Esses elementos referem-se às relações que estabelecem com a natureza e em sociedade. São ribeirinhos pelas formas como se organizam, trabalham, festejam, celebram, etc.

Para exemplificar uma prática comum entre os ribeirinhos que os distingue da sociedade capitalista, vamos destacar o ajuri. $\mathrm{O}$ ajuri é uma estratégia de vida comunitária, também chamada de mutirões, que consiste na troca de dias de trabalho entre famílias, representando um apoio mútuo nas etapas da produção e organização comunitárias.

A constituição do sujeito ribeirinho também se sustenta no âmbito objetivo. Queremos dizer que tal autodefinição é fundamental para que tenham acesso às políticas públicas conquistadas pelos povos tradicionais. A dependência do mundo natural, de seus ciclos e de seus produtos é fundamental para a produção e reprodução do seu modo de vida. Vivem à beira de rios, lagos, igarapés e à beira do mar (DIEGUES, 2007).

Tendo identificado o ribeirinho enquanto sujeito social, agora queremos enfatizar sua corporeidade, que se dá na coletividade. Assim, destacaremos as organizações das comunidades ribeirinhas. Os ribeirinhos da FLONA de Tefé estão organizados em diversas comunidades e localidades. Tais organizações podem ser compreendidas a partir da dimensão objetiva intrínseca às falas dos ribeirinhos. O principal objetivo refere-se ao rompimento de um contexto de exploração por patrões na atividade seringueira.

Para Astrogildo Moraes (2012), analista ambiental do ICMBio/Tefé, a época de atuação do $\mathrm{MEB}^{1}$ favoreceu o

Em meados de 1970, o Movimento de Educação de Base (MEB) trabalhou na união das famílias que viviam dispersas em comunidade e na FLONA de Tefé. 
fortalecimento das organizações comunitárias, pois muitos trabalhadores estavam tentando se desligar de seus patrões. $\mathrm{Na}$ FLONA, a maior parte das famílias veio do Juruá para poder escapar dos seringais (PIRES et al., 2016).

Assim, as organizações comunitárias iniciaram a partir de experiências de extração de seringa, ao longo dos rios da FLONA de Tefé, e depois passaram a ser predominantemente de produção de farinha de mandioca. Enfim, uma das formas do MEB influenciar nessa relação política entre empregado e patrão foi por meio do seu programa de Alfabetização Radiofônica, que incluía a distribuição de rádios. Além disso, havia um monitor na comunidade que poderia auxiliar nas questões apresentadas pelos programas.

A experiência de constituição das comunidades vivida neste período é muito presente na atualidade nas falas dos ribeirinhos. Mesmo os que não estavam presentes no período de influência do MEB na organização comunitária são influenciados pelos relatos orais dos que viveram esse processo. A experiência expressa que o fato de estarem organizados em comunidade é condição (objetiva) para os ribeirinhos alcançarem determinadas conquistas.

Um exemplo é o fato da FLONA de Tefé ser a primeira Floresta Nacional a ser reconhecida no Brasil como alvo de políticas públicas. Isso se deu nos anos 2000, quando o Instituto Brasileiro de Meio Ambiente (IBAMA) e o Instituto Nacional de Colonização e Reforma Agrária (INCRA) iniciaram uma política de reconhecimento das famílias moradoras da unidade de conservação como beneficiárias dos programas de reforma agrária do governo federal. Os principais pontos desse programa foram a aquisição de materiais de trabalhos diversos, desde ferramentas até motores, bem como auxílio para alimentação e habitação.

Do ponto de vista das subjetividades referente à constituição de organizações comunitárias destacamos parte do poema de Heitor Neto, morador da FLONA de Tefé: 
Depois alguns projetos em nossa comunidade começaram a chegar,

nossa vida de repente começou a melhorar,

em casa de qualidade começamos a morar,

diversas outras coisas que passamos a ganhar,

isso veio meu amigo através da asșociação,

em parceria com entidade de instituiçẫo

melhorou em nossas condições financeiras e na nossa profissão. (NETO, 2014)

$\mathrm{Na}$ dimensão normativa, queremos abordar as organizações sociais por meio da formalização de associações comunitárias. As comunidades da FLONA de Tefé estabelecem associações, elegem seus representantes e constroem estatutos. Os estatutos das comunidades expõem atribuições, direitos e deveres. Sendo regras construídas coletivamente, entendemos que essas instituições de gestão comunitária possuem maior capacidade de serem respeitadas e implica uma ferramenta eficiente de gestão comunitária e de recursos ambientais (BERKES, 2006).

Tendo compreendido brevemente as organizações comunitárias da FLONA de Tefé, vamos expor a dimensão intercomunitária do corpo ribeirinho. Essa abordagem se dará a partir do contexto da gestão dos recursos ambientais compartilhados.

Conforme o Plano de Manejo (ICMBio, 2012), o Irmão Falco tinha uma frase muito conhecida entre os ribeirinhos: "preservar pra você e para os outros". Muitas comunidades foram incentivadas ao cuidado e à vigilância comunitários para impedir o uso de métodos predatórios para a pesca. Os comunitários recebiam orientação para que impedissem a entrada desses invasores. Assim, inicia um trabalho de preservação de lagos em que cada comunidade deveria escolher no mínimo três lagos, sendo um de preservação permanente ou de procriação, um para subsistência da comunidade e outro para a pesca comercial, quando necessário.

Para compreender melhor o contexto, em que diversas comunidades reconhecem-se como um corpo ribeirinho, vamos destacar a experiência do Acordo de Pesca do Lago Tefé, Rio Tefé e seus Afluentes. 
A base dos acordos de pesca é o conhecimento tradicional dos pescadores, ou seja, um conjunto de saberes passados ao longo de gerações, transmitidos oralmente, sobre como, onde e quando pescar. Contudo, contemporaneamente devemos entender o dinamismo de transformação dos saberes, os quais, no passado, eram reelaborados na medida em que ocorriam mudanças no ambiente e de acordo com o tempo da natureza e, na contemporaneidade, com a aceleração da transfiguração da natureza, foram sendo erodidos, mas se reinventam em um quadro de conflitos e disputas (DE PAULA, 2013, p.115).

Assim, o contexto no qual se estabelecem acordos de pesca integra diversas experiências vividas pelos ribeirinhos no âmbito da pesca. Tais experiências expõem relações com a natureza, relações entre pescadores (sobretudo mestres e aprendizes) e relações de conflito por recursos ou áreas.

A dimensão objetiva do acordo de pesca caracteriza-se pela intenção de proteger seus lagos e rios contra a invasão dos barcos comerciais, iniciando sistemas de manejo reconhecidos atualmente pelo ICMBio, nos quais alguns lagos são proibidos para a pesca comercial (DIEGUES, 2007).

O principal objetivo do acordo de pesca é estabilizar ou reduzir a pressão sobre os recursos pesqueiros locais. Para tanto, a comunidade cria restrições aos apetrechos de pesca e à capacidade de armazenamento, em vez de delimitar diretamente o tamanho da captura. Além de regular a atividade pesqueira, acordos de pesca frequentemente incluem medidas que pretendem conservar locais considerados importantes para a reprodução das espécies (MCGRATH et al.,1996). Esse estabelecimento de regras de uso é baseado no conhecimento tradicional sobre o desenvolvimento e comportamento das espécies, bem como na viabilidade de monitoramento da atividade pesqueira.

Desse modo, ao mesmo tempo em que o conhecimento tradicional dos ribeirinhos expõe suas subjetividades, também integra dimensões objetivas e normativas. Acreditamos que o equívoco encontra-se em limitarmos a noção de norma ao que está 
escrito na forma de leis. Os povos tradicionais elaboram normas que são amplamente reconhecidas e respeitadas no âmbito das comunidades (DE PAULA, 2013).

O Acordo de Pesca do Lago Tefé, Rio Tefé e seus afluentes vem sendo discutido desde 2005. Ele estabelece direitos de uso dos territórios de pesca pelos ribeirinhos das comunidades e pelos pescadores urbanos. Assim, limita-se o tamanho dos barcos de pesca comercial (7 toneladas líquidas ou 10 toneladas brutas), definem-se as áreas de uso comunitário e as áreas onde pode ser feita a pesca comercial, e definem-se as regras e apetrechos adequados para a pesca.

A experiência dos acordos de pesca deve ser vista também a partir do seu potencial enquanto articuladora das comunidades para alcançarem objetivos comuns. Além disso, aproxima a equipe de gestores do ICMBio que compartilha com os comunitários, pescadores, e entidades parceiras a responsabilidade da gestão dos recursos pesqueiros.

Chegamos então ao ponto de compreender a relação entre esse corpo ribeirinho, quando presentes em unidades de conservação, e suas relações com o Estado, suas instituições e políticas.

Como a gestão das Florestas Nacionais é responsabilidade do governo federal por meio do Ministério do Meio Ambiente, os moradores da unidade passaram a conviver e a dialogar com os funcionários públicos responsáveis pela gestão da floresta. Esses funcionários eram, inicialmente, do Instituto Brasileiro do Meio Ambiente e dos Recursos Renováveis (IBAMA), até que, em 2007, esse órgão foi dividido, passando a gestão das unidades de conservação para o Instituto Chico Mendes de Conservação da Biodiversidade (ICMBio).

Tanto na elaboração como na atualização do Plano de Manejo da Floresta Nacional deverá ser assegurada a ampla participação da população residente. Por isso é que as FLONAS dispõem de um Conselho Consultivo para a Gestão, condição 
obrigatória estabelecida pelo artigo 17 do Sistema Nacional de Unidades de Conservação - SNUC, citado anteriormente. Esse Conselho Consultivo será presidido pelo órgão administrativo responsável, constituindo-se de representantes dos órgãos públicos, das organizações da sociedade civil e das populações tradicionais residentes. O Conselho da FLONA de Tefé foi criado em 2011.

Diante disso, destacamos que, do ponto de vista normativo, a constituição do corpo ribeirinho enquanto comunidade tradicional é condição fundamental para incluir essa população residente no Conselho Consultivo. Ainda a comunidade tradicional tem direito garantido por lei de participar da elaboração do Plano de Manejo, como no caso da FLONA de Tefé. Scelza et al. (2014) destacam:

É importante ressaltar que no processo de elaboração do PM, a criação do Conselho Consultivo da UC foi importante porque cumpriu o papel de acompanhar o andamento do trabalho e preencheu lacunas de informação que houvessem permanecido.

No âmbito das experiências relatadas pelos ribeirinhos, há a compreensão de que a participação no Conselho Consultivo é o meio de garantir a permanência dos seus modos de viver tradicionais. Pela atual composição do conselho e pelo perfil dos gestores ambientais do ICMBio os ribeirinhos entendem que no conselho suas demandas são atendidas e seus conhecimentos tradicionais são respeitados, dentro dos limites da legislação ambiental.

Quanto à construção dos planos de manejo, o processo percorreu "quatro passos principais: construção dos diagnósticos, elaboração do Acordo de Gestão, mapeamento participativo e a construção do zoneamento da unidade de conservação, e a elaboração dos Programas de Gestão" (SCELZA et al. 2014). Do ponto de vista objetivo, os ribeirinhos, tendo seus direitos de participação garantidos, viram nas fases citadas a possibilidade de alcançar conquistas e garantias que viabilizem a manutenção dos seus modos de viver. 
A dimensão objetiva expressa na relação entre o corpo ribeirinho e o Estado será exemplificada no instrumento do Plano de Manejo, denominado Acordo de Gestão:

O acordo de gestão, por sua vez, foi realizado através de oficinas setoriais de um dia, para que a participação das comunidades nos processos de definição das regras de uso realmente fossem representativos da realidade local. O acordo de gestão foi realizado em seis etapas, conforme segue: o primeiro contato, reuniôes comunitárias de definição de regras, oficinas setoriais de definição conjunta de regras, sistematização das regras, oficinas setoriais de apresentação e finalizacão do Acordo de Gestão da FLONA de Tefé. (SCELZA et al. 2014)

Destacamos, então, em contextos de unidades de conservação, as potencialidades de espaços como Conselhos Consultivos e de momentos como a Construção de Planos de Manejo para as comunidades alcançarem seu objetivo principal, que é a manutenção dos seus modos de viver. Contudo, cabe frisar que tal participação se dá a partir do reconhecimento dessas comunidades enquanto corpo social, que no caso apresentado chamamos de corpo ribeirinho.

\section{Conclusões}

Neste texto transitamos do corpo biológico ao corpo social manifesto por meio de um eixo analítico, a condição alimentar. Conforme consideramos, o que aqui denominamos de corpo ribeirinho na FLONA de Tefé tem sua origem no momento em que ocorre a constituição das comunidades. Até então a população local vivia de forma esparsa como seringueiro no interior da grande floresta amazônica.

A partir da constituição das comunidades pelo MEB, os ribeirinhos se organizam em comunidades e se fortalecem por meio da constituição de uma vida comunitária articulada de forma significativa com a paisagem de floresta, quente e úmida, e com a abundância de água. Suas origens e os recursos disponíveis 
permitiram que construíssem um sistema alimentar baseado no consumo de peixe e farinha, associado a outros produtos provenientes da floresta, como o açaí e a castanha, entre outros.

Da mesma forma, as relações comunitárias facilitam a satisfação das necessidades individuais, as quais, em certos momentos, são resolvidas pelo corpo social, como ocorre nas demais esferas da vida, e se desenvolvem em uma paisagem singular, que se revela pela materialidade e, também, pela memória.

O diálogo de saberes permitiu compreender como se construiu esse singular modo de viver e, ao mesmo tempo, revelar suas transformações. A condição alimentar atual vem sendo melhorada pela possibilidade de acesso a outros bens, entretanto, na raiz de suas histórias cotidianas, a farinha e o peixe constituem a base da alimentação.

Foi, sobretudo, para fortalecer seu modo de viver particular que os ribeirinhos se engajaram na constituição de um Plano de Manejo na FLONA de Tefé, que, construído coletivamente, garantiu a manutenção de seus hábitos e relações comunitárias, conforme publicação no Diário Oficial da União, em 22 de fevereiro de 2016.

Em relação ao corpo social, que foi abordado a partir da corporificação do sujeito ribeirinho, vamos destacar que ele se manifesta no âmbito pessoal, comunitário, intercomunitário e no diálogo com o Estado. Tal compreensão, a partir de diálogos de saberes, proporciona entender as dimensões objetivas, subjetivas (da experiência) e normativas das informações dialogadas com os pesquisadores. Assim é possível compreender a expressão do mundo da vida do ribeirinho na FLONA de Tefé.

Ressaltamos que os direitos dos povos tradicionais, entre eles os das comunidades ribeirinhas, são garantidos devido à diferença deles da sociedade capitalista. Tal diferença é autodefinida e defendida a partir dos seus modos de viver, os quais constituem um sujeito - o ribeirinho -, mas se fortalece a partir da conformação de um corpo social na luta por garantias de direitos. 


\section{Referências}

BERKES, F. et al. Gestão de pesca de pequena escala: diretrizes e métodos alternativos. Rio Grande: FURG, 2006.

BERQUE, A. Paisagem-marca, paisagem-matriz: elementos da problemática para geografia cultural. In: CORREA, R. L.; ROSENDHAL, Z. (Orgs.). Paisagem, tempo e cultura. Rio de Janeiro: Eduerj, 1998, p. 84-89.

BRASIL. ICMBio. Portaria n. 13, de 22 de fevereiro de 2016, aprova Plano de Manejo da Floresta Nacional de Tefé, no estado do Amazonas (Processo no 02070.003434/2011-24). DOU: Brasília, 2016.

CASTRO, J. Geografia da fome: a fome no Brasil. Rio de Janeiro: O Cruzeiro, 1946.

CHAUÍ, M. Os trabalhos da memória. In: BOSI, E. Memória e sociedade: lembranças de velhos. São Paulo: Companhia das Letras, 1999.

DE PAULA, C. Q. Gestão Compartilhada dos Territórios da Pesca Artesanal: Fórum Delta do Jacuíl (RS). Dissertação (Mestrado em Geografia) Universidade Federal do Rio Grande do Sul. Porto Alegre: 2013. 129p. Disponível em: http://hdl.handle.net/10183/78031.

DE PAULA, C. Q. et al. A Floresta é a Tua Casa. In: SUERTEGARAY, D. M. A.; PIRES. C. Z.; DE PAULA, C. Q. O Lugar Onde Moro: Geografia da FLONA de Tefé. NEGA/UFRGS: Porto Alegre, 2016, p. 99-126. Disponível em: http://www.ufrgs.br/nega/producao/.

DIEGUES, A. C. Água e Cultura nas Populações Tradicionais Brasileiras. NUPAUB: São Paulo, 2007. Disponível em <http://nupaub.fflch.usp.br/sites/nupaub.fflch.usp.br/files/color/ simbolagua.pdf > . Acesso em: 18 nov. 2014.

HABERMAS, J. Teoria do Agir Comunicativo - sobre a Crítica da Razão Funcionalista. São Paulo: Martins Fontes, 2012. v.2.

LA BLACHE, V. de. Princípios de Geografia Humana. Lisboa: Cosmos, 1954. v.1.

LEFF, E. Racionalidade Ambiental: a reapropriação social da natureza. Tradução Luís Carlos Cabral. Rio de Janeiro: Civilização Brasileira, 2006.

LIMA, A. Amazônia, a terra e o homem. 4 ed. São Paulo: Companhia 
Editora Nacional, 1975.

MARTÍNEZ ALIER, J. O ecologismo dos pobres: conflitos ambientais e linguagens de valoração. São Paulo: Contexto, 2009.

MCGRATH, D. et al. Manejo Comunitário de Lagos de Várzea e o Desenvolvimento Sustentável e a Pesca na Amazônia. Pepers DO NAEA, Belém, 58, 1996. Disponível em: < periodicos.ufpa.br>. Acesso em: 21 jan. 2012.

NETO, $\mathrm{H}$.

Poemas.

Disponível

em < http://heitorpoemasreais.blogspot.com.br/ >. Acesso em: 01 out. 2014.

OLIVEIRA, M. G. et al. Natureza que nos Envolve. In: SUERTEGARAY, D. M. A.; PIRES. C. Z.; DE PAULA, C. Q. O Lugar Onde Moro: Geografia da FLONA de Tefé. NEGA/UFRGS: Porto Alegre, 2016, pp.47-72. Disponível em: http://www.ufrgs.br/nega/producao/.

PIRES, C. Z. et al. Meu Lugar e Minhas Histórias na FLONA de TEFÉ In: SUERTEGARAY, D. M. A.; PIRES. C. Z.; DE PAULA, C. Q. O Lugar Onde Moro: Geografia da FLONA de Tefé. NEGA/UFRGS: Porto Alegre, 2016, p. 21-48. Disponível em: http://www.ufrgs.br/nega/producao/.

SCELZA, G. C. et al. Plano de Manejo da Floresta Nacional de Tefé, a Gente faz Junto! Revista Biodiversidade Brasileira, 2014. Disponível em < http://www.icmbio.gov.br/revistaeletronica/index.php/BioBR/a rticle/view/334>. Acesso em: 05 jan. 2015.

SUERTEGARAY, D. M. A.; FONTANA, C.; BONETTO, H. As Atividades dos Ribeirinhos. In: SUERTEGARAY, D. M. A.; PIRES. C. Z.; DE PAULA, C. Q. O Lugar Onde Moro: Geografia da FLONA de Tefé. NEGA/UFRGS: Porto Alegre, 2016, pp. 73-98. Disponível em http://www.ufrgs.br/nega/producao/. Acesso em julho de 2016.

\section{Agradecimentos}

Embora o texto acima tenha sido sistematizado por três dos pesquisadores, o grupo envolvido, efetivamente, neste projeto (Mapeamento Participativo em Comunidades da FLONA de Tefé 2012-2013) é bem maior. Assim, segue a menção das pessoas sem as quais este trabalho não teria sido possível, organizados pela instituição à que 
pertencem. Grupo do NEGA-UFRGS: Cláudia Luísa Zeferino Pires, Daniele Machado Vieira, Elisa Caminha da Silveira Delfino, Laurindo Antônio Guasselli, Luiz Morelli, Mateus Gleiser Oliveira, Pablo Leandro Proença Ferreira, Pedro Saldanba Frantz, Renato Barbieri, Sinthia Cristina Batista, Theo Soares De Lima. Grupo do ICMBio/Tefé: Astrogildo Martins de Moraes, Gabriella Calixto Scelza, Rafael Suertegaray Rossato. 


\section{Paisagens Vividas e Imaginários Urbanos em Disputa: memórias e paisagens nas narrativas de jovens do Bairro Guajuviras (Canoas/RS)}

Nola Patrícia Gamalho

Álvaro Luiz Heidrich 


\section{Introdução}

$\mathrm{O}$ principal acesso ao bairro Guajuviras é o situado no encontro das avenidas Boqueirão e Dezessete de Abril. Ao pegar esse acesso, logo são avistados os blocos de apartamentos da produção de habitação popular. Nas ruas o movimento é constante, tanto de automóveis, carroças, ônibus, quanto de pedestres, animais... É um vaivém ininterrupto de homens, mulheres, jovens, crianças... Nessa avenida estão localizados diversos estabelecimentos comerciais, educacionais, recreativos e religiosos, constituindo uma centralidade local. Perpendicularmente à avenida principal estão as ruas que dão acesso ao interior dos setores e das vilas. Materialidades distintas são apenas alguns dos indicativos que localizam o visitante. Ruas mais estreitas com calçadas igualmente estreitas são materialidades da paisagem que revelam se o local teve origem no planejamento e produção de habitação popular ou em ocupações de áreas verdes. Nada é homogêneo, e uma mesma rua contém moradias mais estruturadas e outras mais precárias: casas construídas com sobras de madeira, casas pré-fabricadas, casas de alvenaria, algumas com reboco e pintura, outras não. Entre as casas e as ruas, os limites também são diversos e nem sempre consistem em separações. Pouco ocultam as cercas de madeira, fronteiras fluidas em que as crianças vizinhas brincam e pelas quais os cães fogem. Dali, os movimentos nas ruas são visíveis e controlados. Já os muros lembram que ali, como é comum na região metropolitana, o perigo é iminente. Seja nas tardes de inverno, quando o sol brinda o lugar com seu calor, seja no final das tardes de verão, quando ele dá uma trégua, as ruas ficam ainda mais povoadas. Numa delas, dividida em dois times de futebol, crianças ou jovens jogam. Os carros diminuem a velocidade, os jogadores seguram a bola para outros moradores ou visitantes passarem. $\mathrm{Na}$ outra esquina, um grupo de jovens que ali se encontram, paqueram, fumam, riem... $\mathrm{Na}$ praça, enquanto as crianças brincam nos balanços, alguns jovens dividem um beque ${ }^{1}$, jogam bola, conversam, paqueram, consolidam grupos territoriais.

1. Denominação dada ao cigarro de maconha. 
Paisagens Vividas e Imaginários Urbanos em Disputa: memórias e paisagens nas narrativas de jovens do Bairro Guajuviras (Canoas/RS)

Essa espacialidade, cuja paisagem narrada inicia o texto deste artigo, é o bairro Guajuviras², localizado no município de Canoas, região metropolitana de Porto Alegre, no estado do Rio Grande do Sul, na Região Sul do Brasil. O bairro pode ser visto como uma repartição da própria região metropolitana, dada a sua integração espacial com ela. Essa breve introdução apresenta resíduos da vida de bairro apreendidos a partir das paisagens e pelas narrativas de jovens. Essas múltiplas camadas de sentidos (COSGROVE, 1998), lógicas, interesses e temporalidades são vividas, significadas e produzidas por diferentes agentes e atores (DI MÉO; BULÉON, 2007), como comerciantes, moradores e administração municipal. O percurso de formação do bairro, associado a diferentes processos de ocupação urbana e suas representações, corresponde à paisagem como marca e matriz (BERQUE, 1998) que emerge como materialidades e sentidos, atuando nas formas de percepção, concepções e vivências.

A origem do Guajuviras está relacionada ao conflito entre o planejamento público e a população ocupante. Mesmo sendo um espaço planejado inicialmente como habitação popular, é resultado de múltiplos processos de ocupação, primeiro dos prédios e casas construídos pela Companhia Estadual de Habitação do Rio Grande do Sul (COHAB/RS) e, depois, de áreas verdes, cujas ocupações passaram a ser denominadas "vilas" (Figura 1). É constituído por essas materialidades, mas também pelos sentidos associados à subversão à propriedade privada, em função das ocupações tidas como ilícitas e pelos mecanismos de apropriação do espaço (LEFEBVRE, 2013), por exemplo, o uso das ruas e praças como espaços de sociabilidade, gerador de paisagens singulares e de cotidianos intensamente compartilhados.

2. Este artigo é resultado de releituras baseadas na pesquisa de doutorado sobre a produção de espaços e sujeitos jovens no bairro Guajuviras. A tese, de autoria de Nola Patrícia Gamalho, com orientação de Álvaro Luiz Heidrich, intitula-se Entre dominações e apropriações, reproduções e criações, centralidades e periferias: práticas e espaços de representações de jovens do Guajuviras - Canoas/RS. 
As paisagens que compõem o Guajuviras constituem referências identitárias, estabelecendo mútuas relações entre sujeitos e lugar, constituindo múltiplos microespaços. Nesse sentido, a paisagem como um todo atua de forma plurimodal, ou seja, é ativa e passiva nos esquemas de percepção e ação. $\mathrm{Na}$ mesma perspectiva, os agentes atuam na paisagem e simultaneamente são influenciados por ela, ou seja, "[...] a paisagem e o sujeito são co-integrados em um conjunto unitário que se autoproduz e auto reproduz [...]" (BERQUE, 1998, p.86). Nessa mesma linha, Berdoulay, Treyture e Sartre (2010a) argumentam sobre a coprodução de sujeitos e espaço geográfico, o que é focalizado na reflexão proposta a partir de narrativas de jovens.

Figura 1: Divisão do bairro Guajuviras em Conjunto Habitacional Ildo Meneghetti (CHIM) e vilas.

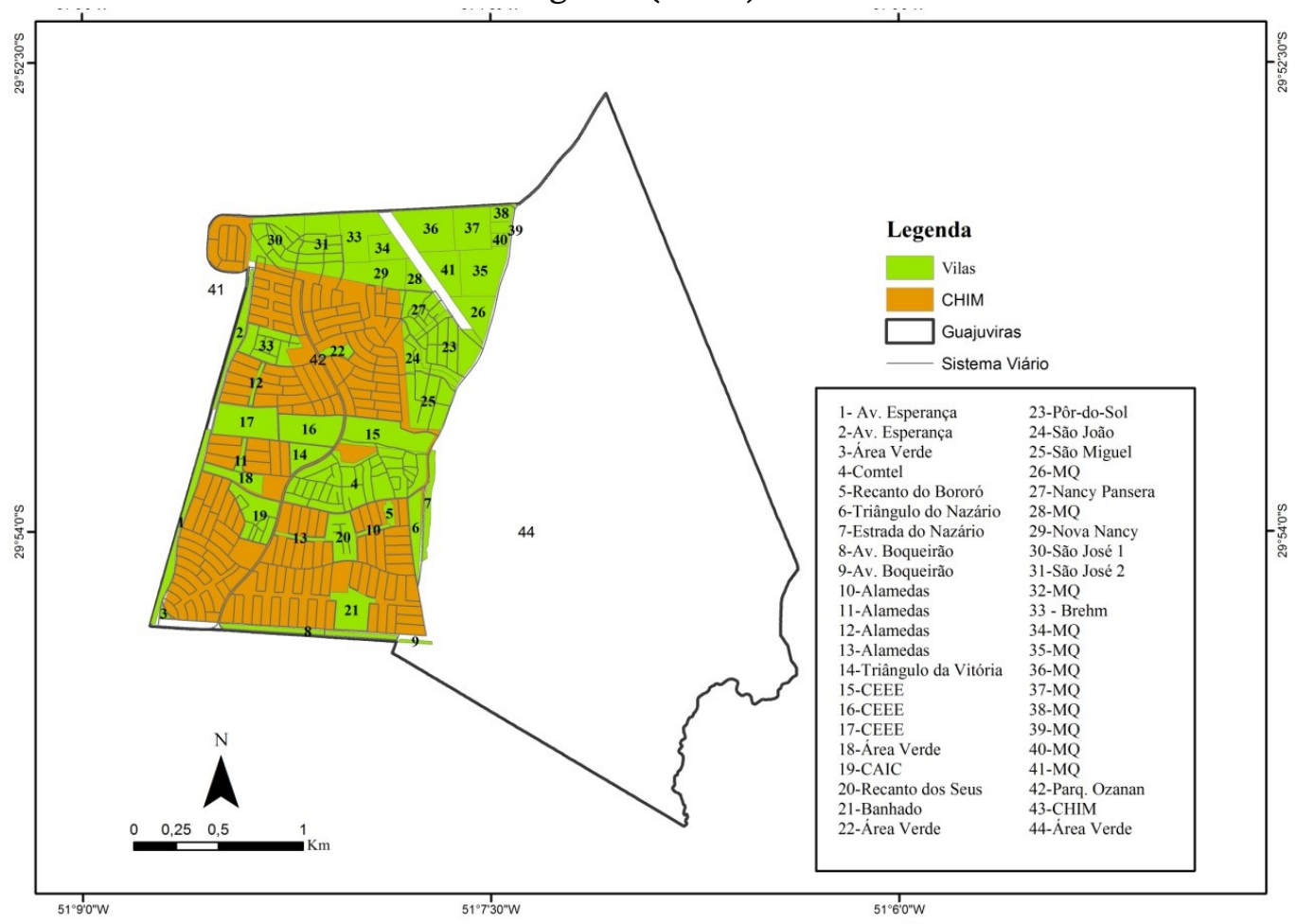

Fonte: Base cartográfica fornecida pelo Instituto Canoas XXI. Elaboração de Nola Gamalho 
Paisagens Vividas e Imaginários Urbanos em Disputa: memórias e paisagens nas narrativas de jovens do Bairro Guajuviras (Canoas/RS)

Como desafio do nosso trabalho de pesquisa, propusemonos compreender as paisagens do Guajuviras a partir das narrativas de jovens do bairro ${ }^{3}$ e de suas práticas espaciais. Esses sujeitos são frequentemente dissociados das memórias de produção do espaço, sendo mais efêmeras as suas formas de marcar as paisagens porque são pontuadas nos próprios corpos em suas práticas espaciais, não se fixam externamente e só podem ser constituídas pela remissão à presença dos próprios sujeitos. Dessa forma, o argumento aqui apresentado explora o quanto o Guajuviras, nas suas dimensões de marca e matriz, está presente nos esquemas de percepção e na coprodução de sujeitos e bairro. As juventudes (DUARTE, 2000), diversas, vivenciam e reelaboram os sentidos do espaço remetidos aos processos de ocupação, ora pelas narrativas herdadas de familiares, ora por suas próprias experiências desse viver. São cruzados os efeitos de paisagem, marca e matriz com os processos e as formas contemporâneos do urbano. As práticas espaciais correspondem a conteúdos das formas de constituição dessas juventudes.

$\mathrm{Na}$ sua concepção inicial, o Guajuviras era destinado a ser um local produzido a partir da política pública de habitação. $\mathrm{O}$ nome original é Conjunto Habitacional Ildo Meneghetti (CHIM), construído pela COHAB/RS. A paisagem projetada, com um ordenamento previsto ${ }^{4}$,era homogênea e padronizada. Entre esse plano concebido e a efetivação da produção do espaço foram realizadas múltiplas ocupações, primeiro do CHIM, em abril de 1987, e, posteriormente, as ocupações dos terrenos remanescentes de plantações de eucaliptos (denominadas áreas verdes).

3. O trabalho de campo com jovens do Guajuviras foi realizado entre abril de 2012 e novembro de 2014. Para o levantamento foram adotadas metodologias qualitativas, com a realização de entrevistas abertas, grupos focais e relatos em diário de campo. Foram entrevistados/as 33 jovens entre 15 e 27 anos (19 do sexo masculino e 14 do sexo feminino). Os nomes foram alterados para preservar o anonimato dos/as jovens.

4. Pequenos lotes de casas e edifícios populares em grandes quarteirões, com arruamentos ordenados e previsão de estabelecimentos comerciais, educacionais e postos de saúde. Orientado para acolher numerosa população na região metropolitana. 


\section{Em suas materialidades iniciais, esses processos} apresentavam os signos da desordem: acesso irregular à moradia urbana, ausência ou precariedade do arruamento, barracos de lona e sobras de madeira, e serviços de abastecimento de água e de energia elétrica precários. No entanto, esses terrenos tornaram-se espaços vividos, apropriados e transformados. O conjunto de situações vivenciadas no início das ocupações (a violência institucional nos conflitos decorrentes das ocupações, a violência simbólica dos estereótipos referentes ao acesso irregular da moradia em espaço urbano, a precariedade ou completa ausência de infraestrutura como abastecimento de água e energia elétrica, acesso a transporte público, entre outros) transformou-se ao longo dos anos: as casas da habitação popular diferenciaram-se, as barracas ou moradias improvisadas foram substituídas por casas de alvenaria ou madeira, as ruas adquiriram calçamento, o abastecimento de água e energia elétrica tornou-se regularizado.

Todavia, ainda que as paisagens tenham sido alteradas, as referências e estigmas permanecem como conteúdos de imaginários, representações e discursos. Ao imaginário e situações do início das ocupações, que remetem à desordem, são acrescidos os medos urbanos, as formas de criminalizar o uso dos espaços como apropriação e os mecanismos mobilizados para encapsular a vida de bairro nos modos de vida ordenados e individualistas. Os jovens transitando ou se agrupando nas ruas tornam-se signos do medo contemporâneo, como se as desordens ligadas aos processos de ocupação em tempos passados fossem transpostas para esses sujeitos e suas formas de vivenciar o espaço. No entanto, nas esquinas, ruas e praças persiste a presença de jovens em práticas de lazer e sociabilidade por vezes violadoras da lei e por vezes apenas vistas dessa forma. Tanto as práticas vão imprimindo marca ao bairro como o viver nele as vai traduzindo como pertencimento e maneira de se conduzir. Tais práticas e tal viver não estão apenas relacionados ao bairro em si, mas também com o bairro na metrópole e, por isso mesmo, como bairro/metrópole/mundo. Desse modo, constata-se o cruzamento de múltiplas escalas de fatos e processos estruturantes e de referências culturais. 
Paisagens Vividas e Imaginários Urbanos em Disputa: memórias e paisagens nas narrativas de jovens do Bairro Guajuviras (Canoas/RS)

Dessa perspectiva, o presente artigo tem como objetivo contribuir para a compreensão da produção de sentidos do bairro a partir das narrativas, marcadamente associadas à memória própria ou apropriada, a experiências e à constituição de paisagens imaginadas e vividas por esses/as jovens. A complexidade da relação sociedade-espaço vai ficando evidente na constituição de múltiplos patamares de significados (COSGROVE, 1998) da paisagem, que ora remete a periferias e vilas, ora a centralidades.

\section{Paisagens: Heranças, Experiências Imaginários}

A ocupação do CHIM (Figura 2) ocorreu há 29 anos e, portanto, esse processo está presente nas narrativas dos(as) jovens entrevistados(as), na forma de histórias herdadas ou mesmo vividas, pois os conflitos subsequentes referentes à precariedade de infraestrutura aparecem como experiência para alguns jovens. Assim, tem-se a elaboração de uma história compartilhada, transmitida e internalizada inclusive por aqueles agentes espaciais que não a vivenciaram. Constitui-se, dessa forma, um imaginário urbano assentado nas materialidades e sentidos, uma bricolagem de referências de propriedade privada, luta pela casa própria, carência infraestrutural e cotidiano compartilhado.

A ocupação do CHIM é um marco na história familiar, tanto pelos conflitos com a ordem pública, inerentes ao processo, quanto pela associação com a segurança que a casa própria confere. Alguns jovens nasceram nos anos iniciais da ocupação. Outros, conforme argumenta Ricardo, um dos jovens entrevistados, estavam em gestação naquela época e, por isso, sentem que participam diretamente, desde o início, da história do Guajuviras: "Aí, depois, em 1987,quando começou a invasão aqui, eles vieram pra cá. [...]. A minha mãe veio pra cá comigo na barriga, quando foi invadido aqui” (Ricardo, 25 anos, em 28/08/2013). 
Figura 2: Paisagem do CHIM.

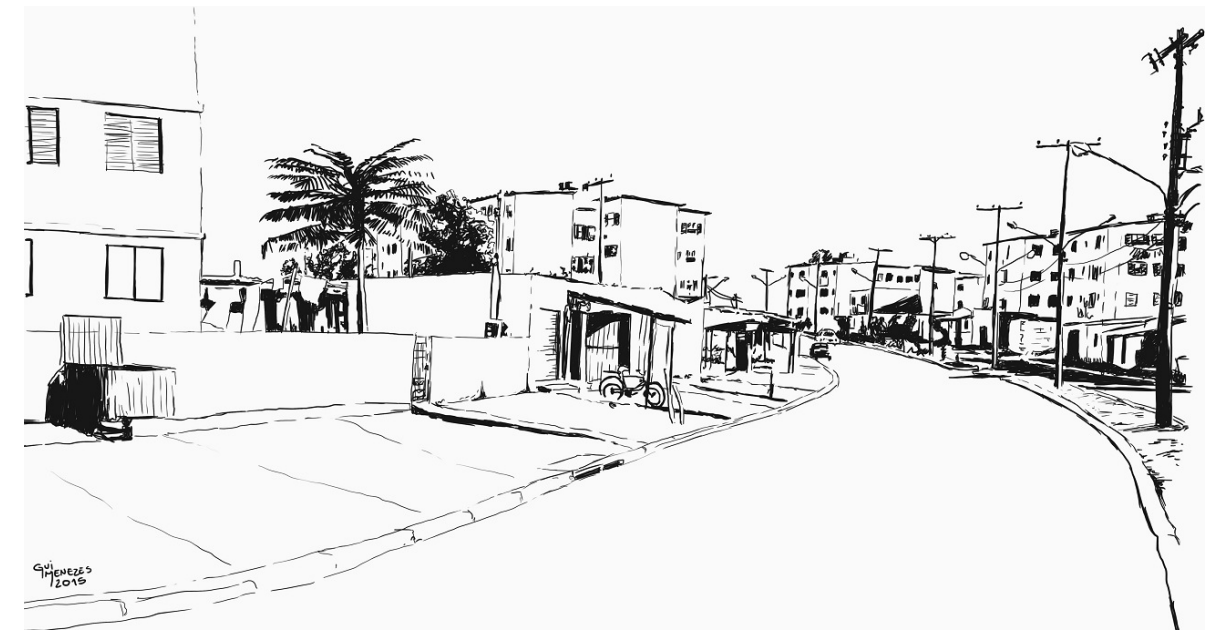

Fonte: Desenho de Gui Menezes (2015)

A partir das narrativas dos jovens, surgem releituras do processo de ocupação como forma de valorização local. Nessas releituras, o Guajuviras é visto como um bairro construído materialmente pelo poder público, porém apropriado pela população que necessitava de moradia própria, mas que não dispunha dos mecanismos legais para adquiri-la. A subversão à propriedade privada é ressignificada como resistência frente às ações institucionais que objetivavam a remoção das moradias improvisadas. $\mathrm{O}$ imaginário urbano inicial sobre o Guajuviras tem sua origem nesse conflito e é resultado de discursos e representações que associavam o local à intensa desordem. É a essa desordem que alude a expressão "Campo de concentração" (Folha de Canoas, 24/04/1987, p. 8-9) ou a manchete "Uma cidade periférica, sem recursos, dentro de Canoas” (RADAR, 19/11/1987, notícia de capa). Essa disputa que funda a formação do imaginário urbano resiste como referência de jovens cujas famílias participaram dessa primeira ocupação, como exemplifica a fala de Ricardo (25 anos, em 28/08/2013): 
Paisagens Vividas e Imaginários Urbanos em Disputa: memórias e paisagens nas narrativas de jovens do Bairro Guajuviras (Canoas/RS)

Eu lembro muito bem de uma vez que meu pai e meu tio falaram, eles não gostam muito de um narrador da rádio Farroupilha, como era o nome dele? O Zambiazi. Meu pai fala até hoje que o cara começou a falar que era pra todo mundo sair de dentro do bairro, porque os caras iriam invadir com. armamento pesado, iam tirar todo mundo daqui. Daí nisso foi um poder de mídia, né? Isso até afugentou algumas pessoas, mas a grande maioria quis permanecer, né? Quis brigar pela moradia.

As narrativas dos familiares são apropriadas como suas pelos(as) jovens. É uma memória viva reafirmada e reinventada cotidianamente e que conserva apenas vestígios da materialidade como conteúdo. Assim, o imaginário alicerça-se tanto nos aspectos pesados e concretos da paisagem quanto em sua leveza, o que Lacarrieu (2007) aponta como sendo o peso da materialidade e do que ali está invisibilizado, o imaterial. Graças a essa perspectiva que se propõe identificar aspectos para além do que é material, pois o "inmaterial se densifica y los sujetos toman protagonismo" (LACARRIEU, 2007, p. 48). Assim, tornar visível o processo formador da paisagem e desnaturalizar/problematizar os sentidos a ela associados é uma estratégia de resistência e de afirmação da memória compartilhada e apropriada que adquire força discursiva e representacional nas disputas em torno da produção desses imaginários. Na narrativa de Janaína (17 anos, em 01/10/2013), a história dos avós é contada como um saber próprio da jovem, ou seja, as histórias deles se cruzam com as dela na experiência do lugar, sendo apropriados os elementos não vivenciados:

Eu lembro que ela veio pra cá [avó], eles [avós] tavam lá [...] primeiro eles foram lá pra Vila Cerne, daí eles tinham casa lá na Vila Cerne, mas a minha vó chegou e conseguiu um apartamento e o terreno da casa, que é onde a gente mora. [...] Daí na casa ela fez um barzinho, que tinha um monte de gente e não tinha onde comprar, né?

O CHIM é uma realidade constante na vida de Janaína, tanto nas memórias quanto na materialidade da casa, que preserva aspectos originais. $\mathrm{Na}$ mesma perspectiva, Joana (25 anos, em 07/01/2014) projeta a história do pai como liderança local na sua trajetória política: "Sou militante do Partido dos Trabalhadores, 
filiada desde 2006 e faz parte, passo por dentro da história. [...] Meu pai era o líder e representava todos os moradores dessa e dessa quadra. Então eu sei como se deu toda a história”. O processo de formação e as materialidades do conjunto habitacional são conteúdos formadores dessa paisagem imaginada e vivida que é marca, matriz identitária e elemento a ser superado quando os/as jovens se defrontam com os sistemas de hierarquização social contidos na diferenciação espacial da cidade. Essa relação vai evidenciando o conflito em torno da produção desse imaginário em que as mesmas formas e processos são utilizados em discursos opostos.

As ocupações das áreas verdes apresentam diferenças tanto no que diz respeito às materialidades do Guajuviras (nessas ocupações não há qualquer traço de planejamento, diferentemente do que ocorre no CHIM) quanto ao universo de sentidos e representações. As ocupações das áreas verdes, que começaram no final da década de 1980, continuaram no decorrer das décadas seguintes em inúmeros eventos, resultando desse processo a diversidade de espacialidades do Guajuviras, denominadas "invasões" ou "vilas" (Figura 3). Nesse contexto, "vila” tem um significado próximo ao das noções de periferia e favela, quando referidos a um espaço cujo crescimento ocorreu numa ordem próxima (LEFEBVRE, 2001).

Isso é, de fato, visível no arruamento sem padrão urbanístico, na disposição ou quase ausência de calçadas e na diferenciação entre as moradias e os prédios do conjunto habitacional. Essas ocupações, por serem mais recentes, estão presentes na memória da experiência de infâncias e juventudes que se desenvolveram nessas espacialidades.

As paisagens emergem no cruzamento e dos conflitos em torno da produção simbólica em discursos que ora afirmam essas espacialidades em sua legitimidade, ora situam as diferenças nas distâncias sociais internas ao Guajuviras, reproduzindo a hierarquia espacial da cidade no bairro. Nesse sentido, invasão e ocupação adquirem localmente sentidos próximos; todavia, são produtores e 
Paisagens Vividas e Imaginários Urbanos em Disputa: memórias e paisagens nas narrativas de jovens do Bairro Guajuviras (Canoas/RS)

produtos de alteridades. É um campo em disputa na produção de sentidos dos lugares e, logo, dos agentes, que são definidos por sua localização na cidade. Por isso, os processos relativos ao CHIM recebem o nome de "ocupações", enquanto os processos desenvolvidos nas áreas verdes são chamados de "invasões”.

Figura 3: Paisagem das vilas.

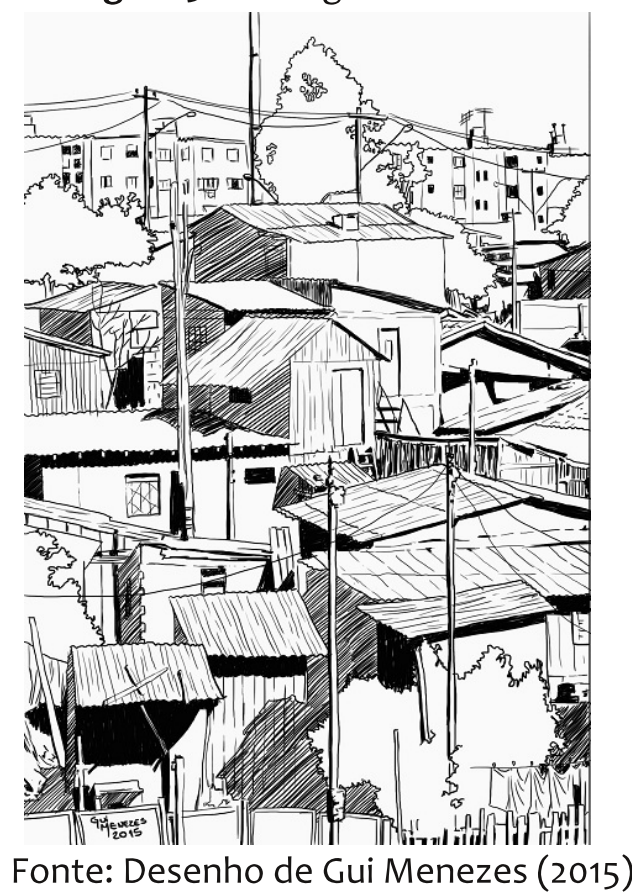

Há diferenças nas materialidades desses processos e na produção do imaginário sobre eles, constituindo o que Lacarrieu aponta como o aspecto pesado (LACARRIEU, 2007) da paisagem ${ }^{5}$. Mas os discursos de criminalização das vilas referem-se também às normativas relativas à propriedade privada, ao prejuízo causado ao desenvolvimento industrial e à defesa da natureza - que correspondem, respectivamente, à referência ao acesso ilegal à moradia, ao argumento de que as vilas afastam as indústrias, que

5. Lacarrieu refere-se ao aspecto pesado e leve contido nos imaginários, sobre materialidades e imaterialidades. Aqui nós transpomos essa reflexão para a compreensão da paisagem. 
seriam a finalidade da área verde da fazenda e, por fim, ao corte dos eucaliptos, identificados como um resquício de área verde na região metropolitana. Esses discursos são reproduzidos também internamente nas distinções entre processos de ocupação e invasões, constituindo-se alicerces da diferenciação entre os eventos do CHIM (subdivido nos denominados setores) e das vilas.

As paisagens (leve e pesada) expressam diferentes articulações, sendo indissociáveis em compreensões que potencializem a identificação da complexidade espacial. Para Santos (2002), na paisagem coexistem formas de diferentes momentos históricos. Suertegaray (1999, p. 51) destaca outro aspecto que diz respeito à junção de múltiplos fatos e fatores, a saber, a "[...] coexistência de objetos e ações sociais na sua face econômica e cultural manifesta”. Por isso, também consideramos a paisagem no plural para evidenciar que o Guajuviras é uma montagem de diferentes paisagens e processos. Isso não fragiliza a potência de pertencimento e identidade que a totalidade do bairro fomenta, em particular, em suas juventudes, que vivenciam intensamente o espaço a partir dos sentidos e das memórias, das práticas espaciais, da identificação com aquele universo material e imaterial, presente e passado.

A distinção entre setores (CHIM) e vilas está presente nas narrativas e formas de ter a experiência do bairro. Ora aparece de forma naturalizada nas concepções e denominações vila e invasão, ora aparece explicitada nas diferenciações, disputas e conflitos em torno da produção do imaginário sobre os processos no uso dos termos "ocupação" e "invasão". Essa relação é evidenciada na narrativa de Rodrigo, morador do CHIM, que identificou, nas ocupações de áreas verdes, formas de depredação da vegetação e dos recursos hídricos restantes. Rodrigo identifica-se, em termos de processo, com a ocupação de 1987:

Teve uma ocupação e invasão. A ocupação foi essa que os prédios não estavam prontos e a construtora não terminou e o povo invadiu. Porém ficaram muitas áreas verdes. $\mathrm{O}$ que aconteceu? O pessoal invadiu essas áreas verdes. Sei lá, em 94- 
Paisagens Vividas e Imaginários Urbanos em Disputa: memórias e paisagens nas narrativas de jovens do Bairro Guajuviras (Canoas/RS)

96. O pessoal confundiu ocupação com invasão. A ocupação foi em 87. A invasão foi 90 e poucos. Não sei dizer a data direito. Engraçado que, se tu for na internet, eles misturam todos os dados. Póem uma imagem da invasão explicando a ocupação. Aí tu olha aquilo e acha que é tudo igual. Mas não tem nada a ver. A invasão é a parte ali da Comtel, ali da Gruta, no Caic. Ali era tudo mata, era lindo ali. Tem uma nascente que até hoje sai água ali em uma casa. Nunca conseguiram tampar, não adianta. Fica saindo ágưa, porque tinha uma espécie de água ali. Era vida, lindo ali. Áí, o pessoal invadiu. (Rodrigo, 27 anos em 12/11/2014)

Por serem mais recentes, as formações das vilas estão presentes nas narrativas dos/as jovens como histórias herdadas e como situações vivenciadas no percurso entre infância e juventude. Primeiro, referidas como consolidação da moradia, são um conteúdo que corresponde tanto às narrativas herdadas (vilas mais antigas, como a São Miguel), como aos processos vivenciados (por exemplo, o percurso entre a escola e a casa, o jogo de bola no campinho, o lugar dos namoros). Segundo, as narrativas remetem à transformação das vilas pelos projetos de regularização fundiária, calçamento e abastecimento regular de energia elétrica e água. Embora os imaginários sobre as vilas as insiram em sistemas hierárquicos que reduzem sua legitimidade, a experiência total ou parcial do processo corrobora com a instrumentalização discursiva de ressignificação e disputa representacional. A produção de estereótipos e estigmas é intensa para as juventudes, objeto privilegiado da associação indiscriminada entre imaginário local e sujeitos. As juventudes necessitam fazer essa reelaboração para, com isso, transformarem os sentidos de suas juventudes comumente remetidas ao desajuste (como uma alusão à desordem de paisagens cuja produção se dá horizontalmente), gerando formas espaciais que destoam das paisagens produzidas pelo planejamento urbano. Márcio localiza-se nessa disputa sem desvincular-se dos sentidos que constroem a imagem pejorativa da vila, mas relocalizando-os afirmativamente como marca identitária. Alice, por sua vez, sendo moradora dos prédios do CHIM e vivenciando as distâncias sociais da metrópole, identifica-se com a questão periférica, remetendo todo o Guajuviras à condição de vila e não apenas as áreas verdes ocupadas: 
Mas daí a gente considera, eu sempre considero uma vila que... "Setor" é uma coisa pra quem... Antigamente falava assim: "ah, ele mora no asfalto, é playboyzinho que tem dinheiro e não sei o quê". E na vila, como posso te dizer? Os favelados, os que vivem na rua, os que é...

[... Por isso que eu acho essa questão de vila e setor, que tem a diferença de quem era playboyzinho e quem não era, mas depois que eu fui vendo não tem nada a ver na verdade. (Márcio, 19 anos, em 24/10/2013)

$\mathrm{Eu}$ acho que a questão de tu te identificar com a periferia. $\mathrm{O}$ Guajuviras é um bairro e tem as suas vilas. E eu me identificar vileira é questão de eu me identificar uma vileira. Na verdade, a maioria do bairro são as vilas, porque, se tu pegar a área da $\mathrm{COHAB}$, não dá a metade. Tanto que os apartamentos quanto as casas dá metade. A maioria é de vila, de ocupação irregular.(Alice, 26 anos, em 06/01/2014)

Vilas, periferias e Guajuviras, em determinados momentos, estão presentes nas narrativas como situações similares. Essas construções e desconstruções aparecem tanto naturalizadas quanto como discursos intencionais. Tem-se a produção em disputa e intencional dos imaginários urbanos. Assim, “[...] las percepciones se transforman en representaciones y éstas, por un proceso simbólico, se constituyen en imaginarios" (LINDON, 2007, p. 8).

Nas vilas mais antigas, a memória é, assim como na ocupação do CHIM, um acervo de histórias compartilhadas e apropriadas. A precariedade das condições de moradia e o sonho da casa própria ${ }^{6}$ estão presentes nas narrativas sobre as motivações da busca dos moradores nessas vilas. São as histórias de família que se tornam memórias sociais, pois em todas as histórias são referidas as mesmas dificuldades decorrentes da moradia improvisada: a precariedade de infraestrutura, os medos vivenciados e provocados

6. Embora o processo seja dividido entre ocupações e invasões, é realizado um intenso comércio de lotes pelos ocupantes iniciais, que adquiriam lotes maiores ou diferentes lotes para o subsequente parcelamento e comercialização. Assim, muitas famílias que participam das ocupações adquirem seus imóveis por mecanismos de comércio irregular, único meio possível para viabilizar a compra da moradia própria por essas famílias. Apesar dessa diferenciação coloquial dos termos, neste texto adotamos o termo "ocupação" como um referente teórico mais adequado por sua abrangência de significado. 
Paisagens Vividas e Imaginários Urbanos em Disputa: memórias e paisagens nas narrativas de jovens do Bairro Guajuviras (Canoas/RS)

pelo risco de despejo, pelas ações institucionais, pela ausência de iluminação. São aspectos do processo de produção das vilas reconhecidos pelos(as) jovens e reproduzidos em suas narrativas. Portanto, a memória espacial abrange desde a densidade de experiências até a apropriação da problemática a partir do compartilhamento de uma história comum. Está presente na paisagem, nas permanências e rugosidades que marcam, mas também nas narrativas compartilhadas, apropriadas e ressignificadas na história própria, que é amalgamada na história espacial.

Foi a conquista de ter a própria residência. Eu entendo, porque eu fiquei ali desde o início, junto com meu pai, fazendo reunióes.[...] Eu moro no Guajuviras há uns 12 anos. $\mathrm{Na}$ Comtel desde que começou. Não lembro a idade que eu tinha, acho que eu tava na $3^{0^{3}}$ série. [...] Todo mundo começou a invadir, e meu pai veio. A gente veio e começou a ficar em barraca. Depois teve a associação e começou a levantar o pessoal da Comtel.(Wagner, 20 anos, em 04/08/2012)

A gente morava na Estância Velhạ. Lá a gente pagava aluguel, mas a gente foi despejado, foi obrigado a sair. A gente morou na rua, uns dois ou três dias. $\mathrm{Na}$ época que meu pai ficou desempregado.(Felipe, 19 anos, em 22/09/2012)

Aí minha mãe acabou namorando meu pai, foram morar juntos e invadiram a São Miguel. Eles fizeram parte da ocupação lá, eu tenho a história dentro de casa, é só a preguiça de saber mais a fundo.(Caio, 18 anos, em 04/06/2013)

Embora os processos de ocupação integrem memórias sociais consolidadas pelas diversas apropriações e experiências, as dificuldades e ausências de estrutura e de transformação do espaço em direção à regularização, não apenas legal, mas também nas paisagens, correspondem a aspectos vivenciados pelos/as jovens. Processos, estruturas, formas e imaginários são nítidos na identificação de paisagens pretéritas e presentes nas descrições e concepções das vilas e do Guajuviras como totalidade.

As referências ao Guajuviras transitam entre escalas, identificando o bairro em sua totalidade como um conjunto integrado das diferentes espacialidades e/ou a partir de suas 
diferenças; as paisagens do Guajuviras marcam fronteiras processuais, concretas e simbólicas. Dessa forma, o local transformase em vilas, periferias, mas também em centralidades, uma vez que as transformações não atingiram apenas as paisagens, mas também a produção dos imaginários sobre elas.

\section{Imaginários em Disputa: Paisagens de Vila, Periferias e Centralidades}

A paisagem emerge a partir do visual e nas concepções e descrições presentes nas narrativas. Essa aproximação entre paisagem e narrativas potencializa a compreensão, para além da forma, do que emerge como materialidade, pois a paisagem está impregnada de sentidos, concepções, visões de mundo, subjetividades, o que não implica uma cisão em relação à forma na medida em que a paisagem vai agregando/integrando as transformações do espaço ao longo do tempo. Assim, é imprescindível operar com os conceitos visando explorar ao máximo sua capacidade explicativa do objeto de estudo. Dessa perspectiva, Verdum (2012, p.18) coloca: "A complexidade da paisagem é o tempo morfológico (forma), constitucional (estrutura) e a funcionalidade, que não pode ser reduzida em partes”.

As diferenças relativas ao período inicial de formação das espacialidades (CHIM e vilas) - referidas acima -integram relatos de transformação dessas paisagens e, consequentemente, atuam como formas de ressignificar e atribuir valor tanto ao bairro quanto aos moradores, em particular às juventudes, que enfrentam também as referências à permanência nas ruas, elemento dessas paisagens e forma de constituição e socialização desses/as jovens (Figura 4). 
Paisagens Vividas e Imaginários Urbanos em Disputa: memórias e paisagens nas narrativas de jovens do Bairro Guajuviras (Canoas/RS)

Figura 4: Paisagem de jovens nas ruas.

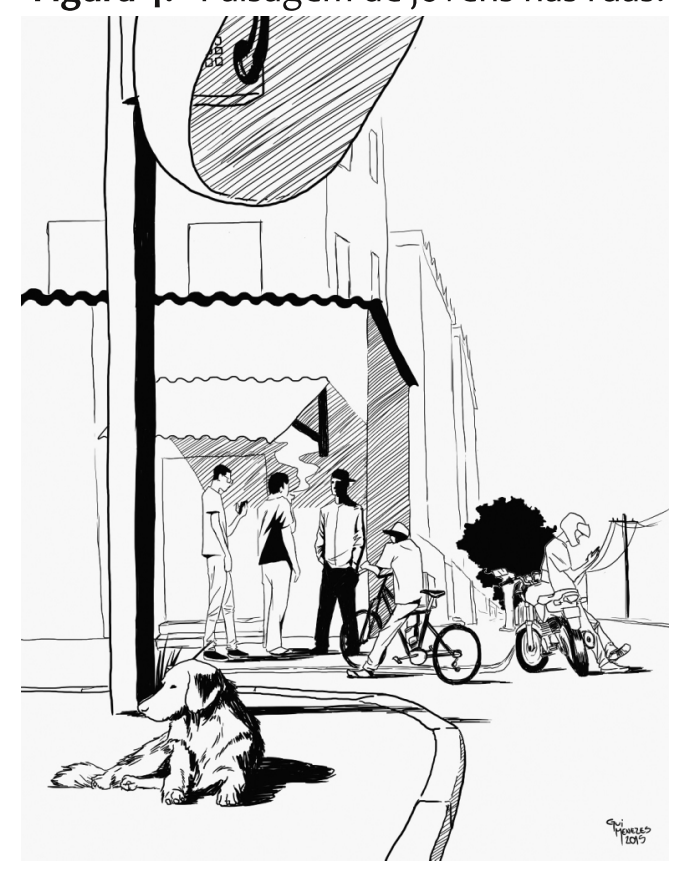

Fonte: Desenho de Gui Menezes (2015)

O Guajuviras é formado por paisagens vividas no embate entre a norma e as táticas microbianas (CERTEAU, 2009). Algumas paisagens, como a das vilas, destoam dos espaços projetados por técnicos e pelo poder público. No entanto, revelam formas de resistência, de fazer uso da cidade segundo as múltiplas necessidades populacionais. Elas são descritas pelos/as jovens em termos de desordem ordenada. Suas transformações, que correspondem ao ingresso na cidade formal, são acompanhadas, ao mesmo tempo, pelas constantes transformações do imaginário.

Pedro, pai de Vítor, vivenciou alguns processos de ocupação das áreas verdes e faz um relato denso da paisagem das vilas no processo de formação: 
A invasão que teve ali, todas as invasões iniciam assim: não tem rua, tem trilhazinhas. Aqui tinham trilhazinhas e tocos no caminho. Aí todo mundo vai e vai pegando um pedaço de terra e não pega uma terra pequena, pega uns 100 metros. Aí vem um parente precisando de um pedaço e vão dividindo. Aí a invasão vai crescendo, porque uma invasão só vinga se tiver bastante gente, com pouca gente não vinga. Aí vão planejando as ruas, aqui vai ter uma rua, mas aí vai crescendo e uma casa da frente vai mais pra trás e assim vai se ajeitando uma invasão. Aí, precisa de água e de luz, que é o gato. Aí puxa a água de um vizinho e não pode brigar, porque aí o vizinho vai cortar a água. $\mathrm{O}$ vizinho que corta aqui a água, todos os de baixo ficam sem água. Aí puxa o fio da AES Sul, que depois vem dizer que não pode fazer isșo. $\mathrm{E}$ aí a invasão vai crescendo. Aí um que tem uma visão cria primeiro uma verduraria, depois coloca também material de limpeza e aí vai crescendo até se tornar um mercadinho. Aí um outro monta uma madeireira, porque o que mais se prẹcisa em uma invasão é de material de construção, madeira, tijolo, cimento, cano, fios... (Pedro, em 16/11/2013)

As juventudes percebem a transformação do Guajuviras e de suas vilas na mudança da paisagem - as melhoras nas moradias, no ordenamento e calçamento das ruas, no abastecimento regular de energia elétrica e água. A ordem próxima é que regulava a distribuição de água e luz, fazendo parte das artes da convivência e conveniência (MAYOL, 2011), conforme o relatado na narrativa acima. As materialidades ao longo do tempo são alteradas, fazendo que as transformações nos sentidos das representações sejam tão conflituosas quanto as das materialidades. Todavia, tem-se um percurso interno de alteração desse imaginário: pela sua adequação à realidade atual, vai sendo apropriado como forma discursiva de ressignificar positivamente essas espacialidades.

Há anos nós esperávamos por pavimentação, por água, por luz, esgoto e agora a gente já tem tudo. Essas coisas todas nós já temos. São coisas que a gente vê que tá evoluindo. Desde que a gente entrou o Guajuviras tem melhorado bastante. (Carolina, 19 anos, em 12/05/2012)

Depois que foi melhorando, com o tempo veio a água, veio a luz, conseguiu fazer a casa. Mas a maior dificuldade foi essa coisa do saneamento básico que não tinha, não tinha água, luz, tinha que buscar a água longe. (Jaqueline, 19 anos, em 27/06/2012) 
Paisagens Vividas e Imaginários Urbanos em Disputa: memórias e paisagens nas narrativas de jovens do Bairro Guajuviras (Canoas/RS)

Esses mesmos símbolos de distinção entre a cidade formal e informal fizeram parte da produção do Guajuviras nos primórdios da ocupação do CHIM. As diferenças estavam na forma homogênea presente no parcelamento dos lotes e na construção das casas e prédios de apartamentos. Mas, no restante do bairro, foram vivenciadas situações similares quanto ao abastecimento de serviços, saneamento e conflitos com o poder público. Constatam-se, de fato, importantes semelhanças entre esses processos, pois ambos correspondem à luta por moradia no contexto metropolitano. Embora alguns elementos estejam presentes em todo o bairro, tornam-se símbolos indicadores da condição de vila e, nas relações com a cidade, significantes do Guajuviras.

Um primeiro ponto de distinção diz respeito à grande heterogeneidade que a paisagem revela: uma maior aproximação com as formas ordenadas almejadas para o espaço urbano nos setores e formas resultantes da formação das vilas. A transformação da moradia é um significante do contexto familiar e do lugar e assentase nas referências de capricho, esforço, evolução, entre outros. Ao mesmo tempo em que essas mudanças da paisagem aproximam essas localidades da cidade formal, contribuem para distanciar as juventudes dos imaginários estigmatizantes associados às vilas e periferias.

Vai de como tu chegou, porque tem gente que invadiu lá e hoje trabalha bem e tem a casa bonita. Vai de como tu chegou lá também. Por causa, que nem minha mãe, minha mãe chegou lá e montou. Minha casa era uma casinhạ, que no caso depois meu pai foi trabalhando e minha mãe foi trabalhando, for crescendo e a casinha ficou pra botar as ferramentas que meu pai tinha. A gente foi crescendo, foi montando a casa. (Caio, 18 anos, em 84/06/2013)

Essas referências são características da configuração socioeconômica associada à população de menor renda. Às condições econômicas somam-se as estratégias de sobrevivência e as relações de proximidade e convivência presentes, por exemplo, nas concepções de bairro e vida de bairro, pois no bairro primam as relações de imediaticidade e pertencimento. Seabra (2013) caracteriza 
a especificidade da vida de bairro pelo predomínio de relações imediatas e diretas pessoa-pessoa, propiciado pelo contato denso resultante das práticas do espaço partilhado. Souza (1989) acrescenta que, para constituir-se como bairro, um espaço deve despertar o sentimento de empatia, o que amplia as condições de configuração de bairros na contemporaneidade. As ruas são apropriadas para a sociabilidade e a visibilidade. São espaços de presença, compondo uma paisagem de materialidades, sentidos, imaginários, sujeitos, animais, etc.

Quem entra na Comtel vê criança, cachorro e carroça. Tem criança na rua, pessoas sentadas na frente da casa. O movimento é intenso. (Felipe, 19 anos, em 15/12/2012)

Essa coisa de vila é muito tumultuado, a São José tem vários pedaços. Tem bagunça, tem funk, agitação, cachorro é o que não falta na vila, cachorro e criança. Aqui na minha casa um dia abriram a rua e ficamos na frente da rua. (Tais, 17 anos, em 08/01/2013)

Vilas, periferias, maloqueiros correspondem a distâncias sociais presentes nas relações que se desenvolvem nos espaços do bairro, da cidade e da metrópole. Entre seus conteúdos estão os modos de vida e práticas do espaço próprias desses bairros de população de baixa renda e que compõem essa paisagem da vida de bairro em que as ruas são movimentadas, apropriadas para o lazer (jogo de futebol, visibilidade, sociabilidades). A formação da identidade juvenil não se dá fora do contexto cotidiano; logo, as heranças de sentidos, os imaginários e as materialidades e suas transformações coadunam-se na percepção de si dos jovens.

Lucas: Ah, pra mim é rua de maloqueiro, as maloqueragens mais. A maioria da maloqueragem mora lá.

Heitor: E difícil tu ver um lixão em um setor. É difícil, pode ver. Pra mim mais o setor é mais assim pessoa que gosta, é mais caprichoso, vamos supor mais caprichoso. E pessoa de vila assim já não... vamos supor assim, e aqueles que uma casa faz a bangu, entendeu?

(Heitor e Lucas, respectivamente 16 e 18 anos, em 17/08/2013) 
Paisagens Vividas e Imaginários Urbanos em Disputa: memórias e paisagens nas narrativas de jovens do Bairro Guajuviras (Canoas/RS)

As juventudes pobres são associadas às paisagens de espaços identificados no senso comum como periferias e vilas. Os corpos, os modos de agir e as formas de constituição dessas juventudes são inseparáveis da paisagem do bairro popular. Logo, as narrativas de transformação vinculam-se à objetividade do processo, mas também aos discursos que repercutem nos(nas) jovens. O imaginário é um campo em constante disputa. Contemporaneamente, não apenas as formas do bairro popular estão contidas no imaginário urbano de depreciação, mas também as formas de apropriação e sociabilidade desenvolvidas nas ruas pelas juventudes.

É bastante nítido o caráter de paisagem matriz presente nas formas de percepção, concepção e ação. As juventudes do Guajuviras identificam-se com o bairro, estabelecem relações de pertencimento fomentadas pelas trajetórias de vida, redes de sociabilidades. Identificam-se com a paisagem como elemento identitário; daí alguns jovens afirmarem que são "vileiros", sendo, então, as materialidades e sentidos da paisagem expressões e conteúdos das formas de reconhecimento desses/as jovens.

Os(as) jovens apontam a relação de suas histórias de vida com a constituição de vínculos espaciais e reafirmam a memória compartilhada por meio de narrativas herdadas e da experiência espacial. Reelaboram os imaginários urbanos sobre o Guajuviras alicerçando-o não apenas nas desigualdades e ilegalidades presentes nas distinções entre bairros, mas também nas diferenças, como a cultura e a valorização dessa memória de luta compartilhada. Hoje, eles são agentes emblemáticos da paisagem do Guajuviras, pois suas ações e experiências estão fortemente relacionadas ao lugar. "Permanecer numa determinada área de modo continuado e repetitivo e compreender uma história da qual se participa, constrói uma experiência que liga o indivíduo ao grupo e a seu respectivo espaço de convivência e uso" (HEIDRICH, 2013, p. 57). Esse uso e apropriação são fortes no bairro popular e são característicos de suas paisagens. 
As transformações nas paisagens do bairro, tanto nos setores quanto nas vilas, bem como o caráter desses locais como espaços de sociabilidade e formação para as juventudes redirecionam as concepções sobre o Guajuviras como uma centralidade viva (Figura 5). Isso torna flexíveis as referências à periferia, mas não à vila, que é um marcador identitário e de distinção espacial fortemente arraigado.

Figura 5: Paisagem de apropriação das praças por jovens.

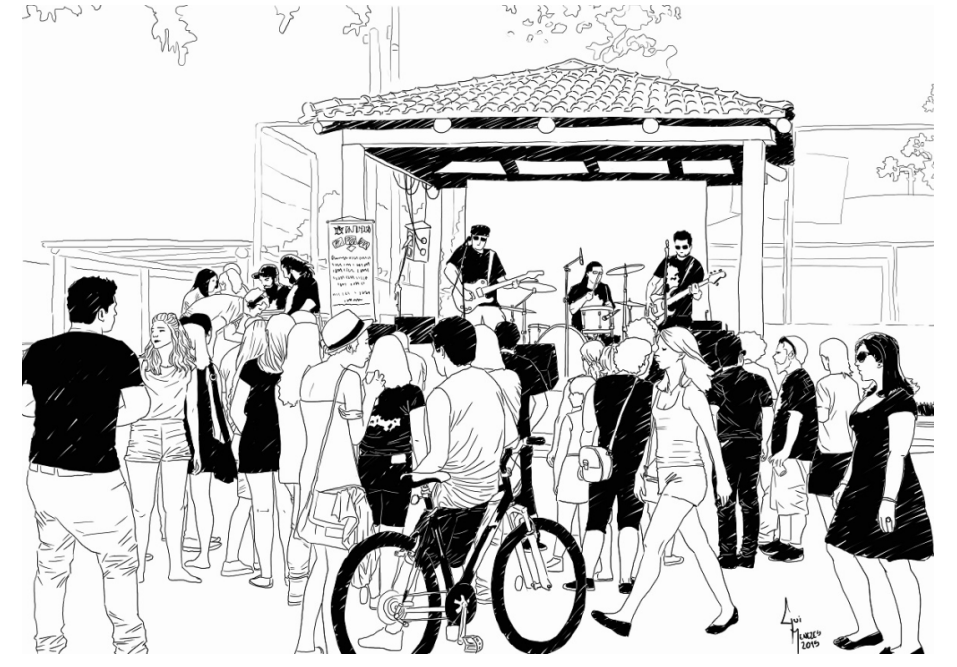

Fonte: Desenho de Gui Menezes (2015)

Os imaginários urbanos sobre espaços periféricos e, nesta análise, sobre as vilas (nesse caso, essa associação se aplicaria a todo o Guajuviras) são combatidos nos aspectos que inserem essas espacialidades nas relações de desigualdade e inferioridade. Como mencionado, as paisagens do Guajuviras revelam espaços intensos, apropriados. O marcador humano não está presente apenas nas construções, mas também nos corpos que se impõem de forma teimosa no urbano contemporâneo, em que as sociabilidades se dariam prioritariamente em espaços institucionalizados e ordenados para isso. A teimosia (CERTEAU, 2009) é característica dessa paisagem, com jovens nas esquinas, ruas, praças. Como consequência objetiva e discursiva, os sentidos que posicionam o bairro à margem são reelaborados: 
Paisagens Vividas e Imaginários Urbanos em Disputa: memórias e paisagens nas narrativas de jovens do Bairro Guajuviras (Canoas/RS)

Eu creio que não deveria ser assim, aqui dentro o Guajuviras é uma metrópole quase. (Jaqueline, 19 anos, em 27/06/2012)

Cidade. Tá quase se tornando uma cidade, pela população. Vou no centro do Guajuviras. O Guaju tem loja que não tem no centro. (Grupo Focal E.M.E.F. Erna Wurth-grupo EJA, em $18 / 10 / 2012$ )

E daí, poxa, o Guajuviras é uma cidade periférica, é quase uma cidade periférica, tem tudo aqui dentro, entendeu? (Ricardo, 25 anos, em 13/09/2013)

Verifica-se que essas paisagens são constituídas por múltiplos patamares de sentidos (COSGROVE, 1998) que, a princípio, aparentam estar em conflito, mas que formam um conjunto coerente nas narrativas. Dessa forma, o Guajuviras é centralidade e vila, simultaneamente, pois ambos são aspectos das disputas acerca do imaginário urbano sobre o local e dos conteúdos de identificação e pertencimento espacial. Quando a periferia é definida por um centro e constituída a partir das desigualdades, são ocultadas as suas diferenças, suas diversidades, sua produção cultural. Essa reprodução de perspectivas hierárquicas reforça o conhecimento produzido no imaginário urbano que associa paisagens e sujeitos à desordem, desajuste e inadequação em relação ao ideário urbano.

\section{Considerações finais}

Os processos de ocupação, a precariedade de infraestrutura, os conflitos com a ordem pública permanecem como referências do Guajuviras tanto nos imaginários urbanos que identificam o local como periferia ou vila quanto na memória compartilhada, a qual associa os processos à luta por moradia e à transformação da paisagem em direção à cidade ordenada. São múltiplas camadas e cruzamentos de sentidos presentes nas formas de ressignificar esses espaços. 
Ainda que as juventudes normalmente não sejam associadas a registros ou referências de memória, ficou evidente na nossa pesquisa o quanto as histórias compartilhadas são conteúdos do espaço, o que se corrobora na consolidação e afirmação dessas paisagens como marca e matriz, como histórias próprias, mesmo não tendo sido vivenciadas em sua integralidade. E, entre as formas de constituição dessa memória, que são múltiplas, foram identificadas a herança e a experiência. A paisagem conta um pouco desse processo nas formas que diferencia setores e vilas, nas recordações das dificuldades enfrentadas quando as ruas não tinham calçamento, na água fraca e nos estigmas resultantes de participar de forma ilegal da cidade, primeiro a partir das ocupações, e depois pelas ligações elétricas irregulares (os gatos, na denominação popular).

Somados aos sentidos e transformações da paisagem ao longo do tempo identifica-se a relevância das práticas de jovens de apropriação de ruas e praças, o que corresponde a um particular conteúdo dessas espacialidades contemporaneamente. É claro que, assim como os processos de ocupação, suas práticas e permanências nas ruas constituem campo em disputa: por um lado, esses jovens são criminalizados e, por outro, conformam paisagens "vivas", nas quais se é espectador e espetáculo. Como consequência, o Guajuviras emerge como centralidade nas narrativas, contradizendo o imaginário urbano que localiza esses jovens agentes à margem social, legal, cultural. Trata-se, assim, de campos em disputa, uma vez que essas paisagens contam histórias, modos de vida, permanências de modos de vida compartilhados e de espacialidades apropriadas horizontalmente.

\section{Referências}

BERDOULAY, V.; TREYTURE, D. L.; SARTRE, X. A. de. La question du sujet et la Géographie. Cahiers de Géographie du Québec, Quebec, v. 54, n. 153, p. 397-418, dez. 2010a. Disponível em: 
Paisagens Vividas e Imaginários Urbanos em Disputa: memórias e paisagens nas narrativas de jovens do Bairro Guajuviras (Canoas/RS)

< http://www.erudit.org/revue/cgq/2010/v54/n153/1005593ar.pdf > Ace sso em: 11 mai.2014.

BERQUE, A.. Paisagem-Marca, Paisagem-Matriz: Elementos da Problemática para uma Geografia Cultural. In: CORRÊA, R. L.; ROSENDAHL, Z. (Orgs.). Paisagem, tempo e cultura. Rio de Janeiro: EdUERJ, 1998, p. 84-91.

CERTEAU, M. A invenção do cotidiano: artes de fazer. 16. ed. Petrópolis: Vozes, 2009.

COSGROVE, D. A Geografia está em Toda Parte: Cultura e Simbolismo nas Paisagens Humanas. In: CORRÊA, R. L.; ROSENDAHL, Z. (Orgs.). Paisagem, tempo e cultura. Rio de Janeiro: EdUERJ, 1998, p. $92-122$.

DI MÉO, G.; BULÉON, P. L'espace social: lecture géographique des sociétés. Paris: Armand Colin, 2007.

DUARTE, K. ¿Juventud o juventudes? Acerca de cómo mirar y remirar a las juventudes de nuestro continente.Ultima Década, Valparaíso, v. $8, \quad$ n. 13 , p. 59-77, set. 2000. Disponível em: $<$ http://www.scielo.cl/scielo.php?script $=$ sci_pdf\&pid =SO718$22362000000200004 \& \operatorname{lng}=\mathrm{es} \& \mathrm{nrm}=\mathrm{iso} \& \mathrm{t} \operatorname{lng}=\mathrm{es}>$. Acesso em: 7 de jul. 2014.

GUAJUVIRAS: "um campo de concentração". Radar, Canoas, 7 maio 1987.

GAMALHO, N. P. Entre dominações e apropriações, reproduções e criações, centralidades e periferias: práticas e espaços de representações de jovens do Guajuviras-Canoas/RS. Tese apresentada ao departamento de Geografia da Universidade Federal do Rio Grande do Sul, Porto Alegre, 2015. Disponível em: < http://www.lume.ufrgs.br/handle/10183/131155>. Acesso em: mar. 2016.

HEIDRICH, Á. L. Território e cultura: argumento para uma produção de sentido. In: HEIDRICH, Á. L.; COSTA, B. P.; PIRES, C. L. Z. Maneiras de ler: geografia e cultura. Porto Alegre: Imprensa Livre, Compasso Lugar Cultura, 2013, p. 52-61. Disponível em: < http://www.compassolugarcultura.com/arquivodoc/FINALManeirasLerGeografiaPDF.pdf > Acesso em: 23 de ago. 2014.

LACARRIEU, M. La 'insoportable levedad' de lourbano. EURE, v. XXXIII, n. 99, p. 47-63, ago. 2007. Disponível em: < http://www.redalyc.org/articulo.oa? $\mathrm{id}=19609905>$. Acesso em nov. 2015. 
LEFEBVRE, H.O direito à cidade. São Paulo: Centauro, 2001.

.La producción del espacio. Madrid: Capitán Swing Libros, 2013.

LINDON, A. La ciudad y la vida urbana a través de los imaginarios urbanos. EURE, v. XXXIII, n. 99, p. 7-16, ago. 2007. Disponível em: < http://www.redalyc.org/articulo.oa? $\mathrm{id}=19609902>$. Acesso em: nov. 2015.

MAYOL, P. O bairro. In: CERTEAU, M.; GIARD, L.; MAYOL, P. A invenção do cotidiano 2: morar, cozinhar. 10. ed. Petrópolis: Vozes, 2011, p. 37-45.

SANTOS, M. A natureza do espaço: técnica e tempo, razão e emoção. São Paulo: EDUSP, 2002.

SEABRA, O. C. L. Urbanização e fragmentação: cotidiano e vida de bairro na metamorfose da cidade em metrópole, a partir das transformações do Bairro do Limão. 2003. Tese (Livre-Docência) Faculdade de Filosofia, Letras e Ciências Humanas, Universidade de São Paulo, São Paulo, 2003.

SOUZA, M. L. O bairro contemporâneo: ensaio de abordagem política. Revista Brasileira de Geografia, Rio de Janeiro, v. 51, n. 2, p. 139172, abr. 1989. Disponível em: < http://biblioteca.ibge.gov.br/visualizacao/periodicos/115/rbg_19 89_v51_n2.pdf >. Acesso em: 28 mar. 2012.

SUERTEGARAY, D. M. A. Cadernos Geográficos. Universidade Federal de Santa Catarina. Centro de Filosofia e Ciências Humanas. n.1, maio de 1999.

VERDUM, R. Perceber e conceber a paisagem. In: VERDUM, R.; VIEIRA, L. F. S.; PINTO, B. F.; SILVA, L. A. P. Paisagem: leituras, significados e transformações. Porto Alegre: Editora da UFRGS, 2012, p. 15-22. 


\section{Políticas Públicas e}

Construção de Um Imaginário Favorável à Instalação da Silvicultura sobre os Areais do Sudoeste Gaúcho

José Carlos Correa Ribeiro

Roberto Verdum 


\section{Introdução}

$\mathrm{O}$ areais constituem depósitos areníticos recentes, pouco consolidados ou arenosos não consolidados, com cobertura vegetal escassa ou inexistente e em constante retrabalhamento por agentes climáticos. A gênese dessas manchas arenosas está relacionada à fragilidade da paisagem em sua totalidade, devido à susceptibilidade das unidades litológicas ao processo de arenização (SUERTEGARAY, 1996). A arenização, por sua vez, corresponde ao processo de formação dos areais. Esse processo morfogenético é visto como "um dos processos mais intensos de degradação ambiental que ocorrem na região da fronteira oeste do estado" (BERTÊ, 2004).

Figura 1: Areal no município de Manoel Viana.

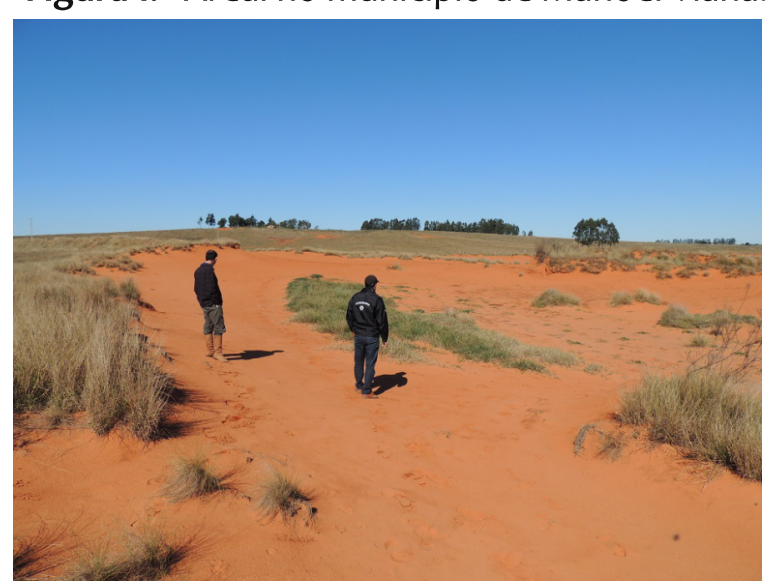

Fonte: Autores (2013).

Foram identificados, em 2004 e 2005, cerca de 3.027 hectares de areais (ANDRADES FILHO; SUERTEGARAY; GUASSELLI, 2006) nos municípios de Alegrete, Cacequi, Itaqui, Maçambará, Manoel Viana, Quaraí, Rosário do Sul, São Borja, São Francisco de Assis e Unistalda (Figura 2). Considerando o percentual do território municipal coberto por areais, os municípios mais afetados são: Manoel Viana (0,44 \%), São Francisco de Assis $(0,28 \%)$, Maçambará $(0,15 \%)$ e Alegrete $(0,12 \%)$. 
Figura 2: Localização dos areais.

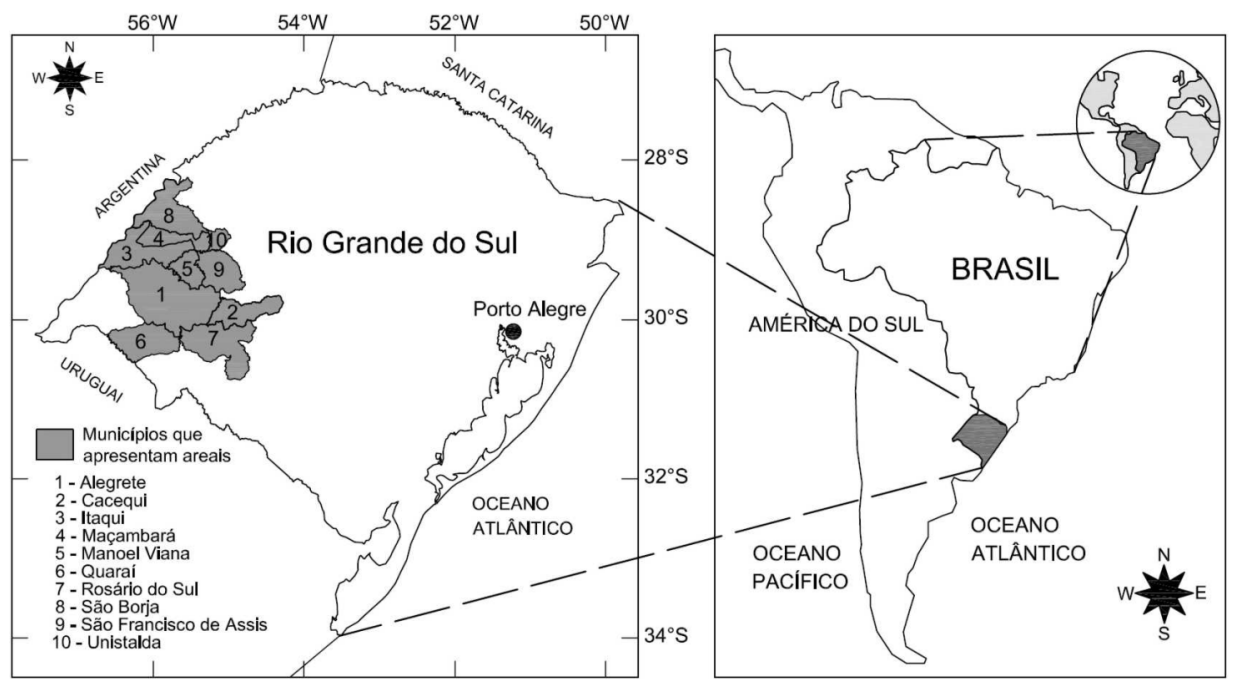

Fonte: Adaptado de Andrades Filho; Suertegaray; Guasselli (2006).

A partir da década de 1970, é propalada a ideia de que existem desertos no sudoeste do Rio Grande do Sul (sic). Dentre os trabalhos científicos que contribuíram para o alarmismo dessa ideia, destaca-se o de Souto (1985) - Deserto: uma ameaça? -, marcado pela ênfase à suposta desertificação de origem antrópica, causada pela expansão da soja nos anos 1970 e também pelas mudanças climáticas.

O contraponto ao paradigma da época é feito por Suertegaray (1987), que resgata o topônimo areal, em oposição à noção de deserto, e demonstra que, no Rincão do Areal (seu estudo de caso em Quaraí), a arenização é um processo natural e antigo, não tendo vínculos com a expansão da soja. Além disso, Verdum (1997) defende a ideia de que o processo de formação dos areais no sudoeste gaúcho não pode ser entendido como desertificação, pois não é decorrente da escassez de água, mas de sua abundância e de seu escoamento concentrado, que dá início aos processos morfogenéticos formadores dos areais.

Entretanto, até chegar ao conceito atual de desertificação como um processo restrito a determinadas zonas climáticas (ONU, 1994) e que exclui a possibilidade de haver esse processo em solo 
gaúcho, o entendimento em relação à desertificação passou por diversas mudanças (VERDUM et al., 2001). À luz de incertezas, principalmente durante as fases descritas por Mainguet (1994), como a "fase percepção exagerada do processo" e a "fase do mito do crescimento do deserto", considerou-se que qualquer área do mundo poderia ser atingida pela desertificação. Em meio a esse contexto alarmista, o estado do Rio Grande do Sul deu início as suas primeiras políticas de combate à desertificação.

Entre 1976 e 1984, a Secretaria de Agricultura e Abastecimento do Rio Grande do Sul implantou o Plano Piloto do Alegrete, unidade experimental que consistia no plantio de espécies arbóreas sobre os areais. Como resultado desse experimento, a espécie que melhor se desenvolvia sobre os areais era o eucalipto. No início da década de 1990, desta vez por iniciativa privada, intermediada pelo governo do estado do Rio Grande do Sul, surgem novas tentativas de recuperação dos areais mediante o plantio de eucalipto e acácia-negra com vistas não somente ao controle da desertificação, mas à industrialização da região. A partir de meados dos anos 2000, a empresa sueco-finlandesa Stora Enso, do setor da celulose, instala bases florestais de grande escala na região de ocorrência dos areais, com o propósito de inseri-los em uma nova matriz econômica com a silvicultura para fins industriais.

Arenização e a silvicultura são temas fortemente associados nas políticas ambientais voltadas à região sudoeste. Enquanto a primeira é apontada como o principal problema ambiental da região, a segunda é, correntemente, privilegiada como solução técnica ideal para esse problema socialmente construído. $\mathrm{O}$ resultado dessas políticas, que se manifesta no espaço, é a controversa e paulatina transformação das paisagens vernaculares do bioma Pampa (ou bioma dos Campos Sulinos), predominantemente campestres, em paisagens exóticas, mediante a introdução da monocultura arbórea (Figura 3). 
Políticas Públicas e Construção de Um Imaginário Favorável à Instalação da Silvicultura sobre os Areais do Sudoeste Gaúcho

Figura 3: Silvicultura no bioma Pampa.

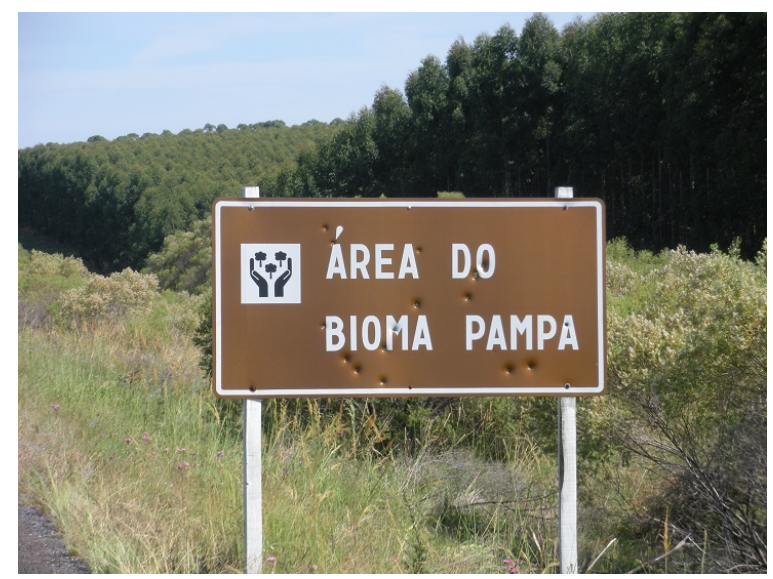

Fonte: Autores (2013).

Buscamos investigar, em sentido amplo, as dimensões subjetivas dessa ampla transformação na paisagem, a partir de uma abordagem humanista. Merleau-Ponty fornece-nos elementos para compreender as dimensões existenciais do espaço ao afirmar que "os padrões de comportamento instalam-se nos da natureza, sendo depositados na forma de um mundo cultural" (MERLEAUPONTY, 1962, p. 147). Do mesmo modo, Eric Dardel afirma que “é nos lugares onde vive e através do manejo dos campos, rios e pradarias [...] que o homem externa sua relação fundamental com a Terra" (DARDEL 1952, p. 47). David Lowenthal estabelece uma dialética entre o imaginário e a materialidade do espaço quando afirma que "as pessoas veem seu entorno através das lentes da preferência e do costume, e tendem a moldar o mundo a partir do que veem.” (LOWENTHAL, 1968, p. 6). Essas ideias trazem, em sua essência, a relação entre o material e o imaterial, entre o objetivo e o subjetivo, entre o espaço cartesiano e o espaço social, entre a paisagem (material) e a cultura (imaterial), cada relação afetando e sendo afetada uma pela outra, sendo "marca e matriz", conforme descrito por Augustin Berque (1998). Do mesmo modo, Nassauer (1995) mostra-nos que a cultura estrutura a paisagem, ao mesmo tempo em que é estruturada por ela. A paisagem construída mostrase, portanto, como manifestação material das imagens que as 
diferentes sociedades têm sobre o ambiente, o qual retroalimenta as sociedades com mais imagens, numa infindável dialética. James Duncan salienta que "as paisagens constituem práticas retóricas que parcimoniosamente fazem surgir na mente do observador uma narrativa completa" (DUNCAN, 2004, p. 113). De modo semelhante, Santos (1997) revela a relação entre a intencionalidade humana e a materialidade do espaço construído, cuja "forma supõe informação para o seu uso e ela própria constitui informação, graças à intencionalidade de sua produção. Como hoje nada fazemos sem esses objetos que nos cercam, tudo o que fazemos produz informação" (SANTOS, 1997, p. 257). Nesses termos, as noções de discurso e ideologia permitem-nos refletir sobre os laços entre as dimensões subjetivas e objetivas do espaço. A materialidade da ideologia é o discurso. A materialidade do discurso é o texto, que pode ser tanto um texto escrito, quanto uma paisagem. Um areal coberto de árvores, mais que paisagem, é um texto, materialidade do discurso, e que carrega uma ideologia. Podemos, então, pensar em paisagens da ideologia. Pensar nas dimensões subjetivas da recorrente transformação da paisagem no sudoeste gaúcho implica, portanto, desvelar o modo como os areais, que compõem as paisagens naturais dos Campos Sulinos, foram apresentados à sociedade como algo nefasto, e o modo como o eucalipto, espécie exótica, mostrou-se algo paradoxalmente benéfico para a natureza. Faz-se necessário investigar a influência das mídias, como na investigação de Torres (2013), e das políticas públicas elaboradas por técnicos e políticos, como investigado por Ribeiro (2015), na formação do imaginário acerca dos areais e da silvicultura.

No presente texto, apresentamos e discutimos uma síntese dos resultados da tese desenvolvida por Ribeiro (2015), na qual se demonstrou que as formulações presentes nas políticas voltadas à arenização no sudoeste do Rio Grande do Sul consolidaram um ideário amplamente favorável aos interesses privados em relação à região (em especial ao setor da silvicultura). Esse ideário desempenha importante papel na construção do imaginário social sobre os areais e a arenização, principalmente entre os técnicos e políticos da região. 
A validação da pesquisa realizada por Ribeiro (2015) passou pela análise do discurso das políticas públicas e privadas voltadas à arenização/desertificação e pelo estudo da análise perceptual dos mediadores locais, técnicos e políticos. Apresentamos aqui o contexto de desenvolvimento das políticas de intervenção no processo de arenização - entre 1975 e 2012 - e a análise do discurso contido nessas políticas, além da visão dos mediadores locais como reflexo da construção do imaginário acerca dos areais.

\section{Contexto das políticas de intervenção no processo de arenização entre 1975 e 2012}

O contexto político e institucional no qual foram desenvolvidas as políticas de intervenção no processo de arenização está dividido em quatro fases: a primeira, entre 1975 e 1987, foi caracterizada pelo fatalismo e pela percepção exagerada em relação ao processo de arenização; a segunda, entre 1987 e 1992, foi caracterizada pelo protagonismo da iniciativa privada nas políticas voltadas à arenização; a terceira, entre 1992 e 2003, foi caracterizada pela busca do conhecimento acerca dos areais e a quase ausência de intervenções no processo; e, finalmente, a quarta, entre 2003 e 2012, foi caracterizada pela consolidação de bases florestais na região de ocorrência dos areais e na metade sul do estado (RIBEIRO, 2015).

Entre 1975 e 1987, são desenvolvidas políticas públicas de intervenção no processo de arenização no sudoeste gaúcho, em sinergia com as políticas federais, à época dos presidentes militares Ernesto Geisel e João Figueiredo. O Plano Piloto do Alegrete (19771984), nesse contexto, foi executado pela Secretaria de Agricultura e Abastecimento do Rio Grande do Sul, à época de Sinval Guazzelli, filiado à Aliança Renovadora Nacional (ARENA), no governo do estado. Esta política tinha como centralidade a Superintendência para o Desenvolvimento da Região Sul (Sudesul) e estava em sinergia com as preconizações do Plano Nacional de Conservação do Solo (PNCS). Esse arranjo institucional garantiu, principalmente durante o governo Geisel, o suporte técnico e financeiro para a consecução 
do Plano Piloto do Alegrete. Esse projeto foi desenvolvido pelo agrônomo João Souto (SOUTO, 1985), técnico da Secretaria de Agricultura e Abastecimento do Rio Grande do Sul, no areal de cerca de $\mathbf{2 0 0}$ hectares conhecido como Deserto do São João, situado no interior da Fazenda Tio João (Distrito São João/Alegrete) (Figura 4). No Deserto do São João, o agrônomo João Souto deu continuidade ao experimento realizado pelo Serviço Estadual de Fixação de Dunas (SEFD), com sede em Tramandaí, que realizou, dentre outras ações, o plantio de espécies florestais (pinus e eucalipto) e a semeadura de Acácia trinervis (SOUTO, 1985, p. 108). Resultou das observações de Souto (1985) a conclusão de que o eucalipto é a espécie vegetal melhor adaptada aos desertos gaúchos.

Figura 4: Plano Piloto do Alegrete em 1985.

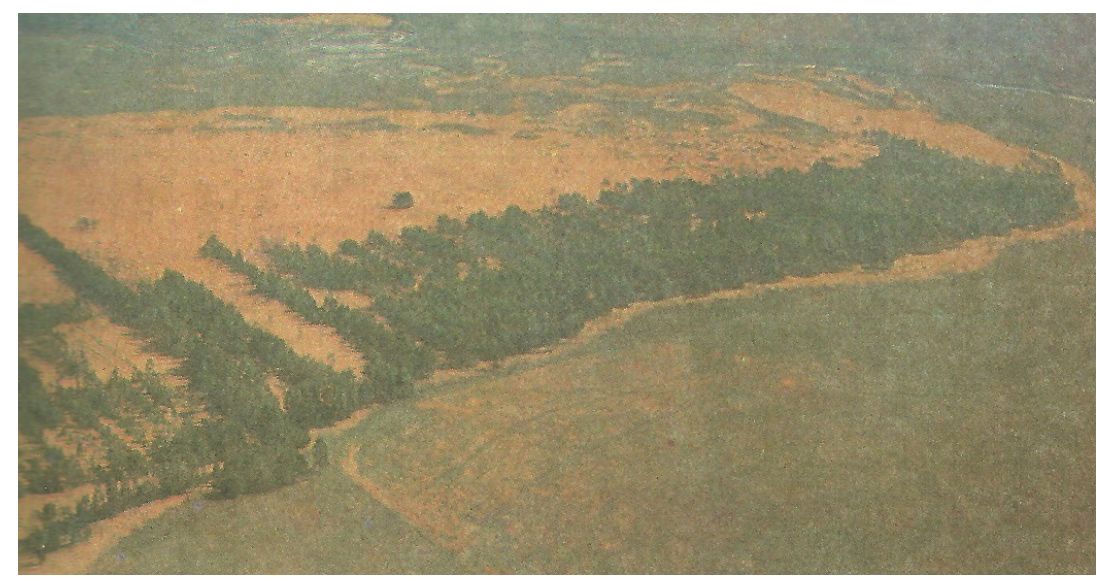

Fonte: Souto (1985).

Por meio do Plano Piloto do Alegrete, o Rio Grande do Sul combatia seus desertos ainda de acordo com a Conferencia das Nações Unidas sobre Desertificação/CONUD (ONU, 1978), especialmente em relação à preconizada urgência do combate à desertificação por meio da introdução da silvicultura de grande escala. Desse modo, o Plano Piloto do Alegrete afirma-se como política pioneira de combate aos desertos por meio da introdução de bases florestais de eucalipto em grande escala. Enquanto política, tanto na forma de documento escrito quanto na forma de experimento materializado no espaço, comunica e estrutura o 
modo de pensar a arenização pelas décadas seguintes.

Entre 1987 e 1992, com mais força em 1990, o referencial técnico produzido pelo Plano Piloto do Alegrete (SOUTO, 1985) é cooptado pelos interesses da iniciativa privada, em especial as empresas do setor florestal, que assumem o papel de financiadores e colaboradores técnicos. Com a crise econômica vivenciada a partir de 1987 e com a política de redução do tamanho do Estado, radicalizada em 1990 durante o governo de Fernando Collor de Mello, a qual resultou na extinção da Sudesul e da Empresa Brasileira de Assistência Técnica e Extensão Rural (Embrater), a centralidade das políticas públicas voltadas à arenização no sudoeste gaúcho é deslocada para o governo do estado do Rio Grande do Sul, à época de Pedro Simon, filiado ao Partido do Movimento Democrático Brasileiro (PMDB) e Sinval Guazzelli, (ex-ARENA e atual PMDB). A solução para a continuidade do Plano Piloto do Alegrete, com Marcos Palombini (PMDB) à frente desse projeto e da Secretaria de Agricultura e Abastecimento do Rio Grande do Sul, foi o fortalecimento das instituições estaduais, como a Associação Riograndense de Empreendimentos de Assistência Técnica e Extensão Rural (Emater/RS) e a Fundação Estadual de Pesquisa Agropecuária (Fepagro), e, simultaneamente, a aproximação de empresas do setor florestal privado, como a Rio Grande Companhia de Celulose do Sul (Riocell) e a Tanac, empresa líder mundial na produção de extratos vegetais de acácia-negra. Além da continuidade do Plano Piloto do Alegrete, as ações contemplavam a distribuição de mudas de eucalipto entre produtores rurais, a instalação de viveiros de mudas e a qualificação técnica de produtores rurais e extensionistas como políticas de expansão das bases florestais dessas empresas na região sudoeste do estado.

A Tanac, em parceria com a Fepagro, deu início ao pioneiro experimento envolvendo a instalação de Sistemas Silvipastoris (SSP), que teriam continuidade na Fepagro, em 2006, e na Empresa Brasileira de Pesquisa Agropecuária (Embrapa), entre 2002 e 2009. O combate aos desertos, mais que uma política de Estado, tornou-se interesse da iniciativa privada, que transferia conhecimentos técnicos 
aos extensionistas e produtores e tinha como principal preconização a introdução do eucalipto e da acácia-negra como instrumentos técnicos capazes de reverter a grave situação da desertificação em solo gaúcho (sic). Essa sinergia entre interesses políticos e econômicos privados e estatais, que consistiu na consecução do Plano Piloto do Alegrete, tinha como principal paradigma científico o experimento realizado por Souto (1985) na primeira etapa do Plano Piloto do Alegrete. Também, nessa fase, havia grande sinergia entre os objetivos do Projeto Florestas e Ambiente Brasil, ou Projeto Floram Brasil (MARCOVITCH, 1990), e o Painel Global sobre Mudanças Climáticas (IPCC). O IPCC, realizado em 1988, em Hamburgo, pressionava o Brasil para se tornar território de implantação de bases florestais de grande escala como forma de reverter as propaladas mudanças climáticas. O Projeto Floram, atendendo ao clamor internacional, tinha como objetivo o plantio do eucalipto com o pretexto de diminuir os níveis de dióxido de carbono na atmosfera e incorporar áreas desmatadas, ou pobres, do ponto de vista agrícola, ao processo produtivo (SUERTEGARAY, 1996).

Foi também após os anos de 1990 que a Emater/RS (fundada em 1977), a partir de seus escritórios municipais, tornou-se a protagonista das políticas públicas de intervenção nos processos de arenização. Havendo herdado os encargos do Projeto Sudoeste, pela extinta Sudesul, e recebendo recursos e encargos do Programa Nacional de Bacias Hidrográficas, Pnmbh (que, em 1987, substituíra o Programa Nacional de Conservação do Solo (PNCS), a Emater tornou-se o principal órgão estadual em extensão rural, atuante em várias políticas como autora ou coautora.

Foi nesse contexto que, em 1992, a Prefeitura Municipal de São Francisco de Assis, em parceria com a Secretaria de Agricultura e Abastecimento do Rio Grande do Sul e com a Emater/RS, intentaram a "superação das dificuldades produtivas no interior do quinto distrito da Vila Kraemer” por meio da adoção do Plano de Manejo Integrado da Microbacia Hidrográfica Sanga da Areia (Emater/RS, 1992). Este plano de manejo, adotando o paradigma do 
Projeto Floram e do Plano Piloto do Alegrete, propunha o plantio de florestas para uso industrial, ecológico e econômico nessa microbacia caracterizada por intensos processos morfogenéticos formadores de ravinas, voçorocas e areais. Algumas dessas propostas de intervenção foram protagonizadas pela Emater, na década de 1990. De acordo com Mósena (2006) e Ribeiro (2008), essa década, marcou a bacia hidrográfica Sanga da Areia por profundas modificações na paisagem local, ocasionadas pela adoção de novas práticas de aproveitamento e conservação do solo. Exemplo disso foi a introdução das pastagens temporárias e exóticas (braquiária e a pangola), dos cultivos de soja (verão) e aveia (inverno) em sucessão e, ainda, a proliferação de capões de eucalipto e pinus - Figura 5.

Figura 5: Plantio de pinus e braquiária sobre um areal.

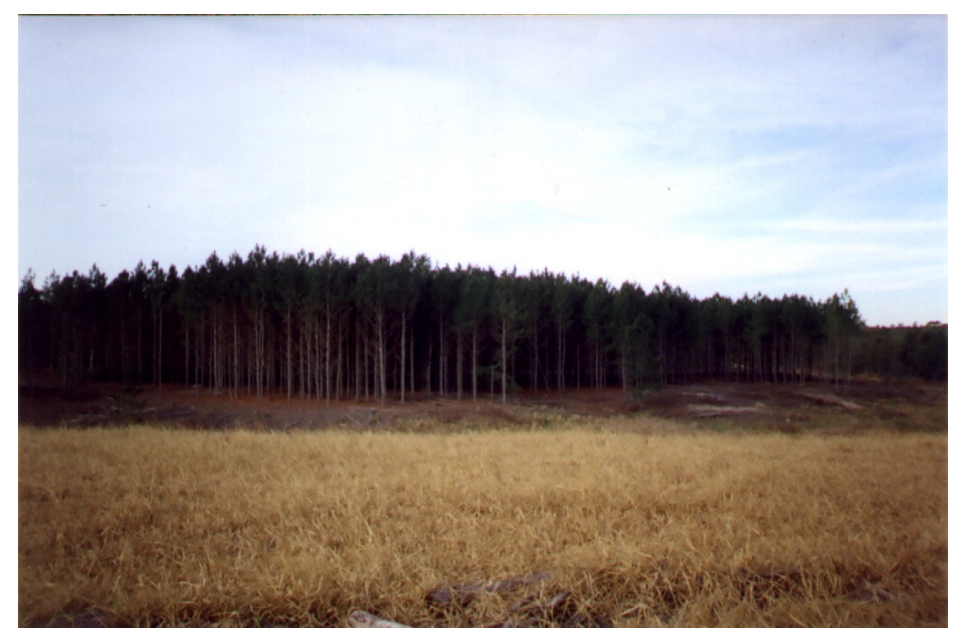

Fonte: Autores (2007).

O período compreendido, aproximadamente, entre o ano de 1992 e 2003 marca a transição de paradigmas científicos sobre a temática da desertificação e arenização. No âmbito das políticas públicas estaduais, foi um período de quase ausência de políticas públicas voltadas para a intervenção nos processos de arenização. Durante os governos federais de Fernando Collor de Mello, filiado ao Partido da Reconstrução Nacional (PRN) já ao final, de Itamar Franco (PRN) e de Fernando Henrique Cardoso, filiado ao Partido da Social Democracia Brasileira (PSDB), desenvolveu-se o arcabouço 
legal voltado para o combate à desertificação, com reflexos nas políticas regionais. Essas mudanças iniciam em junho de 1992, quando o documento resultante da Conferência Rio 92 (ONU, 1992) criava uma distinção entre desertos, definidos como ecossistemas importantes, e desertificação, definida como processo de degradação ambiental causado pela ação antrópica. Em 1994, a Conferência de Combate à Desertificação das Nações Unidas (Unccd) (ONU, 1994) utilizou o índice de aridez para definir não somente as regiões atingidas pela desertificação, mas aquelas contempladas pela colaboração financeira vinda dos países desenvolvidos para o combate à desertificação. Em 1997, o Congresso Nacional aprovou a adesão à Conferência de Combate à Desertificação, adequando sua legislação, por meio da Resolução do Conselho Nacional de Meio Ambiente (CONAMA 238/1997), e elaborando o Plano Nacional de Combate à Desertificação. Essas mudanças refletiram nas políticas gaúchas de combate aos areais, considerados como "áreas de atenção especial", e não mais como áreas em processo de desertificação. Além disso, o conceito de arenização (SUERTEGARAY, 1987), consensual no meio acadêmico, é consagrado no âmbito das políticas públicas, principalmente após a publicação do Atlas da Arenização, de Suertegaray, Guasselli e Verdum (2001). Somando-se a essas mudanças de paradigma científico, jurídico e político, está a diminuta atuação do PMDB gaúcho (pois não estava à frente do governo estadual, ou não desenvolveu políticas voltadas ao controle da arenização) e o predomínio de partidos de oposição, como PDT e PT, resultando na quase ausência de intervenções no processo de arenização.

O período que abrange, aproximadamente, os anos de 2003 a 2012 é caracterizado, no âmbito estadual, pelo retorno do PMDB ao governo do estado e pela atração de projetos de silvicultura em larga escala como principal política desse governo para a metade sul do estado, região mais abrangente que o sudoeste gaúcho. Essa política foi efetivada, já no governo PSDB, com a instalação da empresa Stora Enso, nas áreas mais suscetíveis à arenização da região, acompanhada de um acirrado debate ambiental entre ambientalistas e defensores do projeto de desenvolvimento florestal. No centro 
desse debate, estava a controversa modificação das paisagens do bioma Pampa, ou bioma dos Campos Sulinos, para a instalação de projetos de silvicultura em escala industrial. No meio técnico estatal (Embrapa, Fepagro, Escolas Técnicas) e privado (Stora Enso), proliferaram os experimentos com base em sistemas silvipastoris. A silvicultura, a partir dessa fase, não é mais vista como alternativa de combate aos areais, mas como um sistema agrícola adaptado aos solos frágeis e à tradição pecuarista, capaz de introduzir na metade sul uma nova matriz econômica.

Nesse contexto, foi desenvolvido o Projeto de Pesquisa por Demanda, denominado Validação elou geração de tecnologias em manejo conservacionista para a recuperação de áreas em processo de degradação ou já degradadas, de solos com substrato arenito Botucatu na fronteira oeste (EMATER/RS, 2001). Esse projeto tem como local de implantação o assentamento Santa Maria do Ibicuí (Incra), no interior do município de Manoel Viana. Este projeto foi elaborado pela Regional da Emater em Bagé, em parceria com a Universidade Federal de Santa Maria (UFSM) e a Embrapa, e propunha a instalação do sistema de recuperação de áreas arenizadas com base na instalação de quebra-ventos vegetal (eucalipto) - Figura 6. O projeto propunha, ainda, a repetição desse experimento em 23 municípios da região da fronteira oeste.

Figura 6: Sistema de recuperação de áreas arenizadas proposto pela Emater/RS.

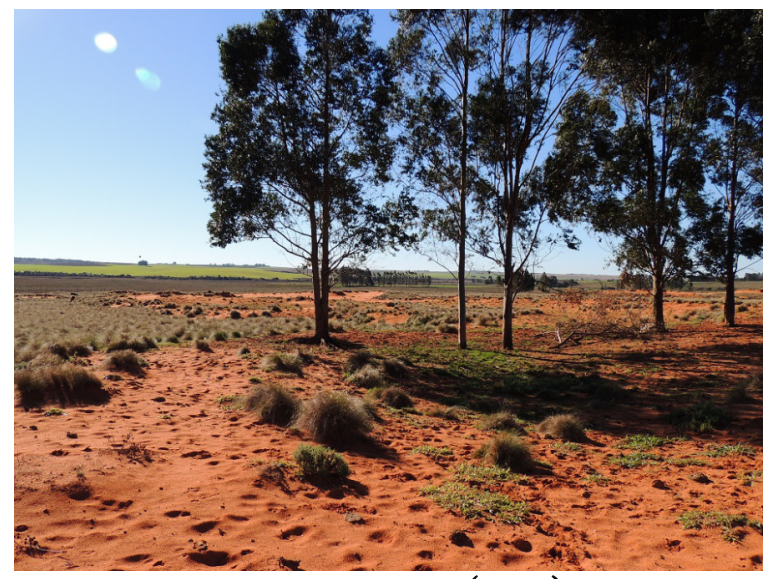

Fonte: Autores (2013). 
Em 1992, a Secretaria de Agricultura de Alegrete realizou tentativas de introduzir uma unidade experimental no Areal Costa Leite, ou Deserto Costa Leite e Jacaquá, nos mesmos moldes do Plano Piloto do Alegrete, mas sem que houvesse continuidade do projeto. Em outubro de 2002, a Secretaria de Meio Ambiente de Alegrete retomou o Areal Costa Leite para desenvolver uma série de novos experimentos e, em 2004, a recuperação do Costa Leite recebeu novo impulso por iniciativa das secretarias de agricultura e de meio ambiente do município, capitaneadas por políticos do PMDB, em conjunto com a Emater e agricultores, e com a colaboração da UFSM e da Organização Não Governamental Fundação Maronna. A iniciativa consistiu na recuperação pelas bordas, plantando-se eucalipto nas bordas do areal (Figura 7), do mesmo modo que preconizara Souto (1985) no Plano Piloto do Alegrete.

Figura 7: Recuperação do Areal Costa Leite/Alegrete.

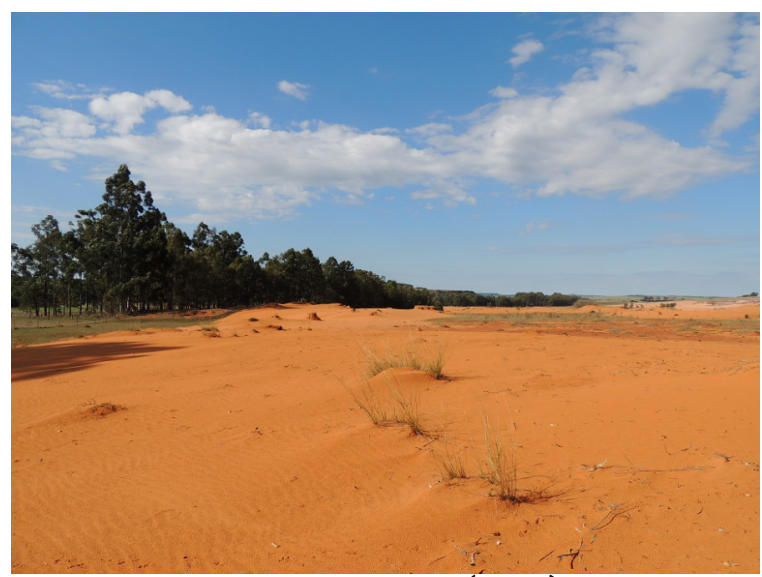

Fonte: Autores (2013).

O experimento no Areal Costa Leite, que contou com, além do plantio de eucalipto, programas de educação ambiental e atividades de campo, foi considerado referencial técnico a ser copiado pelos prefeitos de Cacequi, São Francisco de Assis, Manoel Viana, Maçambará, São Borja, Rosário do Sul e Alegrete, os quais se reuniram para discutir e elaborar o Plano de Gerenciamento da Arenização do Sudoeste Gaúcho (SOBROSA et al., 2003). 
A fase que compreende os anos entre 2003 e 2012 caracterizou-se, ainda, pela proliferação dos sistemas silvipastoris, em que a pecuária e a silvicultura são consorciadas em solos suscetíveis à arenização. A partir do início dos anos 2000, a Embrapa Clima Temperado, de Pelotas, passou a trabalhar em um projeto amplo, denominado Projeto Fronteira Oeste, em parceria com técnicos da Universidade Federal de Santa Maria e da Fundação Maronna (CASSOL, 2004). Unidades de observação foram instaladas em Alegrete no ano de 2002 e, posteriormente, em 2009 (Figura 8). Os resultados desses experimentos foram publicados sob o título Sistemas Silvipastoris: Estratégias para o Desenvolvimento Rural Sustentável para a Metade Sul do Estado do Rio Grande do Sul (RIBASKI et al., 2005).

Figura 8: Sistemas silvipastoris na Estância Sá Brito I.

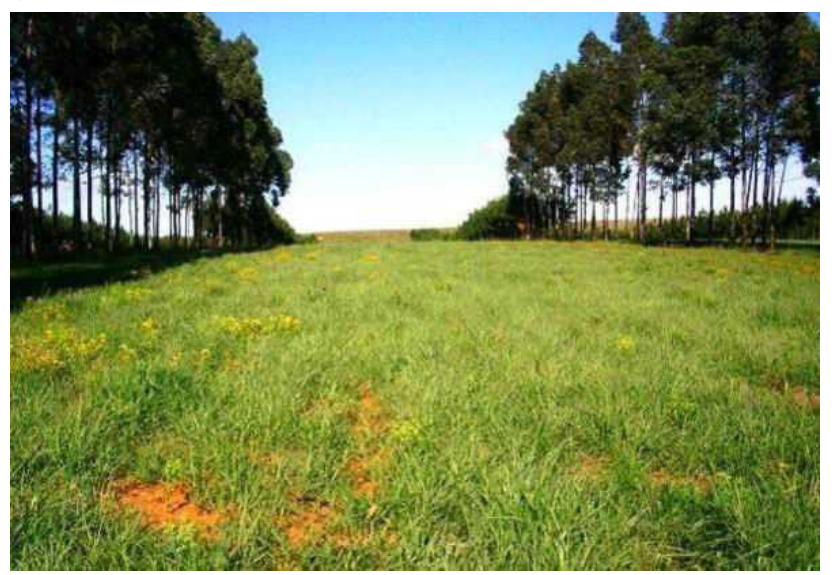

Fonte: RIBASKI (2005).

Em junho de 2006, o presidente da FEPAGRO, Marcos Palombini (PMDB), anunciou o projeto de combate à arenização do solo gaúcho (FEPAGRO, 2006). Já em agosto de 2007, a Fepagro iniciou o projeto Avaliação Inicial do Comportamento de Espécies em Solos Suscetíveis à Arenização no Sudoeste do Rio Grande do Sul (FEPAGRO, 2008), o qual consistiu em avaliar a sobrevivência e adaptação do eucalipto e da acácia-negra em solos arenosos. Foi instalada uma unidade experimental de 12 hectares, no distrito de São João, Alegrete. Esse experimento foi apresentado como exemplo 
de recuperação de areal, em 2008, durante as audiências públicas da Comissão Especial sobre Arenização da Assembleia Legislativa do Estado do Rio Grande do Sul (ASSEMBLEIA DO RS, 2008).

No município de Maçambará, as principais ações em relação aos areais tiveram como protagonistas a empresa suecofinlandesa Stora Enso, a Escola Técnica Estadual Encruzilhada, o Departamento Municipal de Meio Ambiente e o escritório municipal da Emater. As ações fomentadas pela empresa de celulose Stora Enso iniciaram em 2007, quando da instalação das áreas para aproveitamento industrial, na bacia do rio Puitã, localidade da Encruzilhada/Maçambará, caracterizada como uma das áreas mais afetadas pela arenização neste município. As ações contemplam a distribuição de mudas de eucalipto entre os produtores rurais e o desenvolvimento de um experimento em parceria com a Escola Técnica Estadual da Encruzilhada em que é desenvolvido um sistema silvipastoril no qual as plantas clones de eucalipto são consorciadas ao plantio de forrageiras (Figura 9).

Figura 9: Aveia e pastagens nativas no sistema silvipastoril em Maçambará.

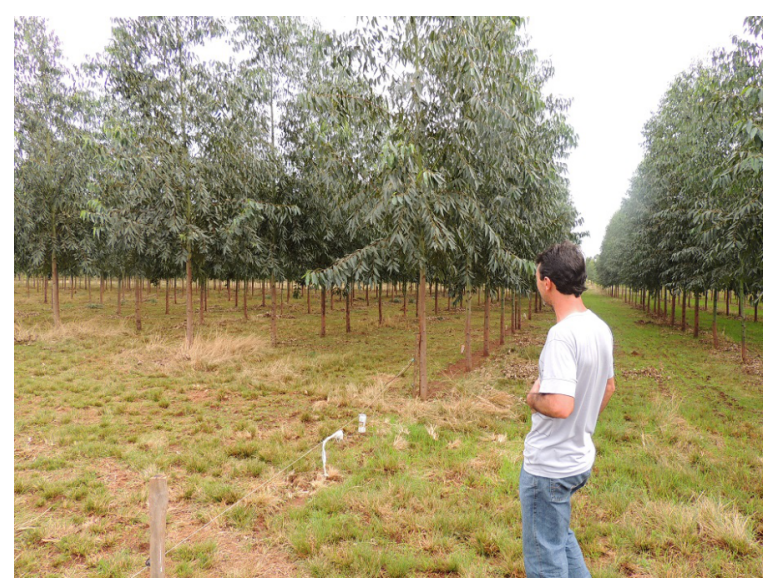

Fonte: Autores (2013). 
Finalizando esse período (2003 a 2012), temos o Projeto de Recuperação de Área Degradada (EMATER/RS, 2012), elaborado para o assentamento Santa Maria do Ibicuí, Manoel Viana/RS, por contratação do Instituto Nacional da Colonização e Reforma Agrária (INCRA), mantenedor do Projeto de Assentamento. Exceção à regra, o PRAD não preconizou plantio de espécies arbóreas, mas a introdução de espécies adaptadas, dentre elas o capim torpedo (Panicum repens L.) e o tremoço nativo (Lupinus albescens), visando recuperar não mais os areais, mas as áreas em processo de arenização no assentamento.

Essas e outras políticas desenvolvidas entre 1977 e 2012 foram impulsionadas pela forte vontade política de membros do Partido da Mudança Democrática Brasileira (PMDB), entre eles os governadores Sinval Guazzelli (PMDB e ex-Arena), Pedro Simon (PMDB) e Germano Rigotto (PMDB), os quais contaram com o forte protagonismo de Marcos Palombini (PMDB), que esteve à frente de várias entidades, como a Secretaria de Agricultura e Abastecimento do Rio Grande do Sul, o Arranjo Produtivo de Bases Florestais e, inclusive, a Fepagro (como presidente). Durante os períodos em que Marcos Palombini (PMDB) não esteve à frente de órgãos do governo do Rio Grande do Sul, praticamente não houve elaboração de políticas públicas de intervenção no processo de arenização, no âmbito estadual. Não se pode negligenciar, portanto, o protagonismo de Marcos Palombini na produção do discurso e na orientação das ações de intervenção no processo de arenização no sudoeste do estado, as quais são embasadas, essencialmente, nas formulações técnicas do Plano Piloto do Alegrete, executado pelo agrônomo João Souto e que materializa uma gama de enunciados.

A partir de 2007, com o fim do governo estadual de Germano Rigotto (PMDB) e a entrada de Yeda Crusius (PSDB) no governo do estado, o protagonismo de Palombini (afastado da presidência da Fepagro em 2007, e falecido em 2009) é paulatinamente substituído pelo protagonismo do deputado Berfran Rosado (PPS). Colocando-se, simultaneamente, na liderança da Frente Parlamentar Pró-Florestamento, também conhecida como "a bancada da celulose", e da Comissão Especial sobre Arenização no 
Sudoeste do Rio Grande do Sul (ASSEMBLEIA DO RS, 2008), o deputado Berfran estabeleceu a ponte entre o controle da arenização e os interesses das empresas silvicultoras, em especial da empresa sueco-finlandesa Stora Enso. As principais formulações científicas cooptadas por Berfran Rosado para corroborar seus interesses econômicos e políticos foram: a própria Stora Enso; a Fepagro, que participava ativamente no Arranjo Produtivo de Base Florestal; e o professor Foletto Eltz, da UFSM; ao mesmo tempo em que negligenciou as formulações de Suertegaray contidas no Atlas da Arenização (SUERTEGARAY; GUASSELLI; VERDUM, 2001). O protagonismo de Berfran Rosado fica mais evidente quando, após ser nomeado presidente do Conselho Estadual de Meio Ambiente, o deputado aprova uma versão do Zoneamento Ambiental para a Silvicultura (CONSEMA, 2009), considerada “mais agradável aos investidores estrangeiros”. Esse documento veta as atividades da Stora Enso sobre os areais consolidados, por força de influências do Atlas da Arenização (SUERTEGARAY; GUASSELLI; VERDUM, 2001), editado pela Universidade Federal do Rio Grande do Sul (Ufrgs) em coautoria com o Centro Estadual de Sensoriamento Remoto e Meteorologia (Cesrm), e, ainda, por força da mudança de paradigma promovido pela resolução Conama 238/97 e pela Convenção de Combate à Desertificação (ONU, 1994), que excluíam o Rio Grande do Sul do escopo do acordo entre o Brasil e as Nações Unidas para combate à desertificação. Tem-se, então, como principal política voltada à arenização, nos anos 2000, a Comissão Especial sobre Arenização da Assembleia Legislativa do RS (ASSEMBLEIA DO RS, 2008), liderada por Berfran Rosado (PPS) e Rossano Gonçalves (PDT). Essa política preconizou o plantio de eucalipto como técnica de controle da arenização, ao mesmo tempo em que reivindicou aplicação, no sudoeste gaúcho, de recursos financeiros destinados à desertificação do semiárido nordestino por países desenvolvidos que faziam parte da Convenção de Combate à Desertificação, da ONU. Arenização, desertificação e silvicultura (eucalipto), ainda no final dos anos 2000, mostram-se, portanto, assuntos indissociáveis, especialmente quando há interesses políticos e econômicos em jogo. 


\section{O ideário construído pelas políticas voltadas à arenização e mediação local}

A Teoria da Análise do Discurso, fundamentação teóricometodológica utilizada na análise dos documentos elaborados no âmbito das políticas voltadas à arenização, no sudoeste gaúcho, e à desertificação, no âmbito das Nações Unidas, demonstrou a transversalidade que conecta políticas desenvolvidas em diferentes contextos, demonstrando o caminho trilhado pela ideologia manifesta no discurso resultante das décadas de elaboração dessas políticas. Essa análise abarca as políticas voltadas à arenização no sudoeste gaúcho elaboradas entre 1975, quando o Rio Grande do Sul passa a ser visto como suscetível à desertificação, e 2012, ano do último documento localizado. Essas políticas consistem, majoritariamente, nas unidades experimentais instaladas nos municípios de Alegrete, Manoel Viana, São Francisco de Assis e Maçambará, ou nos projetos para captação de recursos financeiros para o desenvolvimento de técnicas de manejo de solos suscetíveis à arenização, ou já arenizados. Desenvolvidos por instituições de Estado - como a Emater/RS; a Fepagro; a Embrapa; as secretarias municipais e estaduais; as empresas do setor privado, como a Stora Enso e Riocell; e as organizações não governamentais, como a Fundação Maronna -, esses projetos tinham como objetivo a divulgação de tecnologias nos demais municípios da região sudoeste. Seus resultados e aprendizado compõem uma base de conhecimento técnico sobre a arenização em solo gaúcho. Essas políticas foram influenciadas pelas políticas de combate à desertificação, razão pela qual incluímos a análise de políticas elaboradas no âmbito das Nações Unidas. Em um segundo momento, a análise perceptual dos mediadores locais, em relação à arenização no sudoeste do Rio Grande do Sul, investigou o imaginário desses intervenientes e suas filiações ao discurso construído nas políticas analisadas. Esse momento da pesquisa, realizado entre 2013 e 2014, contemplou enquetes com extensionistas rurais, secretários municipais, 
vereadores, membros de ONGs, comitê de bacia hidrográfica, entre outros, nos municípios em que ocorre a arenização e em outros da região.

Durante as décadas em que a arenização, no sudoeste do Rio Grande do Sul, esteve na pauta das questões ambientais gaúchas, consolidou-se um ideário, uma "formação discursiva", termo que tomamos de Orlandi (2007), ou, ainda, um "reservatório de sentidos”, nos termos colocados por Berguer e Luckman (2004), determinante para as políticas, ao mesmo tempo em que é determinado por elas. A descrição do conjunto de enunciados (discursos) presentes nos documentos analisados, bem como a "regularidade em uma mesma formação discursiva" (FOUCAULT, 2004), favoreceu identificar a existência de uma transversalidade (interdiscurso) que conecta as políticas públicas (e privadas) voltadas tanto à arenização quanto à desertificação, em diferentes escalas espaciais (do global ao regional) e temporais (dos anos 1970 ao tempo presente).

Passados, aproximadamente, 40 anos desde que o mundo e o Rio Grande do Sul descobriram os "desertos", ainda constata-se uma regularidade de enunciados que filia as políticas mais recentes àquelas elaboradas na década de 1970. Nessa década, as políticas internacionais de combate à desertificação, engendrando-se à crise socioecológica da década de 1970, continham um forte viés agronômico, em especial o novo ideário agronômico. Em termos específicos, referimo-nos a um novo ideário agronômico de bases ecológicas e influenciado pela Teoria Geral dos Sistemas, denominado "agronomia global [...], voltada a gestão, conservação e recuperação do meio ambiente global” (ALMEIDA, 2000). Esse novo viés, do final do século XX, visava, ainda, superar as consequências perniciosas da "agronomia moderna”, do século XX, descrita por Almeida (2000) como sendo baseada na lógica da produção em massa e na modernização da agricultura como forma de suplantar os limites impostos pela natureza. 
Nesse contexto, a desertificação (de lá) e a arenização (de cá) são processos reduzidos, à luz do paradigma sistêmico, a uma tríade de problemas considerados ecologicamente relacionados e que devem ser combatidos com urgência: fome - seca - desertificação. A fome, problema de consequências humanas, agrava-se pela desertificação, que por sua vez agrava-se com a seca originária das mudanças climáticas (globais) e das ações humanas (locais e globais). Esse ciclo se retroalimenta na medida em que amplia, indefinidamente, o problema. A desertificação, nesses termos, ganha tom alarmista e fatalista, na medida em que, supostamente, é capaz de engolir as terras agriculturáveis em regiões inteiras, uma vez que as mudanças climáticas ampliam as zonas suscetíveis à desertificação.

Tem-se, então, como reflexo regional desse contexto a produção de sentidos em relação ao processo de arenização no sudoeste do Rio Grande do Sul, que pode ser traduzido e resumido nas seguintes noções: a arenização é um processo análogo à desertificação; é reflexo do desequilíbrio ambiental e dos ecossistemas; é uma anomalia causada pela perturbação humana no equilíbrio natural; é um problema ambiental que reduz a produtividade biológica (biomassa) e agrícola (alimentos); causa prejuízos econômicos e sociais que conduzem ao empobrecimento da região; e, por fim, coloca em sério risco a sobrevivência da sociedade.

A esse ideário dos anos 1970 acrescentaram-se formulações em relação à gênese da desertificação no contexto das Nações Unidas, entre 1992 e 1994, e da arenização no sudoeste gaúcho, a partir de 2001. No âmbito estadual, a diferenciação entre os areais mais antigos, considerados de origem natural, e aqueles em formação, em virtude de ação antrópica, autorizava a intervenção e uso dos areais de origem antrópica, causando nova orientação no âmbito das políticas públicas e privadas. Em ambos os contextos, tanto o da arenização quanto o da desertificação, considerou-se a combinação de fatores naturais e antrópicos na gênese dos processos, assim como deu-se mais destaque aos fatores locais. Entretanto, ainda recai um forte estigma sobre os produtores rurais, 
considerados, no âmbito das políticas analisadas, tecnologicamente atrasados, irracionais e inadequados em relação ao seu modo de uso do solo. Fatores naturais, como a pedologia, são utilizados, especialmente, para especular as áreas suscetíveis aos processos, no caso da arenização, e, inclusive, justificar a abrangência espacial de determinadas políticas públicas, ou a necessidade de intervenção. Acrescentam-se, a esse ideário, ainda, as noções de que: a predisposição natural não é causa primeira, mas sim, a pressão humana sobre as áreas de fragilidade natural; e o solo exposto ao vento, devido ao manejo inadequado, dá início, e continuidade, aos processos de arenização e desertificação, ampliando esses processos até os limites da unidade de solo considerada frágil.

A esse conjunto de enunciados, relacionados à concepção do processo de arenização, associam-se formulações voltadas à intervenção no processo de arenização, corroborando a ideia de que às estruturas do pensar (e do imaginar) vinculam-se as estruturas do agir.

Dentre as principais ações preconizadas, no âmbito das políticas voltadas à desertificação e também à arenização, pode-se elencar: o urgente combate/controle dos areais e/ou desertos, evitando a resultante degradação ambiental, social e econômica da região afetada ou suscetível; a recuperação dos areais e desertos, ou de sua capacidade produtiva e econômica; e a conservação do solo, com base nos preceitos do desenvolvimento sustentável.

As ações específicas incluem conservar o solo e sua capacidade produtiva, ou seja, aplicar modernas e adequadas técnicas de manejo e uso do solo, diferentes daquelas praticadas pelos produtores rurais, considerados tecnologicamente atrasados, irracionais e inadequados. A conservação do solo inicia, então, com a conscientização desses agricultores e a com a qualificação das instituições de extensão rural, assim como dos gestores e políticos, que têm que estar a par da gravidade do problema.

As modernas técnicas a serem utilizadas na conservação do solo consistem em: proteger o solo da ação dos agentes erosivos, $\underline{\text { principalmente o vento; proteger o solo do vento, instalando }}$ 
cortinas vegetais por meio de espécies de crescimento rápido, como o eucalipto; e introduzir plantas de cobertura nas áreas frágeis de solos arenosos originários do arenito Botucatu, que evitam a exposição do solo desprovido de cobertura vegetal em razão da pressão humana de uso inadequado do solo. As plantas de cobertura incluem pastagens exóticas, como a braquiária, mas, recentemente, recomenda-se o tremoço nativo.

Em relação à proposição do plantio de eucalipto na forma de grandes bases florestais, o ideário consolidado reforça a noção de que: em toda a região, não somente no sudoeste gaúcho, mas em toda a metade sul, e mesmo que esses solos frágeis ainda não estejam sofrendo processos de arenização, deve-se optar pela silvicultura do eucalipto, em consórcio com a pecuária, que é vocação da região. Desse modo, garante-se a conservação dos recursos naturais e agregase valor econômico à propriedade. Essas palavras sintetizam o discurso presente ao longo das políticas públicas voltadas à arenização no sudoeste gaúcho.

Embora esse discurso esteja presente na maioria das políticas públicas desenvolvidas no Rio Grande do Sul, cabe salientar que esse discurso não se veicula de modo espontâneo. Há, pois, uma forte vontade política de atores sociais que, agindo por meio de instituições, transferem esse ideário na medida em que as tecnologias preconizadas coincidem com os interesses políticos e, principalmente, com os privados. Os acordos de cooperação entre as instituições favorecem a transferência de tecnologias e de conhecimentos em relações que variam da oferta de recursos financeiros até a coautoria no desenvolvimento de projetos. Desse modo, pode-se afirmar que as políticas voltadas à intervenção no processo de arenização estabelecem conexões institucionais transescalares.

Ao descrever e analisar o discurso contido nas políticas públicas, bem como o meio técnico e político de origem e difusão desse discurso, o qual cria visões depreciativas em relação aos areais, ao mesmo tempo em que prescreve ações técnicas, como o plantio de eucalipto, acopladas a interesses econômicos e políticos, 
demonstramos que, mais que objeto natural (ou de estudo das ciências naturais), a arenização consiste em objeto político, cuja problematização é construída unilateralmente. Não raro, as formulações construídas acerca dos areais difundem-se no senso comum, fazendo que as formulações da elite política e técnica coincidam com aquelas dos produtores rurais. Essa transferência, na escala quotidiana, ocorre com a mediação, principalmente, de extensionistas rurais, de políticos locais, de ONGs, de sindicatos rurais, de comitês de bacia hidrográfica e, ainda, de técnicos das próprias empresas silvicultoras. Comumente, esses mediadores locais prestam aconselhamentos ou assistência técnica, ou atuam publicamente em audiências públicas e outras reuniões que têm a arenização na pauta.

Dentre os mediadores locais, ou seja, os participantes/respondentes de nossa pesquisa, constata-se uma forte coincidência entre as formulações presentes nas políticas públicas (e privadas) analisadas, cuja regularidade atrela-se à existência do discurso. Acreditam os respondentes da pesquisa que os areais (ao lado das ravinas e voçorocas e do assoreamento dos recursos hídricos) consistem no principal problema da região e que, ainda, esse problema é muito preocupante ou, em alguns casos, é preocupante. Muitos ainda acreditam na existência, real ou potencial, de desertos na região. Em outros casos, reconhecem a arenização como processo análogo à desertificação. Em sua maioria, entendem que a arenização tem origem natural, mas que a ação antrópica é a principal intensificadora dos processos de ampliação dos areais. Segundo uma grande parcela dos respondentes, essa ampliação está a acontecer. Em outros casos, em que se instalaram as medidas preconizadas, estão a diminuir. Acreditam, ainda, que a arenização (processo que amplia os areais) ocorre devido a agentes antrópicos (mecanização da agricultura e pastoreio) e ao vento. A partir dessas percepções, preconizam, basicamente, a introdução de árvores exóticas (eucalipto, pinus e acácia-negra) e a cobertura do solo com forrageiras (braquiárias, pensacola, pangola, etc.), visando, principalmente, evitar exposição do solo ao vento e ao pisoteio animal. 
Interpelados por esse discurso, nossos respondentes constituem-se em sujeitos, passando a mediadores desse discurso que desvaloriza os areais, estigmatiza o produtor rural e aponta a silvicultura como solução para um problema construído socialmente. Podemos, ainda, refletir de que modo esses respondentes da pesquisa foram interpelados pelo discurso, ou em que momento sofreram mediações. Fontes variadas de informações acerca dos areais chegaram a esses respondentes, como as mídias (conforme demonstrou Torres, 2013), a assistência técnica local, a conversa com amigos e vizinhos, a participação em cursos técnicos ou agrícolas, etc. Mas não se pode desprezar o fato de que a maioria dos nossos respondentes é graduado nas ciências agrárias (Agronomia, Técnico Agrícola, Engenharia Florestal) e, ainda, que a maioria performou ou atua junto às entidades que performaram as políticas públicas (e privadas) de intervenção no processo de arenização. Temos que o imaginário dos respondentes da pesquisa é representativo, no tempo presente, de um discurso de forte viés agronômico (o novo ideário agronômico, ou "agronomia global", como descreveu Almeida, 2000) perpetuado e cristalizado por instituições ao longo de, pelo menos, quatro décadas em que os desertos gaúchos se tornaram um problema para a sociedade e uma oportunidade para a iniciativa privada.

\section{Considerações finais}

Podemos concluir que as formulações científicas internacionais sobre desertificação ainda estão presentes nas políticas públicas voltadas à arenização no Rio Grande do Sul. As conexões institucionais multiescalares cristalizam, através dos tempos, pela memória, uma ideologia marcada por formulações técnicas específicas. O meio político busca o respaldo nessas formulações científicas, por melhor atenderem seus interesses políticos. $\mathrm{O}$ discurso científico, como descrito por Foucault (2004), confere poder ao discurso político. O viés naturalista/científico adotado pelas políticas públicas prioriza o paradigma da "agronomia global", 
que reconhece os areais/desertos como anomalias ou perturbações ecológicas. Atrelado a esse paradigma está o pseudoconservacionismo do solo que, sob o pretexto de recuperar a natureza, ou o equilíbrio ecossistêmico, conserva apenas as capacidades econômicas do solo, em detrimento da conservação das reais funções ecológicas dos areais, como as demonstradas por Silva (2008), que revela espécies de fauna com respostas adaptativas peculiares nos areais, e Freitas (2010), com seus estudos sobre aspectos florísticos adaptativos aos solos arenosos do sudoeste do Rio Grande do Sul.

Demonstramos, aqui, que a relação da sociedade com o ambiente de seu entorno é mediada por imagens feitas dele, ou seja, pelo imaginário construído, pela ideologia materializada na linguagem sob a forma de discurso. Demonstramos aqui que essas imagens motivam as ações que materializam, no espaço, formas vinculadas a essas. A noção de que o plantio de espécies arbóreas (eucalipto) é uma alternativa viável para a redução dos efeitos considerados perniciosos da arenização na agricultura exemplifica essa situação. Essa noção desvela a unilateralidade, do ponto de vista dos paradigmas técnicos e políticos, verificada nas políticas ambientais em relação à arenização no sudoeste gaúcho. Sendo portadores dos argumentos científicos autorizados, legitimados, os mediadores dessas políticas estão imbuídos do poder de decidir sobre as transformações espaciais consideradas necessárias para a região sudoeste do Rio Grande do Sul.

\section{Referências}

ALMEIDA, J. A agronomia entre a teoria e a ação. Revista de Educação Agrícola Superior, Brasília, v. 18, n. 2, p. 7-13, 2000.

ANDRADES FILHO, C. O.; SUERTEGARAY, D. M. A.; GUASSELI, L. A. Arenização no sudoeste do Rio Grande do Sul: investigação sobre a relação entre areais, drenagem e orientação do relevo. In: SIMPÓSIO NACIONAL DE GEOMORFOLOGIA, 6, 2006. Goiânia, GO, 2006. 
BERGER, P. L.; LUCKMANN, T. Modernidade, pluralismo e crise de sentido: a orientação do homem moderno. Petrópolis: Vozes, 2004. $94 \mathrm{p}$.

BERQUE, A. Paisagem-Marca, Paisagem-Matriz: elementos da problemática para uma geografia cultural. In: CORRÊA, R. L.; ROSENDAHL, Z. (Org.). Paisagem, tempo e cultura. Rio de Janeiro: UERJ, 1998, p. 84-91.

BERTÊ, Ana Maria de Aveline. Problemas ambientais no Rio Grande do Sul. In: VERDUM, Roberto; BASSO, L. A.; SUERTEGARAY, D. M. A. (Org.). Rio Grande do Sul: paisagens e territórios em transformação. Porto Alegre: UFRGS, 2004, p. 61-70.

CASSOL, D. Areia ameaça o pampa. Revista Panorama Brasil. São Paulo: SESC, SENAC, n. 362, mar./abr., 2004. < http://www.sescsp.org.br >. Acesso em: 13 jul. 2012.

CONAMA. Conselho Nacional do Meio Ambiente. (Brasil). Resolução CONAMA 238/97: Dispõe sobre a aprovação da Política Nacional de Controle da Desertificação. 23 dez. 1997. Brasília: CONAMA, 1997.

CONSEMA. Conselho Estadual do Meio Ambiente. Rio Grande do Sul. Zoneamento Ambiental para atividade de silvicultura no RS. Porto Alegre, Fundação Estadual de Proteção Ambiental Henrique Luiz Hoessler, 2009. Disponível em < http://www.FEPAM.rs.gov.br > . Acesso em: 10 jan. 2014.

DARDEL, Eric. L'homme et la Terre: nature de la réalité geographique. Paris: Universitaires de France, 1952.

DUNCAN, J. S. A paisagem como sistema de criação de signos. In: CORREA, R. L.; ROSENDAHL, Z. (Org.). Paisagens, textos e identidade. Rio de Janeiro: UERJ, 2004, p. 91-132.

EMATER/RS. Associação Rio-grandense de Empreendimentos de Assistência Técnica e Extensão Rural. (Rio Grande do Sul). Plano de manejo integrado da microbacia hidrográfica Sanga d'Areia. São Francisco de Assis: Emater/RS, Secretaria de Agricultura e Abastecimento, Prefeitura Municipal de São Francisco de Assis, 1992.

- Validação e/ou geração de tecnologias em manejo conservacionista para a recuperação de áreas em processo de degradação ou já degradadas, de solos com substrato arenito Botucatu na fronteira oeste: Projeto de Pesquisa por Demanda. Emater/RS, 2001. 
- Projeto de recuperação de áreas degradadas no núcleo fronteira oeste no plano de assentamento Santa Maria do Ibicuí em Manoel Viana/RS. Emater/RS. Escritório municipal de Manoel Viana, 2012.

ESTADO DO RIO GRANDE DO SUL. Assembleia Legislativa do Rio Grande do Sul. Comissão Especial sobre a Arenização da Região Sudoeste do RS. Porto Alegre, 2008.

FEPAGRO. Fundação Estadual de Pesquisa Agropecuária. (Rio Grande do Sul). Projeto de pesquisa: avaliação inicial do comportamento de espécies em solos suscetíveis à arenização no sudoeste do Rio Grande do Sul. In: ASSEMBLEIA LEGISLATIVA DO ESTADO DO RIO GRANDE DO SUL. Comissão Especial sobre a Arenização da Região Sudoeste do RS. Cap. 14, p. 32-33, 2008.

- Palombini anuncia projetos para Fronteira Oeste. Porto Alegre, FEPAGRO, 9 jul. de 2006. <www.fepagro.rs.gov.br>. Acesso em: 17 nov. 2013.

FOUCAULT, M. Verdade e poder. In: Microfísica do poder. Rio de Janeiro: Graal, 2004.

FREITAS, E. M. de. Campos de solos arenosos do sudoeste do Rio Grande do Sul: aspectos florísticos e adaptativos. Tese (Doutorado em Botânica). Instituto de Biociências, Curso de PósGraduação em Botânica, Universidade Federal do Rio Grande do Sul, Porto Alegre, 2010.

LOWENTHAL, D. Finding valued landscape. Toronto: University of Toronto, 1968. (Working Paper; 4).

MAINGUET, M. Desertification natural background and human mismanagement. 2nd ed. Berlin: Springer-Verlag, 1994.

MARCOVITCH, J. As origens do Projeto Floram. Revista do Instituto de Estudos Avançados. Universidade de São Paulo: São Paulo, n. 9, 1990.

MERLEAU-PONTY, M. The structure of behaviour. Boston: Beacon, 1962.

MÓSENA, M. Agricultura em áreas frágeis: as transformações decorrentes do processo de arenização em São Francisco de Assis/RS. 2006. 143 f. Dissertação (Mestrado em Desenvolvimento Rural). Faculdade de Ciências Econômicas, Programa de Pósgraduação em Desenvolvimento Rural, Universidade Federal do Rio Grande do Sul, Porto Alegre, 2006. 
NASSAUER, J. I. Culture and changing landscape structure. Landscape Ecology, Amsterdam, v. 10, n. 4, p. 229-237, 1995.

ONU. Organização das Nações Unidas. Conferência das Nações Unidas sobre o Meio Ambiente e Desenvolvimento, 1992. Rio de Janeiro. Agenda 21. Rio de Janeiro: ONU, 1992.

Convenção das Nações Unidas para o Combate à Desertificação nos países que sofrem seca grave e/ou desertificação, particularmente na África. Assembleia Geral da ONU, Set. 1994. (Versão em língua portuguesa do Ministério do Meio Ambiente, dos Recursos Hídricos e da Amazônia Legal, Brasil, 1996).

.United Nations Conference on Desertification. 29 ago. 9 Set., 1977. Nairobi, (Quênia) Nova York: ONU, 1978.

ORLANDI, E. P. Análise do discurso: princípios e procedimentos. 7. ed. Campinas: Pontes, 2007.

RIBASKI, J. et al. Sistemas Silvipastoris: Estratégias para o Desenvolvimento Rural Sustentável para a Metade Sul do Estado do Rio Grande do Sul. Embrapa. Comunicado técnico 150. Colombo/PR: Embrapa, dez. 2005.

RIBEIRO, J. C. C. A verticalização da paisagem nos campos de areia da Vila Kraemer. São Francisco de Assis/RS. 2008. 187 f. Dissertação (Mestrado em Geografia). Instituto de Geociências, Programa de Pós-graduação em Geografia, Universidade Federal do Rio Grande do Sul, Porto Alegre, 2008.

. Discurso e construção do imaginário acerca dos areais nas políticas voltadas à arenização no sudoeste gaúcho, 2015. $224 \mathrm{f}$. Tese (Doutorado em Geografia). Instituto de Geociências, Programa de Pós-graduação em Geografia, Universidade Federal do Rio Grande do Sul, Porto Alegre, 2015.

SANTOS, M. A natureza do espaço: técnica e tempo, razão e emoção. São Paulo: HUCITEC, 1997. 308 p.

SILVA, L. A. P. da. Narrativas das percepções e conectividades de caminhantes nas paisagens dos areais pampeanos. Perspectivas ambientais para geração de ambiências. 2008. Dissertação (Mestrado em Geociências). Instituto de Geociências, Curso de Pós-graduação em Geografia, Universidade Federal do Rio Grande do Sul, Porto Alegre, 2008.

SOBROSA, J. N. P. et al. Plano de gerenciamento da arenização do sudoeste gaúcho. Prefeituras de Cacequi, São Francisco de Assis, 
Manoel Viana, Maçambará, São Borja, Rosário do Sul, Alegrete: 2003.

SOUTO, J. J. P. Deserto, uma ameaça? Estudo dos núcleos de desertificação na fronteira sudoeste do Rio Grande do Sul. Porto Alegre: Secretaria da Agricultura, 1985.

SUERTEGARAY, D. M. A. A trajetória da natureza: um estudo geomorfológico sobre os areais de Quaraí-RS. 1987. Tese (Doutorado em Geografia). Departamento de Geografia, Curso de PósGraduação em Geociências, Universidade de São Paulo, São Paulo, 1987.

. Desertificação: recuperação e desenvolvimento sustentável. In: GUERRA, A. J. T. (Org.). Geomorfologia e meio ambiente. Rio de Janeiro: Bertrand Brasil, 1996.

SUERTEGARAY, D. M. A.; GUASSELLI, L.A.; VERDUM, R. (Org.). Atlas da arenização: sudoeste do Rio Grande do Sul. Porto Alegre: Secretaria da Coordenação e Planejamento (Rio Grande do Sul), 2001. 84 p.

TORRES, R. B. Representação social dos areais e mídia. Tese (Doutorado). Universidade Federal do Rio Grande do Sul. Programa de Pós-graduação em Geografia. Porto Alegre, 2013.

VERDUM, R. Approche géographique des "déserts" dans les communes de São Francisco de Assis et Manuel Viana, État du Rio Grande do Sul, Brésil. 1997. Tese. (Doctorat en Géographie et Aménagement). Unité de Recherche em Géographie et Aménagement, Université de Toulouse Le Mirail, Toulousse, 1997.

VERDUM, R. et al. Desertificação: questionando as bases conceituais, escalas de análise e consequểncias. GEOgraphia, Niterói, v. 3, n. 6, p. 111-132, 2001. 
A paisagem no corpo. $O$ corpo na paisagem 



\section{Tellusmorfismo: A Reconceptualização Corporal da Paisagem Através da Memória como Narrativa de Movimento}

Ricardo Nogueira Martins 
$\mathrm{P}$ artindo da uma noção de 'deformação espacial' e envolvendo as dimensões dos afectos e do trauma, este capítulo versa a tentativa de compreensão de como as relações entre lugar, tempo e memória, produzem uma reconceptualização da paisagem pelo corpo, trabalhado através de narrativas biográficas e da tecnologia digital. No presente estudo, a narrativa do corpo fotograficamente representada responde ao trauma que o sujeito carrega e que se pretende superar através do contraponto entre o conceito de antropomorfização da paisagem e do conceito de tellusmorfismo, a metáfora da superfície terrestre no corpo humano. Espaço, lugar e paisagem têm um papel crucial no moldar da memória humana e na problemática que aqui se apresenta. Num só tempo, a sociedade tal como a experiência individual vive o presente mas também o passado, pelos resquícios memoriais de outrora e pelas projeções futuras baseadas em parte no revisitar da experiência das ações passadas.

A Geografia Cultural contemporânea tem estado a repensar o papel da memória enquanto narrativa de movimento, através da qual se recolocam estratégias de auto representação. Recentemente uma publicação editorial intitulada "Geography and Memory" (2012) de Owain Jones e Joanne Garde-Hansen pôde finalmente apaziguar os já há muito revelados interesses da Geografia no campo da memória. A memória para a Geografia humana tem servido de base de análise dos seus parceiros mais próximos, o afeto, a emoção e a imaginação. De facto, o momento presente do lugar na prática do espaço torna-se complexo, um terreno afetivo singular, tendo em conta outros momentos prévios e materialidades, através do corpo. O trabalho da Geografia no que concerne à memória é precisamente o de provocar um debate ativo da importância da subjetividade da memória humana, no confronto com a subjetividade da memória homogénea e hegemónica que os modelos de poder e de conhecimento tendem a promover, bem como no suscitar de interesse pela história ambiental, ou seja, o desprender todas as deformações espaciais que o lugar deteve na formação da memória que representa actualmente. 
Pierre Nora (1989), ainda que numa base muito historicista e patrimonial, alertava para o facto da aceleração dos eventos e da capacidade memorial destes mesmos para e com os sujeitos. Para Pierre Nora, a tradição da memória teria acabado na transformação dos lugares em lugares de prece à memória, em que estes "seriam um meio não-espontâneo de se guardar a memória, de se legitimar um passado coletivo (do Estado-Nação) cada vez mais ameaçado pelo individualismo que procura legitimar o futuro" (HOLZER, 1999, p. 75). Na obra do autor "Les lieux de Mémoire", editada a partir de 1984, o lugar assume-se como "acelerado", uma narrativa cada vez mais em movimento. Uma "derrapagem cada vez mais rápida do presente para um passado histórico que se foi para sempre, uma perceção geral de que qualquer coisa e tudo pode desaparecer" (NORA,1989, p. 7). Esta aceleração de eventos torna difícil pensar o tempo, e desta forma o lugar, compreendido como o espaço vivenciado afetado pelo desejo de entender o presente cruzado com a dificuldade de dar ao passado próximo um significado. Estaria justificada a obsessão atual arquivista, para Nora, através da "completa preservação do presente bem como a total preservação do passado", bem como o "medo de um rápido desaparecimento final combinado com a ansiedade sobre o significado do futuro e a incerteza do presente" (NORA, 1989, p. 13). Este medo do desaparecimento e da ansiedade sobre o significado do futuro, é retratado através da criação de museus, catedrais, memoriais, comemorações históricas ou publicação de manuais de memória e criação de simbologia. Um lugar de memória (lieux de memoire), para o autor, é assumido como "uma qualquer entidade significativa, seja material ou não material na natureza, que por força da vontade humana ou o trabalho do tempo se tornou um elemento simbólico do património memorial de qualquer comunidade" (NORA,1996) onde a "memória (cultural) cristaliza e se segrega (NORA 1989, p. 7). Neste sentido, o estudo das memórias é crucial para entender como as identidades são nutridas pelo sentido de lugar e de que forma os indivíduos dão sentido às paisagens afetivas que, apesar do seu caráter de palimpsesto, são regularmente organizadas na forma 
de narrativas lineares espacializadas. Estas assumem papel crucial nos processos intra e intersubjectivos.

Organizada por rotinas de emoções e afetos, a experiência pessoal é acomodada num sistema de signos geográficos, representações culturais instituídas. Representações de espaço, lugar e paisagem que, por via da ciência, arte e tecnologia, accionam poderosos circuitos de comunicação, que ora aprisionam os sujeitos a memória e a matéria em categorias de deformação, ora permitem, a posteriori, a reorganização de um espaço semiótico-material de transformação, um sistema pessoal de signos em que a ideia de deformação acciona narrativas de movimento, despoletando a emancipação dos corpos. A questão de partida que norteou o estudo de que aqui se dá conta foi a seguinte: Podem as fotografias produzidas partindo de narrativas biográficas em que o trauma do 'corpo deformado' é tema central, integrar sistemas de signos geográficos, representando lugar, natureza e em especial paisagem?

\section{Contribuindo com reformuladas aproximações} epistemológicas no seio da Geografia Cultural e procurando a interceção com outras ciências, estudos deste tipo salientam a componente artística como coadjuvante da ciência e da investigação. Em última análise, procura-se aqui uma reconceptualização da paisagem através da construção de uma geografia dos afetos. O corpo como paisagem e a paisagem como corpo através de uma geografia de contacto, da intimidade do acto de pesquisa, da apropriação da tecnologia digital e da edição de imagem para a produção de um renovado sentido de lugar, a desconstrução da ideia de deformação espacial.

\section{Do corpo à Paisagem}

A paisagem conta com uma longa tradição artística que poe em relação o sujeito e a natureza assentando na reprodução mimética de imagens que se foram disseminando e que, de certa forma, sustentaram, estereótipos de lugar, corpo e identidade. A paisagem, 
Tellusmorfismo: A Reconceptualização Corporal da Paisagem Através da Memória como Narrativa de Movimento

na sua moderna aceção, é o resultado "de um arranjo hierárquico numa vista dos componentes físicos e simbólicos do território" (AZEVEDO; PIMENTA; SARMENTO, 2009, p. 17), que daria resposta às novas relações entre o ser humano e o ambiente físico, enaltecendo o consumo e produção de imagens com base em técnicas que remontam ao quatrocento. Com a evolução da arte, a paisagem foi-se organizando em composições pictóricas, um sistema de signos geográficos que foi sendo culturalmente codificado. A paisagem foi-se constituindo como experiência estética, configurando discussões críticas e múltiplas formas de análise (SANSOT, 1983), tornando-se posteriormente alvo de experiência científica. Porém, a paisagem surge tardiamente entendida não só pelo seu caráter físico, mas pelo seu caráter de repulsa ou atracção, na sua componente de interferência com o sujeito e as suas ações, enquanto paisagem cultural. A paisagem é uma marca e matriz expressando uma civilização, porque participa dos esquemas de perceção, de conceção e de ação - ou seja, da cultura. Todavia o corpo por si só pode também, e em escalas diferentes, ser representação e performance da paisagem.

Desde Carl Sauer, em "The Morphology of Landscape" (1925), reinventar a paisagem tem contado com o diálogo entre um conjunto de formas naturais e culturais associadas a uma narrativa situada, a uma epistemologia de espaço e lugar. Se o objetivo confessado da pintura foi, em certo momento, a representação mais fiel do real, a cópia, comportando a subjetividade da ideia de natureza, a fotografia, acredita-se, veio a ser um dos meios para realizar este sonho. Até ao século XVIII, a "paisagem pictórica é sobretudo um pano de fundo e são os românticos que começam a tratá-la como um assunto em sim mesmo" (AMAR, 2007, p. 54). As implicações da invenção da fotografia para a manutenção da ideia moderna de paisagem encontram-se precisamente no modo como "se deu continuidade a um processo de 'naturalização' da paisagem como forma de ver. Isto, pela reprodução de um sistema de significados que se encontrava já codificado pictoricamente pela ação de um género artístico, a pintura em paisagem (AZEVEDO, 2012). 
Dos desenhos demorados dos viajantes de outrora, a fotografia satisfez a necessidade de mostrar e vender outros recantos do mundo que se iam descobrindo aos olhos do sujeito do humanismo. Mas a evolução da arte efectuou em si mesma a ruptura com este paradigma.

Recorrendo a exemplos como René Magritte (figura 1) tenho intenção de questionar o que existe para lá da visão e dos significados das 'coisas'. Uma perspetiva des-construtiva e analítica do presenciado. Em que o mínimo pode ser o máximo, o negativo o positivo ou o micro, o macro.

Figura 1: René Magritte.The key to dreams (1930)

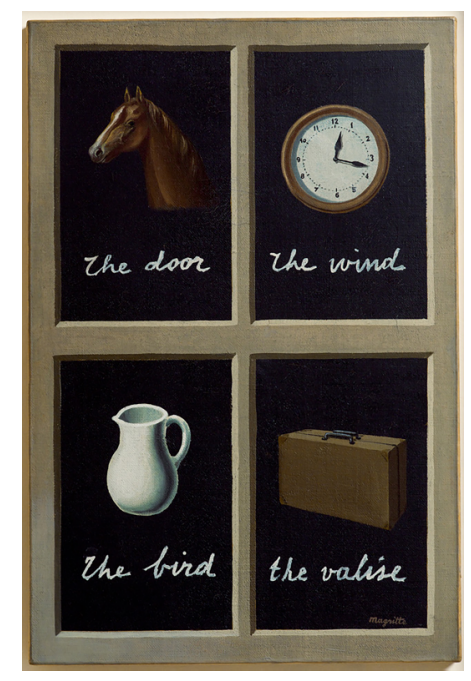

Fonte: http://www.magritte.be/

No excerto abaixo disposto da carta escrita por René Magritte a Michel Foucault a 23 de maio de 1966, o pintor argumenta não existir entre as coisas semelhanças mas sim similitudes. As representações de paisagem, hoje produzidas, forjarse-iam em contextos de semelhança ou similitude?

As palavras Semelhança e Similitude permitem ao senhor sugerir com força a presença - absolutamente estranha - do mundo e de nós. Entretanto, creio que essas duas palavras não são muito diferenciadas, os dicionários não são muito edificantes no que as distingue. Parece-me que, por exemplo, 
as ervilhas possuem relação de similitude entre si, ao mesmo tempo visível (sua cor, forma, dimensão) e invisível (sua natureza, sabor, peso). O mesmo se dá no que concerne ao falso e ao autêntico etc. As "coisas" não possuem entre si semelhanças, elas têm ou não têm similitudes. Só ao pensamento é dado ser semelhante. Ele se assemelha sendo o que vê, ouve ou conhece, ele torna-se o que o mundo lhe oferece. (MAGRITTE, 2001, p. 520-521).

As 'coisas' não possuem entre si semelhanças, elas têm ou não têm similitudes. Só ao pensamento é dado ser semelhante. $\mathrm{Na}$ contemporaneidade, novas formas de pensar a paisagem têm vindo a surgir, nomeadamente no caso das artes visuais por via da fotografia que discutem os conceitos levantados por Magritte de semelhança, similitude ou mesmo de mimese. Estes tipos de abordagem configuram hoje uma renovada ideia de paisagem que atua com base em arquivos de memória individual, de quem a interpreta, e de quem cria a representação, neste caso particular questionando o conceito de paisagem, apelando ao facto de que cabe ao pensamento ser semelhante àquilo que interpreta. Cabe-nos debater a paisagem, território e corpo, já que, usualmente, a paisagem em comparação, é alvo de antropomorfização. Ou seja, a visualização de uma fisionomia humana nos elementos constituintes da morfologia da paisagem, como por exemplo formações geológicas ou flora, em diversas perspetivas e planos de quem a identifica.

A indexação de tipos fisionómicos a paisagens naturais configura, "um dos mais graves mal entendidos da modernidade, tendo aberto caminho para a cristalização no espaço e no tempo dos processos de formação de subjetividades" (AZEVEDO; PIMENTA; SARMENTO, 2009, p. 22). Em particular para Azevedo, Pimenta e Sarmento (2009), esta "estética da representação", abriria caminho para uma "ética da representação", já que ao sermos confrontados com "representação de um corpo o nosso sistema emocional e afetivo é ativado e, paralelamente somos transportados para uma Geografia concreta" (2009, p. 22). Espera-se pois, contrariar o antropomorfismo representacional da paisagem e evidenciar os modos convencionais da representação de um território ou paisagem 
no corpo como estratégia subversiva da ideia de deformação espacial. Pensar a paisagem através do corpo, como uma superfície de representação ou de inspiração, para a construção, não de uma geografia "concreta", mas de uma geografia imaginativa na exploração de novas metáforas e alegorias.

$\mathrm{O}$ interesse geográfico nos processos de significado e representação é relevante, pois se conecta com questões mais amplas de discussão para a ciência geográfica, como o mimetismo, o real/ficcional, perspetiva e escala, as geografias mais do que humanas e na perspetiva da paisagem e corpo, pondo em debate o papel das representações como componente fulcral dos processos de produção de conhecimento.

Uma vez mais através da arte, ciência e tecnologia, desafia-se o sujeito a uma outra experiência de paisagem, que contrarie a noção do mundo-retrato para exibição e consumo em massa. No cerne desta questão, o território transformou-se em paisagem visivelmente apreendida e que se tornou estrutura conceptualizada não limitada àquilo que se experimenta subjetivamente mas também àquilo que organiza a experiência, porque vivenciado afectivamente, pela partilha de histórias e narrativas, pela dimensão táctil, do háptico para o óptico. Interessa antes de tudo entender como se apresenta de forma regular o impulso a enaltecer conceções de paisagem individuais de forma a criar peças artísticas, acompanhando cognitivamente o sujeito na sua leitura e permitindo-o emancipar-se dos quadros convencionais de representação em paisagem. Da mesma forma cria-se uma alienação relativamente à representação mimética da paisagem, sem, de qualquer modo, prescindir dela.

A representação de paisagem será repensada como método e instrumento, através da fotografia, do corpo e da memória. Da paisagem como vista de uma porção de território, como construção descorporizada, à paisagem como tecnologia para a organização da experiência do corpo como lugar, de fazer territórios-outros, conforme propõe Azevedo (2007; 2012). Na exploração destes outros quadros de paisagem, o being-in-the-world de Heidegger (1965), traz a debate a formação identitária do sujeito na associação aos espaços e 
Tellusmorfismo: A Reconceptualização Corporal da Paisagem Através da Memória como Narrativa de Movimento

lugares que nos constituem. Precisamente, o que é estar no mundo, ou o ser no mundo, quando, um sujeito assume características físicas que limitam a sociabilização e construção da identidade e do lugar, ou pelo menos uma limitação e entrave após o acontecimento traumático que o 'deslocalizou'?

A identidade e a memória na relação do território para com a corpo é formada pela associação do contacto com espaços, lugares e representações de paisagem nos quadros da consciência do sujeito, do seu percurso existencial e da sua intencionalidade. Do corpo, em particular como paisagem: "If landscape becomes a body, the body conversely becomes a site of mapping” (BRUNO, 2002, p. 233). Em "Atlas of Emotion: Journeys in Art, Architecture, and Film" (2002), Giuliana Bruno afirma que a própria carne se torna espaço na paisagem, ao assumir o corpo como entidade espacial, não só porque o ocupa mas porque é, em si mesmo, reflexo do espaço e lugar que faz o corpo. Possamos pois assumir o corpo como forma de mapeamento da paisagem, ou seja alvo, de representação e ideia de uma ou várias paisagens, requacionando-as.

$\mathrm{O}$ conceito de paisagem tem vindo a mudar não só teoricamente e na sua representação artística, mas também na forma como nos posicionamos para com o espaço e o lugar. Assume-se o corpo como uma identidade sustentada da constituição reconhecível dos limites, marcas, saliências e formas que constroem um sistema matricial do sujeito, que dará lugar à identidade cultural e à identidade de um lugar refletido numa função social da memória. Tal como a paisagem revela a narrativa de uma história ambiental, o corpo também possui narrativa: "é no corpo que o ser humano se faz presente no mundo; é no corpo que se torna possível a experiência do espaço e dos outros; e é o corpo que afinal vive e constrói o quotidiano, através da açao (que é o movimento no espaço) e do encontro com outros corpos (a base das relações sociais)" (BRITO-HENRIQUES, 2009, p. 92). De facto, os nossos corpos segundo Longhurst (2005) assumem-se como "superfícies de inscrições sociais e culturais, que albergam subjetividade, são sítios de prazer e de dor, são públicos e privados, têm fronteiras 
permeáveis que são atravessadas por fluidos e sólidos; são materiais, discursivos e físicos” (2005, p. 91). O autor explicita que os cientistas sociais, incluindo geógrafos (AZEVEDO; PIMENTA; SARMENTO, 2009; RODAWAY, 2011), têm adotado diversas aproximações para entender o corpo. A psicanalítica, a fenomenológica e a cultural ${ }^{1}$, no papel preponderante do corpo para com o lugar e paisagem. Destas aproximações para entender o corpo, sob a égide de que construir o conhecimento social é tanto um processo de interpretação como de compreensão (PICKLES, 1988), norteou-se a proposta aqui em análise.

\section{Narrativas biográficas, arte e a fotografia}

A utilização das narrativas biográficas suportou a aferição da perceção e da recolocação do sujeito para com o espaço, lugar, paisagem e corpo. Do ponto de vista prático propicia uma resposta mais focada e conduz os intervenientes através de percursos existenciais, conversas e silêncios, em tom informal, que permitem uma resposta aberta dos participantes pelas suas próprias palavras, em vez de um 'sim ou não como resposta rígida (CLIFFORD \& VALLENTINE \& FRENCH, 2003). Por outro lado, a observação participante permite estar mais próximo do fenómeno espacial em estudo, diferenciando-se bastante de metodologias que enfatizam a distância e objetividade. No que diz respeito às técnicas utilizadas, a edição digital de imagens permitiu uma aproximação e desvirtualização do corpo/pele, acentuando por sua vez as características paisagísticas em direcção às quais 'o diálogo' se foi desenvolvendo. A técnica de edição digital de fotografias foi também decisiva. Os instrumentos e materiais utilizados incluíram o recurso a duas máquinas fotográficas compactas (Sony DSC-W90; Olympus FE3010,X895), bem como a utilização do software Picasa 3 de edição

1. Em especial, a abordagem cultural coloca o corpo e espaço como mútuos constituintes, presente na delineação do planeamento urbano e na gestão de espaços sociais (GROSZ,1992). 
digital das imagens que permitiu em alguns casos introduzir a deformação pretendida nos documentos fotográficos produzidos.

Importa salientar o motor e a origem deste debate. A presente reflexão correspondeu a um estágio de co-produção com o sujeito de investigação, dizendo respeito ao realizado nas mais íntimas instalações espaciais; a casa, e os seus diferentes compartimentos, o lugar do sujeito, sendo que o objectivo último era pré-dispor um sujeito 'traumatizado' para uma melhor aceitação do seu corpo, aferindo o possível contributo da produção de conhecimento geográfico neste tipo de processos. $O$ contacto afincado desenvolvido durante um prolongadíssimo período de tempo com o sujeito da investigação e a sua participação na discussão desta pesquisa desde os seus primórdios, transpõem-se no projeto fotográfico que adiante se explora, em jeito de obra final desta relação de co-produção que resultou em progressivos estádios de emancipação do sujeito através da performance da paisagem.

Modificando vidas de forma profunda, a pesquisa em forma de co-produção revelou-se tarefa árdua mas profundamente gratificante. A construção de uma narrativa biográfica e respectiva partilha despoletou uma cascata de efeitos que conduziu à vontade de exploração de formas de auto-representação e à reconfiguração de significados articulados em torno dos eixos paisagem-corpomemória. Neste contexto, o recurso a formas de arte revelou-se também de extrema importância. A arte pode ser aplicada como terapia através de duas formas primárias, do traumatizado em livre expressão artística ou através de projetos de representação artística e performance, como neste caso concreto ocorreu.

Para Owain Jones (2011), as memórias decorrentes da interação do sujeito como parte integral do espaço, carregadas emotivamente, tem a capacidade de redefinir o sujeito através do seu percurso no espaço ao albergarem o poder de nos fazer reconhecer a passagem do tempo, e fazer notar quão breve e precioso o "hoje" realmente é. O sujeito é assim uma aglomeração de experiências passadas e atuais, incluindo as suas texturas espaciais e registos afetivos; 
Tal e qual o corpo coberto de cicatrizes e marcas, o lugar acabaria por ser "o espaço imediato da experiência do mundo, espaço onde gerações sucessivas deixaram suas marcas, projetaram suas utopias, produziram seu imaginário (CARLOS, 2007). É aqui que nos apraz diferenciar por influência de Halbawacks a memória em duas divisões, que segundo Jones (2011) são a memória individual e a memória colectiva. A centralidade da memória nas Geografias individuais e coletivas faz com que seja necessário estabelecer parâmetros de caracterização que Jones (2011) tão bem explicita e que estão na ordem do dia, em termos de discussão. Primeiro, a memória cobre não só um processo mas sim um todo interrelacionado, em que de acordo com o autor, podemos apresentar três tipos de memória: a memória de curto termo, de longo termo e a sensorial. Segundo, a importância da memória na formação do sujeito pela ação recíproca entre a consciência e subconsciência (os conteúdos da mente que se encontram em um nível inferior de consciência), no sentido de perceber quando e se, a memória deixa de ser memória e passa a ser pensamento, já que esta não permanece enquanto "informação estática mas é retrabalhada à luz da pratica corrente" (JONES, 2011, p. 877), no decorrer do momento de contacto do sujeito. Por último, a memória intimamente conectada ao corpo, emoções e sentidos e à criatividade, no sentido que as potencialidades do presente são largamente influenciadas por ações passadas ao tornar a nossa relação com os outros multidimensional e não linear, complexa a nível informacional e material. Em particular, a constante disseminação da memória, em parte provocada pela memória mediada reflete a construção contemporânea da memória humana e da memória de lugar, em que nos apropriamos de atividades e objetos que produzimos pelo uso de tecnologias digitais ao criar e recriar o sentido de passado, presente e futuro, de nós mesmos em relação aos outros (VAN DJICK, 2007), manipulando memórias biográficas por meios tecnológicos.

Quando as palavras não chegam, imagens e simbologias diversas complementam o estágio de superação traumática no 
decorrer das próprias narrativas em movimento, na reinvenção da memória tornada material de trabalho. De certa forma ao narrar através da arte, podemos encontrar um caminho para a saúde e bemestar, reparação emocional e recuperação física. Donde o recurso à ideia de arteterapia. Entenda-se por arterapia, a forma expressiva que combina tradicionalmente a teoria e técnicas psicoterapêuticas através de um entendimento dos aspetos psicológicos no decorrer da criatividade do processo, seja efetuado pelo próprio sujeito. $\mathrm{O}$ acto deliberado de 'fazer arte' para atender às necessidades psicológicas e emocionais de contacto com o espaço e outros sujeitos prende-se com a experiência de que, "a arte terapia tem proporcionado tratamentos de saúde mental para sujeitos que sofreram de trauma, dor e perda, depressão, doença crónica, abuso de substâncias, entre outros" (IATO, 2009). Segundo Malchiodi (2005), o propósito da arterapia assemelha-se à modalidade da psicoterapêutica, melhorando ou mantendo a saúde mental e o bem-estar emocional do sujeito. Juntamente com outras modalidades de coprodução que utilizam as artes performativas para propósitos expressivos, a arte terapia geralmente utiliza o desenho, a pintura, escultura, fotografia ou outras formas de expressão artística visual assumindo formas de liberdade, expressão, sensibilidade e criatividade.

A arte, para Carl Gustav Jung (1988), tem o poder de nos libertar das estreitezas e dificuldades insuperáveis de tudo o que seja pessoal, elevando-nos para além do sentido existencial efémero. Foi precisamente Jung, psiquiatra e psicoterapeuta suíço e fundador da psicologia analítica ${ }^{2}$, que originalmente fizera da arte um passo para o tratamento psicoterapêutico na década de 20 do século passado, ao crer que a criatividade é uma função psíquica natural possuindo a capacidade de auxiliar a estruturação do indivíduo, podendo assumir componentes de 'cura': "dando novamente a cada um a possibilidade de encontrar o acesso às fontes mais profundas da vida que, de outro

2. O ramo de conhecimento e prática da Psicologia, iniciado por Carl Gustav Jung o qual se distingue da psicanálise, iniciada por Freud, por uma noção mais alargada da libido e pela introdução dos conceitos de inconsciente coletivo, sincronicidade e individuação. 
modo, the seria negado" (JUNG apud GRINBERG, 2003, p. 1). Ao contrário de Sigmund Freud, com o qual Jung mantinha estreita relação até ao momento de discórdia, Jung não acreditava no trauma com base numa experiência estritamente sexual e de libido, por sua vez Freud, não denotava do mesmo modo a influência espiritual não admitindo o interesse de Jung pelos fenómenos espirituais como fontes válidas de estudo em si mesmas. Enquanto Freud usava imagens como dados para a análise racional, Jung, aproximava-se do processo de imaginação e em criar imagens como o "processo primário" das suas técnicas terapêuticas e psicológicas (MALCHIODI, 2005). Para Jung, a criatividade é naturalmente estruturante do sujeito. Os seres humanos possuiriam disposições inatas para a configuração de imagens e ideias análogas, às quais denominou de arquétipos $^{3}$, que surgem nos sonhos e trabalhos artísticos, beneficiando por sua vez, a compreensão do comportamento individual.

No século XX, Jung antecipava o que hoje se desenvolve em arterapia entendendo as mãos trabalhando com argila, o corpo ao interpretar um sonho através do movimento, ou todas as faculdades expressivas de uma pessoa decretando dramaticamente um conflito podendo oferecer compreensões e soluções que não podem ser estudados por meio de discussões verbais mais lineares" (MALCHIODI, 2005, p. 12). Em particular, interessa entender a arteterapia como acto de comunicação simbólica, estando implícita a comunicação não só para quem possa acompanhar o processo de produção artística mas principalmente para o sujeito que o produz, ao comunicar consigo mesmo. É no decorrer dos anos 70 que a arterapia emerge como um campo de estudo especializado no desenvolvimento de aproximações à prática clínica. De facto, Randy M. Vick (2003) observa que a arterapia é uma disciplina híbrida que advém da arte e da psicologia. No caso particular este tipo de aceitação científica da sua hibridez deu força a este trabalho,

3. A forma imaterial à qual os fenómenos psíquicos tendem a se moldar. As estruturas inatas que servem de matriz para a expressão e desenvolvimento da psique. 
colocando aparte o sentimento de intromissão em algo que 'não diz respeito à Geografia'. De facto, se o intuito particular era retrabalhar um conceito geográfico (a paisagem) fazia sentido utilizar todo e qualquer método, de base teórica ou empírica que permitisse alcançar o objetivo final do estudo. A ciência faz-se, "contaminandose"!

Ainda acerca da utilidade da arte como método central neste estudo, os trabalhos de Vick (2003) ajudaram a fundamentar a sua importância como intervenção primária: a expressão artística como forma de linguagem visual através da qual os sujeitos expressam pensamentos e sentimentos que não o fariam por palavras, e a forma de comunicar experiências difíceis de verbalizar, como o abuso sexual ou psicológico, traumas, dor ou outras experiências emocionais. Usada em diversas ciências, no caso particular da Geografia, Cheryl Mcgeachan da Universidade de Glasgow e Candice Boyd da Universidade de Melbourne, entre outros, têm vindo a explorar este campo de estudos. Harriet Hawkins (2013) por seu lado, tem vindo a escrever sobre arte e/na Geografia, acompanhando a evolução dos grupos de pesquisa de geohumanidades e das Humanidades espaciais, alegando que se tornou imperativo aprofundar as considerações das formas de arte e importar as relações da Geografia e arte em novos moldes. Este tipo de reflexões reverberam no seio da Geografia, e em particular na Geografia Cultural, na medida em que permitem rever e apontar novas interseções entre arte e Geografia, não só na sua qualidade relacional mas também na interpretação do mundo 'real'. No livro "For Creative Geographies", Harriet Hawkins, sublinha que as "práticas artísticas têm feito parte da natureza e da expressão do conhecimento geográfico durante séculos” (HAWKINS 2013, p. 15), quer nas primeiras missões e viagens auxiliando a representação de povos, bem como na realização de paralelismos com relação à experiência em quadros artísticos.

Refletindo sobre o acto de 'curar', Allete Willis (2009) diznos que os indivíduos jamais se poderão curar em isolamento tendo uma necessidade notória de se transformar em e através de relações 
sociais dentro de uma gama de 'lugares'. A totalidade do sujeito envolverá assim e sempre os outros. Um exemplo claro para a autora que avança a ideia de um curar coletivo remete para o campo de estudos das 'Paisagens Terapêuticas' dizendo respeito a locais de culto como Lourdes em França ou Epidauro na Grécia, que unem o sujeito coletivo num objetivo comum. Este tipo de aproximações à 'cura' ou superação do trauma, à intromissão na complexa área da deformação (espacial), dentro da Geografia e associada ao campo das paisagens terapêuticas, tem, recorrentemente, sido atingido por diversas críticas. As críticas baseiam-se essencialmente na descriminação do lugar, sendo comum o foco em lugares 'excecionais' ao invés dos mais ordinários onde a maioria da população despende mais tempo. Por outro lado, discute-se com suspeição o facto de existir uma clara ou secreta suposição de atributos inerentes aos lugares que os tornam terapêuticos (ALLETTE, 2008).

No presente estudo, a paisagem e a fotografia surgem em formato terapêutico, tendo subjacente o trabalho em torno das narrativas biográficas do corpo como lugar e de lugares de memória, através do conjunto de imagens produzido que aponta para a potência de um corpo para criar paisagem no encontro com a fotografa a preto e branco deixando os contrastes entre formas e tons mais marcantes na constituição da imagem e ganhando então mais força nos contornos, aproximando-se da estética da paisagem encontrada pela intromissão em si mesmo do 'corpo deformado'. Aqui se procura uma paisagem terapêtica que emerge do próprio corpo, ou seja a procura de atributos paisagísticos pelo sujeito através de um processo colaborativo de uma catarse da memória que emerge no processo narrativo e que se reinventa através do material fotográfico. Neste processo, a totalidade do sujeito é revista não somente na sua experiência individual mas incorporando experiências coletivas.

A fotografia terapêutica é o nome dado a atividades baseadas em fotografias que são auto-iniciadas (ou como parte de um grupo organizado ou projeto), mas onde nenhuma terapia formal 
ocorre, isto é, sem terapeuta ou conselheiro a orientar a experiência para o propósito de utilizar a experiência mais tarde como parte de um processo de aconselhamento maior estruturado. Ou seja, em contexto de não terapia, com o propósito de crescimento pessoal dos envolvidos, um processo criativo ou declaração artística, como um agente de mudança pessoal, político, cultural, de reforço pessoal ou comunitário. Para além deste propósito, e neste caso concreto, esperando-se que possa ainda ser recebido como modesto contributo para ampliar o debate em torno dos procedimentos científicos e académicos.

\section{Bionota do sujeito da investigação}

O sujeito da investigação nasceu em 1949 na freguesia de Sequeira, concelho de Braga, Portugal. Portadora da síndrome de Marfan que causa desordens no tecido conjuntivo, o seu corpo molda-se, produzindo-se paralelamente alterações na estrutura óssea, cardíaca, pulmonar e ocular. Fruto desta síndrome, é submetida a três cirurgias principais: a primeira, uma cirurgia ocular aos cristalinos e cataratas, a segunda, uma cirurgia vascular a um aneurisma localizado próximo da artéria renal e uma terceira e última cirurgia cardiotorácica a um aneurisma na aorta ascendente. A última cirurgia acabaria por levar a mobilidade reduzida. Logo imediatamente, e ainda no decorrer do seu período de recuperação cirúrgica, o conjugue faleceu.

As novas formas que o corpo adquiriu, características dos portadores da síndrome de Marfan, são fatores que provocam distúrbios de ajustamento psicológico com limitações no desenvolvimento emocional e social. A aparência física nesses indivíduos frequentemente leva a alterações no esquema corporal, na autoestima e, consequentemente, no desenvolvimento global da personalidade. As posições de destaque do indivíduo induzem, inibição, sentimentos de menos valia e tendência ao isolamento. Por ser uma doença peculiar, que atinge precocemente, a síndrome de 
Marfan pode provocar danos na área afetivo-relacional em cada etapa do crescimento biológico. Da mesma forma, na vida adulta, as dificuldades não são menos traumáticas já que pode ser comum o sentimento de insegurança quanto a ser aceite por sujeitos 'normais'. No quadro específico da mulher, pode haver interdição relativa para a gestação, o que implica a perda da integridade e o luto pela renúncia à maternidade, ou então a experiência da gravidez de alto risco. A reduzida expectativa de vida em ambos os sexos é outro fator causador de danos emocionais como os variados graus de estados depressivos, limitando a realização de projetos pessoais e profissionais. Por sua vez, a autoimagem, afetada pela aparência, tem repercussões negativas no comportamento social, caracterizado por introversão (MARFAN FOUNDATION, 2014; UNIFESP4, 2004).

\section{Memória e trauma numa paisagem reconcetualizada}

A cultura de consumo do corpo, associada às novas possibilidades de domínio técnico sobre a fisionomia fizeram "difundir a ideia de que é sobretudo à forma como cada um gere e valoriza o seu corpo que se deve uma imagem pessoal mais ou menos favorável, e não tanto, ou mesmo não já, aos inelutáveis e imponderáveis da natureza (BRITO-HENRIQUES, 2009, p. 90). Numa tentativa de tensionar o modo antropomórfico como a experiência da paisagem se retrata pelo 'dobrar do corpo humano na terra' insere-se o trabalho com o conceito de paisagem, por via da fotografia, como última etapa do processo. Imagens que, associando legendas àquilo que nos habituamos a chamar de 'formas da terra' enquanto legado da tradição paisagística debatendo a naturezacultura a um grau de interpretação que rompe com a dicotomia préestabelecida, favorecendo a paisagem e o corpo como mediadores culturais de raiz, numa co-construção da narrativa do mundo essencialmente semiótica e material.

4. Grupo Multidisciplinar Síndrome de Marfan da Universidade Federal de São Paulo. 
Acerca do que Brito-Henriques expõe, relativamente à cultura de consumo do corpo, frequente é o surgimento de conflitos, quando o assunto são fisionomias e formas de gerir o corpo não convencionais. Diz-nos Gabriela Maldonado \& Marta Rezende Cardoso (2009) que se por um lado o trauma aponta para uma "narrativa impossível, pelo excesso de realidade que comporta, por outro, paradoxalmente [...] (pode ser emancipatório), para aquele que experimentou uma situação traumática, poder relatar ao outro a sua história" (2009, p. 55). Do campo simbólico do trauma, impõemse a necessidade de o narrar ao outro, e sobretudo, o aspeto mais notório, a necessidade da sua representação. $\mathrm{Na}$ verdade, neste "passado que não passa" (SELIGMANN-SILVA, 2008, p. 68), que desconstrói o próprio teor da realidade, representar fotograficamente o trauma com o intuito de arteterapia pode, segundo diversos autores (KAPYTAN, 2010; RUBIN, 2010; HINZ, 2009; MALCHIODI, 2005), ajudar na superação de uma memória traumática ou na melhoria da relação do sujeito com o espaço que ocupa. Isto na relação permanente com o exercício da narrativa biográfica e o refluir do movimento da memória.

A memória de que aqui se trata parte de um trauma físico, remetendo a um quadro clínico que compõem (deforma) o corpo em moldes tidos como não convencionais. Um corpo deformado é um lugar fora do espaço absoluto e homogéneo da abstracção, dentro do qual nos habituamos a situar. Encontra-se portanto fora das categorias convencionais de espaço, é o lugar ambíguo e ininterrupto do movimento da matéria, do tempo e do espaço relativos, da deformação espacial. Por limitar a mobilidade do sujeito e lhe trazer desmotivação psicológica e dor profunda conduz a um isolamento progressivo. A memória e o trauma são explorados com base na construção de conhecimento sobre a paisagem e sobre o sentido de ser na sua relação com a memória e o lugar, o arquivo corporal que inclui a biografia e a relação com o espaço e por último o arquivo fotográfico.

Etimologicamente, derivado do grego, o termo trauma, diz respeito à relação corporal e às feridas físicas, sendo comum, ainda 
hoje, a aplicação do termo no dicionário médico atual. Ao não descurar as implicações físicas de que o corpo possa ter sido alvo no decorrer do processo de ativação traumática, importava compreender a mudança na valoração do trauma no sentido mental, quanto à influência social e espacial que provoca. É em 1885, numa tese $^{5}$ defendida pelo médico francês, Doutor Rouillard, ao incluir um capítulo destinado ao "traumatisme morale" ou trauma psíquico, que a sociedade científica e civil tomam conhecimento de um novo campo de estudos (HACKING,1996). A teoria física do trauma havia sido suplantada pelas 'marcas' corporais e estudava-se agora os efeitos ao nível da 'alma', e nos traços traumáticos cerebrais. Mais do que "relembrar o que nos afetou, era o que foi esquecido" (ou aparentemente esquecido) que importava refletir (HACKING,1996, p. 76). A teoria anatómica da memória veio confirmar que tudo o que acontece é preservado em alguma pequena parte do nosso cérebro. E assim, disponível para ser resgatado. Da mesma forma, também Sigmund Freud, contribuiu para este debate ao sublinhar o cariz corporal e físico do termo, a sua pertinência quanto a uma mente ferida, cimentando a ideia do trauma psíquico. O trauma psíquico seria compreendido por este autor, como as experiências emocionais que se constituem como fator para o distúrbio de afectos, a vivência de medo, susto ou vergonha e que o sistema psíquico tem dificuldade para resolver por meio do pensamento associativo ou por reação motora ${ }^{6}$.

Os eventos traumáticos no sujeito podem assumir dois tipos de memória: a memória mental e a memória corporal. A memória mental inclui, segundo Young (1996), "as memórias intrusivas e reexperienciadas de trauma bem como os esforços sintomáticos para evitar circunstâncias que possam despoletar memórias, e entorpecimento emocional". No que respeita às memórias corporais,

5. "Essai sur les amnésies, principalement au point de vue étiologique" (1885).

6. A abordagem de Freud é bastante controversa nomeadamente no que diz respeito ao uso do termo histeria. Não há aqui espaço para aprofundar as discussões decorrentes. Não obstante, aproximações posteriores de Sigmund Freud, introduziriam a noção de libido como extremamente significativa para a compreensão da noção freudiana de trauma. 
estas são na maior parte das vezes, "sinalizadas através de violência explosiva, híper vigilância e irritabilidade” (YOUNG, 1996, p. 9697). Dependendo do tipo de acontecimento de experiências que tenham afetado o ser humano na forma física ou/e psicológica, a memória traumática varia tanto no tempo como no espaço.

No caso específico deste estudo, tentamos abordar estas questões partindo do princípio que remete para a liquidez do trauma, tão líquido quanto a sociedade que o forma. A memória traumática é líquida porque não se pretende que se solidifique ao ponto de interferir na formação identitária do sujeito, condicionando o contacto com outros espaços: "Experiências traumáticas não são uma história mas uma cascata de experiências, erupções e fendas, um deslizamento de placas tectónicas que sustentam o ser" (KIRMAYER,1996, p. 182). A metáfora da liquidez excelentemente fundamentada pelo autor Zygmunt Bauman (2000), foi usada como recurso analítico e operacional para lidar com a questão traumática e da memória, no sentido em que podemos considerar a ação de solidificação de uma memória como uma não ação desejada do sujeito. Ou seja, procura-se constantemente uma liquidez da memória que pode afetar levemente, ou mesmo profundamente, a ação do sujeito, de forma temporalmente espaçada, mas que não se deseja ver tornada numa rotina de convívio com o facto (o trauma) que afeta o sujeito.

Da situação do sujeito da investigação percebeu-se uma centralidade de lugar num corpo e a dificuldade do mesmo em deixar-se habitar, já que a fricção pelo modo como se relacionava com outros corpos 'normalizados' fazia claramente sentir-se. Intromete-se pois, a proposta da expressão autoral na resolução do trauma, no que diz respeito à mediação, como fórmula de uma iniciativa que surgira da convivência entre dois sujeitos, o sujeito de investigação e o sujeito investigado. Esta passou pela negociação de um trabalho conjunto para a revisão do sentido de lugar do corpo, na direção de uma outra ideia e experiência de paisagem.

Contrariando a solidificação da memória posta em movimento através das narrativas, é proposto ao sujeito tentar a sua 
desconstrução em articulação com um projeto fotográfico e a rearticulação da ideia de paisagem através da experiência. "Vamos tirar fotos? O quê? Só inventas! (...) está bem!”. (B. - comunicação pessoal, junho 14, 2014). O sujeito da investigação, não se sente parte da paisagem, não se admira a si mesma, os outros e a efemeridade dos compostos que nos fazem sentir integrados na terra, nos afetos, nas relações. Conhecer o outro e a nós mesmos, é doar a timidez que nos nutre. A loucura, dizem alguns. Da ideia de deformação corporal que a comunidade médica decide impor como real nos portadores da síndrome que a forma introduz-se uma mais aflita deformação, o não formar o amor por nós mesmos, pelo espaço que nos rodeia e pelo lugar que nos completa, fundamentado pelos traços e rasgos que o corpo e a pele portam. Justificava-se a intervenção conjunta de pensar a paisagem entre o sujeito da investigação e o sujeito investigado por via da fotografia digital, partindo precisamente da escala mais íntima que formatou todos os pensamentos de limitação espacial, do corpo e da pele. "Paisagem é terra e verde, e as pessoas...”. (B. - comunicação pessoal, maio 11, 2014). Decorrente deste processo o facto da mobilidade reduzida fazer depender o sujeito em estudo no contacto com outros espaços fez com que, sempre presente, estivesse o cariz de reconstrução. Particularmente, a componente biográfica e de narrativa, é retomada neste estudo pela alegoria à ideia paisagem e pelo refazer da narrativa perdida. Para Judith Lewis Hermans (1992) a recuperação de uma memória traumática, apresenta três estágios fundamentais: o estabelecimento de uma situação de segurança, lembrança e luto e uma terceira que corresponde a uma reconexão com a vida 'normal'. Foi nestes três estágios que se centrou o processo de trabalho de que aqui se dá conta. O primeiro foi o mais demorado e prazeroso, decorrendo de uma profunda ligação afectiva e convivência íntima. No que diz respeito ao segundo estágio, as narrativas biográficas foram exploradas à luz das metodologias qualitativas em Geografia. No segundo estágio da recuperação o sujeito "conta a história do trauma [...] de modo profundo e detalhado” (Herman, 1992, p. 175), transformando a memória traumática e sendo possível uma 
Tellusmorfismo: A Reconceptualização Corporal da Paisagem Através da Memória como Narrativa de Movimento

integração da mesma no ser do sujeito. O empoderamento do sujeito é o objetivo final deste estágio, induzindo a procura da coragem para direcionar a atenção para o fenómeno da sua doença e reconstruindo a narrativa. "A sociedade é muito injusta. No meu tempo não existia educação. Sempre me acompanharam nomes feios desde que era criança. A malota, a girafa, a caixa de óculos...”. (B. - comunicação pessoal, maio 10, 2014). O facto deste corpo não arrecadar nos seus registos de memória a aceitação social, torna-o automaticamente a metáfora do lugar, no sentido em que independentemente do espaço que preenche, torna-se ele, o agente que molda e que produz lugar na combinação das experiências anteriormente sentidas e que vive no momento. Estes lugares de trauma que advêm do sentido de lugar, da ideia e da experiência do ser com o outro, interceptam o conceito de deformação espacial ao dificultar a descodificação que o sujeito imprime no espaço: a perceção, a cognição, e a representação.

Por sua vez, o terceiro estágio de reconexão do sujeito para consigo e com os outros, foi-se construindo mas foi sobretudo atingido com a finalização da obra fotográfica. Tendo contacto com o passado traumático, o sujeito, enfrenta no terceiro estágio uma reconstrução do ser e cria o futuro, pregado de sonhos e ilusões. Sendo que "lamentou o anterior 'eu' que o trauma destruiu, deve agora estar apto para desenvolver o seu novo eu” (HERMAN, 1992, p. 198). As reconstruções de memórias traumáticas envolveram a construção de uma paisagem de coerência local para a melhor gerir ou contê-la na melhor gestão, para apresentar de forma convincente a outros (KIRMAYER,1996). Por último no que diz respeito ao trabalho com a memória, interessa também construir o sentido de comunhão /comunidade há muito perdido por via da aceitação social do 'eu' em contacto com outros corpos e espaços. Herman (1992) apela a este sentido, que os eventos traumáticos destroem as ligações entre o individuo e a comunidade. No caso particular deste estudo, a cirurgia acoplada ao facto de induzir a mobilidade reduzida e por inerência a dependência de outros para as mais diversas atividades, provocou precisamente um afastamento social, para com o espaço público e de outras relações de sujeitos. A integração, e o 
retomar do elo do 'eu individual' com o 'eu público' pretendeu atingir-se por via da publicação do material fotográfico em formato de exposição numa fase posterior, quer através dos canais virtuais (Web) quer físicos pela inclusão numa exposição em galeria.

Se de forma automática, toma-se a paisagem como estando (já presente) no corpo ou sendo (parte) do corpo, compreende-se o papel da imagem enquanto possibilidade de ser constituído através dela, no encontro entre corpo e fotografia (cores, ângulos, desfoques, linhas de profundidade...). Apelando novamente aos escritos e pensamentos de Magritte como já acontecera no início deste texto, os seus pensamentos voltam a enriquecer este diálogo. Lembremos a obra "La trahison des images" de 1929. A composição de Magritte, sugere um cachimbo (figura 2) calmamente flutuando na tela, com a inscrição ceci n'est pas une pipe. Figura e texto apresentam-se ao intérprete.

Figura 2: "La trahison des images" de Magritte.

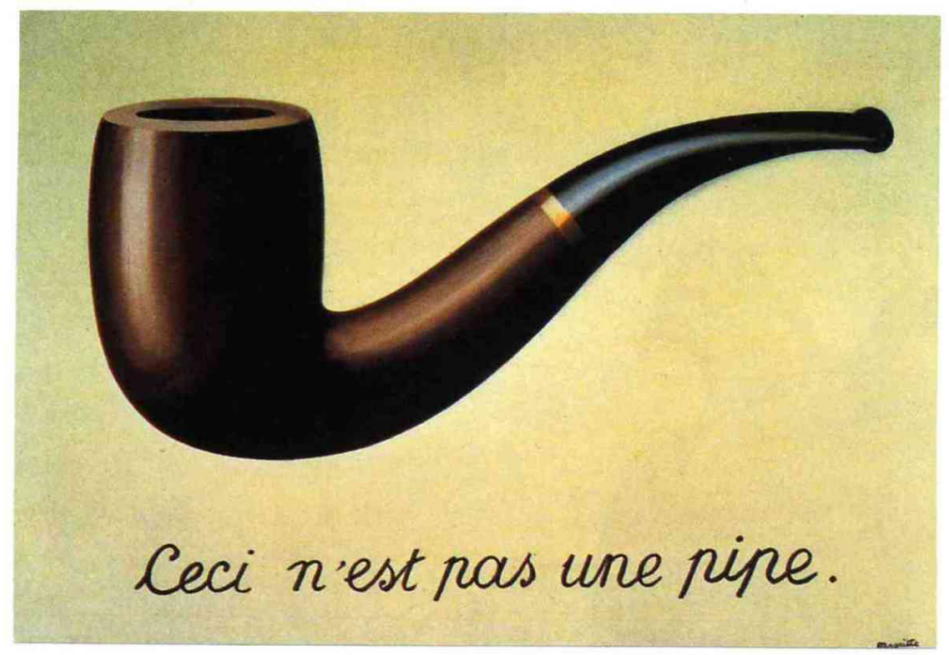

Fonte: http://www.magritte.be/

A série de interrogações que pôde a sociedade pensar com base na obra artística do pintor é curiosa:

imagem, ao mesmo tempo afirmando e negando a existência do cachimbo, como que nos incita a perceber sua condição de representação duplamente referenciada. Por outro lado, as palavras, ao afirmarem que não se trata de um cachimbo, e se 
afirmarem assim enquanto tais, indicariam sua condição de imagem, de representação de algo que apenas simula ser uma frase. Ao mesmo tempo, são oferecidos dois níveis de leitura e de interpretação - um que, explícito (visual) tenciona o implícito (lógico) e um outro que, implícito, relativiza o que é explicitado. (CAMPOS, 2004, n.d).

As relações entre 'linguagem e coisa' foram através de Magritte debatidas, proporcionando à arte contemporânea a autonomia em relação à linguagem que estaria 'atada' ao realismo representacional. A subjetividade trabalhada nas fotos coloca $\mathrm{O}$ espetador na condição da experiência de estar a 'ver' paisagens no corpo. Mais, focando as fotografias em algumas partes do corpo que sofreram intervenções cirúrgicas acredita-se poder divagar sobre o quanto existe de potência paisagística justamente naquelas partes em que os instrumentos e a ação humana (ciência e tecnologia) intervieram na 'natureza natural', deixando marcas visíveis na superfície da pele. Aludindo às escalas, associou-se a escala macro do território a um sentido mais diminuto no corpo humano. A interferência de legendagem 'não concordante' cujo intuito foi confundir o leitor assemelhando-se ao praticado por René Magritte induz sobre a relação produzida entre a 'linguagem' (legenda da imagem) que ao mesmo tempo é corpo e remete a paisagem. Mas remete ainda a paisagens evocadas/familiares ao sujeito e parte da sua biografia. $\mathrm{O}$ apelidar das imagens de partes do corpo fotografadas e trabalhadas digitalmente com nomes de lugares mais ou menos imaginários que emergiam como formas paisagísticas habituais, implicou trazer o lado mimético da superfície terrestre e do corpo como modo de rasurar sistemas codificados de significação, levando ao limite a fisionomia paisagística. A escala, a profundidade, o ritmo, as biografias, interferem nas relações que o leitor estabelece com as imagens, produzindo um diálogo entre paisagem e corpo no qual um e outro não aparecem propriamente indistintos. Pelo contrário, surgem metamorfoseado 7 .

7. Explica-nos Wenceslao Oliveira Jr, que a “metamorfose" é um conceito utilizado em ciências sociais por Gilles Deleuze para o processo de entrar em variação sem perder totalmente os contornos iniciais: as imagens continuam sendo corpos e paisagens: a potência está justamente em não se conseguir dizer qual deles é, fazendo tudo oscilar. 
Da mesma forma que Parr (2007) explorando a produção colaborativa de filmes como parte do desenvolvimento da sensibilidade e metodologias participativas adequadas para aceder aos mundos de pessoas com graves e permanentes problemas de saúde mental, no presente trabalho utiliza-se a fotografia em formato colaborativo como meio para atingir o pressuposto teórico da tellusmorfismo, ao mesmo tempo que aplicada como terapia de um trauma que rege corpo e mente de um sujeito particular. A fotografia digital ao por em questão a própria unidade espaço-temporal (SELIGMAN-SILVA, 2010) pela aceleração generalizada da vida, aponta também a consequência desta aceleração, a dissolução de identidades e espaços: "A fotografia era pensada como índice capaz de designar e atestar uma singularidade física de um aqui e agora. Este aqui e agora foi abalado pela era das imagens eletrónicas. As imagens tornam-se agora mais 'maleáveis', manipuláveis" (2010, p. 48). Neste jogo de dissoluções, acreditamos encontrar uma via mais adaptável aos objetivos propostos. Se, por um lado, o processo dilui a identidade do sujeito fotograficamente representado, por outro, permitiu a dissolução do corpo/pele em paisagem. O movimento é antes de tudo a valência mais bem explorada e desejada do sujeito. Um curioso ponto de vista desta 'liquidificação' e fluidez da memória, anteriormente sinalizada é sem dúvida o movimento que a arte e a fotografia em formato digital permitem. Em particular explora-se o movimento do sujeito entre espaços no ato de suavizar a memória traumática. $\mathrm{O}$ movimento subjacente, a narrativa do movimento da memória decorreu em todo o processo prático desde o lidar com os traumas, o processo de criação de significados, a representação e a constituição da obra final em formato fotográfico.

$\mathrm{Na}$ sua recuperação e no lidar com a sua mobilidade reduzida, a arte fotográfica com alusão a uma reconceptualização da ideia de paisagem permitiu atingir o tão ansiado movimento, ao produzir obras passíveis de desmaterialização virtual e passíveis de se tornarem alvo de crítica por diversos agentes e sujeitos. Por albergar um caso clínico, o sujeito da investigação acabava por colocar o corpo em posições socialmente não convencionais. Contava o sujeito 
Tellusmorfismo: A Reconceptualização Corporal da Paisagem Através da Memória como Narrativa de Movimento

da investigação que dependendo dos espaços o "à vontade do corpo" era comprometido. Teatros ao ar livre, estruturas de concentração de massas, e autênticos currais humanos, o pensamento urbanístico contemporâneo, soube conceber Lojas do Cidadão, Centro Comerciais e outros demais pavilhões votados ao voyeurismo. Das limitações de mobilidade mas não de pensamento do sujeito da investigação, a produção das imagens permitiu romper barreiras físicas e dar aso à imaginação. "Ainda vou andar pelo mundo com as fotos...” (B. - comunicação pessoal, julho 2, 2014), implica a aceitação da fotografia como representação do eu, que mesmo infinitas vezes recortado, ou alterado digitalmente interliga o sujeito com a obra criada ao ponto de se compreender que a disseminação e reprodução das imagens implica conquistar o espaço e tornar móvel, mais que nada os pixéis representados do sujeito e a base da sua formação identitária que acompanha a foto.

Da limitação geográfica do presente, o sujeito move-se agora de forma desinibida, derrubando fronteiras e reajustando-se culturalmente a outras realidades. Desta ausência do movimento por entre outros espaços, do sujeito, intromete-se pois, a necessidade de narrar, seja qual forem as formas de narração, o trauma, porque "tem em primeiro lugar este sentido primário de desejo de renascer" (SELIGMANN SILVA, 2008, p. 66). Foi isso que fizemos.

Discutindo-se a forma como o processo de fotografia pode atuar como um texto que mantém valiosos dados sobre o impacto da 'arte' na saúde mental, facilitando uma série de resultados benéficos mútuos, a paisagem cultural aqui construída, apresenta-se não como uma entidade física mas como um conteúdo intelectual de memórias, relacionadas com a terra e conectadas através do corpo pela cultura. Cada incisão cirúrgica, cada forma do seu corpo, surgira em momentos temporais no espaço da vida do sujeito da investigação ao longo da sua biografia. Enquanto técnica de registar o instante, revelando-o, a fotografia pode aproximar-se da cena do trauma sendo que as imagens servem tanto de reprodução do abalo e da potenciação do trauma, como também de terapia de choque. É pois na capacidade de reescrever e sintetizar a vida proporcionada 
pela fotografia digital que reside um dos pontos centrais deste trabalho: "[...] a metáfora fotográfica digital representa apenas um aspeto da revolução em nossa visão do mundo. [...] é apenas um pequeno fato se colocado ao lado da verdadeira revolução por que passamos agora, que é, antes de mais nada, uma revolução no nosso próprio organismo. A possibilidade de manipular imagens é apenas um fenómeno menor se comparado à nossa possibilidade de sintetizar a vida" (SELIGMANN-SILVA, 2010 p. 50). SeligmannSilva (2010) vai ainda mais longe ao refletir que hoje predomina a reprodução técnica não só de imagens mas também a síntese técnica de corpos e organismos.

Se a paisagem se tornou em cenário pela pintura, a paisagem tornar-se-ia numa área percebida e observada a partir de um determinado lance de vista, a construção digital permitiu novas conceções de outras paisagens. Entendendo a paisagem como uma "tecnologia para a organização da experiência" (AZEVEDO, 2012), de recorporização do sujeito, também neste trabalho ela se foi traduzindo numa construção de sentido de lugar mais do que legítimo e agora reclamado para ação e partilha. $\mathrm{O}$ "conseguiste fazer arte de uma fotografia", afirmação proferida pelo sujeito da investigação, denota a capacidade de orgulho do trabalho feito em que ela própria é autora. A descoberta da possibilidade de autorepresentação acresce a legitimidade daquele corpo num lugar de significados partilhados afectivamente.

Desde a realização das fotografias, poses, transferência e visualização das fotografias, tratamento digital e escolha das peças, tudo foi efectuado em cumplicidade com o sujeito da investigação, partindo frequentemente do mesmo as propostas de trabalho. Tentou-se o maior afastamento possível da aplicação de técnicas de 'Eu, Investigador - Outro, Investigado', sendo crescente o desenvolvimento de técnicas de investigação colaborativa em que a autoria do processo e resultados da pesquisa foram realmente partilhados. As fotografias desenvolvidas foram utilizadas para reinventar a ideia de paisagem, a consciência dos sujeitos que as percecionaram e o sujeito retratado, melhorando o relacionamento 
sobre si mesmo, os outros e ativando uma mudança social positiva diminuindo a instabilidade emocional e a relação com o mundo. Da mesma forma, como método de emancipação do sujeito, acreditamos ter servido o propósito inicial. O sujeito da investigação demonstrara a posteriori da produção e arranjo fotográfico uma disposição para a captura e divulgação de imagens, tendo este projeto contribuído para uma mudança positiva nos processos de socialização. Do ponto de vista territorial, o acesso a espaços preenchidos por outros olhares desmistificou-se, manifestando uma maior aceitação da inserção do seu corpo em espaços povoados. Recordo o desejo de planificar novas viagens; "quero ir a São Bentinho (...) o Centro (Centro de dia) em outubro deve ir à praia", a participação em rituais familiares e as poses naturais para o retrato "deixa-me ver como fiquei... tira outra" (B. - comunicação pessoal, setembro 24, 2014). Numa ode à memória, a vida consome-se num influxo, e expira-se num sopro ao considerarmos apenas usufruir dentro de um prazo de válida idade. Vive-se as vezes quantas quisermos, em que cada vislumbre solar é um renascer e uma etapa mais para nos tornamos melhores homens e mulheres. Em analogia, a fotografia permite viver quantas as vezes que desejarmos e proporcionando o movimento por entre sujeitos, lugares e sobretudo experimentar outras paisagens. Isto é, também, sair do lugar, lançando o repto do explorador, revisitado agora num outro quadro de alteridade. A fotografia dá vida a um corpo, prolongandoo numa outra validade, eternizando a paisagem e o território que este tocou. A execução e divulgação do material fotográfico como memória biográfica, apoiado nos quadros da tecnologia digital, movem um sujeito ditado à mobilidade reduzida. Um sujeito já não presente no mundo de quem respira, mas que inspira, move-se e mobiliza, sempre. 
Figura 3: Ao fundo, o Santuário da Nossa Senhora da Peneda, Portugal.

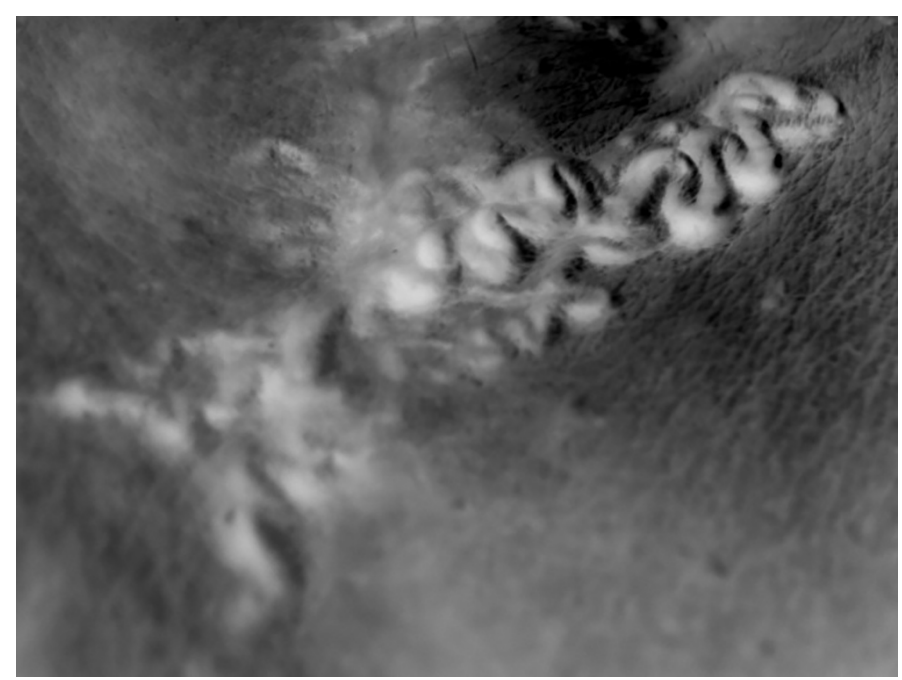

Fonte: Autor.

Figura 4: Encosta do Bom Jesus, Braga, Portugal.

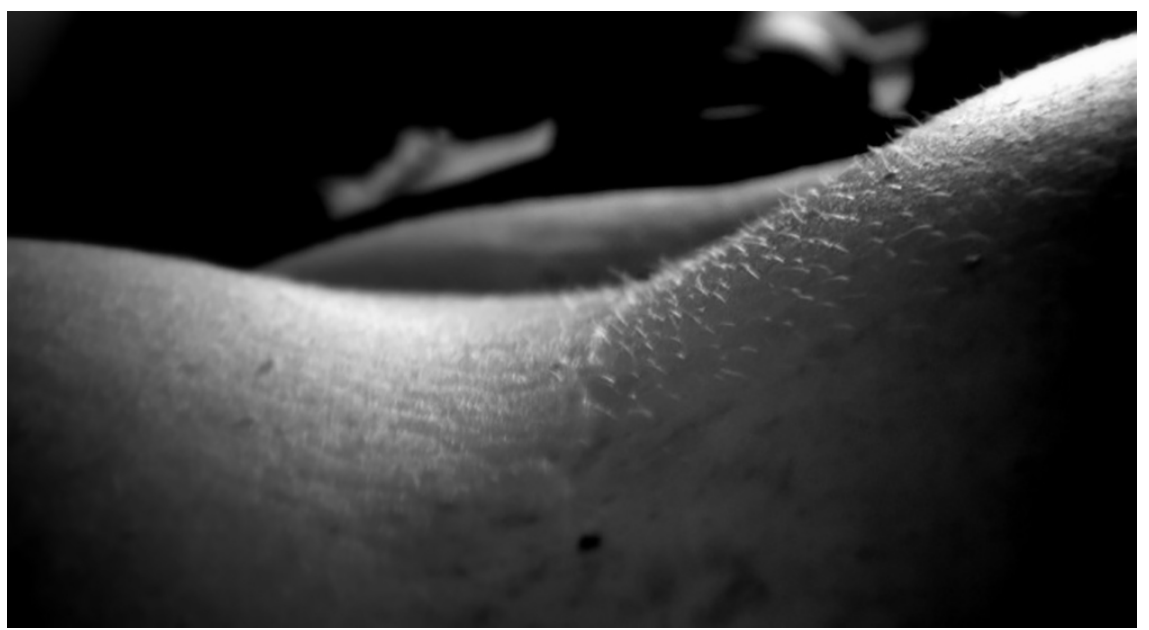

Fonte: Autor.

Geografias e (In)visibilidades: Paisagens, Corpos, Memórias 304 
Tellusmorfismo: A Reconceptualização Corporal da Paisagem Através da Memória como Narrativa de Movimento

Figura 5: Albufeira da Caniçada, Terras de Bouro/Vieira do Minho, Portugal

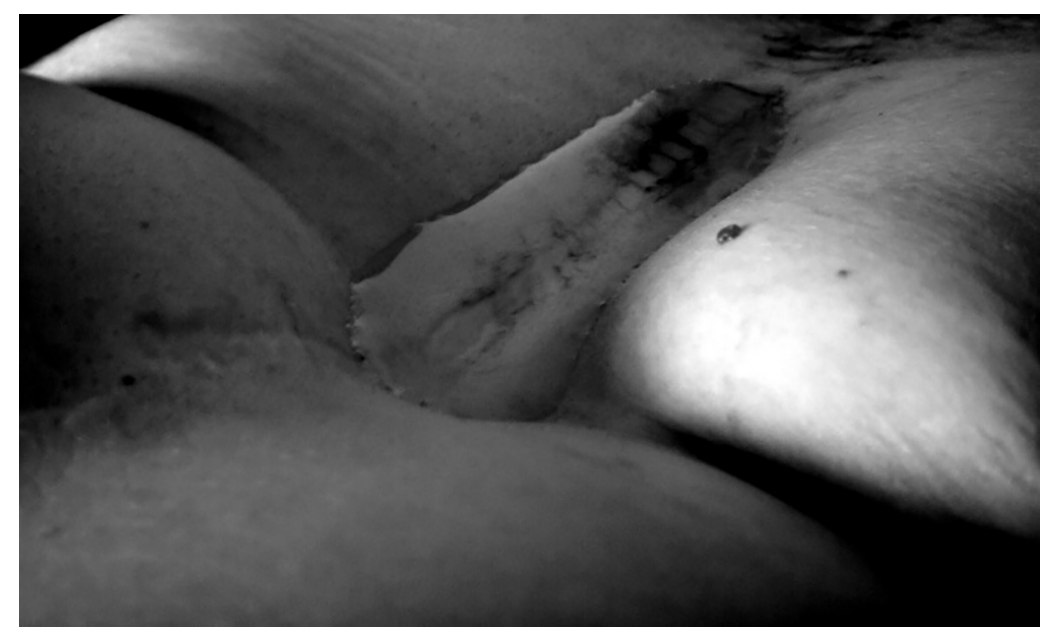

Fonte: Autor.

Figura 6: Vale encaixado do Tua, Portugal

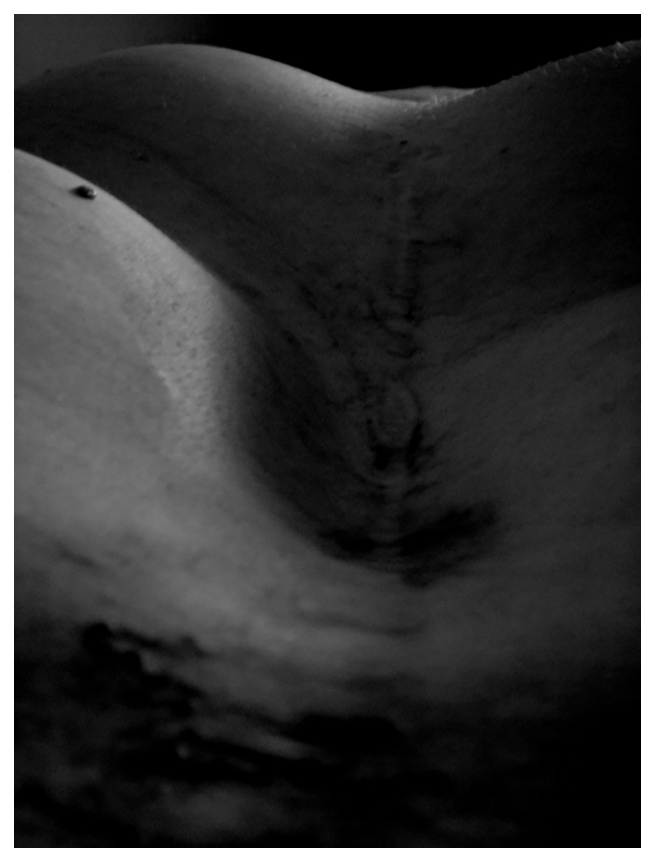

Fonte: Autor. 
Figura 7: Caminho em terra batida.

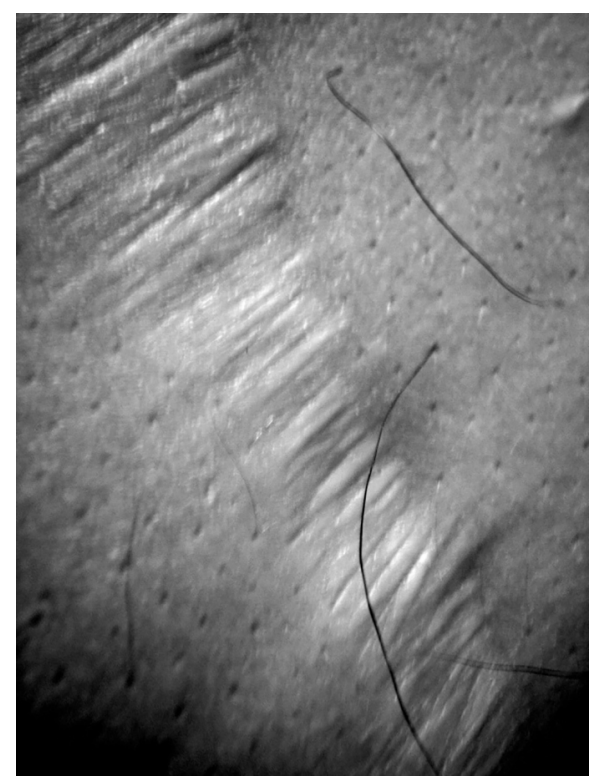

Fonte: Autor.

Figura 8: Bacia Hidrográfica do Rio Cávado - imagem de satélite (1949)

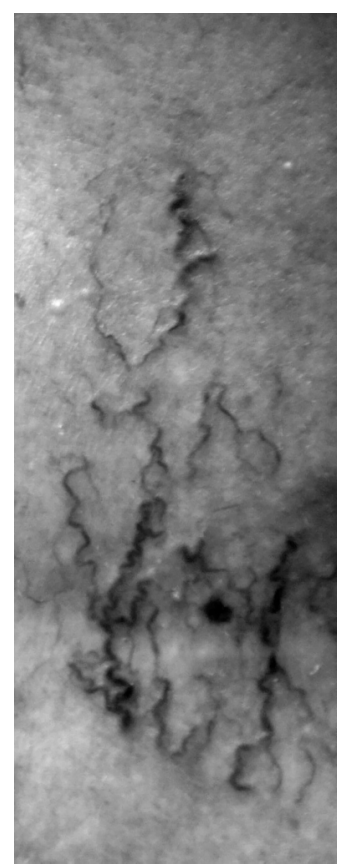

Fonte: Autor. 


\section{Referências}

AMAR, P.J. História da Fotografia. Lisboa: Edições 70, 2007.

AZEVEDO, A.F. Geografia e cinema: representações culturais de espaço lugar e paisagem na cinematografia portuguesa (Dissertação de Doutoramento, Universidade do Minho), Local: 2007.

. A Experiência de Paisagem. Porto: Figueirinhas, 2012.

AZEVEDO, A. F. \& PIMENTA, J. \& SARMENTO, J. (Eds.). Geografias do corpo. Porto: Editora Figueirinhas, 2009.

BAUMAN, Z. Modernidad Líquida. Argentina: Fondo de Cultura Económica, 2002.

BERGSON, H. Duration and Simultaneity. New York: Bobbs-Merrill Company, 1965.

BRITO-HENRIQUES, E. Fausto entre nós. In: A.F., Azevedo \& J.R. Pimenta \& J. Sarmento (Eds.), Geografias do Corpo - Ensaios de Geografia Cultural. Porto e Lisboa: Figueirinhas, 2009, p. 81-98.

BRUNO, G. Atlas of emotion: journeys in art architecture and film. Nova Iorque: Verso, 2002.

CAMPOS, J. L. Eis dois cachimbos: Roteiro para uma leitura foucaultiana de Magritte. Espéculo. Revista de Estudios Literarios, 2014.

Disponível

$\mathrm{em}$

http://www.ucm.es/info/especulo/numero27/magritte.html.

Acesso em...

CARLOS, A .F. A. O lugar no/do mundo. 2007. São Paulo: FFLCH. Disponível em http://www.controversia.com.br/uploaded/pdf/12759_o-lugar-nodo-mundo.pdf

CLIFFORD, N. \& VALLENTINE, G \& FRENCH, S. (Eds.) Key methods in Geography. London: Sage Publications, 2003.

GROSZ, E. Lived Spatiality: Insect Space/Virtual Sex. Agenda, v. 26, n. 7, p. 5-8, 1992.

HACKING, I. Memory Sciences, Memory Politics. In: P. Antze \& M. Lambeck (Eds.), Tense Past: Cultural Essays in Trauma and Memory. Nova Iorque: Routledge. 1996, p. 67-88.

HAWKINS, H. For Creative Geographies Geography, Visual Arts and the Making of Worlds. Nova Iorque: Routledge, 2013. 
HERMAN, J. L. Trauma and Recovery. Nova Iorque: Basic Books, 1992.

HERMANS, H. J. M.; HERMANS-JANSEN, E. Self-Narratives: The Construction of Meaning in Psychotherapy. Nova Iorque: The Guilford Press, 1995.

HINZ, L. D. Expressive Therapies Continuum: a Framework to use art in therapy. Nova Iorque: Routledge, 2009.

HOLZER, W. O lugar na Geografia Humanista. Revista Território, v. 7, p. 67-78, 1999.

JONES, O. Geography, memory and non-representational geographies. Geography Compass, v. 5, n. 12, p. 875-885, 2011. Disponível em: http://dx.doi.org/10.1111/j.1749-8198.2011.00459.x. Acessado em ...

JONES, O. \& GARDE-HANSEN, J. Geography and Memory: Explorations in Identity, Place and Becoming. Basingstoke: Palgrave Macmillan, 2012.

JUNG, C.G. O espírito na arte e na ciência. Petrópolis: Vozes, 1988.

KAPYTAN, L. An introduction to Art Therapy Research. Nova Iorque: Routledge, 2010.

KIRMAYER, L. J. Trauma, Time, Illness, adn Culture: an antropholigcal Approach to traumatic Memory. In: P. Antze \& M. Lambek (Eds.). Tense Paste: Cultural Essays in Trauma and Memory. New York: Routledge, 1996, p.151-172.

LONGHURST, R. The body. In: D. Sibley, P. Jackson, D. Atkinson, N. Washbourne (Eds.) Cultural Geography: A critical Dictionary of Key concepts. Nova Iorque: I.B.Tauris \& Co Ltd, 2005, p. 91-96.

LORIMER, H. Cultural geography: the busyness of being 'more-thanrepresentational. Progress in Human Geography, v. 29, n. 1, p. 83-94, 2005.

MAGRITTE, R. Écrits complets. Paris: Flammarion, 2011. (Edition établie e annotté par André Blavier).

MALCHIODI, CATHY, A. (Ed.). Expressive Therapies. Nova Iorque: The Guilford Press, 2005.

MALDONADO, G. \& CARDOSO, M.R. O trauma psíquico e o paradoxo das narrativas impossíveis, mas necessárias. Psic Clin, v. 21, n. 1, p. 45- 57, 2009.

NORA, P. Between Memory and History: Les Lieux de Mémoire. Representations, n. 26, Special Issue: Memory and Counter- 
Memory. Spring, 1989, p. 7-24.

. From lieux de mémoire to realms of memory. In: L.D. Kritzman (Ed.). Realms of memory. Nova Iorque: Columbia University Press,1996, p.15-24.

PARR, $H$. Collaborative film-making as process, method and text. Mental health research Cultural Geographies, v. 14, n.1, p. 114-138, 2007.

. Mental Health and Social Space: Towards Inclusionary Geographies? Nova Iorque: Blackwell Publishing, 2008.

PICKLES, J. Nowledge, Theory, and Practice: The Role of Practical Reason. In R.G. Golledge \& H. Couclelis \& P. Gould (Eds). A Ground for Common Search. Santa Barbara: The Santa Barbara Geographical Press, 1988, p. 71-90.

RODAWAY, P. Sensuous Geographies: Body, Sense and Place. London: Routledge, 2011.

RUBIN, J. A. Introduction to Art Therapy: Sources and Resources. Nova Iorque: Routledge, 2010.

SELIGMAN-SILVA, M. Narrar o trauma - a questão dos testemunhos de catástrofes históricas. Psic. Clin., v. 20, n. 1, p. 65-82, 2008.

- Fotografia como arte do trauma e imagem-ação: jogo de espectros na fotografia de desaparecidos das ditaduras na América Latina. Resgate, v.18, n. 19, p. 46-66, 2010.

VAN DIJCK, J. Mediated Memories in the Digital Age. Palo Alto: Stanford University Press, 2007.

VICK, R.M. A brief history of art therapy. In C.A. Malchiodi (Ed.). Handbook of Art Therapy. Nova Iorque: Guilford Press, 2003, p. 5-12.

WASHBOURNE (Eds.) Cultural Geography: A critical Dictionary of Key concepts. Nova Iorque: I.B.Tauris \& Co Ltd., 2005, p. 91-96.

WILLIS, A. Bearing Witness: Restorying the Self in Places that are Always More than Human Made. Animal Studies Journal, v. 2, n. 1, p. 827, 2013.Disponível em <http://ro.uow.edu.au/asj/vol2/iss1/3>. Acessado em ... 



\title{
Desconstrução Imagética da Mulher Negra na Bahia
}

\section{Camila Xavier Nunes}

\author{
Juliana Cunha Costa Radek
}

Nelson Rego 


\section{O Corpo Feminino como Objeto de Representação}

Da Antiguidade à Modernidade as mulheres são representadas antes de serem descritas. (DUBY; PERROT, 1992)

A história do corpo feminino é também a história de uma dominação na qual os simples critérios da estética já são reveladores. (CORBIN; COURTINE; VIGARELLO, 2009)

$\mathrm{A}_{\text {extensamente descritas. } \mathrm{Na} \text { iconografia ocidental, elas foram }}$ representadas a partir de perspectivas e de parâmetros masculinos, o que contribuiu para a composição de imagens próximas de idealizações, e não para uma representação do que efetivamente o corpo feminino apresentava em seu cotidiano. Antes de tudo, é preciso situar que esse é um ponto crucial para entender o motivo de as imagens produzidas terem sido (e ainda serem) tão cruéis com as mulheres: são representações de idealizações e escondem relações de poder culturalmente naturalizadas. Todavia, “convém não esquecer que estas imagens, que geralmente nos chegam isoladas, não eram à partida imagens isoladas, mas faziam parte de um conjunto coerente de signos [...]” (DUBY; PERROT, 1992, p. 13).

Quando observamos a evolução dos padrões estéticos, a beleza é reveladora das relações de poder alicerçadas na produção iconográfica do feminino ${ }^{1}$. Desde as sociedades mais remotas, a construção cultural de gênero opõe masculino e feminino por meio de um discurso em que os marcadores identitários são constantemente reforçados e atualizados, principalmente para as mulheres. Dentro dessa lógica de pensamento, a força estaria associada aos homens, enquanto a beleza estaria atribuída às

1. "Uma imagem converte-se em representação à medida que ultrapassa seus elementos constitutivos e transforma-se em uma expressão concreta de si, expressão que não permite a redução a nenhuma outra forma semelhante - não pode ser avaliada por critérios de autenticidade, sua potência está na capacidade de mobilização e de reconhecimento social.” (NUNES, 2014, p. 14) 
mulheres. A relação entre beleza e representação é uma totalidade que naturaliza a opressão, a violência e o controle sobre o corpo feminino: "[...] A sobreposição da beleza e da representação não simplifica as coisas" (DUBY; PERROT, 1992, p. 175). Hermeneuticamente, a fertilidade e a beleza estética são os principais atributos femininos definidos a partir de critérios masculinos. A mulher, compreendida como propriedade do homem, deveria se comportar, falar, agir, vestir-se e pensar de acordo com a aprovação masculina (COSTA, 2014)2. Wolf (1992) acredita que a beleza estética é uma das últimas barreiras para autonomia da mulher contemporânea, e para Tiburi (2008, p. 53) “o útero é o que se revela como foco último da estrutura de poder no que tange à modelagem que o sistema do feminino (como construção de poder dos homens) exerceu sobre as mulheres”. Desse modo, a maternidade compulsória e a ditadura da estética ainda são os principais obstáculos para equiparação dos direitos e oportunidades para as mulheres. Esses obstáculos são escamoteados por meio de discursos religiosos, políticos, sociais e culturais que naturalizam as condições pouco vantajosas de grande parte das mulheres. Nesse sentido, a idealização do corpo feminino, ao mesmo tempo em que o enaltece, exerce um controle por meio da anatomopolítica e biopolítica ${ }^{3}$.

A distinção ideológica entre a esfera pública e a esfera privada, bem como a hierarquização dos papéis sociais exercidos nessas diferentes esferas, são em grande parte responsáveis pelo desenvolvimento de competências, habilidades e funções sociais diferenciadas para mulheres e para homens. Segundo Biroli: "A crítica às desigualdades de gênero está geneticamente ligada à crítica às fronteiras convencionais entre o público e o privado nas

2. "Nas próprias representações artísticas na forma de pinturas se percebe o papel de submissão da mulher em relação ao homem. Apesar de ser homenageada devido à questão de gerar vidas, era também dividida entre a imagem de honra e vinculada à criação de filhos, ou como perversa, egoísta e movida por instintos sexuais." (COSTA, 2014)

3. Para Foucault (2001), a anatomopolítica torna o corpo como máquina e a biopolítica configura-se como o controle da vida da população - polos distintos do biopoder. 
abordagens teóricas, na prática política, nas normas e nas instituições" (BIROLI, 2014, p. 34).

A extensa iconografia do corpo feminino ocupa espaços de fala e poder que seriam restritos às mulheres. No entanto, por serem tão representadas, a produção de suas próprias narrativas visuais parece se esgotar: "[...] se a filosofia em sua história lutou contra as imagens, não o fez contra a imagem da mulher. Ao contrário, ajudou no processo de definição de uma mulher "como imagem" da falsidade, da ignorância e da anatomia como destino" (TIBURI, 2010, p. 303). Nesse caso, a mulher compreendida como objeto de representação impede a expressão dos discursos femininos e, por consequência, de suas subjetividades. A mulher ainda é compreendida como objeto a ser retratado pelo outro, não tendo direito à expressão própria de si: “[...] no decurso dos séculos, as imagens perpetuaram assim o postulado de uma incapacidade fundamental da mulher, entregue, passiva, embonecada para belprazer dos homens" (PERROT, 1992, p. 32). A beleza estética como principal atributo feminino não é um paradigma fácil de superar, uma vez que a normatização estética e suas tendências vão se alternando ao longo de séculos e alimentam lucrativos nichos de mercado, tais como a indústria de cosméticos/estética, o fitness, a moda, etc. As influências podem ser religiosas, sociais, culturais, econômicas, entre outras, ou até mesmo uma complexa combinação de variáveis que estabelecem o perfil ideal para cada período histórico. A normatização estética se traduz, entre outros aspectos, em um mimetismo impulsionado pelos meios de comunicação a partir de uma estética que, muitas vezes, não condiz com próprio biotipo nem com suas práticas culturais. Segundo Nunes: "As imagens não nos chegam isoladas, mas integram um conjunto de signos com suas coerências e incoerências" (NUNES, 2014, p. 105).

A beleza estética como principal atributo feminino também está intimamente associada à experiência de dor. A aceitação de sua imagem corporal condicionada à aprovação alheia pode favorecer o desenvolvimento de transtornos psicológicos, fisiológicos e sociais, uma vez que a mulher pode produzir uma perigosa distorção da sua 
imagem (dismorfia corporal), levando a comportamentos extremos que podem resultar em óbito, como a severa restrição de calorias (anorexia), a compulsão alimentar seguida de indução ao vômito (bulimia), o excesso de exercícios e atividades físicas (vigorexia), o uso de medicamentos que alteram o funcionamento metabólico, a submissão a intervenções cirúrgicas que requerem muitos cuidados nos períodos pré e pós-operatório, entre outros procedimentos invasivos não cirúrgicos (aplicação de toxina botulínica (Botox), peeling, bioplastia, depilação a laser, branqueamento de dentes e pele etc.). E quando todas essas possibilidades se esgotam, a não aceitação de sua imagem corporal pode incidir em baixa autoestima, doenças psicossomáticas e práticas de violência autoinfligida, podendo resultar em suicídio - tudo em decorrência da insatisfação com a própria imagem corpórea não adaptável aos modelos hegemônicos que determinam o que é a beleza feminina.

$\mathrm{O}$ modo como as mulheres foram e ainda continuam a ser representadas é indicativo de como nossa cultura visual tem sua parcela de responsabilidade para que a beleza estética ainda seja o principal atributo associado à condição feminina, pois “o mito da beleza na realidade sempre determina o comportamento, não a aparência" (WOLF, 1992, p. 17). Mas é preciso reconhecer que críticas relacionadas à ditadura estética aumentaram, como também aumentou a participação feminina nos mais variados âmbitos da sociedade contemporânea. A iconografia do feminino é um importante recurso para situar e analisar como ideologias colonialistas e patriarcais foram incorporadas e ocultadas pela naturalização dos parâmetros universalizantes e estruturantes dessas representações culturalmente construídas. O representacionismo é um importante elemento do processo civilizatório no Ocidente e um dos fundamentos da cultura patriarcal sob a qual ainda vivemos (MARIOTTI, 2001).

$\mathrm{Na}$ primeira metade do século $\mathrm{XX}$, a Europa ainda enfrentava a crise das guerras mundiais, enquanto a economia norteamericana, especialmente a do entretenimento, encontrava-se em plena ascensão. No Brasil, o padrão de beleza imposto estava 
associado à boa aparência física e à juventude, critérios relacionados ao fenótipo caucasiano impulsionado pela indústria hollywoodiana ${ }^{4}$. A política do embranquecimento favorecia o discurso racista da sociedade brasileira fomentado pela elite, criando um legado cultural baseado na supremacia branca. Como parte do projeto de modernização do país - fundamentado na proposta civilizatória e higienista - o mito da "Democracia Racial", disseminado por Gilberto Freyre $^{5}$ em Casa Grande $\mathcal{E}$ Senzala, publicado originalmente em 1933, passava a representar negros e mestiços como seres impuros e incivilizados que viviam em plena harmonia com os seus senhores no contexto da sociedade patriarcal brasileira.

Sob esta lógica, foram atribuídas às mulheres negras as funções domésticas e sexuais da Casa Grande. Elas eram responsáveis pela geração de filhos destinados a mão de obra escrava e também eram obrigadas a servirem aos seus senhores como serviçais, "amas de cama", "amas de leite" e iniciadoras sexuais de jovens rapazes. Segundo Freyre (2003, p. 367), a mulher negra "[...] nos iniciou no amor físico e nos transmitiu, ao ranger da cama-de-vento, a primeira sensação completa de homem”. Além disso, o autor narrava, com certo romantismo, a tese de que os homens brancos possuíam

4. O cinema hollywoodiano passava a fabricar as celebridades, e o ideal de beleza cinematográfico alcançava dimensões mundiais. A representação de mulheres como Greta Garbo (1905-1990) e Marilyn Monroe (1926-1962) trazia a valorização do corpo curvilíneo com cinturas acentuadas e seios volumosos, cabelos loiros, longos e medianos, sobrancelhas delineadas e arqueadas, enquanto a pele branca era valorizada pela maquiagem.

5. O autor "[...] dimensionou de outro modo a mestiçagem. Para ele, a mestiçagem era etnicamente bela, sadia e culturalmente enriquecedora, além de elemento central para o equilíbrio de antagonismo. Também descreveu a colonização portuguesa, defendendo a tese do 'luso-tropicalismo', segundo o qual os portugueses foram os que melhor se adaptaram às Américas. Desta tese, surgiu a 'teoria' da democracia racial brasileira. Escrevia na perspectiva da elite dominante, mostrando o forte traço de mandonismo da 'casa-grande', a constituição da família patriarcal e o complexo sociocultural do Nordeste com base na monocultura fundiária da cana-de-açúcar, utilizando mão de obra africana escravizada" (MELO SILVA, 2011, p. 20-21, grifo nosso). 
predileção sexual por mulheres escravizadas ${ }^{6}$, uma vez que os garotos cresciam em um ambiente "[...] rodeado de negra ou mulata fácil [...]. Conhecem-se casos no Brasil não só de predileção, mas de exclusivismo: homens brancos que só gozam com negra” (Ibidem). A cultura do estupro enquanto violência secular contra a dignidade da mulher negra colaborou para a construção de um imaginário popular e socialmente preconceituoso de que as negras são sexualmente liberais e vulgares, sustentando a prerrogativa de que elas são mais propensas a serem violadas e abusadas. Todavia, Freyre (2003) deixa evidente que a preferência do homem branco brasileiro pela mulher negra estava restrita às relações físicas do trabalho doméstico e sexual:

Pode-se, entretanto, afirmar que a mulher morena tem sido a preferida dos portugueses para o amor, pelo menos para o amor físico. A moda de mulher loura, limitada aliás às classes mais altas, terá sido a repercussão de influências exteriores do que a expressão de genuíno gosto nacional. Com relação ao Brasil, que o diga o ditado "Branca para casar, mulata para fornicar, negra para trabalhar"; ditado em que se sente, ao lado do convencialismo social da superioridade da mulher branca e da inferioridade da mulher preta, a preferência sexual pela mulata. Aliás o nosso lirismo amoroso não revela outra tendência senão a glorificação da mulata, da cabocla, da morena celebrada pela beleza dos seus olhos, pela alvura dos seus dentes, pelos seus dengues, quindins, e embelegos muito mais do que as "virgens pálidas" e as "louras donzelas". Estas surgem em um ou em outro soneto, em uma ou em outra modinha do século XVI ou XIX. Mas sem o relevo das outras (FREYRE, 2003, p. 71-72, grifo nosso).

A partir da segunda metade do século XX, o ideal de beleza feminino estava associado à geração saúde (1960), ao movimento bippie e andrógeno (1970-1980), à geração heroin-chic, à era das

6. No Brasil, o estupro colonial perpetrado pelos senhores brancos portugueses e brasileiros sobre negras e indígenas está na origem de todas as construções sobre a identidade nacional e construções hierárquicas de gênero e raça presentes em nossa sociedade, configurando aquilo que Angela Gilliam define como "a grande teoria do esperma da formação nacional', mediante a qual, segundo ela: 1) o papel da mulher negra na formação da cultura nacional é rejeitado; 2) a desigualdade entre homem e mulher é erotizada; 3) a violência sexual contra as mulheres negras é romantizada" (CARNEIRO, 2002, p. 180). 
supermodelos (1990) e aos corpos musculosos (período atual). A imagem icônica da mulher de alta estatura, de características fenotípicas europeias e magreza excessiva e/ou corpo musculoso torna-se o padrão de beleza estética dominante. Com o auxílio de técnicas de maquiagens e recursos digitais ${ }^{7}$, a mídia cria modelos corporais que não condizem com a realidade de muitos indivíduos. Porém, a mulher negra encontra-se em desvantagem, já que está ainda mais distante dessas representações hegemônicas. Dentro desse panorama, o padrão de beleza não eurocêntrico foi posto a planos coadjuvantes na linha histórica da cultura visual ocidental. Como resultado, a identidade nacional normalizada pelas elites brasileiras também estava associada à cultura e ao biotipo caucasiano, enquanto os elementos culturais afrodescendentes à animalidade, ao primitivismo, ao grotesco e ao pitoresco.

Fixar uma determinada identidade como a norma é uma das formas privilegiadas de hierarquização das identidades e das diferenças. Normalizar significa eleger - arbitrariamente uma identidade específica como o parâmetro em relação ao qual as outras identidades são avaliadas e hierarquizadas; significa atribuir a essa identidade todas as características positivas possíveis, em relação às quais as outras identidades só podem ser avaliadas de forma negativa. (SILVA, 2000, p. 83).

\section{As Representações da Mulher Negra em Salvador e o Duplo Preconceito}

Se a percepção está envolvida no campo dos preconceitos, isso quer dizer que os preconceitos sâo, em primeiro lugar, estéticos. Negação ao que, na esfera das formas, escapa a um padrão, os preçonceitos servem de defesa para um paradigma, um modelo prévio a seguir. (TIBURI, 2016)

A historiografia nacional e a baiana têm visibilizado a presença, as ocupações e as profissões femininas que se desenvolveram pelas ruas das vilas e cidades da América portuguesa. (VANIN, 2015)

7. Entre inúmeros programas de computador para edição de imagem, o Adobe Photoshop é o mais difundido no meio profissional e amador. 
Como visto, a beleza estética interfere na vida das mulheres por requerer gastos de tempo e recursos financeiros, configurando-se como um obstáculo material e simbólico para que outras atividades sejam exercidas. Trazendo isso para a mulher negra, a situação agrava-se, uma vez que ela está mais distante dos padrões ditados pela colonização estética ocidental - os quais se alteram de acordo com o período histórico, as técnicas e as tecnologias disponíveis. A hierarquização étnico-cultural arraigou-se na sociedade brasileira para justificar as desigualdades sociais de um país mestiço. No Brasil, a colonização dos corpos pela estética que representa um fenótipo dominante afeta a mulher negra, que é alvo de duplo preconceito: de gênero e étnico. Percebe-se que esse tipo de distinção e hierarquização também estava intrinsecamente en raizado à gênese da cidade de Salvador. Segundo Vanin (2015, p. 530): "Não só cor e classificação social, mas também gênero caracterizava os sujeitos que protagonizavam as relações de trabalho que envolviam os ofícios. Ou seja, havia ofícios que eram exercidos por mulheres”.

[...] A mulher serviu para a colonização como complemento e preenchimento demográfico do novo território. A diferenciação étnica da mulher determinava sua respectiva função social no Brasil colonial. Enquanto a nativa e, mais tarde, a negra contribuía com o corpo e o trabalho a mulher branca trazia da metrópole o modo de viver e a maternidade que garantia o alvor da pele. (OLIVEIRA, 2008)

Assim, pode-se afirmar que na nascente Salvador do século XVI, trabalhadores de três continentes atuavam com matizes culturais distintas e diferentes graus e formas de inserção e participação no empreendimento colonial. Esses vários agentes sócio-ẹconômicos, diferenciados de acordo com sua categoria funcional, prestígio atribuído as suas origens étnicas, importância dada as suas atividades e à condição de homens livres e escravos, recebiam ou não variadas formas de remuneração pelo seu trabalho. (SANTOS, 2004, p. 62)

Salvador é conhecida como a Roma $\mathrm{Negra}^{8}$, por ser a cidade com maior população negra fora do continente africano. Mas isso não quer dizer que essa população tenha melhores condições do que a população no restante do país, pelo contrário, em muitos aspectos as desigualdades apresentam-se bem mais extremas do que em outras 
capitais brasileiras. É possível afirmar que Salvador tem a opressão marcada nos corpos de seus habitantes. Apesar de congregar a maior população negra fora da África, dentro do contexto brasileiro, Salvador é a metrópole onde o nível de cidadania e a desigualdade se percebe pela cor: "[...] a cidadania dos negros é afetada pela corporeidade. $\mathrm{O}$ fato de ser visto como negro já é suficiente para infernizar o portador deste corpo" (SANTOS, 1996, p. 10)9.

A baianidade, com todas as práticas cotidianas que a tornam singular, é uma composição midiática explorada como produto de consumo cultural. Além disso, a banalização da pobreza ocorre a partir do discurso ideológico que estetiza sua corporalidade para a constituição de determinados personagens como, por exemplo, a baiana de acarajé, com sua gênese na mulher escravizada do século XIX que circulava com o tabuleiro de quitutes e que carregava consigo o estigma que permeava toda mulher negra (NUNES, 2007). O perfil do mercado de trabalho na Região Metropolitana de Salvador (RMS) confirma essa herança colonial: a forte presença do trabalho informal figura como importante alternativa de obtenção de renda devido ao alto índice de desemprego. O contexto soteropolitano contemporâneo é reflexo da segregação socioespacial que se materializou na divisão hierárquica do trabalho e na ocupação diferenciada da cidade. Segundo dados da Pesquisa de Emprego e Desemprego da Região Metropolitana de Salvador (PED-RMS, 2015a; 2015b), embora o trabalhador negro

8. "Segundo Vivaldo da Costa Lima, o termo Roma Negra seria resultado da expressão "Roma Africana", cunhada por Mãe Aninha, fundadora do terreiro Ilê Axé Apô Afonjá. A famosa ialorixá havia declarado à antropóloga Ruth Landes nos anos de 1940 que a Bahia era a Roma Africana, não apenas por seu grande número de terreiros de candomblé, mas principalmente pela sua centralidade no culto transatlântico dos orixás. A metáfora inspirada, inspirada pela fé católica da ialorixá, expressava que, se Roma seria o centro do catolicismo, Salvador seria o centro do candomblé, portanto uma Roma Africana. O termo teria sido traduzido para a língua inglesa por Ruth Landes em Cidade das Mulheres, como Negro Rome e depois re-traduzida por Roma Negra” (PINHO, 2004, p. 44).

9. Para Santos (1996), existe uma relação indissociável entre corporalidade, individualidade e socialidade, as três dimensões que auxiliam na espacialização do cotidiano. 
seja maioria na RMS, possui renda bem inferior a do trabalhador não negro, e corresponde ao maior contingente de desempregados e de trabalhadores em condição vulnerável de trabalho (ver Gráfico 1 e Tabela 1).

Gráfico1: Variação da PEA*, por condição de atividade, segundo raça/cor e sexo. Região Metropolitana de Salvador - 2014/2013.

- PEA $\square$ Ocupados $\square$ Desempregados

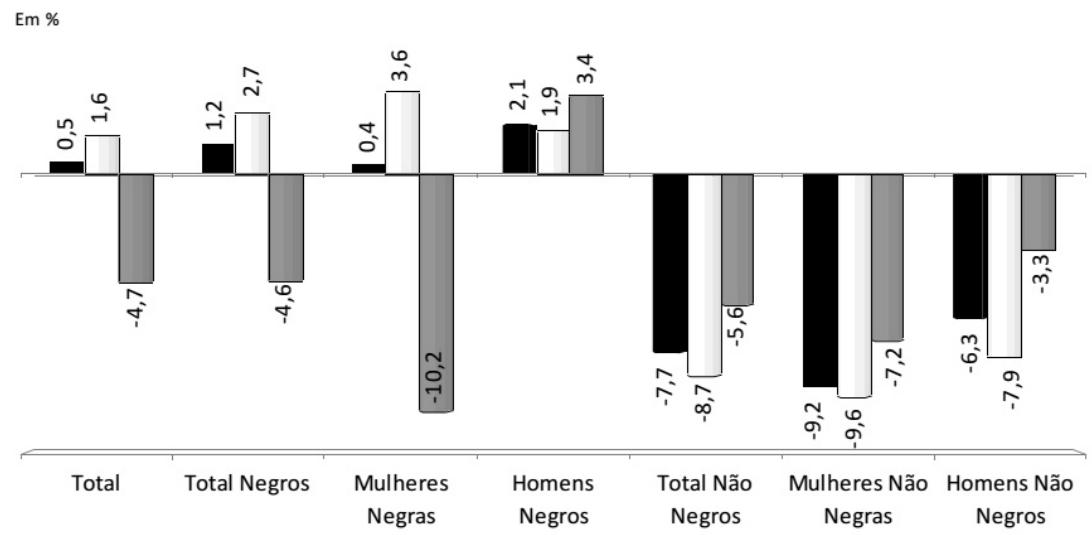

Fonte: PED - Pesquisa de Emprego e Desemprego. Convênio SEI/Setre/Dieese/Seade. Apoio: MTE/FAT

Nota: Raça/cor negra= negros e pardos; raça/cor não negra= brancos e amarelos (PED-RMS, 2015a, p. 3).

*PEA - População Economicamente Ativa.

Tabela 1: Taxas de desemprego e de participação, por raça/cor e sexo.

Região Metrodolitana de Salvador - 2011/2014 (em \%).

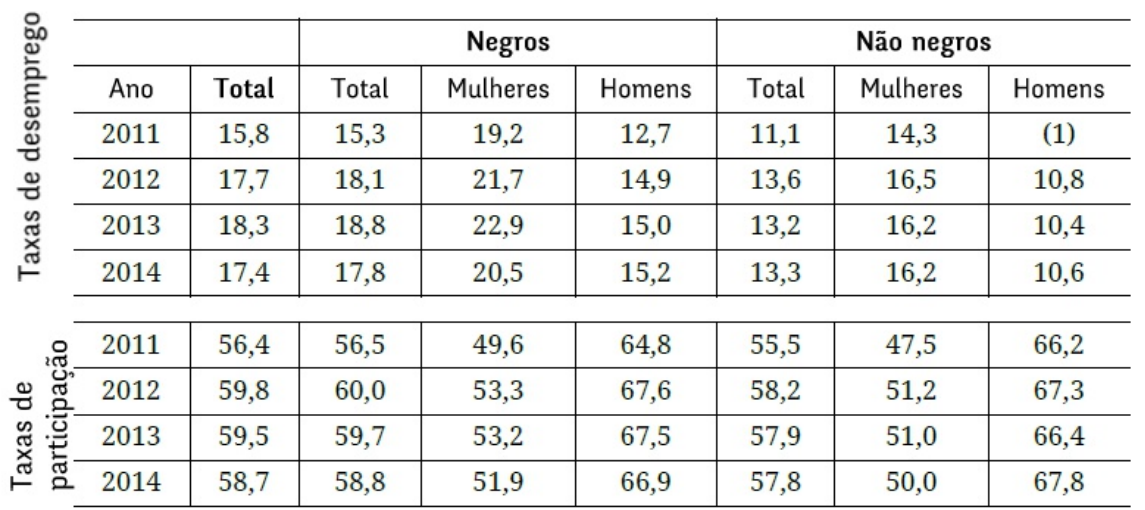

Fonte: PED - RMS - Convênio SEl, Setre, Dieese, Seade, MTE/FAT.

Nota: Raça/cor negra= pretos e pardos; raça/cor não negra= brancos e amarelos (PED-RMS, 2015a, p. 4).. 
A hierarquização social ainda é presente, pois a RMS é caracterizada pelo maior percentual de trabalhadores negros, além de carregar consigo o maior índice de desemprego das significativas regiões metropolitanas ${ }^{10}$ do Brasil e ter o trabalho informal como uma importante estratégia de sobrevivência. Os problemas sociais são ocultados por um discurso econômico que projeta o turismo como a grande solução para esse contexto. O corpo soteropolitano é marcado por estigmas acentuados pela construção midiática que justifica e fetichiza suas desigualdades sociais. A baianidade é explorada como produto de consumo cultural e é inserida dentro do pacote turístico que vende a cidade a partir de representações que a tornam única. Nesse sentido, as marcas herdadas da sociedade colonial escravocrata ainda podem ser vislumbradas no corpo soteropolitano: "os negros representam $92 \%$ dos ocupados e $94,2 \%$ dos desempregados” (PED-RMS, 2015a, p. 4). A RMS possui a maior taxa de desemprego das regiões metropolitanas brasileiras e, comparativamente, o maior desnível de rendimento entre o trabalhador negro e o não negro.

A mulher brasileira (negra) ainda é cativa do estereótipo moldado desde o período colonial - apesar de ser historicamente representativa na economia e na provisão do lar -, possuindo as piores condições de trabalho e os menores níveis de renda. No que se refere às disparidades existentes devido às diferenças de gênero: a corporalidade da mulher negra soteropolitana carrega consigo um duplo preconceito (por ser mulher e por ser negra); as suas condições de trabalho configuram-se como as mais insalubres e com as piores remunerações; $\mathrm{e}$ as mulheres negras representam as maiores taxas de desempregados. No caso, podemos incluir a discriminação de classe, uma vez que, dentro da divisão do trabalho, as mulheres negras ocupam as posições mais frágeis e excludentes: "[...] a posição

10. Essa informação está na Pesquisa de Emprego e Desemprego da Região Metropolitana de Salvador (PED-RMS) sobre as condições de inserção da população negra no mercado de trabalho da RMS, no período 2013/2014, a partir dos dados da Pesquisa de Emprego e Desemprego na Região Metropolitana de Salvador (PED-RMS), realizada em parceria com o Dieese, a SEI, a Fundação Seade do estado de São Paulo, a Setre-BA e com apoio MTE/FAT. 
de classe incide também sobre o entendimento que se tem da vida doméstica e familiar" (BIROLI, 2014, p. 38).

A Salvador midiática é feminina, festiva, acolhedora e funde-se numa identidade homogeneizante da Bahia. A imagem da baiana negra que extrapola a sua condição de pobreza e preconceito e que ainda consegue ser alegre e afetuosa, apesar do seu contexto social, é a grande constituidora da corporalidade soteropolitana. A perversidade da condição social da mulher soteropolitana negra é ocultada e acrescida de glamour, que transforma a imagem midiatizada da mulher baiana em um ícone identitário para o consumo cultural. A mulher negra ainda carrega consigo os estigmas impostos pela sociedade patriarcal e branca que explorou tanto sua força de trabalho (manual/físico) quanto seu corpo (erotizado) e ainda construiu um discurso que transferiu para sua corporalidade toda a segregação social e o preconceito do qual é refém. Segundo Carneiro:

Historiadores, romancistas, poetas retrataram-nas ora como trabalhadoras adequadas a serviços desumanizantes, ora em personagens lascivas e promíscuas. Em contraste com a mulher branca, exaltada como santa ou musa, a bestialização da "mãe-preta" e exacerbação da sexualidade da "mulata" são imagens fartamente exploradas nas representações sociais. (CARNEIRO, 2006 [?], p. 47)

\section{A Imagem da Mulher Negra nas Propagandas Institucionais da Bahia}

A escolha dos galãs, dos protagonistas, celebra modelos ideais de beleza européia, em que quanto mais nórdicos os traços físicos mais destacado ficará o ator ou atriz na escolha do elenco [...]. E, no lado contrário, os atores de origem negra e indígena serão escalados para representar os estereótipos da feiúra, da subalternidade e da inferioridade racial e social, de acordo com a intensidade de suas marcas físicas, seu formato de rosto, suas nuanças cromáticas de pele e textura de cabelo, portanto, de acordo com o seu grau de mestiçagem. (ARAUJO, 2006)

Para Schaun e Schwartz (2008), a representação midiática contemporânea da mulher continua a seguir uma ordem 
colonialista, patriarcal, machista e sexista, refletindo as bases da sociedade brasileira. Sua imagem constitui-se sob dois pilares: a mulher objeto sexual e a mulher submissa ${ }^{11}$. A primeira tem suas características erotizadas e sensualizadas, enquanto a segunda transfigura-se pelo ícone da esposa submissa que dedica sua vida ao cônjuge em uma relação heterossexual monogâmica. Além desses fatores citados, o uso imagético da mulher negra na publicidade brasileira ainda é mais perverso, sendo associado a papéis secundários e coadjuvantes.

No contexto das representações midiatizadas pela publicidade e propaganda da cidade de Salvador na Bahia, a figura negra feminina está, também, atrelada à sensualidade e lascividade, bem como a cordialidade dela está vinculada à subserviência símbolos fortemente constituídos sob os pilares do mito da "democracia racial". Aliada à sua condição de vulnerabilidade socioeconômica, a maioria das soteropolitanas negras continuam a ser representadas por uma realidade ora disforme do seu cotidiano vivido, ora preconceituosa e oportunista por parte da mídia hegemônica, que marginaliza tanto a sua subjetividade quanto a sua corporalidade. "Sua corporeidade é fragmentada por um discurso que a insere em uma função-signo, no qual seu corpo é considerado apenas um objeto de desejo e de consumo" (CASAES; NUNES; COSTA, 2009, p. 7).

A capital baiana possui a atividade turística como principal fonte de renda para os cofres públicos. Por isso, a imagem de "Terra da Alegria"12 congrega as belezas naturais e culturais como objetos

11. Nos Estados Unidos da América, a estética erotizada das pin-ups, paradoxalmente, contrasta e complementa a estética das "rainhas do lar.

12. Concomitantemente com o desenvolvimento do Polo Petroquímico na Região Metropolitana de Salvador, a expansão da atividade turística ganhou suporte das agências nacionais e estaduais de turismo (EMBRATUR e BAHIATURSA) na década de 1980 e 1990. A participação desses órgãos em feiras e exposições internacionais de turismo, com a finalidade de transformar a Bahia em um dos maiores pontos de entrada para o Brasil, cria a imagem da "Bahia Terra da Alegria" por meio da sexualização do corpo feminino negro, da exaltação às belezas naturais e culturais ligadas à cultura afro-brasileira. 
comerciais altamente exploráveis. Nesse cenário, a figura da mulher negra, em diversas peças publicitárias, torna-se um atrativo cultural utilizado pela mídia para simbolizar a cordialidade do povo baiano por meio da alegria, disponibilidade e felicidade. Por isso, a corporalidade negra, que durante muito tempo foi propriedade dos senhores da "Casa Grande", ainda é associada a estereótipos e generalizações culturais e midiatizados pela publicidade e propaganda.

Desta forma, a Figura 1 apresenta um anúncio impresso para o Centro de Convenções da Bahia no ano de 1979. O título da peça, Congresso na Babia é Coisa pra Homem Nenhum Botar Defeito, buscava "[...] aliar o útil ao agradável" enfatizando as belezas culturais em contrapartida das belezas naturais de Salvador. A partir da análise visual-discursiva dos personagens em relação à paisagem visual, é possível identificar, por exemplo, que o título - escrito em fonte sem serifa média, em caixa-alta, na cor preta - faz referência à seriedade, masculinidade, força, confiança, ao mundo dos negócios e ao sucesso, elementos que compõem o imaginário midiático associado à figura do homem branco de sucesso. O cenário - uma barraca de praia com muitas bebidas alcoólicas - serve de pano de fundo para ilustrar o corpo feminino a ser, metaforicamente, consumido, enquanto o corpo masculino negro opera como um objeto visual de cordialidade com função coadjuvante e posicionado em segundo plano. 
Camila Xavier Nunes, Juliana Cunha Costa Radek \& Nelson Rego

Figura 1: Estereótipo da mulher negra jovem como objeto sexual.

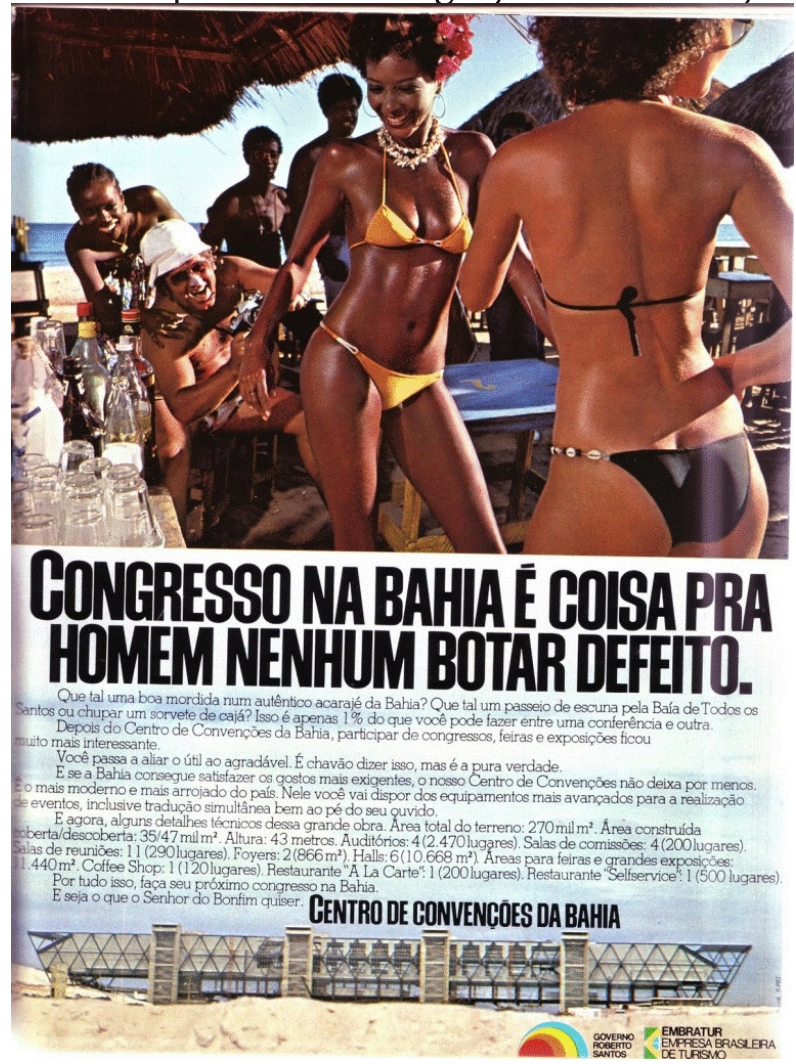

Que tal uma boa mordida num autêntico acarajé da Bahia? Que tal um passeio de escuna pela Baía de Todos os Santos ou chupar um sorvete de cajá? Isso é apenas $1 \%$ do que você pode fazer entre uma conferência e outra.

Depois do Centro de Convenções da Bahia, participar de congressos, feiras e exposições ficou muito mais interessante.

Você passa a aliar o útil ao agradável. É chavão dizer isso, mas é a pura verdade.

$E$ se a Bahia consegue satisfazer os gostos mais exigentes, o nosso Centro de Convenções não deixa por menos. É o mais moderno e mais arrojado do país. Nele você vai dispor dos equipamentos mais avançados para a realização de eventos, inclusive tradução simultânea bem ao pé do seu ouvido.

E agora, alguns detalhes técnicos dessa grande obra. Área total do terreno: $270 \mathrm{mil} \mathrm{m}^{2}$. Área construída coberta/descoberta: 35/47 mil m². Altura: 43 metros. Auditórios: 4 (2.470 lugares). Salas de comissões: 4 (200 lugares). Salas de reuniões: 11 (290 lugares). Foyers: 2 $\left(866 \mathrm{~m}^{2}\right)$. Halls: $6\left(10.668 \mathrm{~m}^{2}\right)$. Áreas para feiras e grandes exposições: $11.440 \mathrm{~m}^{2}$. Coffee Shop: 1 (120 lugares). Restaurante "A La Carte": 1 (200 lugares). Restaurante "Selfservice": 1 (500 lugares).

Por tudo isso, faça seu próximo congresso na Bahia.

E seja o que o Senhor do Bonfim quiser.

(Centro de Convenções da Bahia).

Fonte: Anunciante: Governo Roberto Santos e Empresa Brasileira de Turismo (Embratur). Criação: Agência DM9. Publicação: Revista Veja (0703-1979, p. 35).

Disponível em: <http://veja.abril.com.br/acervo/home.aspx> 
Os homens negros exaltam a figura do consumidor potencial (homem branco) que está no centro do anúncio caracterizado pela figura do turista com chapéu de praia, filtro solar no nariz e uma câmera fotográfica na mão. A demarcação simbólica de papéis socioeconômicos é nítida em relação ao indivíduo servido e aos indivíduos que o servem. Ainda de acordo com as técnicas de composição visual (DONDIS, 1997), o ser humano do mundo ocidental realiza o percurso de leitura visual da esquerda para a direta no sentindo descendente. Assim, os glúteos da mulher mais à direita são posicionados em primeiro plano para o leitor e estão localizados no ponto de maior retenção visual. Enquanto que a mulher em segundo plano tem seus glúteos posicionados para o turista. Essa composição visual apresenta um ambiente de descontração e atribui à mulher negra o sinônimo de objeto sexualizado. Isso ainda é reforçado pelas conotações sexuais de sua anatomia através das seguintes metáforas presentes no texto: “[...] uma boa mordida num autêntico acarajé da Bahia”, “[...] chupar um sorvete de cajá", "Isso é apenas $1 \%$ do que você pode fazer entre uma conferência e outra”. Dessa forma, é possível perceber a subliminar publicidade institucional da mulher negra pelo Governo da Bahia através do turismo sexual. Por meio desse tipo de turismo, a cidade transmite a ideia de que é outorgada à mulher jovem negra a função puramente sexual (físico-motor), sem considerar seus aspectos intelectuais, afetivos, emocionais e sociais ${ }^{13}$.

A ascensão social dos negros no Brasil foi historicamente impedida pela elite branca através de políticas racionalistas que permitiam que esses exercessem apenas ofícios considerados degradantes e que exigiam o emprego de grande força física. Para essa elite, o corpo era considerado o instrumento de trabalho de quem não podia se desenvolver intelectualmente (CASAES; NUNES; COSTA, 2009, p. 5).

13. O desenvolvimento humano deve ser compreendido como uma globalidade, mas, para efeito didático, tem sido abordado distintamente a par $\neg$ tir de quatro aspectos básicos: físico-motor, intelectual, afetivo-emocional e social. As teorias do desenvolvimento humano consideram a indissociabilidade desses quatro aspectos, mas podem trabalhar o desenvolvimento global a partir da ênfase em um dos aspectos. 
$\mathrm{Na}$ contemporaneidade, a representação imagética dos negros e das negras na produção audiovisual brasileira (telenovelas, filmes, propaganda, etc.) continua a reproduzir a normatização do Registro Branco do Brasil. De acordo com Martins (2011, p. 51), este registro "[...] consiste no apagamento ou na detração da figura do negro nos espaços de representação simbólica (manifestações artísticas, produções culturais, entre outros), em favor de uma valorização da imagem do branco". Assim, quando se analisam as propagandas audiovisuais institucionais veiculadas com o intuito da autopromoção do governo baiano (Figura 2), nota-se a invisibilidade e/ou o estereótipo do perfil negro masculino e, principalmente, feminino. Nota-se também a divulgação de Salvador para atividades turísticas, comerciais e econômicas (Figura 3). Além disso, há uma desproporcionalidade do cotidiano com as imagens construídas e veiculadas da população soteropolitana em relação ao espaço de vivência. As propagandas de autopromoção governamental de cunho assistencialista $^{14}$ retratam, na sua totalidade, os negros como protagonistas por meio do estereótipo do indivíduo carente social em posição de inferioridade, passividade e vulnerabilidade socioeconômica e que utiliza os serviços básicos governamentais de saúde, educação, seguridade social e segurança. De acordo com Martins (2011, p. 54), o estereótipo do carente social “[...] poderia ser encarado como uma releitura, ou atualização, do escravo dependente, tido como incapaz de integrar-se ao 'mundo dos brancos' e sobreviver sem a tutela de seu senhor". Esses sujeitos são os personagens ilustrados com sorrisos de satisfação após serem amparados pela iniciativa pública, expressando total gratidão em seu discurso. Desta forma, a Figura 2 apresenta uma mulher idosa negra em um ambiente não urbanizado e carente que comemora e agradece ao Governo da Bahia por "proporcioná-la” uma cirurgia ocular de catarata pelo Programa Saúde em Movimento de 2012.

14. As propagandas institucionais fazem uso de pessoas que são cidadãos comuns e de atores que representam esses cidadãos comuns. Porém, os textos interpretados pelos personagens, nas peças publicitárias, são escritos por redatores de agências de mídia na sua quase totalidade. 
Figura 2: Estereótipo da negra idosa como carente social.

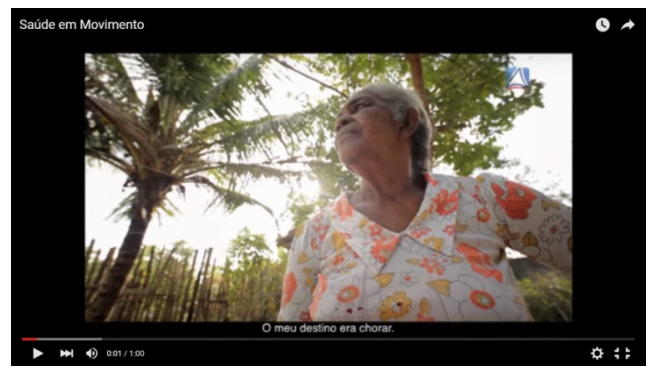

Posição: 00:00:01

"O meu destino era chorar. Os meus dois bisnetos que nasceram e eu não vi".

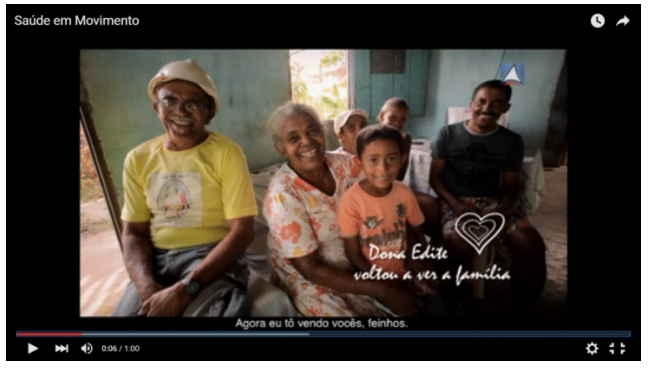

Posição: 00:00:06

"Agora eu tô vendo vocês, feinhos."

Fonte: Anunciante: Secretaria de Saúde - Governo da Bahia. Criação: Tempo Propaganda.

Formato: Vídeo 60'. Programa Saúde em Movimento (maio/2012). Disponível em: https://www.youtube.com/watch?v=HD22tnPOI64

Todavia, ainda mais contraditório é o fato de a idosa de linguajar simples afirmar que, após o procedimento cirúrgico, ela conseguiu ver os seus bisnetos que são "feinhos". Além do estereótipo de carente social, o discurso institucional do Governo da Bahia apresenta uma estética preconceituosa, pois simboliza a bisavó decepcionada por reconhecer seus bisnetos como negros. Subjetivamente, isso fortalece a ideologia do branqueamento e prejudica os esforços de combate ao racismo e de elevação da autoestima das crianças negras por meio de trabalhos psicopedagógicos conduzidos por entidades que buscam evitar o desenvolvimento do preconceito e da inferiorização dos negros perante a sociedade.

Assim, em 2015, a associação privada Salvador Destination $^{15}$, em conjunto com a Prefeitura de Salvador, lançaram a propaganda turística institucional ${ }^{16}$ intitulada Salvador de Braços Abertos (Figura 3), com a finalidade de autopromover a cidade.

15. Segundo o site da empresa Salvador Destination, ela é "uma associação que tem como missão promover e divulgar a cidade no segmento de eventos nacionais e internacionais. Criada com o objetivo de gerar negócios, a entidade assessora e apoia realizadores de eventos e empresas atuantes neste setor [...] é uma associação 
Figura 3: Análise de conteúdo da propaganda institucional turística Salvador de Braços Abertos.

\section{Mulheres}

Branca

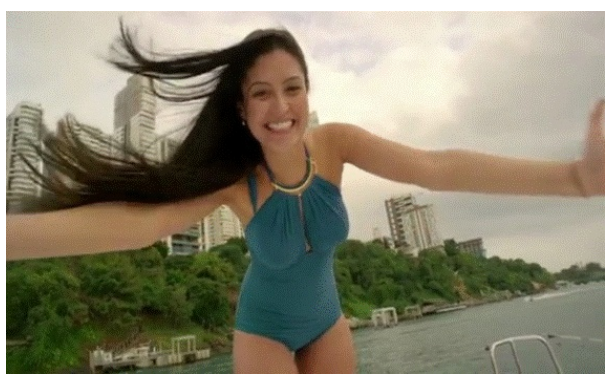

Posição: 00:03:00

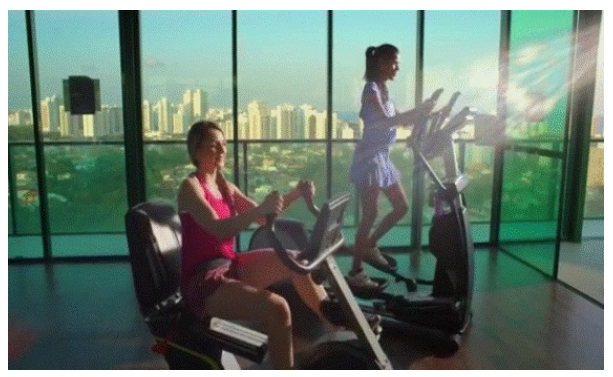

Posição: 00:00:19
Negra

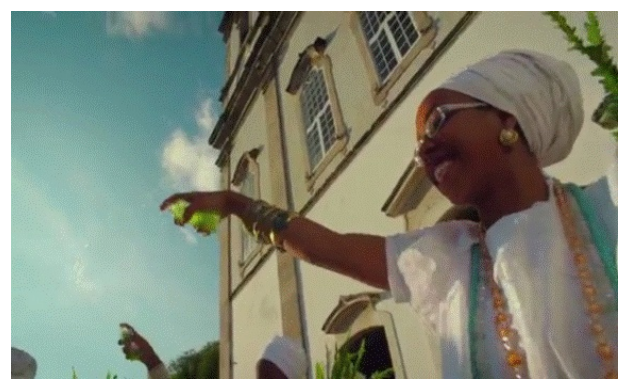

Posição: 00:01:38

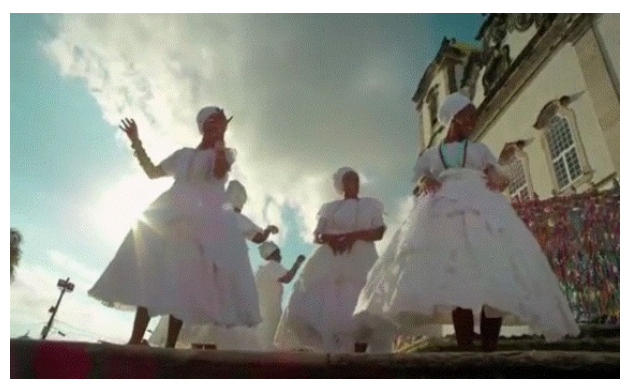

Posição: 00:00:52

mantida por empresas locais associadas. São hotéis, organizadoras de eventos, shopping center e agências de receptivo e provedores de serviços para eventos" (http://www.salvadordestination.com.br/).

16. Campanhas turísticas com peças impressas e audiovisuais para autopromoção da cidade no Brasil e no exterior e que possuem um grande alcance de público, pois são exibidas e disponibilizadas em revistas, jornais, televisão aberta, TV por assinatura e de bordo, salas de cinema e Internet. 


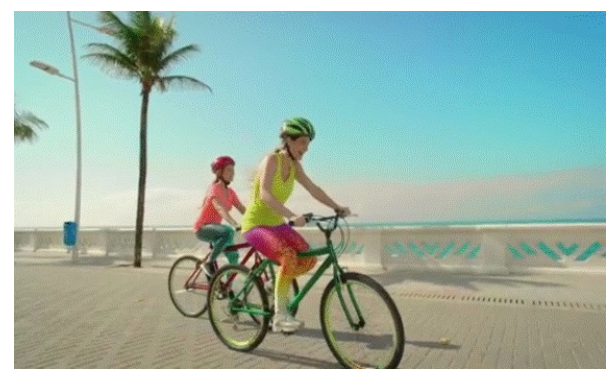

Posição: 00:00:22

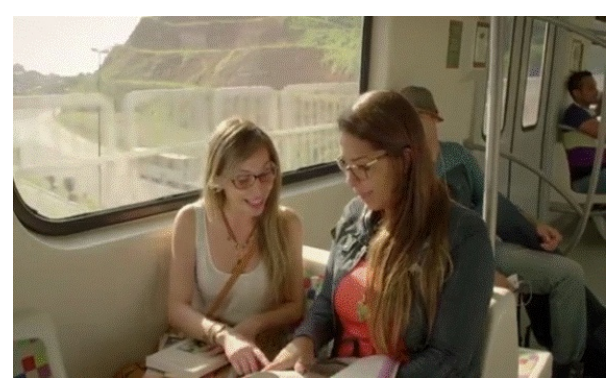

Posição: 00:01:00

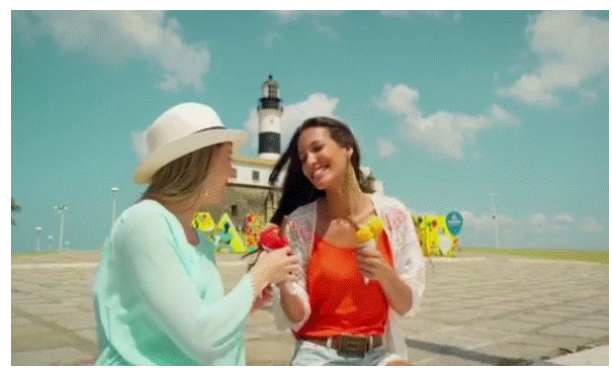

Posição: 00:00:42

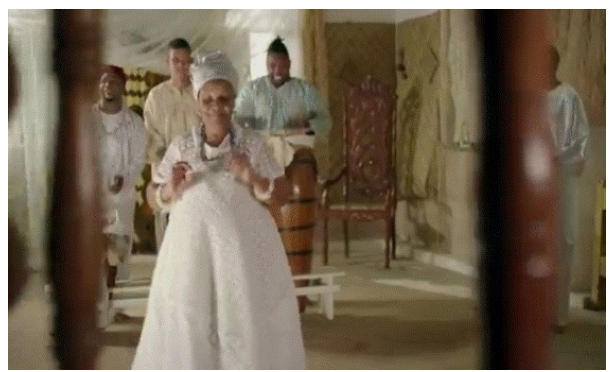

Posição: 00:01:36

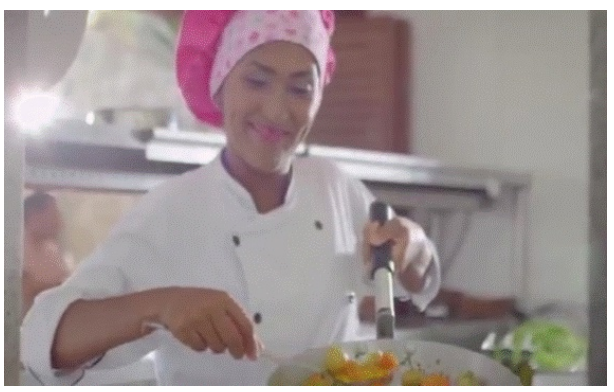

Posição: 00:02:16

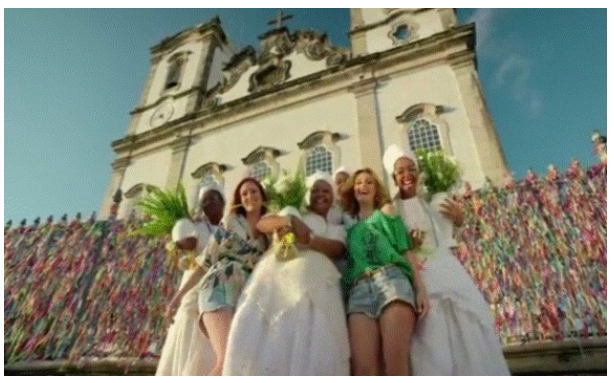

Posição: 00:00:15 


\section{Homens}

Branco

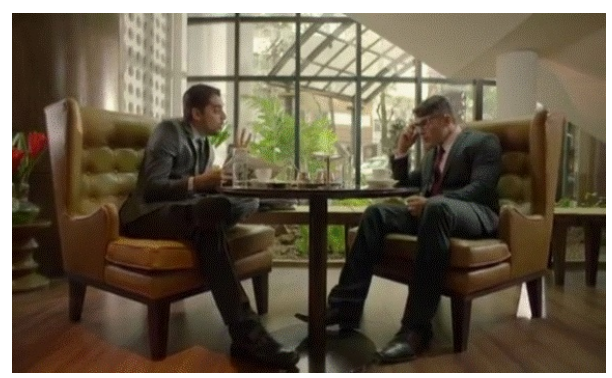

Posição: 00:00:27

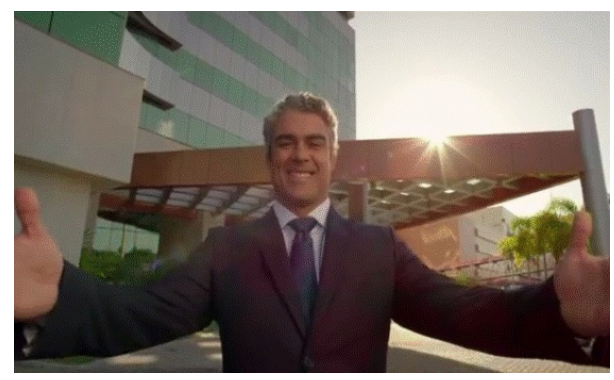

Posição: 00:03:01

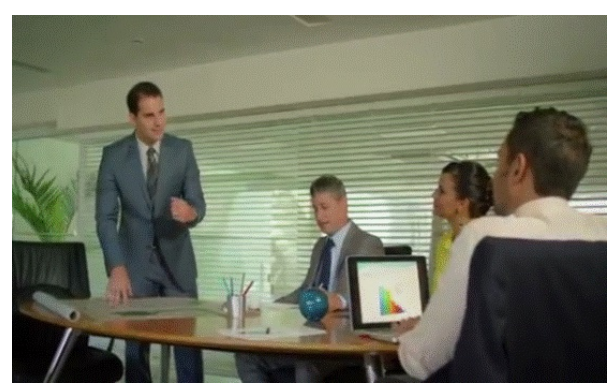

Posição: 00:01:01
Negro

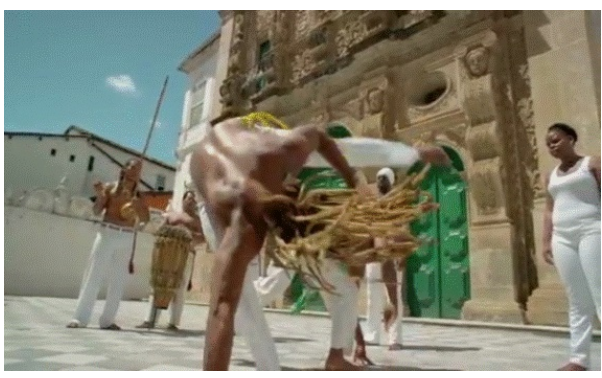

Posição: 00:01:07

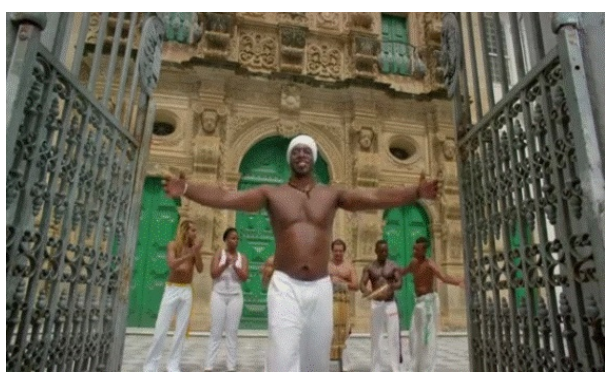

Posição: 00:03:02

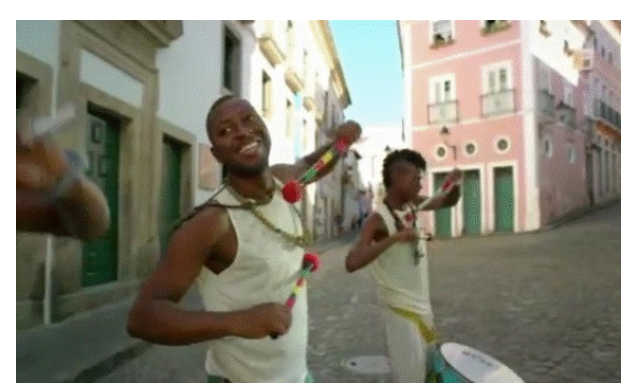

Posição: 00:02:42 


\section{Casais Brancos}

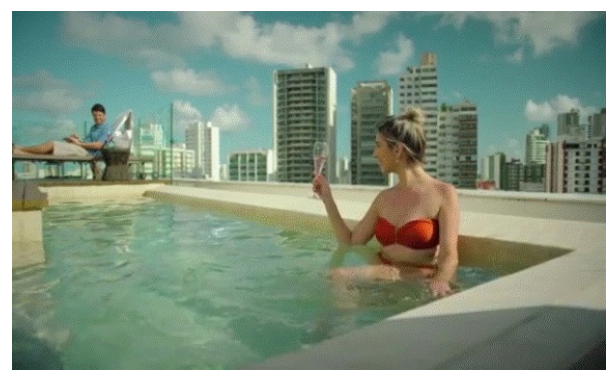

Posição: 00:00:28

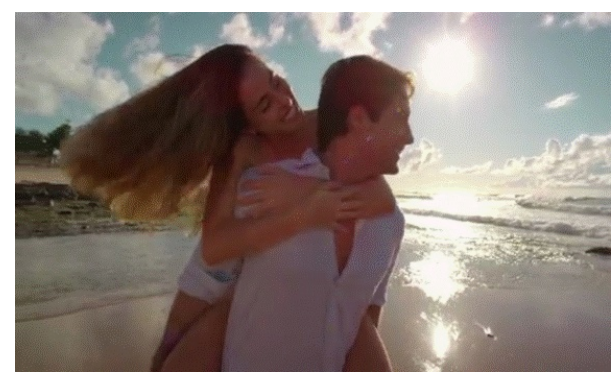

Posição: 00:02:10

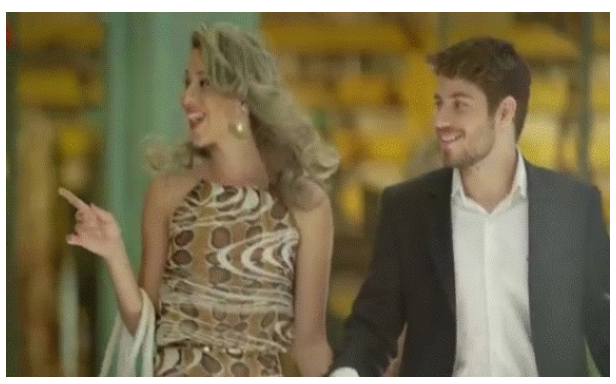

Posição: 00:01:19

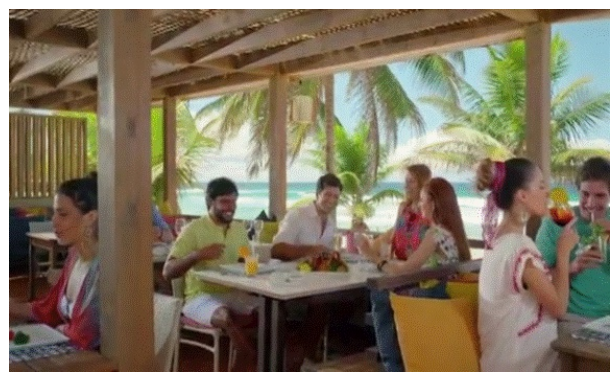

Posição: 00:02:12

Fonte: Anunciante: Salvador Destination e Prefeitura de Salvador. Criação: Mandacaru Filmes. Formato: Vídeo 199'. Salvador de Braços Abertos (Outubro/2015).

Disponível em: https://www.youtube.com/watch?v=Z88-7ucueBs

Todavia, é muito explícita a preservação de estereótipos degradantes da população negra, uma vez que homens e mulheres são, majoritariamente, representações de capoeiristas e baianas que dançam na frente das igrejas do Pelourinho e do Bonfim. De modo simbólico, esses sujeitos são representados como alegorias da subalternidade por meio de imagens preconcebidas da limitação de suas funções econômicas e intelectuais na cidade. Segundo Melo Silva (2011, p. 21), "passados 122 anos de abolição, as imagens referentes ao segmento social afro-descendente nos meios de 
comunicação continuam mantendo o estigma”, associadas a clichês midiatizados para grandes audiências. Além disso, o vídeo descreve Salvador e seus habitantes de modo fetichizado a partir de uma narrativa visual racista que conserva a política do embranquecimento, agredindo simbolicamente negros e mestiços. Para o cineasta Araújo (2006, p. 72-73), a história das mídias audiovisuais estava intimamente ligada à política do embranquecimento que "fundamentada no final do século XIX, tornou-se convenção e naturalizou-se como estética audiovisual de todas as mídias, incluindo-se aí especialmente a TV, o cinema e a publicidade nos séculos XX e XXI". De acordo com Strozenberg (2011), tanto publicitários quanto anunciantes afirmam evitar a utilização da imagem de negros nas propagandas por que desvalorizariam o produto/serviço oferecido, “[...] provocando um sentimento de rejeição tanto por parte de consumidores brancos quanto dos próprios negros” (Ibidem, p. 193). Além disso, a condição socioeconômica corroboraria para uma teoria de discriminação, pois, dentro do discurso publicitário, negros e negras não representariam o público-alvo de muitos produtos/serviços, devido ao seu fraco poder aquisitivo.

Desse modo, a partir da metodologia de Análise de Conteúdo Qualitativo e Quantitativo ${ }^{17}$ desta peça publicitária, foi possível declarar que a representatividade de brancos e negros é bastante disforme. Assim, o Quadro 1 e o Quadro 2 demonstram

17. O método de pesquisa de Análise de Conteúdo Qualitativo e Quantitativo (Qualitative and Quantitative Content Analysis) é um dos mais populares na análise de conteúdos simbólicos aplicados nas Ciências Sociais, sendo desenvolvido para avaliar dados escritos, falados e visuais. De acordo com Schreier (2012), este método tem uma característica interpretativa que é aplicada a materiais que requerem interpretação pessoal, social e cultural. A Análise de Conteúdo Qualitativo é bastante difundida quando o objeto de pesquisa demanda interpretação subjetiva do seu conteúdo através do processo de classificação sistemática de codificação e identificação de temas e padrões. A qualidade da Análise de Conteúdo Quantitativo será muito útil para a contagem da frequência de certos tipos de personagens e suas relações com o ambiente, as mensagens textuais e imagéticas nas narrativas. 
que a frequência e o tempo de tela ocupados pelos homens brancos (16 cenas $=44$ segundos $)$ e pelas mulheres brancas $(26$ cenas $=79$ segundos) são maiores do que os preenchidos pelos homens negros $(4$ cenas $=27$ segundos $)$ e pelas mulheres negras $(7$ cenas $=25$ segundos). $\mathrm{Ou}$ seja, indivíduos brancos são considerados protagonistas, e os negros, elementos figurativos de segundo plano; uma distribuição que não é compatível com a estimativa da população afrodescendente da cidade de Salvador. De acordo com Araújo:

A internalização da ideologia do branqueamento provoca uma 'naturalidade' na produção e recepção dessas imagens, e uma aceitação passiva e a concordância de que esses atores realmente não merecem fazer parte $\mathrm{da}$ representação do padrão ideal de beleza do país. Naturalmente, para todos nós, por força, da nossa formação cultural, o padrão superior estético só pode ser representado por aqueles ou aquelas que continuam com o privilégio ('tiveram a sorte') de nascer de famílias brancas com características nórdicas acentuadas (ARAUJO, 2006, p. 77).

Quadro 1: Aparição dos personagens/paisagens (número de cenas).

\begin{tabular}{|c|c|c|c|c|}
\hline \multicolumn{2}{|c|}{ Brancos } & \multicolumn{2}{c|}{ Negros } & Paisagens \\
\hline Homens & Mulheres & Homens & Mulheres & \\
\hline 16 & 26 & 4 & 7 & 15 \\
\hline
\end{tabular}

Quadro 2: Tempo de tela (representatividade em segundos/porcentagem).

\begin{tabular}{|c|c|c|c|c|}
\hline \multicolumn{2}{|c|}{ Brancos } & \multicolumn{2}{c|}{ Negros } & Paisagens \\
\hline Homens & Mulheres & Homens & Mulheres & \\
\hline $44^{\prime \prime}$ & $79 ”$ & $277^{\prime \prime}$ & $25{ }^{\prime \prime}$ & $60 ”$ \\
\hline $22,11 \%$ & $39,69 \%$ & $13,56 \%$ & $12,56 \%$ & $30,15 \%$ \\
\hline \multicolumn{2}{|l}{ Quadro produzido pelos autores (2016) } \\
\hline
\end{tabular}


Como parte do mise-en-scène ${ }^{18,}$ os figurinos e os acessórios usados pelos personagens desempenham papel essencial na narrativa. Segundo Corrigan e White (2014), esses objetos reproduzem características espaciais e temporais apoiando a criação de realismo cênico, realçam a personalidade dos personagens através da identidade e os conduzem ao desenvolvimento da sua estória na narrativa. Assim, os papéis socioeconômicos dos personagens na propaganda são bem delimitados e retratados pelo seu figurino (Quadro 3), bem como sua relação com o espaço e com os demais personagens nas cenas (Quadro 4). Enquanto homens e mulheres brancos são representados por uma variedade de figurinos que ilustram as diferentes posições sociais, os(as) personagens negros(as)

Quadro 3: Figurino dos personagens

\begin{tabular}{|c|c|}
\hline \multicolumn{2}{|c|}{ NEGROS } \\
\hline HOMENS & MULHERES \\
\hline $\begin{array}{l}\text { Trajes do Candomblé (calça, camisa e 0já brancos } \\
\text { na cabeça) }\end{array}$ & $\begin{array}{l}\text { Trajes do Candomblé e de Baianas de Acarajée } \\
\text { (bata, saia com anágua, pano da costa e ojá } \\
\text { branco na cabeça, e contas coloridas dos Orixás) }\end{array}$ \\
\hline Trajes de Capoeira (calça branca sem camisa) & Uniforme de Cozinheira (camisa branca) \\
\hline Terno e Gravata (tons escuro e preto) & Terninho (terno e calça/saia escuro) \\
\hline $\begin{array}{l}\text { Casual Esportivo (bermuda e camisa em tons } \\
\text { claros) }\end{array}$ & $\begin{array}{l}\text { Casual Esportivo (jeans, camiseta, tênis, jaqueta, } \\
\text { óculos de grau em peças coloridas) }\end{array}$ \\
\hline $\begin{array}{l}\text { Esporte Fino (calça e camisa polo em tons pastéis } \\
\text { e escuros) }\end{array}$ & Esportivo (leggings e camisetas coloridas) \\
\hline \multirow{3}{*}{$\begin{array}{l}\text { Casual Chic (calça e camisa de alfaiataria em tons } \\
\text { escuros) }\end{array}$} & Casual Chic (vestidos longos em tons escuros) \\
\hline & $\begin{array}{l}\text { Roupas de Banho (biquínis coloridos, saídas de } \\
\text { praia/pareôs branca, roupão de banho branco) }\end{array}$ \\
\hline & $\begin{array}{l}\text { Roupas Despojadas (shorts e blusas, vestidos } \\
\text { longos e curtos coloridos) }\end{array}$ \\
\hline \multicolumn{2}{|l|}{ Quadro produzido pelos autores (2016) } \\
\hline
\end{tabular}

18. Mise-en-scène é um termo francês derivado do teatro, no final do século XIX e início do XX, que significa o espaçamento de objetos e personagens em cena. Adotado pelo cinema, o mise-en-scène toma forma através dos princípios de composição visual derivados da pintura e da fotografia. "O Mise-en-scène contém os elementos cênicos de um filme, incluindo os atores, os aspectos de iluminação, cenários e sets, figurinos, maquiagem, e outras características da imagem que existem independentemente da câmara e dos processos de filmagem e edição" (CORRIGAN; WHITE, 2014, p. 64, traduzido pelas autoras). 
Quadro 4: Atividades desempenhadas na narrativa.

\begin{tabular}{|c|c|}
\hline \multicolumn{2}{|c|}{ NEGROS } \\
\hline HOMENS & MULHERES \\
\hline \multicolumn{2}{|c|}{ Fazem apresentação de capoeira na frente da Igreja de São Francisco no Pelourinho. } \\
\hline \multicolumn{2}{|l|}{ Participam de um culto de candomblé. } \\
\hline \multirow[t]{3}{*}{ Tocam tambor no carnaval do Pelourinho. } & $\begin{array}{l}\text { Dançam na frente da Igreja do Bonfim e } \\
\text { lavam as escadarias desta igreja. }\end{array}$ \\
\hline & Cozinham em restaurante. \\
\hline & Dançam na boate à noite. \\
\hline \multicolumn{2}{|c|}{ BRANCOS } \\
\hline HOMENS & MULHERES \\
\hline \multicolumn{2}{|l|}{ São servidos em restaurantes, hotéis, bares. } \\
\hline \multicolumn{2}{|c|}{ Caminham no hotel, aeroporto, shopping, e fazem compras no Shopping Barra. } \\
\hline \multicolumn{2}{|c|}{ Dançam no Pelourinho pela manhã e na boate à noite. } \\
\hline \multicolumn{2}{|l|}{ Arquitetos discutem um projeto em grupo. } \\
\hline Praticam surfe. & Banham-se na praia. \\
\hline Executivos conversam. & Admiram o mar e consomem frutas. \\
\hline $\begin{array}{l}\text { Leem jornal enquanto tomam café da } \\
\text { manhã no hotel do Centro Histórico } \\
\text { (Pelourinho). }\end{array}$ & $\begin{array}{l}\text { Fazem registros fotográficos na Igreja do } \\
\text { Bonfim e no Elevador Lacerda. }\end{array}$ \\
\hline $\begin{array}{l}\text { Transitam em espaço arquitetônico de } \\
\text { vidro, moderno e iluminado. }\end{array}$ & $\begin{array}{l}\text { Tomam sorvete no Farol da Barra, comem } \\
\text { acarajé no Pelourinho e moqueca em } \\
\text { restaurante. }\end{array}$ \\
\hline \multirow{3}{*}{$\begin{array}{l}\text { Fazem bebidas em boate rodeados por } \\
\text { mulheres. }\end{array}$} & Acordam no quarto de hotel de luxo. \\
\hline & $\begin{array}{l}\text { Estudantes discutem conteúdo de livro no } \\
\text { metrô de Salvador. }\end{array}$ \\
\hline & $\begin{array}{l}\text { Praticam exercícios em academia privativa, } \\
\text { na praia, e andam de bicicleta no Calçadão } \\
\text { da Barra. }\end{array}$ \\
\hline
\end{tabular}

são apenas portadores de trajes de candomblé, de baiana de acarajé e de capoeira relacionados as suas práticas religiosas e culturais. Eles possuem um papel terciário de figuração na narrativa da cidade através da propaganda. Ao contrário do retrato da negra e da mulata erotizada, na propaganda da década de 1970, através de corpos disponibilizados, a imagem da baiana em 2015 reproduziu o imaginário da iconografia da mulher negra do século XIX pela perspectiva brasileira e europeia. 
Trazendo essa perspectiva para a atualidade, a imagem do homem branco, que ocupa $22,11 \%$ do tempo de tela, está sempre associada a papéis socioeconômicos de sucesso, prestígio, riqueza, luxo e poder. São representados por turistas, hóspedes de hotel, arquitetos, surfista e, repetidamente, por consumidor/cliente de restaurantes, shopping centers, hotéis, bares, aeroporto, e por empresário/executivo - com seus figurinos reforçando o status privilegiado na sociedade. Os homens brancos também ocupam a cena transfigurados de barman, garçom e bellboy de hotel. As mulheres brancas, que preenchem o maior tempo de tela (39,69\%), têm seus papéis meramente ilustrativos, uma vez que não desempenham atividades econômicas em grande parte do tempo. Para Schaun e Schwartz (2008) as imagens das mulheres expostas nas pinturas europeias expunham-nas ao desejo do espectador, enquanto na atualidade esse papel é tomado pela propaganda, em que elas são configuradas como "superfície visual”. Por isso, são retratadas como acompanhantes de homens brancos, em companhia de outras mulheres brancas em atividades esportivas e de lazer e, quando estão sozinhas, são trajadas em roupas de banho em praias ou piscinas. Seus papéis resumem-se a turistas, hóspedes de hotel, arquiteta, estudantes, consumidora/cliente de restaurante, academia de ginástica, shopping centers, hotel, bares, aeroporto e, curiosamente, na única baiana de acarajé.

O corpo da mulher branca é hipervalorizado, e sua exposição está atrelada aos padrões de beleza vigentes, que as expressam em cenas românticas com o seu parceiro branco heterossexual, ambos carregando a juventude física. Os cenários e os objetos em cenas denotam status social e poder aquisitivo. De acordo com Pinheiro: "Na publicidade, o amor é demonstrado pelo investimento das pessoas nos 'objetos' de seu interesse, sejam esses 'objetos' pessoas, o si mesmo, bens de consumo, imagens, símbolos, uma instituição, um local, etc.” (PINHEIRO, 2006, p. 171). Por isso, as atividades desempenhadas por casais brancos na narrativa são: tomar café da manhã em hotel no Centro Histórico (Pelourinho); almoçar e jantar em restaurante; consumir bebidas alcoólicas em 
bares, clubes noturnos, cobertura de prédios; brindar com coquetéis em restaurante próximo à praia; chegar de carro e fazer compras no Shopping Barra $^{19}$; admirar e caminhar na praia no final de tarde. Todavia, a narrativa visual desta propaganda evitou o uso de imagens de casais negros e inter-raciais.

Por outro lado, a população negra continua ocupando pouco espaço midiático, pois o homem negro e a mulher negra preenchem, respectivamente, $13,56 \%$ e $12,56 \%$ do tempo de tela do total de 3 minutos e 19 segundos do vídeo. Eles são os personagens secundários que estão ora servindo, ora entretendo os personagens brancos através de sua prática cultural e serviço braçal. Os papéis sociais distanciam-se muito do "modelo ideal" de sucesso dos personagens brancos, já que se referem à subalternidade, passividade e cordialidade por meio da personificação do capoeirista, pai, mãe e filhos de santos, percursionistas, baianas e cozinheiras, sempre vestindo roupas brancas e carregando consigo um sorriso no rosto. Os estereótipos mais comuns nesta propaganda retratam homens e mulheres negras como trabalhadores braçais e informais não qualificados, fato que remete ao período de escravidão brasileira, pois são "profissões de menor remuneração ou consideradas de pouco prestígio" (MARTINS, 2011, p. 54) dentro da sociedade brasileira. Em segundo lugar, o estereótipo do artista (capoeiristas, percursionistas e baianas) seriam as únicas representações válidas para que o negro ascendesse socialmente (Ibidem). É através da arte que os negros e as negras perpassam pelo espaço dos brancos, em que sua presença e circulação são percebidas como algo comum e aceitável. Enquanto o trabalho braçal dignificaria a vida do negro, a arte valorizaria sua imagem de jovem, alegre e com possibilidade de "subir na vida". Desta forma:

19. Localizado na Barra, um bairro nobre de Salvador, este centro comercial é voltado para um público de maior poder aquisitivo. No entanto, possui um significativo fluxo diário de pessoas por conta do SAC (Serviço de Atendimento ao Cidadão), instalado no primeiro piso para atender ao público de todas as classes sociais. 
Durante o período escravocrata, os trabalhos considerados humilhantes, insalubres ou que exigiam força física eram reservados aos negros, considerados "peças" mais apropriadas a esse tipo de serviço. Essa condição, associada a um processo de exclusão que impediu o negro de competir com igualdade no mercado de trabalho no período pós-abolição, acabou por reproduzir e naturalizar a situação e a imagem do negro como trabalhador braçal (MARTINS, 2011, p. 54).

Assim, a representatividade do corpo feminino negro é irrisória, e sua função é alegórica e de subserviência. As imagens das mulheres e dos homens negros usadas como recursos coadjuvantes para demarcação de papéis sociais continuam a representar os estereótipos dominantes de um imaginário que preza pela conotação da estética do belo por meio da exaltação da branquitude em um espaço constituído pela maioria de negros. Deste modo, é perceptível que a propaganda da atualidade continua a manter o mesmo padrão de exclusão social e cultural do início do século, através da exaltação da iconografia branca em detrimento da imagem negra. O uso de recursos visuais, de iluminação, de edição, seleção, inclusão e omissão de personagens e lugares da cidade de Salvador é um artifício para exaltar as "belezas da cidade" constituídas pela ideologia do branqueamento.

Fazer um bom cinema no Brasil deve ser um ato de purificação de nossa realidade através daquilo que merece sẹr projetado na tela: nosso progresso, as obras de engenharia moderna, nossos brancos bonitos, nossa natureza. $\mathrm{E}$ preciso um cinema de estúdio, como o norte-americano, com interiores bem decorados e habitados por gente simpática (CINEARTE, 1929 apud LINO, 2009, p. 96).

\section{Considerações finais}

Como representação, a composição do feminino está diretamente associada a padrões estéticos que são constantemente adaptados para a conservação de uma perspectiva colonialista masculina. A complexidade dessas construções imagéticas intensifica-se quando situamos a produção de sentido e de discursos sobre gênero em diferentes culturas. A objetificação da mulher é 
reificada por estereótipos corporais que integram um sistema simbólico que atualiza conceitos, representações e opressões. Assim, faz-se necessária a compreensão de como a ditadura da beleza estética e o discurso de gênero (que restringe a mulher ao espaço privado e doméstico) são utilizados como poderosos instrumentos de controle do corpo feminino. A conceptualização do feminino vai muito além de sua composição imagética, pois é, também, agenciadora de transformações éticas e estéticas. Nesse sentido, a despatriarcalização da linguagem e do simbólico pode ser compreendida como um processo que emerge da necessidade de uma maior participação feminina na produção de imagens e representações - neste caso, a mulher negra na Bahia.

A partir dessa perspectiva, a publicidade e a propaganda, com suas características simbólicas, persuasivas e ideológicas, passam a ser consideradas, por um lado, ferramentas importantes para criar necessidades e estimular o consumo de bens e serviços; por outro lado, instrumentos marcantes para a veiculação de ideologias que irão influenciar o comportamento social dos indivíduos. Desta forma, as mensagens (que buscam difundir ideologias correspondentes aos interesses de certos grupos) tendem a manipular a realidade, criando estratégias discursivas através de códigos compreensíveis e memorizáveis que garantirão a autenticidade da mensagem, evitando que o receptor decodifique-as de forma contrária. O turismo, enquanto importante atividade econômica para o estado da Bahia, em suas propagandas institucionais, exalta suas belezas naturais e riquezas culturais. Porém, através da análise visual-discursiva e da Análise de Conteúdo Qualitativo e Quantitativo, percebe-se que tais propagandas fazem uso subliminar e consciente de mulheres negras como ícones da sensualidade e da lascividade, bem como da cordialidade vinculada à subserviência aspectos que foram construídos sob o mito da "democracia racial" na primeira metade do século XX. Além disso, constata-se que, em Salvador, a igualdade social insere-se apenas no discurso institucionalizado e que certas corporalidades são ocultadas por não se enquadrarem nos padrões que regem a cidade-espetáculo. 
Ao longo da história, a ideologia do branqueamento na sociedade brasileira foi responsável por reproduzir imagens de negros e mestiços (na publicidade e na propaganda comercial e institucional) como sujeitos coadjuvantes, subalternos, racial e socialmente inferiores aos indivíduos fenotipicamente caucasianos. Além disso, o racismo atrelado ao contexto patriarcal brasileiro foi ainda mais perverso com mulheres negras. Estereótipos direcionados aos seus corpos carregam consigo estigmas da inferiorização estética e, consequentemente, social; por isso, sua representatividade midiática é menor se comparada com a dos indivíduos de características fenotípicas europeias. Assim, as imagens dos negros continuam a ser utilizadas nas propagandas como função demarcadora de papéis socioeconômicos, pois homens e mulheres brancos, que ocupam os espaços privilegiados na sociedade, são, constantemente, contrapostos com a representatividade irrisória de negros e negras em seus papéis narrativos coadjuvantes. Por fim, é possível observar que, apesar da intensificação da participação dos negros nas diferentes narrativas imagéticas, muitos discursos e representações ainda trazem consigo conotações repletas de heranças coloniais e patriarcais.

\section{Referências}

ARAÚJO, J. Z. "A Força de um Desejo-a Persistência da Branquitude como Padrão Estético Audiovisual”. Revista USP, São Paulo, n. 69, p. 72-79, março/maio, 2006.

BIROLI, F. "O Público e o Privado". In: MIGUEL, Luis Felipe; BIROLI, Flávia. Feminismo e Política. São Paulo: Boitempo, 2014, p. 31-46.

CARNEIRO, S. S. "Estrelas Com Luz Própria". História Viva Temas Brasileiros. A Presença Negra, São Paulo, n. 3, p. 46-51, [s.d.]. [2006?]

CARNEIRO, S. "Gênero e Raça". In: BRUSCHINI, C. e UNBEHAUM, S. Gênero, Democracia e Sociedade Brasileira. São Paulo: FCC: Ed. 34, 2002, p. 167-193.

CORBIN, A.; COURTINE, J.; VIGARELLO, G. "Prefácio à História do Corpo” (Orgs.). In: CORBIN, A.; COURTINE, J.; VIGARELLO, 
G. (Orgs.). História do Corpo: da Renascença às Luzes. Petrópolis, RJ: Vozes, 2009, p. 7-13. v.1.

CORRIGAN, T.; WHITE, P.. Film Experience: An Introduction. 4th Edition. Boston: Bedford St Martins. 2014.

CASAES, D.; NUNES, C. X.; COSTA, J. C. "A Semântica Cordial: Representações da Mulher Negra no Turismo de Salvador". In: Anais do Encontro de Estudos Multidisciplinares em Cultura, 5, 2009, p. 1-15. Salvador, 2009. Disponível em: < http://www.cult.ufba.br/enecult2009/19542.pdf> Acesso em: 15 fev. 2016.

COSTA, M. G. "Violação dos Direitos da Mulher: Um Panorama, Histórico Cultural e Jurídico”. Seara Jurídica, v.1, n. 11, jan.jun. 2014.

Disponível em: http://revistas.unijorge.edu.br/searajuridica/artigos2014_1.html > Acesso em: 20 jan. 2016.

DONDIS, D. A Sintaxe da Linguagem Visual. São Paulo: Martins Fontes, 1997.

DUBY, G.; PERROT, M. Imagens da Mulher. Tradução Maria M. M. da Silva. Porto: Edições Afrontamento, 1992.

FREYRE, G. Casa Grande e Senzala: Formação da Família Brasileira sob o Regime da Economia Patriarcal. São Paulo: Global, 2003.

FOUCAULT, M. História da Sexualidade I: A vontade de saber. Rio de Janeiro: Graal, 2001.

LINO, S. C. "Cinematographo: Doença da Moda". Revista do Arquivo Público Mineiro, v. XLV, n. 1, p. 90-103, 2009. Disponível em: < http://www.siaapm.cultura.mg.gov.br/acervo/rapm_pdf/dossie0 5_2009.pdf> Acesso em: 09 ago. 2015.

MARIOTTI, H. "Prefácio". In: MATURANA, H.; VARELA, F. A Árvore do Conhecimento: as Bases Biológicas da Compreensão Humana. Tradução Humberto Mariotti e Lia Diskin. São Paulo: Palas Athena, 2001.

MARTINS, C. A. M. "A Publicidade e o Registro Branco do Brasil”. In: BATISTA, L. L.; LEITE, F. (Orgs.). O Negro nos Espaços Publicitários Brasileiros: Perspectivas Contemporâneas em Diálogo. São Paulo: ECA-USP/Prefeitura de São Paulo, 2011, p. 4759.

MELO SILVA, D. "A Imagem do Negro no Espaço Publicitário". In: BATISTA, L. L.; LEITE, F. (Orgs.). O Negro nos Espaços Publicitários Brasileiros: Perspectivas Contemporâneas em 
Diálogo. São Paulo: ECA-USP/Prefeitura de São Paulo, 2011, p. 1924.

NUNES, C. X. Geografias do Corpo: por uma Geografia da Diferença. 2014. 245f. Tese (Doutorado em Geografia) - Instituto de Geociências, Universidade Federal do Rio Grande do Sul, Porto Alegre, 2014.

NUNES, C. X. Um Diálogo entre Espaço e Corpo em Salvador. 2007. 183f. Dissertação (Mestrado em Geografia) - Instituto de Geociências, Universidade Federal da Bahia, Salvador, 2007.

OLIVEIRA, D. F. Desmundo: o cotidiano da mulher no Brasil Colonial. Uma análise cinematográfica. Mneme - Revista de Humanidades. UFRN. Caicó (RN), v. 9, n. 24, set/out. 2008. Disponível em: <www.cerescaico.ufrn.br/mneme/anais > Acesso em: 10 dez. 2015.

PED-RMS. Pesquisa de Emprego e Desemprego na Região Metropolitana de Salvador: A Inserção da Mulher Negra no Mercado de Trabalho da Região Metropolitana de Salvador. Superintendência de Estudos Econômicos e Sociais da Bahia, 2001; Salvador: SEI, 2015b.

PED-RMS. Pesquisa de Emprego e Desemprego na Região Metropolitana de Salvador: Os Negros no Mercado de Trabalho. Superintendência de Estudos Econômicos e Sociais da Bahia, 2001; Salvador: SEI, 2015a.

PERROT, M. Minha História das Mulheres. 2. ed. Tradução de Angela S. M. Corrêa. São Paulo: Contexto, 2012.

PINHEIRO, M. C. T. "Publicidade: A Procura Amorosa do Consumo". In: Comunicação, Mídia e Consumo. (Epistemologia da Comunicação). São Paulo, v. 3, n, 8, p.169-187, 2006. Disponível em: < http://200.144.189.42/ojs/index.php/comunicacaomidiaeconsum o/article/viewFile/5040/4665 > Acesso em: 22 mar. 2016.

PINHO, P. S. Reinvenções da África na Bahia. São Paulo: Annablume, 2004.

SANTOS, M. Por uma Geografia cidadã: por uma epistemologia da existência. Boletim Gaúcho de Geografia, Porto Alegre, n. 21, p. $72-$ 88, agosto 1996.

SANTOS, P. V. P. Trabalhar, Defender e Viver em Salvador no Século XVI. 2004. 130f. Dissertação (Mestrado em História Social) Faculdade de Filosofia e Ciências Humanas, Universidade Federal da Bahia, Salvador, 2004.

SCHAUN, A.; SCHWARTZ, R. "O Corpo Feminino na Publicidade: 
Aspectos Históricos e Atuais". In: IV COMCULT: Cultura da Imagem e Gêneros. São Paulo: Centro Universitário Belas Artes de São Paulo, 2008, p. 1-11, Disponível em: http://www.ufrgs.br/alcar/jornal-da-alcar-no-3-agosto-de2012/O\%20corpo\%20feminino\%20na\%20publicidade.pdf. Acesso em: 15 mar. 2016.

SCHREIER, M. Qualitative Content Analysis in Practice. London: Sage. 2012.

SILVA, T. T. (Org.). "A Produção Social da Identidade e da Diferença”. In: SILVA, T. T. (Org.). Identidade e Diferença: A Perspectiva dos Estudos Culturais. Petrópolis: Vozes, 2000, p. 73-102.

STROZENBERG, I. "O Apelo da Diferença: Reflexões sobre a Presença de Negros na Propaganda Brasileira”. In: BATISTA, L. L.; LEITE, F. (Orgs.). O Negro nos Espaços Publicitários Brasileiros: Perspectivas Contemporâneas em Diálogo. São Paulo: ECAUSP/Prefeitura de São Paulo, 2011, p. 189-196.

TIBURI, M. "Branca de Neve ou Corpo, Lar e Campo de Concentração: As Mulheres e a Questão Biopolítica”. In: TIBURI, M.; VALLE, B. (Eds.). Mulheres, Filosofia ou Coisas do Gênero. Santa Cruz do Sul: EDUNISC, 2008, p. 53-73.

. "Ofélia Morta - Do Discurso à Imagem”. Estudos Feministas, Florianópolis, v. 8, n. 2, p. 301-318, maio-agosto 2010.

- "Direitos Estéticos - Plasticidade: uma questão entre Ética e Estética”. Cult, São Paulo, v. 210, p. 19, março 2016.

VANIN, I. M. "Regateiras, Ganhadeiras, Vendeiras: Gênero, Perfume e Cor pelas Ruas da Salvador Colonial.” Bahia Análise \& Dados, Salvador, v. 25, n. 3, p. 525-539), julho-setembro 2015.

WOLF, N. O Mito da Beleza. Como as Imagens de Beleza São Usadas Contra as Mulheres. Rio de Janeiro: Rocco, 1992. 


\section{Glossário}

Acarajé - Palavra composta da língua iorubá: acará (bola de fogo) e jé (comer), ou seja, "comer bola de fogo". Bolinho característico do candomblé, tem sua origem explicada a partir de um mito sobre a relação de Xangô com suas esposas, Oxum e Iansã. $\mathrm{O}$ acarajé tornou-se uma oferenda a esses Orixás.

\section{Anatomopolítica - Conjunto de processos de} disciplinamento corporal que vêm a corresponder com toda uma eficácia física do corpo.

Baianidade - Expressão frequentemente usada para definir características do modus vivendi dos baianos, mais especificamente dos que nascem em Salvador e no Recôncavo da Bahia. Inserido no contexto da construção de tradições.

Biopolítica - Termo utilizado por Michel Foucault para designar a forma pela qual o poder tende a se modificar no final do século XIX e início do século XX. Tem como alvo a população. Representa um discurso medicalizante e biologizante que se aplica à população a fim de controlar a vida.

Colonização estética - Imposição de referências coloniais históricas, culturais, artísticas e linguísticas. No começo do século XX, o Movimento Antropofágico Brasileiro questionou o discurso das vanguardas europeias como um modelo externo; uma nova figura de colonização estética e política da América Latina.

Empoderamento - Conscientização de ser parte de um grupo maior, o que vai além da expressão individual. Socialização do poder entre os sujeitos. Inclusão social e exercício de cidadania.

Ideologia do branqueamento - Ideologia que surge como uma adaptação das teorias raciais clássicas ao contexto brasileiro no final do século XIX. Elemento-chave para uma melhor compreensão do racismo no Brasil.

Representacionismo - Processo civilizatório no Ocidente que compôs discursos acerca do corpo e de suas práticas culturais e no qual a produção visual de representações ocupa um lugar central. 
Reificada/Reificação - Coisificação das relações sociais. Processo no qual tudo se transforma em mercadoria e os sujeitos se automatizam, perdendo a capacidade de serem protagonistas de suas próprias ações. Conceito utilizado por Theodor Adorno em sua crítica à indústria cultural.

Soteropolitana/Soteropolitano - Do grego, soter (salvador) mais polis (cidade). Aquela/aquele que nasce na "cidade do Salvador na Bahia”.

Subserviência - Obediência irrestrita, beirando à docilidade, a uma lei/autoridade/orientação. Herança colonial escravocrata enraizada nas relações sociais das populações pobres brasileiras.

Violência autoinfligida - Caracterizada como uma violência invisível. Inclui o autoabuso, a automutilação e o comportamento suicida. Uma morte é considerada suicídio quando as circunstâncias e as evidências corroboram para um atentado suicida, descartando o homicídio, as mortes naturais e não intencionais.

Violência institucional - Termo criado em 1996 pela Organização das Nações Unidas. Refere-se a um dos três tipos de violência que ocorrem em contextos sociais (violência interpessoal, institucional e estrutural). A violência institucional, por sua vez, ocorre quando o ato violento é cometido por agentes de instituições sociais no desempenho dos seus papéis dentro do contexto institucional (de educação, de saúde, de segurança, de direitos, de práticas religiosas, do trabalho).

Violência simbólica - Termo cunhado por Pierre Bourdieu que significa imposições de categorias de pensamento e de percepção fundamentadas no discurso dominante de crenças, valores, hábitos e comportamentos. É uma violação sutil, muitas vezes imperceptível, já que não é claramente visível como a violência física. Todavia, o dano causado por este tipo de violência é muito mais poderoso, uma vez que está incorporada nos modos de estruturação e cognição dos indivíduos, e sua prática é legitimada pela ordem social. 
Trajes de candomblé - Vestimentas das mães e pais de santo, bem como das baianas. Compostas por: Ojá (um tecido branco que cobre a cabeça tanto de homens quanto de mulheres); bata (uma blusa) e saia para as mulheres e calça e bata para os homens; pano da costa para as mulheres (tecido amarrado no meio das costas em respeito às ancestrais que eram obrigadas, pelas senhoras da Casa Grande motivadas pelo ciúme dos seios volumosos das negras escravizadas, a cobrirem-se com este tecido das costas em direção aos seios). 


\title{
O Corpo e a Geografia do Cotidiano
}

\author{
Benhur Pinós da Costa
}

Edipo Djavan dos Reis Goergen

Flávia R. Durgante

Taiane Flôres do Nascimento 
F ste artigo tem o desafio de entender a perspectiva do corpo no Ucampo de análise geográfica. Desde já, evidenciamos a dificuldade em tratar o tema em virtude da tradição da Geografia brasileira em conceber o espaço geográfico como uma extensão de um fenômeno ou conjunto de fenômenos e seus limites (MORAES, 2007). Neste aspecto, o espaço aparenta ser concebido como um campo de relações que agrega uma coletividade, podendo ele ser enfocado por: um princípio "nomotético" de espacialização de certo fenômeno e suas relações de dispersão e configuração espacial, definindo algo que se espraia e se pontua em uma rede de relações espaciais, entre evidências de reprodução deste fenômeno e suas conexões; ou um princípio “ideográfico”, no qual o espaço é a própria relação singular de diferentes fenômenos que apresentam uma extensão sistemática (conjunto de princípios, singularidades, funções e conexões). De certo, temos a predisposição de conceber o espaço a partir de relações de objetos e seres, ora em conexões em malha, que ligam pontos de conexões distantes, ora em uma base contínua de relações e funcionalidades em uma proximidade de extensão espacial.

Doreen Massey (2009) irá criticar estas abordagens na Geografia que entendem o espaço como uma "prisão" a partir das noções de "sincronia" e "diacronia". A sincronia, como tendência forte dentro da tradição geográfica, irá representar os espaços de extensão, cujos fenômenos se espraiam em uma continuidade de relações que apresentam um limite. A sincronia do espaço define uma extensão fixa e monolítica, passível de ser fixada pela Geografia e seus métodos diversos de representação. A diacronia procura entender as relações descontínuas dos fenômenos que se espacializam, como formas de espacialização descontínuas, porém, contíguas, ou produções espaciais de certas ordens que se reproduzem em descontinuidades espaço-temporais. Diferente da continuidade, a contiguidade é aquilo que está ao lado, mas sem definir uma extensão dentro de algo. $\mathrm{Na}$ esfera das análises nomotéticas e das abordagens das relações de escala na teoria da dispersão dos fenômenos espaciais em tempos de globalização, as 
análises descontínuas e contíguas ganharam destaque ao observarem os fenômenos espaciais reproduzidos em longas distâncias na produção das redes de relações. Se, por um lado, a sincronia produz um conjunto de relações espaciais cujo tempo de produção se perde, a diacronia representa uma fixação do tempo no espaço. Ambos os métodos de análise traduzem-se na premissa de configurações espaciais além dos corpos sociais, como se as espacialidades substituíssem as pessoas, os agentes de espacialidades, os humanos, na velha máxima de que a ciência estuda os lugares, não os "homens" (LA BLACHE apud RELPH, 1979).

Será na rodada cultural na Geografia (CLAVAL, 2001) no Brasil ao longo dos anos de 1990 e 2000 que outras formas de espacializações começam a ser atendidas por esta ciência. A Geografia Cultural, com forte influência da fenomenologia de Husserl e Merleau-Ponty, começa a entender outras formas de produção do espaço além da perspectiva da extensão relacional estruturada por relações econômicas e de poder. Husserl (2012) entra no escopo metodológico da Geografia para entender as forças de produção do espaço além do estruturalismo. A Geografia Cultural com base na fenomenologia irá enfocar a sensibilidade dos sujeitos no contato com os diferentes fenômenos experienciados. A base metodológica define-se pela ideia de “époche”, de Husserl (1929), como uma crítica ao conhecimento positivista e da ciência moderna, no sentido de propor desconsiderar todas as premissas teóricas e científicas quanto ao entendimento dos fenômenos pelos sujeitos, colocando-as em "suspenso" e proibindo qualquer posição vertical e hierárquica do pensamento que alterasse aquilo que é sentido e observado por aqueles que vivem as condições dos fenômenos espaciais. A ideia seria limpar qualquer processo de objetivação e trabalhar com as essências dadas pelas subjetividades e intersubjetividades dos sujeitos em suas vivências espaciais, desconsiderando qualquer "a priori” científico metodológico que determine o pensamento sobre os homens e as mulheres, sobre a sociedade e sobre o espaço. 
A ideia da "intencionalidade", de Merleau-Ponty (2011), procura apreender os fenômenos como eles aparecem à consciência, sendo essa sempre consciência de alguma coisa orientada para algo e nutrida pelas experiências de alguém. A ideia, neste sentido, seria radicalizar a experiência única de uma determinada consciência, tornando emergentes as possibilidades múltiplas de diferentes ações socioespaciais ajustadas às singularidades de cada experiência vivida. Neste aspecto, a corporeidade dos sujeitos torna-se perspectiva importante para os estudos geográficos, traduzidos nas relações de seus corpos com as percepções e representações mentais complexas, definindo singularmente outras formas de produções espaciais além das sincronias e diacronias estruturantes do espaço positivista cartesiano. Os estudos de Y-FU Tuan (1980; 1983) irão dar consistência a esta relação próxima entre corpo e espaço, transformando o vínculo geográfico com as estruturas de fenômenos espaciais sem corpos e sem sujeitos. Os estudos sobre lugar e paisagem irão abarcar esta relação do corpo e seu trabalho de projeção, percepção e representação de espaços, enfatizando que sentimentos singulares de corpos singulares também produzem espaços (formas de espaços e formas de agir em espaços).

Schutz (2012) irá relacionar a teoria da ação social de Weber com as ideias de Husserl (ALLEN-COLLINSON, 2011). Nessa perspectiva, as análises procuram ir além do corpo, no sentido de entender as associações e negociações para produção de relações intersubjetivas singulares, conferindo outras formas sociais e outras formas espaciais entre entendimentos estruturantes da sociedade e do espaço social. As interações localizadas são produções de sociedade e de espaço (BERGER; LUCKMAN, 2002). Estas pequenas objetivações de subjetividades inter-relacionadas em contextos diversos do que seria uma estrutura social desconstroem as bases estruturais do espaço social, propondo diferentes e outras relações, assim como também são consistências que fomentam o dinamismo das produções hegemônicas que pretendem organizar a estrutura socioespacial. Mas, antes de uma relação escalar baseada em instâncias e produções ideais e concretas intersubjetivas, pressupõe-se 
o importante trabalho dos corpos na significação dos fatos e realidades do mundo social, tornando-os predispostos à inserção e reprodução ou à emergência da afirmação da diferença. Temos, assim, uma nova postura de entendimento do espaço social que refuta a universalização e a uniformização de uma estrutura em um conjunto de instituições fixas no tempo e integradas em processos. $\mathrm{O}$ mundo social tende a tornar-se fluido e sempre em construção, porque as relações sociais são uma constante negociação em que posições, ações e apresentações são trocadas, performatizadas e propõem a reconstrução de ordens e poderes. Estas bases desconstrucionistas evidenciam o papel dos corpos expressivos em destaque frente à imagem das estruturas espaciais sem pessoas. Para isso, procuram entender diferentes relações escalares da produção do espaço, que transitam entre o espaço como produção e reprodução imediata do corpo e para o corpo, assim como espaço como mediação entre a esfera do vivido praticado pelos corpos e concebido reproduzido pelas instituições.

Observamos, então, que existem quatro perspectivas de método na análise geográfica, e elas estão relacionadas com o pensamento sobre a escala: a) a primeira perspectiva é a forma sincrônica do espaço, em que as espacializações dos fenômenos se dão pela diversidade das integrações deles em uma extensão sistêmica que apresenta limites (cabe ao geógrafo encontrar as interações, a escala, a extensão e os limites); b) a segunda perspectiva é a diacrônica, conduzida pelas espacializações descontínuas e contíguas na configuração das representações em rede que definem pontos de fixação de certas atividades e circuitos que fazem circular trabalho e energia, possibilitando dispersões em formação de grandes arenas (a ideia na diminuição da arena e ampliação da área geográfica (SANTOS, 1999); c) a terceira é a definição de estruturas espaciais cujos fenômenos, embora sejam produzidos por agentes espaciais, definem hierarquias e conjuntos de formas, processos, funções de coisas inanimadas (objetos e ações sem exatamente estabelecer a filosofia do humano nestas condições); d) a quarta é a desconstrução das estruturas e a valorização do vivido em uma relação teórica 
escalar diretamente ligada ao corpo humano, cujos espaços e espacializações ora emanam deste corpo, ora conduzem à formação deste corpo.

Tomando em conta a última perspectiva metodológica, o corpo é produto de conjuntos de processos de disputas (historicamente regidas por relações de poder que ligam política, economia e cultura) discursivas conduzidas através do tempo e que se traduzem em configurações de pensamento e de materialidade que geram os atributos, as funções e as ações corporais. Foucault (1993) traduz isso na ideia das genealogias do poder em disputa, traduzidas como marcos de eventos historicamente produzidos, que geram configurações materiais e discursivas hegemônicas, que abarcam as "formas", os "fazeres" e os "seres" sociais (FOUCAULT, 1988); nas configurações de espaços disciplinares (FOUCAULT, 1984), que representam conjuntos de formas espaciais historicamente produzidas para objetivar e colmatar as éticas (formas de agir) e as estéticas (formas de se apresentar) corporais; na produção de discursos sobre os "seres" e sobre o social (na configuração de papéis e deveres corporais na ordem social) (FOUCAULT, 1996), que conduzem à subjetivação corpórea da ordem objetivamente produzida. Em sua complexa geografia, Foucault nos conduz a pensar uma nova ordem de espacializações, principalmente na sua relação entre concepção ideal de espacialidades, na configuração de realidades materiais e na função/ação exercidas por corpos contidos em ordens de discursos e em complexas hierarquias sistêmicas que ligam o cotidiano imediato às superestruturas normativas institucionais (formadas historicamente por atos/eventos concretos na unificação da sociedade moderna).

Para Raffestin (1993), a geografia de Foucault traduz-se em atos espaciais além do visível: são as configurações de poder que produzem as causas e consequências materiais do espaço e as ações corporais contidas nele. O poder com " $\mathrm{p}$ ” minúsculo representa a ordem territorial exercida e emanada pelos corpos que a produzem e que são produzidos por ela, sem foco físico e evidente, contido nas próprias relações sociais, nas expressões e nas funções/ações que 
exercem. O território, assim, é produto desta relação entre materialidade e ação/representação dos corpos, construtoras e construídas nelas, mobilizadas a partir de uma complexa rede de discursos que normalizam o espaço social. É neste aspecto que Sahr (2007) frisa a teoria sobre espacialidade contida em Foucault (2001) em uma relação imbricada entre discurso, corpo e objetivação. A construção da doença implica três espacializações: a primeira espacialização conduz o discurso construído pela ciência sobre aspectos da doença (seus sintomas, suas formas, sua dinâmica, sua maneira de diagnóstico, sua maneira de tratamento); a segunda espacialização define-se pela evidência do corpo doente e a marcação de um conjunto clínico e discursivo que transmite a realidade da doença para a formação dos corpos doentes na realidade social (os sujeitos corpóreos acreditam nas doenças de si e dos outros no conjunto de relações sociais definido pela busca da saúde e bemestar); finalmente, os sistemas de procedimentos de um conjunto social, acompanhados de suas respectivas dimensões materiais, que se organizarão para controlar/disciplinar a doença e o corpo doente (os hospitais, as enfermarias, os segmentos de corpos especializados para o tratamento da invenção da doença). Essa construção que liga o discursivo e o pensado ao material, e que liga a objetividade e o subjetivado ao conjunto de predisposições individuais e coletivas corpóreas e àquilo que abarca suas relações (a materialidade), representa uma geografia que precisa ser melhor discutida no Brasil.

Enquanto as fenomenologias de Husserl e Merleau-Ponty influenciaram a Geografia brasileira em entender espaços espontâneos conduzidos pela atividade intencional de sujeitos simples e seus cotidianos, desapegados de uma estrutura social e, inclusive, desvinculados pela formação de espaços de originalidades, a teoria Foucaultiana desdobra-se pela ordem espacial que disciplina corpos e os conduz novamente a uma relação escalar que liga corpo, estrutura e superestruturas produzidas material e historicamente. Nesse contexto, aparece Lefebvre que procura estabelecer ligações entre uma fenomenologia das construções das formas (espaços) sociais e predisposições estruturais originadas das ideias de 
totalização do social (tanto de ordem marxista como de ordem Foucaultiana, embora o último procure resolver, a partir da evidência de dispositivos, o problema da relação entre corpo/indivíduo e ordem social estrutural). Na lógica marxista, o corpo é objeto de alienação e aparece, sobretudo, em Heller (1991), na discussão da esfera do cotidiano. Para a autora existe o "homem particular" e o processo de "individuação", sendo ambas as noções contradições em sua teoria: a primeira noção irá representar os corpos alienados imersos na complexidade de uma sociedade em que, ao mesmo tempo que se estrutura, também se diversifica em disciplinas e formas materiais que produzem ações particularizadas e especializadas, condição da alienação; na segunda noção, o discurso da particularidade e da alienação transmite a ideia da necessidade de individuação, ou seja, não somos indivíduos, somos "homens particulares”, e a saída da alienação é a condução dos corpos aos caminhos da "práxis social", ou algo que liga vivido rotineiro e alienado (minuciosamente estruturado em suas formas, processos e funções que abarcam os corpos em atividades particulares, disciplinadas e coerentes com uma complexa estrutura social) àquilo que o produz e que produz os particulares como tal (o fundamento de tudo, da complexidade da estrutura, dos agentes que se perpetuam e que objetivam seus pensamentos sobre o social). Os corpos então são conduzidos por objetivações, ou seja, existem “objetivações genéricas em si”, ou corpos inseridos nas formas e nas funções sociais, conduzidos a pensarem e a agirem de acordo com ordens organizadas complexamente na estrutura multidimensional do espaço social, e as "objetivações genéricas para si”, ou instituições que produzem a configuração do social e dos corpos contidos nas diversas formas objetivadas deles (a ciência, o Estado, o capital, as classes de poder, a produção dos discursos e das ideologias). $\mathrm{O}$ cotidiano como esfera de alienação é a relação intrínseca entre as duas formas de objetivações e ele serve para disciplinar, alienar e particularizar os corpos.

A dialética lefebvriana é conduzida por uma tríade interessante que se debruça sobre diferentes espacializações: o vivido, 
o percebido e o concebido (LEFEBVRE, 2013). Essas espacializações representam algo que permite tanto entender a espontaneidade dos corpos e seus cotidianos (o vivido), como entender outras escalas de configuração de objetivações normativas (a do percebido e a do concebido). Pensamos que as ideias de Lefebvre nos permitem fazer pontes entre as relações do corpo com o espaço, sendo o corpo um próprio espaço, definido pela capacidade de ação e de pensamento sobre si e sobre as coisas na natureza social. Na relação do vivido, o corpo emerge como espaço produzido e produtor de ações e reações. $\mathrm{O}$ vivido é o espaço corpóreo e tudo aquilo que ele contém: sua capacidade de significar a si e as coisas do mundo externo, assim como sua capacidade de movimento, que produz práticas singulares, espontâneas e privadas de espaço. O corpo é a espacialidade vivida, contido nele mesmo, só explicado por ele mesmo, conduzido por remodelações de atos e pensamentos externos a ele, efetivos por sua originalidade de avaliar-se em relação ao que acontece ao redor. $\mathrm{O}$ corpo é produto e produtor da relação de si com os outros, sendo algo autêntico, mesmo quando mais determinado. É ele que contém os aprendizados do social, mas é ele que também questiona isso e estabelece a originalidade original. Ele condiciona uma singular escala de produções éticas e estéticas, ora reproduções, ora produções, ora padronizações, ora originalidades. O corpo é a concentração das complexidades explicativas e expressivas construídas socialmente, mas é, principalmente nele, que elas são rompidas, reinventadas e desconstruídas. É tanto expressão máxima do privado (o corpo consigo mesmo) quanto representação unitária do público (a necessidade de inserção público-social). Como expressão máxima do privado é espaço da forte capacidade de transgressão, porque poderá não se permitir ser definido, em uma relação com ele mesmo.

As relações de um espaço privado corporal remetem a originalidades vividas que definem uma forte política imaginária e concreta da transgressão das normas sociais. Os situacionistas entendiam essa possibilidade de transgressão do espetáculo da vida pública. A possibilidade $\mathrm{da}$ análise $\mathrm{da}$ situação torna possível as 
evidências de outro olhar sobre o social, além da massificação espetacular calculada das informações e das reproduções imagéticas e míticas que organizam o social. Além das relações sociais conduzidas por formas espetaculares condicionadas, as relações privadas corporais permitem outras vivências: de espontaneidade e, assim, de originalidade e transgressão ao dado. De acordo com Duarte (2014), "talvez a obscura e inconfessada consciência de que o elemento genuinamente político consiste exactamente nesta incomunicável e quase ridícula clandestinidade da vida privada”.

Mas a tríade de Lefebvre continua. Além da espontaneidade e capacidade de transgressão do vivido corpóreo, há o percebido, como o social imediato, transversal às capacidades de significações corpóreas próprias, que está condicionado a um conjunto de jogos de apresentações e representações, em uma complexa relação de espelhos entre "mim" e o "outro", tornando possível a formação do "eu” (como self). O vivido corpóreo é aquilo que se dá pelo movimento e pela manifestação das ações e movimentos biológicos e psíquicos por entre o social, como um "mim" que age e que tem capacidade de aprender e ser espontâneo em um conjunto de erros e acertos (representações sociais). Os outros do espaço percebido estabelecem um jogo de interdições e possibilidades localizadas nas práticas sociais, tornando receptáculo das condições existenciais normativas (nos regramentos de poderes minúsculos disciplinares que emanam das relações sociais diretas, como o poder com "p" minúsculo em Foucault e Raffestin), mas também possibilidades de coletivização de desejos e contradições a estas normas. Nesse contexto, entre as ações vividas de “mim" em confluência com outros, na construção de intersubjetividades (espaço percebido), há a corporeidade do "eu" como alguém que fala na terceira pessoa (entre "mim" e o "social”) (MEAD apud HONNETH, 2003). O corpo do "eu" conforma e possibilita também as transgressões das regras. É o trabalho corporal de avaliação sobre "si" que avalia os movimentos de "mim" e poderá convergir ou não para as aceitações tácitas de "nós” e seus conjuntos de interdições de espontaneidade. Esse jogo corpóreo entre o vivido e o percebido ainda é complexificado pelo 
concebido, como um espaço das produções institucionais, munidas de formações ideológicas com propósitos subliminares de comando. Elas contêm o corpo e suas espacializações, assim como a espacialização do corpo. Representam a força das representações sobre a construção das relações espaciais - das (representações) corpóreas às (representações) coletivas e institucionais. Conduzem as objetividades das construções ideais dos regramentos e das produções de ações funcionais e materiais da vida social. Vemos que as categorias de vivido, percebido e concebido de Lefebvre nos permitem entender as complexas relações espaciais entre corpo, grupo (imediações praticadas) e sociedade. Elas evidenciam primordialmente o corpo como construtor e construído de espacialidades múltiplas e em constante conflito e interação.

Nas suas construções sobre imaginário, Silva (2014) discute as ideias, os símbolos, as percepções e as representações grupais e coletivas de acontecimentos e lugares do urbano. $\mathrm{O}$ autor pretende entender como se coletivizam formas imaginárias da cidade, como vivências desmaterializadas da urbe, mas que pressupõem relações que ligam produções psíquicas e corpóreas, como as coletivas, com determinadas experiências de determinadas materialidades e de determinados acontecimentos. Estes sintomas imaginários não necessariamente respeitam uma sincronia corpo-grupo-espaçotempo, sendo produzidos em relações espaço-tempo muitas vezes divergentes e múltiplas, influenciadas por experiências e fundamentos psíquicos que partem tanto do corpo ao coletivo vivido quanto do coletivo vivido ao corpo e à subjetividade. Além disso, em tempos de alta produção imagética e discursiva, os imaginários sobre a cidade são altamente influenciados pelas concepções produzidas em espaços de informação de escalas/esferas além do local. Pensamos que esta ideia conversa muito bem com a tríade de espacialidades pensada por Lefebvre entre vivido, percebido e concebido. Para Silva (2014), o que menos existe é cidade (como simples forma material), mas, sobretudo, idealizações de cidade, produzidas em diferentes escalas (do corpo a prática coletiva e a representações institucionalizadas pelas hegemonias discursivas 
diversas, e vice-versa), tornando preponderante aos sujeitos a vida de um urbano sem necessariamente ter cidade (embora a forma e os acontecimentos sejam preponderantes para esta formação imaginária).

Metaforicamente, Silva (2014) relaciona imaginário com "fantasmas" urbanos e estabelece outras tríades de construção concebidas por ele como "inscrições dos imaginários": a) a primeira inscrição é a psíquica, evidenciando os "sentimentos" que constroem "mapas mentais" e que se sobrepõem sobre a realidade da cidade, organizando uma urbanidade de emoções diversas, em tempos diversos e sobrepostos, que preza uma "geografia cognitiva", além de uma "geografia de arquitetônicos"; b) a segunda inscrição é a social, em que representações estabelecidas sobre a cidade influenciam a ordem psíquica e corporal dos sujeitos, sendo produzidas por um conjunto de discursos e imagens grupais que afetam a cognição e a percepção de cada membro e suas relações com os lugares da cidade; c) a terceira inscrição é a tecnológica, em que tecnologias disseminadas para todo ecúmeno produzem representações públicas que afetam o coletivo (os grupos) e as cognições (a psique individual). Observamos que, tanto em Lefebvre como em Silva, a produção das éticas e das estéticas sobre as espacialidades são relações íntimas entre corpo, formas coletivas e sociedade, principalmente envoltas em relações complexas entre o vivido, o praticado e o concebido.

Finalmente, as leituras de Rose (1993) e Massey (2009) buscam, nos condicionamentos e transgressões espaciais dos corpos, uma nova perspectiva de leitura em Geografia. O feminismo na Geografia aponta, em um primeiro momento, para a estruturação das hegemonias ideais de espaço que se reproduzem nas materialidades e que privilegiam determinados corpos em seus usos e fazeres. A time-geography, de acordo com Hagerstrand (apud ROSE, 1993, p. 21), é "uma perspectiva de estruturação espacial e temporal da vida social", na qual éticas e estéticas de corpos estão em interseção com uma dinâmica estrutural de reprodução da sociedade como totalidade. A construção espacial unificada da time-geography é 
concebida pelo privilégio étnico branco, generificado masculino, sexuado heterossexual e classista burguês, permitindo a ampla ação/prática dos corpos convergentes a essas polarizações. A composição dos objetos e das ações espaciais permite o sucesso de algumas condições hegemônicas de "ser" e "estar" social, hierarquizando as possibilidades de ação e a existência de outras. Tais construções são possíveis porque o espaço de concepção (balizado pela eficiência comunicacional das instituições conservadoras) é eficiente na produção discursiva que camufla tendências de privilégios. Assim, ele se divulga e se constitui como neutro e como acessível às causas da maioria, ou seja, se legitima como um poder invisível que se agrega à própria construção de pensamentos e de corpos sociais, reproduzindo-se entre as relações e entre as cognições, como o poder com "p" minúsculo explicitado por Raffestin (1993).

No entanto, tais leituras feministas apresentam-se como críticas e denúncias às condições ideológicas das espacializações hegemônicas, que se constituem como interdições à ação e expressão de determinados corpos e que produzem hierarquizações e privilégios sociais. Essas denúncias estão ligadas diretamente às causas e lutas de reconhecimento social, em que se evidenciam as relações intrínsecas entre academia e política da vida cotidiana. A existência destas leituras intelectuais é acionada por agentes sociais ligados diretamente a vivências das exclusões e interdições cotidianas. Sendo assim, emerge, de forma dialética, outra postura feminista sobre o espaço social, concebendo seu caráter dinâmico, em constante produção, como espaço de interação e de conflito pela junção de corpos. Essa é a política da espacialidade de Massey (2009), que observa que o caráter da tradição de fixar, estabelecer e tornar eternas certas concepções de espaço é produto da força discursiva de certos poderes que utilizam a Geografia para se constituírem como verdades. Daí suas críticas à tradição da Geografia na produção de estruturas fixas, sincrônicas e diacrônicas de espaço. Para a autora, os espaços são os próprios corpos e a junção/encontro de corpos, em constante negociação, como um conjunto de "estórias até agora", 
que se reconstituem em diversidade de formas espaço-temporais e escalares. Desses encontros e produções singulares de espacializações, suas escalas de atuação e seus tempos de duração são diversos e múltiplos, gerando a principal característica do espaço: seu forte dinamismo e fluidez, e nunca sua fixidez.

É assim que Rose (1993) nos apresenta a política das espacialidades paradoxais e critica a tradição da Geografia em procurar entender extensões de sistemas relacionais ausentes de conflitos (a Geografia institui discursos sobre espaços de extensão que abarcam todos os corpos, sem nenhum conflito, como se a identidade espacial dada fosse algo inquestionável, arbitrário e pacífico a todos). Assim, os paradoxos espaciais estão constituídos pela presença concomitante de relações de corpos que se estabelecem por representarem as formatações ideais de poder, e de corpos que se chocam por estarem subjugados a determinações de hierárquicas sobre os privilégios espaciais. Nesta leitura de espaço, não necessariamente existem insiders e outsiders, que funcionam como elementos de configurações de extensões espaciais pacíficas, mas o espaço dos "mesmos" também é espaços dos "outros”, assim como o espaço dos “privilegiados” também é espaço dos “excluídos”, em uma trama de conflitos e negociações que alteram constantemente os posicionamentos dos corpos dos sujeitos socioespaciais. É claro que a força discursiva e ideológica, marcadamente tendenciosa privilegiando determinados segmentos, produz configurações materiais hegemônicas que marginalizam certos corpos, os quais produzem outras espacialidades que contornam as interdições primeiras, em um constante movimento de "desespacialização" e "reespacialização". No entanto, em relação à ideia de um espaço que se constitui como hegemônico pelos privilégios dados historicamente a certos corpos e à ideia da constituição de outros espaços gerados pela marginalização da configuração inicial, há a concepção do espaço que se constitui essencialmente pelas disputas, pelos jogos de influência e interdições, pelo conflito entre os diferentes e pela dinâmica das disputas de influência e poder espacial. A espacialidade paradoxal de Rose (1993) institui espaços que 
colocam determinados corpos no centro das decisões e das produções materiais e discursivas; e outros espaços que se colocam à margem, produzindo suas próprias hierarquias, que são constantemente superadas e nas quais os corpos, em seus jogos complexos, posicionam-se diferenciadamente, em uma constante luta por reconhecimento e estabelecimento.

\section{Três realidades de pesquisa que relacionam corpo e espaço}

A partir de agora, iremos trazer à tona três pesquisas desenvolvidas no laboratório do grupo de pesquisa Espacialidades Urbanas, da Universidade Federal de Santa Maria, Rio Grande do Sul, Brasil. A primeira pesquisa aborda as formas de interdição espacial heteronormativa das travestilidades e transexualidades no espaço social e discute as performatividades desses corpos e seus trabalhos de negociação junto ao espaço social, bem como a constituição de espacialidades possíveis, enfocando principalmente as existências corporais performáticas das travestis e transexuais nos espaços das religiosidades afro-brasileiras. A segunda pesquisa aborda as construções históricas e discursivas que impõem performances estritamente restritas a diferenças de gênero condicionadas à heteronormatividade nos espaços do tradicionalismo gaúcho (formas culturais do regionalismo do Estado do Rio Grande do Sul, Brasil). No entanto, esse segundo estudo observa os paradoxos da constituição e expressão de diversidades sexuais homoafetivas no cerne dessas espacialidades, o que produz aproximações homoeróticas entre corpos fortemente generificados. A terceira pesquisa aborda a construção do espaço escolar como discursivamente criado pelo privilégio das posturas e expressões misóginas sobre os gêneros, o que condiciona certas margens em disputa, principalmente pela expressão livre das mulheres e das diferentes sexualidades. 


\subsection{Travestilidades nos "terreiros" das religiosidades afro- brasileiras}

A primeira pesquisa desenvolvida no grupo Espacialidades Urbanas do Departamento de Geociência da Universidade Federal de Santa Maria (UFSM), em Santa Maria, província do Rio Grande do Sul, Brasil, aborda as formas de interdição espacial heteronormativa das travestilidades e transexualidades no espaço social e enfoca as possibilidades dessas existências corporais performáticas nas especificidades espaciais das religiosidades afrobrasileiras. Em termos teórico-metodológicos, atentamos ao caráter fenomenológico das análises das geografias feministas, privilegiando as discussões sobre percepção como balizadores filosóficos que podem auxiliar na compreensão dos fenômenos espaciais relacionados à subjetividade de determinados sujeitos e grupos, principalmente aqueles marginais e invisibilizados socialmente pela ciência moderna. Nesta linha de pensamento, a ciência geográfica torna-se uma ciência social que procura dar ênfase à interação dos indivíduos e à constituição de intersubjetividades como produtoras de espacialidades. Considerando que os sujeitos sociais estão corporalmente inseridos no mundo, ou seja, que suas relações com os outros sujeitos e com a materialidade são mediadas primeiramente pelo corpo, este trabalho tem como objetivo discutir sobre as possíveis relações entre o corpo/subjetividade nos espaços religiosos, baseando-se na fenomenologia das experiências travestis e transexuais.

Nesta perspectiva, a fenomenologia valoriza a consciência de cada sujeito e descreve o mundo da maneira como emerge na consciência, nas intenções e percepções acerca das especificidades sensíveis do entorno. É o estudo da essência voltada para apreender e compreender como cada sujeito percebe o mundo que o rodeia, valorizando a experiência. Merleau-Ponty (1908-1961) ressalta que, antes de ser um objeto, o corpo é nosso modo próprio de ser-nomundo: "O corpo é nosso meio geral de ter um mundo" (MERLEAU-PONTY, 2006, p. 203). O corpo, assim, é o primeiro objeto da percepção, vindo antes da própria reflexão, sendo ele 
produto e produtor de consciência. Neste sentido, o gênero e os balizadores de sexualidade revelam-se pelo que o corpo sente, pelas suas intenções e relações com o mundo, com outros corpos, em um constante processo, ora de interação, ora de conflito com o dado corpo e com relações corporais concebidas socialmente. São nessas relações e intenções conflituosas entre as subjetividades criativas e espontâneas e as concepções dadas pelas exterioridades sociais que os sujeitos constroem seus próprios mundos e que suas intenções e ações se revelam singulares as suas corporeidades e objetivações partilhadas de intersubjetividades nas diversidades de vivências socioespaciais.

A “corporeidade” apresenta-se como um conceito filosófico importante para o entendimento do espaço geográfico em uma perspectiva dos estudos do cotidiano, principalmente na relação de abordagens que pressupõem o marco espacial, como a fenomenologia e o interacionismo simbólico. A primeira discute muito as relações entre objetividades significantes e repercussões/transgressões subjetivas corpóreas sobre as concepções e/ou percepções de espaço e de tempo; a segunda discute as objetividades corporais (éticas e estéticas) expressas em espaços interacionais de trocas simbólicas intersubjetivas. Assim, para evidenciar o conceito de corporeidade em uma perspectiva fenomênica, ressaltamos os fundamentos de Merleau-Ponty (1999, p. 193) quando faz uma relação do corpo e espaço:

Não se deve dizer que nosso corpo está no espaço nem tampouco que ele está no tempo. Ele habita o espaço e o tempo [...] Enquanto tenho um corpo e através dele ajo no mundo, para mim o espaço e o tempo não são uma soma de pontos justapostos, nem tampouco uma infinidade de relações das quais minha consciência operaria a síntese e em que ela implicaria meu corpo; não estou no espaço e no tempo, não penso o espaço e o tempo; eu sou no espaço e no tempo, meu corpo aplica-se a eles e os abarca.

Próximo a essa concepção fenomênica de corpo e suas relações de espaço e de tempo, os interacionistas defendem a ideia de que o papel das ciências sociais é estudar a concepção que os atores constroem para si do mundo social que os cerca (TEDESCO, 1999). 
Em outras palavras, o fundamental é inteiramente o ponto de vista dos atores sociais, ou seja, o modo como eles formam seu mundo social, ressaltando as diferentes formas de integração e construção de espacialidades que integram. No caso de nossa pesquisa, o grupo social das travestis e transexuais apresenta-se como um exemplo concreto de singularidades intersubjetivas construtoras de espaços de interações específicas que reconstroem as objetividades normativas que compõem as hegemonias estéticas e éticas que procuram unificar as expressões corporais na composição basilar do espaço social. Seus corpos não se aplicam às normativas de um espaço social heteronormativo e misógino, e são interditadas, em sua maioria, as objetividades relacionais do espaço social. Em relação as suas construções corporais, que confundem definições representacionais de gênero e de sexualidades, elas organizam e/ou se adequam a outras condições espaciais que transgridem ou se apresentam como alternativas específicas a formas de apresentação e comportamento que não se compõem de elementos de representação simbólica que se concretizam como normalidades e/ou regras de expressão social. Mesmo assim, constituem espacialidades que só podem ser explicadas por meio de intrínseca relação entre subjetividades divergentes em choque com formas de convivências hegemônicas de ser e estar em sociedade. As interações e construções representativas de espaço, neste caso, só são possíveis de serem entendidas a partir das especificidades perceptivas desses sujeitos e de suas condições existenciais, que transitam constantemente entre uma série de interdições espaciais e formas possíveis de localização da integridade de suas expressões corporais. Assim, seus corpos aplicam-se ou não aos espaços, em uma complexa rede de possibilidades ou de negação às interações espaciais.

Sabe-se que as travestis e as transexuais representam grupos sociais reclusos de certos espaços. Elas se destacam pelo modo de vestir, pelo modo de se comunicar e, principalmente, pelo modo que vivem. Essas expressões de gênero e sexualidade ocorrem pelos movimentos corporais, por especificidades afetivas e por expressões simbólicas singulares, que as diferenciam enquanto seres sociais. Suas 
formas de experimentação e interação com determinadas espacialidades são específicas de suas existências estéticas e de suas formas de subjetivação sobre suas lutas de reconhecimento quanto à expressão de seus corpos. A suas existências muitas coisas de um campo de representação social e institucional não se aplicam, e nenhum intelectualismo poderá se sobrepor como simplificador explicativo de seus movimentos contraditórios às formas hegemônicas de representações dos seres sociais. Seus corpos transgressores e seus trabalhos de constituição de espacialidades possíveis, porém invisíveis e marginalizados aos "olhares" hegemônicos das teorias socioespaciais, só se aplicam as suas próprias autenticidades discursivas como fontes de desconstrução de representações intelectuais - essas que se acumulam para normalizar as formas de agir e de se apresentar em sociedade. Para os interacionistas, são os significados subjetivos da interação social que servem de ponto de referência para o conhecimento científico. Eles priorizam o vivido e interpretam a realidade social atrás dos olhos do sujeito. A intencionalidade é que dá ao pesquisador formas de adentrar no subjetivismo do sujeito, pois o que se toma como objeto são formas não conceituais narradas tomadas da consciência subjetivada pelas experiências dos sujeitos.

No caso das travestis e transexuais nos terreiros de cultos afro-brasileiros, a corporeidade associa-se às suas performances diante das relações sociais que estabelecem não só dentro do terreiro, mas também como uma forma de vivência e conexão com a religiosidade. A ideia é que os terreiros sejam espaços possíveis à vivência de diferentes expressões de gênero e sexualidade, ao contrário de outros espaços religiosos. Com isso, abrem-se possibilidades de expressões autênticas de subjetividade e produção de intersubjetividade alternativas, podendo admitir que suas corporeidades performáticas, impedidas em outros espaços sociais, integrem toda e qualquer experiência.

Sugere-se que as religiões de origens africanas sejam abertas a essas performances por entenderem (em suas místicas) o corpo como um objeto de transição para a passagem de entidades 
(transcendências) sem distinção de gênero. O terreiro é um espaço onde o gênero não é colocado em evidência normativa, e isso possibilita as travestis e transexuais sentirem-se parte do lugar, vivenciando novas formas de relações sociais. Salienta-se que não se pode generalizar, pois alguns terreiros mantêm rígidos os padrões heteronormativos e misóginos. No entanto, é importante destacar que, em termos geográficos, é um espaço peculiar no qual se possibilitam diferentes formas de relações entre os sujeitos e apresentações de individualidades, e no qual formas difusas de relações de gênero se produzem e se reinventam, possibilitando revelações diversas em contínuas experimentações de pluralidades expressivas. Assim, a corporeidade, reconhecida como espacialidade, impulsiona uma nova perspectiva na qual o corpo é possivelmente visto como uma dimensão de resistência à homogeneização do espaço e das próprias relações sociais estabelecidas. Em certos espaços, as corporeidades dissidentes encontram espaços para se revelarem e para disseminarem possibilidades de transformação das formas representacionais rígidas contidas nas normalidades dos papéis sociais. Nos espaços de espontaneidade, como ocorre nos terreiros de religiosidades afro-brasileiras, novas formas de significar o social são construídas e fortalecidas a partir do poder das formas de apresentação das corporeidades dissidentes.

Para finalizar, podemos dizer que o corpo é explicado como um espaço que contém um conjunto de representações sociais. Porém, essas representações podem ser transgredidas em virtude de novas formas intersubjetivas que colocam a corporeidade em processo de representações dinâmicas e transitórias. O corpo é um espaço representado socialmente, assim como é aplicado a uma representação de espaço. O corpo também é um espaço praticado, assim como uma prática do espaço. Além disso, é um espaço subjetivado, assim como uma subjetivação do espaço. Nestas relações complicadas entre representação, prática e subjetivação, que ligam interioridade (lugar corpo próprio) e exterioridade (lugar do corpo), relações de corporeidades fundam-se próprias de formas simbólicas de reprodução social, de dispositivos de normalidade, mas 
também se rebelam nos pensamentos e ações transitórias em relação a formas em desacordo, em processos de transgressão. Tanto para os acordos quanto para os desacordos entre corpos em relações espaciais e relações espaciais dos corpos, há a necessidade de ver as pontes que ligam os espaços corpos com os corpos nos espaços, ou seja, as configurações possíveis e impossíveis dos espaços corpos (suas relações entre subjetividades e objetividades corporais) relacionadas às configurações espaciais nas quais os corpos estão (em prática e em relação com outros corpos). Assim, os terreiros de religiosidades afro-brasileiras são espaços de exterioridade relacionais que possibilitam inclusões de diferentes espaços corporais.

A vivência corporal gera e amplia as possibilidades de conhecimento de diferentes espacialidades, trazendo novas percepções à medida que o sujeito interage com o mundo físico e aumentando as trocas afetivas quando essa interação acontece com o meio social. A princípio, vistas juntas, essas categorias (gênero e religião) podem se tornar algo generalizador, porém é importante apresentar esses espaços religiosos, mesmo que sejam em menor número, pois estão abertos diante da perspectiva de relações sociais. A Geografia é uma ciência plural, capaz de entender espacialmente essas ligações, ainda que sejam tão subjetivas e locacionais.

\subsection{Homossexuais nos espaços de interação do Movimento} Tradicionalista Gaúcho

A segunda pesquisa, de uma maneira não muito diferente da primeira, vai tratar da inserção de indivíduos não socialmente aceitos em uma espacialidade historicamente machista, elitista e heteronormativa: o Movimento Tradicionalista Gaúcho', ou a

1. De acordo com o site da Confederação Brasileira de Tradições Gaúchas (CBTG), trate-se de uma associação civil, inscrita no Cartório de Títulos e Documentos em 27 de novembro de 1967. Possui personalidade jurídica e se caracteriza como de direito privado, sem fins lucrativos, abrangendo já todo o território nacional, com mais de 2.700 centros físicos de difusão, os Centros de Tradições Gaúchas. Segundo Golin (1983), o Movimento Tradicionalista Gaúcho tem início com a inauguração do 35 CTG, criado por um grupo de acadêmicos, estudantes de Porto 
territorialidade tradicionalista gaúcha. Os indivíduos pesquisados são autoidentificados como homossexuais ou, até mesmo, não heterossexuais, ressaltando que é amplo e fluido o campo das sexualidades. Para entender a maneira como tais sujeitos se compreendem e se relacionam com esta territorialidade que, a princípio, é excludente a tais vivências, utiliza-se o método fenomenológico; logo, seguindo o mesmo caminho metodológico da pesquisa anterior.

Percebe-se o corpo como um "veículo do ser no mundo" (MERLEAU-PONTY, 1999, p. 112), compreendendo-se que é por meio dele que se chega ao entendimento dos fenômenos, levando em conta o olhar do indivíduo que está inserido no processo. Da mesma forma, entende-se também que o corpo possui uma "simbologia comunicativa expressiva de um acontecimento e conhecimento social" (TEDESCO, 2003, p. 77), ou seja, ele apresenta determinadas "posturas, movimentos, atitudes" em concordância com específicas situações. Assim sendo, pensando nos corpos dos tradicionalistas gaúchos, é possível perceber uma série de códigos de conduta, principalmente quando se encontram inseridos nos centros de convivência (os Centros de Tradições Gaúchas, por exemplo) ou nos eventos promovidos pelo Movimento Tradicionalista Gaúcho. Por exemplo, a "indumentária”, a qual segue moldes preestabelecidos pelo próprio movimento; a postura corpórea, principalmente nas danças e nos momentos de confraternização; a maneira de gesticular, assim como a de falar, que varia adequando-se ao espaço em que se encontram inseridos. Adotando os dizeres de Judith Butler, é como que se os integrantes do MTG adotassem "atos, gestos e atuações" em específico, permitindo pensar em um ato performativo característico dos tradicionalistas, os quais, mesmo sendo fruto de

Alegre, filhos de fazendeiros do Rio Grande do Sul, que tinham por ímpeto o encontro e o culto à maneira de ser vivenciada por eles no interior do estado; logo, à maneira de "se viver" no passado. Com o passar dos anos, a ideia foi sendo aceita e novos núcleos de reunião foram sendo construídos pelo restante do estado e país. Atualmente, após alianças entre MTG e governo, crê-se na posse da "cultura gaúcha" nas "mãos" do MTG. 
"um núcleo ou substância interna", o produzem "na superfície do corpo" que os identifica. Usando as próprias palavras da autora:

Esses atos, gestos e atuações, entendidos em termos gerais, são performáticos, no sentido de que a essência ou identidade que por outro lado pretendem expressar são fabricaçóes manufaturadas e sustentadas por signos corpóreos e outros meios discursivos. (BUTLER, 2003, p. 194).

Exemplificando construções e manipulações identitárias, Tau Golin, ao tratar do "Gauchismo", afirma que o Movimento Tradicionalista Gaúcho criou um personagem mítico para o Rio Grande do Sul (província do sul do Brasil), o qual embasa toda conduta performática dos tradicionalistas. Este "gaúcho" é visto pelos seguidores do MTG como um ser autóctone do solo sul-riograndense, ignorando a História, a qual explicita, dentre outras coisas, a colonização heterogênea do Rio Grande do Sul. Conforme comenta o autor:

No estágio atual da cultura rio-grandense, encontram-se elementos cujos valores sociais foram esterilizados pelo gauchismo. Foi preciso desarmar toda a história real e construir uma outra história, que, antes de ser entendida como manipulação, deve ser compreendida como a criação de um complexo arcabouço cultural que colocou a história humana em uma inversão. (GOLIN, 1983, p. 23)

Assim sendo, ao se pensar no "gaúcho", não se remete mais ao habitante do Rio Grande do Sul, mas sim a um ser quase mitológico e presente apenas na literatura e nas práticas do Movimento Tradicionalista Gaúcho. Esse "gaúcho" porta botas e bombachas, e fala, se veste e se manifesta como se estivesse num tempo passado historicamente inexistente. Ao se observar um indivíduo "trajado" de "gaúcho", sabe-se que pertence a tal territorialidade, ou melhor, aderindo às ideias de Bonnemaison (2002), o corpo deste indivíduo compõe a territorialidade, pois está fazendo a comunicação entre o território e o exterior a ele, entre o que é fixo e o que é móvel.

Unindo as concepções de território à identidade, Claval argumenta dizendo que "o sentimento identitário permite que se 
sinta plenamente membro de um grupo, dotá-lo de uma base espacial ancorada na realidade" (CLAVAL, 1999, p. 16). Para tanto, "a construção das representações que fazem certas porções do espaço humanizado dos territórios é inseparável da construção das identidades” (p. 16). Assim, percebe-se a importância do corpo para o entendimento das concepções identitárias e performáticas de território e territorialidade.

Ao falar de identidade, vale lembrar as concepções pósmodernas de identidade descritas por Stuart Hall. De acordo com ele, um mesmo indivíduo pode manifestar diferentes identidades, sendo essas, inclusive, conflituosas para si mesmo. Para o autor:

$\mathrm{O}$ sujeito assume identidades diferentes em diferentes momentos, identidades que não são unificadas ao redor de um "eu" coerente. Dentro de nós há identidades contraditórias, empurrando em diferentes direçôes, de tal modo que nossas identificaçôes estão sendo continuamente deslocadas. [...] A identidade plenamente unificada, completa, segura e coerente é uma fantasia. Ao invés disso, à medida em que os sistemas de significação e representação cultural se multiplicam, somos confrontados por uma multiplicidade desconcertante e cambiante de identidades possíveis, com cada uma das quais poderíamos nos identificar - ao menos temporariamente. (HALL, 2005, p. 12-13)

Dessa forma, um corpo pode possuir várias identidades e, consequentemente, manifestar, através de sua "superfície corpórea" (BUTLER, 2003), diferentes performances, dependendo de sua posição espaço-temporal, de seu espaço ocupado ou, então, do território ou territorialidade que está compondo. Logo, um indivíduo que frequenta uma entidade tradicionalista pode, em outras circunstâncias espaço-temporais, "assumir" demais identidades, como a de homossexuais - caso dos sujeitos entrevistados para esta pesquisa. Tão importante quanto compreender que um indivíduo pode assumir mais de uma identidade é compreender que um território não é composto, homogeneamente, de indivíduos iguais. Quem ressalta isso é Gillian Rose (1993). Segundo ela, um território é movimentado por constantes disputas internas, tornando consequente a conclusão de que, nessas espacialidades, formam-se porções centrais e marginais. 
A performance tradicionalista reflete um comportamento fortemente conservador, machista, elitista e heteronormativo. Porém, o corpo que assume a identidade tradicionalista é capaz de assumir outra identidade e manifestar novas performances. De que maneira os homossexuais entrevistados construíram suas identidades (homossexual e tradicionalista) em meio a uma territorialidade tão contraditória e contrária às concepções não heteronormativas de se ser? Percebe-se, levando em conta Rose (1993), que tais indivíduos compreendem a parte marginal desses territórios e territorialidades, sendo o que a autora viria a chamar de espaços paradoxais, os quais transgridem as concepções socialmente aceitas de heteronormatividade.

\subsection{As relações sexistas e machistas no espaço escolar}

A terceira pesquisa busca investigar se os discursos de professores e alunos de uma escola pública de Ensino Fundamental e Médio da cidade de Chapecó/SC contribuem para a construção de um espaço escolar heteronormativo e sexista que impede a livre expressão das mulheres e das diversidades sexuais. Para o desenvolvimento desta pesquisa utilizamos a metodologia da “pesquisa-ação" que, segundo Thiollent (1986, p.14), consiste em uma "pesquisa social com base empírica que é concebida e realizada em estreita associação com uma ação ou com a resolução de um problema coletivo". Segundo esse autor, na pesquisa-ação “os pesquisadores e os participantes representativos da situação ou do problema estão envolvidos de modo cooperativo ou participativo" (1986, p. 14).

Se considerarmos que alunos e professores são sujeitos sociais que estão corporalmente inseridos dentro de um espaço chamado escola, podemos dizer que suas relações sociais são primeiramente dadas pelo corpo. Quando analisamos a questão das mulheres dentro desse espaço da escola, é preciso lembrar que a relação da sociedade com o corpo feminino não é pacífica. Há um padrão normativo construído historicamente caracterizado pelo 
poder do masculino na constituição das esferas públicas e privadas que regula o corpo feminino. Essas regulações produzem e inserem os corpos das mulheres perante as relações sociais mediante diferentes submissões relativas a padrões determinados de comportamento e de expressões estéticas. Quando uma mulher destoa do "bom" comportamento obediente e casto que preza uma estética de disciplina do que pode e do que não pode mostrar, ela é repreendida. Caso transgrida esta disciplina e sofra algum tipo de abuso/violência devido a isso, ela será automaticamente culpada. $\mathrm{O}$ paradoxo é que, ao mesmo tempo, o corpo dessa mulher e a sexualidade feminina não pertencem a ela, existindo para a reprodução ou para satisfazer os homens.

Em regra, o espaço escolar segue a lógica de um modelo de hegemonia masculina e de submissão do feminino. Como um exemplo disso, são muitas as vezes em que meninas têm interrompido um dia de aula por serem obrigadas a voltarem para casa a fim de trocarem de roupa, ou são dispensadas porque suas roupas não estão adequadas à convivência rígida que define o regramento sobre a expressão de seus corpos. Além disso, as regras, dentro das escolas, no quesito vestuário, são sempre direcionadas às roupas femininas, com a proibição de decotes, minissaias, entre outras. Para os meninos, quando existem regras, a maioria refere-se somente à proibição do uso de bonés, elemento forte de representação de certas culturas dissidentes existentes na periferia do Brasil e que são comumente relacionadas à transgressão social de grupos que ferem a preservação econômica de classes sociais mais abastadas.

Apesar do sexo biológico de um corpo ainda permanecer como um aspecto definidor do gênero e da sexualidade dos sujeitos, Louro (2008) lembra que muita coisa mudou desde o final dos anos 1940, quando a filósofa Simone de Beauvoir publicou o seu livro $O$ Segundo Sexo e propôs que o gênero nada tem de natural, nem é dado e que o processo de ser homem e ser mulher vai se constituir no âmbito da cultura. Judith Butler (2003) afirma que o gênero é performático, ou seja, não existe em si, pois se institui por meio de 
atuações contínuas. Os corpos, por um lado, expressam as normas de gênero, mas também produzem desconstruções destes papéis, revelando configurações que se encontram fora dos eixos restritivos da bipolaridade do masculino e feminino e da heterossexualidade compulsória. Para Butler, o gênero é um mecanismo, uma função reguladora, em que são naturalizadas as noções de masculinidade e de feminilidade, que acabam desconstruídas na experiência. Os mesmos corpos que são nomeados e que carregam expectativas sociais, paradoxalmente, também escapam dessas expectativas. Como explica Silva:

Gênero, nesse sentido, não é uma categoria fixa e prédiscursiva; ele se constrói por meio de atos repetidos e estilizados pelo sujeito generificado, constituindo uma complexidade aberta, jamais plenamente exibida em qualquer situação. Utilizando os termos de Butler, o gênero seria um aparato, ou uma matriz de inteligibilidade cultural. (SILVA, 2009, p. 85)

A ideia da linearidade entre sexo, gênero e desejo também se desconstrói, pois os seres humanos, durante suas vivências, compõem variações inúmeras desses elementos, numa complexidade e conjuntos de transformações constantes. Os corpos não são mais dóceis e rigidamente definidos pela estrutura social, mas se inventam e transgridem as normas impostas, seguindo seus desejos. Nesse contexto está a escola, que é um dos espaços institucionais que constrói e é construído pelas relações de gênero. Como explica Massey (2009), precisamos entender aqui o espaço como um produto das inter-relações, que é constituído pelas interações.

Segundo, compreendemos o espaço como a esfera da possibilidade da existência da multiplicidade, no sentido da pluralidade contemporânea, como a esfera na qual distintas trajetórias coexistem; como a esfera, portanto da coexistência da heterogeneidade. Sem espaço, não há multiplicidade; sem multiplicidade, não há espaço. Se espaço é, sem dúvida, o produto de inter-relações, então deve estar baseado na existência de pluralidade. Multiplicidade e espaço são coconstitutivos. Terceiro, reconhecemos o espaço como estando sempre em construção. (MASSEY, 2009, p. 29) 
Admite-se que o espaço escolar é produto de inter-relações e que abarca a diversidade de corpos de sexualidades múltiplas, mas é preciso também salientar que tal espaço possui um aspecto normalizador vinculado a uma tradição heteronormativa e a um modelo de hegemonia do masculino e submissão do feminino. Junqueira (2010) afirma que a escola brasileira está estruturada a partir de normas, valores e crenças que desvalorizam a figura do "outro" que não se encaixa nas definições do masculino, branco, heterossexual, burguês, cristão, física e mentalmente tido como "normal".

A escola tornou-se um espaço em que rotineiramente circulam preconceitos que colocam em movimento discriminaçốes de classe, cor, raça/etnia, sexo, gênero, orientação sexual, crença, capacidade físico-mental, etc. Assim, classismo, racismo, sexismo e homofobia, entre outros fenômenos discriminatórios, fazem parte da cotidianidade escolar como algo cotidianamente cultivado na escola e que produz efeitos sobre todos. As marcas permanentes que atribuímos às escolas não se referem aos conteúdos programáticos que elas possam nos ter apresentado, mas sim a situações do dia-a-dia vividas no seu interior (LOỤRO, 1999, p.18-19). As marcas que nos fazem lembrar dessas instituiç̧ôes têm a ver com as formas como construímos nossas identidades sociais e os processos de edificação de complexas hierarquias. (JUNQUEIRA, 2010, p. 2)

Por outro lado, inseridas neste espaço escolar também existem as expressões transgressivas, tanto de feminilidades quanto de masculinidades, que geram conflitos, pois representam situações de mudança nas posições de poder, causando um mal-estar nessa estrutura heteronormativa do espaço escolar. São corpos que não assumem as posições preestabelecidas e lutam por reconhecimento. Neste conjunto de lutas espaciais diárias, tais corpos se constituem ora em posições marginais, ora em posições centrais. $O$ espaço escolar, assim, compõe-se como relacional e como palco de um conjunto de jogos de possibilidades de expressões que ora asseguram a construção da normalidade das definições binárias de gênero e sexualidade, ora as transgridem. 
Esse conceito de espaço relacional é trazido pela geógrafa feminista Gillian Rose. Ela afirma que o padrão de gênero é mantido pela força dos sujeitos que apresentam maior poder e maior força de mobilização para se constituírem na posição de poder. Indo além dessa concepção, a geógrafa Joseli Maria Silva vai trazer para o debate da Geografia brasileira o conceito de espaço paradoxal, com base na discussão da teoria de Gillian Rose (1993), como um espaço de luta.

O espaço paradoxal é complexo, envolve variadas articulações e dimensốes e se constitui em uma interessante construção metodológica na geografia. Qualquer mulher não pode ser vista constituindo apenas um gênero, mas, também, a sexualidade, a raça, a religião e a classe social. Todos esses elementos são experienciados simultaneamente, podendo, portanto, subverter a ordem de forças entre 'nós' e os 'outros' devido à sua plurilocalidade no território. Qualquer posição é imaginada não apenas por ser localizada por múltiplos espaçoş sociais, mas também por ambos os pólos de cada dimensão. E importante conceber que há pluralidades de masculinidades tanto quanto existem de feminilidades e que não se configuram como blocos homogêneos, pelo contrário, são construídos por significações repetidas na ação, e toda ação é passível de, variação. A realidade sócio-espacial assim, construída é um campo contratual, através do qual é redesenhada, redefinida e, também, transformada. Através da contemplação dos elementos materiais e simbólicos que constituem as relações entre gênero e espaço pode-se ir além do espaço da reprodução, instituindo, assim, o espaço da transformação. (SILVA, 2007, p. 123-124)

Dessa forma, definimos a escola como um espaço relacional e paradoxal no qual se condensam dispositivos de normalização que tornam rígidas as expressões de corpos generificados, mas em que, também, se produzem lutas de reconhecimento de formas de expressões destoantes das representações binárias e paralelas entre gênero, corpo biológico e sexualidade. Neste espaço construído historicamente como forma disciplinar relacionada ao patriarcado, acabam-se gerando conflitos entre divergências criativas relacionadas a gêneros e sexualidades e tentativas de retomadas das posições conservadoras pelos agentes do poder escolar. Nisto estão colocados o conjunto de agentes escolares, que se veem a todo o momento tendo que lidar com tais conflitos. Nessa perspectiva, Louro (2004) 
afirma que o assunto merece atenção dos educadores, pois não se trata apenas de assumir que as relações de gênero se multiplicaram, mas que a complexidade está na instabilidade e na contínua transformação. É de fundamental importância pensar não só os corpos, mas as sexualidades, dentro desse espaço escolar, pois aquele espaço que se constituiu como normalizador acaba sendo sempre desafiado, transgredido. Como realidade de tais conflitos, tal espaço se apresenta singular ao exercício de práticas alternativas reveladoras da diversidade e do diálogo de subjetividades e de culturas.

\section{Considerações finais}

O texto procurou refletir sobre a relação do corpo como uma categoria e uma realidade de análise geográfica. Refletimos sobre a pouca tradição de refletir o corpo na Geografia brasileira e aproximamos a análise geográfica do corpo pelo viés dos estudos do cotidiano, em especial a perspectiva fenomenológica. $\mathrm{O}$ campo da Geografia Cultural, que investiga as relações singulares dos sujeitos com o espaço social, ganha destaque na possibilidade de inserção da categoria corpo como perspectiva de vivência, percepção e representação do espaço. Em virtude disto, o cotidiano torna-se um objeto de análise fundamental, uma vez que procura ligar as discussões sobre esfera corporal, esfera cultural direta e esfera das representações socioespaciais de escalas além do espaço imediato do corpo. A interação entre fenomenologia e perspectivas feministas da Geografia abre amplas possibilidades teóricas que poderão embasar melhor pesquisas e discussões científicas sobre tal temática. No caso da fenomenologia, com as discussões sobre percepção e esfera subjetiva e intersubjetiva e, no caso das perspectivas feministas da Geografia, com seus interesses de entender as singularidades de movimentos de corpos em meios às produções e relações de poder que configuram as relações no espaço social. Finalmente, o campo dos estudos do cotidiano e suas diferentes abordagens, incluindo a feminista, permite entender os cruzamentos de escalas que 
conduzem vivências diretas dos sujeitos como corpos estéticos e éticos.

Como proposta de entendimento introdutório, discutimos três pesquisas que estão sendo desenvolvidas no grupo Espacialidades Urbanas do Departamento de Geociências da Universidade Federal de Santa Maria (UFSM), Santa Maria, RS, Brasil. A primeira tratou $\mathrm{da}$ inserção de corpos das travestilidades e transexualidades nos terreiros de religiosidades afro-brasileiras, que se constituem espaços possíveis para as convivências de diversidades de expressões de gênero e sexualidade em meio a um espaço social total misógino e heteronormativo. A segunda pesquisa abordou a configuração de performances corporais misóginas e heteronormativas do movimento tradicionalista gaúcho na província do Rio Grande do Sul, Brasil, e os paradoxos de experiências de relações espaciais homoeróticas de sujeitos homoafetivos que também se identificam com o tradicionalismo gaúcho em eventos e territórios deste movimento cultural. A terceira pesquisa mostrou as relações de corpos e espaço escolar na rígida expressão ética e estética dos papéis e binarismos de gênero, assim como as implicações hierárquicas entre expressões masculinas e femininas neste espaço, e as possíveis rupturas à normatividade machista a partir do empoderamento dos corpos femininos no espaço escolar. As discussões das três pesquisas estabelecidas neste texto podem servir como exemplo de tratamento da perspectiva do corpo nos estudos de Geografia.

Esperamos ter contribuído para as discussões.

\section{Referências}

ALLEN-COLLINSON. Feminist phenomenology and the woman in the running body. Sport, Ethics \& Philosophy, v. 5, n. 3, 2011.

BERGER, P. L.; LUCKMANN, T. A construção social da realidade. Petrópolis: Vozes, 2002.

BONNEMAISON, J.; VANUATU. O. Viagem em torno do território. In: CORRÊA, R. L.; ROSENDAHL, Z. (Org). Geografia Cultural: um século. Rio de Janeiro: EDUERJ, 2002. 
BUTLER, J. Problemas de gênero: Feminismo e subversão da identidade. Rio de Janeiro: Civilização Brasileira, 2003.

CLAVAL, P. O território na transição da pós-modernidade. In: GEOgraphia, Niterói: UFF, ano 1, n. 2, p. 7-26, 1999.

. O papel da nova geografia cultural na compreensão humana. In: ROSENDAHL, Z.; CORREA, R. L. (Orgs.) Matrizes da Geografia Cultural. Rio de Janeiro: EdUERJ, 2001.

CONFEDERAÇÃO BRASILEIRA DE TRADIÇÃO GAÚCHA (CBTG). Disponível em :

<http://www.cbtg.com.br/_sitio/ctgs/mapa.php>. Acesso em: $14 \mathrm{de}$ out. 2014.

DUARTE, T. F. Guy Debord e a clandestinidade da vida privada. (Prólogo de "O Uso dos Corpos" de Giorgio Agambem). Notícias. São Leopoldo: Instituto Humanitas Unissinos, 29 de outubro de 2014. Disponível em: http://www.ihu.unisinos.br/noticias/536810-guydebord-e-a-clandestinidade-da-vida-privada-prologo-de-o-uso-doscorpos-de-giorgio-agamben. Acessado em 08 de outubro de 2015.

FOUCAULT, M. Vigiar e punir. Petrópolis: Vozes, 1984.

História da sexualidade: a vontade de saber. Rio de Janeiro: Graal, 1988.

. Microfísica do poder. Rio de Janeiro: Graal, 1993.

. A ordem do discurso: aula inaugural no Collége de France, pronunciada em 2 de dezembro de 1970. São Paulo: Loyola, 1996. 2001.

. O nascimento da clínica. Rio de Janeiro: Forense Universitária,

GOLIN, T. A ideologia do gauchismo. Porto Alegre: Tchê, 1983.

HALL, S. A identidade cultural da pós-modernidade. 10. ed. Rio de Janeiro: DP\&A, 2005.

HELLER, A. Sociologia de la vida cotidiana. Barcelona: Península, 1991.

HONNETH, A. Luta pelo reconhecimento: a gramática moral dos conflitos sociais. São Paulo: Editora 34, 2003.

HUSSERL, E. Conferência de Paris. 1929. Tradução Artur Morão e Antônio Fidalgo. Lisboa: LusoSofia press, s/d. Disponível em: http://www.lusosofia.net/textos/husserl_conferencias_de_paris.pdf. Acesso em: out. 2013.

A crise das ciências europeias e a fenomenologia

Geografias e (In)visibilidades: Paisagens, Corpos, Memórias 
transcendental: uma introdução à filosofia fenomenológica. São Paulo/Rio de Janeiro: Forense Universitária, 2012.

JUNQUEIRA, R. D. Currículo, Cotidiano Escolar e Heteronormatividade em relatos de professoras da rede pública. Fazendo Gênero 9, Diásporas, Diversidades, Deslocamentos. Florianópolis 2010.

LEFEBVRE, H. La producion del espacio. Madrid: Capitán Swing Libros, 2013.

LOURO, G. L. Um corpo estranho: ensaios sobre sexualidade e teoria queer. Belo Horizonte. Autêntica, 2004.

. Gênero e sexualidade: pedagogias contemporâneas. Pro-Posições, v. 19. 2008.

MASSEY, D. Pelo espaço: uma nova política da espacialidade. Rio de Janeiro: Bertrand Brasil, 2009.

MERLEAU-PONTY, M. Fenomenologia da percepção. 2. ed. São Paulo: Martins Fontes, 1999.

. Fenomenologia da percepção. 3. ed. São Paulo: Martins Fontes, 2006.

. Fenomenologia da percepção. 4. ed. São Paulo: Martins Fontes, 2011.

MORAES, A. C. R. Geografia: pequena história crítica. São Paulo: AnnaBlume, 2007.

RAFFESTIN, C. Por uma geografia do poder. São Paulo: Ática, 1993.

RELPH, E. C. As bases Fenomenológicas da Geografia. Revista de Geografia, Ageteo Rio Claro: São Paulo, v. 4, n. 7, 1979.

ROSE, G. Feminism and Geography: the limits of Geographical Knowledge. Cambrige: Polity Press, 1993.

SANTOS, M. Modo de Produção técnico-científico e diferenciação espacial. Revista Território. Rio de Janeiro, v. a.IV, n. 6, 1999.

SAHR, W. D. Signos e espaços mundos - a semiótica da espacialização na Geografia cultural. In: KOSEL, S.; SILVA, J. da C.; GIL FILHO, S. F. Da percepção e cognição à representação: reconstruções teóricas da Geografia cultural e humanística. São Paulo: Terceira Imagen; Curitiba: NEER, 2007.

SCHUTZ, A. Sobre fenomenologia e relações sociais. Petrópolis: Vozes, 2012. 
SILVA, A. Imaginários: estranhamentos urbanos. São Paulo: SESC, 2014.

SILVA, J. M. Gênero e sexualidade na análise do espaço urbano. Geosul, Florianópolis, v. 22, n. 44, p. 117-134, jul./dez. 2007.

- Ausências e silêncios do discurso geográfico brasileiro: uma crítica feminista a Geografia eurocêntrica. In: SILVA, Joseli Maria. Geografias subversivas: discursos sobre espaço, gênero e sexualidades. Ponta Grossa-PR: Todapalavra Editora, 2009.

TEDESCO, J. C. Paradigmas do cotidiano: introdução à constituição de um campo e análise social. Santa Cruz do Sul: EDUNISC, 1999.

. Paradigmas do cotidiano: introdução à constituição de um campo e análise social. 2. ed. Santa Cruz do Sul: EDUNISC; Passo Fundo: UPF, 2003.

THIOLLENT, M. Metodologia da pesquisa-ação. São Paulo: Cortez, 1986.

TUAN, Y. Topofilia: um estudo da percepção, atitudes e valores do meio ambiente. São Paulo/Rio de Janeiro: Difel, 1980.

. Espaço e lugar. São Paulo: Difel, 1983. 


\section{Geografia, Imaginário e Performances de Gêneros e Sexualidades}

Benhur Pinós da Costa 


\section{Introdução}

$\mathrm{E}$ ste texto irá se ocupar do pensamento sobre a relação entre imaginário, espaço social e relações de gênero e de sexualidade. Essa relação é importante para entender as formas de agir e de se mostrar dos sujeitos investidos de identidades gays, lésbicas, travestis e transgêneros. Essas formas perpassam a realização de produções imaginárias que são representadas nos corpos individuais e nas imitações e ritualizações coletivas em espaços de convivência das homossexualidades. Podemos entender, por outro lado, que as características hegemônicas binárias que definem o masculino e o feminino são reproduções e imitações de formas e ações imaginárias dos corpos partilhadas coletivamente.

As apresentações dos gêneros como performance (BUTLER, 2010) são repetições de estéticas, gestos e comportamentos produzidos discursivamente nos intermédios das relações sociais e encarnados nas formações e ações dos corpos dos sujeitos generificados. Por um lado, as manutenções e reforços das apresentações binárias dos gêneros são imitações simbólicas realizadas e partilhadas coletivamente, como ritualizações corporais acertadas por normas coerentes com as relações sociais. Por outro lado, as transgressões e trânsitos simbólicos realizados hibridamente, nos corpos divergentes das apresentações binárias e fixas de gênero, também se referem a plurais realizações imaginárias das intimidades individuais. Essas últimas são reforçadas por imitações coletivas em espaços simbólicos restritos e divergentes do espaço social normatizado (normatizado pelos binarismos e pelas restrições de expressões de gênero de acordo com a naturalização do sexo).

$\mathrm{Na}$ verdade, de acordo com a defesa de Butler (2010), não há uma dicotomia clara entre norma e transgressão à norma, mas um campo normativo espetacular que se pretende reproduzir e realizar nos corpos em relação a um conjunto de dispositivos sociais (FOUCAULT, 1988) que força, pela vigilância impregnada entre as relações e espaços de relações sociais, a aplicação dos atos discursivos e a reprodução/imitação normatizada. Aos processos de vigilância 
estabelecidos nos atos e ações de interação social, diferentes percepções, incapacidades e, até mesmo, resistências às imitações e reproduções são instauradas. Nos complexos simbólicos normativos, cujos corpos são forçados (pelas interações sociais) a imitar e se realizarem, tais divergências são produzidas e reintroduzidas nas relações sociais diretas. Muitas vezes, não são consciências de incapacidades ou de resistências, mas simplesmente manipulações subjetivas diversas dos contextos simbólicos normativos que rearranjam novas formas de representação e apresentação das expressões corporais e interacionais em situações e contextos espaciais diversos.

Mesmo entendendo uma desconstrução geral dos atributos normativos de gênero perante as instabilidades interpretativas das subjetividades e intersubjetividades sociais, as formas imaginárias ainda se realizam por meio de processos ritualísticos que reforçam, mesmo que em tempos e espaços restritos e instáveis, certos atributos, éticas e estéticas de vivências das masculinidades e feminilidades. Entre uma instabilidade objetivada pelas interações de corpos, existe um conjunto de performances de normatização e de transgressão às representações binárias de gêneros. Parece que existem imaginários diversos transitando nas consciências coletivas dos sujeitos em interação que reforçam processos de imitação; sejam eles normativos pautados na heterossexualidade compulsória e nas representações binárias de gênero conforme um sexo "naturalizado"; sejam eles outras produções imaginárias que reforçam repetições de estéticas (formas) e éticas (agires) transgressivas. Pensamos que os campos imaginários reproduzem-se como formas simbólicas que circulam pelas imagens, discursos e atos que se repetem pela visibilidade ou capacidade de se mostrar coletivamente e de atingir a intimidade e subjetividade das individualidades. Porém, são as individualidades e seus esforços situacionais de repetição e realização dos imaginários compartilhados que produzem a instabilidade, que retornam como um conjunto de repetições das contradições às formações imaginárias compartilhadas, que novamente são reconstituídas e que voltarão a se repetir, sucessivamente. 
De fato, temos uma tríade performática: a) a performance da norma da heterossexualidade compulsória e das apresentações binárias dos gêneros produzidos pela naturalização do sexo; b) a performance das transgressões que são novas produções normativas produzidas em contextos interacionais subversivos dos espaços de relações das populações lésbicas, gays, bissexuais, transgêneros (LGBTs) como, por exemplo, as transgressões repetidas pela constituição de uma realização de um imaginário travesti e/ou pelas repetições de gestos, ações e apresentações de homens gays masculinizados; c) além das intersubjetividades partilhadas que apresentam realizações de repetições das normas e transgressões sobre gênero e sexualidade, as individualidades rearranjam e sobrepõem as próprias normas e transgressões, criando situações de divergência ética e estética quanto ao sexo, sexualidade e gênero em realização.

Para entender melhor as ideias produzidas até aqui iremos pautar, primeiramente, o conceito de imaginário e suas relações com a realização das interações sociais e da produção e apresentação dos corpos. Em um segundo momento, aproximaremos a ideia de imaginários da noção de performance para compreender a realização desses imaginários nas apresentações dos corpos LGBTs. Nos dois âmbitos seguintes deste texto, exploraremos a capacidade de entendimento geográfico deste assunto, evidenciando o teor espacial destes processos, ou seja, a importância do elemento espacial para a construção dos imaginários e das performances na tríade comentada no parágrafo anterior.

\section{As geografias do espetáculo e do imaginário}

Nesta seção argumentaremos sobre as diferenças cruciais entre a ideia de "espetáculo", desenvolvida em Debord (1997), e a de “imaginário", desenvolvida por Silva (2001 e 2014), para entendermos as impregnações desses sentidos aplicados idealmente ao conceito de "performance" desenvolvido por Butler (2010) em 
relação aos gêneros e as sexualidades. Desenvolveremos estes sentidos teóricos ao empirismo das ações dos corpos humanos socializados em espaços de relações intersubjetivas. Essas relações são tanto reproduzidas, estética e eticamente, por representações espetaculares, mobilizadas por comunicações simbólicas hegemônicas, quanto são produtos localizados da objetivação de suas subjetividades variantes e das trocas instáveis dos singulares espaços de sociabilidade. Pensamos que a tríade relacional conceitual que liga espetáculo, imaginário e performance nos permite entender a tríade acionista: da produção empírica dos corpos entre reprodução das formas espetaculares binárias e naturalizadas biologicamente dos gêneros; das espetacularizações de outras formas transgressivas (os paradoxos subculturais) de apresentação dos corpos sexualizados das situações localizadas contidas nas diferentes culturas lésbicas, gays, travestis e transgêneros; e das diferenciações todas, em todos os lugares, das instabilidades de representações e apresentações dos corpos que mobilizam criativamente, em situações sociais inusitadas, novas éticas e estéticas a partir de percepções diferenciadas dos espetáculos dos gêneros, ou seja, as próprias performances desconstrucionistas.

\subsection{Espetáculo}

Debord (1997) inicia seu livro com uma citação de Feueberch (do prefácio da segunda edição do livro $A$ essência do cristianismo) para introduzir as ideias que irá construir no capítulo $A$ separação consumada. Essa citação enfatiza a separação entre imagens e realidade e entre cópias e coisas originais, tônica "dos nossos tempos" que irá preferir as primeiras às segundas. Assim, Debord (1997) defende que a vivência do cotidiano é composta de representações espetacularizadas socialmente. Para o autor, “o espetáculo não é um conjunto de imagens, mas a relação social entre pessoas, mediada por imagens" (p. 14). Em suas discussões, defende uma separação entre imagens e realidade e, posteriormente, as imagens invadem as relações sociais tornando-se a própria realidade. A realidade vivida é, assim, primeiramente, uma contemplação do espetáculo na qual esse, além de contemplação, retorna como a 
própria realidade vivida, mediada pelas relações sociais, conduzidas pelas representações e pelas imagens. As consequências desta produção espetacular da vida é a afirmação da aparência substituindo a vida social como realidade. Os elementos simbólicos trazidos pelas imagens e pelos discursos disseminados socialmente substituem as coisas reais e produzem as faces das aparências. Nesse contexto, a vida torna-se negada pelas aparências e as superfícies simbólicas substituem as profundidades diversas dos seres sociais, como "negação da vida que se tornou visível" (DEBORD, 1997, p. 16). O espetáculo, assim, é um conjunto de resultados de formas de aparências conduzidas por uma formação econômica e social no tempo, e destina-se a tornar aparente o que é "bom" e o que é "mau", realizando a totalidade do espetáculo das coisas e seres que são "bons", assim como os esconderijos e separações das coisas e seres que são "maus". Como aparências, as imagens e discursos espetaculares realizam-se como verdades no investimento das cópias a serem produzidas como possibilidades normalizadas do social, assim como cópias desviantes que deverão ser refutadas e separadas da totalização desta realidade.

Podemos entender estas realizações espetaculares simbólicas no texto de Foucault (2001) e de Sahr (2007), sendo o segundo autor importante para trazer para a linguagem geográfica as produções simbólicas dos significados da doença (uma epistemologia da doença) construídas em Foucault (2001) e seu método genealógico. A atenção ao texto de Sahr (2007) permite-nos entender as realizações simbólicas nas construções de "espaços corporais” e de "espaços geométrico-abstratos” (p. 72). Assim Foucault (apud SAHR, 2007, p. 14-15) produz as realizações dos discursos (podemos pensar também em realizações das imagens do mundo atual, desenvolvidas por Debord (1997)) em três espacializações:

a) As espacializações primárias como denominações de doenças e as sistematizações de fenômenos reais (sintomas) que "ligam significante - nome das doenças - e significado - imagem dos sintomas": espacializam-se as doenças aos níveis das palavras ou as "espacializações de uma distribuição (mental) de signos e 
enunciações, não construídas por sujeitos individuais, mas apenas vagamente disponíveis para todos como horizontes de conhecimentos" (DELEUZE apud SAHR, 2007, p. 72).

b) As espacializações secundárias são as projeções das doenças nos corpos, ou seja, as doenças (denominações significantes e sintomas significados) se materializam ("no doente os nomes das doenças"), e as relações entre pacientes e médicos realizam os espetáculos simbólicos das doenças.

c) as espacializações terciárias são as formas geográficas materiais "dos lugares que determinam a formação do discurso e que fixam o tratamento do doente de forma pragmática” (SAHR, 2007, p. 73), ou seja, são os contextos espaciais produzidos para incorporarem as constituições espetaculares simbólicas nas relações sociais diretas, previamente institucionalizadas para determinados fins.

No caso do exemplo das doenças na invenção da clínica de Foucault, elas são espetacularizadas por atos discursivos (denominações significantes) estrategicamente enunciados por redes de comunicações que permitem a disseminação dos significados (sintomas) nas representações dos cuidados dos corpos em uma sociedade e um espaço social ampliados. São conjuntos simbólicos ou horizontes de conhecimento compartilhados de formas difusas e incompletas, mas que, efetivamente, se realizam nas enunciações dos discursos técnicos sobre os corpos doentes perante as relações sociais diretas. Essas relações realizam-se privilegiadamente em lugares sociais singulares, nos quais elas poderão ser melhor analisadas, nas interações mediadas por horizontes de conhecimentos científicos especializados, entre médicos e pacientes. Butler (2010) constrói uma crítica parecida nas produções simbólicas dos gêneros, porém ela trabalha a crítica à construção de um horizonte de conhecimento sobre os gêneros que força realidades de interações sociais e assunções binárias de papéis contrários, mas interdependentes, que, ou por insuficiências representativas, ou por inadequações das ações dos sujeitos sociais, ou por resistências conscientes das inadequações, não se realizam ou se realizam em parte. 
A crítica da autora remete a um esforço de desnaturalização do sexo, porque defende que o sexo é intrínseco na constituição dos gêneros. Os corpos denominados (significantes) masculinos são significados pelo pênis (imagem do masculino), enunciados pelas ciências biológicas e médicas e realizados nas trocas simbólicas nas ações perante as relações sociais, estabelecidas privilegiadamente em espaços de instituições sociais: desde o hospital maternidade, perpassando as relações familiares, escolares e profissionais (a definição de aparatos estéticos e fazeres funcionais e comportamentais que distinguirão os corpos sexuados e os transformarão em generificados). $\mathrm{O}$ esforço da autora procura desmistificar a naturalização dos sexos tanto pelas ciências biológicas e médicas quanto pela psiquiatria e, também, pelas teorias e discursos feministas. Para Butler (2010, p. 23):

A identidade do sujeito feminista não deve ser fundamento da política feminista, pois a formação do sujeito ocorre no interior de um campo de poder sistematicamente encoberto pela afirmação deste fundamento. Talvez, paradoxalmente, a 1deia de 'representação' só venha realmente a fazer sentido pelo feminismo quando o sujeito 'mulher' não for presumido em parte alguma.

Em Foucault (1988), os sexos se desnaturalizam e se constituem como conjuntos de atos discursivos engendrados por relações de poder que produzem horizontes válidos de conhecimento disseminados nos discursos biológicos e médicos. Os sexos são significantes (denominações científicas partilhadas socialmente), significados (imagens corporais e estéticas dos corpos produzidos discursivamente) e realizados (perante as normas que conduzem relações dos corpos sexuados). Para o autor, estes horizontes simbólicos ocultam diversidades de funções sexuais distintas dos corpos e/ou classificam funções e ações sexuais em hierarquias de valores entre normas/normalidades e desvios. Existem, assim, formas espetaculares de sexo que encobrem realidades e, ao mesmo tempo, produzem outras como hegemônicas.

Butler (2010) se esforça para entender as consonâncias destas produções discursivas dos sexos (não naturais) e suas intrínsecas 
produções dos gêneros e das sexualidades binariamente representadas. Instauram-se os espetáculos normativos do pênis, da masculinidade e da heterossexualidade, que são dependentes de formas simbólicas subalternas da vagina, da feminilidade e da homossexualidade. Mas a autora vai além e identifica no próprio Foucault uma incapacidade de se desvencilhar dos próprios horizontes de pensamentos que tanto critica, pois, para ela, a manutenção de uma política emancipatória que reforça o pensamento de que os jogos de poderes reproduzem corpos significados e interações subjugadas a estas significações acaba reforçando os horizontes significativos que normalizam o social. Assim, é necessária uma radical política de realidades desconstrucionistas destes significantes e significados hegemonizados, mesmo das teorias e das militâncias práticas que as criticam. Partimos, assim, para a análise do imaginário.

\subsection{Imaginário}

Para Silva (2001), a imaginação simbólica refere-se aos significados que não podem se apresentar como uma descrição única, sendo o símbolo exigente de múltiplos sentidos e de processos de interpretações. $\mathrm{O}$ autor adverte que as diferenças entre signo e símbolo (definindo o signo como a palavra em uma dada linguagem) transpõem a restrição de sentido do próprio signo e convergem a multiplicidades de simbolismos próprios - de alguém - adquiridas de diferentes "encruzilhadas de sentido social" (SILVA, 2001, p. 44) religiosidades, mitos, artes, comunicações, psiques, etc. O simbólico é a diversificação de sentidos do signo dada pela diversidade de sentidos da "equação consciente-inconsciente".

Para o autor, inconsciente refere-se "ao espaço da vida psíquica onde se estrutura o simbolismo individual” (SILVA, 2001, p. 44). No entanto, em uma dada situação social, o inconsciente produz diferentes reações não previsíveis a uma dada compreensão consciente dos signos, o que os torna variáveis em virtude das situações de reinterpretações simbólicas calcadas no inconsciente múltiplo/híbrido. Pensamos, então, que os signos referem-se aos 
conjuntos de representações, como horizontes de pensamentos construídos social e linguisticamente sobre as coisas e seres do mundo. Porém, "os simbólicos" são as construções próprias das pessoas atravessadas por diferentes mediações significativas do social (religiões, artes, publicidades e comunicações, conhecimentos cotidianos, etc.) e que são manifestadas em circunstâncias nas quais os signos (conscientes) são permeados pelos simbólicos (inconscientes). Dessa maneira, se desfazem as espacialidades primárias e secundárias constituídas por Foucault (2001) nas circunstâncias das espacialidades terciárias, em que as consciências representativas dos signos (construídas socialmente para aquelas interações) são reinventadas por efeitos simbólicos inconscientes dos sujeitos que se enunciam e que agem.

Por outro lado, estes processos não fogem a conscientes construções significativas das espacialidades terciárias, e "o social” se constrói em espaços significativos partilhados consciente e socialmente, como a ideia de "representações do espaço" de Lefebvre (2013). No entanto, as situações e/ou as circunstâncias são atravessadas pelas espontaneidades simbólicas dos sujeitos em interação, trazendo à tona seus inconscientes e multiplicidades simbólicas, que desestruturam o propósito primeiro das espacialidades terciárias. Pensamos, assim, que ao tripé de espacialidades construído por Foucault (2001), e retrabalhado por Sahr (2007), há a necessidade de incluir uma quarta forma de espacialidade, relacionada à equação entre "consciente-inconsciente" nas situações espaciais de interação entre sujeitos sociais. Assim, além das "representações de espaço", há de se pensar os "espaços de representações” (LEFEBVRE, 2013), produzidos pelas espontaneidades dos sujeitos em interações.

É assim que Silva (2014, p. 39-42) constrói sua ideia sobre imaginário social envolvendo três inscrições: a) a inscrição psíquica, que se refere à circunstância que mobiliza a equação entre consciente e inconsciente ou o impacto do real que refaz os signos pelos processos simbólicos; b) a inscrição social, ou a matriz de representações que produz os signos construídos socialmente em 
uma dada comunidade de linguagem, como um "cimento invisível" (SILVA, 2014, p. 39) que fixa as identificações que, entretanto, acabam não sendo elas mesmas (pois são sempre retrabalhadas pelo simbólico); c) a inscrição tecnológica, na qual "os dois níveis citados de condição ontológica, a inscrição psíquica e social, encontram em seu dispositivo técnico o arché de seu mecanismo, sua expressividade [...]” (SILVA, 2014, p. 41), ou seja, o híbrido de inscrições sociais e psíquicas (o imaginário, para o autor) irá encontrar nas técnicas (o autor nos dá o exemplo da fotografia) suas realizações (são produzidas outras representações). São nas materialidades das inscrições técnicas que espaços de representações poderão ser construídos, pois elas darão visibilidade às equações entre conscientes-inconscientes ou aos imaginários das circunstâncias sociais que alteram os signos.

É neste conjunto de processos que "o imaginário" impacta as realidades construídas socialmente ou as espacialidades terciárias (FOUCAULT, 2001; SAHR, 2007), instituindo as espacialidades quaternárias, como propusemos anteriormente. Gonçalves e Silva (2010) já nos ensinam a entender essas espacialidades quaternárias para além das formas instituídas na urbe, em relação a algumas equações que integram "o real” e "o imaginário".

A primeira equação é a "a imaginário > real”: quando as pessoas não percebem a forma real socialmente produzida (espacialidades terciárias), mas um imaginário radical ou algo "fantasmagórico". O autor nos dá o exemplo de uma rua da cidade do México onde as pessoas caminham rapidamente devido a um odor desagradável. Esse odor existia em um tempo passado e não mais na atualidade, mas, mesmo assim, passa a existir devido a este radical imaginário.

A segunda equação é "real > imaginário": quando quase não existe um trabalho imaginário frente a uma realidade espacial (uma materialidade instituída) dada (ou uma espacialidade terciária). $\mathrm{O}$ autor nos dá o exemplo de pesquisas sobre Montevidéu imaginária, na qual o centro histórico da cidade só existe na cidade, pois os cidadãos não o usam, não o visitam e não o recriam. 
A terceira equação é “imaginário > real < imaginário”: quando "a consciência do imaginário é realidade verificável” (GONÇALVES; SILVA, 2010, p. 33), ou seja, quando as espacialidades terciárias (produtos dos conceitos e pensamentos sobre o espaço) coincidem com os imaginários produzidos por cidadãos. $\mathrm{O}$ autor dá como exemplo os medos urbanos imaginários coincidindo com as estatísticas dos lugares de maior incidência de crimes. Este modelo representa as próprias espacialidades terciárias, nas quais se ajustam pensamentos sociais instituídos e conscientes sobre os espaços e agregações imaginárias a formas, fazeres e representações.

Nós gostaríamos de pensar outra equação, pelo que viemos construindo até agora. É a equação imaginário= real, ou seja, quando o imaginário produz realidades espaciais quaternárias propriamente ditas, nas quais as técnicas (arte, grafite, apropriação de arte popular do espaço, apropriações coletivas expressivas de corpos culturais específicos) são usos do imaginário para produzir outras materialidades espaciais e agregar o imaginário próprio além das espacialidades terciárias primeiras (a forma instituída, social e institucionalmente falando), como as ruas e os cantos das cidades apropriados pelos movimentos culturais diversos e expressões juvenis. Armando Silva explora esta ideia radicalmente, mas não a coloca nas equações da publicação de 2010.

\section{Geografia e Performance}

Vamos interpretar o conceito de performance na obra de Butler (2010) à luz das discussões estabelecidas até aqui, basicamente em suas relações entre espetáculo, imaginário e espacialidades construídas por Foucault (2001) e Sahr (2007). Seguindo os propósitos da autora, nossos centros de análise irão se referir às relações de gênero, sexo e sexualidade. Organizaremos distinções didáticas sobre a compreensão de performance por três principais vieses: o primeiro refere-se à performance e ao seu teor espetacular, 
como o acertamento de espacialidades terciárias; o segundo refere-se à performance e ao seu teor imaginário, como situações de partilhas coletivas de transgressões criativas, que se inscrevem como novos rituais de repetição; o terceiro refere-se às situações criadoras espontâneas das instabilidades das situações de interações sociais.

Este modelo refere-se à construção dos gêneros pelo viés cultural, sendo a cultura engendrada historicamente em uma complexa rede de disputas sociais nas quais hegemonias instauradas lançam as bases dos signos que se constituem em representações e instituições sociais. Esta perspectiva é entendida por Beauvoir (1980) na ideia de que, socialmente, torna-se mulher e não se nasce mulher. Butler (2010) irá se debruçar nesta afirmativa de entender gêneros como culturalmente produzidos, o que produz uma separação entre sexos (que se naturalizam) e gêneros (que se culturalizam). Para a última autora, as lutas feministas baseadas na visão culturalista dos gêneros, que mascara a produção discursiva dos sexos, mantêm o paralelismo entre sexos-gêneros-sexualidades, ao invés de desconstruí-lo. Se os gêneros são culturais, então os sexos são prédiscursivos, ou seja, fenômenos naturais. Se os sexos são naturais, há a afirmação de suas formas binárias (macho e fêmea pela naturalização dos órgãos genitais) e, consequentemente, uma sexualidade também relacionada estritamente a este binarismo (a relação heterossexual). Podemos perceber que, quando os gêneros escapam da naturalização, os sexos e as sexualidades se mantêm como naturalizadas, reforçando os binarismos entre macho e fêmea e entre homossexual e heterossexual (relações sexuais entre sexos diferentes é a norma da heterossexualidade, e entre mesmos sexos é o desvio, a homossexualidade).

Mas Butler (2010) trabalha outro viés desta construção: a ideia da manutenção dos sexos como naturais (pré-discursivos) e das sexualidades como também construídas discursivamente (culturalmente). Se pensarmos os engendramentos genealógicos que transformam os sexos em sexualidades (FOUCAULT, 2001), as formas e os usos dos corpos sexuados são minuciosamente estudados e trazidos para o campo das normativas linguísticas para se 
encaixarem em classificações que servirão para hierarquizar, de um lado, normalidades - regras, formas e ações saudáveis - e, de outro, anormalidades - desvios, transgressões, maldades e vícios. Mas, ainda, tudo parte de uma visibilidade das formas binárias naturais dos sexos (macho e fêmea), e os usos dessas formas pelos sintomas de desejos (sexualidade) são culturalmente produzidos: primeiro para normatizar os usos certos e errados; segundo para criticar as normativas na construção das sexualidades não binárias, principalmente a ideia de uma bissexualidade original. $O$ novo problema é ainda naturalizar uma bissexualidade original e apagar o fluxo histórico de ideologias que mantêm os sexos como naturais e que permite produzir uma série de regramentos dos corpos sexuados.

Butler (2010) esforça-se para construir um entendimento de que sexos, gêneros e sexualidades constituem-se como uma tríade discursiva para conduzir formas e apresentações regradas dos corpos. Além disso, denuncia que a diversidade de teorias construídas sobre tais fenômenos engendram-se sempre em campos de linguagem normativos (ideologicamente conduzidos). Assim, propõe pensar além desses próprios campos normativos de linguagem (acadêmica e militante, por exemplo), fazendo o contrário: pensar que tudo é construído em campos de linguagem (tudo são representações), mas que tudo é acionado (nas situações de interações sociais diversas) de forma difusa e instável. As próprias formas naturalizadas dos sexos, que se centralizam nas figuras sígnicas das genitálias, são tornadas senso comum perante as relações sociais, mas engendradas de complexas clínicas médicas e biológicas construídas na emergência da modernidade (LAQUER, 2001). Socialmente, há uma formatação rígida entre signo e coisa real na emergência das genitálias do macho e da fêmea (suas formas, suas funções, suas doenças, seus sintomas, seus usos). Ao mesmo tempo, há uma dispersão cultural, além da fixação genital natural, dos restos dos corpos, dos gêneros e das sexualidades (o que produz a instabilidade dos usos dos sexos naturais, mas também suas hierarquias sociais). A partir do momento em que se descontrói a naturalidade dos sexos (a 
visibilidade deles como conjuntos de discursos médicos e biológicos engendrados pelos valores sígnicos das ciências), desmoronam todos os paralelismos e instauram-se as situações diversas e circunstanciais dos corpos em atividades de desejo e visibilidade estética. Não há mais sentido, assim, em entender de forma paralela sexos, gêneros e sexualidades.

Explicando de outra forma, os sujeitos sociais são abarcados por signos hegemonicamente produzidos, e esses signos constroem os corpos, as instituições sociais, os papéis dos corpos nessas instituições sociais, e os espaços institucionais em que corpos, papéis e ações são conduzidos (espacialidades primárias, secundárias e terciárias). Ao mesmo tempo em que estas construções hegemônicas fixam e normatizam os corpos sociais, esses corpos reagem em conjuntos de situações sociais que os desestabilizam, em situações nas quais emerge uma relação equacional entre "conscienteinconsciente", ou entre normas sociais produzidas e formas múltiplas de interpretá-las. Mais além, para Butler (2010), as próprias teorias que reforçam a visibilidade das construções das hegemonias sociais são pensadas por valores sígnicos e linguísticos dessas próprias hegemonias e, mesmo querendo criticá-las para produzir uma libertação delas, acabam por reforçá-las. Para a autora, "gênero é "construído" (aspas da autora), mas há um agente implicando em sua formulação, um cogito (grifo da autora) que de algum modo assume ou se apropria desse gênero, podendo, em princípio, assumir algum outro" (BUTLER, 2010, p. 27). Mais além, a ideia de que gênero é construído reforça a ideia de que existe uma assunção privilegiada para ele e de que os sujeitos não são capazes de subvertêlo completamente, para além da linguagem.

A autora irá trabalhar Kristeva (apud BUTLER, 2010, p. 121-139) para entender uma linguagem poética como campo de apropriação instável do sujeito poeta da linguagem socialmente construída. $\mathrm{Na}$ linguagem poética, os signos são modificados pelas escritas "conscientes-inconscientes" dos poetas, tornando os significados múltiplos. Para Kristeva, a linguagem socialmente construída é o campo da lei paterna, como princípio estruturador da 
cultura, na ótica de Lacan, e o campo poético é “a recuperação do corpo materno nos termos da linguagem, um resgate que tem potencial de romper, subverter e deslocar a lei paterna" (KRISTEVA apud BUTLER, 2010, p. 122). Esta operação teórica é rica no livro de Butler, mas não vamos nos aprofundar nela aqui. Queremos ressaltar que a leitura de "simbólico" para Lacan e Kristeva, na interpretação de Butler (2010), é a linguagem socialmente construída como corpo paterno e a hegemonia do masculino. Por outro lado, no "semiótico" é que prevalecem os significados múltiplos e a semântica em aberto, ao contrário da compreensão de Silva (2001).

Ao mesmo tempo, Butler afirma que Kristeva entende o "semiótico" (aberto) como subordinado ao "simbólico" (normativo), mas que o primeiro é uma ação sígnica reconstruída na linguagem poética, na qual emerge o inconsciente e o instável. A construção de Silva (2001) está fortemente influenciada por Ricoeur, que já trata o simbólico não como o conjunto sígnico da linguagem normativa culturalmente produzida, mas como a desestruturação radical da linguagem ou, até mesmo, a incapacidade da inexistência dela - uma vez que as interpretações dos signos pelos sujeitos e suas atividades de compreensão, fala e interação compõem campos simbólicos instáveis e não uniformes. De signo a simbólico e a semiótico, existe um caminho (em Kristeva, Butler, Ricoeur e Silva) que acompanha uma base de construção social da linguagem pela cultura e que é produzido pelas relações de poder que organizam signos fixos para compor os significados das coisas e seres da realidade. Por outro lado, as realizações destas operações (as situações de encaixe entre signo e coisa/ser real) são instáveis e abertas, gerando significações diversas e alterando constantemente a linguagem.

É assim que se constitui o performático. Greimas (apud SILVA, 2001, p. 76) afirma que "para análise do relato, propõe-se conceber o sujeito da cidade como sujeito em processo: sujeito virtual - sujeito atualizado -, sujeito realizado (performance) (grifo do autor)”. O performático é, assim, a realização simbólica dos sujeitos em interação. É quando o real e o simbólico se constituem na ação. O performático é aquela interação (apresentação e relação 
dos corpos e dos atos de fala) entre médico e paciente na constituição das espacialidades terciárias de Foucault (2001) e Sahr (2007), ou seja, quando especificidades de pensamentos epistemologicamente delimitados (espacialidade primária) e imagens produzidas (imagem dos corpos, coisas e seres) se realizam nas falas, comportamentos e interações de sujeitos reais, tornando acoplados à realidade os signos normativos ou a constituição de um campo simbólico fechado (as estruturas sígnicas normativas da linguagem técnica médica, por exemplo). Por outro lado, o performático também é a abertura simbólica ou o "semiótico" de Kristeva (apud BUTLER, 2010) da linguagem poética. Além da própria linguagem, a poética é a realização simbólica aberta dos sujeitos sociais em interação, que perturba a estabilidade da linguagem normativa e exerce desconstruções dos signos quando deparada com a reinterpretação deles e deles em relação a coisas e seres reais. No contexto de normatizações, criatividades são realizadas na imbricação de esferas simbólicas abertas com as situações diversas de realização dos corpos em interação. Performances instáveis e criativas assim são produzidas, para além das repetições alienadas dos gestos, comportamentos e falas dos corpos.

Assim, temos três relações performáticas quanto aos sexos, aos gêneros e às sexualidades:

\subsection{Performances e espacialidades terciárias (quadros de} ação e apresentação institucionalizados dos corpos)

Os corpos imitam representações simbólicas normativas, e estabelecem-se mútuas vigilâncias sobre formas de se apresentar (estéticas) e formas de agir (éticas). Horizontes de pensamento mais ou menos especializados conduzem mútuas vigilâncias dos corpos perante as relações face a face. Discursos conduzem atos de fala que identificam pejorativamente corpos individuais dissidentes para instaurar a imitação de uma norma sígnica normativa. Horizontes de pensamentos (espacialidades primárias) e imagens e sintomas (espacialidades secundárias) acoplam-se às realidades interativas (espacialidades terciárias). 
Há fatos simbólicos mais precisos e fatos simbólicos menos precisos (mais abertos às interpretações), tornando os discursos mais duros e a realidade estabelecida mais instável. Espaços de interações mais machistas e determinados pela heterossexualidade compulsória usam signos pouco precisos para instaurar a rigidez de expressões e comportamentos dos corpos generificados e sexuados. Os enunciados são mais duros que a realidade expressiva, mas os enunciados desafiam os corpos, gerando uma série de prejuízos individuais e conflitos interpessoais baseados no preconceito e na discriminação. A existência de corpos dissidentes nestas espacialidades normativas serve para reforçar os enunciados normativos daqueles que determinam a reprodução dos binarismos que privilegiam o machismo e a heterossexualidade compulsória.

Em primeiro plano, realizam-se discursos e imagens que determinam elementos de macheza e de feminilidade acoplados rigidamente à visibilidade de corpos de homens e de mulheres, assim como, em consequência, estabelecem-se ritmos de relações sexuais fundadas na heterossexualidade. Por outro lado, torna-se importante tornar enunciados as formas corporais de gêneros e de sexualidades discordantes dos sexos biológicos, para tomá-las como elementos a serem reprimidos que servirão à ordem binária primeira. Rege-se o paralelismo de sexos-gêneros-sexualidades como privilégio das relações, mas conduzem-se formas binárias desviantes para torná-las o oposto necessário à afirmação do primeiro. Esta é a realidade da necessidade de totalização do machismo e da heterossexualidade compulsória em que, ao mesmo tempo em que expulsa, pela discriminação, corpos dissidentes, os mantém como exemplos necessários a não serem seguidos. As relações são enunciadas sempre como normas e contrários, conduzindo a imitação constante dos binarismos entre norma e desvio.

No Brasil, um dos lugares de maior expressão da homofobia são os estádios de futebol. A charge na Figura 1 representa este sintoma na constituição desta espacialidade. Enunciações homofóbicas, machistas e, até mesmo, racistas, são estabelecidas facilmente e produzem um "clima" de regramento dos corpos no 
sentido da misoginia, da rigidez à heterossexualidade, do poder do "macho" e da branquidade.

Figura 1: Charge representando o machismo e a homofobia no futebol.
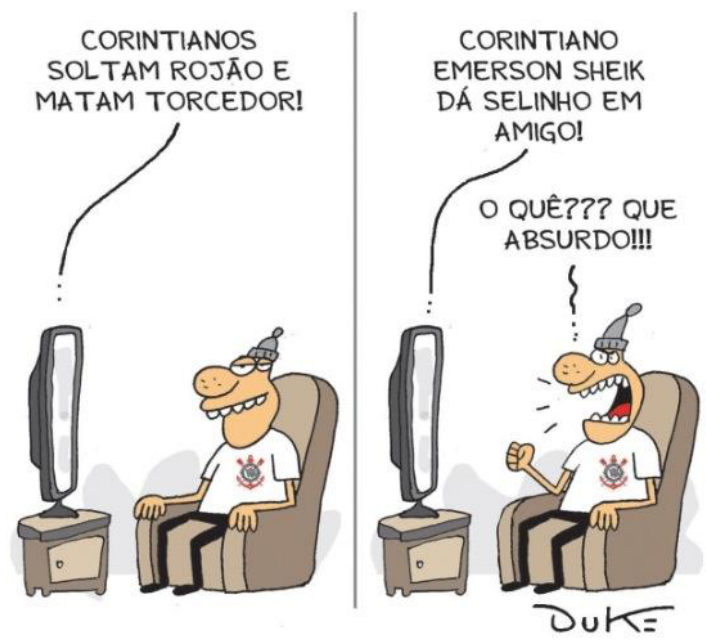

Fonte: http://dukechargista.com.br/.

A espontaneidade do futebol converge para a rigidez das regras discriminatórias em relação a qualquer contranorma sobre sexo, sexualidade, gênero e racialidade. No Brasil o futebol é um dos esportes mais cultuados e praticados. As vivências das espacialidades dos campos de futebol representam um laboratório cujos sujeitos reafirmam e transpõem para o restante da sociedade as regras rígidas de produção e ação dos corpos. Atualmente existem muitas campanhas para o combate ao machismo, à homofobia e ao racismo nos campos de futebol, mas elas ainda estão engatinhando na realidade brasileira. Observamos, na espacialidade dos campos, um conjunto de enunciações que reforçam os elementos simbólicos pejorativos contra as homossexualidades, e esses elementos simbólicos são reproduzidos, como imitações, em outros espaços do cotidiano. Temos, por exemplo, uma íntima reprodução destas ações e enunciações que ocorrem nos campos de futebol com o espaço da escola. As crianças e adolescentes apreendem das espacialidades de 
vivência do futebol certas formas simbólicas e capacidades enunciativas que são reproduzidas nas relações sociais diretas com seus colegas. Pela força de socialização que o futebol representa no contexto do Brasil, acreditamos que ele traduz uma esfera de espacialidade cujos corpos representam e enunciam formas de repreensão à conformação de outros corpos dissidentes, que convergem em atos de preconceito, discriminação e violência fóbica.

\subsection{Performances e espacialidades quaternárias de} estabilização coletivas de realizações simbólicas transgressivas (quadros de ação e apresentação subculturais dos corpos)

Corpos dissidentes expulsos das relações normalizadas balizadas pelos enunciados que reforçam o machismo e a heterossexualidade compulsória encontram outros corpos dissidentes e alicerçam espacialidades comuns de trocas de informações sobre suas condições desviantes, dissidentes e transgressivas. Tais espacialidades representam rotas de fugas coletivas que ressignificam positivamente os próprios corpos dissidentes e os fundamentos de seus desejos e entendimentos sobre sexo, emoção e amor. Como partem de hegemonias compulsórias do machismo e da heterossexualidade, retiram a visibilidade negativa de seus próprios atributos e os transformam em elementos de empoderamento e de felicidade de pertencimento.

Para estes fenômenos, espaços concretos se constroem como à parte de um fenômeno espacial de totalização heteronormativa e machista. São condições de espaço e de tempo necessárias para se estabelecerem rotas de fuga de corpos transgressores que ficam à margem do espaço concreto-simbólico normativo. Nesses espaços concretos, são criadas ressignificações simbólicas abertas dos signos normativos que compõem a totalização socioespacial do machismo e da heterossexualidade compulsória, além de outras espacialidades serem construídas, como a relação aberta das incapacidades e das transgressões de realização corporal das formas binárias dos sexos, dos gêneros e das sexualidades. Constituem-se espacialidades 
quaternárias do simbólico aberto e instável, mas que se conduzem pelas reelaborações coletivas dissidentes, novas formas de admirações e de repetições, só que, agora, de conjuntos específicos de formas de se mostrar (estéticas) e formas de agir (éticas) dissidentes.

Pensamos que essas espacialidades quaternárias são imitações intersubjetivas de elementos comuns das culturas de grupos de diversão lésbicos, gays e transgêneros. $\mathrm{Na}$ cultura gay urbana, por exemplo, o fenômeno drag queen transforma-se em um imaginário que se espetaculariza como formas ritualísticas de admiração e de fortalecimentos dos laços entre dissidentes. $O$ uso de palavras femininas entre homens gays para se tratarem, as estéticas de exagero quanto ao feminino e ao masculino na construção dos corpos, a dança como expressão de liberdade (regrada ao corpo masculino pelo machismo) são alguns atributos partilhados nas espacialidades quaternárias, trazidos da mobilização e reinvenção das ideias de desvios das espacialidades terciárias normativas do machismo e da heterossexualidade compulsória. Seguem-se processos de imitação performática dos corpos, porém como atos de empoderamento e consciência transgressora reivindicatória da transformação do espaço e das relações sociais normativas quanto às sexualidades. As Figuras 2 e 3 representam o desenvolvimento do fenômeno drag queen na cidade de Santa Maria/RS. 
Figura 2: Foto de Eros Ariel com Micka Valga e Donna LeBlanc em Macondo Lugar em Santa Maria/RS.

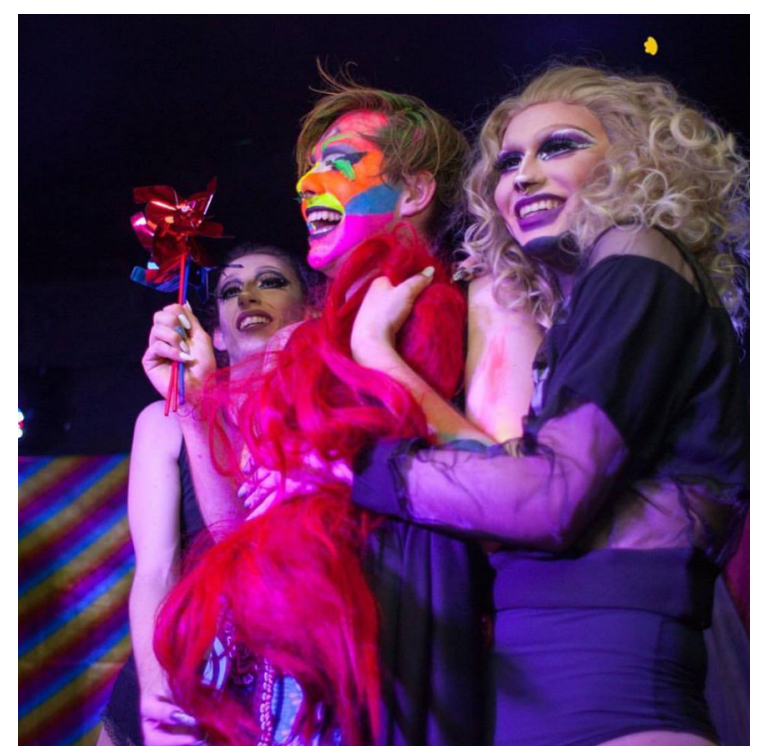

Fonte: Perfil do Facebook de Micka Valga, Santa Maria/RS. Foto do perfil de Facebook de Eros Ariel marcando Micka Valga.

Figura 3: Foto de Donna LeBlanc em Macondo Lugar em Santa Maria/RS.

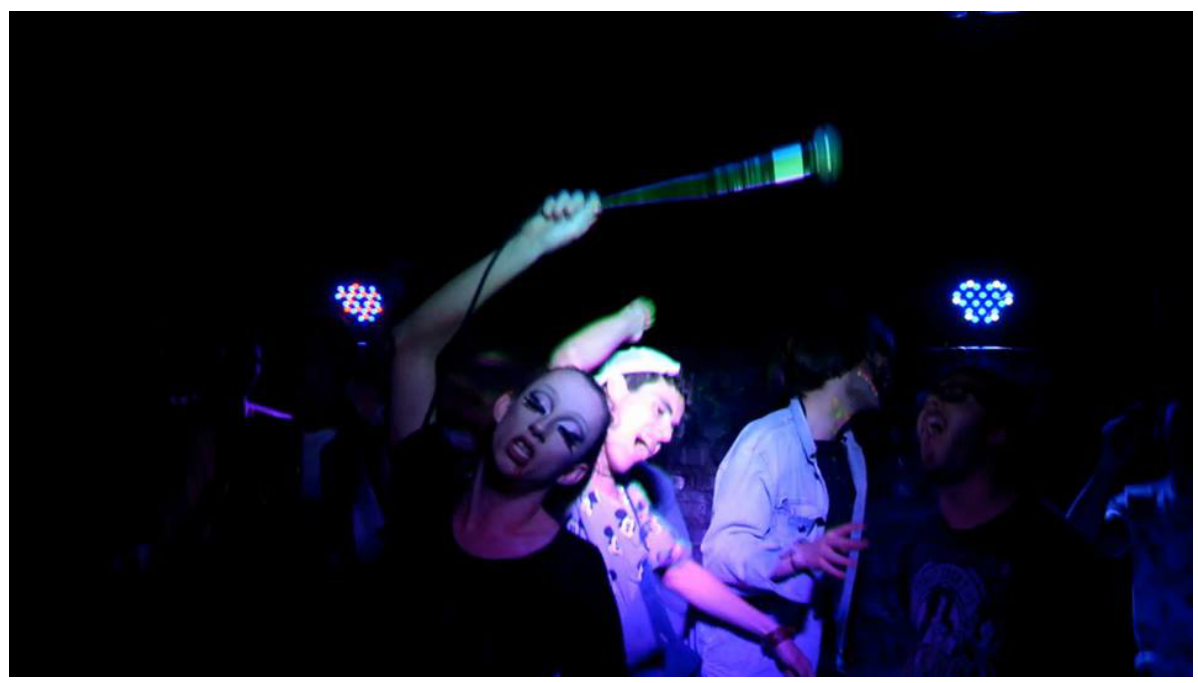

Fonte: Perfil de Facebook de Micka Valga, Santa Maria/RS. Foto do perfil de Facebook de Donna LeBlanc, marcando Micka Valga. 
Figura 4: Micka Valga no Macondo Lugar em Santa Maria/RS.

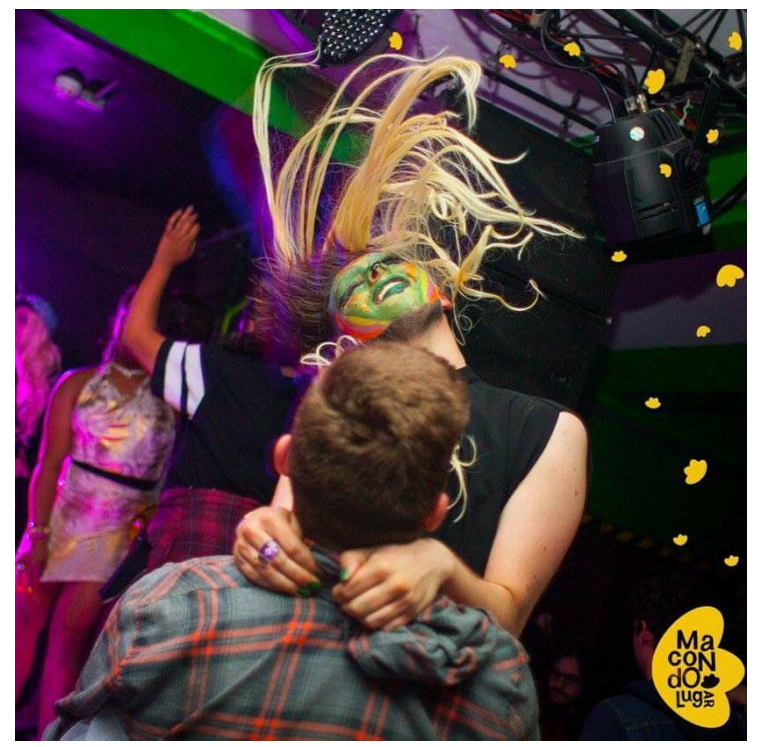

Fonte: Foto de Micka Valga no site do Macondo Lugar Bar.

Disponível em < http://www.macondolugar.com.br/>

Santa Maria é uma cidade média de aproximadamente 300 mil habitantes no interior do estado do Rio Grande do Sul, Brasil. A cidade é habitada por estudantes universitários provenientes de diferentes outros pequenos centros urbanos e do espaço rural do interior do Rio Grande do Sul e do Brasil. É um polo de atração populacional em virtude da existência da Universidade Federal de Santa Maria e de vários centros universitários privados. Estudantes de diferentes cidades menores chegam a Santa Maria e encontram um espaço urbano propício para o encontro com a diversidade cultural, de gênero e de expressões de sexualidade. Atualmente, muitos jovens universitários encontram na cidade um espaço de expressão de rompimento com a rigidez de expressões de gênero e sexualidade encontrada em suas cidades de origem. A cidade universitária permite um encontro com a diversidade e possibilidades e comunhão de expressões de sexualidade divergentes do padrão heteronormativo. A cidade sempre comportou lugares de diversão noturna para a população LGBT - desde muitos anos. 
Atualmente, o Macondo Lugar, uma casa noturna que reúne grupos diversos de jovens, produz festas mais específicas para a comunidade LGBT. No Macondo Lugar, grupos de homens gays jovens desenvolvem uma arte de questionamento e rompimento com os rígidos padrões de expressão de gênero e vivências de suas sexualidades. $\mathrm{Na}$ cidade tem ocorrido um fenômeno de apresentações performáticas drags, que se apropriam do espaço de diversão do Macondo Lugar. Podemos observar nas fotos alguns exemplos de reinvenção dos atributos de gênero performatizados contraditoriamente nos corpos de jovens homens gays, produzindo a expressão drag. Nas Figuras 3 e 4, observamos ações de felicidade, empoderamento e liberdade de expressão diversas dos corpos destes jovens, como a construção de um espaço de celebração à desconstrução da realidade de uma sociedade que se reproduz como misógina, heteronormativa e machista.

\subsection{Performances e espacialidade também quaternárias} quanto a expressões dissidentes tanto das espacialidades terciárias quanto de estabilidades coletivas de realizações simbólicas transgressivas

A terceira relação performática é a instabilidade e a desconstrução de tudo que se normatiza, desde a incapacidade de se realizarem signos que definem as masculinidades e as feminilidades compulsórias, tendo as relações sexuais heterossexuais como regra. A ideia construída por Butler (2010) é que nada é efetivamente masculino e/ou feminino, porque os horizontes de representações simbólicas destes sintomas são muito abertos e indefiníveis em diferentes circunstâncias sociais. Há insuficiências e exacerbações múltiplas entre tais sintomas binários. Assim como não há definições rígidas de gênero nas diferentes relações sociais, as sexualidades se abrem a desejos instáveis e voláteis que atravessam contraditoriamente situações tanto de reforço das relações generificadas binárias quanto das próprias transgressões delas. $\mathrm{O}$ “corpo é uma situação” (BEAUVOIR apud BUTLER, 2010, p. 27), 
assim ele produz interpretações diversas de elementos sígnicos variáveis e constrói formas simbólicas situacionais perante relações interativas diferenciadas, mobilizando diferentes esferas de significações simbólicas e realizando-se instavelmente entre elas, dependendo das circunstâncias.

Assim, tanto para os primeiros esforços performáticos, de repetição dos gêneros e das sexualidades compulsoriamente definidas como normativas, como para as imitações de transgressões construídas intersubjetivamente em espaços culturais lésbicos, gays, transgêneros e travestis, existem as pessoas (as pessoas em interação) que conduzem equações diversas entre consciente e inconsciente e constroem éticas e estéticas fluidas intersubjetivamente. O tempo e o espaço situacionais definidos por trocas intersubjetivas acionam o simbólico (ou o semântico de Kristeva) aberto e conduzem fatos performáticos dissidentes. Pode haver um conjunto de enunciados que definem a situação coletiva, mas há relações e expressões paradoxais reais divergentes da conformação simbólica que define a relação. São os espaços paradoxais de mudanças de posicionamentos, de novas conformações de empoderamento e de mobilizações estéticas diversas em dadas situações espaciais do social trabalhados por Rose (1993). Não existem ligações rígidas entre formas culturais preestabelecidas e enunciados normativos nas realizações dos corpos em interação, mas existem os paradoxos dos mínimos atos e expressões momentâneas dos corpos em relação. Destas instabilidades podem surgir espacializações quaternárias que conduzem suas repetições e imitações, mas novas instabilidades criativas voltam a ser realizadas no efêmero do "aqui" e "agora".

Como exemplo desta relação em paradoxo, temos a tão conhecida "pegação" (atos sexuais diversos) em espaços públicos normatizados como espaços de frequência estritamente masculina e heterossexual. Os banheiros públicos masculinos (e também os banheiros de espaços semipúblicos, como os de shopping centers) são materialidades produzidas pelos atos discursivos que simbolicamente separam e performatizam os gêneros nas sociedades modernas. A divisão dos banheiros entre masculino e feminino é expressão 
máxima da materialização das relações binárias de gênero que repercutem no regramento da sexualidade - principalmente o regramento da heterossexualidade - , na divisão rígida de espaços em combate aos atos sexuais em público, assegurando a reprodução de comportamentos específicos tanto para o masculino como para o feminino. Os banheiros públicos também representam a construção de espaços em que as necessidades fisiológicas de defecar e urinar devem ser separadas da publicidade da rua e, assim, constituídas como tabus de expressão pública. A constituição desses espaços objetiva o regramento da sexualidade (separação do contato entre sexos diferentes) e dos fluidos e dejetos humanos, que devem ser sanitariamente organizados e limpados. Por outro lado, em todas as cidades, de qualquer tamanho, os banheiros públicos, principalmente os masculinos - pela frequência de homens e pela exposição de seus órgãos sexuais em ambiente fechado -, tornam-se espaços de práticas sexuais diversas e de apresentações e ações corporais dos corpos masculinos conflitantes em relação à ética heterossexual e misógina da sociedade moderna, sendo que é a própria sociedade moderna que constitui o banheiro masculino. $\mathrm{O}$ banheiro público permite o encontro e ações homossexuais diversas, assim como a expressão de diferentes desejos homoeróticos, inclusive paradoxais à vida cotidiana de sujeitos homens, muitas vezes, identificados como heterossexuais.

A Figura 5 representa a enunciação de um desejo sobre o corpo masculino expresso de forma bem específica em um banheiro público da cidade de Presidente Prudente, estado de São Paulo, Brasil, durante a atividade de pesquisa do autor em 2014. Se procurarmos na internet, existem muitas fotos de "pegação" em banheiros públicos, com corpos flagrados em atos de transgressão aos sentidos simbólicos que a materialidade banheiro representa, a qual, pretensamente, pretendia regrar as práticas sexuais e as atividades fisiológicas pessoais. Decidimos colocar esta foto no texto, não os corpos em atos de práticas sexuais homoeróticas, porque ela representa uma especificidade de tantos desejos homoeróticos existentes e que podem ser expressos de formas veladas em banheiros 
públicos masculinos. Os sentidos aqui remetem justamente a um exemplo entre tantas transgressões diversas e instáveis das ordens constituídas nestes espaços. Estas transgressões dos corpos em ação desestabilizam qualquer classificação referente à sexualidade, às ações $\mathrm{e}$ às identidades sexuais.

Figura 5: Enunciados escritos em banheiro masculino público da praça da Bandeira em Presidente Prudente - SP.

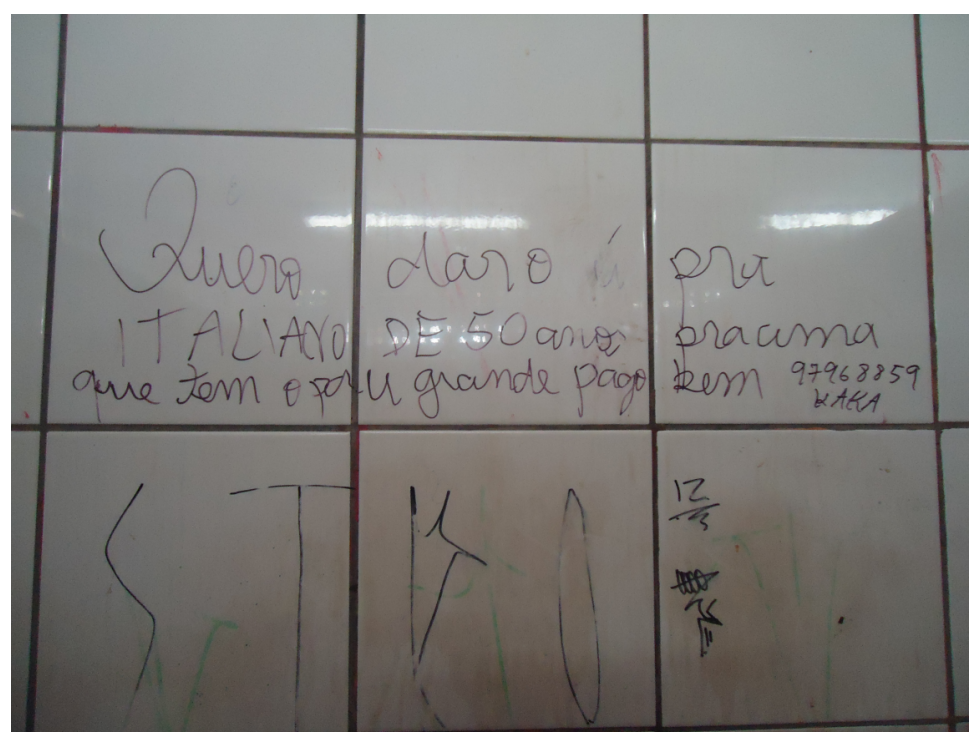

Fonte: Autor (2014), em pesquisa na cidade de Presidente Prudente.

A Figura 6 é uma das imagens de Nei D’Ogun do documentário de curta metragem de Diego Tafarel (2016), Preto, Puto, Pobre, que retrata a trajetória de vida do militante negro LGBT e agitador cultural na cidade de Santa Maria/RS. O documentário é belíssimo em trazer a discussão sobre a condição de um homem negro homossexual de periferia em uma cidade do interior do Brasil, suas dificuldades e sua história de empoderamento e superação das sobreposições de preconceito e discriminação que estão contidas em sua corporeidade. A discussão sobre as reproduções de preconceito e discriminação entre grupos sociais já marginalizados é pauta dos debates sobre gênero e sexualidade na atualidade. 
Figura 6: Foto de Nei D'Ogun, militante e movimentador cultural de Santa Maria/RS, do documentário Preto, Puto, Pobre.

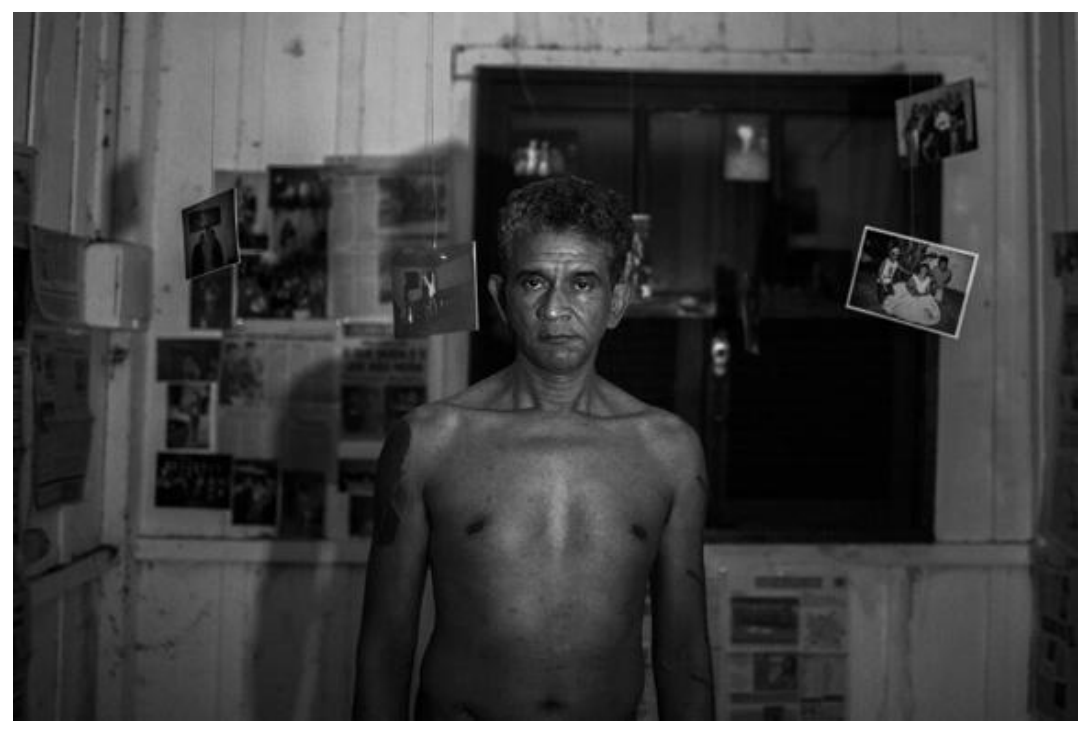

Fonte: Tafarel (2016).

Crenshaw (2002) trabalha a "interseccionalidade" como sistemas múltiplos de discriminação compostos por dois ou mais eixos de subordinação contidos nos corpos discriminados, ou seja, as interseções entre gênero, raça, etnia, orientação sexual, classe, identificações estéticas, origem, cultura, etc. Para a autora, as políticas de combater a discriminação da mulher e a história da trajetória do próprio movimento feminista estão condicionadas a formas de entendimento sobre preconceito e discriminação concentrados nas vivências de mulheres brancas de classe média, e isso não representou nem representa as condições de outras mulheres de outras classes sociais e de outras etnias e racialidades. Os corpos negros e pobres de mulheres e de homossexuais do Brasil estão condicionados a sistemas de marginalizações existentes também entre os grupos marginalizados. Atualmente existem sistemas de inserção dos corpos homossexuais, principalmente em lugares de consumo e diversão, que são privilégios de corpos brancos e de classes médias e mais altas, tornando difíceis esses espaços para as convivências de corpos homossexuais pobres de periferia, assim 
como acontece com aqueles que são negros, idosos e, por exemplo, gordos.

Em relação aos estudos de homossexualidades, têm sido discutidos os padrões de "homonormatividades" (DUGGAN 2002; BROWN, 2013). A "heteronormatividade" é concebida como a permanência de uma moral social moderna que estabelece polarizações de sexualidade cujas relações sociais e interações cotidianas seguem o privilégio da promoção dos papéis e afetividades heterossexuais. Por outro lado, há uma crítica sobre a inclusão e o reconhecimento social das homossexualidades na atualidade, estando incluídas e reconhecidas socialmente em virtude da “interseccionalidade" entre branquidade e poder de consumo. Isto gera a hierarquização entre os corpos identificados como homossexuais e discriminações múltiplas entre populações LGBTs, como mostra França (2012) e Costa (2011), em São Paulo. Por outro lado, estes sujeitos produzem esforços redobrados para romperem as barreiras de convivência em espaços de convivência de homossexualidades balizadas pelo: a) poder de consumo no local (poder pagar para entrar e para consumir); b) poder se vestir de acordo com os parâmetros de boas vestimentas da moda atual; c) estar representado entre corpos brancos malhados e masculinizados que são padrões de beleza hegemônicos e que conduzem a maior inclusão social das homossexualidades.

No entanto, os espaços de privilégio de homens gays brancos, bem vestidos e de classe média, estão sempre sendo transgredidos por outros homens, negros, de classe baixa, não tão bem vestidos e não tão malhados e masculinizados como os primeiros. Em alguns espaços públicos, como praias brasileiras por exemplo, a Praia Mole em Florianópolis e o posto 9 na Praia de Ipanema, Rio de Janeiro -, podemos perceber facilmente a hegemonia da branquidade, dos corpos masculinizados e super trabalhados nas academias de ginástica e da capacidade de consumir no local. Mesmo assim, existem "microperiferias" de outros homens cujos corpos não são tão masculinizados, não são tão malhados, que pertencem a outras classes sociais e que persistem em estar no lugar, 
rompendo a barreira da homonormatividade estabelecida. Em algumas boates gays cujos princípios de encontros de homens homossexuais seguem o mesmo padrão de homonormatividade, sempre existem presenças de outros homens com outras expressões corporais não hegemônicas. Essas presenças, por um lado, produzem-se como necessárias ao reforço da hegemonia primeira, como exemplos que repercutem em microdiscriminações (deboches e olhares de estranhamento) para manutenção da estabilidade das hegemonias de apresentação, repercutindo, também, paradoxalmente, na construção de experiências de desejos e encontros afetivo-sexuais diversos. Caso estes encontros entre as diferenças de posicionamentos dos corpos aconteçam, as práticas, muitas vezes, não repercutem na transformação dos enunciados e atos discursivos que dão preferência às hegemonias estabelecidas.

É esta construção conflituosa de espacialidades que queremos trabalhar também neste item: há, além da produção de espacialidades das divergências contra as hegemonias de construção dos corpos e das ações sociais, outras espacialidades que corrompem hegemonias construídas no próprio espaço marginal. Apresentamos, assim, duas condições de produção deste tipo de espacialidades quaternárias. Primeiro, as realizações transgressivas diversas dos corpos em ação em espaços produzidos pelas condições normativas sobre a apresentação e a ação dos corpos em relação, como é o caso das práticas homossexuais diversas em banheiros públicos masculinos, as quais transgridem este espaço que regra (do público) a sexualidade e a evidência da existência dos fluidos e desejos humanos. Segundo, as outras marginalizações contidas nos próprios espaços de convivência social marginal - como é o caso dos corpos homossexuais pobres, negros, de classe baixa e não trabalhados pelos exercícios físicos - , as quais lutam para se estabelecer entre poucas possibilidades de convivência das homossexualidades, sendo elas mesmas já materializadas por outras construções de hegemonias caracterizadas pelo poder dos corpos brancos, de classes altas, masculinizados e bem trabalhados por exercícios físicos de academias de ginástica. 


\section{As performances criativas como retorno do espaço como primário}

A defesa de Butler (2010) sobre uma nova política da instabilidade aponta para a desconstrução radical das teorias e horizontes de pensamento que são produzidos pelos próprios atos de linguagem normativos. Mesmo buscando uma política crítica, o reforço sobre a evidência das normas e dos desvios, mesmo valorizando os segundos, acaba por manter o status quo da regra. A ideia de que os corpos estão e são em situação valoriza o espaço como encontro e criatividade efêmera e estável, de onde partem as repetições, mas que voltam como evidências situacionais de suas desconstruções.

Tudo é efêmero e se reconduz pelos paradoxos sobre aquilo que é performance de repetição. As equações entre consciência e inconsciência de corpos em atividades intersubjetivas abrem-se para as manipulações simbólicas diversas e realizam criativamente espacialidades novas que são o primordial e que podem se repetir ou não. O espaço interacional é, então, um retorno como "espacialidade primária”, antes do pensamento, e conduz ao pensamento, este agora como "espacialidade secundária", que poderá ou não se realizar como continuidade do espaço primeiro e do pensamento segundo, aqui voltando a ser "espacialidade terciária".

O fato das espacialidades terciárias não existirem e serem realidades espaciais de trocas intersubjetivas abertas coloca o espaço como elemento primeiro e primordial para realização das interpretações simbólicas abertas trazidas do social. Há, então, uma evidência do espaço como elemento constituinte do simbólico, e não o contrário, como queria Foucault (2001). Tudo, então, é situação, e instaura-se o privilégio do sujeito e suas interpretações simbólicas abertas que jogam com outros corpos imediatos, em uma troca entre consciências sobre padrões sígnicos (o signo) e abertura da interpretação dele na situação da ação (a emergência do inconsciente que reinterpreta na ação e produz o simbólico ou o semântico). 
As espacialidades quaternárias, neste encontro de corpos (consciências e inconsciências) abertos à manipulação simbólica dos enunciados que se pretendem normativos (mas nunca o são, somente por força incapaz de seus discursos) são espacialidades sempre em construção como espaços de encontros e interações sociais "até agora”, que se abrem em uma configuração espacial sempre nova (e assim por diante). Esse caráter instável e sempre em produção do espaço é o centro das discussões de Massey no texto de 2009.

\section{Considerações finais}

Organizamos um quadro que discute relações de sexo, gênero e sexualidade a partir de uma tríade que representa: a) a construção de normas binárias da naturalização dos sexos e de construções culturais rígidas sobre os gêneros e as sexualidades; b) o trabalho simbólico aberto das outras expressões de gêneros e sexualidades que desconstroem a ideologia dos sexos pré-discursivos e naturais e mobilizam novas representações dos corpos por misturas simbólicas sobre corpos geneficados e sexualizados; c) a evidência das instabilidades e efemeridades de corpos em relações intersubjetivas que constantemente reconduzem novas performances sobre sexos, gêneros e sexualidades.

Para tratarmos desta tríade utilizamos o espetáculo, o imaginário e a performance como conceitos que nos permitiram entender estes paradoxos ideais. O espetáculo irá representar a alienação da repetição de realização de formas sígnicas normativas sobre os sexos, os gêneros e as sexualidades. O imaginário vai entender os processos sociais como campos de interpretações abertos de elementos simbólicos normativos. As performances transitam ora entre a instabilidade, ora entre as realizações repetidas dos signos normativos, ora entre a repetição das transgressões contrárias às normas simbólicas, ora entre a instabilidade generalizada da criação e realização simbólicas efêmeras dos corpos em interação. Para entendermos estes paradoxos performáticos utilizamos a estratégia 
de Foucault (2001) e Sahr (2007), que visibiliza metodologicamente a relação entre simbólico e realidade a partir das construções de espacialidades primárias, secundárias e terciárias. Dos horizontes de pensamento a imagens e a realizações dos corpos em interação, que ligam as normas simbólicas da língua e a realidade das expressões, construímos uma quarta espacialidade que representa o campo de realização transgressiva, aberta e instável do simbólico. Finalmente, valorizamos o espaço como fundamento de constituição dos campos simbólicos que transitam entre normativos e imitativos e abertos e instáveis na produção de performances criadoras sobre os enunciados, as éticas e estéticas sobre sexo, gênero e sexualidades. Esperamos ter contribuído para a discussão no campo da Geografia.

\section{Referências}

BEAUVOIR, S. O segundo sexo. Rio de Janeiro: Nova Fronteira, 1980.

BROWN, G. Pensando além da homonormatividade: explorações performativas de economias gays diversificadas. Revista LatinoAmericana de Geografia e Gênero, Ponta Grossa, v. 4, n. 1, jan./jul. 2013.

BUTLER, J. Problemas de gênero: feminismo e subversão da identidade. Rio de Janeiro: Civilização Brasileira, 2010.

COSTA, B. P.. Espaço urbano, cotidiano, cultura e espaços de proximidade: o caso das microterritorializações de sujeitos orientados sexualmente para o mesmo sexo. In: RIBEIRO, M. A.; OLIVEIRA, R. S. (Orgs.). Território, sexo e prazer: olhares sobre o fenômeno da prostituição na geografia brasileira. Rio de Janeiro: Gramma, 2011.

CRENSHAW, K. Documento para o encontro de especialistas em aspectos da discriminação racial relativos ao gênero. Revista Estudos Feministas, Florianópolis, Ano 10, 2002.

DEBORD, G. A sociedade do espetáculo. Rio de Janeiro: Contraponto Editora, 1997.

DUGGAN, L. The new homonormativity: the sexual politics of neoliberalism. In:

CASTRONOVO, R.; NELSON, D. D. Materialising democracy: 
towards a revitalized cultural politics. Durham, NC: Duke University Press, 2002.

FOUCAULT, M. História da sexualidade: a vontade de saber. Rio de Janeiro: Graal, 1988. v. 1. 2001.

O nascimento da clínica. Rio de Janeiro: Forense Universitária,

FRANÇA, I. L. Consumindo lugares, consumindo nos lugares: homossexualidade, consumo e subjetividades na cidade de São Paulo. Rio de Janeiro: EdUERJ, 2012.

GONÇALVES, L. R.; SILVA, A. (Orgs.). Cidades imaginadas IberoAmericanas. São Paulo: MAC USP/SESC, 2010.

LAQUEUR, T. W. Inventando o sexo: corpo e gênero dos gregos a Freud. Rio de Janeiro: Relume Dumará, 2001.

LEFEBVRE, H. La producion del espacio. Madrid: Capitán Swing Libros, 2013.

MASSEY, D. Pelo espaço: uma nova política da espacialidade. Rio de Janeiro: Bertrand Brasil, 2009.

ROSE, G. Feminism and Geography: the limits of Geographical Knowledge. Cambrige: Polity Press, 1993.

SAHR, W. D. Signos e espaços mundos - a semiótica da espacialização na Geografia cultural. In: KOSEL, S.; SILVA, J. C.; GIL FILHO, S. F. $\mathrm{Da}$ percepção e cognição à representação: reconstruções teóricas da Geografia cultural e humanística. São Paulo: Terceira Imagem; Curitiba: NEER, 2007.

SILVA, A. Imaginários urbanos. São Paulo: Perspectiva, 2001. . Imaginários: estranhamentos urbanos. São Paulo: SESC, 2014.

TAFEREL, D. Preto, Pobre, Puto. Documentário de curta metragem. Santa Cruz do Sul: Pé de Coelho Filmes, 2016. 
O papel das Mãos: a Leitura e a Costura entre Memória, Paisagem e Corpo

Janderson Gonçalves 


\section{Apresentação}

$\mathrm{O}$ s dedos enrugados mantêm a mesma perícia de há muito. Prende as duas pernas e a cauda bem na altura da dobra dos joelhos e posiciona o balde. Alumbra-se o canto do galpão adjacente a casa. O lampião a querosene destaca os gestos. As mãos seguem a mesma trilha todos os dias: a direita desce em apenas um golpe, enquanto que a esquerda se eleva com a mesma desenvoltura; a recíproca é verdadeira. Ártemis continua se impondo a Apolo, nessa batalha diária e eterna. $\mathrm{O}$ jorro do jato soa no aço galvanizado como uma torneira, à alta vazão, sendo ligada e desligada, ligada e desligada... Chama a Filomena. Mais a Doralice. E a Mimosa. À medida que o balde se enche, o fluido materno bovino vai sendo conduzido como numa dança de passos para frente e para trás. $\mathrm{O}$ tarro está vestido com um coador de pano de prato que, apesar de improvisado, é mais branco que a Lua, ainda fulgurante no firmamento. As veias saltadas do dorso pulsam ao mesmo ritmo que jorra o leite.

As mãos são as fiadoras desse fandango madrugueiro. Essa via láctea tem o mesmo efeito que uma migalha de rocha que se deposita sobre os ombros da mulher a que assisto. Uma herança pétrea que, ao cristalizar-se, se torna tão ou mais pesada que o próprio balde que está sendo transportado. Todo o esforço se irradia e pressiona as primeiras vértebras da coluna. Sentada ao banquinho, a coluna arqueada ressalta a corcunda. A má postura se agrava. Os nervos que movimentam as falanges, ao passar de décadas, não têm a mesma elasticidade de outrora. A fluência é garantida pela prática. Mesmo assim, as palmas ásperas de calos e gretas massageiam os tetos e orientam o fluxo. Ainda jorra o leite.

Encontramos a severidade de julho. Um nevoeiro convectivo se instala sobre a velha casa de madeira. $\mathrm{O}$ vento assovia, se esgueirando pelo relevo. Os campos das coxilhas fumegam. De tão denso o ar, não se avista mais que poucos palmos ao longe. $\mathrm{O}$ frio resseca os lábios. A expiração esfumaça a face. $\mathrm{Meu}$ nariz escorre. $\mathrm{O}$ casaco lanoso umedece. O cheiro do estrume se esgota, fruto das 
narinas congestionadas. Os bugios, por sobre as araucárias, se acercam. E roncam. O leite continua a jorrar.

O sono pesa minhas pálpebras, como se fosse uma força oculta que tenta fechar a persiana. Um piscar prolongado é interrompido de sobressalto pela luz pendulante, que se aproxima. Dou uma passada larga para trás. Afasto-me da fresta da porta, para que não perceba que estava espionando. Ela surge com o lampião em uma mão. Na outra, me traz uma caneca metálica esmaltada transbordando de leite. É viscoso, gordo e o cheiro é forte - nunca o tinha inalado - suas propriedades não lembram em nada aqueles que compramos no mercado perto de minha casa, na cidade. A espuma me deixa com um bigode fino e pálido. Fecho os olhos para aproveitar melhor o sabor do esforço daquela manhã.

Eu era apenas um garotinho que ainda se escondia à barra da saia da mãe quando pela primeira vez vi, espiando pelas frestas, a tia tirar leite das vacas. Quase a vejo aqui, na minha frente, repreendendo-me quando eu pedia pra assistir àquele acontecimento: "não dá, fío! As vaca esconde o leite". Nunca tive autorização para invadir aquele território durante a ordenha, tampouco entendia o que é "esconder o leite". O que me lembro, como se hoje fosse, era daquela mulher, antes do sol nascer, trabalhando no galpão.

Isso que acabei de narrar não advém apenas de uma lembrança remota de minha infância. É a soma de muitas lembranças. Provavelmente, nem ocorreram no mesmo dia, mas a sequência da narrativa apresentou-se satisfatoriamente lógica. Não me interessa discutir, neste texto, tampouco averiguar, se essas lembranças ocorreram exatamente como foram relatadas. A pergunta mais adequada a ser feita, para a perspectiva que pretendo desenvolver aqui, é: por que essas lembranças e não outras? Além disso, discorro sobre a relação entre a memória e a paisagem e o papel do corpo na mediação entre ambas.

A pessoa que protagoniza a narração é minha tia paterna Maria Isabel, que era carinhosamente chamada de Belinha pelos familiares e amigos. Infelizmente, ela nos deixou no ano de 2013, vítima de enfisema pulmonar. Mesmo tendo nome e endereço, a tia 
foi apenas um exemplo de tantas outras mulheres do campo. Ela mora no interior do município de São Francisco de Paula - que fica no Rio Grande do Sul (Figura 1), o estado mais ao sul do Brasil numa localidade rural chamada Pai Bitu (Figura 2). A tia Maria Isabel, no entanto, representa as camponesas do interior brasileiro que trabalham arduamente, de lua a lua, todos os dias da semana, para sustentarem a si mesmas e aos filhos e filhas. Os feitos delas apesar de serem encarados como simples, triviais, por muitos - ainda são fantásticos, grandiosos. Pelo menos para mim.

Figura 1: A letra A indica o estado do Rio Grande do Sul. A letra B apresenta o nordeste do estado. Já a letra C apresenta a região onde se encontra a pequena localidade do Pai Bitu.

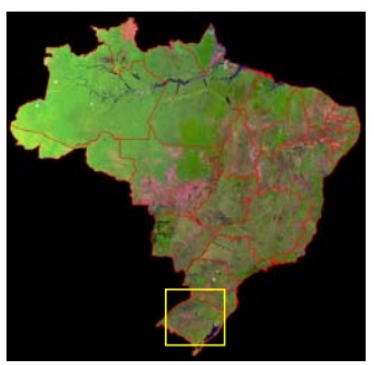

A

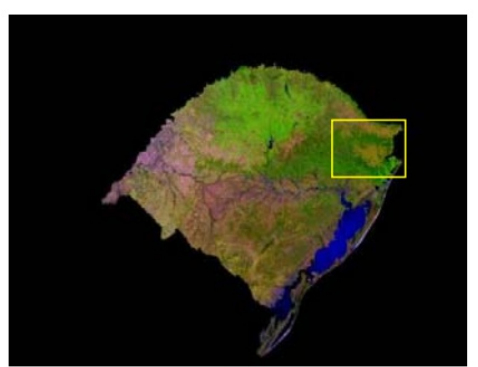

B

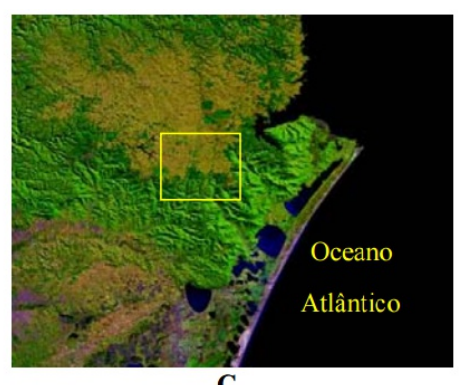

C

Fonte: EMBRAPA, 2004.

Figura 2: Mapa do município de São Francisco de Paula e a indicação da localidade do Pai Bitu.

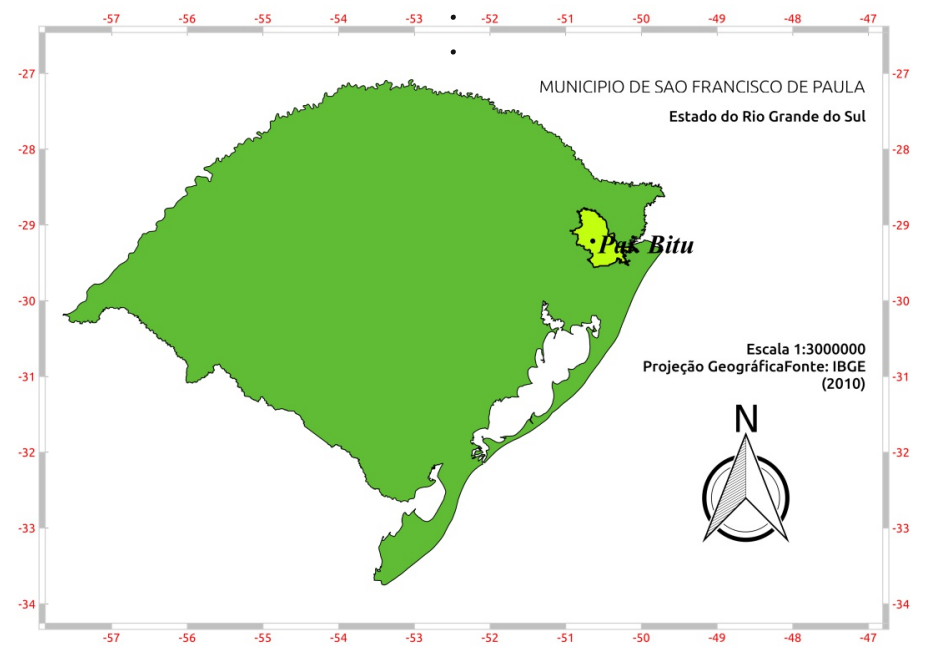

Fonte: (GONÇALVES, 2015). 


\section{O Memorioso}

O que quis demonstrar na história que inaugura o capítulo é que a memória, devido ao seu conteúdo fragmentado, nem sempre é precisa - quase nunca, diria. A própria fotografia em tonalidade sépia (Figura 3) é um registro que contribui para lembrar um instante que se passou. Mas o que aconteceu logo antes da fato ser tirada, ou imediatamente depois não há recordação. Justamente, porque a memória, em sua essência, é incompleta. Nessa incompletude, suas lacunas estão sempre sendo preenchidas. Além disso, ela é dinâmica, na medida em que um fato, por menor que seja, pode modificar completamente uma lembrança primeira. Em alguns casos extremados, até mesmo contradizê-la.uma lembrança primeira. Em alguns casos extremados, até mesmo contradizê-la.

Figura 3: A tia Maria Isabel dando de comer a uma de suas vacas leiteiras.

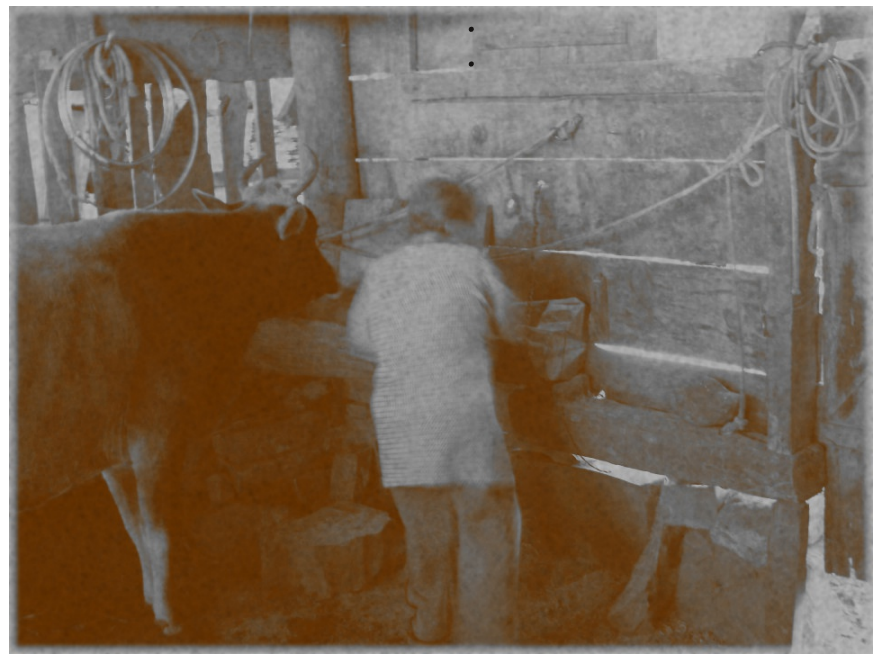

Fonte: (GONÇALVES, 2015).

Para o geógrafo e historiador David Lowenthal (1998) “o passado nos cerca e nos preenche; cada cenário, cada declaração, cada ação conserva um conteúdo residual de tempos pretéritos. Toda consciência atual se funda em percepções e atitudes do passado" (LOWENTHAL, 1998, p. 64). Somos formados por imagens e ideias que nos acompanham. É o legado que pavimentamos, gradativamente, ao longo da vida. 
Embora as escolhas nem sempre sejam conscientes, toda lembrança é seletiva. Essa afirmação justifica-se e consolida-se na medida em que estamos expostos, cada vez mais, à interação com um oceano de informações. Exceto para Funes, o memorioso, protagonista de um conto homônimo de Jorge Luis Borges que de tudo recordava, esquecer é nossa sina. Muito poucos, em sã consciência, gostariam de viver como Funes. Seria muito duro! Se não esquecêssemos, o presente seria sempre nossa tônica e, em consequência, não haveria passado, porque a razão de ser do passado, obviamente, é passar. Caso não se sucedesse, ficaríamos nos remoendo, aprisionados às amarguras que nos atormentariam. Sem digeri-las, dificilmente, seríamos capazes de seguir em frente. A vida só se torna suportável pela capacidade que exercemos de esquecer.

$\mathrm{O}$ personagem do escritor argentino sugere uma dimensão política da memória: ela é determinante para o domínio de um grupo sobre o outro, o controle sobre aquilo que se deve lembrar e tão importante quanto - o que pode ser esquecido. A partir de um passado fragmentado, que nos edifica, elegemos o que recordar pelo que fica mais conveniente para nós.

A preservação da memória que constitui nossa identidade manifesta-se desde o cuidado que temos e o esforço que fazemos para recordar e tomar conta do que é significativo para nós. Lowenthal (1998), aliás, fez a seguinte consideração sobre o assunto:

Uma consciência do passado mais completa envolve familiaridade com processos concebidos e finalizados, com recordações daquilo que foi dito e feito, com histórias sobre pessoas e acontecimentos - coisas comuns da memória e da história. (LOWENTHAL, 1998, p. 65)

Sendo assim, toda consciência do passado está fundamentada na prerrogativa e na manifestação da memória. Lowenthal diz que é pelas lembranças que "recuperamos consciência de acontecimentos anteriores, distinguimos ontem de hoje, e confirmamos que já vivemos um passado" (LOWENTHAL, 1998, p. 75). Acontecimentos passados necessitam da comparação com $O$ presente para se manifestarem, assim como comparamos as paisagens 
atuais com aquelas de nossa recordação. Faz-se necessário ao presente, portanto, as referências do passado para que se consolide como o aqui e o agora.

A partir de uma leitura geográfica, o espaço é conditio sine qua non para o desenrolar do tempo. A memória, assim, é determinada tanto pelo espaço quanto pelo tempo em igualdade de condições, ou melhor, pela amálgama de ambos. Antes de chegarmos a uma já renomada compressão do espaço-tempo, devemos refletir por uma compressão em espaço-tempo. Como argumenta a geógrafa Doreen Massey (1999), ao "considerar a temporalidade/história como genuinamente aberta é que a espacialidade tem que ser integrada como uma parte essencial deste processo da 'contínua criação de novidade”" (MASSEY, 1999, p. 274, tradução do autor).

Doreen Massey (2008), em Pelo Espaço, avança nessa discussão ao analisar o debate que teóricos, como a filósofa belga Isabelle Stengers, multiplicam sobre a teoria da complexidade e a ciência. Ela sublinha a supervalorização da relação entre contexto e memória com suas referências históricas.

Realçar a espacialidade de nossos passados e geografia de nossas histórias - a dispersão de nossos próprios selves - inclui uma interpretação com mentalidade mais aberta, na qual todas essas coisas são, necessariamente, por e através de contatos, relações e interconexões com outros. (MASSEY, 2008, p. 189)

Não que esses referenciais históricos sejam equivocados. Contudo, eles se expressam de modo inacabado, pois "memórias e contextos são também espaciais". Portanto, para uma leitura mais completa e complexa, temos de acrescentar às ideias de "passados e histórias" as noções de "alhures" e, além do mais, "geografias" (MASSEY, 2008, p. 188-189).

A memória, por meio de seu contexto, se faz em conjunto: acumulação de tempos em sobreposição a espaços. Assim, podemos nos defrontar com passados remotos e tempos recentes em lugares contíguos e distintos. A conjugação desses componentes nem sempre se dá de maneira dócil. Muito pelo contrário! Variadas vezes, isso se dá pelo conflito. Quando a novidade tenta se estabelecer, há uma 
reação do antigo. Em muitos casos, a novidade se estabelece de forma lépida e feroz. No entanto, quanto maior for a reação do antigo, mais conflitiva será a coexistência de ambos.

Certa feita, no ano de 2011, fui ao Pai Bitu para comemorarmos o aniversário da tia Belinha. Fazia uma década que não a via. Passaram-se 10 anos desde a última vez que estive por lá. As recordações de tudo, confusas, iam se reorganizando, aos poucos, à medida que me aproximava daquelas bandas. A própria estrada e uma que outra porteira davam a sensação de familiaridade - como se fossem um quebra-cabeça com o qual há muito eu brincara - que ia, aos poucos, se remontando ao longo do trajeto.

Não tinha expectativas de como aquele lugar, que fizera parte de minha infância, poderia estar. $\mathrm{Na}$ verdade, esperava encontrá-lo exatamente igual como o deixara. Logo lá, onde eu passava as férias escolares de verão, entre as casas de tios e primos, numa peregrinação que estreitava os vínculos familiares. Não pensava na possibilidade de que tudo também poderia estar diferente.

As transformações paisagísticas, no entanto, ocorreram muito mais velozes do que duram os tempos dos ciclos da natureza. Nesse sentido, a intervenção foi tanta que mal reconheci o Pai Bitu da minha família. O quadro que as lembranças armazenaram não era nem um pouco igual àquele pintado nos dias de hoje.

Muito havia mudado por lá. Primeiramente porque, há cerca de 5 anos, a energia elétrica chegara àquelas casas. Não eram apenas os postes de luz que circundavam aquelas residências. A cultura do pínus disseminou-se maciçamente sobre o que antes eram pastos destinados ao gado leiteiro. A chegada dessa monocultura é o marco de aproximação da localidade com o modo de produção capitalista, que teve grande eficácia na reorganização do espaço pela silvicultura.

Além disso, as impressões que eu tinha da tia e daquelas paisagens não eram apenas minhas. Levava em consideração tudo que minha mãe contava. Atendia também às recordações de todas as 
outras pessoas à minha volta: meus irmãos maiores, meus tios e tias, primos e primas, que vivenciavam o lugar há mais tempo ou mais intensamente que eu.

$\mathrm{O}$ que faz as pessoas de um grupo se identificarem umas com as outras é a quantidade de lembranças em comum que elas se permitem compartir. Quanto maior for esse número de recordações, desencadeada pelo contato entre essas pessoas, maior será o vínculo que as relacionam entre si. Tempo e espaço são imprescindíveis para o resgate de lembranças e, também, para a convivência - que cintila as lembranças de hoje e que as produzirá mais ainda no futuro.

O sociólogo Maurice Halbwachs (2003) salienta a relação entre os indivíduos e os grupos aos quais eles pertencem para a produção da memória:

O primeiro testemunho a que podemos recorrer será sempre o nosso. Quando dizemos: "não acredito no que vejo", a pessoa sente que nela coexistem dois seres - um, o ser sensível, é uma espécie de testemunha que vem depor sobre o que viu, e o eu que realmente não viu, mas que talvez tenha visto outrora e talvez tenha formado uma opinião com base no testemunho de outros. Assim, quando voltamos a uma cidade em que já havíamos estado, o que percebemos nos ajuda a formar um quadro de que muitas partes foram esquecidas. (HALBWACHS, 2003, p. 29)

O discípulo de Durkheim aponta para a participação do indivíduo em dois tipos distintos de memória: primeiro, aquela em que "suas lembranças teriam lugar no contexto de sua personalidade e de sua vida pessoal”. Essa forma de memória seria capaz, em certos momentos, "de se comportar simplesmente como membro de um grupo que contribui para evocar e manter lembranças impessoais, na medida em que estas interessam ao grupo" (HALBWACHS, 2003, p. 71).

Embora julguemos que muitas de nossas recordações, em sua essência, sejam individuais, elas só têm razão de ser e recebem a devida importância porque são, acima de tudo, coletivas. De modo geral, dificilmente há memórias que sejam completamente pessoais e que não estejam inscritas numa coletividade. A memória coletiva é a 
outra tipologia apresentada por Halbwachs. Para ele, nossas recordações de cunho mais individual estão estrategicamente posicionadas no que ele chama de "encruzilhada das redes de solidariedade múltiplas em que estamos envolvidos” (HALBWACHS, 2003, p. 12).

Tanto a memória individual quanto a memória coletiva são elaboradas pela contínua negociação. No entanto, é necessário convir que ambas formam um todo inseparável, como as duas faces de uma mesma moeda. Enquanto uma se manifesta, a outra se dissipa. Mesmo assim, em maior ou menor medida, ambas estão expressas.

No primeiro plano da memória de um grupo se destacam as lembranças dos eventos e das experiências que dizem respeito à maioria de seus membros e que resultam de sua própria vida ou de suas relações com os grupos mais próximos, os que estiveram mais frequentemente em contato com ele. As relacionadas a um número muito pequeno e às vezes a um único de seus membros, embora estejam compreendidas em sua memória (já que, pelo menos em parte, ocorreram em seus limites), passam para o segundo plano. (HALBWACHS, 2003, p. 51)

Minha mais tenra lembrança da casa da tia Maria Isabel é de quando eu tinha por volta de 4 ou 5 anos de idade. Eu acordava de madrugada, lá pelas $4 \mathrm{~h}$ da manhã, e exigia que me deixassem andar a cavalo, dizendo: "Quero andar 'de a' cavalo. E é de agora! E é de agora!”. Certamente, essa lembrança tenha ficado mais vívida, porque, todas as vezes que visitávamos a tia, ela a reforçava. Ela sempre fazia questão de recordar essa história. Isso constituiu tanto a minha quanto a memória do grupo da família.

Não só as pessoas são centrais para a propagação dessa anedota familiar. A paisagem também o é. A história aconteceu numa casa específica, e era naqueles campos em volta dela que eu queria correr a cavalo, visitando cada ponto que eu tinha deixado de explorar no dia anterior. Sem os atores e a paisagem, certamente o enredo desse filme teria sido completamente diferente. Essa recordação não teria sentido algum de ser armazenada e se perderia em meio a tantas outras recordações mais marcantes. 
Objetos e lugares são, também, elementos principais da conformação de nosso corpo de memórias. A grande maioria de nossas lembranças - se não todas - está vinculada a uma imagem, sobretudo na atualidade, devido à onipresença dessa. Nas vezes em que nos lembramos de alguma abstração, em muitos casos pensamos na palavra escrita que a corresponde. Essa legenda nos confere uma referência, algo que recordar. Os objetos se configuram nesses referenciais visuais que se presentificam em nossas retinas quando nos empenhamos em refletir sobre o passado.

Assim, os objetos - esses espaços diminutos -, quando significativos para nós, tornam-se "de estimação". Uma fotografia, por exemplo, mais do que ser um objeto (estimado), é ainda um espaço, ou melhor, a captura - baseada em técnicas de obtenção de imagens por meio da exposição à luminosidade - de um segmento dele, uma paisagem, mais uma peça desse grande quebra-cabeça que convencionamos chamar, de modo geral, espaço.

Fala-se muito em fluidez do tempo e compressão do espaço nos dias de hoje, que só são possíveis pela velocidade das informações e pela automação do cotidiano. Essa liquidez da vida, no entanto, não é absoluta, porque tão importante quanto o que passa é o que permanece, ou, como preferia Milton Santos (2006), os fluxos e os fixos. Esses, "fixados em cada lugar, permitem ações que modificam o próprio lugar”. Já “os fluxos são um resultado direto ou indireto das ações e atravessam ou se instalam nos fixos, modificando a sua significação e o seu valor, ao mesmo tempo em que, também, se modificam" (SANTOS, 2006, p. 38).

Logo, a fotografia ampara a memória nesse processo de liquefação de lembranças ao qual as vidas de hoje estão sujeitas. Ela vem assumir uma funcionalidade importante no auxílio à recordação. Essa prática é necessária justamente porque estamos expostos a um sem-fim de informações. Assim, elegemos quais são as informações mais significativas pelas quais passamos e as registramos de alguma forma, quer seja pela escrita, ou por uma imagem. A fotografia, portanto, produz fixidez ao que é efêmero. 
Talvez muitos hoje tirem mais fotos em um dia do que minha tia tirou ao longo de toda a vida - do que os pais delas, certamente. As fotografias que eles batiam, por exemplo, eram dos momentos sublimes da vida: do casamento ao nascimento dos filhos. "Bater um retrato", não era algo acessível. Constituía-se em um ritual familiar. Tanto que as fotos mais comuns encontradas eram o registro que se tinha disponível da composição familiar: todos perfilados em frente a casa, apresentando a família à sociedade.

Outro desdobramento importante é que recordar é, também, repetir. Toda recordação, no entanto, é um fragmento do pretérito. Logo, cabe ao recordante colar esses estilhaços e reconstituir o vitral do passado, na clara intenção de presentificar esse mosaico socioespacial. $O$ preenchimento das brechas que dificultam nossa realização se dá pelo empenho intelectivo, solucionado por meio do processo narrativo.

Nesse sentido, o geógrafo e historiador Alberto Lins Caldas (2006) prima pela ousadia e autenticidade na concepção a seguir:

Para nós a memória é uma composição, é um momento narrativo, é momento textuali determinada ordem "escolhida", certa maneira de ler e dizer a experiência com e no vivido: é a experiência singular do sujeito ao dizer-se em movimento e relação; é a ficção segunda de uma vivência entre as ficcionalidades do mundo social: é a maneira singular de dizer e ordenar essas ficcionalidades; a memória é relação; como momento textual não é nem o passado nem uma narrativa definitiva; é um momento do sujeito que se traduz em ordem narrativa, em ordem de palavras e sentidos. (CALDAS, 2006, on-line)

Portanto, a memória está mais para um entrecruzar de lembranças, que nos fazem ancorar para a posteridade o que de fato é significativo para nós, do que um arquivo-morto em que jogamos ao acaso nossos resquícios recordativos. Estabelecida entre a conexão de elementos psíquicos - como os sentimentos e as sensações - e o processo narrativo, as lembranças são o legado com o qual a vida nos presenteia, e juntas formam nossa substância. Essa herança, de tão multidirecional, é ao mesmo tempo generalizada e particular. Sua síntese é a minha, a nossa, a síntese de minha tia; constitui a narrativa vivaz que nos corporifica. 
Ecléa Bosi (2012), ao analisar os estudos sobre memória do filósofo Henri Bergson, afirma que uma de suas grandes contribuições foi entender que a articulação entre passado e presente - ou melhor, entre presente e passado, pois é desde hoje que nos apropriamos de ontem - faz-se por meio da "confluência da memória e da percepção” (BOSI, 2012, p. 49).

O sociólogo Maurice Halbwachs (2003) adverte para a questão dos sentimentos e, ainda, dos sentidos na mediação e na constituição de nossas lembranças:

Diferente das reflexões, ou das ideias, as percepções enquanto percepções - limitam-se a reproduzır os objetos exteriores, não contêm nada mais do que esses objetos e não podem nos conduzir além deles. Daí a conviçção (temos de admitir) de que elas șerviram unicamente para nos deixar em determinada disposição física e sensivel, favorável ao reaparecimento da lembrança. Pressupomos então que não tendo sido reconstruída, mas evocada, a lembrança teria sido guardada assim mesmo em nosso espírito. No entanto, o certo e que o único meio de preencher essa lacuna da nossa memória seria retornar a esse local, abrir os olhos. (HALBWACHS, 2003, p. 53-54)

A ligação estreita entre sentimento, paisagem e memória define por que nos recordamos de determinados detalhes enquanto outras pessoas se recordam de outros detalhes do mesmo acontecimento. Quanto maior a proximidade entre as pessoas, maior é a chance de terem lembranças similares, justamente porque há um maior número de sentimentos - e paisagens - em comum entre essas pessoas.

\section{O Ronco do Bugio}

A expressão paisagem sempre conduz meus pensamentos na direção de um quadro. Não apenas aqueles que ficam pendurados, imóveis, nas paredes dos museus ou até mesmo de nossas casas, mas também aqueles na moldura da janela, um quadro vivaz, pintado e retocado todas as manhãs. Desde idos tempos, quando frequentava o Pai Bitu nas férias escolares, tenho essa impressão. Vez que outra, 
voltam à minha retina as cenas da janela do velho rancho da tia Belinha. A madeira antiga, porém livre da praga do cupim, emoldurando a figueira. Até hoje parece que uma nesga de sol de verão vence sua copa e transpassa a veneziana para ofuscar-me a mirada. O aroma dos frutos da árvore arrebatando o recinto. Os mais que maduros se indo ao chão, com o intuito de pintar de um roxo quase negro o jardim. Alguns nutriam as aves, sobretudo os beija-flores - de voos desassossegados, assim mesmo, sincopados e elegantes. Outros figos, descerrados, expondo suas vísceras de semente e polpa, seguiam o contínuo vital, fertilizando o pé de onde provinham. A boca se agita em saliva ao recordar o açúcar da figada, acompanhado pela parceria marcante do queijo, que destacava o sabor do doce, apurado pacienciosamente no toque da colher de pau - esse prolongamento da mão - no fundo do tacho de cobre, em um ritual antigo e hereditário, que vai se dissipando com os arroubos do vento serrano. Causava-me espanto a agonia dos bugios na mata. Aqueles gritos de baixo tom, que repercutiam a léguas, pareciam ser proferidos lá de dentro da cozinha. Procurava com o olhar a lateral do fogão a lenha. Espremia as pálpebras, evitava o contato. Cruzava os braços no afã de proteger as mãos agora trêmulas (sempre as mãos). Talvez se escondessem em outro canto da casa. Seus grupos sempre faziam questão de me assombrar às noites. Nunca os víamos, imaginava-os seres extraordinários, como um grifo ou uma quimera, que a qualquer momento alçaria voo e faria queimar a casa com seu hálito flamejante. A tia dizia que esses macacos de pelos ruivos são bichos bons, afinal de contas, eles chamam a chuva. Quem vive no campo entende o real valor da chuva.

Afinal, o que é paisagem? A fotografia (Figura 4) pode ser considerada uma paisagem? Mesmo que a imagem tenha sido editada utilizando um filtro para parecer uma pintura a óleo. 
Figura 4: A tia Maria Isabel dando de comer à sua vaca leiteira .

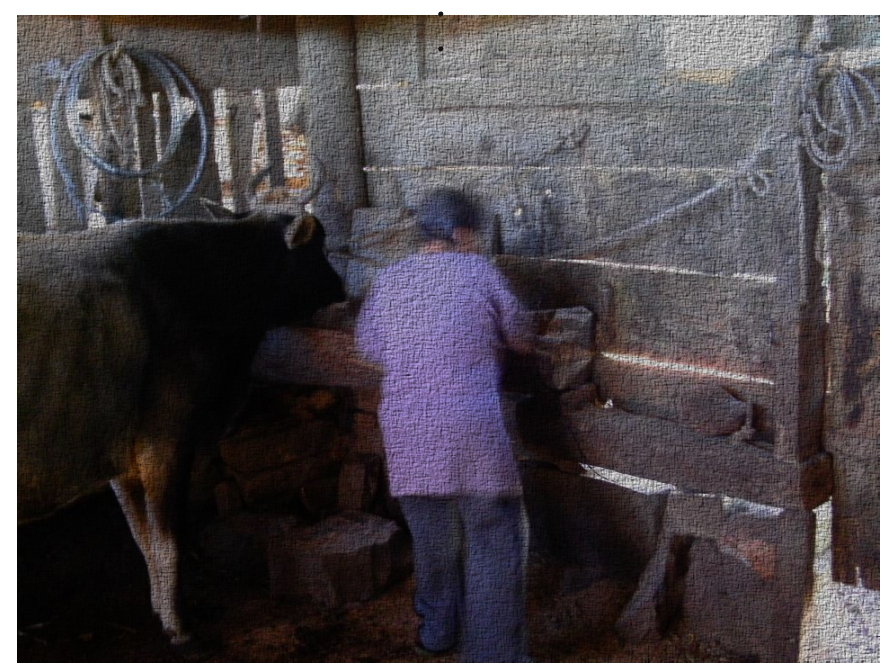

Fonte: (GONÇALVES, 2015).

Das temáticas mais significativas e polissêmicas da Geografia, a paisagem foi considerada um conceito-chave para a constituição da disciplina desde sua origem. Presente em diversas ciências e no linguajar cotidiano, ela nos remete, frequentemente, ao campo visual. O Míni Dicionário Aurélio de Língua Portuguesa traz as seguintes definições para o verbete (FERREIRA, 2010, p. 557):

1. Espaço do terreno que se abrange num lance de vista;

2. Pintura, gravura ou desenho que representa uma paisagem.

As definições apresentadas no dicionário indicam a delimitação da paisagem. A visão é o sentido que a baliza, na medida em que é delimitada pelo lance de vista, ou seja, ela vai (apenas) até aonde a "vista alcança". Nesse sentido, Roberto Lobato Corrêa e Zeny Rosendahl (1998) escrevem que a efetiva tarefa do geógrafo é "decodificar o significado da paisagem" (CORRÊA; ROSENDAHL, 1998, p. 11). Eles propõem, ainda, que essa tarefa não se restringe aos estudos geomorfológicos. As cidades e suas construções também devem ser abordadas e são importantes fontes paisagísticas de 
pesquisa, porque "afinal de contas, a paisagem, este objeto geográfico e portanto a Geografia, está em toda parte” (CORRÊA; ROSENDAHL, 1998, p. 11).

As definições deixam transparecer, também, como o conceito está fortemente vinculado à natureza. Há quem não distinga os termos paisagem e natureza, tratando-os como se sinônimos fossem. Há muito, ambos estão imbricados. A contemplação da natureza e a descrição minuciosa do observado era um modo predominante de fazer Geografia, desde os primórdios de sua constituição como ciência.

Carl Sauer (1998), na década de 1920, já alertava para essa problemática. Ao argumentar sobre a antiga Geografia, ele chegou à seguinte conclusão: "Ela era casualmente ou mesmo trivialmente descritiva em vez de crítica” (SAUER, 1998, p. 18). A crítica que se faz a essa Geografia primordial é, justamente, a falta de crítica, porque havia muito mais preocupações com descrever paisagens do que com entender o que nelas acontecia.

Para fugirmos dessa cilada conceitual, herança da Geografia, encaramos a paisagem, em seu conteúdo, nas inter-relações entre elementos naturais e culturais. Como natural entendemos o que é externo aos seres humanos e em que não há sua intervenção. Como cultural, tudo o que resulta das ações humanas. Tanto cultura quanto natureza estão, na maioria das vezes, presentes e compõem a paisagem como um todo.

Essas inter-relações, ao longo do tempo, concebem a paisagem como uma contínua pendência. A imagem dos prados verdejantes que recobriam um relevo de suave ondulado da localidade de Pai Bitu estava cristalizada no meu imaginário. Aquelas paisagens eram absolutas, ao menos em minhas lembranças. Não temos a noção, principalmente quando somos mais novos, de que tudo se transforma. É certo que algumas paisagens são muito mais suscetíveis a mudanças que outras. Mesmo assim, de um modo geral, ela está em constante movimento: a paisagem é uma roda que nunca para de girar. 
Jean-Marc Besse (2014) justifica que a paisagem é uma maneira de "ver e imaginar o mundo" (BESSE, 2014, p. 30). Ele diz, no entanto, que, antes de tudo, ela é uma realidade material e objetiva que é produzida pelos seres humanos. Eis aí o destaque ao papel da humanidade na apreensão da paisagem. Besse entende que “toda paisagem é cultural, não essencialmente por ser vista por uma cultura, mas essencialmente por ter sido produzida dentro de um conjunto de práticas (econômicas, políticas, sociais), e segundo valores que, de certa forma, ela simboliza” (BESSE, 2014, p. 30).

Não há intenção, com este texto, de contrapor os elementos naturais e culturais e averiguar qual seria o mais significativo para a Geografia. A meu ver, essa seria uma discussão, do ponto de vista epistemológico, de pouca valia. Com efeito, a abordagem de paisagem que busco é justamente a síntese entre os elementos culturais e naturais. Entendo que a pessoa da tia Belinha ou o trabalho na ordenha que ela desempenhava são tão paisagem quanto o gado pastando, as araucárias, os campos, as coxilhas, entre outros, que formam os quadros pretéritos que constituíram as características paisagísticas do Pai Bitu de hoje.

Besse preanunciou o papel da leitura da paisagem a partir de nossa percepção. Essa se entende, à maneira de Milton Santos (1994), como "um processo seletivo de apreensão da realidade" (SANTOS, 1994, p. 62). Sob o guarda-chuva da percepção, estão tanto nossos cinco sentidos quanto as emoções que nos acompanham no momento e ao longo da vida. O geógrafo brasileiro enfatiza essas características perceptivas ao propor que "se a realidade é apenas uma, cada pessoa a vê de forma diferenciada; dessa forma, a visão pelo homem das coisas materiais é sempre deformada" (SANTOS, 1994, p. 62).

Por menor que seja o contato com aquilo que nos é externo, a interação é uma forma de deformamos aquilo ou aquele a quem estamos a perceber. Apenas o olhar, por exemplo, é suficiente para que isso ocorra, porque essa chamada deformação é uma interpretação, ou seja, o modo como lemos o que se sucede ao nosso entorno. 
Aliás, seria a paisagem apenas a dimensão do visível? Se assim o fosse, um cego estaria fadado, para todo o sempre, a não poder interagir com a paisagem que o circunda. Apesar de a visão preponderar - nos dias de hoje, muitas vezes sufocar - os outros sentidos, também os utilizamos para lermos os contextos nos quais estamos inseridos. O cheiro de pão feito em casa e o gosto de goiabada com queijo me fazem viajar de volta ao fim dos anos 1980; em um piscar de olhos, estou sentado à mesa da tia, pronto para o café da manhã. O ronco do bugio na mata, certamente, é um componente de importância para a paisagem dos serranos (e amedrontador para mim, quando na infância).

Assim, podemos utilizar o mesmo que Caldas (2006) citado anteriormente - atribuiu para memória, apenas substituindo esse termo por paisagem: aqui a paisagem “é uma composição, é um momento narrativo, é momento textual; determinada ordem 'escolhida', certa maneira de ler e dizer a experiência com e no vivido: é a experiência singular do sujeito ao dizer-se em movimento e relação" (CALDAS, 2006, on-line).

Como um livro, a paisagem também necessita ser lida. Apenas leitura, no entanto, não é suficiente para uma compreensão mais integral dos fenômenos que se quer investigar. Carecemos, também, de interpretá-los. Por interpretação, entendo o modo como representamos esse livro-paisagem que chega ao alcance de nossas mãos. Santos (1994) ressalta o caráter provisório dessa narrativa paisagística da seguinte forma: "uma paisagem é uma escrita sobre a outra, é um conjunto de objetos que têm idades diferentes, é uma herança de muitos diferentes momentos" (SANTOS, 1994, p. 66).

Augustin Berque, nesse sentido, traz uma contribuição bastante significativa ao abordar as questões paisagísticas:

A paisagem é uma marca porque expressa uma civilização, mas também é matriz porque participa dos esquemas de percepção, de concepção e de ação, ou seja, da cultura, os quais canalizam a relação de uma sociedade com o espaço e com a natureza. (BERQUE, 1998, p. 78) 
Essa perspectiva abarca tanto a dimensão concreta da paisagem, ou seja, suas marcas no tempo e no espaço, quanto seu caráter simbólico, evidenciado na percepção que cada um tem sobre o mundo. A marca, portanto, é como a memória inscreve-se na paisagem. A matriz se dá no modo como lidamos quando entramos em contato com essa paisagem, que vem se constituindo ao curso do tempo e ao longo do espaço.

Kathryn Woodward (2000) chama a atenção para o papel da representação nessa trama, que outorga sentido à experiência e identidade, ao compor sistemas simbólicos presentes e perspectivos. Ela indica que os sistemas simbólicos "tornam possível aquilo que somos e aquilo no qual podemos nos tornar" (WOODWARD, 2000, p. 17). Assim, Woodward destaca o papel da identidade na representação. Apesar de ela não tratar de paisagem em seu texto, a aplicação dessa ideia ajusta-se perfeitamente ao modo como representamos os elementos paisagísticos.

A identidade, aliás, se constrói a partir do sentimento e da vivência. São esses que mediam o querer e o necessitar pertencer a determinado grupo. $\mathrm{O}$ desejo que liga as pessoas e as faz sentirem-se parte de algo é um elemento fundante da formação identitária. A identidade se estabelece a partir da semelhança entre as pessoas de um grupo, que se aproximam de acordo com suas características comuns - que podem ser tanto afinidades físicas quanto culturais, ou ambas.

A identidade é reflexiva. A "consciência de si” é o primeiro passo para sua constituição. No entanto, a identidade é marcada, sobretudo, pela diferença, que se estabelece pelo que Kathryn Woodward chama de uma "marcação simbólica relativamente a outras identidades” (WOODWARD, 2000, p. 14). Essa distinção está estreitamente ligada às formas como existimos em sociedade. $\mathrm{O}$ caráter relacional faz da identidade algo mais complexo do que se imagina, na medida em que essas vinculações estabelecem-se de indivíduo para indivíduo e do indivíduo para com os grupos a que ele pertence. 
Woodward (2000), ainda, ressalta que à identidade estão vinculadas, ainda, condições tanto sociais quanto materiais. São essas condições que permitem a identificação e qualificação do outro. "Se um grupo é simbolicamente marcado como o inimigo ou como tabu, isso terá efeitos reais porque o grupo será socialmente excluído e terá desvantagens materiais" (WOODWARD, 2000 p. 14).

Por sua vez, Doreen Massey destaca o conteúdo geográfico da representação:

É fácil ver como a representação pode ser compreendida como uma forma de espacialização - aquela tarefa de dispor coisas lado a lado; certamente a produção de uma simultaneidade, uma multiplicidade discreta. (Nesta base o espaço também seria fácil de representar, se o espaço fosse apenas isto). (MASSEY, 2008, p. 53)

A disposição pressupõe o modo como os objetos estão ordenados, ou seja, como a ordem se estabelece entre eles. Certamente, esse fato tem uma influência decisiva tanto na organização do espaço, na continuidade dessa lógica ou em sua superação, quanto na própria condição social que vigora. Ampliando essa argumentação, podemos dispor as pessoas em papéis socioespaciais diferenciados. Essa disposição, inclusive, dar-se-á no modo como elas representam e se apropriam de seus corpos.

A arte é um ótimo modo de expormos essas representações. Sensíveis a perspectivas e atentos às minúcias mais singelas, os artistas criam em suas obras novas concepções estéticas a partir das percepções que têm sobre o corpo e, também, sobre a paisagem. A pintura ressalta significativamente a leitura que o artista ou a artista faz das experiências que vive. Assim como a fotografia, a pintura também é uma expressão artística obviamente pensada, porém ela é resultado de uma ação manual, isto é, um quadro é concretizado pela utilização das mãos. Elas são as ferramentas de trabalho do e da artista. Elas são as ferramentas de todo trabalho.

O renomado pintor modernista Cândido Portinari faz - em seu quadro intitulado Café, concluído no ano de 1935 - uma leitura muito significativa da paisagem e do papel das mãos nas lavouras cafeeiras brasileiras do fim do século XIX e início do XX. 
Ao analisarmos a obra (Figura 5), percebemos como os corpos dos personagens são ressaltados: o jogo de sombras os confere volume aos pés e, sobretudo, às mãos. Os trabalhadores transformam seus corpos a partir do peso dos sacos de café. Essa grandeza transmite a ideia que eles são superutilizados. As mãos, além dos pés, são exageradamente grandes em relação ao restante da estrutura corporal. O próprio conceito utilizado para esses trabalhadores indica como eles eram aproveitados nas colheitas: mão de obra.

Figura 5: Café, de Cândido Portinari (1935). Pintura a óleo sobre tela de tecido com 1,30 $\mathrm{m}$ de altura por 1,95 $\mathrm{m}$ de largura.

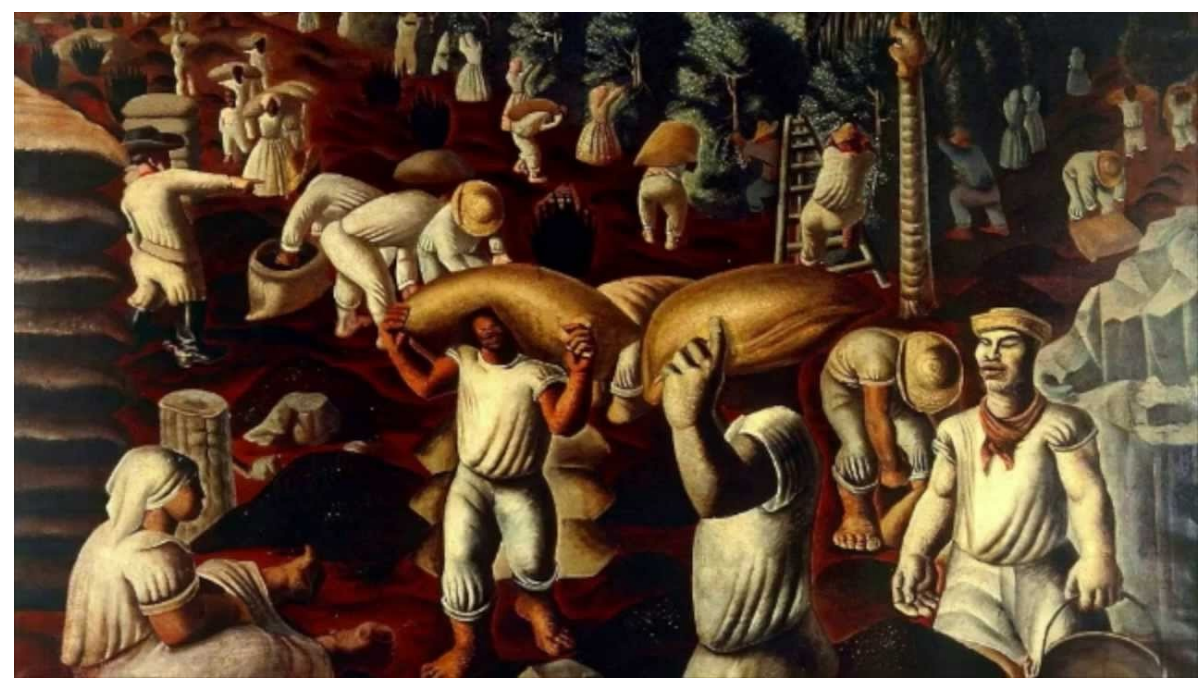

Fonte:www.portinari.org.br.

A tela, ainda, indica a divisão do trabalho na lavoura: enquanto uns colhem, alguns ensacam e outros carregam o café. Portinari deixa transparecer seu compromisso social ao retratar os trabalhadores escravizados. Ao representá-los como os personagens principais, em uma de suas obras-primas, ele demonstra como era difícil o cotidiano trabalho na lavoura cafeeira.

Além da divisão do trabalho, também há uma representação de gênero, pois homens e mulheres são retratados. Tanto o gênero quanto o trabalho estão intrinsecamente ligados. Os homens são os principais carregadores das sacas de café colhidas, em sua maioria, 
pelas mulheres, como se verifica pelas roupas utilizadas, no plano de fundo do quadro. Carregadores e ensacadores estão em destaque, em primeiro plano na obra.

À primeira vista, a obra chama atenção pela desproporcionalidade das mãos dos trabalhadores em relação ao restante dos seus corpos. Toda análise que se fizer a partir disso estará condicionada a essa impressão primeira. Ela expressa a intervenção das mãos humanas na transformação da paisagem. Café é uma paisagem feita por e para as mãos.

\section{A Pele que Ela Habita}

O tarro está, cada vez mais, pesado. O tio pega de um lado, a tia de outro. Soltam o tarro. Ela derrama o coagulante. Vão para a lavoura. Ela retorna. Põe a pasta coalhada dentro do saco de linho branco e amassa. O soro escorre. As bordas da mesa queijeira orientam todo o líquido para um balde, cujo destino é servir de alimento aos porcos. Sova tanto que apenas resta uma massa branca dentro do saco. Preenche o conteúdo da forma. Posiciona-a sob um braço de madeira de metro e meio, preso à parede, que atravessa a mesa no sentido do comprimento. Segura na alça, feita de vergalhão de aço de construção, de um cubo de $30 \mathrm{~cm}$ de puro granito. Suspende o peso, que comprime os joelhos, a coluna e os ombros. $\mathrm{O}$ toque na haste metálica se assevera. As mãos estremecem ao suportála. O passar gradativo dos anos rouba disposição, assim como um moleque travesso rouba frutas do pátio do vizinho. Prende o cubo no sulco da extremidade do bastão. Aguarda a carga escoar os últimos resquícios de soro da massa. Hesita na descida. Retira da forma. Leva a produção para uma despensa do galpão. Lá, secam, em prateleiras suspensas, inúmeros queijos serranos. Do mesmo formato $(15 \mathrm{~cm} \times 20 \mathrm{~cm} \times 10 \mathrm{~cm})$ e com cerca de $1 \mathrm{~kg}$ cada, com as faces convexas. Aos fins de semana, o tio ia comerciá-los nos mercadinhos da cidade. 
Entre todos os sentidos, para a tia Belinha, o mais importante em seus afazeres diários era o tato. Ela não trabalhava sem tocar os objetos. A ordenha, a fabricação do queijo, o plantio na lavoura são, sobretudo, manuais. Indispensável é o contato com a pele. Sem o toque não haveria leite, queijo, hortaliças e todas as outras realizações de uma vida inteira. Por issso mesmo, a Fotografia (Figura 6) procura destacar a importância da sensibilidade do corpo da Maria Isabel na paisagem do galpão e, sobretudo, nas lides cotidianas.

Figura 6: A tia Maria Isabel dando de comer à sua vaca leiteira .

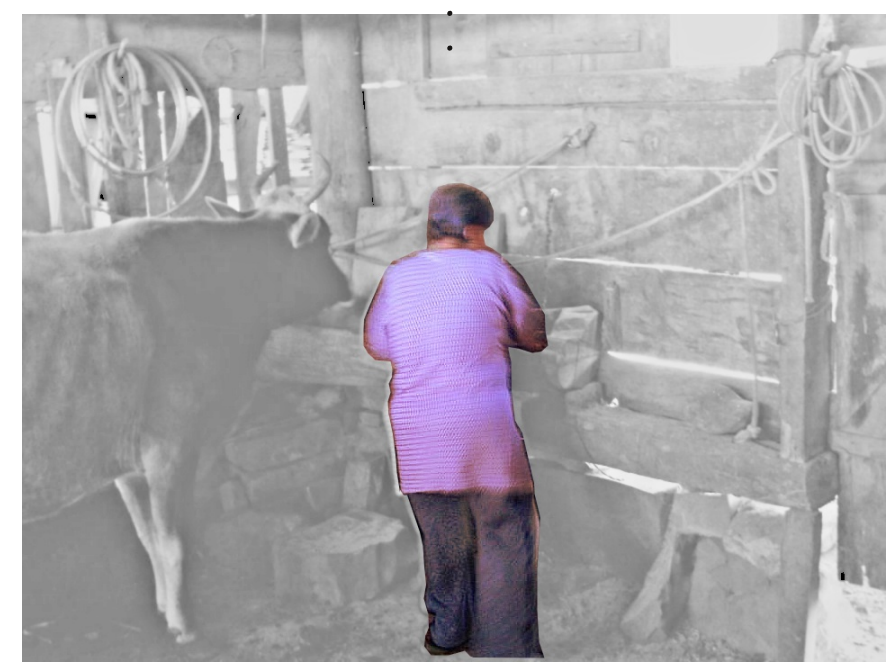

Fonte: (GONÇALVES, 2015).

Entre todos os sentidos, para a tia Belinha, o mais importante em seus afazeres diários era o tato. Ela não trabalhava sem tocar os objetos. A ordenha, a fabricação do queijo, o plantio na lavoura são, sobretudo, manuais. Indispensável é o contato com a pele. Sem a sensibilidade do toque não haveria leite, queijo, hortaliças e todas as outras realizações de uma vida inteira.

Aliás, não há trabalho sem tato. Mesmo o mais intelectual dos trabalhos exige o contato com a pele. Em sua execução, o trabalho sempre exige uma fase manual. As linhas a seguir não existiriam sem o uso das mãos (ou algo que, temporária ou permanentemente, as substitua). Neste exato momento, elejo as 
letras, toco teclas e digito palavras. Muitas e muitas, que vão seguindo num ritmo, muitas vezes, demasiado lento. Essa é, inclusive, a fase mais vagarosa, e trabalhosa, na elaboração deste texto.

Embora compartilhe a ideia de que o aspecto sensorial deva sempre ser abordado, não me restringi à expectativa tátil de nossas características epidérmicas. Vejo a pele como uma carapaça carregada de conteúdo social e que cada um de nós veste de acordo com a bagagem que sustenta. Além disso, se a pele é o contato imediato com as exterioridades, as mãos são nosso carro-chefe.

Abordo as mãos, portanto, como uma metonímia para o corpo. Esse é a instância mais básica de nossa vivência espacial; a condição para a interação com as dimensões que nos alicerçam no mundo. Para aonde, inclusive, todos os outros níveis do espaço, numa perspectiva escalar, convergem forças e influências. O corpo é o condicional para nos relacionarmos e apreendermos o que o mundo tem a nos oferecer. É por meio de uma existência corpórea que experienciamos, mediados pelos nossos sentidos, sentimentos e pontos de vista, o que nos envolve e nos engloba.

Aliás, as marcas corporais que ostentamos contam suas próprias histórias, compõem narrativas que se justificam em si mesmas. Cada ruga de nosso rosto ou cicatriz de nossas mãos é a memória do que passamos e experimentamos durante a vida. Também são aparências, (micro)paisagens às quais conferimos significação.

Apesar de constitutivos essenciais, não somos apenas carne e osso, reflexos e sensações. A leitura que se faz do corpo é fundamental para entendê-lo. Segundo Silvana Goellner (2013, p. 31):

O corpo é também a roupa, os acessórios que o adornam, as intervenções que nele se operam, a imagem que dele se reproduz, as máquinas que nele se acoplam, os sentidos que nele se incorporam, os silêncios que por ele falam, os vestidos que nele se exibem, a educação de seus gestos. 
Consideramos como extensão corporal tudo aquilo que usamos. Não apenas extensão física, mas também extensão de símbolos culturais e sociais. São marcas que emolduram nossa existência. Sendo assim, os adereços que levamos junto ao corpo e as vestes que o envolvem devem ser entendidos em seu conteúdo político, já que são escolhas dos padrões estéticos que representam o que somos e onde estamos.

Busquei neste texto enaltecer o que as mulheres têm a dizer, no que se refere às citações utilizadas. É no corpo que incidem as relações de poder que articulam as pessoas entre si e com o mundo, seria honesto de nossa parte ouvi-las. Assim como ouvir Michel Foucault (1987), ao propor que a política é uma das dimensões que mais marcas produz em nossos corpos:

As relações de poder têm alcance imediato sobre ele; elas o investem, o marcam, o dirigem, o supliciam, sujeitam-no a trabalhos, obrigam-no a cerimônias, exigem-lhe sinais. Este investimento político do corpo está ligado, segundo relaçôes complexas e recíprocas, à sua utilizaçẫo econômica; é, numa boa proporção, como força de produção que o corpo é investido por relações de poder e de dominação; mas em, compensação sua constituição como força de trabalho só é possivel se ele está preso num sistema de sujeição (onde a necessidade é também um instrumento político cuidadosamente, organizado, calculado e utilizado); o corpo só se torna força útil se é ao mesmo tempo corpo produtivo e corpo submisso. (FOUCAULT, 1987, p. 28)

Somos, portanto, constantemente classificados de acordo com nossos atributos corporais. Não era de graça que a tia sempre usava saia ou vestido. Não me lembro de tê-la visto trajando calças. A vestimenta frisava qual o papel dela no casal e na casa. Frisava, também, as atribuições que ela deveria exercer no dia a dia de trabalho.

Assim, cabia à tia cuidar da casa, lavar, passar, cozinhar, entre outros, além dos trabalhos manuais que exigiam maior delicadeza, como: fiar, coser, tricotar e tantas outras obrigações que estão dentro do cesto dos “afazeres domésticos". No entanto, boa parte das atividades que o tio desempenhava - embora em menor medida, devido ao tempo gasto nos cuidados com a casa - era 
compartilhada com ela: a própria ordenha, as lidas na lavoura e o trato com o gado. Essas eram as couraças sociais que ambos vestiam.

Tomar conta dos filhos era outra tarefa de exclusividade feminina. Foram três: duas mulheres e um homem. Como os dois maiores eram bem mais velhos que eu, haviam saído de casa. No meu imaginário infantil, não faziam mais parte daquela família, tampouco daquela paisagem.

As diferentes posições socioespaciais de gênero produzem distintas perspectivas. Certamente, a tia via o passar do dia mais de dentro de casa, que foi o espaço que circunscreveu a existência dela durante boa parte da vida. As paisagens de onde ela viveu produziam-se emolduradas pelos esquadros das janelas do velho rancho.

O modo como ela percebia o Pai Bitu era bem distinto do meu. Além do conflito de gênero, havia o problema da distância etária. Embora ainda exígua, eu levava uma bagagem de garoto da cidade da qual ela não dispunha. Havia, porém, uma semelhança: meu mundo era dependente do mundo de minha mãe. No caso dela, tinha de considerar o mundo dos filhos e marido.

Dentro daquela casa, a última alternativa da tia era sempre a Maria Isabel, porque ela, primeiro, era a esposa ou a mãe e, depois, se sobrasse tempo, era si própria. Consideradas o "sexo frágil", as mulheres apresentam outra força, a força da permanência, de se importar com o outro antes de si própria. Mesmo transcorridas algumas décadas dessas lembranças, a relação existente entre as famílias não se modificou muito - quer dizer, aos meus olhos, não se modificou como deveria. Tenho convicção em dizer: a tia Maria Isabel era muito forte!

Apesar de nos ter deixado em 2014, ainda hoje, quando bebo um copo de leite, comparo o gosto com aquele da caneca esmaltada que a tia me servia. Minhas retinas enuviam-se com a neblina que toma de assalto os campos, vejo-a sair da névoa, arrastando as chinelas de rua, a caminho do galpão. O som metálico da alça batendo no balde. Eu, querendo espiar... "As vaca esconde o 
leite, fío!”. No seio do Pai Bitu, não há mais leite. Entretanto, as memórias continuam a jorrar.

\section{Referências}

BERQUE, A. Paisagem-Marca, Paisagem-Matriz: Elementos da Problemática para uma Geografia Cultural. In: CORRÊA, R. L.; ROSENDAHL, Z.. Paisagem, Tempo e Cultura. Rio de Janeiro: EdUFRJ, 1998.

BESSE, J. O Gosto do Mundo: exercícios de paisagem. Rio de Janeiro: EdUFRJ, 2014.

BOSI, E. Memória e Sociedade: lembranças de velhos. 17. ed. São Paulo: Companhia das Letras, 2012.

CALDAS, A. L. Espaço e Experiência: História Oral e Geografia Humana. Revista Eletrônica Zona de Impacto, v. 8, Ano VIII, 2006. Disponível em:

< http://www.albertolinscaldas.unir.br/espacoexperiencia.htm > .

Acessado em: 20 fev. 2016.

CORREA, R. L.; ROSENDAHL, Z. Apresentando Leituras sobre Paisagem, Tempo e Cultura. In: CORRÊA, R. L.; ROSENDAHL, Z.. Paisagem, Tempo e Cultura. Rio de Janeiro: EdUFRJ, 1998.

FERrEIRA, A. B. H. Míni Aurélio: o Dicionário da Língua Portuguesa. 8. ed. Curitiba: Positivo, 2010.

FOUCAULT, M.. Vigiar e Punir: história do nascimento das prisões. Petrópolis/RJ: Vozes, 1987.

GOELLNER, S.. A Produção Cultural do Corpo. In: LOURO, G.; FELIPE, J.; GOELLNER, S. (Orgs.). Corpo, Gênero e Sexualidade: um debate contemporâneo na educação. 4. ed. Petrópolis: Vozes, 2013, p. 28-40. v.1.

HALBWACHS, M. A Memória Coletiva. Tradução de Beatriz Sidou. São Paulo: Centauro, 2003.

LOWENTHAL, D. Como Conhecemos o Passado. Projeto História. São Paulo, PUC-SP, n. 17, novembro 1998, p. 28-46.

MASSEY, D. Space-Time, 'Science' and the Relationship between Physical Geography and Human Geography. Transactions of the Institute of British Geographers, v. 24, n. 3, p. 261-276, set. 1999. 
. Pelo Espaço: uma nova política para a Espacialidade. Tradução de Hilda Pareto Maciel e Rogério Haesbaert. Rio de Janeiro: Bertrand Brasil, 2008.

PROJETO PORTINARI. Acervo. Disponível em: < http://www.portinari.org.br>. Acesso em: 10 abr. 2016.

SANTOS, M. Metamorfoses do Espaço Habitado: fundamentos teórico e metodológico da Geografia. São Paulo: Hucitec, 1994.

A Natureza do Espaço: técnica e tempo, razão e emoção. 4. ed. São Paulo: Editora da Universidade de São Paulo, 2006.

SAUER, C. O. Morfologia da Paisagem. In: CORRÊA, R. L.; ROSENDHAL, Z. (Orgs.). Paisagem, Tempo e Cultura. Rio de Janeiro: EdUERJ, 1998, p. 12-74.

WOODWARD, Kn. Identidade e Diferença: uma introdução teórica e conceitual. In: SILVA, T. T. (Org.). Identidade e Diferença: A Perspectiva dos Estudos Culturais. Petrópolis: Vozes, 2000, p. 7-72. 


\section{ÁLVARO LUIZ HEIDRICH}

Bacharel em Geografia, Doutor em Geografia, docente e pesquisador no Departamento de Geografia e no Programa de Pós-Graduação em Geografia da Universidade Federal do Rio Grande do Sul, Brasil

\section{ANA FRANCISCA DE AZEVEDO}

Bacharela em Geografia, Doutora em Geografia, docente e pesquisadora no Departamento de Geografia e no Programa de Pós-Graduação em Geografia da Universidade do Minho, Portugal, pesquisadora no Laboratório da Paisagem de Guimarães, Portugal

\section{BENHUR PINÓS DA COSTA}

Licenciatura em Geografia, Doutor em Geografia, docente e pesquisador no Departamento de Geografia e no Programa de Pós-Graduação em Geografia da Universidade Federal de Santa Maria, Brasil

\section{CAMILA XAVIER NUNES}

Bacharela em Geografia, Doutora em Geografia, pesquisadora no Grupo de Pesquisa em Produção do Espaço Urbano na Universidade Federal da Bahia, Brasil

\section{CLÁUDIA LUÍSA ZEFERINO PIRES}

Bacharela em Geografia, Doutora em Geografia, docente e pesquisadora no Departamento de Geografia e no Programa de Pós-Graduação em Geografia e pesquisadora no Núcleo de Estudos de Geografia e Ambiente da Universidade Federal do Rio Grande do Sul, Brasil

\section{CLEDER FONTANA}

Licenciado em Geografia e Filosofia, Doutor em Geografia, docente no Instituto Federal Rio Grande do Sul - IF RS, Brasil

\section{CRISTIANO QUARESMA DE PAULA}

Bacharel e Licenciado em Geografia, doutorando em Geografia na Universidade Federal do Rio Grande do Sul, Brasil 


\section{DAIANE DA SILVA ELLIAS}

Trabalhadora autônoma e liderança comunitária do Quilombo dos Alpes, Porto Alegre, Brasil

\section{DIRCE MARIA ANTUNES SUERTEGARAY}

Licenciada em Geografia, Doutora em Geografia Física, Professora Titular vinculada ao Programa de Pós-Graduação em Geografia e pesquisadora no Núcleo de Estudos de Geografia e Ambiente da Universidade Federal do Rio Grande do Sul, Brasil

\section{EDIPO DJAVAN DOS REIS GOERGEN}

Licenciado em História, mestrando em Geografia na Universidade Federal de Santa Maria, docente na Rede Municipal de Ensino em São Pedro do Sul, Brasil

\section{FLÁVIA R. DURGANTE}

Bacharela em Comunicação Social com habilitação em Jornalismo, mestranda em Geografia na Universidade Federal de Santa Maria, assessora de imprensa na Universidade Federal da Fronteira Sul, Campus de Chapecó, Brasil

\section{JANDERSON GONÇALVES}

Licenciado em Geografia, Mestre em Geografia, docente na Rede Municipal de Ensino em Porto Alegre, Brasil

\section{JOSÉ CARLOS CORRÊA RIBEIRO}

Bacharel e Licenciado em Geografia, Doutor em Geografia, docente na Rede Municipal de Ensino em Porto Alegre, Brasil

\section{JULIANA CUNHA COSTA RADEK}

Bacharela em Comunicação Social com habilitação em Publicidade e Propaganda, doutoranda em Geografia na Universidade Federal da Bahia, Brasil, e doutoranda em Intercultural Humanities na Jacobs University Bremen, Alemanha, pesquisadora no Grupo de Pesquisa em Produção do Espaço Urbano na Universidade Federal da Bahia, Brasil 


\section{KARINA REJANE DA SILVA ELLIAS}

Agente comunitária de saúde e liderança comunitária do Quilombo dos Alpes, Porto Alegre, Brasil

\section{LARA MACHADO BITENCOURT}

Bacharela em Geografia, pesquisadora no Núcleo de Estudos de Geografia e Ambiente da Universidade Federal do Rio Grande do Sul, Brasil

\section{LUCIMAR DE FÁTIMA DOS SANTOS VIEIRA}

Bacharela em Biologia e Geografia, Doutora em Geografia, pós-doutoranda em Geografia na Universidade Federal do Rio Grande do Sul, Brasil

\section{MARILIA GUIMARÃES RATHMANN}

Licenciada em Geografia, pesquisadora no Núcleo de Estudos de Geografia e Ambiente da Universidade Federal do Rio Grande do Sul, docente na Rede Municipal de Ensino em Porto Alegre, Brasil

\section{MARTA RODRIGUES}

Licenciada em Geografia e Planeamento, Mestra em Geografia em Planeamento e Gestão do Território pela Universidade do Minho; Doutoranda em Geografia, Department of Geography, University of Sheffield.

\section{MATEUS DOS SANTOS VIEGAS}

Bacharelando em Geografia e pesquisador no Núcleo de Estudos de Geografia e Ambiente da Universidade Federal do Rio Grande do Sul, Brasil

\section{MATHEUS EILERS PENHA}

Licenciando em Geografia e pesquisador no Núcleo de Estudos de Geografia e Ambiente da Universidade Federal do Rio Grande do Sul, Brasil

\section{NELSON REGO}

Bacharel em Geografia, Doutor em Educação, docente e pesquisador no Departamento de Geografia e no Programa de Pós-Graduação em Geografia da Universidade Federal do Rio Grande do Sul, Brasil 


\section{NOLA PATRÍCIA GAMALHO}

Bacharela em Geografia, Doutora em Geografia, docente e pesquisadora na Universidade Federal do Pampa, Campus de São Borja, Brasil

\section{RICARDO NOGUEIRA MARTINS}

Licenciado em Geografia e Planeamento, Mestre em Geografia ? Planeamento e Gestão do Território, pós-graduado em Políticas Comunitárias e Cooperação Territorial pela Universidade do Minho, e investigador em Geografia no Laboratório da Paisagem de Guimarães Portugal

\section{ROBERTO VERDUM}

Bacharel em Geografia, Doutor em Geografia, docente e pesquisador no Departamento de Geografia e no Programa de Pós-Graduação em Geografia da Universidade Federal do Rio Grande do Sul, Brasil

\section{ROSÂNGELA DA SILVA ELLIAS}

Presidente da Associação Quilombo dos Alpes, Porto Alegre, Brasil

\section{TAIANE FLÔRES DO NASCIMENTO}

Bacharela em Geografia, Mestre e doutoranda em Geografia na Universidade Federal de Santa Maria, Brasil

\section{TIAGO CAMPOS VIEIRA CARVALHO DA SILVA}

Licenciado em Cinema e Audiovisual pela Escola Superior Artística do Porto e Mestre em Comunicação, Arte e Cultura pela Universidade do Minho, Portugal

\section{WINNIE LUDMILA MATHIAS DOBAL}

Licenciada em Geografia e pesquisadora no Núcleo de Estudos de Geografia e Ambiente da Universidade Federal do Rio Grande do Sul, Brasil 


\section{Filiação}

Lab2PT, Escola de Arquitetura, Universidade do Minho, Azurém, 4800-058 Guimarães

\section{AGRADECIMENTOS}

Este trabalho tem o apoio financeiro do Projeto Lab2PTLaboratório de Paisagens, Património e Território - AUR/04509 com o apoio financeiro da FCT/MCTES através de fundos nacionais (PIDDAC) e o cofinanciamento do Fundo Europeu de Desenvolvimento Regional (FEDER), ref ${ }^{a}$ POCI-01-0145-FEDER-007528, no âmbito do novo acordo de parceria PT2020 através do COMPETE 2020 - Programa Operacional Competitividade e Internacionalização (POCI).

\section{Filiation}

Lab2PT, School of Architecture, University of Minho, Azurém, 4800-058 Guimarães, Portugal

\section{ACKNOWLEDGMENTS}

This work has the financial support of the Project Lab2PT Landscapes, Heritage and Territory laboratory - AUR/04509 with the financial support from FCT/MCTES through national funds (PIDDAC) and co-financing from the European Regional Development Fund (FEDER) POCI-01-0145-FEDER-007528, in the aim of the new partnership agreement PT2020 throught COMPETE 2020 Competitiveness and Internationalization Operational Program (POCI).

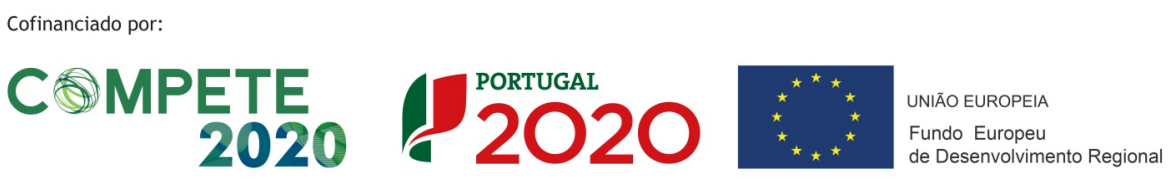

\section{FCT Fundação para a Ciência e a Tecnologia}

MINISTÉRIO DA CIÊNCIA, TECNOLOGIA E ENSINO SUPERIOR 
Essa obra foi editorada pela Editora Compasso LugarCultura em Porto Alegre. $\mathrm{Na}$ composição utilizou-se as fontes Garamond No8 e Candara. 
Geografias e (in)visibilidades busca demonstrar essa dialética entre visível e invisível, ou seja, revelar espaços geograficamente opacos e trazê-los à "luz" do conhecimento geográfico. Abrindo com isso a possibilidade de construir uma geografia que revele a multiplicidade, a diversidade e a desigualdade da vida humana e, ao mesmo tempo, a multiplicidade, a diversidade e a desigualdade das paisagens habitadas. Podem ser essas paisagens reconstituídas pela memória daqueles que as habitam, invisíveis à Geografia sob outras análises, mas certamente visíveis a quem as habita.

Dirce Maria Antunes Suertegaray

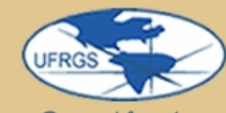

